Transportation of Hazardous Materials

July 1986

NTIS order \#PB87-100319

\section{Transportation of Hazardous Materials}

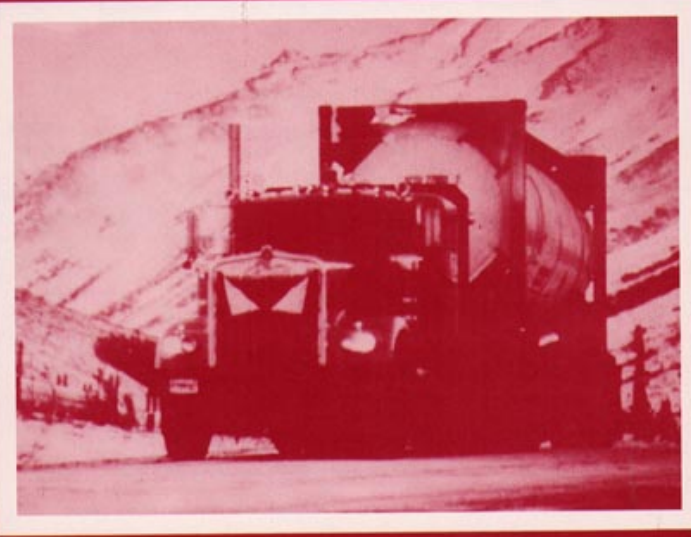

$9=\ldots$ 


\section{Recommended Citation:}

U.S. Congress, Office of Technology Assessment, Transportation ofHazardous Materials, OTA. SET-304 (Washington, DC: U.S. Government Printing Office, July 1986).

Library of Congress Catalog Card Number 86-600542

For sale by the Superintendent of Documents, U.S. Government Printing Office Washington, DC 20402 


\section{Foreword}

Over 11/2 billion tons of hazardous materials are transported annually in the United States. Most of these materials reach their destinations safely because it is in society's and industry's best interests to have them do so. We Americans take for granted the convenience of our transportation system and the amenities of modern life that the petroleum, chemical, and nuclear industries help make possible. Sometimes, however, an accident occurs, and a hazardous material is released, causing damage to the public and the environment. The occasional serious accident is both frightening and worrisome, while a disaster, such as the thousands of deaths and injuries in Bhopal, India, and the enormous release of radioactivity at Chernobyl, raises public apprehensions dramatically. Indeed, few activities with such statistically low risks as the transportation of hazardous materials arouse such intense public concern.

The Hazardous Materials Transportation Act, passed in 1975, is the primary Federal law governing this transportation. Largely unchanged in the past dozen years, the Act will be scrutinized carefully by Congress in the near future as it comes due for reauthorization. To determine whether major safety problems exist in the transportation of hazardous materials that should be addressed through legislation, and whether appropriate technologies exist that could improve this essential portion of our Nation's commerce, the Senate Committee on Science, Commerce, and Transportation requested the Office of Technology Assessment to undertake this study. Subsequently, the House Committee on Public Works; the Subcommittee on Commerce, Transportation, and Tourism of the House Committee on Energy and Commerce; and the Subcommittee on Government Activities and Transportation of the House Committee on Government Operations endorsed the study. OTA's report on Transportation of Hazardous Materials includes a comprehensive assessment of the regulations, information systems, container safety, and training for emergency response and enforcement for consideration by Congress as it deliberates on reauthorization of the Hazardous Materials Transportation Act.

The advisory panel, workshop participants, and contributors for this study played key roles in developing the major issues and contributed a broad and invaluable range of perspectives. OTA thanks them for their commitment of time and energy. Their participation does not necessarily represent endorsement of the contents of the report, for which OTA bears sole responsibility.

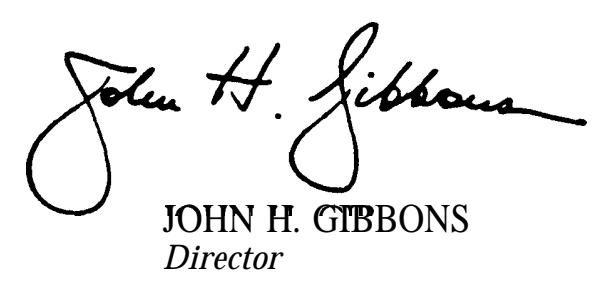




\section{Transportation of Hazardous Materials Advisory Panel}

Garnet Bernhardt'

Supervisor, Colerain Township

Cincinnati, OH

Keith J. Bunting

Manager, Distribution, Government,

and Public Affairs

Dow Chemical Co.

Midland, MI

Robert A. Christman

Vice President, Purchasing

Mobay Chemical Corp.

Pittsburgh, PA

John Cooper

'Manager of Waste and Transportation

Illinois Department of Nuclear Safety

Springfield, IL

Richard E. Cunningham

Director, Fuel Cycle and Material Safety Division

Nuclear Regulatory Commission

Silver Spring, MD

Ed Dietz ${ }^{3}$

Manager of Barge Transportation

Union Carbide Corp.

Charleston, WV

Edward S. Ford

Senator, General Assembly

Commonwealth of Kentucky

Lexington, KY

Roger Kasperson

Center for Technology, Environment and

Development

Clark University

Worcester, MA

Kevin Kenzenkovic ${ }^{4}$

City Manager

Slater, MO

Charles N. Lovinski

Corporate Manager for Restricted Articles

Federal Express

Memphis, TN
John W. Barnum, Panel Chairman

White \& Case, Washington, DC

Charles H. Mayer

Vice President, Nuclear and Hazardous Materials

Division

Tri-State Motor Transit Co.

Joplin, MO

Warren Owen

Executive Vice President

Duke Power Co.

Charlotte, NC

Paul Remick, Jr.

Distribution Advisor

Exxon USA

Houston, TX

Cathy Reynolds

Councilwoman-at-Large

City of Denver

Denver, Colorado

Alan I. Roberts

Director, Office of Hazardous Materials Transportation

U.S. Department of Transportation

Washington, DC

Raymond D. Scanlon

Economic Development Department

The Port Authority of New York and New Jersey

New York, NY

Bill R. Teer

Vice President

Transnuclear, Inc.

White Plains, NY

A.D. Williams

Director of Environmental and Mechanical Engineering

Union Pacific Railroad

Omaha, NE

${ }^{1}$ During Advisory Panel tenure.

'pro forma.

'Retired December 1985.

'During Advisory Panel tenure. Currently City Administrator, City of Oak Ridge North, The Woodlands, TX.

NOTE: OTA appreciates and is grateful for the valuable assistance and thoughtful critiques provided by the advisory panel members. The panel does not, however, necessarily approve, disapprove, or endorse this report. OTA assumes full responsibility for the report and the accuracy of its content.

$$
\text { iv }
$$




\section{Transportation of Hazardous Materials OTA Project Staff}

John Andelin, Assistant Director, OTA

Science, Information, and Natural Resources Division

Nancy Carson Naismith

Science, Education, and Transportation Program Manager

Edith B. Page, Project Director

Eric Butler, Analyst

Ann Carroll, Research Assistant

Francine Rudoff, Analyst

R. James Arenz, Senior Analyst

Jonathan Atkin, Research Assistant

Lucia Turnbull, Analyst

Marsha Fenn, Administrative Assistant

Betty Jo Tatum, Secretary

Christopher Clary, Secretary

Gala Adams, Clerical Assistant

Contractors

Mark Abkowitz Lawrence Bierlein Julia Connally

Theodore Glickman Nina Graybill George List

Science Concepts, Inc. Porter Wheeler 


\section{Reviewers and Contributors}

Edward A. Altemos, U.S. Department of Transportation

Paula Alford, National Association of Towns and Townships

Frederic E. Allen, Allen Enterprises, Inc.

John C. Allen, Battelle Columbus Laboratories

George C. Allen, Jr., Sandia National Laboratories

Louis J. Amabili, Delaware State Fire School

Lindsay Audin, Goldman, Sopkolow, Copeland, P.C, Joe Bahnick, U.S. Environmental Protection Agency

Steve Ballou, Iowa Department of Water, Air, and Waste Management

Lake Barrett, U.S. Department of Energy

Charles Batten, National Transportation Safety Board

Lawrence W. Bierlein, Lawrence W. Bierlein, P.C.

Frank Black, Air Transport Association

Guy Boruff, State of Indiana

Nancy J. Brown, Kansas House of Representatives

Steve Brown, California Highway Patrol

Phil Bryant, Shell Oil Co.

Thomas S. Carter, Jr., The Kansas City Southern Railway Co.

Sherwood Chu, U.S. Department of Transportation

James M. Davis, Jr., Carolina Power \& Light Co.

Richard M. Doyle, Chemical Manufacturers Association

Elaine Economies, U.S. Department of Transportation

Philip E. Eggers, Eggers, Ridihalgh Partners

Ike Eigenschenk, Shell Oil Co.

Max Eisenberg, Maryland Department of Health

Sam Elkind, Hazardous Materials Advisory Council

Johnny Elliott, Duke Power Co.

Robert D. Ervin, University of Michigan

Max Fessler, LPS Industries, Inc.

Barbara Foster, National Conference of State Legislatures Joseph Fulnecky, Federal Highway Administration

John C. Gerard, National Fire Protection Association John Gillick, Kirby, Gillick, Schwartz, \& Tuohey, P.C.

Kurt Goldmann, Transnuclear, Inc.

David Goodman, Transportation Safety Institute

Steve Gordon, U.S. Postal Service

George R. Graham, Jr., Chemical Leaman Container Corp.

Walt Greiner, Federal Aviation Administration

Al Grella, U.S. Nuclear Regulatory Commission

John F. Grimm, Quality Carriers, Inc.

William H. Gushard, Greif Brothers Corp.

Barbara L. Harsha, National League of Cities

Clifford J. Harvison, National Tank Truck Carriers, Inc.

John Hassett, International Bridge, Tunnel, and Turnpike Association

Jim Haugen, U.S. Coast Guard

Gary D. Hilberg, International Association of Fire Chiefs

Edward L. Hillsman, Oak Ridge National Laboratories

Cynthia Hilton, Chemical Waste Transportation Council

Ron Hinkle, United Parcel System

Bob Hirsch, American Trucking Associations, Inc.
Mary Sherwood Holt, Newport News, VA

Warren E. Isman, Fairfax County Fire and Rescue Department, Fairfax, VA

Will Johns, American Trucking Associations, Inc.

Raphael Kedar, Federal Railroad Administration

William Keffer, U.S. Environmental Protection Agency, Region VII

Dan Kessler, North Central Texas Council of Governments

Marcie Kinter, American Waterways Operators, Inc.

Dale Klein, University of Texas at Austin

Wendell Knight, Environmental and Safety Designs, Inc.

Jack Kooyoomjian, U.S. Environmental Protection Agency

George Kramer, Tennessee Emergency Management Agency

Genevieve Laffly, American Petroleum Institute

Donald Lewis, Washington Utilities and Transportation Commission

Charles E. MacDonald, U.S. Nuclear Regulatory Commission

James MacKenzie, Union of Concerned Scientists

Dominic Maio, Transportation Systems Center

James Makris, U.S. Environmental Protection Agency

Clark Martin, American Trucking Associations, Inc.

Lee Martin, Dow Chemical Co.

Tony Massaro, City of Denver

Robert McGuire, U.S. Department of Transportation Thomas A, McKenna, E.I. du Pent de Nemours \& Co.

William Metz, Argonne National Laboratories

Fred Millar, Environmental Policy Institute

Donald Monroe, American Bureau of Shipping

James Moran, Association of American Railroads

Darrell F. Newman, Battelle Pacific Northwest Laboratories

Bill Niggle, Mobay Chemical Corp.

Sam Niniss, Chemical Leaman Corp.

Terry Novak, City of Spokane, WA

James O'Steen, U.S. Department of Transportation

Bim Oliver, State of Utah

Edward D. Olmo, Shell Oil Co.

Reuben W. Peterson, Battelle Columbus Laboratories

Earl A. Phillips, Union Tank Car Co.

Richard E. Phillips, Ethyl Corp.

Edward W. Pritchard, U.S. Department of Transportation

Richard R. Rawl, Oak Ridge National Laboratories

Roger Reisinger, Dow Chemical Co.

Paul Rhine, Union Pacific Railroad

Bob Robison, State of Oregon

Albert B. Rosenbaum, National Tank Truck Carriers, Inc.

Paul Rothberg, Library of Congress, Congressional Research Service

Don Ryan, Ohio State Fire Marshal's Office 
Stephen N. Salomon, U.S. Nuclear Regulatory Commission

Barry L. Schwartz, New York City Law Department

Thomas Sell, U.S. Environmental Protection Agency

John Siegel, Atomic Industrial Forum

Barbara Sonnonberg, Memphis City Council

David Speights, U.S. Environmental Protection Agency

Richard Staebler, Heil Manufacturing Co.

Douglas Stancell, Science Applications International Corp.

Joseph Strohl, Wisconsin State Legislature

Joe Thomas, Virginia Department of Fire Programs
Leonard Trosten, LeBoeuf, Lamb, Leiby, \& MacRae Robert D. Vessey, American Red Cross

Don Vierimaa, Truck Trailer Manufacturer's Association Lynn Wallis, General Electric Co.

Gene T. West, Consolidated Freightways, Inc.

Ned Weatherford, Shell Oil Co.

Robert Wilkerson, Federal Emergency Management Agency

Paul B. Williams, Association of American Railroads Edwin Wilmot, U.S. Department of Energy

David A. Xander, University of Illinois 


\section{Participants in Sister Agency Workshop on Transportation of Hazardous Materials:}

Technology Issues, October 10, 1984

James Blume

Issue Area Planning Director for

Transportation

U.S. General Accounting Office

Daniel Carroll

Assistant Analyst

Natural Resources and Commerce Division

U.S. Congressional Budget Office

Edward Morahan

Evaluator

U.S. General Accounting Office
Vincent Price

Evaluator

U.S. General Accounting Office

Paul Rothberg

Specialist in Science and Technology

Science Policy Research Division

Congressional Research Service
Kenneth Rubin

Principal Analyst

National Resources and Commerce Division

U.S. Congressional Budget Office

Janie Wishart

Principal Analyst

Natural Resources and Commerce Division

U.S. Congressional Budget Office

\section{Participants in Containers Workshop, January 24, 1985}

Timothy Burbrink

Manager

Hazardous Materials Activity

Consolidated Freightways

Robert D. Ervin

Assistant Head Engineer

Research Division

Highway Safety Research Institute

The University of Michigan

Max Fessler

Vice President for Sales

LPS Industries, Inc.

Joseph Fulnecky

Chief, Hazardous Materials Branch

Bureau of Motor Carrier Safety

Federal Highway Administration

B.J. Barrett

Director, Marketing and Sales

Chemical Leaman Container Corp,

William H. Gushard

Vice President

Greif Brothers Corp.

Darlene Walters Hunt

Senior Restricted Articles Specialist

Federal Express

Fred Krysel

Chief Engineer

Polar Tank Trailer, Inc.
Lawrence W. Bierlein, Panel Chairman

Lawrence W. Bierlein, P.C.

Robert M. McClanahan

Assistant Chief

Fairfax County Fire and Rescue Division

Fairfax, VA

Lawrence Gibson

Cargo and Hazards Branch

Office of Merchant Marine Safety

U.S. Coast Guard Headquarters

Thomas A. McKenna

Senior Supervisor

Materials and Logistics Department

E.I. DuPont de Nemours and Co.

Donald Monroe

Principal Surveyor

American Bureau of Shipping

James O'Steen

Chief, Engineering Branch

Office of Hazardous Materials Transportation

Research and Special Programs Administration

U.S. Department of Transportation

Earl A. Phillips

Vice President for Engineering

Development

Union Tank Car Co.
Richard E. Phillips

Engineer for Transportation Equipment Ethyl Corp.

Harlan Pierson

Supervisor, Size and Weight Unit

Maine State Police

Edward W. Pritchard

Engineer, Maintenance Programs Division

Safety Office

Federal Railroad Administration

U.S. Department of Transportation

Paul Seay

Consultant

Patrick J. Student

Manager

Hazardous Materials and

Environmental Control

Union Pacific Railroad Co.

Robert L. Temper

Manager

Hazardous Materials Packaging

Mallinckrodt, Inc. 


\section{Participants in Nuclear Materials Packaging Workshop, February 8, 1985}

Roger Kasperson, Panel Chairman

Center for Technology, Environment and Development

George C. Allen, Jr.

Supervisor

Transportation Systems Development and Testing Division

Transportation Technical Center

Sandia National Laboratories

Robert Anderson

Manager of Cask and Transportation Systems Engineering

Chem-Nuclear Systems, Inc.

Lindsay Audin

Mechanical Engineer

Goldman, Sokolov, Copeland, P.C.

Philip E. Eggers

Nuclear Consultant

Eggers, Ridihalgh Partners

Kurt Goldman

Chief Engineer

Transnuclear, Inc.

Robert J. Hughes, Jr.

Vice President

James Hughes, Inc.
Dale Klein Clark University

Director of Nuclear Engineering Teaching Laboratory

University of Texas, Austin

Charles E. MacDonald

Chief

Transportation Certification Branch

Office of Nuclear Material Safety and Safeguards

Nuclear Regulatory Commission

Heinz Mueller

Assistant Director

Hazardous Materials Section

Illinois State Police

Reuben W. Peterson

Chief Transportation Engineer

Battelle Columbus Laboratories

Richard R. Rawl

Development Staff

Oak Ridge National Laboratories
Paul Rhine

Manager

Train Energy Conservation

Energy and Environmental Programs

Union Pacific Railroad

Joseph Strohl

Member

Wisconsin State Legislature

John Van Hoomissen

Manager of High Level Radioactive Waste Services

General Electric Co,

Thomas White

Member of the City Council

Greenbelt, MD

Edwin Wilmot

Transportation Specialist

Office of Civilian Radioactive Waste

Management

U.S. Department of Energy

\section{Participants in State and Local Workshop, May 30, 1985}

\section{John C. Allen}

Principal Laboratory Scientist

Battelle Columbus Laboratories

Peter E. Baker

Hazardous Materials Transportation Unit

New Jersey State Police

Stanley Brand*

Manager of Hazardous Materials and

Operator for Emergency Response

Monsanto Co.

Juanita Crabb

Mayor

Binghamton, NY

L. Joe Deal

Acting Director

Radiological Assistance Controls Division

Office of Nuclear Safety

U.S. Department of Energy

Warren E. Isman

Chief

Fairfax County Fire and Rescue Department

Fairfax, VA

Robert Robison, Panel Chairman

Radioactive Materials Emergency Coordinator State of Oregon

William Keffer

Chief

Emergency Planning and Response Branch

Region VII

U.S. Environmental Protection Agency

George Kramer

Hazardous Materials Instructor

Tennessee Emergency Management Agency

Richard P. Landis

Associate Administrator for Motor Carriers

Federal Highway Administration

U.S. Department of Transportation

Donald Lewis

Rail and Motor Carrier Training Officer

Washington Utilities and

Transportation Commission

State of Washington

Paul Melander, Jr.

Manager of Transportation Investigation

Tennessee Public Service Commission
Fred Millar

Director of Hazardous Transportation Environmental Policy Institute William H. Nalley Chief

State Programs Division

Bureau of Motor Carrier Safet

U.S. Department of Transportation

Richard O'Boyle

Safety Director

Quality Carriers, Inc,

Susan Peres

Emergency Management Specialist

Technological Hazards Division

Federal Emergency Management Administration

Robert Philpot

Transportation Program Branch Chief

U.S. Department of Energy 
Kenneth L. Pierson

Director

Bureau of Motor Carrier Safety

Federal Highway Administration

U.S. Department of Transportation

Dennis L. Price

Director

Safety Projects Office

Virginia Polytechnic Institute
Valerie Sandstrom

Federal/State and Private Sector Initiatives Division

Office of Hazardous Materials

Transportation

Research and Special Programs

Administration

U.S. Department of Transportation

Bruce Smith

Assistant Chief

Colerain Township Fire Department

Cincinnati, $\mathrm{OH}$
Thomas White

Member of the City Council Greenbelt. MD

Charles Wright

Training Officer

Union Pacific Railroad 


\section{Contents}

Chapter

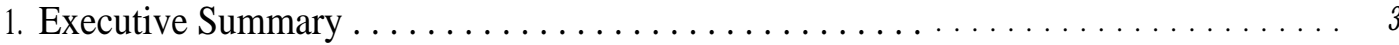

2. Data and Information Systems for Hazardous Materials $\ldots \ldots \ldots \ldots \ldots \ldots$

3. Containers for Hazardous Materials Transportation . . . . . . . . . . . . . 89

4. Hazardous Materials Transportation Regulation . . . . . . . . . . . . . . . . . . . 145

5. Training for Hazardous Materials Transportation Enforcement and Emergency Response . . . . . . . . . . . . . . . . . . . . . . . 201

Appendix

A, Hazardous Waste Regulations . . . . . . . . . . . . . . . . . . . . . . . . . 241

B. U.S. Department of Transportation Inconsistency Rulings . . . . . . . . . ........248

C. Emergency Response Planning . . . . . . . . . . . . . . . . . . . . . . . . 255

D. List of Acronyms and Other References $\ldots \ldots \ldots \ldots \ldots \ldots \ldots \ldots \ldots \ldots \ldots$

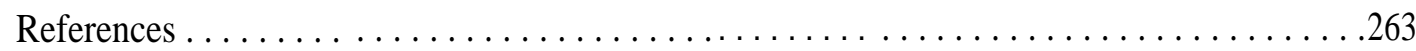




\section{Chapter 1}

\section{Executive Summary}

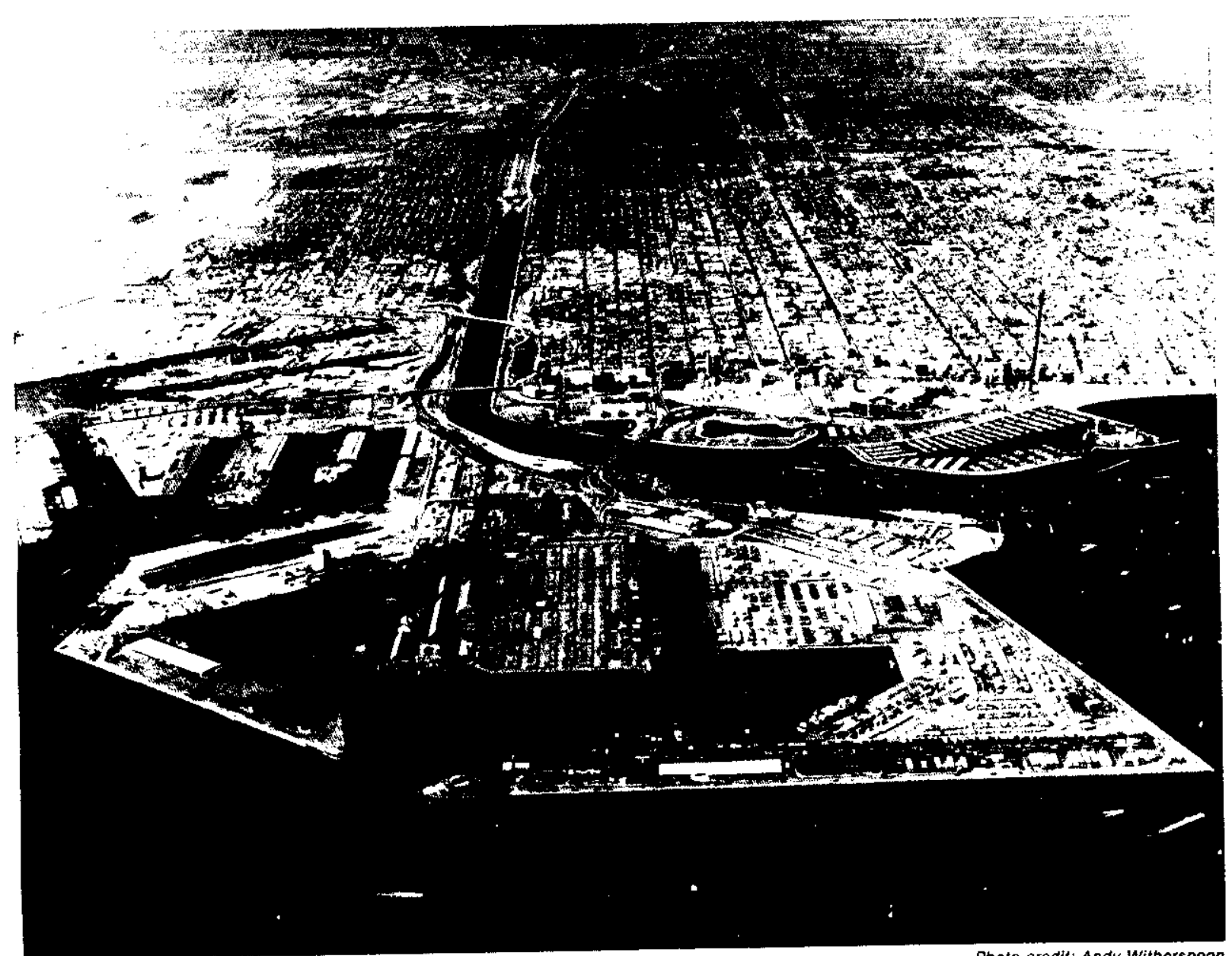

Photo credit: Andy Witherspoon

Port of Long Beach 


\section{Contents}

Federal Government Responsibilities. .................... 7

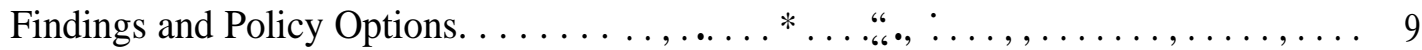

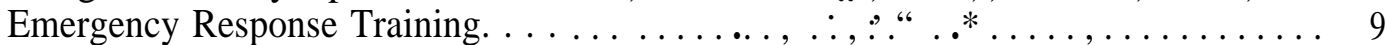

Training for Enforcement. . . . . . . . . . . . ., . i. . . . . . . . . . . 12

Financing Emergency Response and Enforcement Training . . . . . . . . . . 13

Regulatory Consistency . . . . . . . . . . . . . .......... . . . . . . . . 15

Data and Information Programs . . . . . . ......, $;. . ._{\mathrm{f}} \ldots \ldots \ldots \ldots \ldots \ldots 20$

Containers for Radioactive and Hazardous Materials. . $; \ldots \ldots \ldots \ldots \ldots \ldots \ldots \ldots 26$

Defining Roles and Coordinating Programs .*+*..*@.*\$*+................. 37

Table No,

\section{List of Tables، , .}

1-1 Estimated Transportation of Hazardous Materials in the United States,

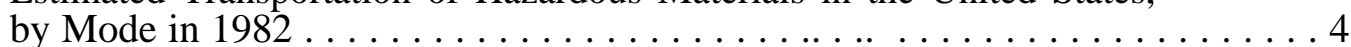

$1-2$ Federal Activities in Hazardous Materials Transportation. . . . . . . . . . . . . 8

1-3. Calculations for Costs of Hazardous Materials Emergency Response Training for First Responders . . . . . . . . . . . . . . . . ......' ... . . . . . . . . . 10

1-4, Hazardous Materials Transportation Inspectors... $\ldots_{\ldots} \ldots \ldots \ldots \ldots \ldots \ldots \ldots$

1-5. Commodity Flow Databases . . . . . . . . . . * ., ., , .., .........., . . . 21

1-6, Modal Characteristics of Bulk Shipping of Hazardous Materials . . . . . . . . . 33

1-7, Cargo Tank Table . . . . . . . . ..........*, . . . . . . . . . . . . . 35

\section{List of Fiigures}

Figure No. Page

1-1. The Chemical Plants: Where They..Are***.+, ,............ 15

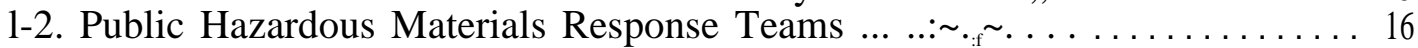

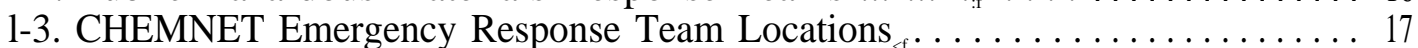

1-4. Regions Used in This Analysis ..\$ ..., .,., ,..* :. '* $, \ldots, \ldots \ldots \ldots \ldots .22$ 


\section{Executive Summary}

Hazardous materials are transported safely every hour of every day. Yet few activities with such statistically low risks arouse such intense public concern. Houston citizens did not remain calm when a speeding truck carrying an intermodal tank of highly flammable methyl methacrylate hit an exit ramp guardrail. The driver was killed. The tank broke open, its contents ignited, and the resulting inferno destroyed part of the freeway and dropped burning debris on the street below. Fortunately, no one else was hurt, and the Houston Fire Department already had a hazardous materials response team with the knowledge and equipment to handle the accident. ' Denver residents were similarly stunned when atruckload of Navy torpedoes overturned one Sunday morning on a city freeway exit loop. No one was injured, but hours passed before experienced Federal assistance arrived. Worried State and local officials did not know whether the scattered weapons needed to be defused before cleanup could begin.

Although by now most Americans are aware that hazardous materials can wreak enormous health and environmental damage, we continue to take for granted both transportation and the amenities of modern life brought to us by the petroleum, nuclear, and chemical industries. Consequently, spectacular accidents, while relatively infrequent, remind us of the harm that can be done and underscore a demand that something be done to keep them from happening-or at least help us be prepared to handle them safely.

Over 1.5 billion tons of hazardous materials were transported by land, sea, and air in the United States in 1982.* (For a tonnage breakdown by mode, see table 1-1.) Truck transport, by a fleet of 467,000 trucks, accounts for more than half of all hazardous materials shipments, or about 927 million tons per year. Because this means a great many truck

'Jack Douglas and Dan Grothaus, "Trucker Dies in Fiery Crash," The Houston Post, July 31, 1985, p. 1A.

*Based on OTA calculations from data supplied by the U.S. Bureau of the Census and other sources. See ch. 2 of this report. This does not include pipeline transportation, which would more than double the annual total.

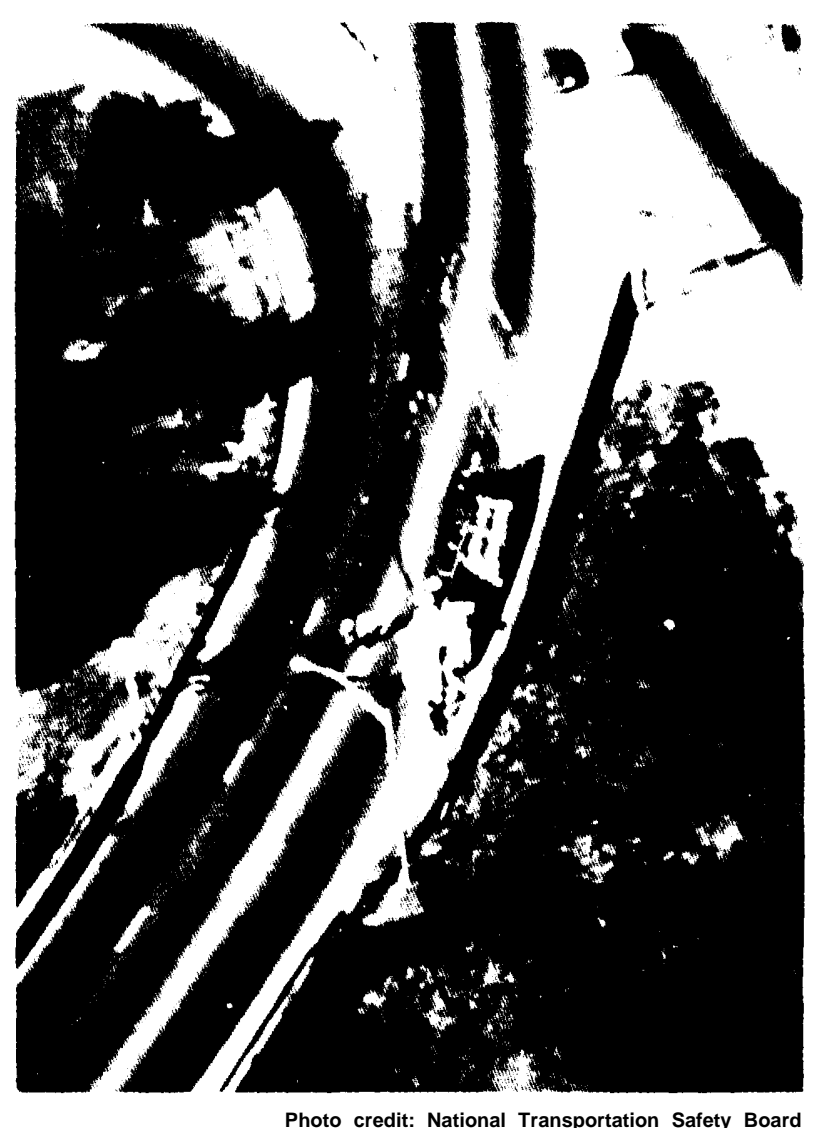

Tractor-trailer carrying torpedoes overturned on an off ramp of a Denver freeway.

shipments, hazardous materials emergency response training is especially important for State and local public safety officers who are usually the first called to an accident.

The types of vehicles carrying hazardous materials on the Nation's highways range from cargo tank trucks to conventional tractor-trailers and flatbeds that carry large portable tank containers or nonbulk packages, such as cylinders, drums, and other small containers. Rail shipments are usually bulk commodities such as liquid or gaseous chemicals and fuels, carried in tank cars. Most hazardous materials transported by water are moved in bulk containers, such as tank ships or barges, while air shipments are typically small packages, often high-value or time-critical material. 
Table 1=1.-Estimated Transportation of Hazardous Materials in the United States, by Mode in 1982

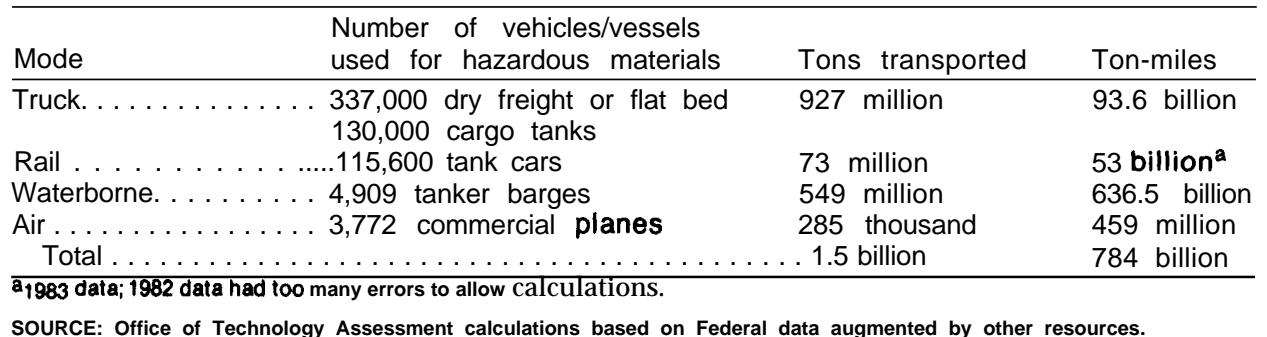

People are most concerned about those risks that are involuntary, uncontrolled, unfamiliar, immediate, manmade, and catastrophic. ${ }^{2}$ Hazardous materials transportation possesses many and sometimes all of these attributes. Risk assessments can help to address two fundamental questions, one quantitative and objective and one qualitative and subjective:

-What is the level of risk?

What levels of risk are acceptable to the parties concerned?

The first question is relatively readily addressed with adequate data and proper methodology, although two essential components must be documentedprobability and consequence. The second question, however, involves numerous judgments and often a great deal of discussion and negotiation, especially when large numbers of people and several governmental jurisdictions are involved. It is the balance between the answers to these two questions that this report is all about. The Office of Technology Assessment (OTA) can address primarily the first question; decisions about the second fall in the province of public officials at every level of government and citizens across the country.

Public concerns expressed to Congress are rooted in the facts that the level of understanding about hazardous materials transportation in or near a jurisdiction is generally low, and that the technical experts, both industry and Federal regulators, are not trusted to provide complete information about the level of risk or to ensure safety. State and local governments, finding that Federal regulations have not

${ }^{2}$ N.C. Rasmussen, "The Application of Probabilistic Risk Assessment Techniques to Energy Technologies," Annual Review of Energy, vol. 6,1981 , pp. 123-138. prevented accidents in their cities, have passed legislation requiring permits and fees or restricting hours of travel for hazardous materials, in an effort to control what is perceived to be a substantial public risk. In addition, some large jurisdictions have formed special fire department hazardous materials teams to respond to accidents or spills. Some State and local government and industry groups have united to form a Hazardous Materials Coalition to lobby for greater Federal support for training.

Public apprehensions notwithstanding, most hazardous materials are transported safely to their destinations because:

- Industry-manufacturers, shippers, and carriers -is, for the most part, aware of the dangers of the products and its liability for the personal, property, and environmental damage and expense that an accident could cause and takes appropriate precautions.

- Hazardous materials transportation is heavily regulated by several governmental bodies.

The basic regulatory structure has been developed, largely by industry, over the last 100 years, and mostly before public awareness of the dangers of toxic substances and understanding of the complex measures necessary to protect public health and the environment reached their present levels. There have been no far-reaching regulatory reforms and no strategic changes to help the system cope with late 20th century technologies and public awareness. For instance, changes in container regulations have addressed individual container designs and specific situations, rather than recognizing that the interaction between container and carrying vehicle has an enormous impact on safety. Although longestablished Federal regulations and industry care have helped to maintain the public safety, it is time 
to modernize our approach and address some of the very real shortcomings in the current system.

More often than not it is people problemsinadequately trained personnel, poor coordination and communication-or lack of information and advance planning, rather than technological shortcomings, that cause accidents, injuries, or environmental damage. * Yet, the roles of the many Federal agencies charged with meeting the complex problems are poorly coordinated and defined. Federal programs that provide technical assistance to State and local governments for emergency response enforcement, accident prevention, and planning activities are uncoordinated, and many find them insufficient and underfunded as well.

The Nation's 39,000 local governments know that their public safety officers will be first on the accident scene and are demanding assistance in being prepared. ${ }^{3}$ Differing Federal, State, and local regulations mean that a highway transporter may need to pay four or five different registration fees and have an equal number of permits to complete one shipment through several States. ${ }^{4}$ State and local officials find it difficult and sometimes impossible to acquire the basic information on hazardous materials production and transportation that they need to plan and prepare for emergencies. ${ }^{5}$ Data available from the Federal Government is disparate, incomplete, and not helpful for these purposes. Moreover, the regulatory process for containers works against innovation in design, thus making the United States less competitive in the international market. In short, the system is burdensome to industry without providing adequately for public health and safety.

The cumbersome system has endured in part because Federal records imply that hazardous materials accident rates are low. However, OTA finds that Federal accident records suffer from significant

\footnotetext{
*Sixty-two percent of reported hazardous materials spills are caused by human error. See ch. 2 of this report.

${ }^{3}$ Paula N. Alford, National Association of Towns and Townships, "A National Hazardous Materials Emergency Response Fund," unpublished background paper, December 1985, p. 4 .

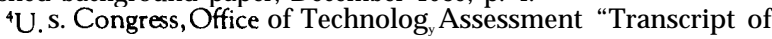
Proceedings-Workshop on State and Local Activities in the Transportation of Hazardous Materials," unpublished typescript, May 30, 1985.

5lbid.
}

underreporting and do not provide an accurate assessment of the level of safety in the transportation of hazardous materials. In any case, arguments over statistics are immaterial to the public safety person first at the scene of the accident. He is likely to be one of the Nation's 1 million largely untrained volunteer firefighters and may be confronted with a placarded, derailed railroad tank car spewing a mysterious cloud that burns his eyes. * Chances are his basic training has included suiting up, moving in, and spraying water or foam on such a car. He probably has not heard that the simplest equipment for dealing with a hazardous materials accident includes tennis shoes and binoculars-tennis shoes to run away and binoculars to read the hazardous materials placard from a distance before calling for expert help. He also will not know that State enforcement records show that between 25 and 50 percent of trucks are incorrectly placarded, ${ }^{6}$ so if he must respond to a truck accident, accurate identification of the substance involved may be difficult and timeconsuming.

Where does the local official look for help in training emergency response people? He could turn to one of four or five agencies in the U.S. Department of Transportation (DOT), the Federal Emergency Management Agency (FEMA), or the U.S. Environmental Protection Agency (EPA). However, the Federal Government offers no guidance about who offers what kind of training or how much it will cost. At the State level, he might seek assistance from the Departments of Environmental Health, Transportation, Public Works, or any of several others, or from the State Fire Marshal's Office. Even if he should succeed in discovering the right group, no funding may be available, and no national training standards have been developed to help choose the appropriate course.

While no national framework for ensuring training exists, all levels of government have a potent tool for dealing with problems/regulations. The massive regulatory code governing the transportation of all hazardous materials except bulk water trans-

\footnotetext{
*Emergency response to a railroad accident often involves an industry/railroad response team as well as public response personnel ${ }^{6} \mathrm{U}$ S Congress, Office of Technolog Assessment, Transportation of Hazardous Materials: Stare and Local Activities, OTA-SET-301 (Washington, DC: U.S. Government Printing Office, March 1986), p. 63 .
} 
port is Title 49 of the Code of Federal Regulations (known as 49 CFR). More than 30,000 hazardous materials are subject to these regulations. However, although DOT is authorized to regulate all hazardous materials shipments, and does so for rail, air, and water, it has chosen to exclude intrastate highway transport specifically from regulatory coverage under 49 CFR. In addition, individual States and regional and local governments enact laws, set regulations, and undertake enforcement activities-primarily for the highway mode - that overlap or vary from those set by the Federal Government and by neighboring jurisdictions. The result is a complicated and constantly changing set of controls. Even those Federal officials who write or work directly with the regulations or the memoranda of understanding governing the process can explain only the Federal roles clearly. Hazardous materials enforcement officers and transportation industries-manufacturers, shippers, and carriers-find this welter of regulations inefficient, confusing, and difficult to comply with and enforce.

Moreover, data and information about shipments are so poor and difficult to acquire that State and local regulations are often developed with little or no understanding of the magnitude or nature of the problems to be controlled. For example, gasoline is by far the most frequently transported hazardous material, accounting for almost half of all hazardous materials transported over the highways. Furthermore, almost all gasoline truck trips are local deliveries, making the risk of exposure to the public higher for gasoline than for any other substance. Not surprisingly, therefore, gasoline transport is responsible for more injuries and dollar damages than all other hazardous materials together. Yet State and local transportation restrictions are usually aimed at shipments of hazardous wastes or radioactive materials, which together account for less than 3 percent of all hazardous materials shipments and are already heavily regulated.

This report discusses transportation of all hazardous materials-commodities, radioactive materials including spent nuclear fuel, and hazardous wastes - that travel by truck, rail, water, or air. Pipeline transport is not considered, as its regulation is entirely different from that of vehicles or vessels. One

\footnotetext{
${ }^{7} 49$ CFR Part 171.1
}

thing is clear-regardless of whether gasoline, anhydrous ammonia, or high-level nuclear waste is being transported, everyone responsible wants to ensure public safety and prevent environmental damage. Disagreements arise primarily over how best to accomplish these aims and how to distribute the costs of the necessary safeguards equitably. OTA has identified four paramount policy issue areas for congressional consideration:

- Training.-Development of a national strategy to provide training for State and local emergency response and enforcement personnel. Training guidelines, adequate funding, and providing comprehensive information on existing resources are key components.

- Federal/State Regulations.-Greater consistency in Federal, State, and local regulations and enforcement, including extending Federal reporting requirements for hazardous materials releases to intrastate highway transportation. Coordination and cooperation between all levels of government in developing consistent regulations will reduce conflicts and duplication of effort.

- Public Information.-Increased availability of information about the transportation of hazardous materials, including spent nuclear fuel. More coordinated Federal data-collection activities would support regulatory decisions and improve public information programs. National guidelines for community right-to-know legislation and Federal assistance for State and local information gathering could be helpful.

- Containers.-Better Federal coordination in setting container regulations, including those for spent nuclear fuel. Two areas warrant specific attention: 1) technical requirements, such as changes in gasoline cargo tankers and design tests for spent fuel casks; and 2) operational and procedural practices, such as quality control and industry training.

Underlying these four issues is the lack of clear definition of Federal and State roles and of effective program coordination to make activities more accessible and cost-effective. The basis for many programs to address these issues already exists, but lack of communication and integration between and among different levels of government diminishes their effectiveness. 


\section{FEDERAL GOVERNMENT RESPONSIBILITIES}

Authority for issuing Federal regulations and developing and implementing programs rests with many different entities. The Federal Government has four roles related to hazardous materials transportation: regulation, enforcement, emergency response, and data collection and analysis. DOT is the lead agency for establishing and enforcing regulations regarding safe transportation of hazardous materials. The DOT Research and Special Programs Administration (RSPA) has authority to issue regulations on many aspects of hazardous materials containers, except for bulk marine shipments, which are regulated by the U.S. Coast Guard. RSPA shares inspection and enforcement activities with the modal administrations, the Federal Highway Administration, the Federal Railroad Administration (FRA), the Federal Aviation Administration, the National Highway Traffic Safety Administration, and the Coast Guard, which also have authority over the vehicles or vessels themselves. RSPA is responsible for identification of hazardous materials as well as:

- regulation of hazardous materials containers, handling, and shipments;

- development of container standards and testing procedures;

- inspection and enforcement for multimodal shippers and container manufacturers; and

- data collection.

Another group of agencies-the Nuclear Regulatory Commission (NRC), EPA, and the Occupational Safety and Health Administration (OSHA)regulates other aspects of hazardous materials transportation. NRC has jurisdiction over high-level radioactive substances in the civil sector, EPA has responsibilities for chemicals and hazardous nonnuclear wastes, and OSHA is concerned with worker safety. These agencies also undertake training activities and provide technical support for State and local governments.

Three additional agencies have nonregulatory functions related to the transportation of hazardous materials. The U.S. Department of Energy (DOE) will be responsible for high-level nuclear waste movement, storage, and disposal under the Nuclear Waste Policy Act of 1982. The U.S. Department of Defense (DOD) transports many hazardous materials for military purposes. FEMA is responsible for coordinating Federal assistance, planning, and training activities for all types of emergency response with State and local governments. See table 1-2 for a summary of Federal agency activities.

The data-collection function is similarly spread among Federal agencies, most of which record accidents and spills and monitor compliance and, sometimes, carrier performance. RSPA is the principal agency collecting data on releases of hazardous materials during transportation, but every other Federal entity keeps records pertaining to its area of interest. General commodity flow information is collected by the Bureau of the Census, making possible estimates of hazardous materials flows, and RSPA has made good use of some of the census data for a truck flow study. However, budget constraints at the Bureau of the Census have restricted its data collection considerably, and no additional analysis or exchange of hazardous materials transportation flow information from other agencies is evident. ${ }^{8}$ This type of data is essential as a denominator for even crude analysis of accident rates, and its lack is a deficiency in RSPA's planning and regulatory activities.

Perhaps more serious is the lack of interagency coordination for recordkeeping on accidents and releases of hazardous materials. For its own records, RSPA depends primarily on reports filed by mail on its Form 5800.1, which has numerous deficiencies in itself. The databases kept by other DOT modal administrations and the National Transportation Safety Board (NTSB) contain numerous accidents OTA has identified as being related to hazardous materials that are missing from the official RSPA accident file, the Hazardous Materials Information System (HMIS). Although the potential exists for much better data exchange and use, HMIS reporting requirements are so narrow, and data collection and analysis are so inadequate that RSPA

\footnotetext{
${ }^{8}$ However, a good deal of analysis related to risk items, such as transporting outdated chemical weapons over different routes, for example, has been carried out at Oak Ridge National Laboratory. S.A. Carries, et al., Oak Ridge National Laboratory, Preliminary Assessment of the Health and Environmental Impacts of Transporting M55 Rockets From Lexington-Blue Grass Depot Activity, Anniston Arm y Depot, and Umatilla Depot Activity to Alternative Disposal Facilities (Washington, DC: U.S. Department of Energy, November 1985).
} 
Table 1=2.-Federal Activities in Hazardous Materials Transportation

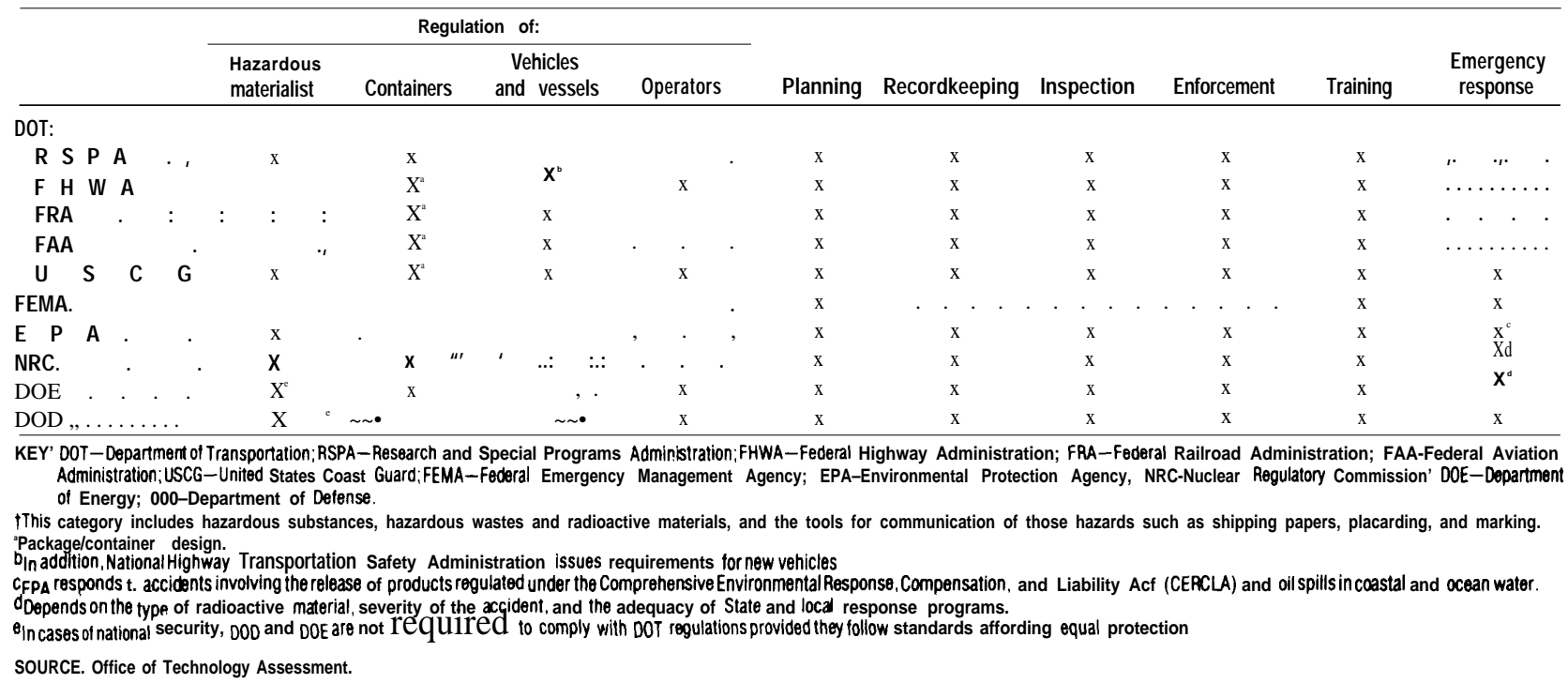

has insufficient information to set timely priorities for regulatory actions. Rulemakings are initiated either by petition from industry or an interested party, or are forced on DOT by widespread public concern, often focused through NTSB or Congress. This kind of reactive rulemaking does not measure up to today's needs. Often research or data analysis could have supported the need for change earlier, or the need was documented some time ago-for example, the reclassification of methyl isocyanate from flammable to toxic inhalant-and no action was taken for years. *

The division of responsibilities among multiple Federal agencies and DOT entities developed on the theory that hazardous wastes, radioactive materials, emergency response training, modal safety concerns, and multimodal hazardous materials questions should be addressed by those with appropriate expertise. The Memoranda of Understanding that have been signed between DOT and NRC, EPA, and DOE focus on delegating responsibility under specific laws. Aside from these agreements, there are no formal mechanisms for interagency regulatory

*This reclassification was suggested at the Williamsburg Conference sponsored by the National Academy of Sciences in 1980 and was the subject of the U.S. Department of Transportation (DOT) activity in the early 1980s. The effort was dropped, until the National Transportation Safety Board and congressional concern highlighted the issue after the tragic deaths and injuries in Bhopal, India. The subsequent DOT rulemaking was completed in under a year. coordination, and no attempt at developing a uniform basis for rulemaking or establishing criteria to set rules and standards has been made. Issues that require the coordinated attention of more than one Federal agency, or Federal and State or industry coordination, often take years to resolve, and no effective effort has been made to improve the situation. The one official Federal coordinating group that does exist, the National Response Team, considers primarily emergency preparedness and response activities and has in the past concentrated on managing Federal response. Until very recently, it has done little to define agency roles, diminish the public's confusion, or meet the crying need for State and local emergency response training with vigorous Federal action.

Complicating matters further, a number of international regulatory bodies have developed recommendations and standards affecting all modes of transport. Federal regulations are being revised to conform with these international codes, particularly those for the air and water modes. Recommendations for objective performance standards for nonbulk packaging issued by the United Nations Committee of Experts on the Transport of Dangerous Goods have been adopted by many countries. However, DOT has not yet adopted performance standards for nonbulk packaging, even though a proposal has been under consideration since 1982 . 
The absence of effective Federal program coordination hampers State and local access to available planning, information, and financial resources. Moreover, authority for matters pertaining to hazardous materials rests with a similar variety of agencies in most States. Frequently, responsibility is equally fragmented at the local level. In view of the numbers of agencies and levels of government involved, it is not surprising that hazardous materials transportation safety and training programs and activities, and even some regulations, are uncoordinated, preventing efficient use of already scarce resources.

\section{FINDINGS AND POLICY OPTIONS}

Hazardous materials transportation safety is not a local, State, or even national problem only; it has global implications. It is decidedly not a partisan issue, and there is little disagreement on the most important problems. However, finding solutions acceptable to a sufficiently broad spectrum of interested parties to achieve the consensus required for legislation is not easy.

Policy options are clustered around the major issues identified earlier: training for emergency response and enforcement activities, regulatory consistency and reform, data collection and information needs, containers, and cutting across these, Federal programmatic coordination.

\section{Emergency Response Training}

Emergency response to hazardous materials incidents is unlike traditional firefighting in that response personnel must identify the specific chemical hazards facing them before approaching an accident or attempting a rescue mission. ${ }^{9}$ An inappropriate response to an accident involving unfamiliar chemical products can endanger individuals, the surrounding community, and the environment. Local fire or police department personnel are usually the first to respond to a hazardous materials ac-cident during transportation, and even in a plant, hence their training is of primary importance. Of the approximately 2 million people in the emergency response network, OTA estimates that a maximum of 25 percent have received adequate training to meet a hazardous materials emergency. Training programs are offered primaril by the States or private organizations, and by the Federal Government.

\footnotetext{
${ }^{9}$ Charles Wright, lecture at Hazardous Materials First Responders Course presented $b_{y}$ Union Pacific Railroad and U.S. Environmental Protection Agency Region VII, April 1985.
}

Most local response forces have insufficient financial resources to take advantage of available training. The spectrum of local hazardous materials training ranges from well organized and funded hazardous materials courses offered by highly trained individuals to little or nothing. 'O

Of the approximately 1.2 million firefighters in the Nation, 85 percent are volunteers and 15 percent are paid employees of municipal, county, or local governments." However, of the roughly 1,000 persons participating annually in the resident training program in hazardous materials emergency response offered by FEMA at its Emmitsburg, Maryland, training center, 85 percent are paid personnel and 15 percent are volunteer.

According to the National Association of Chiefs of Police, there are between 450,000 and 500,000 local sheriffs and police personnel employed by State and local governments; ${ }^{13}$ who are also often called on to provide emergency response. Over 450 training courses in hazardous materials emergency response, planning, and enforcement are available in the Nation, according to a study undertaken at congressional direction by DOT and FEMA in 1985. Costs for these courses are impossible to isolate, since only aggregate figures are available, but the total dol-

\footnotetext{
${ }^{10}$ Association of Bay Area Governments, National Directory of Hazardous Materials Training Courses (San Francisco, CA: March 1985), p. 8. Data supplied by the International Association of Fire Chiefs to CTA.

"Joseph Donovan, National Fire Academy, Federal Emergency Management Agency, Emmitsburg, MD, personal communication, 1985

${ }^{12}$ James Covington, Hazardous Materials Instructor, Federal Emer gency Management Agency, Emmitsburg, MD, personal communication, 1985.

${ }^{13}$ Gerald Arenberg, Executive Director, National Association of Chiefs of Police, personal communication, 1985.

${ }^{14}$ U.S. Department of Transportation and Federal Emergency Management Agency, "Report to Congress: Hazardous Materials Train ing, Planning, and Preparedness, " unpublished draft, January 1986.
} 
lars spent for training in both emergenc response and enforcement, as reported in the Federal study, total $\$ 36$ million for the 5-year period of 1980-84. While the study did not capture the universe of State and local training, OTA's own research implies that the bulk of the dollars spent have been reported. Moreover, the Federal dollars are of the greatest interest.

The majority of Federal expenditures have been for the longer term, advanced level response training courses of the type offered by FEMA at Emmitsburg. Such courses are appropriate for personnel who will be part of a hazardous materials emergency response team in an area with an identified highhazard potential, although these represent a relatively small percentage of the Nation's firefighters. The volunteer firefighters and emergency response forces from small urban and rural areas usually have no hazardous materials training at all. Participants in an April 1985 FEMA-sponsored workshop of national, State, and local experts agreed that emergency response personnel in these areas are most in need of training. ${ }^{16}$ Moreover, according to a FEMA disaster planning survey, ${ }^{17}$ hazardous materials emergencies comprised 4 of the top 10 emergencies considered likely to occur in a community.

OTA concludes that a national strategy to provide an appropriate level of hazardous materials emergency response training, either basic or advanced, to local personnel is an urgent priority. OTA estimates that approximately 1.5 million emergency response personnel need additional hazardous materials training, with the vast majority needing basic first response training. Main" taining the level of expertise through refresher courses for those already trained is also important. Additional expenditures necessary to train 10 to 15 percent of those needing training total $\$ 15$ to \$20 million annually, OTA estimates. This sum could come from a variety of public and private sources, and assumes maximum cooperation between Federal, State, and private groups now providing training and coordinated use of existing

${ }^{16}$ Robert S. Wilkerson, Chief, Technological Hazards Division, Federal Emergency Management Agency, personal communication, June 1985.

L? Federal Emergency. Management Agency, Hazard Identification, Capability, Assessment, and Multi-Year Development Plan for Local Governments, CPG 1-35 (Washington, DC: Januar ${ }_{\mathrm{y}}$ 1985).
}

training resources, including those of industry. (See table 1.3.) The Federal role in developing a comprehensive national training strategy, building on existing training resources, could include assistance in preparing training guidelines, helping to ensure adequate funding, and developing a training information clearinghouse.

The problem is not that courses are unavailable, but rather that those who need them are unable to take advantage of them. The reasons are institutional as well as financial. Better organization and utilization of existing resources could improve training delivery considerably. Existing Federal hazardous materials emergency response training and training support programs in FEMA, EPA, the Coast Guard (DOT), NRC, and DOE need to be coordinated and made complementary. They also could be better utilized to meet State and local training needs as well as those of Federal forces.

\section{Table 1-3.-Calculations for Costs of Hazardous Materials Emergency Response Training for First Responders ${ }^{a}$}

Target audience:

First responders-firefighters, police, hospital emergency room staff, and ambulance drivers.

Size of target audience:

1.5 million (approximate)

Nature of training:

Basic training covering identification of hazardous materials, the importance of self protection, protection of the public and environment, and the notification of authorities.

Duration of training:

Modular training geared to appropriate target audiences would be developed and taught by trained instructors. Must provide opportunities for role playing and group problem solving and acquaint response personnel with the unique dangers of hazardous materials response.

Key cost components:

Course development, handout materials/workbooks, instructional services, training personnel, travel, and equipment.

Estimated average cost per trainee: $\$ 100^{\circ}$

Estimated trainee completions per year. 150,000 to 225,000

Required annual funding total:

$\$ 15$ to $\$ 22.5$ million

a This type of training emphasizes the differences between hazardous materials response and firefighting. Training covers the da, igers inherent in hazardous materials accidents, how to identify hazardous commodities, appropriate re. sponses, and the application and use of protective equipment. Basic training is not designed to cover advanced hazardous materials response techniques is not designed to cover advanced hazardous materials response techniques or cleanup procedures.

on tuition for existing courses and interviews with of $f$ cials and course instructors, Charges vary widely-one large and successful 2-day program is free, whereas another more comprehensive 3-day course charges tuition of $\$ 450$.

SOURCE: Office of Technology Assessment, 
However, choosing the right agency to coordinate Federal emergency response programs and administer any special funding program is problematic. Institutionally, that agency is FEMA. Yet while there is widespread agreement about the need for a strong, central Federal leadership role in emergency response training, there is equally widespread doubt about whether FEMA can provide that leadership. Moreover, States find FEMA's grant requirements so restrictive that they cannot meet their State's program needs and still qualify for FEMA grants. It is only fair to say that some of FEMA's administrative difficulties stem from the statutory restrictions of the Civil Defense Act of 1950, FEMA's primary source of funds for hazardous materials activities. * However, DOT, EPA, DOE, and NRC have narrower areas of emergency response expertise and their responsibilities for training are focused primarily on Federal response.

One congressional option is to charge the $\mathrm{Na}$ tional Response Team with responsibility for coordinating hazardous materials emergency response training and developing guidelines for courses and levels of training using a consensus process. Congress might wish to designate DOT, EPA, or FEMA, as members of the National Response Team with direct responsibility for training, as lead agency for developing a direct contract program with States for funding training. Funds distributed to States for hazardous materials transportation emergency response training might carry a stipulation that some funds be passed through to local jurisdictions.

Over the past decade, hazardous materials manufacturers have taken steps to address safety concerns. Industry's involvement in hazardous materials emergency response ranges from technical assistance to specialized response teams. Many large petrochemical and chemical manufacturers train and maintain company emergency response teams for both their fixed facilities and transportation accidents. The best known effort is the Chemical Transportation Emergency Center (CHEMTREC), established in 1970 by the Chemical Manufacturers Association (CMA). CHEMTREC staff provide chemical information by telephone for use in onsite decisionmaking and notify manufacturers of ac-

\footnotetext{
${ }^{*} \mathrm{Th}_{\mathrm{e}}$ Emergency Management Assistance Program is the vehicle through which States receive funds for activities related to hazardous materials.
}

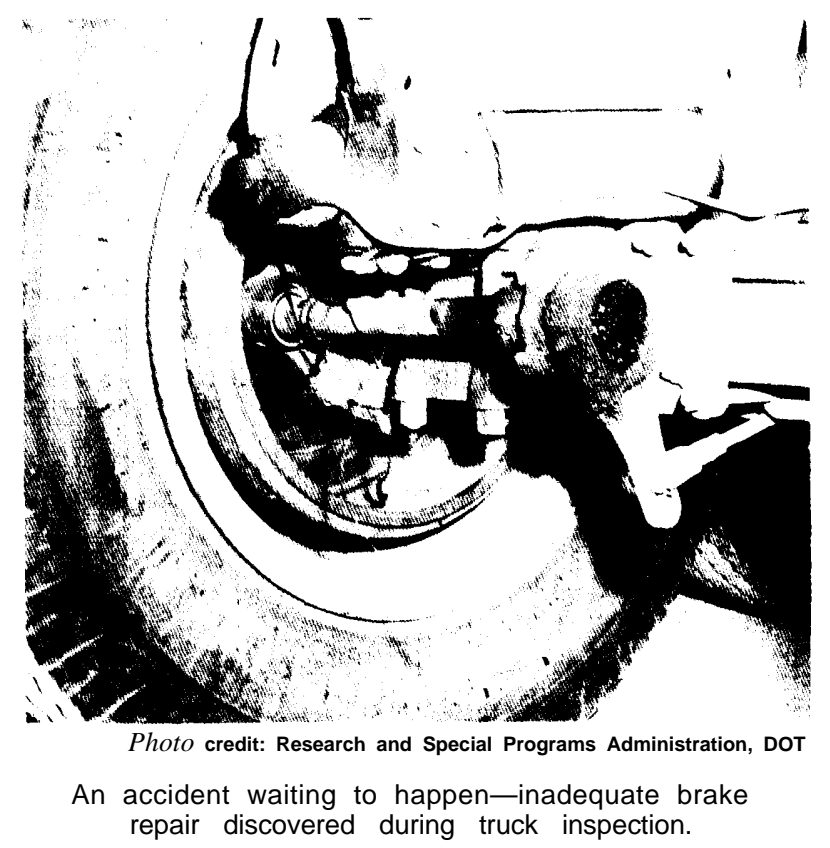

cidents involving their products. CMA has also developed the Community Awareness and Emergency Response Program, which encourages industry and community cooperation in the development of emergency response plans. The Channel industries, the Pesticide Safety Team Network, and Chlorep are other examples of cooperative emergency response capabilities provided by industry.

These specialized information and emergency response units were formed by industries to respond to accidents involving their products. With their specialized resources, detailed knowledge of hazardous materials, and extensive product information, industries can provide a logical adjunct to public safety capabilities for fixed facility and hazardous materials transportation emergency response. Furthermore, some industry training resources have been made available to meet State and local needs. A publicprivate agency cooperative training program has been established by EPA and the Union Pacific Railroad in EPA Region VII. They offer a 2-day training course for hazardous materials identification, free of charge to multidisciplinary groups with emergency response duties.

The most cost-effective training programs are those that use train-the-trainer techniques. These courses also serve as conduits for programs developed according to nationally accepted guidelines. 
Congress might consider giving funding priority to States whose training officials participate in Federal hazardous materials training programs and subsequently develop State training networks using trainthe-trainer courses to improve delivery of training to local emergency response personnel.

OTA concludes that development of national hazardous materials emergency response training guidelines covering course offerings and levels of training is urgently needed by State and local officials. Guidelines for training in equipment use and maintenance would be useful as well. Activities begun this year by the National Response Team and the National Fire Protection Association to develop guidelines are commendable. Broad-based participation of producers, shippers, and emergency response personnel in developing the guidelines is important. At the Federal level, this would mean that DOT, FEMA, EPA, and probably NRC and DOE need to cooperate and reach agreement, as well as firefighters and other safety groups.

Finally, OTA finds that developing a national clearinghouse to make existing information on hazardous materials training programs and resources available to State and local personnel, both in hard copy and online, would provide an extremely useful service to emergency response forces. The 1985 DOT/FEMA study provides basic information already in computerized form for such a service. Several successful programs exist as models in other areas, most notably, a DOT-sponsored microcomputer information exchange administered through a university. ${ }^{18}$

\section{Training for Enforcement}

Consistent, strong enforcement of hazardous materials regulations is a major accident prevention tool. State enforcement activities have become increasingly important as Federal inspection and enforcement manpower has been reduced. The number of DOT vessel and vehicle inspections declined in 1984 for every mode except rail, where special congressional appropriations have been made. The DOT man-years devoted to hazardous materials inspections fell from 237 in 1979 to 111 in 1984,* with

\footnotetext{
${ }^{18}$ Ron Jensen-Fisher, Project Manager, Urban Mass Transportation Administration, Transit Industry Microcomputer Exchange, personal communication, March 1986.

*Complete 1985 data were not available in time for OTA's report.
}

the most notable decline in the Coast Guard. Appropriations to provide additional support for Federal enforcement have not been forthcoming. However, a DOT-State contract program, the multimodal State Hazardous Materials Enforcement Development (SHMED) program, helped 25 States develop hazardous materials enforcement expertise and training capabilities. Developed by RSPA through the DOT Transportation Safety Institute, SHMED used home study materials and train-the-trainer techniques to reach large numbers of enforcement and industry personnel in participating States. The program has been both effective and inexpensive; overall expenditures through 1986, when the program expires, will have amounted to just over $\$ 3$ million.

However, after the SHMED program is phased out, DOT financial support for State hazardous materials enforcement development will continue for motor vehicles only, bolstered by the Motor Carrier Safety Assistance Program (MCSAP), administered by the Bureau of Motor Carrier Safety (BMCS) in the Federal Highway Administration. The MCSAP grant program is designed to improve State capabilities to enforce motor carrier safety regulations, to conduct commercial vehicle inspections both in terminals and along roadsides, and to collect safety data. MCSAP funds may be applied to hazardous materials enforcement activities at the discretion of the State. MCSAP expenditures for 1985 were $\$ 14.2$ million, and the Secretary of Transportation requested the full funding level of $\$ 50$ million for MCSAP funds for 1987.

Hazardous materials flow and accident data, poor as they are, show clearly that truck transport has the greatest risk of accidents, and Federal and State inspectors in 1985 pulled out of service for violations an all time high of about 40 percent of inspected trucks. MCSAP gives priority to general motor carrier safety programs, justifiably in light of these facts. However, concerns that hazardous materials enforcement activities are being slightedespecially for the rail, water, and air modes-have been raised by $\operatorname{man}_{y}$ State, local, and industry officials.* OTA finds that Federal programs developed through the Transportation Safety Institute for enforcement training have provided effective

\footnotetext{
*This has been a pervasive theme throughout OTA's information gathering
} 


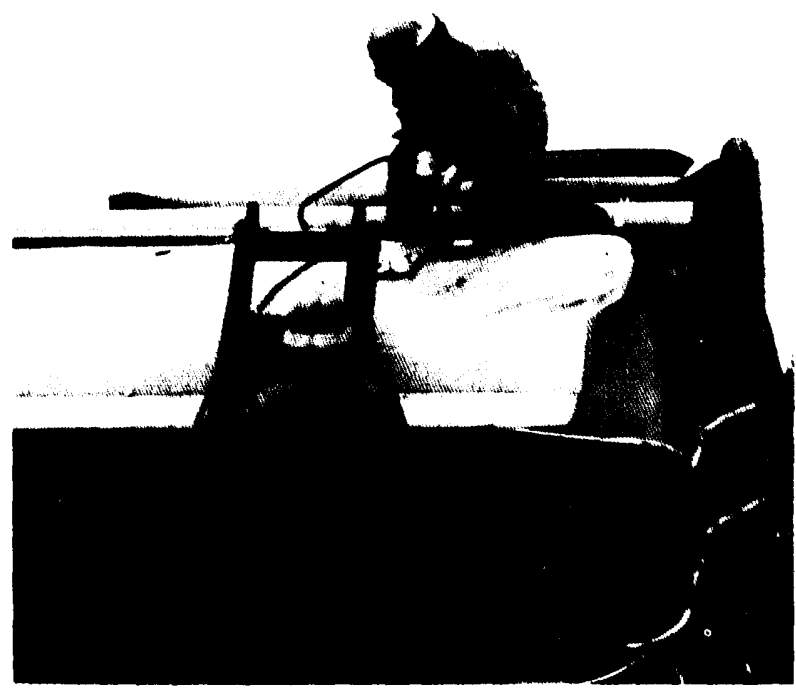

Photo credit: Shell Oil Co.

This petroleum industry training course shows response personnel how to prepare an overturned tank truck for offloading of the product before the truck is righted.

support for State enforcement training needs. In addition, OTA concludes that MCSAP provides essential funding and support for State motor vehicle enforcement and training programs, but that Federal enforcement programs are not adequate for the other modes. If Federal inspections continue to decline, support for development of alternative hazardous materials inspection and en forcement programs for water, rail, and air is needed.

Responsibility for inspections of container man-ufacturing facilities might best be left with the Federal inspection forces. The specialized expertise required and the relatively small number of inspections would make development costly for State capabilities to check compliance with container design requirements. Adequate levels of inspection and enforcement, however, even for these targets, would require increased Federal forces. In 1984, for instance, only 144 of the more than 7,000 container manufacturers were inspected by RSPA and FRA, and only 5,220 of the estimated 100,000 shipping facilities were inspected. 'Q Congress might increase DOT's enforcement budget particularly in the areas of water, rail, and air hazardous materials inspections, which are not covered by State enforcement and inspection programs. OTA coneludes that Federal inspection forces, which have been halved over the past 5 years while shipments of hazardous materials have been increasing, ${ }^{20}$ are now insufficient to ensure adequate inspection levels. (See table 1-4. )

\section{Financing Emergency Response and Enforcement Training}

OTA finds that the approximately $\$ 7.2$ million* spent annually for emergency response and enforcement training is insufficient to provide adequate hazardous materials training. While the SHMED and MCSAP programs have provided basic Federal support for enforcement training, emergency response training has not received similar Federal attention. The management of the SHMED

${ }^{14}$ U.S. Department of Transportation, Annual Report on Hazardous Materials Transportation, Calendar Year 1984 (W'ashington, DC: 1984), p. 42

${ }^{20}$ Mark Abkowitz and George F. List, ' Hazardous Materials Transportation Flow and Incident/Accident Information Systems, " OTA contractor report, January 1986.

*Average annual expenditure reported by traming organizations in the Department of Transportation/Federal Emergency Management Agenc $_{y}$ study

Table I-4.-Hazardous Materials Transportation Inspectors

\begin{tabular}{|c|c|c|c|c|c|c|}
\hline & 1979 & 1980 & 1981 & 1982 & 1983 & 1984 \\
\hline \multicolumn{7}{|l|}{ Total work-years: } \\
\hline United States Coast Guard & 115.5 & 115.5 & 155.8 & 50.0 & 40.0 & 12.0 \\
\hline Federal Aviation Administration , ., ., . . & . 36,9 & 19.0 & 17.8 & 8.2 & 14.1 & 15.0 \\
\hline Federal Highway Administration. ., . . . & .47 .0 & 49.3 & 47.3 & 40.2 & 25.3 & 28.0 \\
\hline Federal Railroad Administration . . . & .28 .2 & 33.6 & 34.7 & 33.0 & 46.4 & 48.0 \\
\hline \multicolumn{7}{|l|}{ Materials Transportation Bureau } \\
\hline (Office of Hazardous Materials Transportation) & 9.0 & 10.0 & 7.5 & 6.8 & 6.8 & 7.5 \\
\hline Total $\ldots \ldots \ldots \ldots \ldots \ldots \ldots$ & 236.6 & 227.4 & 262.9 & 138.2 & 132.5 & 110.5 \\
\hline
\end{tabular}

SOURCE: Office of Technology staff-based on Department of Transportation Annual Reports 
program provides a model for a cost-effective federally supported emergency response training program. It made good use of existing resources, provided uniform training, used train-the-trainer techniques, and required that States adopt Federal regulations, designate a State lead agency, and participate in funding. However, total Federal SHMED expenditures were \$3 million for a program that reached 26 States, and perhaps less than half the national enforcement officer population of about 500,000; a totally different level of need exists for emergency response training.

OTA estimates that the minimum training time needed for an introductory course for first response to hazardous materials emergencies is 2 days, assuming that the trainees are already trained firefighters, enforcement officers, or medical technicians. ${ }^{*}$ Costs for this basic training depend on where and how it is carried out. Table 1-3 shows estimates for an annual training program to begin addressing State and local emergency response training needs. OTA concludes that an annual Federal funding level of approximately $\$ 5$ to $\$ 7$ million, added to $\$ 10$ to $\$ 15$ million derived from other sources and mom ies now being spent, could provide adequate Federal assistance, if existing resources are reorganized and tightly managed.

Possible Federal funding sources include:

- general revenue;

- Federal funding programs related to hazardous materials transportation, such as the Surface Transportation Assistance Act (the fuel tax), the Nuclear Waste Policy Act, or the Comprehensive Environmental Response, Compensation, and Liability Act (Superfund); and

- creation of a dedicated fund based on user fees, such as those generated by a permit or registration fee levied against hazardous materials industries.

The fuel tax is the most broad-based of the three special tax-based funds, and gasoline transport accounts for the largest dollar damages. Since truck accidents require the most frequent emergency response activities, tapping fuel tax funds to support

*OTA calculations, based on interviews with emergency response trainers and OTA staff experience with four types of emergency response training: industry, jointly sponsored public and private courses for community first response personnel, Federal training for public response, and Federal training for Federal response. emergency response training provides for a degree of equity. The Nuclear Waste Policy Act provides some funds for State and local activities related to transportation, but such funds are generated by nuclear utilities, and their shipments represent far less than 1 percent of total annual hazardous materials shipments. Superfund already has substantial claims against it and specifically excludes transportation from some programs.

If used to fund emergency response training, a Federal registration or permit program could have major adverse impacts on similar State and local activities, an issue discussed further in the section on regulatory consistency. Moreover, the administrative costs for such a Federal program need to be carefully considered. If industry is to support a new user fee to fund training, it will require assurance that:

the amounts assessed relate to the magnitude of local training needs,

the funds reach those most in need,

a fixed limit is placed on the amount it must contribute,

local jurisdictions make maximum use of existing regional resources and participate in the funding effort in some way, and

no individual State or local fee programs are implemented for this purpose in participating jurisdictions.

Two independent groups have endorsed creation of a dedicated fund, generated by user fees levied against shippers and carriers to support State and local hazardous materials program development and emergency response training. The groups are the Hazardous Materials Coalition, comprised of State and local government organizations and some industry representatives, and the National Hazardous Materials Transportation Advisory Committee, formed by the Secretary of Transportation and comprised of State and local government officials and representatives of industry and labor. Both groups recognize that many jurisdictions already impose registration or permit fees, using them for a variety of purposes frequently unrelated to emergency response, and that requiring payment of another such fee is unacceptable to many industries.* Restrictions

${ }^{*}$ TWO major industry groups, the Association of American Railroads (AAR) and the Chemical Manufacturers Association (CMA) have opposed such a fund in the past. CMA is modifying its opposition, requesting further study to quantify the need; AAR remains opposed. 
on their own fee programs, suggested for jurisdictions choosing to benefit from the Federal fund, may be difficult for States to accept.

Equity in apportionment of funds is an important consideration, although an appropriate basis is difficult to determine. Funds could be apportioned to States on the basis of population or on the basis of hazardous materials transportation density. However, areas such as the Gulf Coast; California; and the Pennsylvania, Ohio, Indiana, and Illinois corridor, which have the largest amounts of hazardous materials traffic, also have the largest number of industry response teams. (See figures 1-1, 1-2, and 1--3.) Moreover, the need for emergency response training is often not recognized in small urban or rural areas, where the probability of an accident is low, but where the consequences of an accidental spill for untrained response personnel could be severe. Finally, jurisdictions that already have welldeveloped emergency response capabilities have emphasized to OTA that they need financial assistance to maintain training levels and equipment.
Additional local industry involvement in development and delivery of community hazardous materials emergency response training could be encouraged to defray training costs. Support from Federal and private sources for financial assistance to State and local jurisdictions will be more readily forthcoming if jurisdictions can show that they:

- have developed an emergency response plan;

- know what their training needs are;

- have local matching funds or resources available; and

- have cooperated with neighboring jurisdictions in such efforts as joint planning, information collection, and mutual aid agreements.

\section{Regulatory Consistency}

The authority granted to DOT under the Hazardous Materials Transportation Act (HMTA) to regulate hazardous materials is comprehensive. However, putting aside questions of whether RSPA has adequate staff for program administration, several

Figure 1-1.-The Chemical Plants: Where They Are

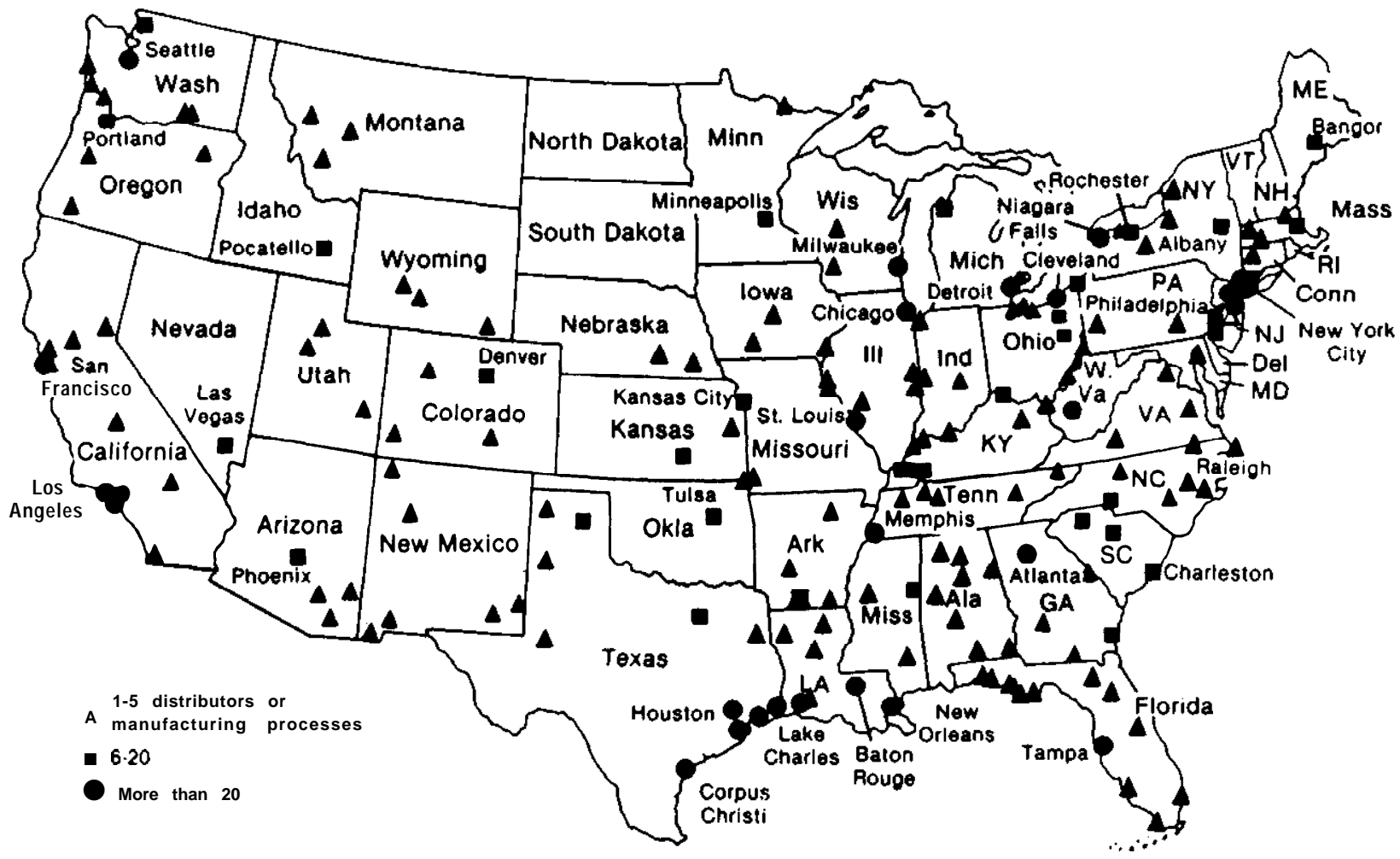

SOURCES Environmental Protection Agency, SPN Directory of Chemical Producers, Chemical Week Buyers Guide,Chemsources U. S. A., individual chemical companies, 


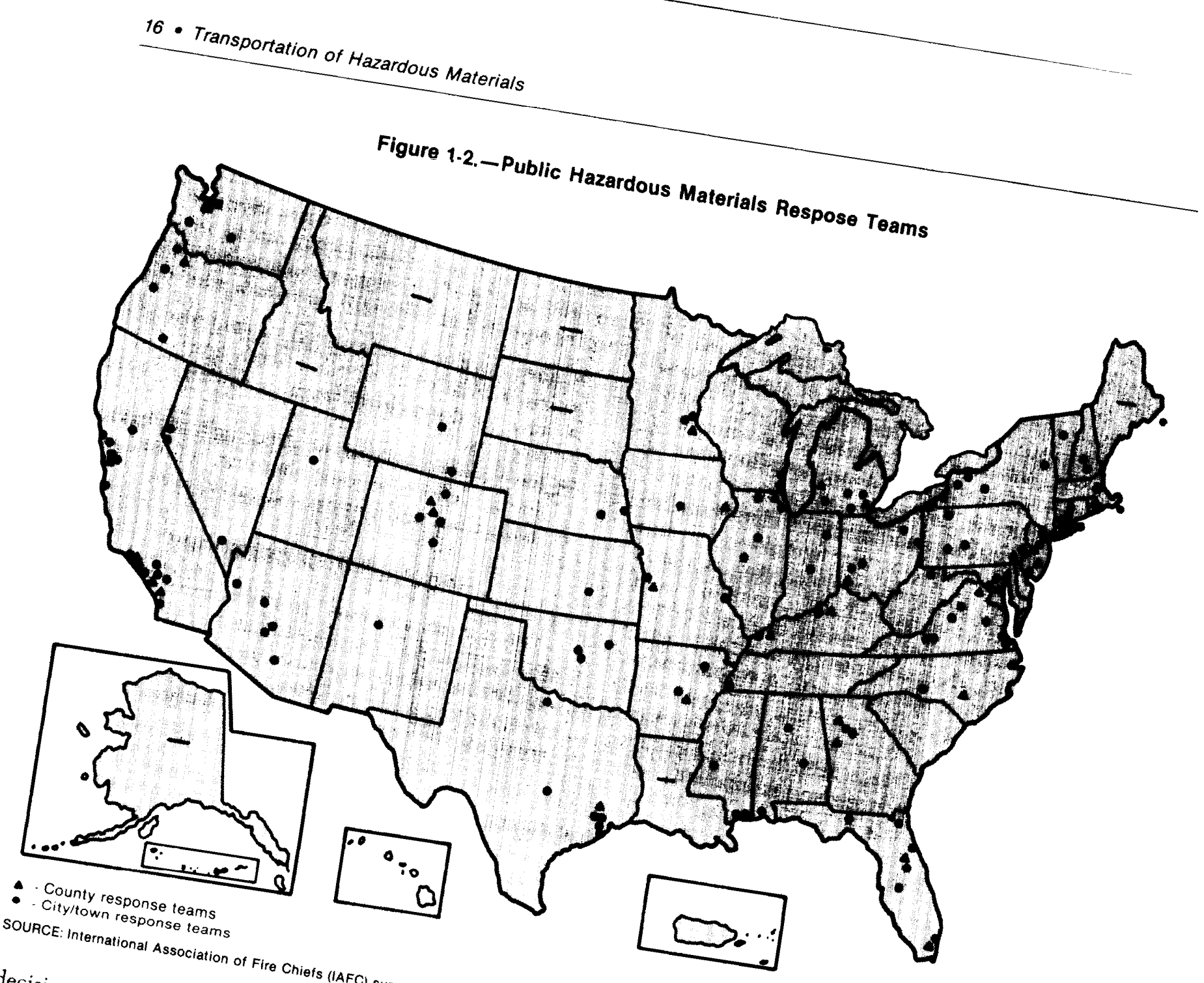

decisions made by DOT about how (IAFC) survey and OTA Statt. authority have by DOT about how to exercise it

lations, motivating internatioplications of its reguState and local governments to organizations and
a need.

First, DOT has chere they saw tions to solely intrastate mot to apply the regula hazardous wastes and motor transport except for Many pubs in portable tanks ances and flammable private carriers officials, common cargo tankers. ${ }^{21}$ state activities that have both interstate and large riers operating are surprised to learn thate and intramany DOT relely intrastate are that most cara hazardous regulations. For example arempt from 49 U.S.C., Part 171.1 (a). pany need not be reported to DOT, and second-
or third-hand cargo tankers that no longer meet Fed-
eral requirements may be operated within
States. While States accepting required to apply 49 accepting MCS within some against intrastate 49 CFR in enforcem funds are the reporting requiriers, this does noment actions tions will be requirements and containere that Second, DOT has establish a registration prot exercised its authority to
riers. This has meant that it does nippers and car-
plete data about the extent of hot have and that the portio extent of the grout have comful to State and lons of the data that woup it regulates Since thearly officials are not would be usehave been early 1970s, State and not available. 
Figure I-3.-CHEMNET Emergency Response Team Locations

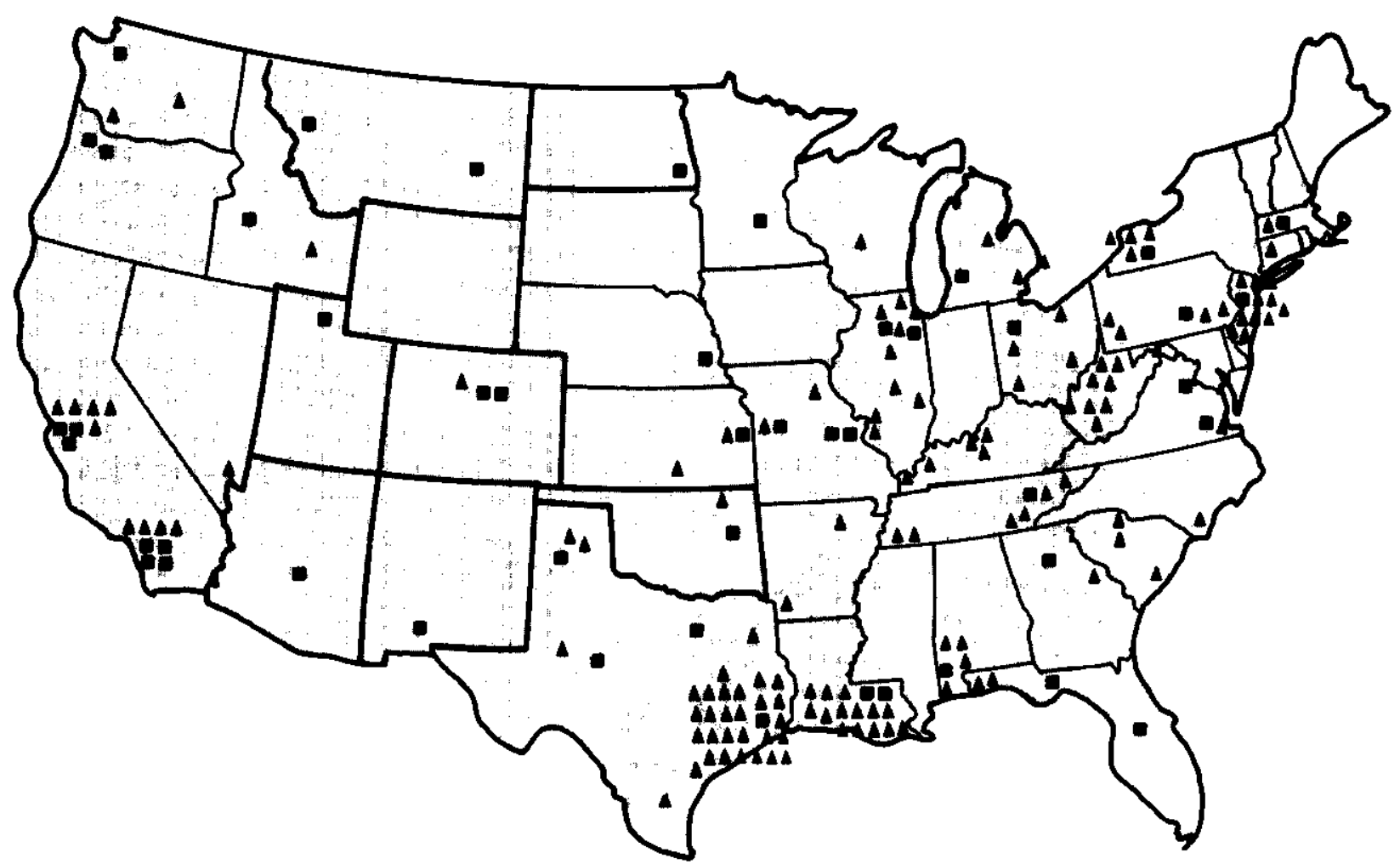

A CH EMN ET chemical industry emergency response teams

- CHEMN ET contractor emergency response teams

SOURCE: Chemical Manufacturers Association.

of hazardous materials to supplement Federal regulations and enforcement and to ensure adequate safety for their jurisdictions. Because each was formulated to meet immediate and separate goals, State programs affecting hazardous materials transportation, like their Federal counterparts, are now characterized by a multiplicity and diversity of activities and areas of jurisdiction. Responsibilities are divided among State utility commissions, transportation, health, environmental, and emergency preparedness agencies. Moreover, great variation among State laws and regulations exists, even though most States have adopted 49 CFR wholly or in part. Finally, the enormous differences in State requirements for truck driver's licenses mean there is no assurance that a qualified driver is behind the wheel of a truck carrying hazardous materials.

Furthermore, finding Federal data lacking in the necessary detail, State and local governments and transportation facilities have enacted a variety of regulations intended to provide information they need for emergency response planning, enforcement activities, and development of local routing restrictions. The result is that shippers and carriers have to comply with multiple State and local registration, licensing, permitting, and shipment notification requirements. Additionally, differing right-to-know laws authorizing public officials to obtain information from facilities within their jurisdictions have been passed at State and municipal levels. The provisions of Good Samaritan laws also vary from State to State; requiring that emergency response personnel, particularly special industry teams that operate in more than one State, be aware of these differences. This wide variation in regulations is clearly at odds with the intent of the HMTA.

Another important regulatory activity of State and local governments is the designation of routes 
that must be followed by transporters of hazardous materials. Existing highway routing policies established by DOT permit State and local route designations to accommodate local traffic conditions. The Federal highway routing rule for radioactive materials requires the use of Interstate highways or alternate routes designated by State agencies, while a more general requirement for nonradioactive materials instructs carriers to avoid heavily populated areas. Although DOT guidance documents advise States and localities to use explicit safety criteria and involve all affected parties early in making route designations, reaching a consensus is often difficult. In some cases, rerouting has shifted risks to jurisdictions lacking emergency response capabilities; other designations have been contested because affected communities or States were not consulted.

The assumption of greater regulatory and enforcement responsibilities has meant heavier financial burdens for States and localities. Although the SHMED program and MCSAP have provided many States with some funds for the development of hazardous materials enforcement programs, local governments usually do not benefit directly from Fed-

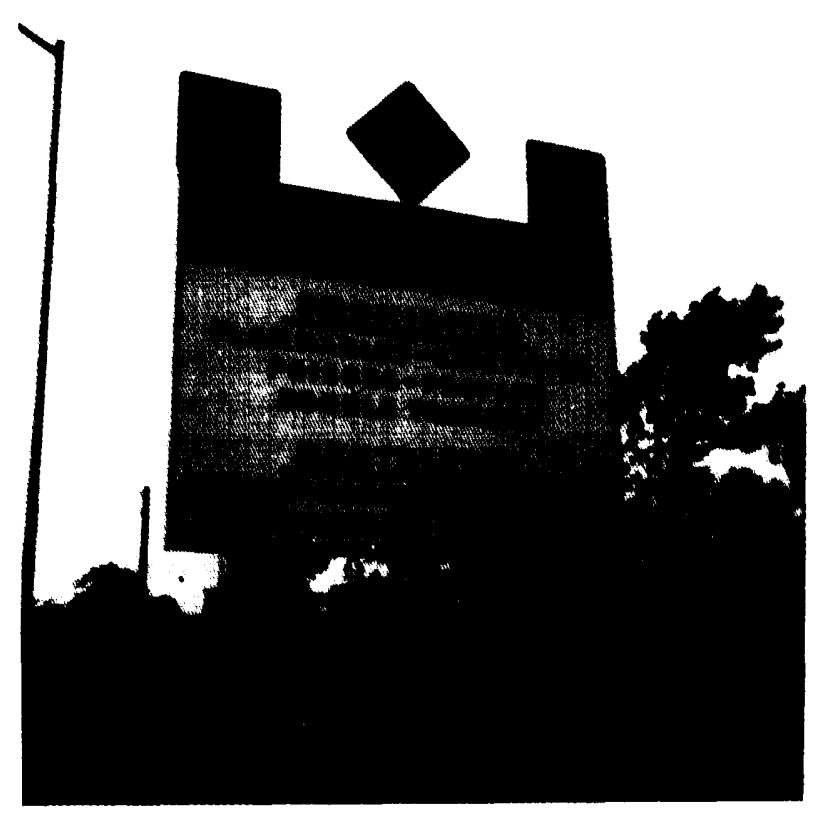

Photo credit: Maryland Transportation Authority

Bridge, tunnel, and turnpike authorities in many areas restrict the movement of hazardous materials, as illustrated by this photograph taken near the Baltimore Harbor Tunnel. eral grant programs to the States. To pay for their inspection, enforcement, or emergency response programs, many States and municipalities require shippers and carriers of hazardous materials to pay a fee when they register or apply for a license or permit. As most State and local fees and requirements apply to highway shipments, the trucking industry has been affected most heavily, and carriers argue vigorously that compliance with differing laws and regulations is time-consuming and expensive. ${ }^{22}$ The costs include not only payment of registration, permit, and licensing fees ranging from several dollars up to $\$ 1,000$ per shipment, but also expenses incurred by special staff to keep track of requirements that continuously change. In addition, carriers point out that certain requirements, such as curfews imposed on some special shipments, cause delays and increase risks. By diverting shipments around their own boundaries, jurisdictions imposing such requirements shift risks to other States and communities.

The roles played by States and localities in the regulation of hazardous materials transportation have grown considerably since the HMTA was passed. The act provided the Secretary of Transportation with broad authority and specified that State and local requirements inconsistent with Federal law and associated regulations should be preempted except under certain circumstances. The legislative history of the HMTA indicates that Congress intended to preclude a multiplicity of State and local regulations, exactly the types of varying and conflicting regulations that now exist. While most State and local governments understand and agree with the need for uniform regulations, especially in areas related to containers and hazard communication, they have also found that DOT activities have not provided adequate safety levels in their jurisdictions. They have thus taken the steps they consider necessary to control the risks associated with the transportation of hazardous materials.

There have been no comprehensive efforts to date to resolve interjurisdictional differences. Resolving questions of inconsistency between local, State, and Federal regulations, a task traditionally left to the courts, has been the focus of an advisory adminis-

\footnotetext{
${ }^{22}$ U.S. Congress, Office of Technology Assessment, Transportation of Hazardous Materials: State and Local Activities, op. cit.
} 
trative review process, established by DOT in 1976. The 16 inconsistency rulings issued since 1978 indicate that DOT believes that permissible State and local regulatory authority is limited to traffic control and eliminating or reducing safety hazards peculiar to local areas, and that each State and localit $_{y}$ must assess the impacts of a requirement, such as a routing rule, on other jurisdictions. However, as the DOT inconsistency ruling process does not preclude judicial review, a number of the cases examined by DOT have also been the subjects of lawsuits.

While case-by-case reviews by DOT and the courts are time-consuming and costly, they provide some criteria for assessing the validity of certain types of laws and regulations. However, OTA believes such reviews will not prevent continued adoption of differing State and local requirements, as these provide both needed revenue and valuable data. Any policy or legislative changes to relieve the present situation must address both the financial and informational needs of State and local governments, as well as ease the burden faced by interstate shippers and carriers.

Carrier associations, insurance industry representatives, and State motor vehicle administrators and enforcement personnel have voiced strong support for a national truck driver's license requiring special training. Congress could authorize the development of such a license with special certification requirements for all hazardous materials, including gasoline. Prerequisites for a license should include training and a clean record, and driver certification could be linked to specific types of vehicles. Uniform license requirements and training standards could be developed by DOT, but States would be responsible for issuing licenses and administering the training requirements. State license fees could be set to cover program costs. California has already developed a graded truck driver's license program. A program created by the European Common Market countries requires a hazardous materials driver's license but allows each country to pass its own implementing legislation.

OTA concludes that even if DOT exercised its authority to establish a registration program for its own purposes, the information collected under the program would not completely meet the data needs of States and communities. Thus, Congress might require development of national guidelines for State information-collection programs in three areas: registration-to determine the number and location of hazardous materials shippers and carriers; licenses or permits-to obtain assurances of fitness from shippers and carriers; and notification-to obtain information on the types of hazardous materials passing through a community or region. Involving Federal, State, local, and industry representatives in developing both the guidelines and a standard form for requesting information, * would permit consensus and a degree of uniformity. Once States have adopted the guidelines, localities could obtain the information they need from their State agencies. However, bridge and tunnel authorities have special information needs that may include prenotification of certain high-hazard shipments. Assuming that alternative sources of financial support are provided for enforcement and emergency response, State and local fees could be limited to amounts sufficient to cover program administration costs. An annual compendium of State, local, and special authority requirements and contacts would be very useful to interstate shippers and carriers. Industry, DOT, and the States might jointly develop the necessary data for such a compendium.

The broader issue of varying State hazardous materials laws and regulations should also be addressed. Complete information about the scope of existing State laws and regulations pertaining to the transportation of hazardous materials is not presently available. While many States have adopted 49 CFR, some have excluded certain types or quantities of hazardous materials and certain intrastate highway shipments. Conversely, other jurisdictions have established regulations more stringent than the Federal ones. OTA concludes that an assessment of State hazardous materials laws and regulations to determine whether they are more or less stringent than Federal regulations would be a useful first step toward greater regulatory consistency. BMCS has already begun, at congressional request, a 5-year study program that will lead to greater highway regulator uniformity, but only in some areas. $^{2 .}$

\footnotetext{
${ }^{*} T_{e}$ Uniform Waste Manifest, developed jointly by the U.S. Environmental Protection Agenc and the U.S. Department of Transportation, is one possible model.

${ }^{23}$ This review is authorized $b_{y}$ the Motor Carrier Safety Act of 1984, Public Law 98-554,98 Stat. 2829. State guidelines for compiling, analyzing, and submitting their laws, regulations, and other information were published by the Bureau of Motor Carrier Safety on Jan. 10, 1985 (50 F.R. 1243).
} 
BMCS is compiling and reviewing State motor carrier laws to determine those that are more or less stringent than Federal requirements in the areas of driver qualifications and training, hours of service, and equipment maintenance. As part of the process, State laws will be reviewed by a panel convened by the Secretar of Transportation. State laws that are less stringent than their Federal counterparts will be preempted; a law that is more stringent will not be preempted unless it has no safety benefit, poses an undue burden on interstate commerce, or is incompatible with Federal regulations. Another study of State motor carrier laws related to finances is being conducted by the National Governor's Association for DOT. Congress could extend these reviews to encompass State hazardous materials regulations or initiate a separate process. Congress might also wish to require DOT to reduce emphasis on inconsistency rulings, which are issued after a regulation is in place, and to provide technical and policy assistance to States or communities during the process of developing regulations.

Congress might also consider requiring the ex. pansion of those parts of 49 CFR promulgated by RSPA, such as reporting requirements and con. tainer regulations, to cover all intrastate highway transportation. Such a requirement would allow RSPA regulations to address safety issues more comprehensively. However, if this approach is adopted, States are likely to insist that the same preemption criteria as mentioned above be applied.

Routing is an extremel important accident prevention tool available to State and local governments. Although it is likel that developing a routing scheme that enhances overall safety will be a difficult process for some regions, experience in Portland, Oregon, demonstrates that it is possible. The existing routing regulation for nonradioactive hazardous materials could be amended to provide more explicit guidance to communities. The use of existing DOT routing guidelines, which contain a risk assessment methodology and recommend interjurisdictional consultation, could be required. States interested in designating alternate routes to those approved by NRC for shipments of radioactive materials are already required to follow the DOT guidelines embodied in the ruling known as HM-164. The development of criteria for routing shipments of radioactive and other hazardous materials by rail and water might also be considered. DOT could provide technical assistance to States and communities for applying risk assessment criteria and working through the route-selection process to avert the need for legal action.

\section{Data and Information Programs}

Federal, State, and local governments need data to help them set regulations, plan for emergenc ${ }_{\mathrm{y}}$ response and accident reduction, and target enforcement efforts. Data and information systems pertaining to hazardous materials transportation are kept by many Federal agencies, regional Federal offices, different departments of State governments, and even some local government offices.

\section{Hazardous Materials Flow Information}

The most basic data needed for all of these activities are the identities and locations of suppliers, manufacturers, and carriers of hazardous materials. A governmental entity may acquire this information by requiring such firms to register, by conducting an inventory, or by searching existing data. Although it has the authorit to do so, RSPA does none of these things and thus has no complete record of the firms it regulates. When they discover that DOT cannot provide them with this important information, State and local governments often impose their own registration requirements or conduct their own inventories. New Jersey and Maryland have completed statewide inventories; Pennsylvania, California, and Denver require registration. These activities, when undertaken by individual States, are costly and time-consuming for both jurisdictions and industry.

To determine what alternative data resources exist at the Federal level, OTA examined current databases. Only one Federal multimodal database exists-the Commodit Transportation Survey, maintained by Bureau of the Census. For a summary of the surveys of data resources on commodit flow, see table 1-5. The nine regional divisions used in the national databases are shown in figure 1-4. Highlights of the commodit flow analysis performed by OTA contractors include the following:

- Truck transport accounted for more than 60 percent of all hazardous materials transport (ex- 
Table 1-5.-Commodity Flow Databases

\begin{tabular}{|c|c|c|c|c|c|c|c|}
\hline Databases & Kept by & Years & Modes & $\begin{array}{l}\text { Commodity } \\
\text { codes }\end{array}$ & $\begin{array}{l}\text { Conversion } \\
\text { table }\end{array}$ & Strengths & Weakness/drawbacks \\
\hline $\begin{array}{l}\text { Commodity Transportation } \\
\text { Survey (CTS) }\end{array}$ & $\begin{array}{l}\text { Bureau of the } \\
\text { Census }\end{array}$ & 1977 & All & 5-digit STCC & Yes & $\begin{array}{l}\text { - Multimodal } \\
\text { - Consistent selection procedure for all } \\
\text { sample data points for all modes } \\
\text { - Cross-checked against the census of } \\
\text { manufacturers }\end{array}$ & $\begin{array}{l}\text { Only 5-digit level of commodities } \\
\text { - No hazardous materials flags } \\
\text { Only shipments from manufacturing } \\
\text { sites to first destinations } \\
\text { Only "principal" mode is reported }\end{array}$ \\
\hline $\begin{array}{l}\text { Truck Inventory and Use } \\
\text { Survey }\end{array}$ & $\begin{array}{l}\text { Bureau of the } \\
\text { Census }\end{array}$ & 1977, 1982 & Highway & Simple classes & No & $\begin{array}{l}\text { - Covers all trucks used in the United } \\
\text { States } \\
\text { Contains hazardous materials-related } \\
\text { data items } \\
\text { Sample biased toward heavy trucks }\end{array}$ & $\begin{array}{l}\text { - No flow data } \\
\text { Only rudimentary commodity infor- } \\
\text { mation } \\
\text { Tractor database, not a trailer data- } \\
\text { base-reflects tractor use, not trailer } \\
\text { use }\end{array}$ \\
\hline Motor Carrier Census & $\begin{array}{l}\text { Bureau of Motor } \\
\text { Carrier Safety, } \\
\text { FHWA }\end{array}$ & $\begin{array}{l}\text { Most recent } \\
5 \text { years }\end{array}$ & Highway & Hazard classes & No & $\begin{array}{l}\text { Comprehensive listing of carriers and } \\
\text { truck fleet operators }\end{array}$ & $\begin{array}{l}\text { - No flow data } \\
\text { Mileage and fleet size data are } \\
\text { sparse }\end{array}$ \\
\hline $\begin{array}{l}\text { TRANSEARCH, FREIGHTSCAN, } \\
\text { etc. }\end{array}$ & Consulting firms & Varies & All & $\begin{array}{l}\text { Varies, up to } \\
\text { 7-digit for rail }\end{array}$ & Yes & $\begin{array}{l}\text { Cross-checked against other produc- } \\
\text { tion/consumption data } \\
\text { Melding of the best available for } \\
\text { each mode }\end{array}$ & $\begin{array}{l}\text {-Truck flows predominantly based } \\
\text { on the CTS data (see above) } \\
\text {. Not in the public domain }\end{array}$ \\
\hline National Motor Truck Database & Consulting firms & $\begin{array}{l}1977 \text { to } \\
\text { present }\end{array}$ & Highway & $\begin{array}{l}\text { Varies, up to } \\
\text { 7-digit STCC }\end{array}$ & $\begin{array}{l}\text { Yes, where } \\
\text { commodity code } \\
\text { is provided }\end{array}$ & $\begin{array}{l}\text { - Focuses on long-distance highway } \\
\text { flows } \\
\text { True flow data } \\
\text { - Describes the vehicle used to carry } \\
\text { the commodity }\end{array}$ & $\begin{array}{l}\text { Purposely excludes short-haul } \\
\text { truck movements, especially in the } \\
\text { Northeast } \\
\text { - Not in the public domain }\end{array}$ \\
\hline Waybill File & $\begin{array}{l}\text { Interstate } \\
\text { Commerce } \\
\text { Commission }\end{array}$ & $\begin{array}{l}\text { At least past } \\
12 \text { years }\end{array}$ & Rail, TOFC/COFC & 7-digit STCC & Yes & $\begin{array}{l}\text { Well-organized sample }(1 \% \text { of all } \\
\text { rail flows } \\
\text { Database is consistent enough to } \\
\text { allow trend analyses } \\
\text { Contains some routing information }\end{array}$ & $\begin{array}{l}\text { Not all hazardous material flows } \\
\text { use the special Hazardous } \\
\text { Materials STCC }\end{array}$ \\
\hline $\begin{array}{l}\text { Waterborne Commodity } \\
\text { Statistics }\end{array}$ & $\begin{array}{l}\text { Army Corps of } \\
\text { Engineers }\end{array}$ & $\begin{array}{l}\text { At least } 12 \\
\text { years }\end{array}$ & $\begin{array}{l}\text { Water, domestic } \\
\text { and international }\end{array}$ & $\begin{array}{l}\text { 4-digit WCSC } \\
\text { code }\end{array}$ & $\begin{array}{l}\text { Only to a limited } \\
\text { extent }\end{array}$ & $\begin{array}{l}\text { " } 100 \% " \text { sample of all vessel } \\
\text { movements } \\
\text {. Complete routing information }\end{array}$ & $\begin{array}{l}\text { Only } 163 \text { commodity codes in ail, } \\
\text { so level of detail is weak } \\
\text { - Conversion table has some incor- } \\
\text { rect cross-references }\end{array}$ \\
\hline TRAIN II & $\begin{array}{l}\text { Association of } \\
\text { American } \\
\text { Railroads }\end{array}$ & Current & Rail, TOFC/COFC & 7-digit STCC & Yes & $\begin{array}{l}\text { - "100\%" data on all movements for } \\
\text { participating railroads } \\
\text {. Routing information }\end{array}$ & $\begin{array}{l}\text { Not specifically designed to record } \\
\text { car movement histories } \\
\text { - Not in the public domain }\end{array}$ \\
\hline $\begin{array}{l}\text { Hazardous Waste Shipment } \\
\text { Data }\end{array}$ & States, for EPA & Varies & Primarily highway & $\begin{array}{l}\text { Either EPA codes } \\
\text { or OHMT }\end{array}$ & No & $\begin{array}{l}\text { - "100\%" sample of ail hazardous } \\
\text { waste shipments } \\
\text {. Actual flow data }\end{array}$ & $\begin{array}{l}\text { Many States do not computerize } \\
\text { the data } \\
\text { - No consistency to commodity code } \\
\text { usage } \\
\text { - No routing information }\end{array}$ \\
\hline \multicolumn{8}{|c|}{$\begin{array}{l}\text { ACRONYMS" EPA }=\text { U.S Environmental Protectlon Agency, FHWA }=\text { Federal Highway Administration;OHMT }=\text { Office of Hazardous Materials Transportation, Research and Special Programs Administration; STCC }=\text { Standard Transportation Commodity } \\
\text { Code; TOFC/COFC = trader on flatcar (piggyback)/contamer on flatcar, WCSC }=\text { Waterborne Commerce Statisitics Center (U S Army Corps of Engineers) }\end{array}$} \\
\hline
\end{tabular}


Figure 1-4.-Regions Used in This Analysis

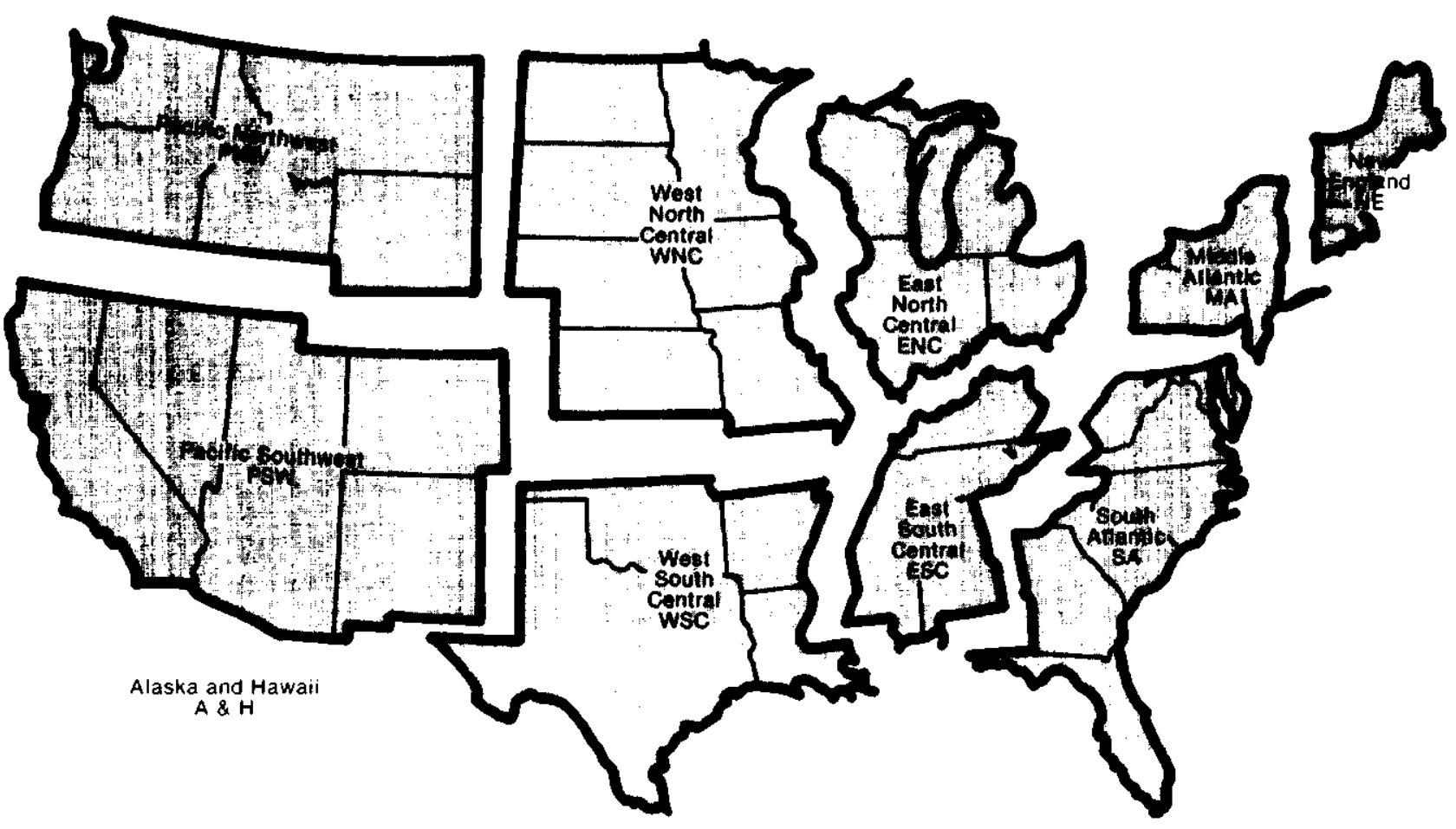

SOURCE: Office of Technology Assessment.

eluding pipeline) in 1982. Gasoline shipments accounted for almost half of the total truck tonnage.

- The average trip length for gasoline trucks was 28 miles, making them predominantly local and intrastate. The average trip length for trucks hauling chemicals was 260 miles, making these trips regional and more likely to be interstate.

- About 90 percent of truck shipments are intraregional, as are a high proportion of rail and water shipments.

- The three regions with the greatest concentration of shipments are West South Central, Middle-Atlantic, and South Atlantic (see figure 1-4), with North Central not far behind.

While these data are instructive in the aggregate, they give State and local planners only some of the information they want about their transportation networks.

OTA finds that Federal data-collection activities are numerous and diverse, each providing modal transportation data of varying completeness.
These activities provide useful information on regional flows of hazardous materials transportation, if carefully analyzed, and a sound basis for additional State or local commodity flow data collection. OTA experience in analyzing Federal databases for this report establishes that additional Federal data is unnecessary, that data integration is not a significant technical problem, and that comparative data on commodity flow can be developed.

City officials and planning personnel have been the most vocal in expressing to OTA a need for a national commodit flow data resource. Although an annual printed summar produced by DOT is most frequently mentioned as an appropriate format, some requests have been made for a real-time notification system for especiall hazardous shipments. However, emergency response officials consulted by OTA generall prefer to do local inventories and transportation surveys to ensure that their personnel are prepared for any eventuality. They point out that annual summaries describe only last 
year's shipments and that detailed real-time information would he overwhelming to track and useless for planning and preparedness. ${ }^{24} \mathrm{As}$ one fire chief said: "What am I supposed to do? Follow the truck around waiting for an accident to happen?" 25 On the other hand, a few local officials and planners want real-time tracking of hazardous materials shipments and have called for the development by DOT of a publicly accessible database to provide this information. ${ }^{26}$

A real-time data system is probably the only way to keep abreast of shipments. Many hazardous materials orders at-e for truck delivery within 36 hours or less, while other shipments are seasonal, related to agricultural or manufacturing cycles. Finally for economic reasons, customers may change supply sources overnight, rendering periodic data collection instantly obsolete. However, the technological groundwork for a system to track hazardous waste shipments, which represent less than 1 percent of hazardous materials shipments, in real time has been developed by a private firm, although the system has not been tested in operation. Even if the technical difficulties for implementing such a system for all hazardous materials could be resolved, the cost has been estimated to be more than $\$ 100$ million. ${ }^{27}$ Online telephone access to real-time information on all hazardous materials shipments is neither feasible nor cost-effective, OTA concludes.

OTA finds that although no current Federal resource can provide shipment information with the specificity desired by State and local jurisdictions, annual DOT summaries of aggregate regional shipments could provide useful regional and State commodity flow data. However, while development of a real-time database to track highly hazardous shipments only is technically feasible, its utility for emergency response is questionable. Finally,

\footnotetext{
${ }^{24}$ U.S. Congress, Office of Technology Assessment, Transportation of Hazardous Materials: State and Local Activities, op. cit., ch. 4.

${ }^{25}$ Thomas Hawkins, Jr., Chief, Arlington County Fire Department, Arlington, VA, personal communication, January 1986.

${ }^{2}$ The National League of Cities (NLC) has retained in its transportation positron paperarequest for a U.S. Department of Transportation report on commodity flow. Barbara Harsha, NLC transportation staff, personal communtcation, January 1986.

${ }^{27}$ John Mulholland, Soure Data Network, personal communication, November 1985.
}

OTA concludes that locally conducted data co1lection, such as hazardous materials facilities inventories and transportation surveys, is useful and has value beyond the data it produces. The process of gathering information provides data for planning and emergency response purposes and has the additional benefit of acquainting the concerned parties with each other and with the hazardous materials transportation in their areas. Some Federal financial assistance for State data collection is available through existing grant programs. Community right-to-know laws are useful took for State and local governments in obtaining data, and national right-to-know legislation would bolster implementation of such laws where industry resistance remains.

If Congress chooses to provide support for data gathering, several options are available. DOT could be required to exercise its authority under 49 CFR, Section 1805(b) and develop a registration program for hazardous materials shippers, transporters, and container manufacturers. OTA finds that a registration program would provide DOT with essen-

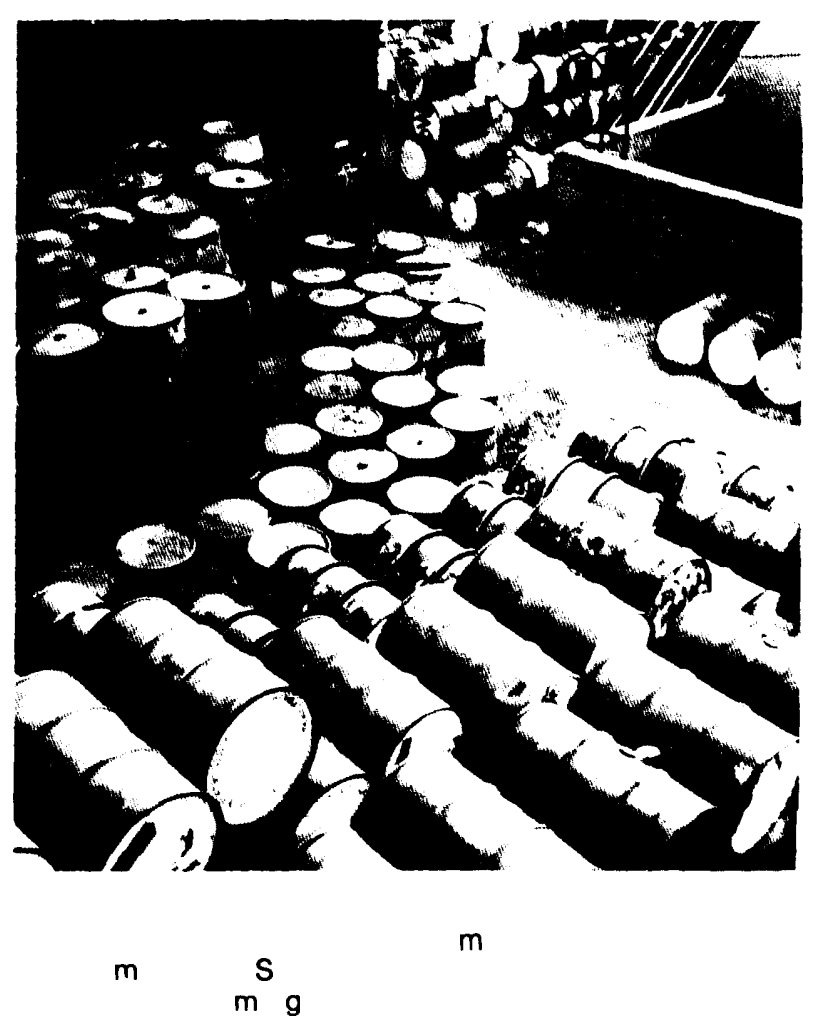


tial information about the community it regulates and with general commodity flow information that could be helpful to State and local jurisdictions. DOT needs the information such a program could provide to help set priorities for rulemaking, research, and enforcement actions. A modest registration fee could be imposed to cover costs of administering the program.

In addition, Congress could require DOT to integrate, analyze, and report annually on trends from relevant Federal databases kept by the modal administrations and the Bureau of the Census. For this effort to be effective:

- the collection of data on truck movements would need to be improved;

- cross-reference keys or bridge tables for the commodity codes used by different agencies and in 49 CFR would need to be created, or each agency might be required to use a common code for commodities; and

- sufficient funds would have to be allocated to support the effort. OTA estimates that the equivalent of one man-year of effort, between $\$ 75,000$ and $\$ 100,000$, would provide a modest start.

A summary of the commodity flow data developed in comparison to DOT accident data in the required annual report to Congress would be useful.

\section{Spill and Accident Data}

By law, RSPA must report to Congress annually on the safety of hazardous materials transportation, a requirement that, at a minimum, necessitates good records of hazardous materials accidents and spills. A complete safety analysis would also require some reliable estimates of the total amounts of hazardous materials shipped annually by each mode, but as pointed out above, that information is not available.

Hazardous materials incidents or releases,* defined as any unintentional release during" interstate transportation, loading, unloading, or temporary storage related to transportation, must be reported to

\footnotetext{
*Releases are referred $t$. as incidents in 49 CFR reporting regulations. The other release and accident databases studied by OTA all have different definitions of an incident. For the sake of clarity, all Research and Special Programs Administration incidents will be called releases in this report.
}

RSPA in writing within 15 days. The written reports serve as the basis for the HMIS, the sole DOT database specifically on releases, casualties, associated damages, and related information on the material, container, cause, and location of the release. All rail, highway, nonbulk water, and air releases occurring during interstate commerce are supposed to be reported on the RSPA Form 5800.1; intrastate highway and bulk marine transport are significant omissions.

Numerous modal hazardous materials release and accident reporting systems had been developed prior to 1971, when HMIS became the official recordkeeping system for release data. The Coast Guard, the National Highway Traffic Safety Administration, FRA, and BMCS, continue to require reports of modal accidents. Coast Guard reporting requirements are particularly extensive, and most water releases are reported to one or another of the Coast Guard systems rather than to RSPA. In addition, carriers are required to make an immediate telephone report to the National Response Center (NRC), staffed 24 hours a day by the Coast Guard, when a release has resulted in serious consequences, such as a fatality or property damage over $\$ 50,000$, as a direct result of the hazardous material. ${ }^{28} \mathrm{NRC}$ has two 24-hour toll-free telephone lines to receive notifications, and several other lines to relay calls to emergency response agencies. Carriers involved in a release sometimes telephone CHEMTREC, a chemical emergency center maintained by the Chemical Manufacturers Association. CHEMTREC is required to notify NRC of significant releases; however, a call to CHEMTREC does not fulfill the RSPA written reporting requirements. Despite this, the CHEMTREC toll-free telephone number is the only telephone number given in DOT's Emergency Response Guide book;* the NRC telephone number is not listed there.

Telephone reports received by NRC are logged every evening into a computer at the DOT-Transportation Systems Center (TSC), where the information is retained and managed by RSPA. Never-

\footnotetext{
${ }^{28} 49$ CFR, 171.15.

${ }^{*} \mathrm{Th}_{\mathrm{e}}$ Emergency Response Guidebook, developed and widely distributed free by the U.S. Department of Transportation (DOT), gives basic hazard and first response information for hazardous materials regulated by DOT.
} 
theless, RSPA does not include most water releases reported to $\mathrm{NRC}$ in its annual report.

Although release reporting is a regulatory requirement, OTA found evidence that the compliance rate is low. The incentive for reporting as required is to avoid the possibility of a civil or criminal penalty; these can include fines ranging up to $\$ 25,000$ and prison terms of up to 5 years. DOT policy requires consideration of the violator's ability to pay when penalties are assessed. When violators are penalized, the penalty level is frequently too low to deter future violations, because the costs of compliance are greater than those of potential penalties. Thus, some operators consider penalties to be an occasional cost of doing business.

To assess the completeness and accuracy of the HMIS, OTA contractors compared it with relevant Federal modal databases, NTSB data, and State data resources. All of these data resources are available to DOT, with many of them housed at TSC. Through careful analysis of reports filed with DOT modal agencies, OTA contractors were able to determine whether or not hazardous materials were involved in the reported accidents, although data for air shipments are poor. Corrected for duplications and incomplete reports, these comparisons showed that for air and marine transport, the number of releases is underrepresented in the HMIS by factors of 10 and 20, respectively. For rail and Interstate highway transport, the number of releases is underrepresented by factors of 3 and at least 2, respectively. Comparisons of damage estimates in the databases lead OTA to conclude that annual damages are at least 10 times the HMIS figures, averaging more than $\$ 160$ million a year.*

OTA finds that RSPA has an incomplete record of accidents and releases and has no documentable idea of how much hazardous material is transported. Moreover, RSPA officials regard data collection as a secondary function ${ }^{30}$ despite its

\footnotetext{
${ }^{24}$ National Conference of State Legislatures, Hazardous Materials Transportation: A Legislative Guide (Washington, DC: February 1984), p. 36.

*The Research and Special Programs Administration reports for 1976 through 1984 included 79,257 incidents resulting in $\$ 144,751,240$ in damage. OTA calculations adjust this to 178,683 incidents resulting in $\$ 1.47$ billion in damage for the 9-year period.

${ }^{30}$ Sherwood Chu, Deputy' Director, Office of Hazardous Materials Transportation, Research and Special Programs Administration, U.S. Department of Transportation, personal communication, March 1986.
}

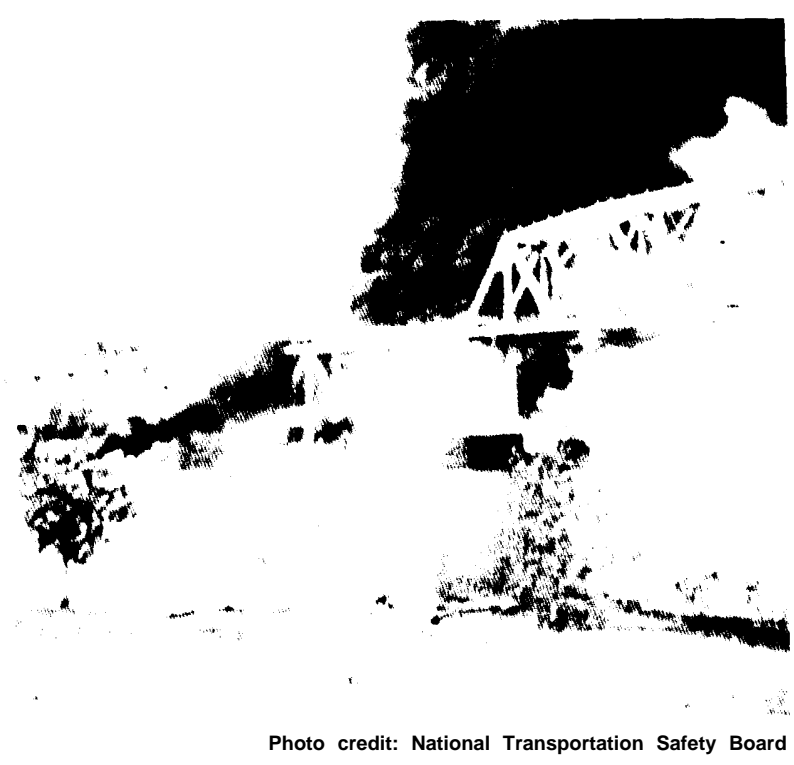

Under DOT reporting requirements, releases occurring during bulk marine transport of hazardous materials are not included in the HMIS.

importance to risk, hazard, and regulatory analysis and to planning for technological and industrial changes. The HMIS is currently an inadequate database. It misses numerous releases recorded in other Federal databases because releases occurring during intrastate highway and bulk marine transportation need not be reported, the reporting requirement is not enforced, and no effort is made to gather accident data other than that reported on Form 5800.1. Augmenting and improving HMIS need not be extremely costly.

OTA analyses of flow and accident data indicate that relatively few of the HMIS data can be used as indicators, and that a major accident in any single year or on any mode can skew the data significantly. However, when combined, current Federal accident and release databases provide more comprehensive information on the dimensions of hazardous materials transportation safety problems. Data results from HMIS that appear to be reliable and are corroborated by other sources include the following:

- the majority of the releases occurred on the highway mode, and most occurred during loading and unloading, rather than over the road; . corrosive substances have the highest accidental release rate; 
- gasoline truck accidents and releases are the most numerous and cause the greatest dollar damage; and

- human error, including speeding and other basic traffic violations, is the leading cause of releases and accidents.

Since trucks carry more hazardous tonnage annually than all other modes together, and there are many more trucks than other vehicles or vessels, the preponderance of truck-related releases is not surprising. A California study, being conducted for the State legislature, compared three separate databases and determined that at least 500 releases occur annually on the State highway system alone, excluding the city streets. Furthermore, the study showed that driver-related factors were the most significant contributory causes in over 50 percent of the accidents. ${ }^{31}$ These results imply that addressing issues such as driver qualifications, training, and performance is essential for safety improvements.

In addition, the data show that reported accidents involving hazardous materials more frequently involve common carriers than private carriers and that they occur more often in Pennsylvania, Ohio, Illinois, and California than in other States. Memphis has the highest release rate for the air mode, reflecting the fact that it is a major air freight hub.

The intent of the HMTA clearly indicates the need for an adequate annual summary of the safety of hazardous materials transportation, making improvement to the HMIS an urgent issue. Congress could require DOT to extend accident reporting requirements to all hazardous materials spills over a certain threshold whether they occur during interstate or intrastate transport and regardless of mode. Furthermore, a coordinated national spill reporting center, with reporting procedures and common data report fields that must be implemented by all Federal agencies, could be designated. The DOT National Response Center or the HMIS staff at RSPA provide natural homes for this coordinating role. Moreover, if formats including common data fields were decided on, accident reports collected at the State level could be submitted periodicall to the regional DOT or EPA office. The regional Federal offices could provide an-

"Linda Turnquist, Analyst, California Transportation (CALTRANS), personal communication, March 1986. nual updates to the national center. Several regional EPA offices already work with the States in their regions and have good computerized reporting systems. Reporting requirements need to be more strictly enforced, and release reports should be crosschecked at the regional level for accuracy and completeness before being submitted to a national datacollection center.

DOT could be required to document, in its annual reports to Congress on the transportation of hazardous materials, accidents by State, container types, mode, and cause. Activities now underway at DOT to improve the RSPA spill report, Form 5800.1 , and to coordinate with modal administrations to develop common data fields that are less open to subjective interpretation, should make the form reflect more accurately the causes and details of the spill. Congress might wish to require display in the DOT Emergency Response Guidebook of the toll-free number for the national report center as the place to call for reporting accidents.

\section{Containers}

The Federal regulatory standards for containers used to ship hazardous materials are comprehensive, requiring that the packaging be adequate to prevent release of its contents during transportation. Indeed, standards for containers for highly radioactive materials are set to ensure the packages withstand severe accident conditions without a dangerous radioactive release. To determine the adequacy of the containers used for transportation, OTA studied the accident and release records for the containers, the modal characteristics affecting the choice of containers, and the regulations governing them. The examination included the unique container issues associated with the transportation of radioactive materials, including spent nuclear fuel, as well as packaging for more familiar hazardous materials such as chemicals, petroleum products, explosives, and poisons.

\section{Containers for Radioactive Materials, Especially Spent Nuclear Fuel}

About 2.8 million packages of radioactive materials are shipped annually, representing between 2 and 3 percent of the Nation's annual hazardous materials shipments. About two-thirds of these shipments are for medical purposes, with the balance 
for industrial and research activities and the nuclear fuel cycle.* ${ }^{32}$ About 7 percent of all shipments are classified as wastes, with the vast majority being lowlevel wastes. ${ }^{33}$

While the primary Federal regulatory responsibil$i_{y}$ for shipments of radioactive materials lies with DOT, NRC and DOE also have specific responsibilities. Under its authority, DOT has issued regulations covering all aspects of transporting radioactive materials, including the containers, the mechanical condition of the transportation vehicles, and the training of personnel, as well as the routing requirements, package labels, vehicle placards, and shipping papers.

Under a Memorandum of Understanding, NRC and DOT cooperate to regulate containers for radioactive materials. NRC, under its own legislative authority, is responsible for regulating, reviewing, and certifying the packaging and certain transportation operations for shipments of fissile and radioactive materials that must be packaged in very secure packages, called Type B containers, when such shipments involve NRC licensees. ${ }^{34}$

DOT sets regulations for all other packaging for radioactive materials in consultation with NRC. NRC approval of routes is required for shipments needing physical protection during transport to prevent theft or sabotage, but the routes chosen must be compatible with DOT regulations.

DOE has authority under DOT regulations (49 CFR 173.7) to approve the packaging and certain operational aspects of its research, defense, and contractor-related shipments of materials requiring Type B packages, although DOE is required to use standards and procedures equivalent to those of NRC. It is in the procedural areas and instances where DOE has chosen to exercise its authority

\footnotetext{
*Shipments associated with nuclear power account for one-twentyfifth of all packages of radioactive materials shipped annually.

${ }^{32}$ HaroldS. Javits, et al., Transport of Radioactive Material in the United States, SAND84-7174 (Albuquerque, NM: Sandia National Laboratories, April 1985).

${ }^{3}$ U.S. Environmental Protection Agency, "Sources, Amounts and Characteristics of Low-Level Radioactive Solid Wastes," Low-Level Radioactive Waste Management, EPA 520/3-79-(X)2 (Washington, DC: May 1979).

34"Transportation of Radioactive Materials: Memorandum of Understanding," Federal Register, vol. 44, No. 128, July 2, 1979. Among

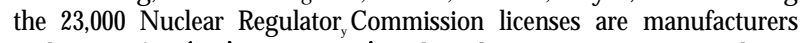
and users of radiopharmaceuticals, oil exploration companies, and nuclear utilities and their supply industries.
}

to use containers and procedures other than those certified by NRC that the greatest conflict between DOE and the States has arisen. For example, officials from New York and New Jerse y $_{\mathrm{y}}$ were outraged to learn in July 1985 that DOE had planned to use a cask that had not been certified by NRC for nuclear waste shipments from Brookhaven $\mathrm{Na}-$ tional Laboratories on Long Island.

Finally, DOD has separate authority for its radioactive shipments, similar to that of DOE. Three different Federal agencies thus can set standards for shipments of highly radioactive materials; two of them are shippers as well.

U.S. regulations for containers used for radioactive materials transportation are based on internationally accepted performance standards. International regulations and standards divide the materials to be shipped into three categories, based on their radioactivity levels:*

- low hazard or very low levels of radioactivit requiring "strong tight" containers,

- somewhat higher levels of radioactivit requiring secure containers called "Type A" packages, and

- fissile materials and those with very high levels of radioactivity requiring exceptionally durable containers called "Type B" packages.

Federal regulations limiting the radioactive contents for the commonly used strong tight and Type A containers are set on the assumption that the containers might break open in an accident and release some of the contents. In contrast, Type B packages are required to be sufficiently strong to withstand severe accident conditions, thus providing for safet $_{\mathrm{y}}$ largely independent of procedural and other controls on the shipment. To assure that Type B packages are adequately designed, constructed, handled, and loaded to protect public health and safety, NRC must approve and certify container designs and make certain that quality assurance procedures are implemented for their manufacture, operation, and maintenance. A summary of radioactive materials and packaging types appears in box $1 \mathrm{~A}$.

While Type B packages are the first and most important device for public protection, additional reg-

\footnotetext{
*International Atomic Energy Agency, Safety Series 6, 1985, now contains a fourth category called "surface contaminated object" which is under consideration to become a U.S. category.
} 


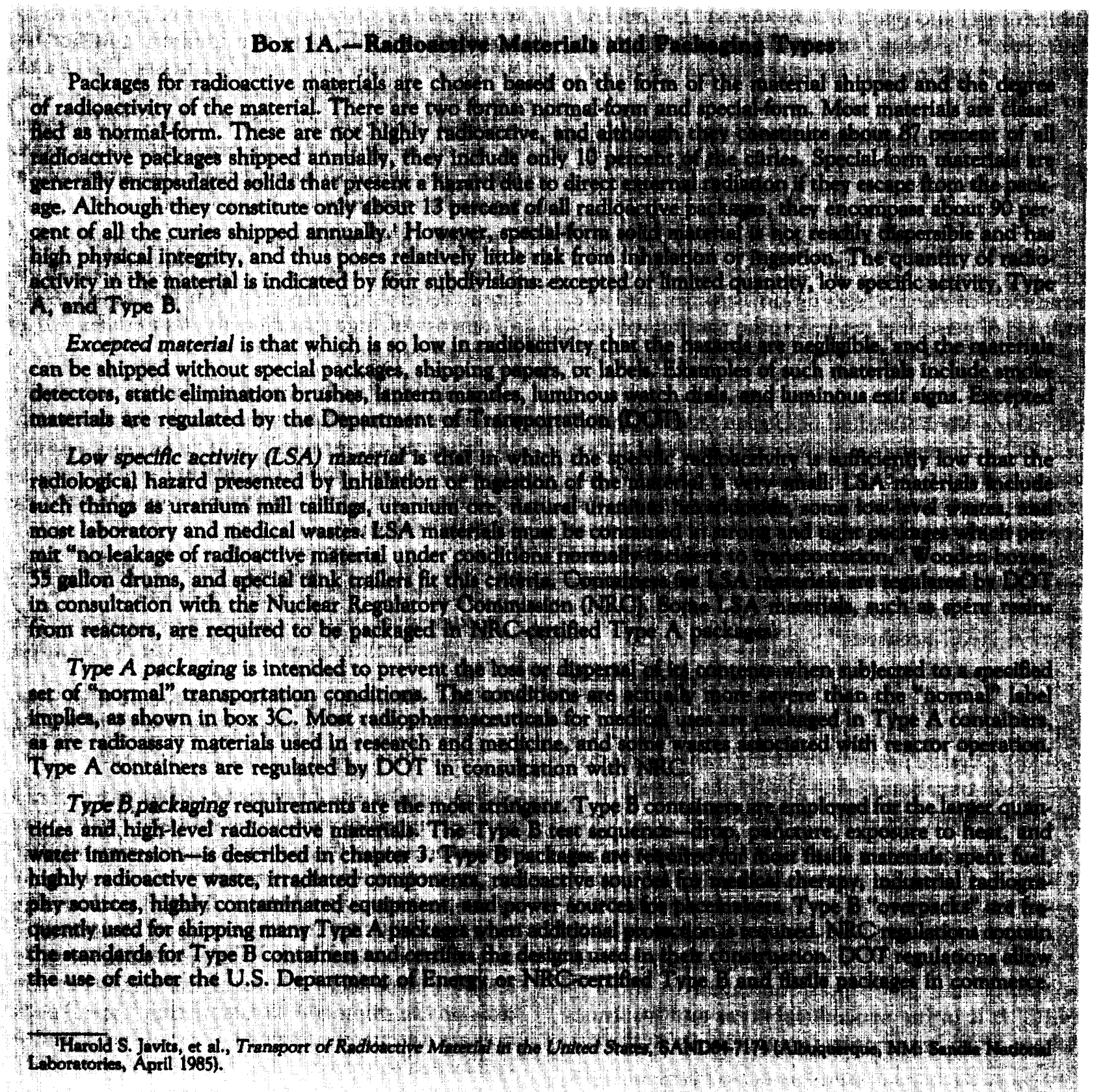

ulations and requirements for transportation o $\Phi$ f $\mathrm{NRC}$ inspection and monitoring depends on the spent fuel have been developed. NRC monitors thespectors' judgment and confidence in the shipper's quality assurance programs of its licensees and quatity assurance programs, training procedures and quires operational checks, such as leak tests, for thbłoughness in following procedures. ${ }^{35} \mathrm{NRC}$ also containers prior to each use. NRC checks for com-

pliance with regulations at its licensees' facilities, ${ }^{35} \mathrm{C} . \mathrm{dMac}$ Donald in U.S. Congress, Office of Technology Assessits inspectors are on hand to monitor the beginnent, "Transcript of Proceedings-OTA Worksho on Nuclear Maof any spent fuel shipping campaign. The stringepritid2. 
conducts routine transportation checks for compliance with regulations, and in the period from July 1983 to June 1985, inspected more than 300 shipments of spent fuel. ${ }^{36}$ As an added precaution, some States through which spent fuel shipments pass require inspection of shipments by State personnel as well.

NRC also requires that the governors of affected States be notified in advance of commercial shipments of spent fuel and certain other highly radioactive materials. The information must include the shipper's name, a description of the material, and estimates of times of arrival at State boundaries. DOE notification procedures are much less explicit, and friction with many States has resulted from this departure from NRC procedures. Moreover, certain shipments that involve national security are exempt from the prenotification requirement.

Both DOT and NRC have the authority to impose fines for violations of regulations. However, the efficacy of the enforcement efforts of both agencies has been the subject of severe criticism. The level of NRC inspection is less a concern than the reliance placed on the judgment of individual inspectors and shipping company personnel. The process provides few outside checks ${ }^{37}$ a situation which under adverse circumstances could have potentially disastrous consequences. ${ }^{38}$ Quality control during cask construction, maintenance, and operational checking, and vehicle operations during loading, transportation, and unloading requires vigorous, constant scrutiny to minimize risk and chances of an accident due to human error.

Because shipments of spent fuel, which are made by both rail and trucks, are of special public concern, Congress expressed particular interest in the adequacy of the regulatory standards that must be met by Type B containers. OTA analyzed these standards and shipping procedures in detail. Such shipments represent less than 0.001 percent of the total number of annual hazardous materials ship-

\footnotetext{
${ }^{36}$ Alfred Grella, Office of Inspection and Enforcement, U.S.Nuclear Regulatory Commission, "NRC Inspection Activities on Recent Shipments of Spent Fuel 1983 to Present, " unpublished typescript of speech presented at the Spent Nuclear Fuel Transportation Seminar, Chicago, IL, Aug. 1, 1985.

Union of Concerned Scientists, Safety Second: A Critical Evaluation of the NRC's First Decade (Washington, DC: February 1985), ch. 4 , especially.

${ }^{38}$ Ibid., p. 155
}

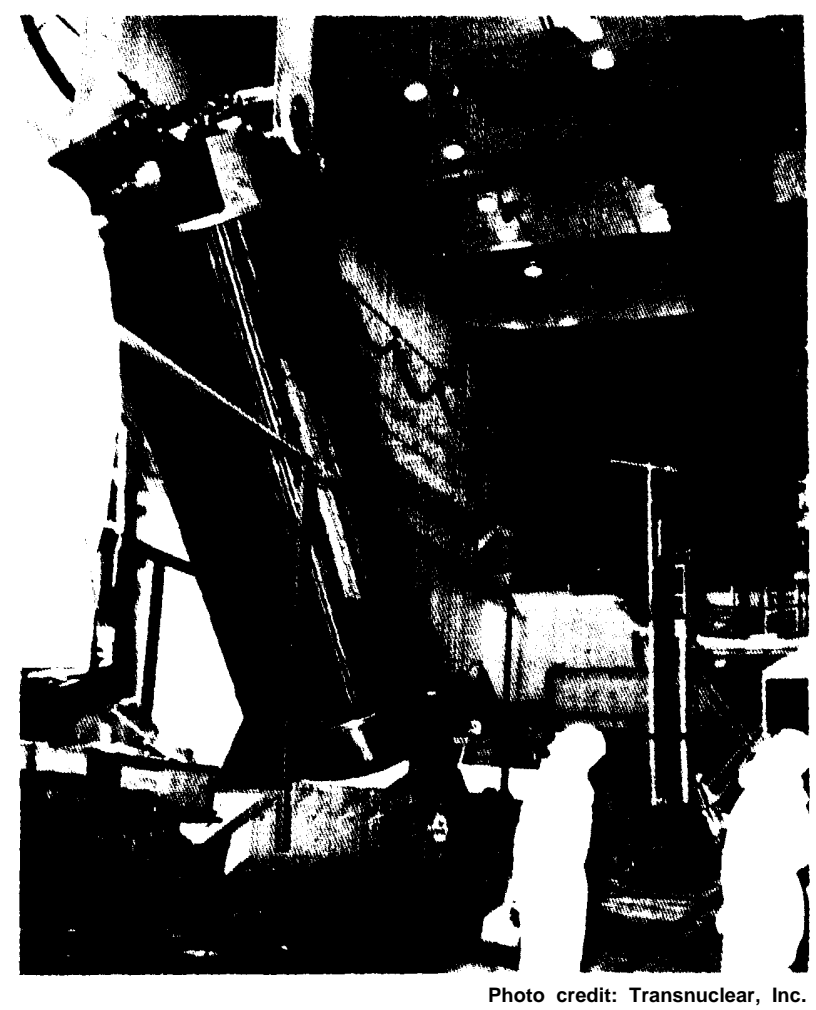

Personnel oversee the loading of the TN8 spent fuel cask, with a capacity of three fuel assemblies, onto a truck bed.

ments, and the probability of an accident involving spent fuel is very low, The potential consequences must be based on technical estimates since no actuarial record exists for such an accident. Currently, somewhere between 100 and 300 shipments of spent fuel occur annually, as utilities shift stored spent fuel from filled cooling pools at one site to other storage pools, or as industry and DOE or DOD move fuel either for storage or research.

\section{Type B Containers for Spent Fuel}

The basic criteria for Type B packages, established in 1946 based on recommendations by the National Academy of Sciences, have been adopted by the International Atomic Energy Agenc ${ }_{y}$ and 53 nations. Current NRC regulations provide a set of performance criteria for the packages, rather than specific design requirements. These remove the need to predict specific accident circumstances and provide a set of engineering test specifications for impact, puncture, temperature, immersion, and leak tight- 
ness that encompass the types of conditions that could occur in an accident.

The most widely recognized Type B containers are the casks for transporting highly radioactive, spent nuclear fuel. Current casks are 10 to over 20 feet long and are constructed of two concentric, welded, stainless steel shells, each typically 1 to 2 inches thick, enclosing a gamma radiation shield of lead or depleted uranium metal and water or other hydrogenous material as a neutron radiation shield. These casks were designed to contain and ship spent fuel that had been removed from the reactor 4 to 5 months previously and that was still relatively radioactive. Potential technical improvements to the casks are examined as a normal part of international research and development and have been a focus of DOE- and NRC-funded research over the years.

The NRC cask certification process is, of necessity, painstaking and time-consuming. The proven safety record of NRC-certified casks, however, provides a degree of public confidence in casks. OTA finds that technical evidence and cask performance in service indicate that NRC performance standards yield spent fuel shipping cask design specifications that provide for a very high level of public protection-much greater than that afforded in any other current hazardous materials shipping activity. However, meticulous adherence to the designs and specified procedures during cask manufacture and to required safety procedures during loading and transport are critical factors in ensuring public and environmental safety. Transportation accidents involving shipments of spent fuel will inevitably occur. However, OTA concludes that the probabilit ${ }_{\mathrm{y}}$ of an accident severe enough to cause extensive damage to public health and the environment caused by a radiological release from a properly constructed cask is extremely remote. OTA further finds that fruitful areas for improvements in the overall safety of spent fuel transportation are to be found in the institutional, procedural, and operational controls and arrangements, such as quality assurance and quality control measures; maintenance activities; operator, handler, and driver training; and inspection. ${ }^{39}$

\footnotetext{
${ }^{30}$ This aspect was a persistent theme in both the OTA workshop and advisory panel meetings; see for example Richard Cunningham, Nuclear Regulatory Commission, in U.S. Congress, Office of Technology Assessment, "Transcript of Proceedings-Transportation of Hazardous Materials Panel," unpublished typescript, June 27, 1985, p. 230.
}

Finally, OTA finds that continued research is needed in certain technical areas to determine where safety improvements could be effective. Such research needs include: the interface between the carrying vehicle and the casks, such as tiedowns and fasteners; additional and ongoing evaluation of real accident stresses as compared to those specified by the current regulations; and methods of extending accident modeling capabilities to encompass accidents more severe than those currently incorporated in the models.

\section{Future Spent Fuel Shipments Under the Nuclear Waste Policy Act}

Under the provisions of the Nuclear Waste Policy Act (NWPA) of 1982, DOE will take title to spent fuel from commercial utilities and be responsible for its movement, storage, and disposal, starting in 1998. DOE has established the Office of Civilian Radioactive Waste Management to plan and prepare for these activities.

As there will be some 90,000 spent fuel assemblies in U.S. spent fuel pools by that time ${ }^{40} \mathrm{DOE}$ may be responsible immediately for a number of shipments to a repository or monitored retrievable storage facility. Depending on the type and carrying capacity of the casks ultimately constructed and certified for these shipments, DOE estimates that approximately 250 rail and 725 truck shipments will be required annually to move spent fuel from reactors in the eastern half of the country to a monitored retrievable storage facility or repository .41 For NWPA shipments, DOE has agreed to meet DOT and NRC safety and security requirements in effect at the time and will use only transportation casks that have received an NRC certificate of compliance. $^{42}$

${ }^{40}$ George Russ, Atomic Industrial Forum, Bethesda, MD, personal communication, 1985. See also U.S. Congress, Office of Technology Assessment, Managing the Nation's Commercial High-Level Radioactive Waste, OTA-O-171 (Washington, DC: U.S. Government Printing Office, March 1985), p. 28.

${ }^{4}$ U.S. Department of Energy, "Environmental Assessment for a Monitored Retrievable Storage Facility," Monitored Retrievable Storage Submission to Congress, vol. 2, RW0035, review copy, unpublished manuscript, p. 2.23 .

${ }^{42}$ U.S. Department of Energy, Office of Civilian Radioactive Waste Management, Office of Storage and Transportation Systems, "Transportation Institutional Plan," unpublished internal review draft manuscript, Mar. 3, 1986, pp. 3 and D-57. 
A new generation of casks is being designed and tested and will be employed to move spent fuel to a national repository under NWPA. Although they must meet the same performance standards as current casks, the new casks are likely to have somewhat different physical characteristics from those of the current casks, because they will be designed to hold older, less radioactive spent fuel. It is thus likely that the next generation of casks will carry the maximum possible number of spent fuel elements within weight and safet limits, to reduce the number of shipments necessary. Innovations in materials and design have yielded nodular cast iron and monolithic steel casks now used in Europe. Some of these designs have been submitted to NRC for certification and are undergoing testing.

DOE is also examining the possibility of employing very large capacity dual-use casks; these offer an opportunity to minimize both the number of shipments and the handling of the spent fuel. Once the fuel has been removed from the reactor and placed in dry, onsite storage in these dual-use casks, the handlin ${ }_{g}$ and worker-exposure risk would be reduced if the same casks could be used to transport the spent fuel to a repository. However, the NRCspecified test conditions for casks used for transportation are more stringent than those for storage casks, and although NRC has pending applications for certification of two such casks, none has yet been certified for both purposes.

Moreover, questions will need to be answered about the effects of lengthy onsite storage on the casks' integrity during transportation and on the effects of the large, heavy casks on the stability of the carrying vehicles, whether truck or railcar. The weight would not be a concern if barge transportation were used, but the increased turnaround time required for reusable casks by slower barge travel is an economic trade-off that must be considered.

OTA concludes that once the new casks for NWPA shipments have been developed, and have met NRC certification requirements, full-scale demonstration tests could assist in gaining a level

\footnotetext{
${ }^{4}$ U.S. Department of Energy, Office of Civilian Radioactive Waste Management, Annual Report to Congress, DOE /RW-0004/2(WashIngton, DC: March 1986), p. 23.
}

of public confidence. So that their concerns are addressed, organizations and individuals critical of the current transportation procedures should be included in planning for a test. An extensive public information program would be important prior to the test to help affected Indian tribes, public officials, citizens, and safety and emergency personnel understand, to the degree possible, the technical background for the test.

However, considering the technical complexities of the issues, it is wise to be realistic about the extent to which a full-scale cask accident demonstration would increase public understanding. A wellplanned, constructed, and staged full-scale demonstration could prove persuasive to many, but no accident demonstration can show all the possible events for all conceivable accidents. ${ }^{44}$

Currently, relations between and among Federal agencies, the nuclear container industry, the nuclear power industry, and State and local governments are strained, as the country struggles to come to grips with the need to dispose of nuclear wastes in a safe manner. The level of public apprehension about shipments of spent fuel requires carefully coordinated programs to address public concerns. Sensitivity to public concerns and programmatic coordination have heretofore not been outstanding at DOE, which will be responsible for NWPA shipments. The technical specifications for the shipping casks are difficult to explain and comprehend, and the stringency of the standards for ensuring spent fuel cask integrity is easily misunderstood. Industry and government will do well to address such apprehensions in a forthright manner. In the meantime, Congress might wish to require DOE to reduce one area of public concern by agreeing to begin using NRC-approved casks and notification procedures immediately for its unclassified shipments. OTA finds that the parts of the nuclear waste transportation process most in need of change are the institutional attitudes of DOE and NRC and their interactions with the State and local governments and the general public. Comprehensive public information efforts are necessary to address concerns about the level of safety provided by Fed-

\footnotetext{
${ }^{44}$ U.S. Congress, Office of Technology Assessment, "Transcript of Proceedings-OTA Workshop on Nuclear Materials Packaging Technology," op. cit., p. 81.
} 
eral regulations and cask specifications. Public participation, outreach, and information activities undertaken by the utilities that ship spent fuel regularly provide useful models for programs that DOE, as a future shipper, could develop.

State, local, and Indian tribal officials want to be full partners with the Federal Government in the NWPA transportation planning and decisionmaking process. In November 1985, DOE sponsored a workshop for State, tribal, and local officials to determine the extent and specific nature of their concerns about DOE's plans for shipments of spent fuel under NWPA. Such activities provide a forum for airing and moving toward resolution of conflicts. OTA concludes that additional meetings, sponsored jointly by DOT, NRC, and DOE, in cooperation with public interest groups, such as the National Governors' Conference, the National Conference of State Legislatures, the International Conference of Mayors, and the National League of Cities, are essential to informing the public and improving intergovernmental coordination.

\section{Containers for Hazardous Materials}

The packaging or containers used for shipping hazardous materials include tank trucks, railroad tank cars, and barges, as well as bottles, boxes, and drums. They are important factors in transportation safety. RSPA is responsible for issuing packaging and hazard communication regulations for all hazardous materials containers except bulk marine containers, which are regulated by the U.S. Coast Guard, and packaging for highly radioactive materials, for which regulations are developed by NRC.

DOT regulations apply to hazardous materials containers of all sizes, with requirements generally different, depending on whether the material is shipped in bulk or in small packages. DOT marks the dividing line between small (nonbulk) and bulk containers at 110 gallons or 1,000 pounds. Small packages of hazardous materials are carried by water, rail, highway, and air in approved packaging including drums, cylinders, boxes, cans, and bags. Bulk packages generally do not travel by air.

OTA's research shows that hazardous materials packaging generally has been adequatel designed. Although there are some problem areas, industry often uses containers more sturdy than required by DOT regulations for very high-hazard materials.

\section{Bulk Packaging}

Because accidents and releases in any mode have a common source-human error-the safety records for bulk transport $b_{y}$ the highway, water, and rail modes differ, according to the opportunities for error in each mode. Thus, more accidents, spills, injuries, deaths, and property damage occur on highways than on rail or water, in both absolute numbers and accidents per ton-mile traveled, ${ }^{45}$ and more occur on rail than on water on a ton-mile basis, due to modal differences in the miles of network, number of operators and individual shipments, traffic densities, and average speed.

Other factors affecting safety include: the extent of coverage by and enforcement of Federal safety regulations for the vessel or vehicle; the amount and quality of training the vessel or vehicle operators and loaders receive; the frequency of maintenance and inspections of the vessel or vehicle; and finally, the coordination between the agencies responsible for regulation, inspection, and enforcement activities. Table 1-6 presents a comparison of modal characteristics for bulk shipping of hazardous materials.

Bulk equipment has a useful life of 20 to 30 years, although maintaining bulk vessels, tank cars, and trucks to high standards can become expensive after the first decade. Because of this long life span, there is little incentive for industry innovation. Changes to the regulations take years to implement, both because the industries involved are economically hard pressed and do not welcome potentially costly changeovers, and because at least two DOT agencies are involved in the decisionmaking process. In times of economic turmoil, such as the transportation industries are now undergoing, fleets may age and deteriorate.

Of the three modes of bulk hazardous materials transport, the highway mode is the most versatile and widely used, carrying over 55 percent of the an-

\footnotetext{
${ }^{45} \mathrm{~A}$ ton-mile is the product of the tons of material carried and the distance carried in miles. For example, a truck with a load of 20 tons that traveled 100 miles would have logged 2,000 ton-miles. Ten trucks each carrying 2 tons and each traveling 100 miles would also have logged 2,000 ton-miles in the aggregate (each truck logging 200 ton-miles).
} 
Table 1-6.-Modal Characteristics of Bulk Shipping of Hazardous Materials

\begin{tabular}{|c|c|c|c|}
\hline & Highway & Rail & Water \\
\hline Containers regulated by $\mathrm{DOT}^{\mathrm{a}}$ & Most & All & All \\
\hline Inspection or testing frequency & Upon manufacture & $\begin{array}{l}\text { Upon manufacture } \\
\text { plus every } 5-10 \\
\text { years }^{\circ}\end{array}$ & Yearly $^{d}$ \\
\hline Commodity flow data ${ }^{\circ}$ & Very little & Nearly complete & Complete \\
\hline Regulators and inspectors* & $\begin{array}{l}\text { RSPA, BMCS, } \\
\text { NHTSA }^{+}\end{array}$ & FRA, RSPA, AAR $U$ & USCG, RSPA \\
\hline Fleet size & $\begin{array}{l}130,000 \text { cargo } \\
\text { tanks' }\end{array}$ & 115,600 tank cars & $\begin{array}{l}4,909 \text { tank } \\
\text { barges }^{k}\end{array}$ \\
\hline Fleet database' & Partial (BMCS) & $\begin{array}{l}\text { Yes, complete } \\
\text { (AAR) }\end{array}$ & $\begin{array}{l}\text { Yes, complete } \\
\text { (ACofE) }\end{array}$ \\
\hline Number of operators & 260,000 & 26,000 & 45,000 \\
\hline Size of load (gals) & $4,000-12,000$ & $10,000-30,000$ & $\begin{array}{l}300,000- \\
600,000\end{array}$ \\
\hline
\end{tabular}

Sac table 1-4 for numbers of inspectors.

a Federal regulations cover the transportation of hazardous materials by rallcar, aircraft, vessel, and interstate transportation by motor vehicle. Intrastate highway transport of hazardous wastes, hazardous substances, and flammable cryogenics in portable tanks or cargo tanks is also covered (49 CFR 171.1). Unless a State has specifically brought intrastate commerce under regulation, containers in such service need not meet any standards. The Department of Transportation does not know the precise extent to which the States have extended the Federal regulations to intrastate commerce. Most gasoline transport by truck is intrastate and these shipments are a large percentage of the total hazardous materials shipments.

bargo tanks must undergo an external visual examination every 2 years but generally do not have to be leak tested or pres. sure tested. However, cargo tanks carrying chlorine must be pressure teeted every 2 years and tanks carrying compressed gas (e.g., liquefied petroleum gas) must be pressure tested every 5 yeara; cargo tanks for flammable cryogenics are inspected prior to each loading. Most tanks, however, are not ieak or pressure tested after they are built unless they have been out of service for a year or more, had repairs or modifications performed on them, are operating under an exemption to the regulations, or are used in an area of nonattainment of Clean Air Act standards for ozone. (49 CFR 177.624.)

cTank cars carrying some cargoes are tested more frequently. For example, tank cars carrying chlorine must be tested every

2 years. Also, the frequency of inspection of some tank cars increases to once per year after they are 22 years old. General American Transportation Corp., GATX Tank Car Manual, 4th Edition (Chicago, IL: 1979).

OData on the identity and amount of hazardous materials shipped over the highways is collected by the Bureau of the Census every 6 to 7 years, however the quality and comprehensiveness of the data is poor. Records of 60 percent of all rail traffic are kept by the Association of American Railroads (AAR). A record of 1 to 6 percent of all rail traffic is kept by the Interstate Commerce Commission. Records of all origins and destinations of hazardous material cargo that travel on U.S. waterways fro kept by the U.S. Army Corp of Engineers (ACofE) of Motor Carrier Safety (BMCS) regulates in-use motor vehicles and drivers, and enforces regulations pertaining to tha manufac. ture, marking, repair, etc., of cargo tanks. The National Highway Traffic Safety Administration (NHTSA) has responsibility for the original manufacture of the vehicle. ment, RSPA adopts the final specifications in the regulations. Both AAR and the Federal Railroad Administration (FRA) inspect tank cars in rail service. Both AAR and FRA inspect tank manufacturers. the inspections, administers licenses, and specifies the design of vessels. RSPA sets the standards for intermodal portable

tanke that can be carried on container ships and barges.
iEstimates from the 1977 Truck Inventory and Use Survey. Of these, 36,000 carry hazardous materials 25 to 49 Percent of the time 14,000 carry them 50 to 74 percent of the time, and 67,000 carry them 75 to 100 percent of the time.

Written communication with AAR. This is about 6opercent of the folal number of tank cars.

$\mathrm{kA}_{\text {mer }} \mathrm{i}_{\mathrm{can}}$ Waterways Operators. This is the number of inland tank barges, most of which carry hazardous materials. There are also a small number of ocean going barges and tankers that carry hazardous materials, but tank barges are responsible for most inland traffic.

'While the Army Corp of Engineers (ACofE) keeps track of the number of active and inactive vessels that may carry hazardous materials in U.S. commerce, and the AAR'e UMLER file lists all tank cars by DOT specification that are in service, there is no comparable database for the highway mode. Although Individual companies know how many and what types of cargo tanks or intermodal portable tanks they have, no single agency has an accounting of all bulk highway vehicles nationwide.

or intermodal portable tanks they have, no single agency has an accounting of all bulk highway vehicles nationwide.
m"Operator" refers to the venicle or vessel "driver." The number of people driving cargo tanks (carving hazardous materials) is estimated by assuming there are two drivers per cargo tank. Large Interstate private carriers often have three or more drivers per vehicle, while other carriers typically have fewer. Information on the rail mode was obtained from AAR and on the water mode from USCG. The number presented in the water mode represents all those licensed by USCG to operate commercial vessels; most of these would not routinely be involved with hazardous materials.

SOURCES: Unless otherwise indicated in footnotes, Office of Technology Assessment, based on information from participants of workshope and panel meetings or comments on draft reports. 


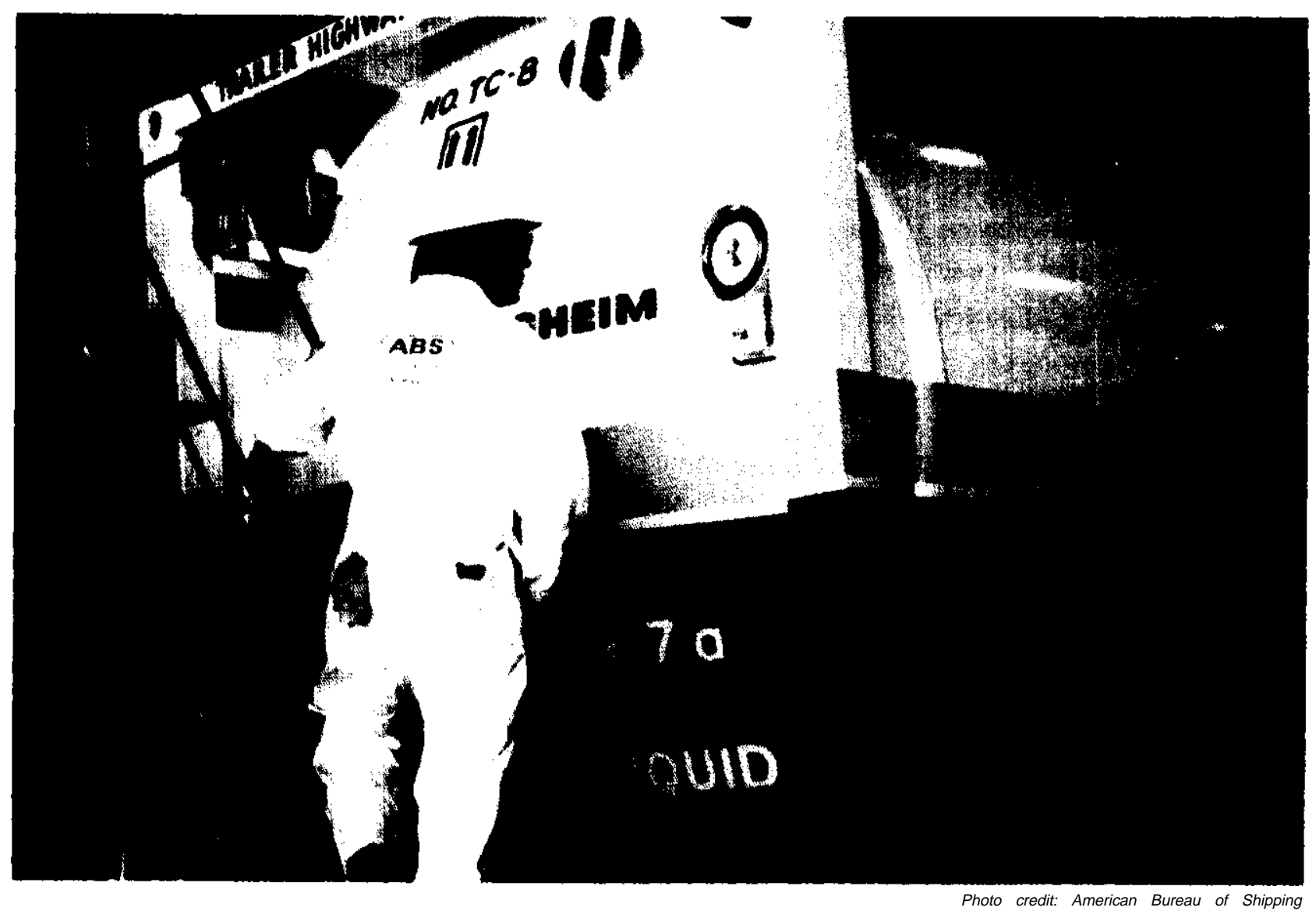

Inspections of vehicles and vessels can be performed by approval agencies recognized by DOT; the American Bureau of Shipping, Lloyds of London, and Bureau Veritas are among the largest of these.

nual total hazardous materials tonnage. (See table 1-1.) The nature of the bulk trucking business is different from that of the rail or water modes of bulk transport in that there are many more carriers of a wider variety, and many businesses are much smaller than those typicall found in the rail or water mode. The carriers include private interstate carriers; large interstate common and contract carriers; and small common, contract, and private intrastate carriers. *

*private carrierstransport commodities that they own, and the transport is integral to their business. Common carriers are transporters of freight for compensation; common carriers must accept all traffic tendered to them that is within their operating authority (to the extent that they have equipment and drivers to do so). Contract carriers are transporters of freight by motor vehicle for compensation in the exclusive service to one or more specific shipper(s) as authorized by duly constituted Federal or State authority. This classification includes owner-operators under long-term lease to certified carriers.
Tank trucks (or cargo tanks) are the main highway carriers of bulk hazardous materials. Usually made of steel or aluminum alloy, tank truck capacities range from about 2,000 to 9,000 gallons depending on the density, vapor pressure, and corrosiveness of the cargo. In some States, however, which allow higher gross weights, tank trucks may carry up to 13,000 gallons, sometimes in double tanks. Table 1-7 lists the main contemporary cargo tanks built to DOT specifications and examples of commodities each of them may carry. Older tank trucks built to outdated specifications may still be used to carry hazardous materials, but all newly constructed tank trucks must meet current specifications. These prescribe the thicknesses of the bodies of the tanks, pressure relief devices, manhole covers, gauging devices, overturn protection, pressure test methods, and the like. 
Table 1-7.-Cargo Tank Table

\begin{tabular}{|c|c|c|}
\hline $\begin{array}{l}\text { Cargo tank } \\
\text { specification } \\
\text { number }\end{array}$ & $\begin{array}{l}\text { Types of commodities } \\
\text { carried }\end{array}$ & Examples \\
\hline MC306 . . . & $\begin{array}{l}\text { Combustible and flam- } \\
\text { mable liquids of low } \\
\text { vapor pressure }\end{array}$ & $\overline{\text { Fuel } 011, \text { gasoline }}$ \\
\hline MC307 & $\begin{array}{l}\text { Flammable liquids, } \\
\text { poison B materials } \\
\text { with moderate vapor } \\
\text { pressures }\end{array}$ & $\begin{array}{l}\text { Toluene } \\
\text { diisocyanate }\end{array}$ \\
\hline MC312 & Corrosives & $\begin{array}{l}\text { Hydrochloric acid, } \\
\text { caustic soda } \\
\text { solution }\end{array}$ \\
\hline MC331 ..... & $\begin{array}{l}\text { Liquefied compressed } \\
\text { gases }\end{array}$ & $\begin{array}{l}\text { Chlorine, anhy- } \\
\text { drous ammonia, } \\
\text { LPG }\end{array}$ \\
\hline MC338 . . . . & $\begin{array}{l}\text { Refrigerated liquefied } \\
\text { gases }\end{array}$ & $\begin{array}{l}\text { Refrigerated } \\
\text { liquid, oxygen, } \\
\text { refrigerated liquid, } \\
\text { methane }\end{array}$ \\
\hline
\end{tabular}

Turnover of equipment is slow, and cargo tanks generally go through several tiers of owners. Large private interstate carriers, often large petrochemical companies, have the resources to purchase new equipment and maintain it well, They use their trucks around the clock, 6 to 7 days a week and find it economical to retain tank trucks in their fleets for only 8 to 10 years. Maintenance costs to keep the vehicles up to their standards then become sufficiently high that they sell the trucks to a common carrier or to a jobber and buy new equipment. ${ }^{46}$ In contrast, the average tank truck in the fleet of one of the country's two largest common carriers is now 12 years old, because economic competition is so fierce that, unable to afford major expenditures, companies are keeping their equipment longer. A second tier owner uses a tanker until it becomes uneconomical and then sells it to yet another owner. This process continues despite the truck's inevitable deterioration, partly because Federal hazardous materials regulations do not generally apply to intrastate motor carrier transport. ${ }^{47}$

\footnotetext{
${ }^{+6}$ Clifford Harvison, National Tank Truck Carriers, and E.E. Eigenschenk, Shell Oil Co., personal communications, 1985.

${ }^{47}$ Hazardous wastes, hazardous substances, and flammable cryogen ics, and nuclear materials regulated by the Nuclear Regulatory Commission, are the only hazardous materials regulated bv the Federal Government regardless of whether the commerce is intrastate or interstate, see 49 U.S. C. 173.
}

OTA's analysis shows that cargo tank trucks transporting gasoline, about 49 percent of all hazardous materials transported by tank truck, are involved in accidents resulting in more deaths and damages than all other hazardous materials accidents combined. Trucks carrying chemicals represent about 20 percent of tank truck transport of hazardous materials. Of the chemicals, corrosive cargos have the highest accidental release rate per ton$\mathrm{mile}^{48}$ and exert the greatest wear and tear on tank trucks. In fact, one safety director told OTA that his acid tanks were ". . . junk after 4 years."

Problems with all varieties of cargo tanks have been studied by DOT over the past 10 years. Study results show that many of the releases from cargo tanks come from discharge valves, pressure relief valves, and manhole covers, and that poor maintenance and inspection of the tanks contribute to the problems. Many parts of a rulemaking proposed $b_{y}$ DOT in September 1985 address these shortcomings," OTA finds that adoption of the proposed changes calling for stringent and more specific manufacturing standards, annual leak testing of all cargo tanks, and stronger manhole covers on gasoline tankers, will improve the performance of cargo tanks. These actions, while not calling for significant redesign, nonetheless directly address many of the inadequacies uncovered in the DOT studies,

Moreover, if registration were required at the time of manufacture of each tank truck built to hazardous materials specifications, subsequent inspections could provide a means of identifying and tracking equipment design and maintenance problems. Release and accident data for the highway mode would be more useful if information regarding container type and primary commodity carried were acquired at the time of registration. Such records are currently kept for bulk marine vessels and railroad tank cars.

Since the early 1980s, when railcars carrying certain hazardous materials began to be equipped with shelf couplers, thermal insulation, and head shields, no catastrophic hazardous materials rail accident has

\footnotetext{
4h. Abkowitz and List, op. cit.

+4"Notice of Proposed Rulemaking, Requirements for Cargo Tanks," Federal Registet, U.S. Department of Transportation, Research and Special Programs Administration, Materials Transportation Bureau, Sept. 17, 1985.
} 
occurred, although there have been numerous accidents and releases. OTA's data analysis shows that corrosives have the highest accident and release rate for commodities carried by rail. Many corrosives such as sulfuric acid and caustic soda are carried in tank car type 11 IA - the tank car type appearing most frequently in the HMIS. OTA concludes that research to address this issue is important. OTA did not make a detailed study of bulk marine vessels, and the data analysis did not indicate technical problems with bulk marine vessels warranting urgent attention.

OTA finds that countermeasures to address nontechnical issues are important for all modes. Special operator training specifically related to hazardous materials, and training for shipper and carrier personnel responsible for loading and unloading, fastening, blocking, and bracing nonbulk loads, could increase safety substantially. Congress might consider mandating the development of specific training guidelines, through a consensus process utilizing shippers, carriers, and freight forwarders, as well as government safety personnel, to take advantage of existing expertise and resources.

\section{Intermodal Containers}

Intermodal (IM) tanks are metal containers that hold 4,000 to 6,000 gallons and are surrounded by a metal protective frame that can lock into special fittings on a truck chassis, a railcar, or in a ship's hold or airplane cargo bay. They are versatile and efficient containers for substances that must travel long distances by several different modes. The United States has very few manufacturers of IM tanks, but rapidly growing numbers of these tanks are being transported into and around this country, often over three different modes in a single trip, as international trade increases. The tanks must be registered by serial number with DOT, but regulatory responsibility for them and their carrying vehicles is shared between RSPA and the modal administrations. The poor interagency coordination at DOT is a particularly acute problem for adequate regulation of the transport of these vessels.

The specific areas of concern are the types of chassis used and the method(s) of securing IM tanks onto truck chassis. DOT regulations permit securing the frame of an IM tank to a flatbed truck chassis with chains and hooks called J hooks-a fastening method of questionable reliability, as accident records are beginning to document.

Few appropriate truck chassis for intermodal tank containers are available in the United States. Most of the chassis available in this country are deficient either in length, securement devices, or overall design, which typically incorporates a high center of gravity. Loaded portable tanks must be carried on 40-foot chassis in order to comply with bridge laws that limit the vehicle weight per axle and per wheelbase. However, only about 40040 -foot chassis in this country have twist locks that positively secure the portable tank to the center of the chassis, preventing lateral or vertical motion, although there are several thousand portable tanks available for commercial use. ${ }^{\text {so }}$ Thus, most intermodal tank containers now travel by highway on 40-foot flatbed trucks secured by chains, or on 20-foot chassis, which often have proper securement devices, but which violate road weight laws. ${ }^{51}$

In addition, few chassis are specifically designed for intermodal tanks. A "low-boy" chassis, with a centered flatbed several feet lower than normal, lowers the center of gravity and makes the vehicle more stable. Such chassis are used throughout Europe, but there are fewer than 100 in the United States. OTA finds that immediate and intensive study of the motor vehicle chassis and securement methods for intermodal portable tanks is urgently needed. The research should be conducted jointly by RSPA, BMCS, and FRA. Congress might wish to require that intermodal tanks travel only on chassis that have twist locks that positively secure the tank against vertical or lateral motion as an interim step.

\footnotetext{
${ }^{50}$ George Graham, President, Chemical Leaman Container Corp., agents for Sea Containers Inc., personal communication, October 1985. ${ }^{51}$ George Graham, president, Chemical Leaman Container Corp., agents for Sea Containers Inc., a major owner, leaser, and transporter of intermodal containers, has strongly advocated that intermodal tanks not be allowed to travel on flatbed trailers secured only by chains. Chains or chain binders allow for tank movement and make the vehicle dangerously unstable. His comments were made at the first semiannual meeting of the Hazardous Materials Advisory Council, held at Hilton Head Island, SC, Nov. 14, 1985, and reported by Laurie Bradford in "Inexperience Poses Major Threat to Safety in Transport of 'HM,' " Traffic World, Nov. 25, 1985.
} 


\section{Small Packaging}

Because of the limited amounts of hazardous material contained in small packages, releases generally do not have serious consequences. Release reports for small packages indicate that accidents occur more frequently through mishandling or misuse of the packaging, rather than because of container failure. Air carriers and the U.S. Postal Service reported to OTA that many problems arise from unwitting violations of regulations and mispackaged hazardous materials. ${ }^{52}$ OTA finds that stepping up public information programs and industry compliance training could improve safety.

Accident and release data are so incomplete that thorough evaluation of the safety record of individual small package designs is impossible. Furthermore, the regulations that govern the packages are lengthy and complex, difficult to understand and follow, and out of harmony with those of our international trading partners.

Performance standards, already in international use for small packages, are likely to be adopted by DOT within the next few years, and the prospective changeover has been widely supported by most of the affected parties. OTA finds that the new systern will simplify the regulations making compliance with them easier, bring U.S. regulations into greater conformity with those of our international trading partners, and make packaging innovations easier and faster to evaluate and implement. Adoption of performance standards should reduce the time required for the relatively small RSPA staff to handle exemption applications and free them for other functions such as data and trend analysis and planning.

OTA concludes that collection of release data for small packages needs to be improved and con tinued, so that packaging deficiencies can be identified and remedied, and the adequacy of the performance tests can be evaluated.

\section{Defining Roles and Coordinating Programs}

Federal agencies with overlapping interests and responsibilities need to coordinate common activi-

\footnotetext{
${ }^{52}$ Steve Gordon, U.S. Postal Service, personal communication, 1986.
}

ties and define transportation-related policies more explicitly. OTA has identified several areas where specific action would increase effectiveness.

Public concerns related to shipments of spent nuclear fuel are focusing on transportation procedures and safeguards in addition to the containers for spent fuel. Congress might consider requiring DOE, NRC, and DOT to work out notification, State container inspection and other operating procedures, routing, and safeguard policies for NWPA shipments in consultation with each other and in conjunction with State and local officials. While DOT and NRC both have regulatory roles and DOE is an operating agency, the policies and activities of all three agencies have a single impact on public perceptions. Moreover, DOT, DOE, and NRC might consider undertaking a joint public information program, using staff specially trained in discussing technical matters with audiences that have widely varying values.

OTA also found that interprogram coordination within DOE has been sadly lacking, although recently, efforts have been made to improve the situation. Staff in offices such as emergenc response and transportation often did not know each other and were not familiar with each other's programs. Continued lack of coordination will hamper implementation of NWPA activities and any interagency cooperative efforts.

Finally, Congress could take steps to promote improved coordination within DOT and among Federal agencies. A standing coordinating committee, perhaps under the umbrella of the National Response Team, could be established with representatives from each DOT modal administration, RSPA, other Federal agencies such as EPA, NRC, DOE, and FEMA, State and local governments, and industry. This committee might be required to meet periodically to: define Federal agency missions and roles in the transportation of hazardous materials, coordinate Federal training programs, oversee the development of national guidelines (described above), set a regulatory agenda for interagency and interagency issues, and oversee the coordination of common activities such as data collection and enforcement.

Subgroups could be formed to address areas of particular concern. More specifically, DOT and EPA 
could be directed to develop a joint program to educate small businesses that generate and transport hazardous wastes about DOT transportation requirements and the compatibility of wastes and containers. With more than 60,000 small-quantity generators of hazardous wastes becoming subject to EPA and DOT regulations, the potential for confusion and use of inappropriate containers is immense.

Within DOT, intermodal agency groups could coordinate far more closely. RSPA could take a more aggressive role as DOT hazardous materials coordinator for research and data-collection programs, leaving modal operational details to modal administrations. Federal research on IM tanks is being done separately by modal administrations, when it is being done at all. FRA, for example, is conducting research on the dimensions of intermodal tanks on trailers and flatcars using truck chassis that violate over-the-road use in most States. Coordination for multimodal research is essential if the work is to be cost-effective. RSPA could act more effectively as coordinator between the Federal Highway Administration, BMCS, and FRA for this effort, to ensure that research results have practical value. 
Chapter 2

\section{Data and Information Systems for Hazardous Materials Transportation}

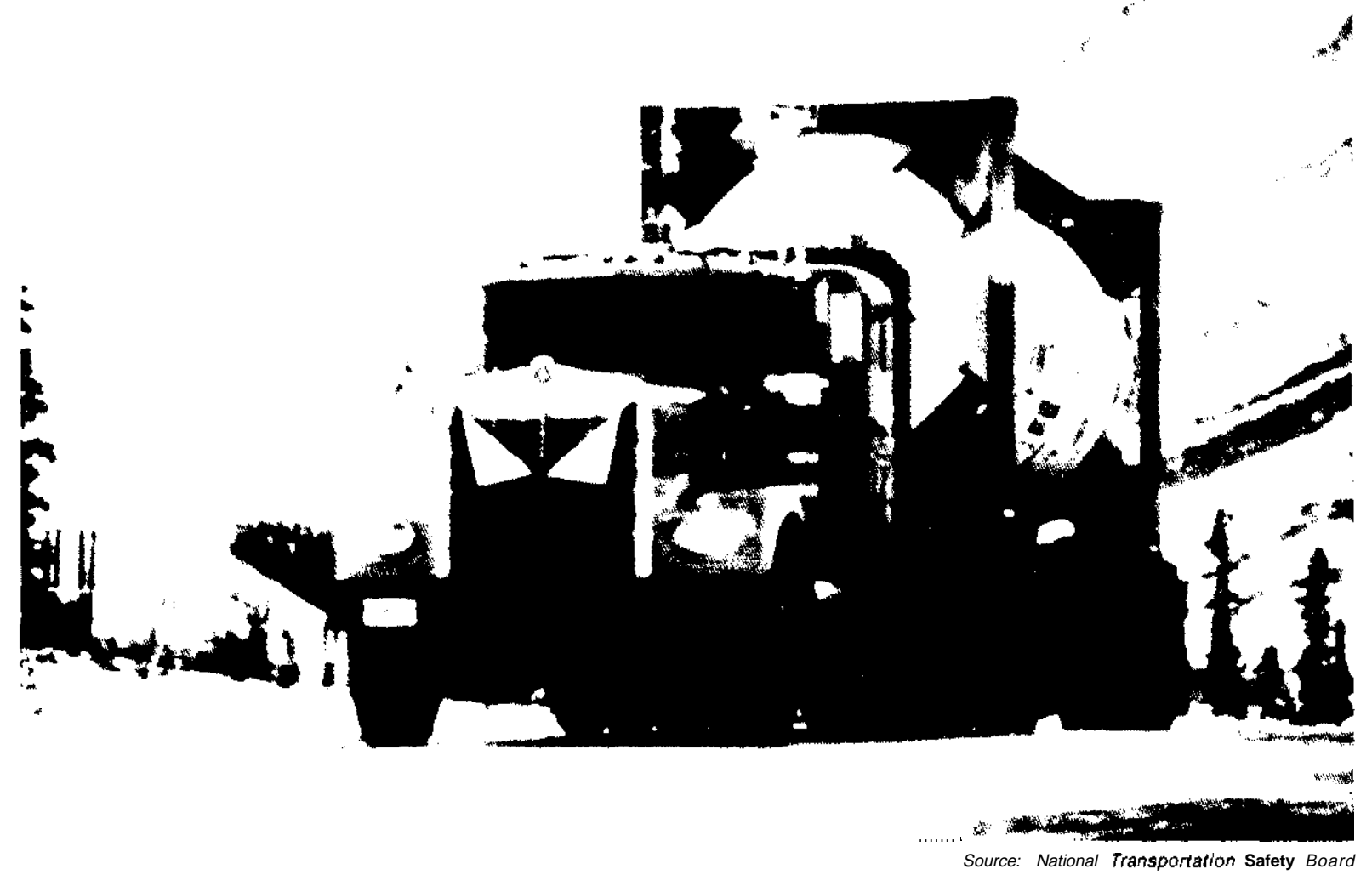




\section{Contents}

Page

Part 1: Hazardous Materials Flow Databases . . . . . 44

National Data Resources . . . . . . . . . . . . . . . . . 44

Data Analysis Issues . . . . . . . . . . . . . . . . . . . . . . . . . . . . . . . . . . .

Truck Transport . . . . . . . . . . . . . . . . 48

Railroads ........................ 52

Water Transport .................... 53

Air Transport. . . . . . . . . ........ . . . . . . . 55

State and Local Studies . . . . . . . . . . . . . . . . .. 58

Conclusions ... . . . . . . . . . . . . . . . . . 65

Part II: Accident and Spill Information

Systems ... . . . . . . . . . . . . . . . . .66 66

Spill Report Systems . . . . . . . . . . . . . . . . 66

Modal Accident Data Systems . . . . . . . . . . . . . . . 70

Carrier Release Data. . . . . . . . . . . . . . . . . . . . . . 75

Completeness and Accuracy of HMIS. . . . . . . . . 76

HMIS Uses.... . . . . . . . . . . . . . . . . . . 81

Conclusions ................... 83

\section{List of Tables}

Table No. Page

2-1. Commodity Flow Databases . . . . . . . . . . . . 42

2-2. Estimated Transportation of Hazardous Materials by Mode in 1982 . . . . . . . . . . . . . 46

2-3. 1982 Truck inventory and Use Survey Breakdown of the Hazardous Materials Fleet . . . . . . . . . . . . . . . . . . . . . . . 49

2-4. Hazardous Commodity Flows by Truck According to the 1977 Five-Digit Commodity Transportation Survey Database ......................... . . 51

2-5. Gallons byproduct Type Based on the American Petroleum institute Survey of Producers With Large Proprietary Fleets. . . . 52

2-6. Fifteen Largest Junction Volumes, 1977 and $1983 \ldots \ldots \ldots \ldots \ldots$. . . . . . . . . . 53

2.7. Hazardous Commodity Flows by Rail According to the 1983 Waybill Statistics . . . 54

2-8. Hazardous Commodity Flows by Water According to the 1982 Waterborne Commerce Statistics Center Database.. . . . . 56

2-9. Hazardous Commodity Flows by Air According to the 1977 Five-Digit Commodity Transportation Survey Database . . . . . . . . . . . . . . . . . . . . 57

2-10. Incident/Accident Databases . . . . . . . . . . . 73

2-n. Waterborne Incidents Reported to the Commercial Vessel Casualty File by Primary Cause, 1976-80
Table No,

2-12. Waterborne Incidents Reported to the Commercial Vessel Casualty File by General Location, $1976-80$. . . . . . . . . . . . . . . . . . . 77

2-13. Commercial Vessel Casualty File Comparison With the Hazardous Materials Information System Database, 1976-80 . . . . 77

2-14. Truck Accidents by General Location Using the Truck Accident File, 1983 . . . . . . . . . . 77

2-15. Truck Accident File Reported Injuries and Deaths, 1983. . . . . . . . . . . . . . . . . . 77

2-16. Truck Accident File Comparison With Hazardous Materials Information System Database, 1983 78

2+17. Hazardous Materials Information System Misreporting Consequences Using the Truck Accident File Databases, 1983. . . . . . . . . . 78

2-18. Hazardous Materials Information System Misreporting Consequences Using the National Response Center Database, 1983.. 78

2-19. Hazardous Materials Information System Nonreporting Consequences Using the National Response Center Database, 1983.. 78

2-20. Hazardous Materials Information System Nonreporting Analysis Using the National Transportation Safety Board Database, 1976-83

2021. Hazardous Materials Information System Nonreporting Consequences Using National Transportation Safety Board Database, 1976-83 .........................................

2-22. Hazardous Materials Information System Misreporting Consequences Using the National Transportation Safety Board Database, 1976-83

2-23 Number of Incidents by Location and Mode, 1976-84 .................... 82

2-24 Cause of Failure by Mode, 1976-84 . . . . . . . 84

\section{List of Figures}

Figure No. Page

2-I. Regions Used in This Analysis . . . . . . . . . . 47

2-2. DOT Incident Report Form F5800.1 . . . . . . 68

2-3. HMIS Incidents by Year . . . . . . . . . . 81

2-4. General Causes of Spills by Mode According to the HMIS... . . . . . . . . . . . . . . . 83

2-5. General Causes for All Modes ..... . . . . 83 


\section{Data and Information Systems for Hazardous Materials Transportation}

Government agencies responsible for the transportation of hazardous materials need data about manufacturers, shippers, carriers, commodity flow, and accidents to help them set regulations, plan for accident prevention and emergency response, and target enforcement efforts. The U.S. Department of Transportation (DOT) has lead Federal responsibility for the transportation of hazardous materials, and many related databases are kept by the various administrations within DOT.

Over the last 10 to 15 years the public has become increasingly aware of the special environmental and public health damage that hazardous materials transportation accidents can cause. With this awareness has come an understanding by State and local officials that, while they have responsibility for public safety in their jurisdictions, they do not fully understand the local risk from the transportation of hazardous materials. Moreover, there is a pervasive feeling that Federal regulations and programs do not take special local circumstances into account and, in any case, may not provide an appropriate and acceptable level of safety. These jurisdictions require data about hazardous materials transportation in their areas to help them establish regulatory, enforcement, and emergency response programs that meet their needs.

The level of public knowledge about the amount and destinations of hazardous materials traveling in or near a jurisdiction is generally low, so it is difficult for policymakers to assess risks for their area. * Once officials realize this, often after a severe hazardous materials emergency for which the jurisdiction found itself ill-prepared, they begin to look for information. For example, a 1979 chemical plant fire in downtown Memphis prompted the mayor to initiate a planning and data-collection effort.

\footnotetext{
*For example, hazardous wastes and radioactive materials represent only about 1 and 2 percent respectively of the hazardous materials shipped annually. The health and environmental risks they present may be matched or exceeded by those of many other commodities shipped routinely, yet these two substances are most frequently the subject of State and local restrictions.
}

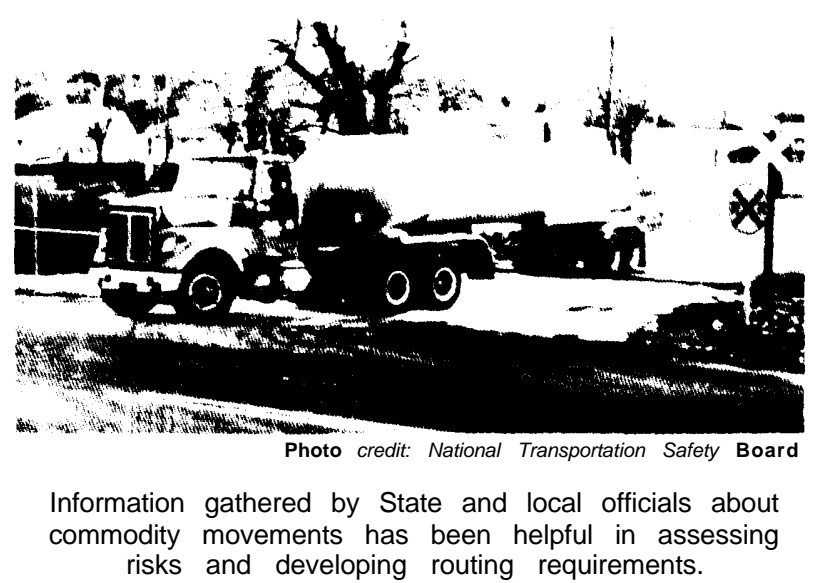

However, acquiring necessary data is not easy. Such data as exist about facilities housing hazardous materials usually reside in fire departments or building permit files and are local in nature. For information on through shipments, the first step taken by a State or local jurisdiction is usually to seek assistance from Federal data sources. Yet, data and information pertaining to different aspects of hazardous materials transportation are kept by eight Federal agencies (see tables 2-1 and 2-10). The data systems are not interactive and do not use common commodity codes to identify the different hazardous materials. Furthermore, no Federal agency has a mandate to compare all the data or to analyze them for a comprehensive look at hazardous materials transportation patterns, although such information would be useful to Federal agencies in establishing program priorities.

Once they have determined that Federal resources are not helpful, some States and local jurisdictions have undertaken their own studies. After deciding what types of information will be most useful, they can tailor their efforts to meet specific needs. In many cases, demands for better Federal data have been voiced. The increasing interest in better in-

\footnotetext{
'The National League of Cities requested formulation of a Federal database on hazardous materials commodity flow as part of its 1985 transportation policy position.
} 
Table 2=1.-Commodity Flow Databases

\begin{tabular}{|c|c|c|c|c|c|c|c|}
\hline Databases & Kept by & Years & Modes & $\begin{array}{l}\text { Commodity } \\
\text { codes }\end{array}$ & $\begin{array}{c}\text { Conversion } \\
\text { table }\end{array}$ & Strengths & Weakness/drawbacks \\
\hline $\begin{array}{l}\text { Federal: } \\
\text { Commodity } \\
\text { Transportation } \\
\text { Survey (CTS) }\end{array}$ & $\begin{array}{l}\text { Bureau of the } \\
\text { Census }\end{array}$ & 1977 & All & 5-digit STCC & Yes & $\begin{array}{l}\text { - Multimodal } \\
\text { Consistent selection procedure for } \\
\text { all sample data points for all modes } \\
\text { - Cross-checked against the cen- } \\
\text { sus of manufacturers }\end{array}$ & $\begin{array}{l}\text { - Only 5-digit level of commodities } \\
\text { - No hazardous materials flags } \\
\text { - Only shipments from manufac. } \\
\text { turing sites to first destinations } \\
\text { - Only "principal" mode is reported }\end{array}$ \\
\hline $\begin{array}{l}\text { Truck Inventory } \\
\text { and Use Survey }\end{array}$ & $\begin{array}{l}\text { Bureau of the } \\
\text { Census }\end{array}$ & $\begin{array}{l}1977, \\
1982\end{array}$ & Highway & $\begin{array}{l}\text { Simple } \\
\text { classes }\end{array}$ & No & $\begin{array}{l}\text { - Covers all trucks used in the } \\
\text { United States } \\
\text { Contains hazardous materials- } \\
\text { related data items } \\
\text { Sample biased toward heavy } \\
\text { trucks }\end{array}$ & $\begin{array}{l}\text { - No flow data } \\
\text { Only rudimentary commodity } \\
\text { information } \\
\text { Tractor database, not a trailer } \\
\text { database-reflects tractor use, } \\
\text { not trailer use }\end{array}$ \\
\hline $\begin{array}{l}\text { Motor Carrier } \\
\text { Census }\end{array}$ & $\begin{array}{l}\text { Bureau of Motor } \\
\text { Carrier Safety, } \\
\text { FHWA }\end{array}$ & $\begin{array}{l}\text { Most } \\
\text { recent } \\
5 \text { years }\end{array}$ & Highway & $\begin{array}{l}\text { Hazard } \\
\text { classes }\end{array}$ & No & $\begin{array}{l}\text { - Comprehensive listing of carriers } \\
\text { and truck fleet operators }\end{array}$ & $\begin{array}{l}\text { No flow data } \\
\text { Mileage and fleet size data are } \\
\text { sparse }\end{array}$ \\
\hline $\begin{array}{l}\text { Radioactive } \\
\text { Materials Routing } \\
\text { Report }\end{array}$ & $\begin{array}{l}\text { Office of } \\
\text { Hazardous } 3 \\
\text { Materials } \\
\text { Transportation }\end{array}$ & $\begin{array}{l}1982 \text { to } \\
\text { present }\end{array}$ & Highway & $\begin{array}{l}\text { Not } \\
\text { applicable }\end{array}$ & & $\begin{array}{l}\text { - Almost complete flow data for } \\
\text { highway route controlled quanti- } \\
\text { ties of radioactive materials } \\
\text { - Gives highway route data }\end{array}$ & $\begin{array}{l}\text { - Data is often not recorded for } \\
\text { months after shipment } \\
\text { - Material description not always } \\
\text { complete }\end{array}$ \\
\hline Waybill File & $\begin{array}{l}\text { Interstate } \\
\text { Commerce } \\
\text { Commission }\end{array}$ & $\begin{array}{l}\text { At least } \\
\text { past } 12 \\
\text { years }\end{array}$ & $\begin{array}{l}\text { Rail, TOFC/ } \\
\text { COFC }\end{array}$ & 7-digit STCC & Yes & $\begin{array}{l}\text { - Well-organized sample }(1 \%) \text { of all } \\
\text { rail flows } \\
\text { Database is consistent enough } \\
\text { to allow trend analyses } \\
\text { - Contains some routing information }\end{array}$ & $\begin{array}{l}\text { - Not all hazardous material flows } \\
\text { use the special hazardous } \\
\text { materials STCC }\end{array}$ \\
\hline $\begin{array}{l}\text { Waterborne Com- } \\
\text { modity Statistics }\end{array}$ & $\begin{array}{l}\text { Army Corps of } \\
\text { Engineers }\end{array}$ & $\begin{array}{l}\text { At least } \\
12 \text { years }\end{array}$ & $\begin{array}{l}\text { Water, } \\
\text { domestic and } \\
\text { international }\end{array}$ & $\begin{array}{l}\text { 4-digit WCSC } \\
\text { code }\end{array}$ & $\begin{array}{l}\text { Only to a } \\
\text { limited } \\
\text { extent }\end{array}$ & $\begin{array}{l}\text { - } * \star 100 \% " \text { sample of all vessel } \\
\text { movements } \\
\text { •Complete routing information }\end{array}$ & $\begin{array}{l}\text { Only } 163 \text { commodity codes in } \\
\text { all, so level of detail is weak } \\
\text { Conversion table has some in- } \\
\text { correct cross-references }\end{array}$ \\
\hline $\begin{array}{l}\text { States: } \\
\text { Hazardous Waste } \\
\text { Shipment Data }\end{array}$ & $\begin{array}{l}\text { States, for the } \\
\text { EPA }\end{array}$ & Varies & $\begin{array}{l}\text { Primarily } \\
\text { highway }\end{array}$ & $\begin{array}{l}\text { Either EPA } \\
\text { codes or } \\
\text { OHMT }\end{array}$ & No & $\begin{array}{l}\text { - "100\%" sample of all hazardous } \\
\text { waste shipments } \\
\text {. Actual flow data }\end{array}$ & $\begin{array}{l}\text { Many States do not computer- } \\
\text { ize the data } \\
\text { - No consistency to commodity } \\
\text { code usage } \\
\text { - No routing information }\end{array}$ \\
\hline $\begin{array}{l}\text { Private: } \\
\text { TRANSEARCH, } \\
\text { FREIGHTSCAN, } \\
\text { etc. }\end{array}$ & Consulting firms & Varies & All & $\begin{array}{l}\text { Varies, up to } \\
\text { 7-digit for rail }\end{array}$ & Yes & $\begin{array}{l}\text { Cross-checked against other } \\
\text { production/consumption data } \\
\text { Melding of the best available for } \\
\text { each mode }\end{array}$ & $\begin{array}{l}\text { - Truck flows predominantly } \\
\text { based on the CTS data } \\
\text { (see above) }\end{array}$ \\
\hline TRAIN II & $\begin{array}{l}\text { Association } \\
\text { of American } \\
\text { Railroads }\end{array}$ & Current & $\begin{array}{l}\text { Rail, } \\
\text { TOFC/COFC }\end{array}$ & 7-digit STCC & Yes & $\begin{array}{l}\text { - "100\%" data on all movements } \\
\text { for participating railroads } \\
\text {. Routing information }\end{array}$ & $\begin{array}{l}\text { Not specifically designed to } \\
\text { record car movement histories } \\
\text { Not in the public domain }\end{array}$ \\
\hline $\begin{array}{l}\text { National Motor } \\
\text { Truck Data Base }\end{array}$ & $\begin{array}{l}\text { Consulting } \\
\text { firms }\end{array}$ & $\begin{array}{l}1977 \text { to } \\
\text { present }\end{array}$ & Highway & $\begin{array}{l}\text { Varies, up to } \\
\text { 7-digit STCC }\end{array}$ & $\begin{array}{l}\text { Yes, where } \\
\text { commodity } \\
\text { code is } \\
\text { provided }\end{array}$ & $\begin{array}{l}\text { - Focuses on long-distance high- } \\
\text { way flows } \\
\text { - True flow data } \\
\text { Describes the vehicle used to } \\
\text { carry the commodity }\end{array}$ & $\begin{array}{l}\text { Purposely excludes short-haul } \\
\text { truck movements, especially in } \\
\text { the Northeast } \\
\text { - Not in the public domain }\end{array}$ \\
\hline
\end{tabular}

ACRONYMS: EPA = Environmental Protection Agency; FHWA = Federal Highway Administration; OHMT = Office of Hazardous Materials Transportation, Research and Special Programs Administration; STCC SOURCE: Office of Technology Assessment. 
formation on movements of hazardous materials and more complete and reliable data on accidents and releases led Congress to identify an analysis of available Federal data and information resources as a specific focus for this Office of Technology Assessment (OTA) report.

By law, DOT is required to report annually on the safety of hazardous materials transportation, including:

1. a thorough statistical compilation of any accidents and casualties involving the transportation of hazardous materials, and

2. an evaluation of the effectiveness of enforcement activities and the degree of voluntary compliance with applicable regulations. ${ }^{2}$

To be responsive to this requirement and prepare an accurate report, DOT would need a comprehensive record of accidents and spills related to hazardous materials and some idea of how much hazardous material is transported annually by each mode. OTA research shows that, in fact, DOT has an incomplete record of accidents and spills and has no documentable idea of how much hazardous material is transported. Moreover, Research and Special Programs Administration (RSPA) officials told OTA that data collection was a secondary function, despite its importance to safety and risk analysis.

Furthermore, because DOT has made no ongoing effort to study hazardous commodity flow, it cannot reliably determine accident rates for various commodities or the containers in which they are carried, or pinpoint high-accident locations or special circumstances. Without sufficient data and accident analysis, DOT cannot plan adequately or set priorities for changing container and vehicle regulations to address risks and problems or evaluate technology advances. For a general discussion of the nature of risk assessment, see box $2 \mathrm{~A}$.

With OTA assistance, a contractor collected and studied relevant databases and other information currently kept by a number of Federal agencies. To check the Federal sources for accuracy and completeness, OTA looked for outside resources; States, 1ocal jurisdictions, and industries provided helpful data.

This chapter includes the findings of the OTA contractor's exhaustive investigation of the current

\footnotetext{
249 U.S.C. $1808(\mathrm{e})$ and 33 U.S.C. 173(C) (173.51-59).
}

\section{Box 2A.-Risk Assessment}

Risk assessment involves estimating the frequencies and consequences of undesirable events, then evaluating the associated risk in quantitative terms. 'The process of risk assessment serves to organize thinking about risks, permitting the judgments of interdisciplinary teams of experts to be integrated in a systematic way. It also helps identify risks that might not have been thought of otherwise and it motivates improvements in data collection by pointing out database deficiencies. The results of risk assessment provide knowledge essential to informed decisionmaking.

Public concern is greatest about risks that are involuntary, uncontrolled, unfamiliar, immediate manmade, and catastrophic.'Hazardous materials transportation possesses many and sometimes all of these attributes. Risk assessments can help to address two fundamental questions, one quantitative and objective and onequalitative and subjective: What is the level of risk? and What levels of risk are acceptable to the parties concerned? The first question is relatively readily addressed with adequate data and proper methodology, whereas the second question involves numerous judgments and often a great deal of discussion and negotiation, especially when large numbers of people and several governmental jurisdictions are involved. Professional risk assessment places heavy emphasis on quantitative results. Where policy issues are involved, however, and involuntary risks exist, such as those associated with the transportation of hazardous materials, qualitative judgments are important.

The question of risk acceptability is complicated further by the fact that some of the concerned parties may have risk perceptions that differ substantially from the actual risks. Risk equity, the appropriate distribution of risks among different members of society, is another complicating factor.

NC. Rasmussen, "The Application of Probabilistic Risk Assessment Techniques to Energy Technologies," Annual Review of Energy, vol. 6, 1981, pp. 123-138.

Federal collection and analysis of information on commodity flows, accidents, and spills associated with the transportation of hazardous materials. ${ }^{\text {In }}$ addition, State and local data-collection efforts were

\footnotetext{
${ }^{3}$ Mark Abkowitz and George List, "Hazardous Materials Transportation: Commodity Flow and Information System s," OTA contrac tor report, January 1986 . This report is available from OT $A$ on request.
} 
reviewed to determine what information was deemed useful and whether Federal data could provide a resource. An OTA workshop and numerous personal interviews also provided information. Part I of the chapter deals with commodity flow data and Part 11 with incidents or releases.* Part I focuses on the quantity and quality of commodity flow (movement) data currently available to:

. identify existing Federal hazardous materialsrelated databases that provide information on hazardous materials movements, and investigate their potential use to develop geographic flow trends and to understand the relative im-

*The Research and Special Programs Administration refers to a release of a hazardous material during transportation as an incident. There is no agreement on the definition of an incident among the other groups collecting data. OTA will hereafter refer to releases rather than incidents. portance of all modes of transport for different regions; and

. identify State and local data-collection efforts and evaluate the need for a standardized database on hazardous materials transportation movement.

Part II explores hazardous materials transport release and accident reporting requirements, information systems, and release and accident trends. Among the issues addressed are:

- the institutional background of release reporting and data collection;

- the completeness and adequacy of the present reporting systems, and ways to make them more useful; and

- statistical analyses of the frequency of releases and related causes and consequences.

\section{PART 1: HAZARDOUS MATERIALS FLOW DATABASES}

Identifying hazardous material flow-related databases is a complex task. Flow, vehicle and vessel fleets, and travel network data must be considered for all four major freight modes-truck, rail, marine, and air.** Moreover, many diverse organizations maintain different pieces of relevant information; these organizations include Federal agencies, State and local governments, trade associations, carriers, shippers, and consulting firms.

\section{National Data Resources}

Several databases are needed to describe the flows for the hazardous materials transportation network. Table 2-1 shows the major sources of hazardous materials flow data and indicates the commodities and modes covered by each one. For example, the 1977 Commodity Transportation Survey (CTS), collected by the U.S. Bureau of the Census, provides ways to estimate market shares and shipment trends. However, it lacks shipment data on major hazardous cargoes-waste materials, agricultural products, and raw materials, such as crude petroleum and natural fertilizers. Moreover, it reflects only shipments from the point of manufacture to the first destina-

\footnotetext{
**This report does not consider pipelines which transport somewhat more than half of all hazardous materials.
}

tion, often a warehouse, missing all subsequent movements in the distribution chain. There is no specific focus on hazardous materials, meaning analysis is limited by the data contained in the commodity flows themselves, and it is not always possible to determine what percentage of the shipments are hazardous. Data submission is voluntary, creating unknown biases due to nonreporting. The scope of the survey is heavily dependent on Federal budget priorities, and the questions asked are not consistent, making trend analyses difficult. Moreover, the Bureau collects data at 5-year intervals and typically takes 2 years to release the data. Recently, budget constraints have made heavy inroads on many of the Bureau's activities. Data from the 1983 CTS was scheduled to be released late in 1985; however, the Bureau decided not to release the results, because the data was faulty and inadequate for analysis. Because the transportation industries have changed dramatically since 1977, not having more recent data is a severe handicap.

Despite these problems, the CTS is the only national multimodal database available. Other organizations, such as State and local governments, do not collect similar information. They rely either on the CTS directly or on its interpretation and enhancement by consulting firms for their multimodal 
flow information.* Consulting firms use the CTS, supplemented heavily with other modal sources, to improve the quality of the data. ${ }^{4}$

Separate, relatively complete databases are available for rail and marine transport. Because the sample waybill data collected by the Interstate Commerce Commission (ICC) has recently been increased to include about 6 percent of all shipments, it is adequate for determining rail flows. Additionally, although costly and difficult to obtain, the proprietary TRAIN II data, kept by the Association of American Railroads (AAR), provides much more complete information representing 100 percent data on at least 80 percent of the rail shipments.

The data for marine vessel movements are essentially complete, although the marine commodity classifications are very broad, making it difficult to determine what specific commodities are being transported. Only 163 identifying codes are provided, of which only 30 pertain to hazardous materials. Additionally, no computer indicator is provided to show that a specific flow involved a hazardous material.

The available data for truck and air shipments are much less helpful. The absence of better truck data is an enormous gap, since trucks carry the most hazardous materials tonnage in the largest number of vehicles, giving the highway mode the most widespread public impact. The CTS is helpful for truck movements, but in addition to the shortcomings mentioned earlier, it misses some major flows. Data from the Truck Inventory and Use Survey (TI\&U), which is also collected by the Bureau of the Census; and the Motor Carrier Census, which is collected by the Federal Highway Administration's Bureau of Motor Carrier Safety (BMCS), provide some useful information. However, these sources give only truck and truck-mile data for hazardous materials movements, not graphic flow information. The only other independent resource is the National Motor Truck Database, a private sector initiative, which is limited by an intentional bias toward long-haul shipments and does not cover the Northeast.

\footnotetext{
*TWO examples are FREIGHTSCAN, marketed by Data Resources, Inc., Lexington, MA, and TRANSEARCH, marketed by Reebie Associates, Greenwich, CT.

${ }^{4}$ Data Resources, Inc., "FREIGHTSCAN Technical Documentation," prepared by the Transportation and Logistics Service, Lexington, MA, no date.
}

The CTS is the only public database for air shipments, and its air flow data is incomplete, as OTA learned from checking other data, Using a hybrid developed from all data available, OTA estimated aggregate modal commodity flows as shown in table 2-2.

\section{Specialized Databases}

Hazardous Wastes. - U.S. Environmental Protection Agency (EPA) regulations require every hazardous waste shipment to have a manifest, copies of which are submitted to the State and eventuall to the EPA regional office. Thus, in theory, a complete hazardous waste flow database exists. In practice, however, the extent of computerization varies widely from one EPA region to another, and OTA did not find any complete flow records. Nevertheless, an outgrowth of the manifest requirement is that States generally have good information on waste movements and carriers. In some cases, the States are collecting and computerizing the data for EPA. Carriers also have fairly complete data, even though they are not actually responsible for preparing the manifests.

Radioactive Materials.-The data on radioactive shipments are also relatively complete. The U.S. Department of Energy (DOE) maintains a list of all high-level radioactive shipments, and it conducts surveys of the low-level radioactive shipments. One such survey was conducted in $1975,{ }^{6}$ and a second was recently completed. ? DOT compiles data on completed highway shipments of radioactive materials. More than 1,000 shipments have been recorded since January 1982 in the Radioactive Materials Routing Report (RAMRT) from DOE, the U.S. Nuclear Regulatory Commission (NRC), and NRC-licensed shippers. However, the RAMRT data may not be recorded for as long as 1 year after a shipment is made, because regulations do not allow release of routing information until after the entire

\footnotetext{
"US. Environmental Protection Agency, "Identification and Listing of Hazardous Waste," 40 CFR, Part 261, November 1984, nn 345.378 .

J.L. Simmons, et al., Battelle Pacific Northwest Laboratories, Survey of Radioactive Materials Shipments in the U. S., NUREG-0073 (Richland, WA: Sandia National Laboratories, 1976).

'Harold S. Javits, et al., Transport of Radioactive Material in the United States, SAND 84-7174 (Albuquerque, NM: Sandia National Laboratories, April 1985).
} 
Table 2-2.-Estimated Transportation of Hazardous Materials by Mode in 1982

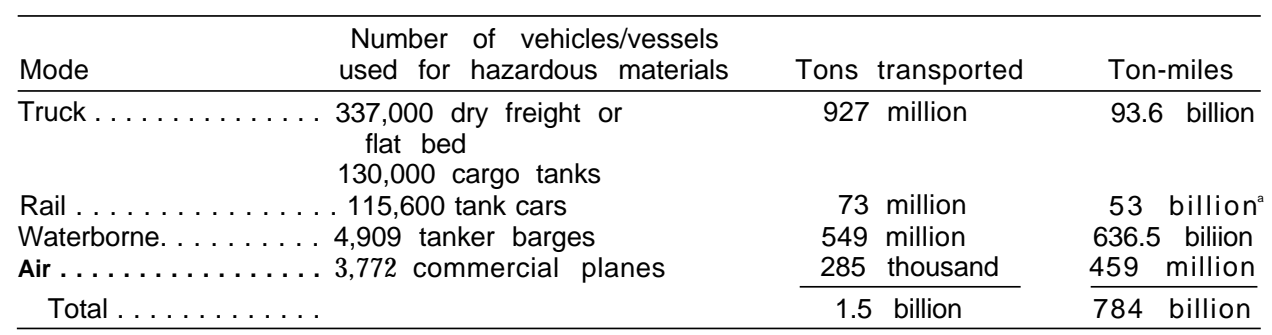

aTechnically 1983 data; 1982 data had too many errors to allow calculations.

SOURCE: OTA calculations based on Federal data augmented by other resources.

shipment is completed. Thus the data are useful primarily from a historical viewpoints

\section{Data Analysis Issues}

To derive useful information on flows for all commodities, OTA contractors had to address three issues before beginning data analysis:

1. What geographical regions should be used in reporting hazardous material flows?

2. What lists of codes should be used in selecting hazardous commodities from the databases?

3. What process should be used in assigning DOT hazard classes to the various commodity codes?

National data resources may not provide State or local flow data at the level of detail that is desired for planning or response. However, regional and State-to-State flow patterns can be obtained and provide helpful information. Figure 2-1 shows the nine regional areas used for this study. The regions correspond closely to those used by the Bureau of Economic Analysis in the U.S. Department of Commerce and to the economic regions of the Nation. They reflect the concentrations of chemical and petroleum production in the West South Central region and manufacturing in the South and Middle Atlantic regions.

Hazardous commodities are defined for this analysis as all commodities listed in 49 CFR, Section 172, including everything from virgin materials to radioactive materials and hazardous wastes. At least 11 hazardous materials commodity codes are used by the different Federal agencies. These include: the

'Charles E. Sell and Bradford W. Welles, Sandia National Laboratories, An Assessment of the U.S. Department of Transportation Radioactive Materials Routing Report (Washington, DC: International Energy Associates Ltd., January 1986), pp. 22-23.
RSPA codes (used in DOT's Hazardous Materials Information System (HMIS) spill database); the EPA codes; ${ }^{9}$ the United Nations/North American (UN/NA) codes; ${ }^{10}$ the Standard Transportation Commodity Codes (STCC), "of which there are two versions, the standard codes and the " 49 " series codes specifically established for hazardous materials; the National Motor Freight Classifications (NMFC); ${ }^{12}$ the Army Corps of Engineers codes (AE) $;^{13}$ and several Bureau of the Census codes, the Transportation Commodity Codes for domestic shipments (1977 Census), ${ }^{14}$ the Standard Industrial Classification (SIC) codes for the 1983 Census (technically speaking, the SIC codes are developed and maintained by the Bureau of Economic Analysis, Department of Commerce), ${ }^{15}$ the Schedule A codes for imports, and the Schedule E codes for exports.

No two databases use the same identifying code numbers. For example:

the railroad waybill file uses seven-digit STCCs, both 49 -series and regular codes;

\footnotetext{
${ }^{9}$ U.S. Environmental Protection Agency, op. cit.

${ }^{1}$ U.S. Department of Transportation, Materials Transportation Bureau, "Hazardous Materials Tables and Hazardous Materials Communications Regulations, " 49 CFR 172, pp. 69-336, November 1984.

'IInterstate Commerce Commission, Standard Transportation Commodity Code Tariff, STCC 6001-M (Chicago, IL: Western Trunk Line Committee, Jan. 1, 1985).

${ }^{12}$ Interstate Commerce Commission, National Motor Freight Classification (Washington, DC: American Trucking Association, May 18, 1985).

${ }^{13}$ U.S. Army Corps of Engineers, Waterborne Commerce of the United States (New Orleans, LA: Waterborne Commerce Statistics Center, 1984).

${ }^{14}$ U.S. Department of Commerce, Bureau of the Census, Instructions for Completing the Commodity Transportation Survey, 1977 Census of Transportation, Form TC-402 (Washington, DC: Sept. 20, 1977),

${ }^{15}$ U.S. Department of Commerce, Bureau of Economic Analysis, Survey of Current Business (Washington, DC: U.S. Government Printing Office, monthly).
} 
Figure 2-1.-Regions Used in This Analysis

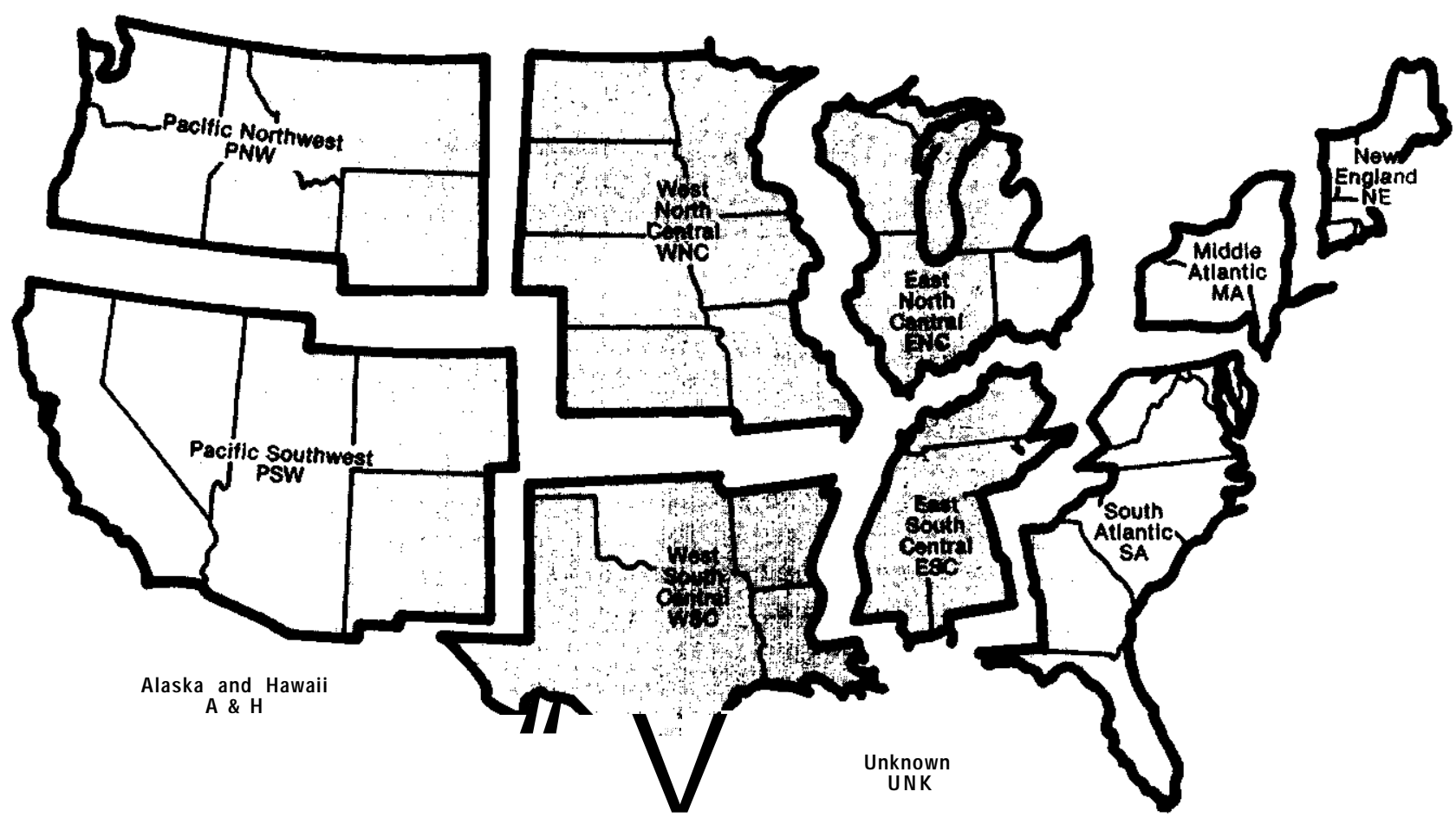

SOURCE: Office of Technology Assessment.

- the CTS uses five-digit STCCs; and

- the waterborne commerce database uses fourdigit Schedule A and Schedule E codes for imports and exports, respectively. See table 2-1 for a summary.

The codes are all used simultaneously, yet very few cross-reference tables have been developed. OTA contractors identified only five:

1. a conversion file between 49-Series STCCs, regular STCCs, and UN/NA codes maintained by AAR; ${ }^{16}$

2. a STCC to SIC conversion table at the fourdigit SIC level maintained by AAR, which is in hard copy only; ${ }^{17}$

3. an NMFC to STCC conversion table maintained by the American Trucking Association (ATA) $;^{18}$

\footnotetext{
"Association of American Railroads, Price List of Publications (Washington, DC: September 1983).

"Ibid.

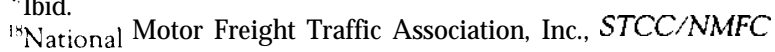
Converter (Washington, DC: June 14, 1971).
}

4. an Army Corps of Engineers' conversion file between $\mathrm{AE}$ commodity codes for water and the Bureau of the Census' Schedules A and E codes for imports and exports; and

5. a SIC, Schedule A, Tariff Schedules of the United States Annotated, and Schedule E translation file maintained by the Bureau of the Census.

The UN/NA numbers appear only once. RSPA and EPA numbers do not appear on any conversion table, a serious omission, as they are the two agencies charged most directly with responsibility for hazardous materials information.

Finally, hazardous commodit lists cannot be generated through computerized selection, making considerable preparatory analysis necessary to develop comparable data. For example, in the case of the Schedules A and E codes, a computer process generated a long list of nonhazardous commodities and missed two major hazardous commodities. For this study, as the database-specific commodity lists were developed, each commodity was given a hazard class 
distinction, so that spill rate statistics could be completed. RSPA has not identified hazard classes for any commodity list except its own, so suitable methods had to be developed to link hazard classes and commodities. This process was complex, and except for the 49-series STCCs, the hazard class assignments were not readily definable and required considerable judgment.

\section{Truck Transport}

Truck transport is the sector with the poorest data, yet it presents the most widespread public risk. Consequently, available data resources for this mode will be described in detail. Three principal national databases are available publicly to help analyze trucking flows: the 1977 CTS and the 1977 and 1982 TI\&U. However, none presents a complete picture, nor were any designed to do so. The CTS provides origin-to-destination flow data on shipments from manufacturing plants to first destinations only, missing the rest of the distribution chain and all nonmanufactured goods.

TI\&U provides a global picture of truck use, but lacks any origin to destination flow information or precise definition of commodities. The 1977 and 1982 TI\&U surveys were both used for this report.

The 1977 TI\&U contains information on each vehicle's registration and vehicle identification number; physical characteristics such as size, type of body, engine size, transmission type, and braking system; operator class (private, for-hire, owneroperator, etc.); range of operation (e.g., 50 to 200 miles); annual mileage; percentage of mileage in the home State; commodities carried (by percent of miles); and percentage of miles carrying hazardous materials. It is based on voluntary responses from the owners of the vehicles selected. It has no crosschecks except the State registration files from which the survey vehicles were selected. The 1982 TI\&U contains data on the character and use of slightly over 90,000 trucks, a State-to-State sample drawn from an estimated universe of 35 million.

Supplementary information is available in the Motor Carrier Census, maintained by BMCS, which contains profiles of approximately 250,000 motor carriers. The database is used primarily to monitor carrier safety, and contains each carrier's State base of operations, the States served, the type of com- modities carried and, for hazardous materials, the kind of container and tank or package used to carry commodities in each of the hazard classes designated by RSPA. Also, it contains information on the carrier's classification, such as: ICC common; ICC exempt; private; miles operated; number of drivers; and number of trucks, truck tractors, and trailers, segmented by type of ownership-owned, leased, or trip-leased.

The ICC Waybill Sample contains data on truck shipments that make use of rail for some portion of the move, such as piggyback or container on flatcar/truck on flatcar shipments.

Trade organizations generally do not keep flow data. ATA, for example, keeps only aggregate statistics on tons and ton-miles. Moreover, the firms submitting data are principally less-than-truckload carriers, so information about bulk shipments is lacking. Shipper organizations, like the American Petroleum Institute (API), the Chemical Manufacturers Association, the Petroleum Marketers Association, and the National Association of Chemical Distributors, are in much the same position as ATA.

Individual firms, however, do keep data on their own movements. Trucking firms generally keep computerized traffic databases that include origin, destination, commodity (by a variety of codes), shipment weight, and shipment date. Major shippers, like the large chemical and petroleum companies, also keep computerized data on their truck shipments. They record origin, destination, commodity (often on the basis of some marketing coding scheme), shipment weight, and shipment date.

Other types of data are kept by consulting firms, such as Transportation Research and Marketing, which has developed a National Motor Truck Data base (NMTDB). ${ }^{19}$ Established to develop marketing information by AAR in 1977, NMTDB contains information on approximately 36,000 movements per year, some 4,000 of which involve hazardous materials. The data is collected at 18 selected truck stops, typically in the West and Midwest, to sample long-haul moves. The database includes origin city and State, destination city and State, commodity, vehicle characteristics, operator characteristics, and an operator profile. It is cross-checked to a limited

\footnotetext{
${ }^{19}$ Frances $M$ Larkin and K. Eric Wolfe, "Rail-Competitive Truck Characteristics, 1977 -1982," unpublished typescript, 1983.
} 
extent against fuel sales at the truck stops and volume counts on selected Interstates.

The TI\&U shows that in $1982,467,000$ trucks were involved in carrying hazardous materials and collectively generated 1.6 billion truck-miles. This compares to 327,000 trucks and 1.3 billion truckmiles in the 1977 TI\&U. The data show a 43 percent growth in the fleet size and a 23 percent growth in truck-miles compared to 1977 data, or 6 and 4 percent per year, respectively. The vehicles were predominantly either large, private tank trucks carrying petroleum and chemicals most of the time, or vans operated by for-hire carriers carrying hazardous materials less than 25 percent of the time. Mixed shipments were carried by 24 percent of the trucks and represented 35 percent of the truck-miles.

\section{Trucks and Truck-Miles Based on the 1977 and 1982 TI\&U Surveys}

Table 2-3 shows the truck fleet breakdown for 1982. The comparable data for 1977 may be summarized as follows. Liquid tank trucks accounted for 30 percent of the fleet and 57 percent of the truck-miles. About 65 percent of the trucks had an operating range under 200 miles and accounted for 56 percent of the truck-miles. The trucks that operated over 200 miles accounted for 21 percent of the fleet and generated 40 percent of the truck-miles. Private carriers operated 78 percent of the trucks and generated 52 percent of the truck-miles. ICC common carriers were the second largest in size, at 12 percent of the fleet, and they generated 26 percent of the truck-miles. The common carrier trucks

Table 2-3.-1982 Truck Inventory and Use Survey Breakdown of the Hazardous Materials Fleet (467,000 trucks; 16,236 million truck-miles)

\begin{tabular}{|c|c|c|}
\hline Statistic & $\begin{array}{c}\text { Trucks } \\
\text { (thousands) }\end{array}$ & $\begin{array}{c}\text { Truck-Mites } \\
\text { (millions) }\end{array}$ \\
\hline \multicolumn{3}{|l|}{$\begin{array}{l}\text { Percent of miles Involved in } \\
\text { carrying hazardous materials: }\end{array}$} \\
\hline 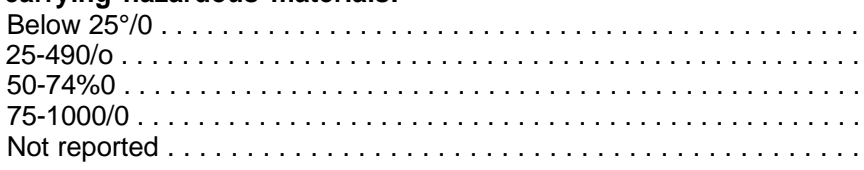 & $\begin{array}{r}243.8 \\
117.0 \\
20.5 \\
80.3 \\
5.0\end{array}$ & $\begin{array}{r}10,282 \\
2,971 \\
776 \\
2,191 \\
15\end{array}$ \\
\hline 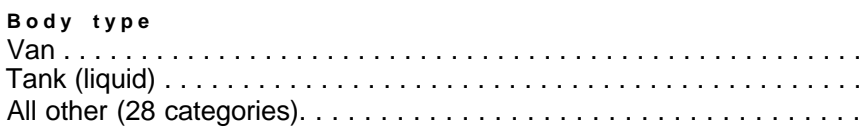 & $\begin{array}{l}140.8 \\
130.3 \\
195.5\end{array}$ & $\begin{array}{l}7,016 \\
4,317 \\
4,903\end{array}$ \\
\hline 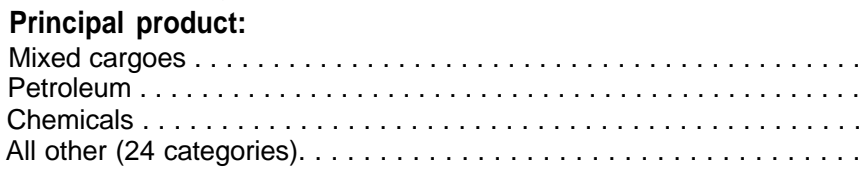 & $\begin{array}{r}113.5 \\
136.6 \\
60.3 \\
156.2\end{array}$ & $\begin{array}{l}5,716 \\
3,491 \\
2,069 \\
4,960\end{array}$ \\
\hline 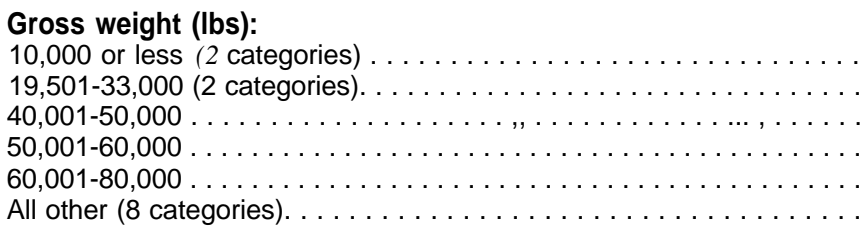 & $\begin{array}{r}122.5 \\
90.8 \\
36.1 \\
34.4 \\
110.9 \\
71.9\end{array}$ & $\begin{array}{l}1,818 \\
1,578 \\
1,479 \\
1,983 \\
8,083 \\
1,295\end{array}$ \\
\hline 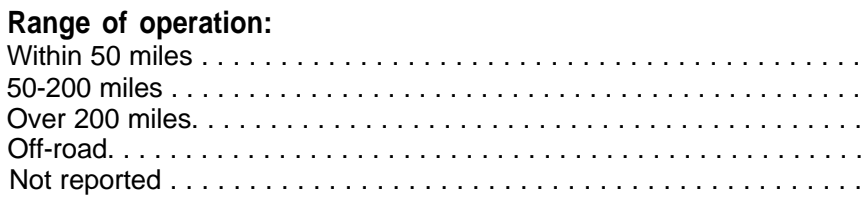 & $\begin{array}{r}269.7 \\
90.9 \\
73.1 \\
32.3 \\
0.6\end{array}$ & $\begin{array}{r}4,888 \\
4,075 \\
6,749 \\
525 \\
-\end{array}$ \\
\hline 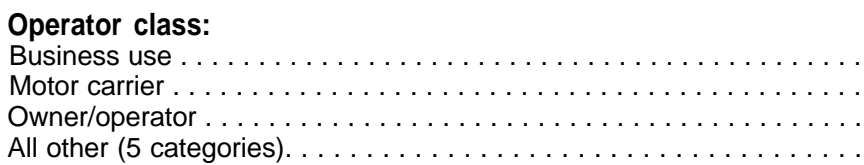 & $\begin{array}{c}275.8 \\
153.3 \\
21.1 \\
16.4\end{array}$ & $\begin{array}{r}6,200 \\
8,391 \\
1,423 \\
222\end{array}$ \\
\hline
\end{tabular}


were driven 76,000 miles per truck per year, and the private trucks 22,000 miles.

The smaller trucks were used for local movements, while the larger ones dominated for operations over 200 miles. In fact, more than 85 percent of the "over 200 mile" truck-miles were in vehicles weighing 60,001 to 80,000 pounds. In addition, detectable populations of large trucks contributed to both fleet size and truck-miles in the under- and over-200 mile categories. The States with the largest fleets were Pennsylvania, California, and Ohio; those that had the most truck-miles were Ohio, Texas, and Pennsylvania.

\section{Tons and Ton-Miles by Hazard Class}

The two largest hazard classes transported by truck are flammable liquids and Poison B, regardless of whether measured by tons or ton-miles. Poison A, flammable compressed gas, and flammable solid are the next most important classes by tonnage; flammable solid, combustible liquid, and corrosive material are most important according to ton-miles.

The 1977 TI\&U showed the truck-mile breakdown among commodities as 47 percent petroleum, 17 percent chemicals, and 36 percent "all other." In contrast, the CTS reported the ton-mile breakdown as 36 percent petroleum, 53 percent chemicals, and 11 percent "all other," thus clearly missing much of the petroleum flow. Furthermore, the CTS shows 65 million tons of petroleum being shipped by truck in 1977, whereas data supplied by API for 1984 indicates at least 105 million tons were delivered by truck. Petroleum consumption declined during the 7-year period. Moreover, the CTS shows no petroleum flow in the Southeast, one of the three largest flows in the API data.

Partial compensation for the missing petroleum flows can be made by assuming that all of the marine and pipeline shipments of gasoline, distillates, and kerosene are eventually made by truck. This assumption boosts the CTS tonnage estimate from 133 million tons to 566 million tons, or more than a fourfold increase. Region-to-region flow patterns based on this hybrid database are shown in table $2-4$. Seventy-two percent of the flows are intraregional, led by shipments in the West South Central, East North Central, and Pacific Southwest re- gions. Classified by hazard class, the CTS data show flammable liquid is the largest class, whether measured in tons or ton-miles. The next largest category is Poison B, reflecting the chemical shipments. These statistics must be viewed as best estimates, however, because the completeness of the commodity flow data is questionable, and the specificity of the commodity definitions is limited.

Petroleum and gasoline shipments account for almost half of all truck transport of hazardous materials. To offset the lack of petroleum truck shipment data in the CTS, OTA requested assistance from the API Transportation Committee. API conducted a survey of oil companies that operate private truck fleets and received responses from nine of the largest companies. Each provided a profile of the distribution patterns at its terminals, broken down by type of product and type of deliverywhether by proprietary fleet or jobber. * Moreover, for the proprietary deliveries, they provided minimum, average, and maximum delivery distances.

The API survey covers 519 terminals, located in 45 of the 50 States, including Hawaii and the District of Columbia. The States with the most terminals are California with 31, Pennsylvania with 30 , and Texas with 28. The survey showed shipments of 27 billion gallons of gasoline (over 25 percent of the national total); 1.0 billion gallons of diesel fuel ( 2 percent); 1.3 billion gallons of distillates ( 5 percent); and 0.8 billion gallons of other products, principally aviation gasoline, Jet A, and turbine fuel.

Among these, 44 percent of the gallons are delivered by jobbers. In fact, jobbers deliver 78 percent of petroleum products other than gasoline and 39 percent of the gasoline (see table 2-5). Hence, oil companies have only partial responsibility for highway movements of petroleum. The average delivery distance is short, at 28 miles, and distances do not differ markedly by geographic region-the maximum delivery distances are all less than 250 miles.

Chemicals represent the second largest category of hazardous materials transported by truck. The TI\&U data show that 13 percent of the trucks carrying hazardous materials 75 to 100 percent of their miles were hauling chemicals and generated 17 per-

\footnotetext{
${ }^{*} \mathrm{~A}$ jobber is an independent petroleum marketer, who buys a truckload of product from the petroleum company at the terminal and delivers it as a private marketer to his own customers.
} 
Table 2-4.-Hazardous Commodity Flows by Truck According to the 1977 Five. Digit Commodity Transportation Survey Database

\begin{tabular}{|c|c|c|c|c|c|c|c|c|c|c|c|c|}
\hline \multicolumn{2}{|c|}{ All flows in thousands of tons: } & \multirow{2}{*}{$\begin{array}{r}\text { Middle } \\
\text { Atlantic } \\
\end{array}$} & \multirow[b]{2}{*}{ South Atlantic } & \multicolumn{4}{|c|}{ East North East South West North West South } & \multirow{2}{*}{$\begin{array}{c}\text { Pacific } \\
\text { Northwest }\end{array}$} & \multirow{2}{*}{$\begin{array}{c}\text { Pacific } \\
\text { Southwest }\end{array}$} & \multirow{2}{*}{$\begin{array}{c}\text { Alaska \& } \\
\text { Hawaii }\end{array}$} & \multirow[b]{2}{*}{ Unknown } & \multirow[b]{2}{*}{ All } \\
\hline From !/To - & New England & & & Central & Central & Central & Central & & & & & \\
\hline New England ...... & 13,863 & 136 & 36 & 202 & 26 & 20 & 28 & 7 & 35 & 0 & 0 & 14,353 \\
\hline Middle Atlantic .... & 1,077 & 63,020 & 3,056 & 2,022 & 269 & 265 & 475 & 34 & 246 & 1 & 20 & 70,485 \\
\hline $\begin{array}{l}\text { South Atlantic..... } \\
\text { East North }\end{array}$ & 238 & 949 & 43,482 & 766 & 474 & 226 & 167 & 3 & 114 & 1 & 342 & 46,772 \\
\hline $\begin{array}{l}\text { Central........... } \\
\text { East South }\end{array}$ & 257 & 1,009 & 953 & 110,434 & 790 & 2,696 & 522 & 53 & 316 & 3 & 25 & 117,05 \\
\hline $\begin{array}{l}\text { Central........... } \\
\text { West North }\end{array}$ & 132 & 341 & 787 & 587 & 9,251 & 282 & 352 & 11 & 158 & 0 & 7 & 11,908 \\
\hline $\begin{array}{c}\text { Central........... } \\
\text { West South }\end{array}$ & 7 & 57 & 75 & 520 & 74 & 22,152 & 229 & 1,572 & 2,518 & 0 & 3 & 27,20 \\
\hline Central.......... & 58 & 729 & 803 & 1,006 & 3,651 & 573 & 171,379 & 63 & 840 & 0 & 1,222 & 180,32 \\
\hline $\begin{array}{l}\text { Pacific Northwest.. } \\
\text { Alaska and }\end{array}$ & 0 & 1 & 3 & 1 & 0 & 285 & 1 & 18,846 & 70 & 1 & 0 & 19,208 \\
\hline Hawaii . . . . & $\ldots-$ & - & - & - & - & - & - & - & - & 3,146 & - & 3,146 \\
\hline $\begin{array}{r}\text { Pacific Southwest .. } \\
\text { All ............ }\end{array}$ & $\begin{array}{r}9 \\
15,641\end{array}$ & $\begin{array}{r}415 \\
66,657\end{array}$ & $\begin{array}{r}17 \\
49,212\end{array}$ & $\begin{array}{r}132 \\
115,680\end{array}$ & $\begin{array}{r}43 \\
14,578\end{array}$ & $\begin{array}{r}110 \\
26,609\end{array}$ & $\begin{array}{r}66 \\
173,219\end{array}$ & $\begin{array}{r}656 \\
21,245\end{array}$ & $\begin{array}{l}73,244 \\
77,541\end{array}$ & $\begin{array}{r}2 \\
3,154\end{array}$ & $\begin{array}{l}1,005 \\
2,624\end{array}$ & $\begin{array}{r}75,699 \\
566,160\end{array}$ \\
\hline
\end{tabular}

aft was assumed that all shipments of gasoline, distillates, and kerosene by marine and pipeline utilized truck for final delivery

Unknownincludes Puerto Rico, Virgin Islands, other U.S. Lerritories, and toreign

SOURCE" Office of Technology Assessment 
Table 2-5.-Gallons by Product Type Based on the American Petroleum institute Survey of Producers With Large Proprietary Fleets (519 Terminals)

\begin{tabular}{|c|c|c|c|c|c|}
\hline \multirow[b]{2}{*}{ Product } & \multicolumn{2}{|r|}{ Proprietary } & delivery & \multicolumn{2}{|c|}{ Jobber delivery } \\
\hline & $\begin{array}{l}\text { Number of } \\
\text { terminals }\end{array}$ & $\begin{array}{l}\text { Gallons } \\
\text { (millions) }\end{array}$ & $\begin{array}{c}\text { Average } \\
\text { distance (miles) }\end{array}$ & $\begin{array}{l}\text { Number of } \\
\text { terminals }\end{array}$ & $\begin{array}{l}\text { f Gallons } \\
\text { (millions) }\end{array}$ \\
\hline Gasoline . . . . . . . . . . . . & 349 & 16,544 & 28 & 424 & 10,588 \\
\hline Diesel fuel . . . . . . . . &. .66 & 251 & 39 & 81 & 830 \\
\hline Other distillates. . . . . . . . & . . 88 & 486 & 32 & 160 & 959 \\
\hline Propane. . . . . . . . . . . . . & 0 & 0 & - & 71 & 469 \\
\hline Other. . . . . . . . . . . . . & & & 18 & & \\
\hline Turbine fuel $\ldots \ldots \ldots \ldots$ & 2 & 75 & - & 5 & 37 \\
\hline Jet fuel . . . . . . . . . & 4 & 17 & - & 19 & \\
\hline Aviation gasoline. . . . . . . & & 0 & & 1 & \\
\hline All $\ldots \ldots \ldots \ldots \ldots$ & $349^{a}$ & 17,373 & 28 & $497^{a}$ & 13,604 \\
\hline
\end{tabular}

cent of the truck-miles. A State-to-State analysis of the CTS indicates 59.7 million tons of chemicals were moved by truck. About 60 percent of the chemical flow was intraregional led by the West South Central, South Atlantic, and Middle Atlantic regions with an average length of haul of 253 miles.

At OTA's request, several major chemical companies provided flow data on their 1983 and 1984 shipments of hazardous materials. Each of the databases included origin State, destination State, commodity, tons, and number of shipments. Combined, the firms encompass 5 percent of the tons for the flows shown in the State-to-State the CTS data. The private flow data agreed with the CTS on 8 of the 10 largest movements, although their rankings differ, indicating that the CTS may be a reasonable reflection of the major flows, although the actual volumes are questionable.

\section{Railroads}

Commodity flow analysis is the easiest for railroads. The ICC waybill database, while encompassing a 1 to 6 percent sample of all railcars, provides information on every movement of these cars, with the exception of detailed routing information. It is not possible to tell which of two or more possible tracks a car has traveled between origin and destination. The waybill shows origin and destination city and State, commodity (seven-digit STCC), number of cars, shipment weight, shipment cost rail revenue, and the railroad junctions traversed. It is based on carloads terminated by all the Class I carriers and some of the Class IIs and Class IIIs. Since
AAR took responsibility for collecting the waybills and preparing the samples in 1983, numerous edits and cross-checks have been introduced, and the quality of the sample has improved.

AAR, the major rail trade organization, maintains a comprehensive database, TRAIN II, on the movements of about 80 percent of all railcars. Each railroad participating in TRAIN II submits location and status information on all the cars on its lines. Shippers, many of whom own their own railcars, and other railroads can determine daily where their cars are and their respective status. For each car, the database includes present location at an origin, destination, or intermediate point; empty/loaded status; and the commodity being carried (seven-digit STCC). AAR presently uses TRAIN II to develop summaries of hazardous material flows; it has prepared tables of carload originations and terminations by STCC for each State, as well as tables showing U.S. flows for all hazardous commodities, ranked by total carloadings.

Most railroads, and certainly the major ones, maintain traffic flow databases. A few keep times and locations for all events in the car movement cycle,${ }^{20}$ while most keep waybill data, such as shipper, consignee, online and offline origins and destinations, cars, tons, and revenue.

This analysis of hazardous materials transported by rail was based on the waybill files for the years 1972 to 1983, and examination of the 1977 CTS.

\footnotetext{
${ }^{20}$ George F. List, et al., Evaluation of MoPac's Freight Car Scheduling Sysrem, FRA-ORRP-8 1-3 (Washington, DC: U.S. Department of Transportation, 1981).
} 
Between 1972 and 1983, the total number of hazardous records in the waybill file grew from 11,388 to 15,687 , a compounded increase of 3 percent a year. For 1983, the waybill file indicates 73 million tons of hazardous commodities were transported by rail, generating 53 billion ton-miles. Chemicals are the largest commodity group, constituting 68 percent of the tons and 66 percent of the ton-miles. Petroleum ranks second at 23 percent of tons and 20 percent of the ton-miles, followed by commodities in the "all other" category.

The largest hazard class was flammable liquids with 26 percent of the tonnage, followed by corrosive materials with 25 percent and flammable compressed gases with 12 percent. In conjunction with combustible liquids and nonflammable compressed gases, these five hazard classes account for 85 percent of the 1983 tonnage. Poisons and radioactive materials are small portions of the flows; radioactive materials are less than 0.03 percent, Poison B is less than 3 percent, and Poison $\mathrm{A}$ is less than 0.1 percent.

Origins and destinations are concentrated and the level of concentration is increasing. The waybill file shows a drop from 1,472 origin and 3,210 destination Standard Point Location Codes in 1972 to 1,129 and 2,410 in 1983, respectively. The 15 largest junction volumes are shown in table 2-6. Region-toregion flows appear in table 2-7. More than 25 percent of the flows originate in the West South Central region; more than 20 percent of them terminate there as well. The three largest flows are West South
Central to West South Central, South Atlantic to South Atlantic, and West South Central to South Atlantic. The private chemical manufacturers data confirm these flow patterns, although there are some differences due to market share.

The primary car type is the tank car, accounting for 85 percent of the tons, 79 percent of the tonmiles, and 81 percent of the car loadings. At the end of 1984, the active tank car fleet numbered 183,000 , of which 115,600 were used for hazardous materials. The majority of these were 111I As, 112s, 103s, and 105 As. Covered hopper cars ranked second in tonnage, carrying 6 percent; but intermodal flatcars ranked second in loadings and ton-miles, due to the large quantities of alcohol being shipped in trailers and intermodal portable tanks.

A breakdown of the hazardous tonnage by length of haul shows that the most tonnage travels between $\mathrm{O}$ to 250 miles, but the distribution extends beyond 4,000 miles, with an average length of haul at 728 miles.

\section{Water Transport}

Commodity flow analysis for the marine transport is straightforward but difficult. The U.S. Army Corps of Engineer's Waterborne Commerce Statistics Center (WCSC) database includes 100 percent of all commodity movements, both domestic and international, missing only military cargo moved in Department of Defense vessels. Information provided on each movement includes: origin district,

Table 2-6.-Fifteen Largest Junction Volumes, 1977 and 1983

\begin{tabular}{|c|c|c|c|}
\hline \multicolumn{2}{|l|}{1977} & \multicolumn{2}{|l|}{1983} \\
\hline Junction & Tons (000) & Junction & Tons $(000)$ \\
\hline New Orleans & 4,198 & New Orleans ......... & 5,149 \\
\hline Chicago ...... & 4,008 & East St. Louis . . . . . . . . . & 4,429 \\
\hline East St. Louis. & 3,509 & Chicago . . . . . . . . . . & 4,038 \\
\hline Kansas City . . . . . . . . . . . . & 2,768 & Shreveport . . . . . . . . . . & 3,331 \\
\hline Shreveport . . & 2,695 & Kansas City $\ldots \ldots \ldots \ldots \ldots \ldots$ & 2,508 \\
\hline Memphis . . . . . . . . . . . & 2,183 & Memphis $\ldots, \ldots \ldots \ldots \ldots \ldots$ & 2,355 \\
\hline Chattahoochee . . . . . . . . . . . & 1,918 & Cincinnati $\ldots \ldots \ldots \ldots \ldots$ & 1,491 \\
\hline Atlanta . . . . . . . . . . . . . . . & 1,716 & Richmond. . . . . . . . . . . . & 1,092 \\
\hline Montgomery. ., . . . . . . . . . . & 1,603 & Potomac Yard (Arlington, VA). . . . & 1,049 \\
\hline St. Louis. . . . . . . . . . . . . . & 1,474 & Effingham $(G A) \ldots \ldots \ldots \ldots \ldots$ & 830 \\
\hline Birmingham $\ldots, \ldots \ldots \ldots \ldots \ldots$ & 1,414 & 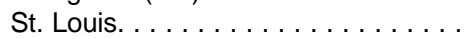 & 773 \\
\hline Cincinnati $\ldots \ldots \ldots \ldots \ldots$ & 1,379 & Corsicana $(\mathrm{TX}) \ldots \ldots \ldots \ldots \ldots$ & 770 \\
\hline Potomac Yard (Arlington, VA). . . . & 1,057 & 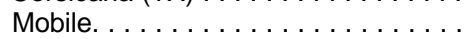 & 702 \\
\hline Effingham $(G A) \ldots \ldots \ldots \ldots \ldots$ & 757 & Fort Worth $\ldots \ldots \ldots \ldots \ldots \ldots \ldots$ & 675 \\
\hline El Paso $\ldots \ldots \ldots \ldots \ldots \ldots$ & 724 & Dallas . . . . . . . . . . . & 663 \\
\hline
\end{tabular}


Table 2-7.-Hazardous Commodity Flows by Rail According to the 1983 Waybill Statistics

\begin{tabular}{|c|c|c|c|c|c|c|c|c|c|c|}
\hline \multicolumn{2}{|l|}{ All flows in thousands of tons: } & \multirow{2}{*}{$\begin{array}{r}\text { Middle } \\
\text { Atlantic } \\
\end{array}$} & \multirow[b]{2}{*}{ South Atlantic } & \multirow{2}{*}{$\begin{array}{c}\text { East North } \\
\text { Central }\end{array}$} & \multirow{2}{*}{$\begin{array}{c}\text { East South } \\
\text { Central }\end{array}$} & \multirow{2}{*}{$\begin{array}{c}\text { West North } \\
\text { Central }\end{array}$} & \multirow{2}{*}{$\begin{array}{l}\text { West South } \\
\text { Central }\end{array}$} & \multirow{2}{*}{$\begin{array}{c}\text { Pacific } \\
\text { Northwest }\end{array}$} & \multirow{2}{*}{$\begin{array}{c}\text { Pacific } \\
\text { Southwest }\end{array}$} & \multirow[b]{2}{*}{ All } \\
\hline From I/To - & New England & & & & & & & & & \\
\hline New England .... & 985 & 53 & 37 & 28 & 6 & 1 & 7 & 2 & 3 & 1,112 \\
\hline Middle Atlantic . . & 681 & 1,710 & 542 & 827 & 110 & 103 & 495 & 10 & 54 & 4,532 \\
\hline South Atlantic .... . & 91 & 732 & 5,842 & 1,215 & 716 & 510 & 364 & 11 & 117 & 9,598 \\
\hline East North Central. & 319 & 1,470 & 820 & 2,527 & 610 & 735 & 629 & 83 & 220 & 7,413 \\
\hline East South Central . & 17 & 400 & 2,933 & 901 & 2,401 & 125 & 1,028 & 8 & 191 & 8,004 \\
\hline West North Central . & 23 & 95 & 110 & 991 & 349 & 1,739 & 642 & 102 & 245 & 4,296 \\
\hline West South Central . & 281 & 1,582 & 4,266 & 3,370 & 3,577 & 1,889 & 10,626 & 283 & 2,038 & 27,912 \\
\hline Pacific Northwest &.- & 66 & 16 & 174 & 11 & 423 & 106 & 1,551 & 488 & 2,835 \\
\hline Pacific Southwest .. & 39 & 144 & 366 & 624 & 130 & 146 & 919 & 551 & 3,331 & 6,250 \\
\hline All $\ldots \ldots \ldots$. & 2,436 & 6,252 & 14,932 & 10,557 & 7,910 & 5,671 & 14,816 & 2,601 & 6,687 & 71,962 \\
\hline
\end{tabular}

Note: Boldface indictes lop five...

SOURCE. Office of Technology Assessment 
port, dock, and date; destination district, port, dock, and date; commodity (four-digit code); shipment weight (short tons); operator; vessel description; and the waterways traversed, including entry and exit mileposts. It is based on data submitted by carriers, shippers, and vessel owners in response to comprehensive reporting requirements. However, two major information shortcomings create difficulties. First, the commodit definitions are very broad; only 30 out of a possible 163 codes pertain to hazardous materials. Second, while complete routing information exists, no mileage data are provided in the basic flow records, which means the mileage information for every flow must be computed and added to the database if ton-mile statistics are to be developed. Because of cost constraints, the OTA analysis did not develop ton-mile statistics.

Analysis of the WCSC data shows that a billion tons of cargo were shipped by marine transport in 1982. Hazardous commodity shipments constituted 55 percent of the total or 549 million tons. The flows are concentrated, as noted in table 2-8, with the 10 top region-to-region flows accounting for 65 percent of the total tonnage. Intraregional shipments in the West South Central region alone account for about 25 percent of the total tonnage. The pattern of flows follows the distribution of petroleum, since 85 percent of the hazardous tonnage is crude or processed petroleum.

From 1977 to 1982 , the tonnage increased less than 4 percent; however, the commodity mix changed significantly. Chemical shipments dropped 13 percent and petroleum products dropped 22 percent, while the "all other" category doubled in size. More importantly, the mix of chemical products changed. Fertilizers rose to the second- and thirdranked positions displacing second-ranked sodium hydroxide and third-ranked benzene and toluene. Furthermore, this trend toward declining large bulk shipments of high hazard chemicals is likely to continue. Manufacturers are substantially reducing their inventories of raw materials in a variety of ways for both economic and safety reasons. ${ }^{21}$

\footnotetext{
${ }^{21}$ Monsanto Co., One Year Later: Report of the Monsanto Product and Plane Safety Task Force (Saint Louis, MO: December 1985); and Ron Jacobsen, Distribution Manager, Rohm \& Haas, personal communication, January 1986.
}

Tankers and tanker barges are the principal vessels (91 percent); the other major vessel type is the dry cargo barge with 8 percent of the total. The fivedigit CTS database captures only 40 percent of the flows and has a vastly different breakout of commodities. It misses the two major waterborne flows, crude oil and fertilizer, because they are not manufactured products.

\section{Air Transport}

Air transport has the weakest data for analyzing hazardous materials commodity flow. The only available database is the CTS, which, as previously noted, includes shipments from point of manufacture to first destination only. Federal Aviation Administration (FAA) inspectors sometimes perform 90-day records checks, but the only information they keep is the number of hazardous class shipments, not the overall percentage or the total volume.

The CTS indicates that 52,700 tons of hazardous materials were transported by air, or 8 percent of all air cargo tonnage. Chemicals account for 80 percent of this total, consisting of cosmetics, drugs, * and agricultural chemicals including fungicides and herbicides. As maybe calculated from table 2-9, 79 percent of the tonnage, including the largest flow, is interregional, unlike the other transport modes. The average length of haul is over 1,000 miles. When the CTS data were compared with a private air carrier's records of its hazardous material flows, the inadequacy of the CTS information became apparent. The air carrier reported substantial hazardous materials shipment volumes for eight of the nine Pacific Northwest originating flows where the CTS showed no movement at all. One of these was the 12th largest region-to-region flow. Of the 72 remaining flows for other originating regions, there were 11 flows where the carrier's tonnage exceeded that shown in the CTS, and 3 more where the carrier's tonnage was nearly equal to the total shown by the CTS. Although the CTS data were for 1977 and the carrier's data for 1983 and 1984, they nonetheless demonstrate that the CTS data are not a useful reflection of hazardous material flows by air.

\footnotetext{
*Because they contain small amounts of hazardous chemicals, cos metics and drugs are regulated as hazardous materials.
} 


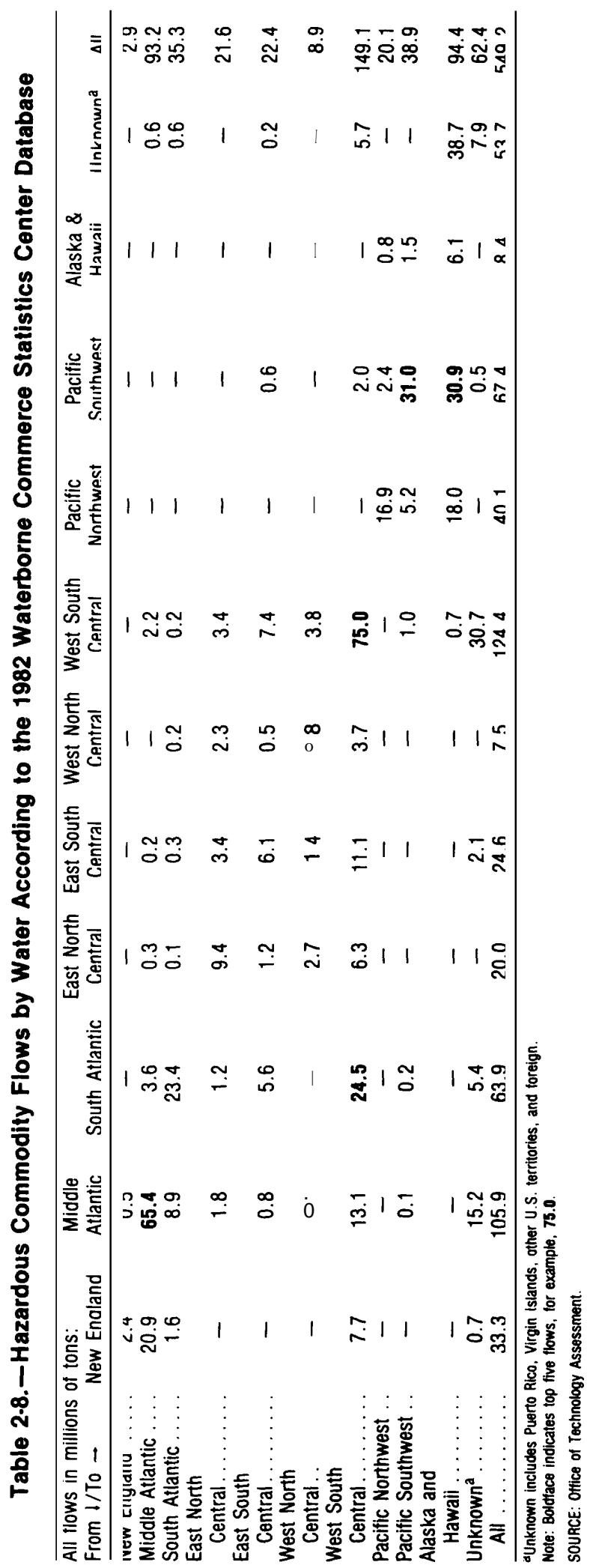


Table 2-9.-Hazardous Commodity Flows by Air According to the 1977 Five-Digit Commodity Transportation Survey Database

\begin{tabular}{|c|c|c|c|c|c|c|c|c|c|c|}
\hline \multirow{2}{*}{$\begin{array}{l}\text { All flows in thousands of tons: } \\
\text { From I/To - } \quad \text { New England }\end{array}$} & \multirow{2}{*}{$\begin{array}{l}\text { Middle } \\
\text { Atlantic }\end{array}$} & \multirow[b]{2}{*}{ South Atlantic } & \multicolumn{2}{|c|}{ East North East South } & \multicolumn{2}{|c|}{ West North West South } & \multirow{2}{*}{$\begin{array}{c}\text { Pacific } \\
\text { Northwest }\end{array}$} & \multirow{2}{*}{$\begin{array}{c}\text { Pacific } \\
\text { Southwest }\end{array}$} & \multirow{2}{*}{$\begin{array}{c}\text { Alaska \& } \\
\text { Hawaii }\end{array}$} & \multirow[b]{2}{*}{ All } \\
\hline & & & Central & Central & Central & Central & & & & \\
\hline New England ........ & 0.2 & - & 0.5 & 0.1 & - & - & - & 0.1 & - & 0.9 \\
\hline Middle Atlantic ..., . 0.2 & 2.1 & 0.9 & 1.9 & 0.1 & 0.5 & 0.8 & 0.2 & 3.9 & - & 10.6 \\
\hline South Atlantic. . . . . 0.1 & & & 0.1 & 0.5 & 0.4 & 0.1 & - & 0.3 & - & 1.8 \\
\hline East North Central . . 0.2 & 0.8 & 0.3 & 0.1 & - & 1.2 & 0.1 & - & 2.2 & - & 4.9 \\
\hline East South Central ... . - & - & 0.1 & - & - & - & 3.8 & - & 0.3 & - & 4.2 \\
\hline West North Central ... - & 0.1 & 0.1 & 0.1 & - & - & 0.3 & - & 0.1 & - & 0.7 \\
\hline West South Central . . - & - & - & - & - & 0.1 & 4.3 & - & 0.1 & - & 4.5 \\
\hline Pacific Southwest. . . 0.8 & 0.1 & - & 18.1 & - & 0.6 & 0,4 & - & 4.4 & 0.4 & 24.8 \\
\hline All $\ldots \ldots \ldots \ldots \ldots$. 1.3 & 3.3 & 1.7 & 20.8 & 0.7 & 2.8 & 9.8 & 0.2 & 11.4 & 0.4 & 52.4 \\
\hline
\end{tabular}

Note, Boldface Indicates top five flows, for example, 18.1 .

SOURCE Office of Technology Assessment. 


\section{State and Local Studies}

OTA reviewed numerous State and local information-collection projects to determine whether a Federal data system would provide useful additional information. The research uncovered a variety of approaches to State and local data collection. When a State undertakes a study, a lead agency is usually designated, often the department of transportation or State Police, with assistance provided by an office of emergency preparedness or comparable agency. For cities, municipal planning staffs, fire departments, private consulting firms, or university-based research groups do most of the data gathering and analysis.

Techniques and results vary according to the particular interests, resources, and experience of the agencies involved. Nonetheless, OTA has identified types of useful data, effective methods, and commonly encountered problems. The following kinds of studies can provide the background information necessary for planning and emergency preparedness:

Inventory of hazardous materials stored at fixed facilities. Records the quantity and type of hazardous commodities stored in manufacturing, wholesaling, distribution, or storage facilities within the jurisdiction. Data are obtained by means of questionnaires, interviews, and inspections; and from public records, such as fire inspection records and business tax records.

- Hazardous materials transportation analysis. Identifies the quantity and type of hazardous materials transported through the jurisdiction by each transportation mode and the most frequently used routes. Data are gathered by questionnaires, roadside inspections, and review of company records.

- Hazard assessment or identification of hazards and high-risk locations. Analyzes factors such as population density, transportation system characteristics, and past incidents to determine where the risk of a hazardous materials incident is greatest or where the impact would be the most severe.

An inventory of fixed facilities is often the first step in the data-gathering process. Any second step is usually a transportation analysis. A hazard assessment is frequently last, since it draws on data collected in the first two studies.

\section{Fixed Facilities Inventories}

Knowledge of the extent and nature of hazardous materials manufacture and storage in the community is essential for prevention and response planning. A facilities inventory can guide the purchase of equipment, choice of training, location of response facilities, and assignment of personnel, and can provide a good indication of the hazardous materials transported in the jurisdiction.

One of the first decisions necessary in undertaking a hazardous materials inventory is what should be inventoried and in what detail. Some jurisdictions studied by OTA chose to locate all hazardous materials, including paint thinner stored in retail stores, but most concentrated on chemicals manufactured or stored in bulk. Memphis, for example, limited its inventory to 255 manufacturing sites. ${ }^{22}$ At the other extreme, the cities of Santa Clara County, California, inventoried all materials identified by DOT as hazardous and stored in any quantity at commercial facilities, including drug stores; the inventory is kept current by the county. The majority of communities, however, have limited their surveys to selected commodities identified by the staff and advisory committees and to major facilities, measured by employment levels.

The methods used for collecting data vary. In Memphis and Indianapolis, the initial data-collection method was a questionnaire. Questionnaires sent under the auspices of the Memphis Fire Department asked for data on storage of material in 19 DOT hazard classes. Although followup to the questionnaire was a lengthy process, the city currently has information on the type, quantity, and location of stored hazardous materials, including site plans and names, addresses, and phone numbers of emergency contacts ${ }^{25}$ In Indianapolis, only 20 to 25 percent of the 1,200 local industries surveyed submitted responses to the questionnaire and ex-

\footnotetext{
${ }^{22}$ National Conference of State Legislatures, Hazardous Materials Transnortation Regional.Workshops (Denver, CO: 1983), p. 65.

${ }^{23}$ Cambridge Systematic, inc., Community Teamwork-Working Together To Promote Hazardous Materials Transportation Safety (Washington, DC: U.S. Department of Transportation, 1983), p. 6. ${ }^{24}$ U.S.Congress, Office of Technology Assessment, Transportation of Hazardous Materials: State and Local Activities, OTA-SET-301 (Washington, DC: U.S. Government Printing Office, February 1986), ch. 4 .

${ }^{25}$ National Conference of State Legislatures, op. cit.
} 
tensive followup was necessary to collect sufficient data. The Association of Bay Area Governments, around San Francisco, identified target commodities but did not have the budget or personnel to administer questionnaires. Instead, Bay Area planners produced a series of small maps, showing the locations of manufacturing firms that frequently used the selected group of hazardous materials, anticipating that each county would eventually survey individual firms. ${ }^{26}$

Santa Clara County collects information by means of a regulatory procedure, which also finances the hazardous materials control program. To obtain a business license, all firms selling, using, or producing hazardous materials must provide local officials with an inventory and pay a fee based on the amount of materials stored. The fees help support the county's emergency response team and hazardous materials inspections. Local manufacturers and merchants are advised on the proper storage and handling of hazardous materials during these inspections.

Inventories can provide information for many purposes in addition to planning. In Oregon, the Multnomah County Fire Department collects information on hazardous materials storage at fixed facilities as part of routine fire inspections. The county's Office of Emergency Management stores the information in a computer along with data on chemical characteristics of the commodities, transportation routes frequently used, and performance profiles of major carriers. The county's specialized hazardous materials team has access to this database through a computer terminal located in the response vehicle. The computer system can provide information on where a specified product can be found at the site, how it is stored, and other chemicals that may be present. The system also provides information on the characteristics of all the chemicals known to be in the county, based on DOT and other standard classifications, and the names of organizations to call for additional product information. ${ }^{27}$

\footnotetext{
${ }^{26}$ Association of Bay Area Governments, San Francisco, CA, Hazardous Spill Prevention and Response Plan, 2 vols. (Washington, DC: U.S. Department of Transportation, Research and Special Programs Administration, 1983).

${ }^{27}$ Puget Sound Council of Governments, Seattle, WA, Central Puget Sound Region Risk Analysis Report: Regional Hazardous Materials Inventory, interim report (Washington, DC: U.S. Department of Transportation, 1980).
}

\section{State Inventory Studies}

Massachusetts is one of the few States that has completed a fixed facilities inventory. For each of the State's 14 fire districts, State analysts used manufacturing directories to locate the firms with more than 100 employees that used or produced hazardous materials. ${ }^{28}$

In March 1983, the State of New Jersey passed a law requiring every firm manufacturing or handling hazardous substances to file a completed survey form with the State Department of Health and the county or local health, fire, and police departments. This information effectively provides a facilities inventory.

The State of Maryland has created a computerized registry of all toxic and carcinogenic substances stored at fixed sites. The State Department of Health and Mental Hygiene began gathering the data in 1979 with funds from an EPA grant. Currently, the registry contains inventories of more than 400 industrial users of toxic or carcinogenic substances. Updated annually, the data comprise detailed information on 54 target chemicals selected by the department, including the maximum quantities stored and how they are transported. The staff estimates that the development of the computerized registr ${ }_{y}$ system cost over $\$ 400,000$, not counting software development funded by the EPA grant, and annual operating costs. ${ }^{29}$

\section{Community Support}

The success of inventory efforts depends on the cooperation of public agencies, such as the fire and police departments, and private groups, such as chemical manufacturers, shippers, and carriers. Advisory committees can be instrumental in obtaining such cooperation. Often appointed by elected officials, such committees are usually multidisciplinary and composed of representatives from first response agencies, local industry, local and interstate carriers, public officials, educators, experts in hazardous materials, and environmentalists.

\footnotetext{
2"Energy Resources, Inc., Phase 1: Determine the Nature and Scope of Hazardous Materials Transportation in the Massachusetts Region, VolumeI (Cambridge, MA: U.S. Department of Transportation, 1982), pp. 4-36.

${ }^{24}$ Max Eisenberg, Environmental Program, Maryland Department of Health and Mental Hygiene, personal communication, March 1985.
} 
Although private sector support has at times been problematical, in April 1985, CMA announced an industrywide program designed to make chemical industry expertise available to local agencies, including furnishing planning groups with material safety data sheets on commodities manufactured and stored in the community .30 However, concerns about protecting trade secrets or other information considered to be proprietary (e.g., health or exposure data) have made some manufacturers unwilling to comply with requests for information. In response, many States and municipalities have enacted "rightto-know" laws requiring the release of information on the hazards associated with chemicals produced or used in a given facility. Such laws are useful tools for data-collection activities.

\section{Transportation Studies}

In addition to fixed facility inventories, State and local governments have tapped a variety of public and private sources to collect data on truck, rail, air, and water transportation. Small towns and rural counties are particularly interested in transportation data because they see their greatest risk as a hazardous materials accident on an Interstate highway or railroad line passing through their jurisdiction. The type and quantity of hazardous materials carried by each mode and the principal routes used comprise the information most frequently collected for planning, risk analyses, routing decisions, and emergency response preparation, Because the data-gathering problems are different for each mode, highway, rail, air, and water transport are discussed separately.

\section{Truck Studies}

State and local data-collection projects reviewed by OTA put the highest priority on information about highway transport of hazardous materials because trucks far outnumber other types of hazardous materials carriers, carry the largest share of the hazardous materials shipments, and are involved in the greatest number of accidents and spills.

Several State databases are currently being developed. New York, for example, is computerizing the data collected by its State Police during their rov-

\footnotetext{
${ }^{30}$ Chemical Manufacturers Association, press release, Washington, DC, April 1985
}

ing truck inspections. Other States with similar information include Virginia, ${ }^{31}$ New Mexico ${ }^{32}$ Washington, ${ }^{33}$ and Colorado. ${ }^{34}$

State and local planners have devised special means to collect data on highway transport of hazardous materials. The primary methods are questionnaires, visual surveys, and inspections. Several jurisdictions have sent out questionnaires to shippers, carriers, and manufacturers requesting information about hazardous materials shipments and the routes most frequently used.

Analysts in the Puget Sound Region of Washington State, using questionnaire responses, truck route locations, and other information provided by local governmental departments, mapped the routes by which 85 target commodities moved within and through the region. Memphis used a questionnaire to gather data from local shippers and manufacturers, ${ }^{35}$ although State Highway Department tax records showed that truckers substantially underreported the flammables category on the questionnaire. In a survey conducted recently of manufacturers and transporters of hazardous materials in the New York City and New Jersey area, only 20 percent of those solicited returned completed questionnaires. ${ }^{36}$

Other jurisdictions have resorted to visual surveys of trucks along major highways. Checkpoints, usually at weigh stations, are set up, and government employees or students count the placarded trucks passing through, recording the commodity class of each shipment. Moreover, several States have conducted surveys of the volume and types of hazardous materials carried by truck. In many cases, the States have had the resources and the authority to

\footnotetext{
${ }^{-31}$ Dennis $\bar{L}$, Price, et 'i' Multi-Modal Hazardous Materials Transportation in Virginia, VDOTS/SPO-16 (Richmond, VA: Virginia Department of Transportation Safety, 1981).

${ }^{32}$ James D. Brogan, "Routing Models for the Transportation of Hazardous Materials-State Level Enhancements and Modifications," prepared for presentation at the 64th Annual Meeting of the Transportation Research Board, unpublished typescript, 1985

${ }^{33}$ National Conference of State Legislatures, Hazardous Materials Transportation: A Legislator's Guide (Washington, DC: February 1984). ${ }^{34} \mathrm{Ibid}$.

${ }^{35}$ City of Memphis, Division of Fire Services, Hazardous Materials Task Force Final Report (Memphis, TN: 1981), p. 24.

${ }^{36}$ Raymond Scanlon, Port Authority of New York and New Jersey, "A Regional Study on Hazardous Materials Transportation," Howard S. Cullman Fellowship 1982-83 Report, unpublished typescript, p. 15.
} 
combine a visual survey with an inspection and driver interview.

A full-scale study was carried out in 1977 to 1978 by the Virginia Department of Transportation Safety as part of a multimodal analysis of hazardous materials transportation. During July and August 1977, all trucks passing 38 survey points on Interstate and primary roads were stopped by State or local police. Shipping papers were inspected, and the drivers were interviewed on the types of materials carried, origin and destination of the trip, and the sequence of routes taken. Officers also checked to see if the placarding was correct and classified the carrier as company-owned, independent, common carrier, or personal vehicle. The study findings provided Virginia officials with a current database on commodity flow and a good measure of the level of compliance with existing Federal and State regulations. The survey found that 13 percent of the trucks carried hazardous materials, of which 76 percent were flammable, combustible, or corrosive liquids. Petroleum products were the most common cargoes. The heaviest hazardous materials traffic was on Interstate highways in and around cities, because urban areas are the principal origins and destinations of petroleum products. The number of placarding violations found by inspectors increased from 34 percent in 1977 to 55 percent in $1978 .^{37}$

Over a l-year period from October 1981 to September 1982, Washington State surveyed the amounts of hazardous materials moving through the State and the type of carrier used. The Washington State methodology was similar to that of the Virginia study. The State Utilities and Transportation Commission set up checkpoints at 11 locations on major highways. All trucks were stopped and checked for 4-hour periods twice a month. The checks included an inspection of shipping papers and an interview with the driver about cargo, quantity carried, origin, destination, and type of carrier. The data were tabulated and sorted using the Automated Hazardous Materials Surveillance Program, a computer program designed for the study that can sort survey data according to date, location, commodity, and truck type and cross-check it with accident and violation data. Researchers found that although in-

\footnotetext{
${ }^{37}$ Price, et al., op. cit., p. XIII.
}

dependent truckers carry 50 percent of the cargo, they are involved in 75 percent of the accidents.

In 1982 and 1983, the South Dakota Department of Public Safety surveyed drivers and inspected approximately 340,000 trucks at highway checkpoints. Fewer than 1 percent of the trucks carried hazardous materials. The most common hazardous materials cargos were flammable liquids, explosives, corrosives, and flammable gases. The survey found that 55 percent of the hazardous materials shipped was intrastate, primarily flammable liquids and gases. Most intrastate shipments were local deliveries of 25 miles or less, usually originating in one of the larger cities. Although most deliveries were local, carriers indicated that their trucks spent as much as 40 percent of their time on Interstate highways.

OTA research indicates that even when a comprehensive State transportation data-collection effort has been undertaken, cities within the State are often unaware of the resource and consequently do not make use of it.

\section{Rail Studies}

Data collection on bulk rail shipments of hazardous materials is extremely important to rail distribution centers such as Memphis and Indianapolis, where data are needed for emergency planning and response purposes. Information on commodities transported, measured by rail carloads, is generally available on request from the major railroads. Information indicating the location of hazardous materials cars in the train and instructions on emergency response procedures are available on the train as well as through railroad offices. However, the availability and detail of the data depend on the extent to which the line is computerized. AAR has compiled a list of the 138 chemicals most frequently carried by the railroads. It has developed detailed fact sheets for these commodities that are incorporated into computerized train information and waybills. $^{40}$

\footnotetext{
${ }^{38}$ U.S. Department of Transportation, Materials Transportation Bureau, SHMED Program Workshop Proceedings, Salt Lake City, Utah, 1983 (Washington, DC: 1983), p. 206.

${ }^{39}$ Ibid., p. 186

${ }^{40}$ Patrick J. Student (cd.), Emergency Handling of Hazardous Materials in Surface Transportation (Washington, DC: Bureau of Explosives, Association of American Railroads, 1981).
} 
Most State and local governments do not collect rail data, although Oregon requests some data from the railroads annually on shipments within its boundaries. Two States with strong rail divisions, New York and New Jersey, do have databases, but these are derived from ICC data. In a few instances, localized data have been collected; the State of Washington $^{41}$ and Indianapolis, Indiana, ${ }^{42}$ are examples.

Massachusetts, as part of a 1981 planning project, inventoried all the major rail lines in the State and obtained information on the types and quantitiesin carloads-of hazardous materials shipped by three of the four largest railroads. Furthermore, Virginia, as part of its multimodal study, collected data from the 10 railroads serving the State. The railroads provided waybill samples for subsections of each line. With this information, analysts estimated the number of cars per day carrying hazardous materials, the tons of hazardous materials carried per day, and the number of trains containing hazardous materials cars. Corrosives accounted for almost half the volume of hazardous materials transported by rail, followed by flammable liquids, and nonflammable compressed gas. The heaviest rail flow of hazardous cargo was in and around cities, a reflection of the demand for petroleum products in urban areas. ${ }^{43}$ Finally, the State of Oregon requires annual summaries by milepost segment of all rail shipments of Class A explosives and poisons. These data are used for emergency response planning.

\section{Air Transportation Studies}

The transportation of hazardous materials by air is controlled by the FAA's Civil Security Division. Since hazardous shipments account for less than 3 percent of total hazardous materials tonnage moved nationally and since shipments, though numerous, are generally small, State and local governments have not been particularly concerned about air transport. Only Virginia has collected any primary data, ${ }^{44}$ consisting of information on hazardous ma-

\footnotetext{
${ }^{41}$ National Conference of State Legislatures, Hazardous Materials Transportation: A Legislator's Guide, op. cit.

${ }^{42} \mathrm{City}$ of Indianapolis, Demonstration Project To Develop a Hazardous Materials Accident Prevention and Emergency Response Program: Final Reports, Phases Z-IV (Washington, DC: U.S. Department of Transportation, Research and Special Programs Administration, 1983). ${ }^{43}$ Price, et al., op. cit., PP. '13"1 15

${ }^{44}$ Ibid.
}

terials passing through many of its major airports. However, FAA conducted surveys of the types and quantities of hazardous materials shipments at the New Orleans, Memphis, and Boston airports, and provided local planners with the data. Data on shipment characteristics for air freight carriers can be obtained to augment FAA data. Local planners do not have access to information on hazardous materials carried by military aircraft.

\section{Water Transportation Studies}

Ports play an important role in hazardous materials commerce. For example, 4.5 million tons of hazardous materials pass through the Port of Seattle each year-about 27 percent of the total cargo handled. Over half of the Nation's chemicals move through the Port of Houston annually. State and local planners rely on data from the Army Corps of Engineers as their primary data source. The Corps provided Massachusetts researchers with the annual tonnage by commodity group for 1978 for both Boston Harbor and the nearby New Bedford Harbor. However, the data classification system used by the Corps does not always identify specific commodities-for example, the "Basic Chemicals" category contains some nonhazardous materials. This leads to overestimates of the actual amounts of hazardous materials, but none of the States or cities contacted by OTA found this a sufficient reason to conduct an additional study. Two port cities, Seattle and Boston, supplemented the Corps' data with information on tonnage of commodities available from local regulatory agencies and the U.S. Coast Guard.

\section{Shipments of Radioactive Materials and Wastes}

In 1973 to 1975 and 1977 to 1981 , two series of studies involving a number of States were conducted jointly by NRC and DOT for the purpose of collecting information on the transportation of lowlevel radioactive materials. Data were gathered on low-level radioactive waste sites; shipments by highway, air, and water; and the history of accidents and incidents. Findings were used to determine gaps in Federal regulatory programs and in Federal and State enforcement efforts. ${ }^{45}$

'jStephen N. Salomon, State Surveillance of Radioactive Materials Transportation, NUREG-1OI5 (Washington, DC: U.S. Nuclear Regulatory Commission, Office of State Programs, 1984), p. 5. 
Data on movement for high-level radioactive materials and wastes, including spent fuel, are treated differently from other hazardous materials databoth legally and institutionally. DOT has primary responsibility for monitoring low-level radioactive materials and wastes, while DOT and NRC share regulatory and enforcement authority for high-level radioactive materials and wastes. NRC requires licensees to provide advance notice for certain nuclear shipments; to provide physical protection of special nuclear materials including spent nuclear fuel to prevent theft, diversion, or sabotage; and to notify NRC regional offices of impending special shipments of nuclear materials. A study conducted by the Battelle Memorial Institute for DOT analyzed States' use of the information on transport shipments of spent nuclear fuel through their jurisdictions. Of the States surveyed, 14 out of 15 maintain a file of notifications. Five States pass the information on to other State agencies; two make subsequent notifications to other divisions of the same agencies; and six subsequently notify officials at both the State and local levels. Two States make no further notification for security reasons. The primary benefit of notification identified by almost all States surveyed was that awareness of impending shipments allowed them to take precautions and alert emergency response agencies. ${ }^{46}$

\section{Registration Notification Requirements as Tools for Data Gathering}

OTA examined registration and notification requirements as potential data resources for hazardous materials planning. The most basic information needed is the identities and locations of suppliers, manufacturers, and carriers of hazardous materials. A governmental entity may acquire this information by requiring such firms to register. Although it has the authority to do so, RSPA does not have a registration program and thus has no complete record of the firms it regulates or their locations. Because RSPA cannot provide this basic information, some State and local governments have imposed their own registration requirements. Pennsylvania, California, and Denver, for example, require registration. However, the purpose of the Denver

\footnotetext{
${ }^{46}$ Battelle Memorial Research Laboratories, Battelle Human Affairs Research Center, Assessment of Stare and Local Notification Requirements for Transportation of Radioactive and Other Hazardous Materials (Seattle, WA: Jan. 11, 1985), pp. 88-112.
}

registration program, enacted in 1985 , is not primarily to gather information, but rather to fund enforcement activities. ${ }^{47}$

State and local governments typically give two reasons for enacting notification requirements: to provide data for planning (including better routing and safety regulations), and to improve emergency response. The Battelle study, cited above, identified 136 State and local notification laws pertaining to hazardous materials transportation. Over two-thirds of the jurisdictions identified information needs for planning as an important reason for their laws, citing the need to know about the types and quantities of materials shipped through their jurisdictions, trip scheduling, and routes frequently used. Many also indicated they require advance notification to alert response teams when a potentially hazardous shipment is due.

The study concluded that most of these regulations produce little usable data either because they apply to a very narrow range of materials or because they are not enforced. For further discussion of registration and notification issues, see chapter 4 .

\section{Hazard and Risk Assessments}

Federal Risk Assessment.-During the last decade, the Federal Government has sponsored a number of efforts to formulate risk assessment models and apply them to hazardous materials transportation safety. The Coast Guard, for example, used models originally developed for emergency response purposes as the basis for its Population Vulnerability Model, which calculates the travel and chemical reactions of marine cargo spills over time, and estimates their effects on the surrounding population and property. Sandia Laboratories quantified the severities of hazardous materials transportation accidents in the air, truck, and rail modes. ${ }^{49}$ Battelle Pacific Northwest Laboratory used Sandia's results to develop a general risk assessment methodology, which was first applied to truck shipments

\footnotetext{
47 Cathy Reynolds, Denver City Council, in U.S. Congress, Office of Technology Assessment, "Transcript of Proceedings-Transportation of Hazardous Materials Advisory Panel," unpublished typescript, June

27 . 1985 . o. 230 . tive Risk Assessment Techniques in the U.S. Coast Guard Regulatory Process, NMAB-402 (Washington, DC: National Academy Press, 1982),

${ }^{49}$ R.K. Clarke, et al., Severities of Transportation Accidents, SLA74-0001 (Albuquerque, NM: Sandia National Laboratories, 1976).
} 
of radioactive materials, ${ }^{50}$ and later extended to other modes of transportation and to other hazardous materials transportation by truck and rail in the Central Puget Sound Region.

DOT has sponsored several risk assessments concerning the rerouting of hazardous materials. For example, a computer-based network model of the U.S. rail system was used to study the effects on risk levels of a policy to reroute railroad shipments of hazardous materials to avoid populated areas. ${ }^{52}$ The model was also used in conjunction with a study of catastrophic derailment risks. ${ }^{53}$ Risk-based criteria have been developed to enable State and local authorities to designate routes for truck shipments of hazardous materials. DOT has also sponsored the development of risk assessment worksheets and guidelines for large and small community routing and emergency planning. ${ }^{54}$

State and Local Hazard and Risk Assessment.Public concerns about the risks of hazardous materials transportation are likely to persist and intensify, accentuating the need for risk or hazard assessment at the regional level. This generally consists of two stages: 1) the development of an inventory of hazardous materials activity and exposure in the region, and 2) the estimation and evaluation of risks based on that information. OTA finds that the first stage can be performed very well at the State and local level. In fact, the data-collection process can be beneficial in itself, because of the contacts and communication it fosters. It is the process of evaluating the risks and making decisions based on them that has been the source of difficulty, especially in

\footnotetext{
${ }^{50}$ T.l. Sweeney, et al., An Assessment of the Risk of Transporting Plutonium Oxide and Liquid Plutonium Nitrate by Truck, Report No. 1846 (Richland, WA: Battelle Pacific Northwest Laboratory, 1975).

"W.B. Andrews, Hazardous Materials Transportation Risks in the Puget Sound Region (Richland, WA: Battelle Pacific Northwest Laboratory, 1981),

${ }^{52}$ TS Ślickman, "Rerouting Railroad Shipments of Hazardous Materials To Avoid Populated Areas," Accident Analysis and Prevention, vol. 15, No. 5, 1983, pp. 329-335.

${ }^{53}$ T S.Glickman and D.B. Rosenfield, "Risks of catastrophic Derailments involving the Release of Hazardous Materials," Management

Science, vol. 30, No. 4, 1984, pp. 503-511.
${ }^{54}$ E.J. Barber and L.K. Hildebrand, Peat, Marwick, Mitchell \& Co., Guidelines for Applying Criteria To Designate Routes for Transporting Hazardous Materials, FHWA-IP-80-20 Implementation Package (Washington, DC: Federal Highway Administration, 1980); and E.R. Russell, et al., A Community Model for Handling Hazardous Materials Transportation Emergencies (Washington, DC: U.S. Department of Transportation, Research and Special Programs Administration, 1981).
}

the cities where disputes over routing decisions have reached the courts. The worksheet approaches developed under DOT sponsorship for highway routing $^{55}$ and community planning ${ }^{56}$ are helpful, but insufficient, because they reduce the results to a single number known as "expected risk." A risk profile showing frequency in comparison to consequence is more helpful than a single number, which provides no insight into whether the concern is about frequent spills that may be of low consequence (gasoline, for example) or infrequent spills of a more dangerous substance like chlorine, and does not usually indicate the uncertainty of the risk estimate.

The importance of making regionally acceptable risk-based decisions suggests that DOT could provide State and local governments with better tools for risk assessment. The technical complexities of a thorough risk assessment could be handled through an assistance program similar to the one employed by the Urban Mass Transportation Administration for those using the Urban Transportation Planning System (UTPS) computer software as a basis for regional transportation planning. ${ }^{57}$ A computer model estimating population at risk along transportation corridors has been developed at Oak Ridge National Laboratory. The model may be revised for microcomputers, and with a good user's manual could be a useful risk assessment tool for State and local governments. ${ }^{58}$ In addition, following the UTPS precedent, a program of training courses could be established and a staff organized for system maintenance and assistance to the users. This type of program would provide practical assistance for jurisdictions considering routing alternatives.

OTA reviewed a number of State and local hazard and risk studies, because they are important for contingency planning, for practical decisions about locating response equipment and allocating manpower, and for developing routing plans. This last area, routing, has been the source of a great deal of interjurisdictional conflict; for further discussion, see chapter 4.

\footnotetext{
${ }^{55}$ Barber and Hildebrand, op. cit.

${ }^{56}$ Russell, et d., op.

${ }^{57}$ U.S. Department of Transportation, User-Oriented Materials for UTPS-An Introduction to Urban Travel Demand Forecasting (Washington, DC: 1977).

${ }_{58}^{5}$ dward L, Hillsman, Research Staff, Oak Ridge National Laboratory, personal communication by letter, $\mathrm{Ma}_{\mathrm{y}} 15,1986$.
} 
Few jurisdictions have used sophisticated mathematical techniques of risk analysis to estimate the probability of an incident and its severity. Most communities find it adequate to map the areas where the risk of a hazardous materials incident is highest or where there would be the greatest public danger or the most damage. Data for this type of study can be assembled either from a fixed facility inventory or a transportation study. Much useful information is also available from public records routinely kept for other purposes by State and local public works, transportation, environmental, and planning departments. Normally, a hazard assessment requires the following kinds of information:

- transportation network maps and descriptions;

- highways and streets used by hazardous materials carriers;

- tunnels, bridges, and rail crossings;

- railroad yards and truck terminals;

- highway, rail, air, and water accident data;

- locations of past hazardous materials incidents and materials involved;

- concentrations of hazardous materials manufacturing or storage sites;

- areas of high population density and environmental sensitivity;

- location of schools, hospitals, and other especially vulnerable sites; and

- water supply and sewer facilities.

A risk assessment could also include special analyses of the types and quantities of hazardous materials transported through the community and the location of emergency response teams and equipment.

\section{Conclusions}

OTA finds that Federal data-collection activities provide modal transportation data of varying completeness. OTA experience in analyzing many Federal databases for this report establishes that data integration is not a technical problem; with careful analysis, comparative data on commodity flow can be developed. However, the quality of the data is not outstanding, and the data are incomplete innumerous areas, particularly for truck and air transport. These shortcomings mean that current policy decisions must be based on inadequate information, a separate concern that warrants further study. ${ }^{59}$ OTA concludes that if RSPA were to conduct analyses of existing data similar to that undertaken for this study, it would benefit by having aggregate commodity flow information to use as a denominator in analyzing its spill and accident records. Such data might not completely satisfy State or local needs for information about shipments, but they can show State-to-State and regional transportation patterns.

Furthermore, OTA concludes that State and local data collection has enormous value in and of itself. The information gathered is only part of that value; the communication, cooperation, and coordination between the public and private sectors that are an inevitable result of the effort are extremely important. Community right-to-know laws are useful tools for State and local governments in obtaining data, and national right-to-know legislation would bolster implementation of such laws, where industry resistance remains.

Some city officials and planning personnel have continued to express a need for a national commodity flow data resource. An annual printed summary provided by DOT is most frequently mentioned, and OTA concludes that annual DOT summaries of shipments would provide useful national, regional, and State flow pattern information. Although some desire for real-time notification of especially high-hazard shipments has been voiced, emergency response officials consulted by OTA generally prefer to do local inventories and transportation surveys and to prepare their personnel for any eventuality. They point out that detailed real-time information would be overwhelming to track and useless for planning and preparedness. ${ }^{60}$ As one fire chief said: "What am I supposed to do? Follow the truck around waiting for an accident to happen?",

However, some local officials who want real-time tracking of hazardous materials, have called for DOT to develop a publicly accessible database to

\footnotetext{
${ }^{59}$ Martin Crutsinger, "U.S. Statistical Problems Seen, "Washington Post, Mar. 18, 1986, p. El.

${ }^{6}$ U.S. Congress, Office of Technology Assessment, Transportation of Hazardous Materials: State and Local Activities, op. cit., ch 4.

${ }^{61}$ Thomas Hawkins, Jr., Chief, Arlington County Fire Department) Arlington, VA, personal communication, January 1986.
} 
provide information on shipments. ${ }^{62}$ Such realtime data are probably the only way to keep current on shipments if that is the goal, since many hazardous materials orders are for truck delivery within 36 hours or less. Other shipments are seasonal, related to agricultural or manufacturing cycles. Finally, customers may suddenly change supply sources for economic reasons, rendering periodic data collection instantly obsolete. The technological groundwork for a real-time system to track hazardous waste shipments, which represent less than 1 percent of hazardous materials shipments, has been developed by a private firm, although the system has not been tested in operation.

However, even if the technical difficulties for implementing such a system for all hazardous materials could be resolved, the cost has been estimated to be more than $\$ 100$ million. ${ }^{63}$ OTA finds that while development of a real-time database limited to tracking only certain highly hazardous shipments is technically feasible, its utility for emergency response is questionable. Furthermore, development of online telephone access to real-time information on all hazardous materials shipments is not feasible, nor would it be cost-effective.

If Congress chooses to provide support for data gathering, several options are available. DOT could

\footnotetext{
${ }^{62}$ The National League of Cities (NLC) has retained in its transportation position paper a request for a U.S. Department of Transportation report on commodity flow. Barbara Harsha, NLC transportation staff, personal communication, January 1986.

6) Mulholland, Source Data Network, personal communication, November 1985.
}

be required to exercise its authority under 49 U. S. C., Section 1805(b) and develop a registration program for hazardous materials shippers, transporters, and container manufacturers. OTA finds that a registration program would provide DOT with essential information about the community it regulates and with some commodity shipment information that could be made available to State and local jurisdictions. DOT could make use of the information for setting priorities for rulemaking, research, and for enforcement actions. A modest registration fee could be imposed to cover costs of administering the program.

In addition, Congress could require DOT to integrate, analyze, and report annuall on trends from relevant Federal databases kept by the modal administrations and the Bureau of the Census. For this effort to be effective:

- The collection of data on truck movements must be improved.

- Conversion or bridge tables for the commodity codes used by different agencies and in 49 CFR, Section 172, must be created. Alternatively, each agency might be required to use a common code for commodities.

- Sufficient funds must be allocated to support the effort. OTA estimates that the equivalent of one man-year of effort, between $\$ 45,000$ and $\$ 75,000$, would provide a modest start.

Finally OTA finds that a summary of commodit flow data in comparison with DOT accident data in the required annual report to Congress would be useful.

\section{PART ॥: ACCIDENT AND SPILL INFORMATION SYSTEMS}

Statistics generated by hazardous materials accident and spill databases can be used within agencies and departments to measure program effectiveness, to improve accident and spill prevention by identifying and analyzing causes and events, and for regulatory and enforcement analysis. A reliable incident/accident database can also be used to im-

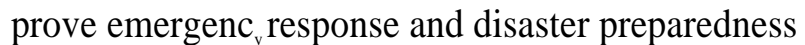
by identifying trouble spots. Knowledge of high accident frequency locations and the flow of hazardous materials provides communities with an under- standing of the probability of an accident or spill and the materials likely to be involved, tools for risk assessment.

\section{Spill Report Systems}

Each of the DOT modal administrations keeps separate modal accident data, and several agencies keep data specifically on releases of hazardous materials. However, RSPA is the official DOT repository of hazardous materials release information. A 
transportation-related incident or release is defined in DOT regulations as any unintentional release of a hazardous material during transportation, or during loading/unloading or temporary storage related to transportation. Every release, except for those from bulk water transporters and those motor carrier firms doing solely intrastate business, must be reported to RSPA in writing as prescribed in 49 CFR, Parts 171, 174.45 (rail), 175.45 (air), and 176.48 (marine vessels). The only other exceptions are consumer commodities that present a limited hazard during transportation, such as electric storage batteries and certain paints and materials. These exceptions do not apply to hazardous waste releases or those involving aircraft. A written response must be prepared by the carrier on a prescribed form, F5800.1 (see figure 2-2), and submitted to RSPA within 15 days of discovery of the release. While carriers are required to report, any interested party may report. A RSPA contractor logs the written report information into a computerized database.

This database, called HMIS, became the central system for spill data in 1971. Prior to that time, hazardous materials regulatory authority had been divided among DOT modal administrations, and a wide range of hazardous materials reporting systems had evolved. Since collecting and maintaining this data became a RSPA responsibility, the only major change in the incident reporting requirements occurred in 1981, when battery spills and spills of less than 5 gallons of paint were eliminated from required reporting, reducing the number of reports processed by RSPA considerably. The HMIS database is the only one devoted exclusively to hazardous materials transportation spills, and consequently is the one most useful for examining packaging, labeling, accident cause, and safety issues.

Carriers are also required to make an immediate telephone report to the National Response Center (NRC) when a spill has resulted in one or more of the following consequences as a direct result of the hazardous material:

- a fatality;

- a serious injury requiring hospitalization;

- estimated carrier or other property damage exceeding $\$ 50,000$;

- fire, breakage, or suspected contamination involving the shipment of radioactive materials or etiologic agents; and
- a situation such onature that th ${ }_{\mathrm{e}}$ carrier judges should be reported. ${ }^{64}$

NRC is staffed 24 hours a day by the Coast Guard and handles the reporting of all significant hazardous materials spills under agreements with DOT and EPA. Established in 1974, NRC has two 24-hour toll-free telephone lines to receive notifications and several other lines to relay calls to emergency response agencies that may need to know of the release. However, the NRC telephone number does not appear in DOT's Emergency Response Guidebook.*

Telephone reports received by NRC are logged every evening into a computer operated at the DOT Transportation Systems Center where the information is retained and managed by RSPA. RSPA uses the NRC telephone reports occasionally, for serious releases, but relies primarily on the written reports that it receives directly as the basis for its database on incidents, casualties, associated damages, and a multitude of descriptors related to the material, container, cause, and location of the release.

In many cases, carriers involved in a release have telephoned CHEMTREC, a chemical transportation emergency center established in 1971 by CMA. Since 1980, CHEMTREC has been required to notify NRC of significant hazardous materials transportation releases - those which have or might cause considerable harm to the public or the environment. A call to CHEMTREC fulfills only the NRC telephone reporting requirements; it does not fulfill the Federal written reporting requirements. The CHEMTREC toll-free telephone number is given in DOT's Emergency Response Guidebook.

Although reporting releases is a regulatory requirement, OTA found evidence that the compliance rate is low. One State official has estimated that 30 to 40 percent of reportable hazardous materials incidents are never reported. ${ }^{65}$ EPA Region VII officials have independently estimated that only about 10 percent of all reportable releases under 100 gal-

\footnotetext{
${ }^{64} 49$ CFR 171.15 .

*U.S. Department of Transportation publishes and distributes the Emergency Response Guidebook free of charge on request. It contains examples of hazardous materials marking and shipping information and basic guidance on appropriate first response actions.

${ }^{65}$ Stephen W.Ballou, "MemoFrom Iowa Department of Water, ${ }^{\text {ir }}$ and Waste Management," unpublished typescript, May 6, 1985.
} 
Figure 2=2.-DOT incident Report Form F5800.1

DEPARTMENT OF TRANSPORTATION

\section{HAZARDOUS MATERIALS INCIDENT REPORT}

INSTRUCTIONS: Submit this report in duplicate to the Director, Office of Program Support, Materials Transportation Bureau, Department of Transportation, Washington, D.C. 20590, (ATTN: DMT-412). If space provided for any item is inadequate, complete that item under Section H, "Remarks", keying to the entry number being completed. Copies of this form, in limited quantities, may be obtained from the Director, Office of Program Support. Additional copies in this prescribed format maybe reproduced and used, if on the same size and kind of paper.

1 INCIDENT

1. TYPE OF OPERATION

$1 \square$ AI R $2 \square$ HIGHWAY 3 RAIL $4 \square$ WATER $5 \square$ FORWARDER $6 \square$ OTHER

2. OA TE AN O TIME OF INCIOEN T (MONTh DeY Year) 3. LOCATION OF INCIOEN

\section{-}

B REPORTING CARRIER, COMPANY OR INDIVIDUAL

\begin{tabular}{l|l} 
4. FULL NAME & 5. AODRESS (Number, Street, Ci ty, slete and Zip Code)
\end{tabular}

6. TYPE OF VEHI CLE OR FACILITY

SHIPMENT INFORMATION

\begin{tabular}{l|l}
\hline 7. NAME AN O A DDRESS OF SHIPPER (Orı ın address) & 9. NAME AN O ADDRESS OF CONSIGNEE (Destination $\bullet$ ddress)
\end{tabular}

10. SHIPPING PAPERS ISSUED BY

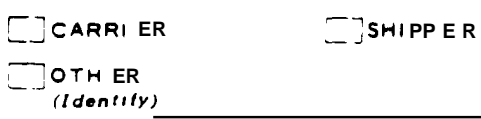

4. ES TIMATED TOTAL QUANTITY OF HAZARDOUS MATERIALS RE LEASED dollers)

S

IA ZARDOUS MATERIALS INVOLVED 15. HAZARD CLASS ("Sec. 172.101, Col, 3) 16. SHIPPING NAME ('Soc. 172.101, Col. 2) 17. TRADE NAME

IATURE OF PACKAGING FAILURE

8. (Check all oppli cable boxes)

\begin{tabular}{|c|c|c|}
\hline ( $\|$ DROPPED I N HAN OL I NG & (2) EXTERNAL PUNCTURE & (3) DAM AG E BY OTHER FR EI GHT \\
\hline (4) WATER DAM AGE & (S) DAM AGE FROM OTHER LIQUI D & (6) FREE ZI NG \\
\hline (7) EXTERNAL HE AT & (8) INTERN AI_ PRESSURE & (9 I CO RRO SION OR RUST \\
\hline $\begin{array}{l}\text {, } 101 \text { DE FECTI VE FITTINGS, } \\
\text { VALVES. OR CLOSURES }\end{array}$ & $\begin{array}{l}\text { (11) LoOS EE FIT'T' NGS, VALVES OR } \\
\text { CLOSURE S }\end{array}$ & $\begin{array}{l}\text { (12) FAILU UE } \\
\text { RECEPTA } \& \text { FES N N R R }\end{array}$ \\
\hline ( 13) 60 TTOM FAILURE & (14) BOOY O R S1 DE FAILURE & (1S) WEL O FAIL U RE \\
\hline (16) CHIME FA। L U RE & (17) OTHER CONDITIONS (Identify) & 19. SPACE FORDOT USE ONLY \\
\hline
\end{tabular}


Figure 2-2.-DOT Incident Report Form F5800.1-Continued

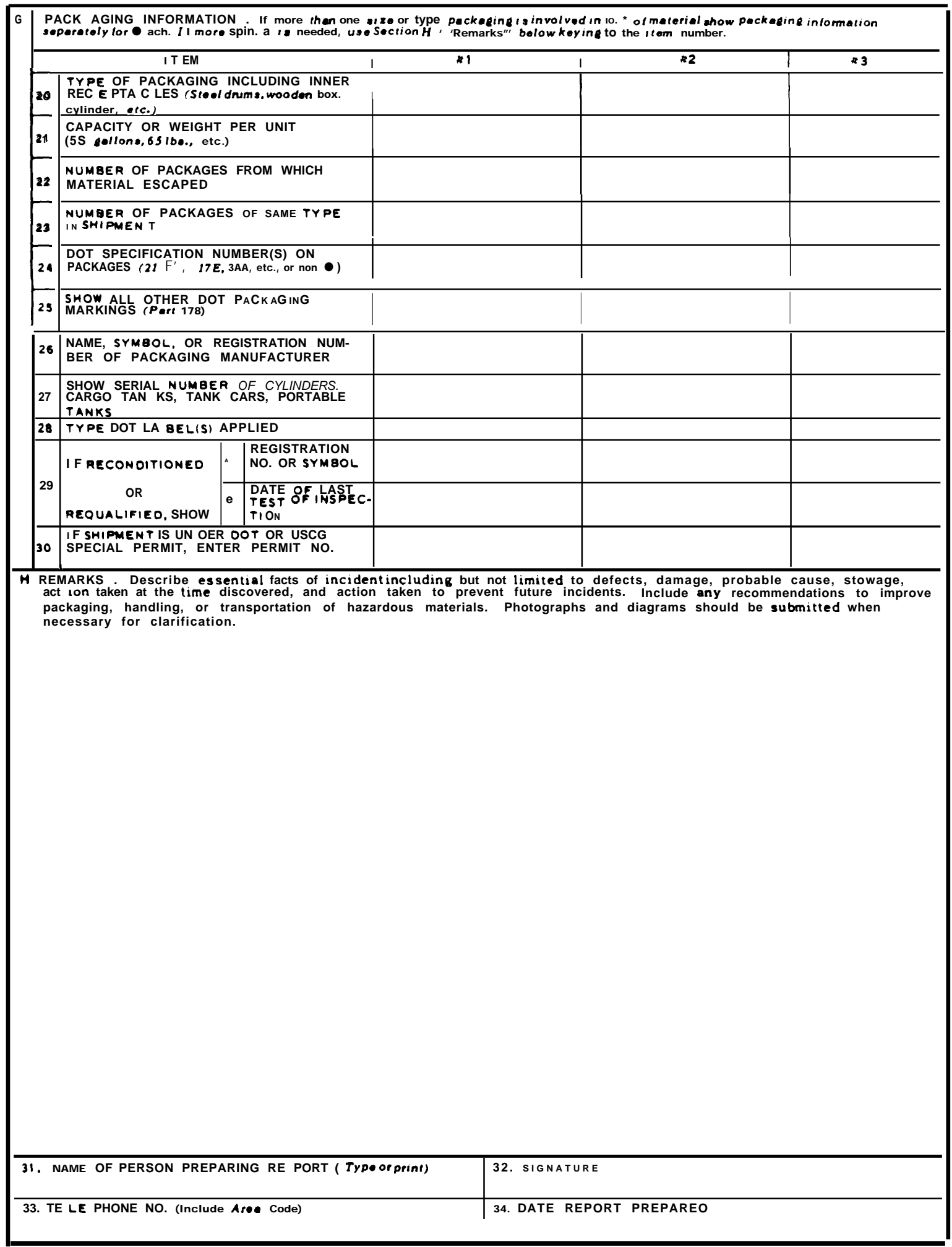


ions are reported to EPA, the States, or NRC, although 90 percent of releases over 100 gallons are reported; and 20 percent of all polychlorinated biphenyl releases are reported. ${ }^{66}$ Transportation spills constitute 26 percent of the total number of incident reports compiled by this EPA region. ${ }^{67}$

The hazardous materials regulated community is so large that inspection of every facility, manufacturer, shipper, and carrier is not feasible. Enforcement agencies use a variety of criteria to determine how best to deploy their inspection resources, and violation and release records are frequently used to identify areas on which to concentrate inspection efforts. The Coast Guard, for example, has redirected its inspection efforts to "high-priority" vessels, the definition of which includes a vessel with a reported previous hazardous materials incident. BMCS and the Federal Railroad Administration also use selection criteria to determine inspection priorities, based in part on release experience. ${ }^{68}$ However, since compliance with the release reporting requirement is low, many firms go for years without seeing an inspector, and problems remain uncorrected.

The incentive for reporting, as required by the Federal enforcement program, is to avoid the possibility of a civil or criminal penalty that can be imposed if a person knowingly violates a Hazardous Materials Transportation Act regulation. Civil penalties, more common than criminal penalties, can include a liability of up to $\$ 10,000$ per violation or 1 year imprisonment, or both. Criminal penalties are subject to a fine of up to $\$ 25,000$ or 5 years imprisonment, or both. However, even when violators are penalized, the level of the penalty is often insufficient to deter future violations, because the costs of compliance are greater than those of potential penalties. Thus, some operators consider penalties to be an occasional cost of doing busi-

\footnotetext{
${ }^{66}$ ICF, Inc., "Economic Analysis of Reportable Quantity Adjustments Under Sections 102 and 103 of the Comprehensive Environmental Response, Compensation, and Liability Act," unpublished typescript, March 1985.

${ }^{67}$ William J. Keffer, "Incident Activity Report," periods covering June-August 1985, memo to distribution, U.S. Environmental Protection Agency Region VII.

${ }^{68}$ U.S. Department of Transportation, Research and Special Programs Administration, A Guide to the Federal Hazardous Materials Transportation Regulatory Program (Washington, DC: January 1983).
}

ness. ${ }^{69}$ For further discussion of penalty levels, see chapter 4.

Despite widespread mistrust in the reliability of the HMIS, its information is acknowledged to be the best available, and frequent requests for Federal accident and spill data come from the private sector, including legal professionals, industry analysts, private citizens, consultants, and university researchers. In most cases, DOT handles these through distribution of a hard copy of the requested material, although a few databases are also accessible through online queries via telephone access.

\section{Modal Accident Data Systems}

Independent of the RSPA release reporting system are several accident reporting systems maintained by various modal administrations.* These systems were designed to cover all transportation accidents under the jurisdiction of the particular administration, not just those involving hazardous materials. In many cases, however, special identifiers have been placed in the reporting format that permit the designation of an accident involving hazardous cargo. These databases are useful secondar data, as the accident reports are usually based on reporting procedures independent of RSPA procedures, and thus are not subject to the same deficiencies. However, the different agencies use different location codes for accidents, ranging from point codes to relative location from a nearby town, making it difficult to identify routes where route characteristics may contribute. In addition, other sources of information exist that are useful for understanding releases and accidents related to the transportation of hazardous materials.

The Coast Guard maintains two databases that include recognition of accidents and spills involving hazardous materials: 1) the Commercial Vessel Casualty File (CVCF), and 2) the Pollution Incident Reporting System (PIRS). These databases could be

\footnotetext{
${ }^{69}$ National Conference of State Legislatures, Hazardous Materials Incident Reports (Washington, DC: U.S. Department of Transportation, Research and Special Programs Administration, February 1984).

*Th term "accident" refers to a vehicular accident. Most hazardous materials transport releases are not caused by vehicular accidents themselves, but by other causes such as faulty valves or closures. Conversely, most vehicular accidents do not involve vehicles that are transporting hazardous materials.
} 
used to fill a gap in the HMIS, which is particularly weak in the marine mode.

CVCF includes all vessel accidents, both domestic and foreign, occurring since 1963 in U.S. waters, subject to the following criteria:

- actual physical damage to property in excess of $\$ 25,000$;

- material damage affecting the seaworthiness, maneuverability, or efficiency of a vessel;

- stranding or grounding (with or without damage);

- loss of life; and/or

- injury causing any person to remain incapacitated for a period in excess of 72 hours, except injur to harbor workers not resulting in death and not resulting from vessel casualty or vessel equipment casualty.

The records include vessel characteristics, event, cause, fatalities/injuries, and monetary damage; specific vessel codes indicate whether the vessel was carrying hazardous cargo.

The PIRS database consists of reports generated in response to requirements of the Federal Water Pollution Control Act and the Comprehensive Environmental Response, Compensation, and Liability Act. It includes all polluting releases into U.S. waters and identifies transport-related releases by hazardous substance name. The database also includes the quantity released, cause of the incident, and the date and location. ${ }^{71}$ According to Coast Guard officials, the PIRS database has unedited files where major errors often appear, and only closed cases are available for analysis from the database.

The Bureau of Motor Carrier Safety has maintained a database on accidents since 1973. It includes any motor carrier accident in which a fatality or injury occurred or for which at least $\$ 2,000$ in property damage was incurred. Reports are filed on Form 50-T, which requests carrier identification and address, location of the incident, characteristics of the event, cause, information on the cargo, and consequences of the accident. The carrier identification, cargo description, and certain accident character-

\footnotetext{
7.S. Coast Guard, Coding Instructions for the Automated File of Commercial Vessel Casualties (Washington, DC: February 1984).

"'U.S. Coast Guard, Polluting Incidents In and Around U.S. Waters, Calendar Year 1981 and 1982 (Washington, DC: December 1983).
}

istics are recorded, so that congruence between the HMIS database and BMCS database maybe achievable for releases caused by vehicular accidents.

The Federal Railroad Administration maintains its own accident/incident database from information generated by railroads, inspectors, and RSPA. The database includes information similar to the accident characteristics described in the Coast Guard and BMCS databases, although FRA has its own definition of incidents and accidents. FRA performs a number of internal consistency checks to strengthen the validity of the database. These include the elimination of double-counting of events when more than one railroad files a report, spot checks of suspicious events, and occasional audits of railroad internal records. Over the past 10 years, over 80,000 records have been included in the FRA file. Approximately 1,000 of these have involved releases of hazardous materials. FRA also maintains an RSPAenhanced database on hazardous materials spills, which includes accident location information, railroad code, and STCC.

The Federal Aviation Administration maintains a computerized accident/incident database at its $\mathrm{Na}-$ tional Field Office in Oklahoma City. This database consists of air accidents officially reported to the National Transportation Safety Board (NTSB) and reports filed by FAA field inspectors. FAA makes a distinction between an accident and an incident based on the dollar damage incurred in the reported event. The FAA database includes the pilot involved, the carrier, time-of-day, and other descriptors such as contributing circumstances and accident (incident) severity. It is apparently possible to identify hazardous materials accidents/incidents in this database; according to FAA officials, 11 accidents/incidents involving hazardous materials have been reported in the past 5 years. Although OTA made several requests for additional information, FAA did not respond.

The National Highway Traffic Safety Administration's (NHTSA) National Center for Statistics and Analysis maintains accident data on policereported accidents, including those resulting in nonfatal injury and/or property damage. The file, the National Accident Sampling System (NASS), was developed to provide an automated, comprehensive national traffic accident database. The accidents investigated in NASS are a probability sample of 
all police-reported accidents in the United States. The data for a NASS-selected accident is collected by each State under contractual agreement with NHTSA and includes characteristics of the accident, driver, occupants, and vehicle. Data relevant to this study include the vehicle number, type of carrier, and whether BMCS regulated; characteristics of the roadway where the accident occurred, vehicle body type, body/trailer configuration, vehicle curb and cargo weight; and impact of the accident. Although the specific commodity being carried is not described, sufficient information exists to track accidents likely to involve hazardous materials, and recently a hazardous materials "flag" was added to the record description. Outside of the date and location of the accident, there is little congruence with the data collected by RSPA; however, the characteristics of the driver, road, and traffic may be important determinants of hazardous materials accidents. $^{72}$

Those accidents resulting in loss of human life are also classified separately in NHTSA's Fatal Accident Reporting System (FARS). The FARS file contains data on vehicles and persons involved in fatal accidents, defined as an accident in which an accident-related death occurred within 30 days of the accident. FARS includes all fatal accidents that occur in the United States. Other than this distinction, however, the information collected parallels the NASS data structure. ${ }^{73}$ Table $2-10$ shows the incident/accident databases.

\section{Other Relevant Databases}

Environmental Protection Agency.-EPA regional offices receive notifications from many sources of releases of hazardous substances; the reports are integrated into a regional release reporting system. Data recorded include the release date, company involved, spill location, nature of the emergency, material spilled and volume, source of the spill, responding agency, nature of the response, and resolution. Several EPA regions maintain this information in computerized files. EPA uses National Response

\footnotetext{
${ }^{7}$ National Highway Traffic Safety Administration, National Accident Sampling System (NASS), Analytical User's Manual (Washington, DC: 1981).

${ }^{73}$ National Highway Traffic Safety Administration, Fatal Acciden Reporting Systems (FARS), User's Guide (Washington, DC: Augus 1981).
}

Center reports in addition to spills reported to EPA regional offices, States, and local governments to formulate regulatory policy.

National Response Center.-Although telephone reports to NRC are primarily to stimulate a response action, the information provided can be used for policy analysis. Data items include the location of the incident, mode of transportation involved, material involved, and quantity released. The material definitions are coded differently from those in HMIS, and causal factors are not considered in any fashion. However, the NRC database provides a more balanced picture of releases by different modes, particularly marine transport.

National Transportation Safety Board.-NTSB investigates transportation accidents in any mode, based on the definition in 49 CFR of a major vehicular accident for each mode. NTSB may use the NRC telephone report information to help determine whether to proceed with its own investigation.

An NTSB investigation includes a multiple-da field investigation involving the shipper, carrier, government agencies, associations, and other interested parties. The investigations take place over several months, so that the full impact of the accident can be assessed. One consequence of this timeframe is that the accident damages reported by NTSB are substantiall greater than those reported by carriers

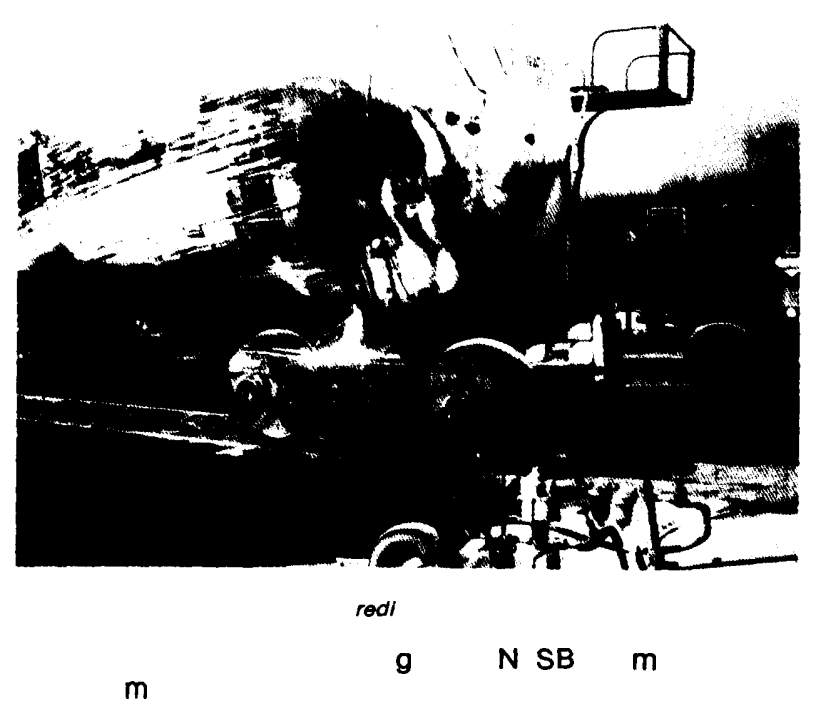


Table 2"10.-Incident/Accident Databases

\begin{tabular}{|c|c|c|c|c|c|c|c|}
\hline Database & Kept by & Years & Modes & Accidents & Incidents & $\begin{array}{c}\text { Exclusive } \\
\text { hazardous } \\
\text { materials } \\
\text { focus }\end{array}$ & $\begin{array}{l}\text { Exclusive } \\
\text { transport } \\
\text { focus }\end{array}$ \\
\hline $\begin{array}{l}\text { Hazardous Materials Information } \\
\text { System }\end{array}$ & $\begin{array}{l}\text { DOT, Office of Hazardous Materials } \\
\text { Transportation, Research and Spe- } \\
\text { cial Programs Administration }\end{array}$ & 1971 to present & All & Yes & Yes & Yes & Yes \\
\hline Commercial Vessel Casualty File & U.S. Coast Guard & 1983 to present & Marine & Yes & No & No & Yes \\
\hline $\begin{array}{l}\text { Pollution Incident Reporting } \\
\text { System }\end{array}$ & U.S. Coast Guard & 1971 to 1985 & All & Yes & Yes & Yes & No \\
\hline Truck Accident File & $\begin{array}{l}\text { DOT, Bureau of Motor Carrier } \\
\text { Safety, Federal Highway Adminis- } \\
\text { tration }\end{array}$ & 1973 to present & Highway & Yes & No & No & Yes \\
\hline Railroad Accident File & Association of American Railroads & 1973 to present & Rail & Yes & Yes & No & Yes \\
\hline Air Accident File & Federal Aviation Administration & - & Air & Yes & Yes & No & Yes \\
\hline National Accident Sampling System & $\begin{array}{l}\text { National Highway Traffic Safety } \\
\text { Administration }\end{array}$ & $\begin{array}{l}1983 \text { (Hazardous } \\
\text { materials flags } \\
\text { added in 1983) }\end{array}$ & Highway & Yes & No & No & Yes \\
\hline Fatal Accident Reporting System & $\begin{array}{l}\text { National Highway Traffic Safety } \\
\text { Administrate ion }\end{array}$ & $\begin{array}{l}1983 \text { (Hazardous } \\
\text { materials flags } \\
\text { added in 1983) }\end{array}$ & Highway & Yes & No & No & Yes \\
\hline National Response Center & U.S. Coast Guard & - & All & Yes & Yes & Yes & No \\
\hline $\begin{array}{l}\text { National Transportation Safety } \\
\text { Board File }\end{array}$ & $\begin{array}{l}\text { National Transportation Safety } \\
\text { Board }\end{array}$ & - & All & Yes & No & No & Yes \\
\hline $\begin{array}{l}\text { U.S. Department of Energy Data } \\
\text { B }\end{array}$ & Sandia National Laboratories & 1979 to present & All & Yes & Yes & Yes & Yes \\
\hline Washington State Accident File & $\begin{array}{l}\text { Washington State Utility and Trans- } \\
\text { portation Commission }\end{array}$ & 1978 & Highway & Yes & No & No & Yes \\
\hline
\end{tabular}


to RSPA. ${ }^{74}$ NTSB maintains a database on the vital statistics of each investigated accident. Railroad and aviation accident data are stored in computer files. Highway and marine accident data are stored on coding sheets, but have not yet been logged into the computer system.

Department of Energy. -At the Sandia Laboratories, DOE maintains an online database on all radioactive incidents, based on the HMIS file and information from the Nuclear Regulatory Commission on the loss of control of radioactive materials. The database consists of approximately 70 percent HMIS records and 30 percent NRC records. NRC is the lead agency in conducting investigations of transport accidents involving radioactive materials. These investigations focus on mechanical analyses of the containers involved in the accident, for the purpose of improving the safet of the containers. $^{75}$ Table 2-2 presents a summary of these databases.

\section{State and Local Agency Accident Data Systems}

Accident and spill databases maintained by State and local agencies vary considerably depending on the authorities involved and the level of commitment the organization has made to managing hazardous materials transportation problems.

The most difficult data-gathering problem in State and local studies has been obtaining reliable information on past hazardous materials releases. Most fire departments do not keep separate records of hazardous materials incidents, although fire departments in some large metropolitan areas are begin-

${ }^{74}$ U.S. General Accounting Office, Programs for Ensuring the Safe Transportation of Hazardous Materials Need Improvement (Washington, DC: November 1980).

"Lawrence Livermore National Laboratory, Mechanical Analysis of a Transportation Accident Involving Empty Shipping Casks for Radioactive Materials Near Hilda, South Carolina in November 1982, NUREG/CR-3452 (Washington, DC: U.S. Nuclear Regulatory Commission, October 1983); Lawrence Livermore National Laboratory, Simulation of Loading Conditions for a Type A Package Containing Americium-241 Involved in an Airplane Crash at Detroit Metro Airporr in January 1983, NUREG/CR-3536 (Washington, DC: U.S. Nuclear Regulatory Commission, January 1984); L2 wrence Livermore National Laboratory, A Highway Accident Involving Radiopharmaceuticals Near Brookhaven, Mississippi, on December 3, 1983, NUREG/CR-4035 (Washington, DC: U.S. Nuclear Regulatory Commission, April 1985); SRI International, Mechanics ofa Highway Accident at Wichita, Kansas, Involving Natural Uranium Concentrate, NUREG/CR.0992 (Washington, DC: U.S. Nuclear Regulatory Commission, August 1979). ning to develop special hazardous materials report forms for use in internal planning. State and local planners usually must rely on outside sources, some of which may be unreliable or contradictory. The experience of San Francisco Bay Area planners illustrates the difficulty of collecting data on releases: of 16 Federal, State, regional, and local sources contacted, only 9 could provide data on past releases within the timeframe requested for the study. Moreover, these sources did not have a common format, and sources reporting the same incident often varied considerably. ${ }^{76}$ The staff conducting a current California study for the State legislature found it necessary to consult three separate databases to develop a reliable release record for the State highway system.

State and local agencies have concentrated on developing accident reporting systems rather than release reporting systems and focus much of their attention on the highway mode. This is due to the role of the State and local police in reporting traffic accidents, and a well established and coordinated network of accident management. ${ }^{78}$ There have, however, been several State and local attempts to focus on hazardous materials releases, many of them funded by DOT as demonstration projects.*

Other State and regional projects have explicitly examined hazardous materials releases, but have relied heavily or exclusively on HMIS for their data. These include an analysis of hazardous materials transport by rail conducted by the State of New Jersey $^{79}$ and a multimodal study of the transportation of hazardous materials in the New York-New Jersey region.

\footnotetext{
${ }^{76}$ Association of $\mathrm{Ba}_{\mathrm{y}}$ Area Governments, "issues and Recommendations," San Francisco Bay Area: Hazardous Spill Prevention and Response Plan, vol. 1 (Washington, DC: U.S. Department of Transportation, Research and Special Programs Administration, February 1983).

${ }^{7}$ Linda Turnquist, Analyst, California Transit (CALTRANS), personal communication, March 1986.

${ }^{78}$ Some States have mandatory reporting of hazardous substance releases similar to CERCLA requirements although many local agencies are unaware of these reporting requirements. See ICF, Inc., Economic Analysis of Reportable Quantity Adjustments Under Sections 102 and 103 of the Comprehensive Environmental Response, Compensation, and Liability Act (Washington, DC: March 1985).

*An additional Federal initiative has been the State Hazardous Materials Enforcement Development (SHMED) program, The focus has been on establishing uniform transportation safety standards for hazardous materials and the enforcement of these standards.

${ }^{79} \mathrm{New}$ Jersey Department of Transportation, Office of Freight Serv ices, Movements and Incidents of Hazardous Materials in New Jersey (Trenton, NJ: The New Jersey State Legislature, December 1984).

${ }^{80}$ Scanlon, op. cit.
} 
More sophisticated State applications include the use of computerized accident recordkeeping systems used with flow data to determine highway accident rates and high risk locations. The States of Utah, Washington, and New York, for example, maintain computerized accident recordkeeping databases that contain police accident investigation reports. When a heav ${ }_{y}$ truck is involved, the carrier name, vehi-

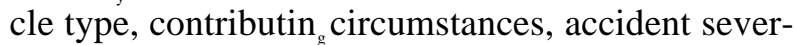
ity, and other information are required. In the case of the State of Washington, the United Nations number of the cargo is also included.

This type of database permits extracting information about heavy vehicle accidents where hazardous cargo was involved. The information can be checked against movement data to determine accident rates of vehicles transporting hazardous cargo. The accident rates can be used subsequently to compute transport risk profiles and identify safer routes for hazardous materials. The capability to do this exists in the States of Washington and New York, but has not been utilized by the States, partly because of the fragmentation of State government responsibilities. Accident and movement data reside in different offices, and still other offices are responsible for policy analysis. Both States are, however, moving toward conducting better analyses of the data that is collected and maintained.

The State of Maryland has largely overcome these problems. Several years ago, Maryland began a surveillance system of hazardous cargo movements at multiple check points and different times of the day. A State release reporting system was also instituted under which any hazardous materials release is entered into the database. These two sources of information are subsequently compared to determine the level of hazardous materials transport safety in the State. This information has been used to demonstrate a preferred nuclear materials routing system in Maryland. However, the accomplishments in Maryland have come only after IO years of activity and significant coordination among State agencies, demonstrating how time-consuming and painstaking such a process is.

State data-collection capabilities will be further enhanced when an integrated Federal-State data network, known as SAFETYNET, is made operational by BMCS. SAFETYNET will tie together the pres- ent BMCS Motor Carrier Safety database with HMIS and various computer-based State systems. The Motor Carrier Safety database now contains information on more than 200,000 interstate carriers and 30,000 hazardous materials shippers. It can report all of the known carriers domiciled in a region, rank them by the average number of driver and vehicle violations found per inspection, list the number of truck inspections each carrier has undergone, and give the date of the most recent safety audit. Once SAFETYNET is operating, BMCS and participating States should be able to:

- input driver-vehicle inspection data,

- update and query inspection data,

- update and query carrier census data,

- query safety management audit summary data,

- query accident report summary data,

- query inspection workload data, and

- generate system reports. ${ }^{81}$

A demonstration program involving four StatesNorth Carolina, Colorado, Oregon, and Michigan -is in progress. The eventual goal is to include all States in SAFETYNET, but this may take 10 years or more to accomplish. Funding is to be provided through a variety of Federal and State programs.

\section{Carrier Release Data}

Virtually all carriers retain copies of reports on accidents and releases that they have filed with the appropriate authorities. However, OTA contractors found, based on conversations with carriers, that the methods used for reporting information on Form F5800. 1 are arbitrary. There was a consensus among carriers that the primary purpose of the form is to record a release, not to establish accurate details, and that the 15-day reporting requirement is too short. For example, relatively small damage is often reported as no damage; when the damage is measurable, the carriers usually report the out-of-pocket cost and include the loss of cargo only and not the cleanup cost. There is little evidence that carriers use the release reports for any purpose beyond fulfilling the reporting requirement. Carriers also em-

"J.A. Reyes Associates, inc., "SAFETYNET: The Motor Carrier Safety Information Network," prepared for the U.S. Department of Transportation, Federal Highway Administration, Bureau of Motor Carrier Safety, unpublished typescript, November 1984. 
phasize that it is inappropriate for them to be required to report releases that occur during loading and unloading, since they often do not perform this function and are unaware of a release having occurred or the details concerning it. *

The Association of American Railroads maintains its own release database from inspector, railroad, Form F5800. 1, CHEMTREC, and telephone reports. Information includes date, location, release type, source of data, deaths and injuries, and estimated damage. The damage estimates can be segmented by equipment, lading, fire, and other damage. The AAR database goes back to 1973 .

\section{Completeness and Accuracy of HMIS}

The HMIS database is extremely important as the basis for most studies of hazardous materials transport safety in the United States. To assess the adequacy of HMIS for this purpose OTA addressed two concerns:

1. nonreporting of spills as documented in other databases that allow identification of hazardous materials releases, and

2. misreporting of spills as documented by information on the same incident in other release and accident databases.

To document the extent of nonreporting and misreporting, OTA contractors compared the HMIS database with relevant secondary databases on releases and accidents. However, in most cases, other reporting systems cover a much broader spectrum of releases and accidents than simply hazardous materials transport, and are thus not oriented for analyses of the industry at the level of detail theoretically available in the HMIS database. Moreover, databases differ on the definition of a reportable release. Despite these difficulties, OTA concludes that analysis of secondary data is essential to ensure adequate records.

At OTA's request, contractors undertook additional analysis to provide further documentation and develop estimates of nonreporting for HMIS keeping in mind that reports to HMIS of injuries and deaths are required only if the release occurs

\footnotetext{
*This point was emphasized by Cynthia Hilton, Manager, The Chemical Waste Transportation Council, personal communication by letter, May 20, 1986.
}

during interstate transportation and if damage is due to the hazardous material. The methodology for this effort was to match accidents with possible releases in secondary databases, such as NTSB and the BMCS Truck Accident File (TAF) with reported incidents in the HMIS database. Those releases for which an HMIS report could not be identified were included in the computation of nonreporting bias.

Misreporting estimates were developed by studying releases in the HMIS database for which the information reported by the carrier is inconsistent with information available in other reports for the same incident. The methodology used to address this issue is based on comparing reported consequences for matching releases.

The Coast Guard's Commercial Vessel Casualty File reporting criteria are detailed earlier in this report. While CVCF criteria differ somewhat from those for HMIS, they reflect similar objectives, including release consequence. While CVCF does not explicitly identify the vessel's cargo, it does have a detailed vessel-type definition from which releases likely to involve hazardous materials can be identified. For the purposes of this analysis, tanker ships and tanker barges were considered. A direct comparison between CVCF and HMIS was conducted for the period 1976-80.

CVCF analysis shows that collisions and grounding constitute the bulk of reported incidents, with relatively few releases caused by fire, explosion, or material failure, The primary cause of failure is most often "fault of other vessel/personnel. "Inclement weather has a relatively minor impact on the overall number of reported incidents. (See table 2-1 1.) The most frequent general locations of marine hazardous materials releases were along the Gulf of

Table 2.11.-Waterborne Incidents Reported to the Commercial Vessel Casualty File by Primary Cause, $1976=80$

\begin{tabular}{|c|c|c|}
\hline & $\begin{array}{c}\text { Number of } \\
\text { incidents }\end{array}$ & $\begin{array}{c}\text { Percentage } \\
\text { of total }\end{array}$ \\
\hline Poor weather . . . . & 208 & 3 \\
\hline Equipment failure . . . . . . . . . & 502 & 8 \\
\hline $\begin{array}{l}\text { Depth less than charted } \ldots \ldots \\
\text { Fault of other vessel/ }\end{array}$ & 138 & 2 \\
\hline personnel . . . . . . . . . & 4,240 & 69 \\
\hline Other. . . . . . . . . . . & 1,066 & \\
\hline Total . . . . . . . . . . . . & 6,154 & 67 \\
\hline
\end{tabular}


Mexico, probably reflecting the major petroleum and chemical activities in that region. (See table 2-12.) This contrasts greatly with the HMIS analysis, which lists high frequency marine release locations as Louisiana, California, New Jersey, Puerto Rico, and Maryland.

A comparison of CVCF release reports and consequences with marine releases contained in the HMIS database appears in table 2-13. The number of reportable releases is off by a factor of 41 ; over four times as many injuries have been reported to CVCF; 24 deaths have been reported to CVCF, with no fatalities listed in HMIS. However, because of the format of the CVCF report, it is impossible to determine if the injury or death was due to the hazardous material or some other cause, such as collision forces. The average damage per release is four times greater in $\mathrm{CVCF}$, implying that the procedures used in CVCF reporting acknowledge more substantial destruction than reported by carriers to RSPA. For the period 1976-80, damage apparently related to hazardous materials releases reported to $\mathrm{CVCF}$ exceeds \$189 million, or over \$50 million more than the damage total in HMIS for 1976 to 1984 on all transport modes combined.

Truck Accident File.-The BMCS Truck Accident File includes all reported vehicular accidents involving hazardous and nonhazardous cargo. Three common descriptive fields exist for HMIS and TAF: year, month, and State of release. Thus, an HMIS incident occurring at a different location in the State or on a different day during the same month might be erroneously matched; hence, the nonreporting estimate from this analysis should be considered a lower bound. A data field within the database permits isolation of accidents involving vehicles carry-

Table 2-12.-Waterborne Incidents Reported to the Commercial Vessel Casualty File by General Location, 1976-80

\begin{tabular}{|c|c|c|}
\hline Inspection unit & $\begin{array}{l}\text { Number of } \\
\text { incidents }\end{array}$ & $\begin{array}{c}\text { Percentage } \\
\text { of total }\end{array}$ \\
\hline New Orleans & 1,065 & 17 \\
\hline New York . . . . . . . . . . . . . & 516 & 8 \\
\hline Galveston . . . . . . . . . . . . . & 424 & 7 \\
\hline Paducah . . . . . . . . . . . & 359 & 6 \\
\hline Memphis. . . . . . . . . . . . . & 357 & 6 \\
\hline Houston . . . . . . . . . . . . & 331 & 5 \\
\hline Port Arthur . . . . . . . . . . . & 324 & 5 \\
\hline Mobile. . . . . . . . . . . . & 300 & 5 \\
\hline
\end{tabular}

SOURCE: Office of Technology Assessment.
Table 2.13.-Commercial Vessel Casualty File (CVCF) Comparison With the Hazardous Materials Information System (HMIS) Database, 1976.80

\begin{tabular}{|c|c|c|}
\hline & CVCF & $\begin{array}{c}\text { HMIS } \\
\text { database }\end{array}$ \\
\hline Number of incidents . . . . . . . . . . . & 6,154 & 150 \\
\hline Injuries $\ldots \ldots \ldots \ldots \ldots \ldots \ldots$ & 57 & 13 \\
\hline Deaths . . . . . . . . . . . . . & $\ldots 24$ & \\
\hline Average damage per incident $(\$) \quad \ldots \quad .$. & $\$ 30,817$ & $\$ 7,843$ \\
\hline
\end{tabular}

ing hazardous materials. Table 2-14 identifies the States where data for 1983 showed that accidents occurred most frequently. The top five States from the RSPA database are Pennsylvania, Ohio, Illinois, New York, and Texas, respectively. Although most of the same States appear at the top of both the TAF and HMIS databases, the order is not the same. Table 2-15 displays the TAF-reported injuries and deaths for 1983 . The impact to the communitythe number of other people killed and injured as a consequence of a hazardous materials accidentdwarfs the impact to the driver and other riders.

A comparison of TAF and HMIS statistics for 1983 appears in table 2-16. The databases contain information on 502 matching incidents, the consequences of which appear in tables 2-17 and 2-18. Carrier-reported incidents underestimate the deaths, injuries, and damages associated with hazardous ma-

Table 2-14.-Truck Accidents by General Location Using the Truck Accident File, 1983

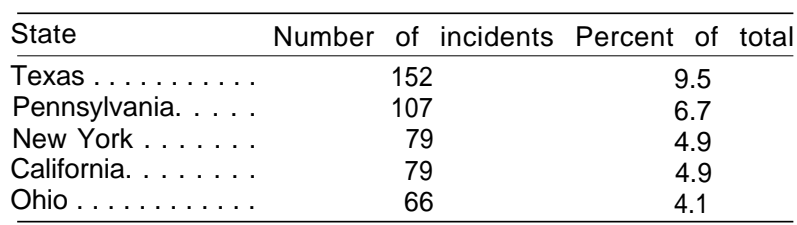

SOURCE: Office of Technology Assessment.

Table 2.15.-Truck Accident File Reported Injuries and Deaths, 1983

\begin{tabular}{|c|c|}
\hline Deaths & Injuries \\
\hline Driver . . . . . . . ..., ., ., . . . . . . . . 28 & 474 \\
\hline Relief driver . . . . . . . . . . . . . . . . . 2 & 38 \\
\hline Authorized rider. , . . . . . . . . . . . . 2 & 62 \\
\hline Unauthorized rider . . . . . . . . . . . 2 & \\
\hline Others. . . . . . . . . . . . . . . . . . 120 & 897 \\
\hline Total . . . . . . . . . . . . . . . . . . . . 154 & 1,479 \\
\hline
\end{tabular}

SOURCE: Office of Technology Assessment. 
Table 2-16.-Truck Accident File (TAF) Comparison With Hazardous Materials Information System (HMIS) Database, 1983

\begin{tabular}{|c|c|c|c|}
\hline & TAF & HMIS & database \\
\hline Number of vehicular accidents. & 1,602 & approx. & 211 \\
\hline Injuries $\ldots \ldots \ldots \ldots \ldots \ldots$ & 1,479 & $\max$ & 121 \\
\hline Deaths . . . . . . . . . & 154 & $\max$ & 8 \\
\hline Average damage per accident & $\$ 16,800$ & approx & \\
\hline
\end{tabular}

approximation is based on the total highway incidents for 1983 multiplied by the percentage of incidents which are result of vehicular accidents $(4.5 \%)$.

totals for all accidents and incidents.

CThis is the average reported damage per incident for 1983

SOURCE: Office of Technology Assessment.

Table 2-17.- Hazardous Materials Information System (HMIS) Misreporting Consequences Using the Truck Accident File (TAF) Databases, 1983

\begin{tabular}{|c|c|c|c|c|}
\hline & $\begin{array}{l}\text { Number of } \\
\text { matching } \\
\text { incidents }\end{array}$ & Deaths & Injuries & Damages \\
\hline $\begin{array}{l}\text { TAF . . . . . } \\
\text { HMIS. . . }\end{array}$ & $\begin{array}{r}502 \\
. \quad 502\end{array}$ & $\begin{array}{r}50 \\
5\end{array}$ & $\begin{array}{r}490 \\
59\end{array}$ & $\begin{array}{r}\$ 10,077,004 \\
4,404,092\end{array}$ \\
\hline
\end{tabular}

Table 2=18.-Hazardous Materials Information System (HMIS) Misreporting Consequences Using the National Response Center (NRC) Database, 1983

\begin{tabular}{|c|c|c|c|c|c|}
\hline \multirow[b]{2}{*}{ Mode } & \multirow{2}{*}{$\begin{array}{l}\text { Number of } \\
\text { matching incidents }\end{array}$} & \multicolumn{2}{|c|}{ Deaths } & \multicolumn{2}{|c|}{ Injuries } \\
\hline & & NRC & HMIS & NRC & HMIS \\
\hline Air. . . . . . . . & & 0 & 0 & 0 & 0 \\
\hline Rail . . . . . . . & 243 & 4 & 0 & 21 & 42 \\
\hline Highway. . . . & 449 & 16 & 6 & 117 & 23 \\
\hline Water ... & 1 & 0 & 0 & 0 & 0 \\
\hline
\end{tabular}

SOURCE: Office of Technology Assessment,

terials transport incidents. Approximately 8 times as many vehicular accidents involving hazardous materials were reported to TAF as to HMIS, resulting in at least 12 times as many injuries and 19 times as many deaths. Finally, the average damage per incident is considerably larger for the TAF database. This can be partially explained by the facts that the HMIS estimate includes other releases, which may be less destructive, than those related to accidents and that damages reported to HMIS are estimated based on the consequences of the hazardous material involved only.

Despite the loosely matching criteria, of the 1,602 hazardous materials accidents appearing in TAF, only 502 or 31 percent could be found in the HMIS database. The missing accidents caused a combined impact of 104 deaths, 989 injuries, and
$\$ 16,867,056$ in damages. Among the more notable nonreported accidents are the following: Highland Park, Illinois, on March 22, 1983, killing one, injuring four, and causing $\$ 120,000$ in damages; Kemmerer, Wyoming, on April 7, 1983, killing five, injuring two, and causing \$26,500 in damages; Georgetown, Kentucky, on May 1, 1983, killing three, injuring nine, and causing $\$ 75,000$ in damages; and Hurricane, Utah, on November 21, 1983, killing three, injuring three, and causing $\$ 100,000$ in damages.

National Response Center.-This database is not designed for policy analysis purposes; however, some limited relevant analyses can be conducted. Reports to NRC could include hazardous substance spills, which EPA requires be reported but RSPA does not, unless the substance is specifically listed in the Hazardous Materials Table.

The matching methodolog $\operatorname{lon}_{\mathrm{y}}$ consisted of searching on four common fields: year, month, day, and State of incident; the results are shown in table 219. Table 2-20 displays NRC and HMIS statistics for numbers of reported incidents, deaths, and injuries in 1983. In total, NRC-reported injuries and deaths are significantl larger than those reported in the HMIS database, although there is considerable fluctuation at the modal level. The data dem-

Table 2-19.-Hazardous Materials Information System (HMIS) Nonsporting Consequences Using the National Response Center Database, 1983

\begin{tabular}{|c|c|c|c|c|}
\hline Mode & $\begin{array}{l}\text { Number not } \\
\text { found in } \\
\text { HMIS database }\end{array}$ & $\begin{array}{l}\text { Percentage } \\
\text { nonmatching }\end{array}$ & Deaths & Injuries \\
\hline Rail . . . . . . & 510 & 68 & 2 & 10 \\
\hline Highway. . & 431 & 49 & 12 & 72 \\
\hline Air. . . . . . & 11 & & 1 & 0 \\
\hline Water .... & 552 & 99 & 0 & 29 \\
\hline
\end{tabular}


Table 2-20.-Hazardous Materials Information System (HMIS) Nonreporting Analysis Using the National Transportation Safety Board (NTSB) Database, 1976.83

\begin{tabular}{|c|c|c|c|}
\hline & $\begin{array}{l}\text { Number of } \\
\text { incidents in }\end{array}$ & $\begin{array}{l}\text { Number not } \\
\text { found in }\end{array}$ & Percentage \\
\hline Mode & NTSB database & HMIS database & nonmatching \\
\hline Rail ...... . & 258 & 165 & 64 \\
\hline Highway. . . & 6 & 3 & 50 \\
\hline Water ..... & 7 & 6 & 86 \\
\hline
\end{tabular}

SOURCE: Office of Technology Assessment.

onstrate serious nonreporting problems for the air transport industry. The NRC database has limited usefulness in quantifying damage estimates, since this is not a reporting requirement. Table 2-19 shows the results of comparisons between the databases for matching incidents; valid comparisons can be made only for the rail and highway modes.

The National Transportation Safety Board examines only hazardous materials incidents that have serious consequences; thus theoretically, all NTSB incidents should also have been reported to RSPA and included in HMIS. NTSB incident reports include information on injuries, deaths, and damages, and share five matching fields with HMIS: year, month, day, city, and State. HMIS files for 1976 to early 1983 were studied to find information matching NTSB data; the results are shown in table 2-20. The analysis indicates that 50 percent or more of the most serious hazardous materials transport incidents go unreported to RSPA. OTA did not attempt to determine whether this percentage changed over time. Most NTSB hazardous materials reports for which sufficient information was available were for rail incidents, and nearly twothirds of NTSB incidents were not reported in HMIS.

Table 2-21 displays the consequences of the unreported incidents. For rail alone, the injuries and damages of unreported incidents appearing in the NTSB database exceed the total reported injuries and damages for all HMIS rail incidents from 1976 to 1984 . Among the more notable omissions are an incident in Maryland, Oklahoma, on December 15, 1976, which resulted in 3 deaths, 11 injuries, and an estimated $\$ 880,700$ in damages; Crestview, Florida, on April 8, 1979, which injured 14 people and caused \$1,258,500 in damages; Pisgah, California, on May 11, 1980, which killed 1 person, injured 3 , and caused $\$ 2,889,000$ in damages; and Benton,
Table 2-21.-Hazardous Materials Information System (HMIS) Nonreporting Consequences Using National Transportation Safety Board Database, 1976-83

\begin{tabular}{|c|c|c|c|c|c|}
\hline \multirow[b]{2}{*}{ Mode } & \multicolumn{3}{|c|}{ Number not } & \multirow[b]{2}{*}{ Injuries } & \multirow[b]{2}{*}{ Damages } \\
\hline & found in & HMIS & Deaths & & \\
\hline Rail & 165 & & 37 & 92 & $\$ 89,443,936$ \\
\hline Highway. . . . & 3 & & 12 & 41 & 125,000 \\
\hline Water ...... & 6 & & 13 & 18 & $16,360,000$ \\
\hline
\end{tabular}

SOURCE: Office of Technology Assessment.

Iowa, on August 15, 1982, which injured 1 and caused $\$ 2,140,000$ in damages.

Although the sample size for highway and marine is too small for good analysis, in two other modes NTSB showed serious incidents that were not reported to HMIS. For example, a highway incident on December 28, 1977, in Goldonna, Louisiana, which killed 2 people, injured 11, and caused $\$ 125,000$ in damages, and a marine incident in Good Hope, Louisiana, on August 30, 1979, which killed 12 and resulted in $\$ 10,500,000$ in damages were not reported to HMIS. (See table 2-17.)

Examples of misreporting include a rail release in Newton Falls, Ohio, on May 9, 1979, that caused an estimated damage of $\$ 1,407,000$ in the NTSB report; according to the HMIS database, no damage was reported. In another case, NTSB reported $\$ 2,540,000$ in damages caused by a rail release in Hastings, Iowa, on July 10, 1980; the HMIS report shows no damage.

NTSB reviews the incidents it investigates over an extended period of time and holds discussions with a number of involved and affected parties. In contrast, RSPA requires reports to be submitted by the carrier within 15 days of the incident. Table 222 displays the consequence statistics of NTSB and HMIS for matching incidents. For the rail mode, RSPA estimates of death and injury are within range of NTSB reports. However, damage estimates are off significantly, by a factor of 7 to 8 .

The Association of American Railroads Data= base.-AAR maintains a hazardous materials incident file that includes a data field identifying the primary source of the report. AAR data corroborate the results of the HMIS comparison with NTSB data; over 60 percent of reportable rail releases are not being reported to RSPA. Of 13,706 incidents 
Table 2-22.-Hazardous Materials information System (HMIS) Misreporting Consequences Using the National Transportation Safety Board (NTSB) Database, 1976-83

\begin{tabular}{|c|c|c|c|c|c|c|c|}
\hline \multirow[b]{2}{*}{ Mode } & \multirow{2}{*}{$\begin{array}{l}\text { Number of } \\
\text { matching incidents }\end{array}$} & \multicolumn{2}{|l|}{ Deaths } & \multicolumn{2}{|c|}{ Injuries } & \multicolumn{2}{|c|}{ Damages } \\
\hline & & NTSB & HMIS & NTSB & HMIS & NTSB & HMIS \\
\hline Rail . . & 93 & 33 & 28 & 192 & 315 & $\$ 62,589,360$ & $\$ 8,437,363$ \\
\hline Highway. . . . . & 3 & 11 & 11 & 21 & 8 & 138,070 & $2,119,820$ \\
\hline Water ....... & 1 & 9 & 0 & 0 & 0 & 0 & 0 \\
\hline
\end{tabular}

examined in the file, the primary sources were reported as follows:

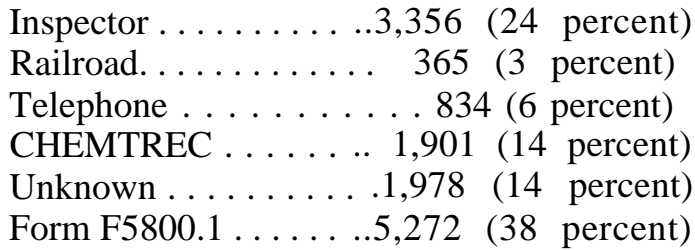

Washington State Accident File (WSAF).WSAF is maintained by the Washington Utilities and Transportation Commission. OTA contractors examined this database because, while it includes all highway freight accidents, it also contains a unique identifier for accidents involving hazardous materials. Moreover, this database has useful information not available in HMIS records, such as location type (urban/rural), type of accident, road surface, light conditions, type of road, truck contributing circumstances, truck driver/vehicle actions, truck vehicle condition, and truck driver sobriety.

Data from 1984 show the following: the locations of hazardous materials accidents were split evenly between rural and urban sites. Two-thirds of the accidents were property damage only, with very few showing major property damage. One-third of the accidents occurred on roads that were wet, icy, or covered with snow. Nearly three-quarters of the accidents occurred in daylight. Roughly 85 percent of the accidents occurred on two-lane or four-lane roads, in contrast to 12 percent at intersections. Eighty percent of the accidents involved flammable liquids. Of the 331 reported accidents, only 11.5 percent resulted in a reported spill. Not including "no contributing circumstances," "driver inattention" was cited as the most frequent contributing factor. Roughly 70 percent of the accidents occurred while the vehicle was being driven along a straight path, followed by right and left turns at 8 and 6 per- cent, respectively. In over 80 percent of the accidents, the vehicle had no cited defect. Finally, driver drinking causing impairment was cited only once.

Spills contained in WSAF were compared to HMIS to explore the issues of nonreporting and misreporting. Only 58 of 331 records, or 18 percent, were found in the HMIS database. For those records that matched, HMIS reported no deaths, no injuries, and $\$ 438,894$ in damages, in contrast to 2 deaths, 22 injuries, and \$956,370 reported in WSAF.

These findings raise serious questions about the integrity of the RSPA reporting system both for unreported incidents and inaccurately reported incidents.

The problem of underreporting in HMIS is most serious for marine incidents, as indicated by NTSB, the National Response Center, and CVCF data; moreover, based on more limited NRC data, underreporting of air incidents is also high. The number of reportable incidents maybe underestimated by factors of at least 10 and 20, for air and water, respectively. For highway and rail transport, the number of reportable incidents may be underestimated by factors of at least 2 and 3, respectively. Furthermore, major events, resulting in deaths, injuries, and significant damage, have gone unreported to DOT. Misreporting creates underestimates of damages more than of deaths and injuries.

When the nonreporting and misreporting estimates for each mode are applied as multipliers to HMIS incident and damage estimates, HMIS reports for 1976 to 1984 of 79,257 incidents resulting in $\$ 144,751,240$ in damage should be adjusted to 178,683 incidents resulting in $\$ 1.47$ billion in damage, according to OTA calculations. This analysis indicates a more serious safety problem than is presend y acknowledged by DOT and lends credence to the concerns voiced by State and local officials. 


\section{HMIS Uses}

The underreporting in HMIS makes it of questionable value for some types of analysis. However, it provides the best data available on container problems. When matched against rudimentary commodity flow data, several conclusions useful for helping to make management decisions can be drawn. Conversely, many issues simply cannot be resolved even by the most painstaking analysis, because too many questions remain unanswered. A review of the possible uses of HMIS follows.

For the 9-year period studied by OTA, the total number of incidents by year reported to HMIS was 79,253 . As figure $2-3$ shows, a general increase in reported incidents occurred through the late 1970s, even after changes in reporting requirements, followed by a significant decline beginning in 1980 . However, because there is no similar annual commodity flow data, it is impossible to establish whether incident rates have dropped, perhaps indicating a safer system, or whether the number of movements has decreased, resulting in similar or worse incident rates. It is also possible that nonreporting has increased or that the loosening of reporting requirements in 1981 led carriers to assume that they need not report any small spills.

Table 2-23 displays the results of a study of incident location by mode. Heavy concentrations of incidents occur in Pennsylvania, Ohio, Illinois, Texas, and California, probably due to major industrial activity and significant truck and rail corridors of travel for materials destined for other States. So few marine releases are reported to HMIS that no conclusions can be drawn about water transport. Tennessee is the most frequent site for air incidents, probably because Memphis is a major air freight hub.

Human error is the primary cause of 62 percent of incidents, followed by package failure, and vehicular accidents. (See figures 2-4 and 2-5.) The more specific reasons for incident occurrence appear in table 2-24. The predominant cause of failure varies considerably by mode, although external puncture and loose and defective fittings are often reported. These problems frequently occur during loading or unloading operations or when cargo shifts during transport, resulting in container bottom, body, or
Figure 2.3.-HMIS incidents by Year

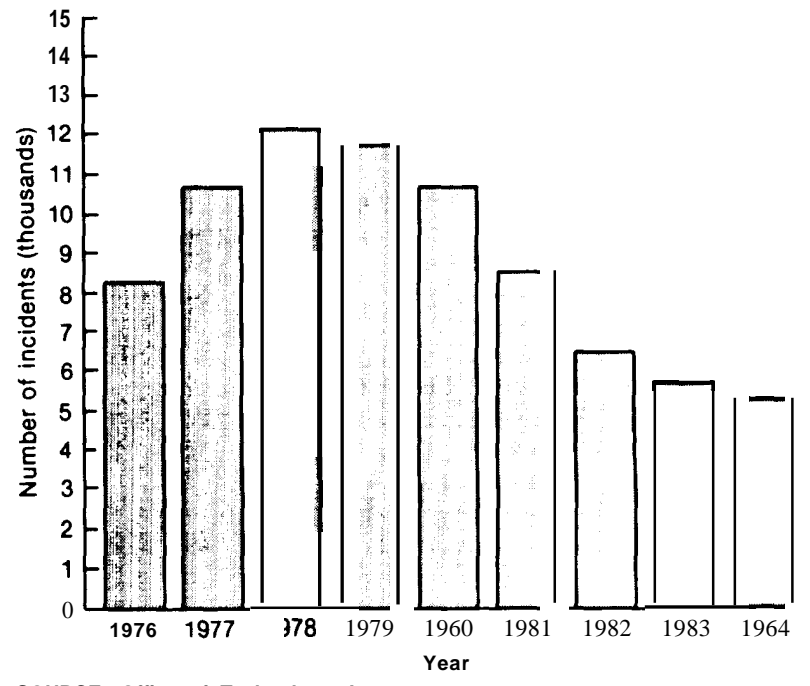

SOURCE: Office of Technology Assessment.

side failure, often caused by damage from other freight.

These conclusions point to issues that deserve recognition and either further study or development of countermeasures. For example, public information programs to reduce the likelihood of hazardous materials being shipped by parcel post as baggage might be undertaken by the Postal Service and the airlines. Thorough analysis of loading, unloading, blocking, and bracing operations and procedures is needed for all modes, but especially for truck, rail, and air. Standard procedures and industry training programs could be developed.

The analyses also identified several other problems in the industry deserving recognition and resolution. The use and integrity of MC-306 tank trucks and trailers for the highway mode, 11 1A tank cars for the rail mode, and 17E containers* warrant further examination, especially those used to carry corrosives, which OTA's analysis shows have the highest incident rate of all commodities. Finally, the condition of containers involved in incidents and the frequent use of nonspecified or unauthorized containers suggest the need for improved governmental inspection and enforcement activities. On the other hand, HMIS data show that vandalism and terrorism have not been serious problems.

${ }^{*}$ 17Es are the most commonly used metal drum or pail container types. 
Table 2-23.-Number of Incidents ${ }^{a}$ by Location and Mode, 1976-84

\begin{tabular}{|c|c|c|c|c|c|c|c|}
\hline \multirow[b]{2}{*}{ State } & \multicolumn{7}{|c|}{ Mode } \\
\hline & $\begin{array}{l}\text { Highway } \\
\text { (for hire) }\end{array}$ & $\begin{array}{l}\text { Highway } \\
\text { (private) }\end{array}$ & Rail & Water & $\begin{array}{c}\text { Freight } \\
\text { forwarder }\end{array}$ & Other & Total \\
\hline Alabama. . . . . . . . . . . . 4 & 1,269 & 67 & $410 \mathrm{~b}$ & - & 5 & - & $\overline{1}, \overline{7} \overline{5} \overline{5}$ \\
\hline Alaska . . . . . . . . . . . 23 & 35 & & & 8 & & 1 & 79 \\
\hline Arizona . . . . . . . . . . 8 & 934 & 59 & 262 & - & 一 & 2 & 1,265 \\
\hline Arkansas . . . . . . . . . . . - & 1,170 & 25 & 251 & 一 & - & 2 & 1,448 \\
\hline California . . . . . . . . . 76 & 2,470 & 430 & 817 & 15 & 3 & 22 & 3,833 \\
\hline Colorado . . . . . . . . . . . . . 34 & 1,119 & 52 & 73 & 一 & 一 & 2 & 1,280 \\
\hline Connecticut . . . . . . . . . 4 & 383 & 53 & 16 & - & 一 & 一 & 456 \\
\hline Delaware . . . . . . . . . . - & 171 & 27 & 68 & - & 2 & - & 268 \\
\hline District of Columbia . . . . . 3 & 71 & 38 & 2 & 一 & 一 & - & 114 \\
\hline Florida . . . . . . . . . . . . . 20 & 1,676 & 89 & 518 & 2 & 2 & 1 & 2,308 \\
\hline Georgia . . . . . . . . . . . . 16 & 2,331 & 41 & 334 & 2 & 2 & 3 & 2,729 \\
\hline Hawaii .............. 9 & 6 & 12 & 一 & 1 & 1 & 一 & 29 \\
\hline Idaho . . . . . . . . . . . . - & 149 & 28 & 60 & 一 & - & 1 & 238 \\
\hline Illinois . . . . . . . . . . . . . 49 & 3,340 & 125 & 828 & 一 & 8 & 3 & 4,353 \\
\hline Indiana ............ 5 & 2,155 & 76 & 189 & & 5 & 1 & 2,431 \\
\hline lowa ................ 3 & 1,110 & 27 & 95 & 一 & 一 & 2 & 1,237 \\
\hline Kansas ............... & 1,167 & 44 & 166 & & 2 & 3 & 1,382 \\
\hline Kentucky . . . . . . . . . 7 & 799 & 135 & 169 & 一 & 二 & 2 & 1,112 \\
\hline Louisiana . . . . . . . . . . . 13 & 1,101 & 84 & 372 & 22 & 3 & 14 & 1,609 \\
\hline Maine . . . . . . . . . . . . - & 68 & 11 & 44 & 一 & 一 & & 124 \\
\hline Maryland . . . . . . . . . . . 10 & 1,105 & 134 & 45 & 9 & 2 & 5 & 1,310 \\
\hline Massachusetts ....... 16 & 832 & 80 & 88 & 2 & 5 & 2 & 1,025 \\
\hline Michigan . . . . . . . . . . 17 & 2,274 & 114 & 254 & 一 & 7 & 5 & 2,671 \\
\hline Minnesota . . . . . . . . . 13 & 1,213 & 44 & 99 & & 一 & 1 & 1,370 \\
\hline Mississippi . . . . . . . . . . . . - & 823 & 47 & 90 & 一 & 1 & 3 & 964 \\
\hline Missouri . . . . . . . . . . . . . . 14 & 2,518 & 101 & 143 & 1 & 4 & 1 & 2,782 \\
\hline Montana . . . . . . . . . . . 1 & 205 & 27 & 72 & 一 & 一 & 1 & 306 \\
\hline Nebraska ............. . 3 & 719 & 7 & 51 & - & 1 & 1 & 782 \\
\hline Nevada . . . . . . . . . 3 & 106 & 11 & 17 & - & - & - & 137 \\
\hline New Hampshire . . . . . . . - & 55 & 9 & 9 & 一 & 一 & & 74 \\
\hline New Jersey . . . . . . . . . . . . 11 & 1,604 & 109 & 180 & 14 & 11 & 8 & 1,937 \\
\hline New Mexico . . . . . . . . . . 4 & 717 & 38 & 94 & 一 & - & - & 853 \\
\hline New York . . . . . . . . . . . . 56 & 3,133 & 210 & 211 & 7 & 5 & 14 & 3,636 \\
\hline North Carolina ........ 5 & 2,408 & 54 & 235 & 1 & 5 & 10 & 2,718 \\
\hline North Dakota . . . . . . . . . . . - & 55 & 28 & & 一 & 一 & 一 & 101 \\
\hline Ohio . . . . . . . . . . . . . . 16 & 4,804 & 143 & 328 & 一 & 14 & 8 & 5,313 \\
\hline Oklahoma . . . . . . . . . . . . 12 & 645 & & 46 & 一 & 1 & - & 754 \\
\hline Oregon . . . . . . . . . . . . 4 & 355 & 59 & 165 & 一 & 一 & - & 583 \\
\hline Pennsylvania . . . . . . . . 28 & 6,473 & 245 & 322 & 3 & 34 & 4 & 7,109 \\
\hline Puerto Rico . . . . . . . . . . . . . 4 & 4 & 3 & 一 & 12 & 1 & 1 & 25 \\
\hline Rhode Island.,.......,., & 107 & 13 & 3 & - & 一 & 一 & 123 \\
\hline South Carolina ........ . 4 & 1,351 & 33 & 108 & 5 & 2 & 3 & 1,506 \\
\hline South Dakota . . . . . . . . - & 84 & 16 & 5 & 一 & & 一 & 105 \\
\hline Tennessee ....,. . . . . . . 337 & 2,478 & 73 & 203 & 2 & 1 & 1 & 3,097 \\
\hline Texas . . . . . . . . . . . . 48 & 2,642 & 212 & 1,265 & 6 & 4 & 14 & 4,191 \\
\hline Utah . . . . . . . . . . . 1 & 494 & 27 & 16 & 一 & 1 & 一 & 539 \\
\hline Vermont . . . . . . . . . . . . & 34 & 16 & 2 & 一 & 一 & 1 & 53 \\
\hline Virginia .............. 3 & 1,671 & 67 & 124 & 7 & 4 & 5 & 1,881 \\
\hline Washington .......... 13 & 812 & 121 & 133 & 7 & 5 & 2 & 1,093 \\
\hline West Virginia . . . . . . . . 1 & 471 & 43 & 65 & - & 1 & 一 & 581 \\
\hline Wisconsin ........... 6 & 1,975 & 49 & 56 & - & 一 & 1 & 2,087 \\
\hline Wyoming ............ 1 & 211 & 51 & 60 & 一 & 1 & 2 & 326 \\
\hline
\end{tabular}

ancidents refers to the number of hazardous materials releases. For highway transport, a report is required only for releases

that occur to a company engaged in interstate transportation.
boldface numbers indicate five states with the highest number of incidents for each category.

SOURCE: Office of Technology Assessment. 
Figure 2-4.-General Causes of Spills by Mode According to the HMIS

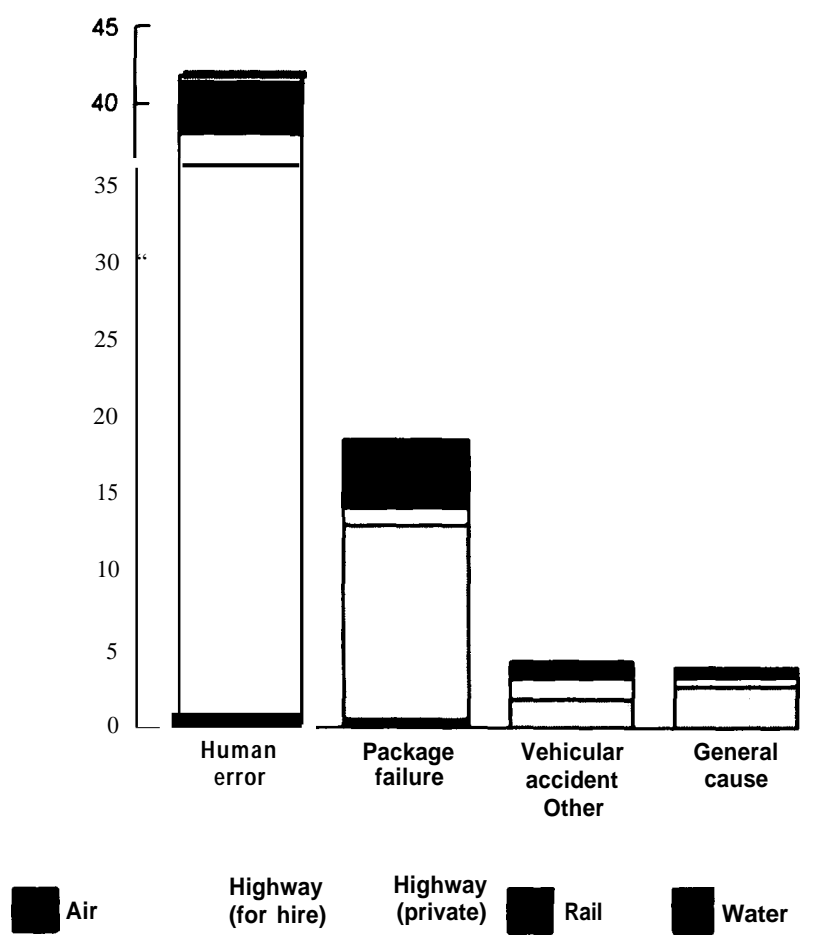

SOURCE: Office of Technology Assessment contractor report.

Figure 2-5.-General Causes for All Modes

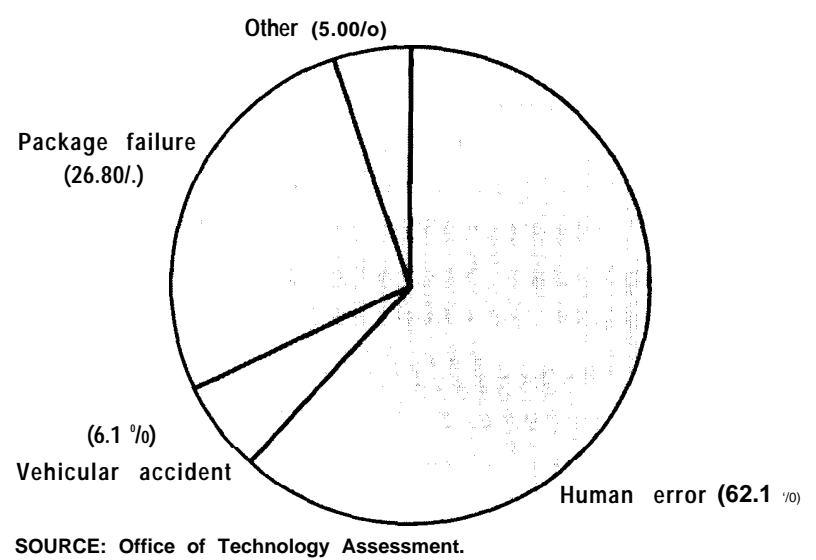

Despite the fact that several years of data can be examined, catastrophic events are rare enough that a single release in a given mode, hazard class, or container category, can distort the analysis of particular segments of the industry. More complete data might provide a more balanced picture, despite this problem, and would permit using release reports as a management tool.

\section{Conclusions}

HMIS was the subject of considerable criticism in 1980 from the U.S. General Accounting office (GAO) for the following reasons: ${ }^{82}$

1. RSPA is not receiving reports on all spills because it relies on voluntary reporting from carriers;

2. companies involved only in the loading, unloading, or storage of hazardous materials (e.g., shippers and freight forwarders) are not required to submit hazardous materials incident reports;

3. reports are not required by RSPA for spills involving hazardous materials shipped in bulk by water;

4. DOT has elected not to require firms involved only in intrastate transportation to submit hazardous materials spill reports;

5 RSPA has no systematic procedure for refining reported data that are incomplete or inaccurate; and

6. the total consequences of spills are understated significantly due to the time limit on reporting and soliciting solely the carrier's perspective.

Each of these factors works to understate the overall impact of hazardous materials transportation releases. OTA finds that the database deficiencies noted in the GAO report persist and that the total volume of hazardous materials releases is seriously underestimated. Moreover, the value of HMIS for deriving distributions of events, causes, and consequences, and multimodal comparative analyses is questionable. OTA finds that improvements to the RSPA incident reporting system are needed to ensure more accurate and comprehensive diagnostic and evaluative studies of hazardous materials transportion safety.

The major areas for improvement include:

. initiatives to ensure complete reporting of hazardous materials releases,

- coordinated working agreements between RSPA and other governmental agencies covering data

${ }^{82}$ U.S General Accounting Office, op.cit. 
Table 2=24.-Cause of Failure by Mode, 1976-84

\begin{tabular}{|c|c|c|c|c|c|c|c|c|c|}
\hline \multirow[b]{2}{*}{ Number } & \multicolumn{9}{|c|}{ Mode } \\
\hline & Code & Air & $\begin{array}{l}\text { Highway } \\
\text { (for hire) }\end{array}$ & $\begin{array}{l}\text { Highway } \\
\text { (private) }\end{array}$ & Rail & Water & $\begin{array}{c}\text { Freight } \\
\text { forwarder }\end{array}$ & Other & Total \\
\hline & Dropped in handling. . . & $239^{a}$ & 4,334 & 95 & 30 & 16 & 18 & 11 & 4,743 \\
\hline & External puncture . . . . & 81 & 12,051 & 362 & 481 & 39 & 56 & 35 & 13,105 \\
\hline 3 & Damaged by other & & & & & & & & \\
\hline & freight $\ldots \ldots \ldots \ldots$ & 62 & 8,192 & 53 & 146 & 8 & 30 & 7 & 8,498 \\
\hline $\begin{array}{l}4 \\
5\end{array}$ & $\begin{array}{l}\text { Water damage } \ldots . . . \\
\text { Damage from other }\end{array}$ & 2 & 62 & 2 & 16 & 2 & - & - & 84 \\
\hline & liquid . . . . . . . . . . & 2 & 69 & 1 & 5 & 一 & - & 一 & 77 \\
\hline 6 & Freezing . . . . . . . . & 一 & 182 & 21 & 12 & & 2 & 一 & 218 \\
\hline 7 & External heat . . . . . . . & 3 & 116 & 17 & 53 & : & 1 & 1 & 194 \\
\hline 8 & Internal pressure. . . . . . & 57 & 666 & 113 & 399 & 19 & 1 & 4 & 1,259 \\
\hline 9 & Corrosion or rust . . . . . & 6 & 641 & 36 & 118 & 4 & 1 & 2 & 808 \\
\hline 10 & Defective fittings . . . . . & 60 & 3,375 & 321 & 2,883 & 27 & 2 & 18 & 6,666 \\
\hline 11 & Loose fittings . . . . . . . & 257 & 7,851 & 421 & 3,684 & 22 & 18 & 29 & 12,282 \\
\hline 12 & Failure inner & & & & & & & & \\
\hline & receptacle . . . . . . . . & 35 & 622 & 17 & 60 & & 一 & 1 & 735 \\
\hline 13 & Bottom failure . . . . . . . & & 3,780 & 66 & & 4 & 7 & 3 & 3,960 \\
\hline 14 & Body/side failure. . . . . . & 64 & 2,517 & 105 & 279 & 14 & 18 & 9 & 3,006 \\
\hline 15 & Weld failure . . . . . . . . & 4 & 728 & 50 & 70 & 13 & 3 & 4 & 872 \\
\hline 16 & Chime failure. . . . . . . & 2 & & 12 & & 1 & 2 & & 610 \\
\hline 17 & Other conditions. . . . . . & 129 & 2,492 & 282 & 328 & 22 & 5 & 20 & 3,278 \\
\hline 18 & Hose burst . . . . . . . . & - & 872 & 83 & 7 & & - & 3 & 966 \\
\hline 19 & Load/unload spill . . . . . & 2 & 5,985 & 1,283 & 72 & 2 & - & 9 & 7,353 \\
\hline 20 & Cargo shifted/fell . . . . . & 30 & 6,127 & 120 & 357 & 14 & 22 & 7 & 6,677 \\
\hline 21 & Improper loading. . . . . . . & 18 & 2,381 & 15 & 62 & 5 & 10 & 1 & 2,492 \\
\hline 22 & Vehicle accident . . . . . . & 3 & 2,145 & 972 & 994 & 3 & 1 & 12 & 4,130 \\
\hline 23 & Venting . . . . . . . . . . & 一 & 13 & 25 & 120 & 一 & - & 1 & 159 \\
\hline 24 & Release of fumes . . . . . & 3 & 46 & 9 & 147 & - & 一 & 2 & 207 \\
\hline 25 & Friction . . . . . . . . . & 1 & 101 & 8 & 17 & 2 & 2 & - & 131 \\
\hline 26 & Static electricity . . . . . . & - & 8 & - & 2 & 一 & 一 & - & 10 \\
\hline 27 & Metal fatigue . . . . . . . & - & 531 & 4 & 12 & 1 & 1 & 一 & 549 \\
\hline
\end{tabular}

aboldface indicates top two causes of fallure in each mode.

SOURCE: Office of Technology Assessment.

sharing and developing the capability to match release reports,

- development of software to identify misreporting and nonreporting, and

- additional data-entry/data-validation clerks and staff to ensure complete, accurate reports.

Moreover, the accuracy of DOT's Hazardous Materials Information System can be improved without large expenditures for technology improvements. For instance, Form F5800. 1 does not clearly specify the data items RSPA attempts to collect from it. The carrier issuing the report is given considerable latitude in describing the incident; consequently, the data-entry staff must make subjective judgments on how the reports should conform to the HMIS record structure. RSPA is currently revising the form. In this process, questions on the form about cause, characteristics, and consequence should be structured so that the respondent selects specific entries from lists of potential choices, as in Part F (Nature of Packaging Failure) on the present form. This would create a uniform basis of reporting and decrease the redundant entries in the database, particularly for container types. Furthermore, it would make the data-entry process more efficient and provide a more concise database.

RSPA has expressed interest in condensing the information required on Form F5800. 1, citing the cumbersome problem of managing a large historical database. ${ }^{83}$ However, the amount of information now requested on Form F5800. 1 is not excessive when contrasted with that for other reporting systems such as NASS, FARS, TAF, and CVCF. In comparison to other incident/accident databases, the volume and complexity of reports received annually by RSPA are relatively small.

\footnotetext{
\$3" Detailed Hazardous Materials Incident Reports," Federal Register, vol. 49, No. 53, Mar. 16, 1984, pp. 10042-10047.
} 
The data fields in the current HMIS database cover most of the major elements of a hazardous materials transport incident. However, additional information on the age and registration number of the vehicle, driver, weather conditions, cargo weight, type of event (e.g., in transit/loading/unloading), and package type (e.g., bulk/nonbulk) would be useful. Inclusion of the telephone number for the $\mathrm{Na}-$ tional Response Center on Form F5800. 1 could remind the carrier to provide a telephone report if warranted.

Revising the criteria for requiring a written report has been recently proposed by RSPA. ${ }^{84}$ Since most small package incidents have minor consequences, RSPA is considering a new reporting criteria for Form F5800.1 requiring its completion only if an incident results in any of the circumstances set forth in 49 CFR 171.15 or involves:

- bulk packaging,

- shipments aboard aircraft or in air terminals,

- property damage equal to or in excess of $\$ 1,000$ including cleanup,

- evacuation,

- packages or hazardous materials under an exemption, or

- any quantity of hazardous waste that has been discharged during transportation.

Deleting the requirement for reporting smaller spills would deprive DOT of its primary source for evaluating small packages carried in less-than-load lots. See chapter 3 for a discussion of the impact of such a change on small packaging requirements.

The issue of the carrier's primary responsibility for notification of releases warrants examination. Possible changes include extending the reporting time limit to 30 days to encourage more complete evaluation of incident characteristics and consequences. Furthermore, shippers and receivers could be held responsible for reporting loading/unloading incidents, if RSPA develops a system to indicate possible redundant reports. Immediate telephone followup to obtain information missing from reports would permit complete data to be entered into the HMIS database. Finally, comparisons of HMIS reports to reports filed with other systems, such as NRC, CVCF, TAF, and NTSB, could iden- tify discrepancies and identify nonreported incidents meeting HMIS reporting criteria.

These changes would require the cooperation of several agencies in furnishing data to RSPA and designing their reports with common data fields to permit direct comparisons. Although modifying reporting and database formats can be costly and timeconsuming, two alternatives could make expensive changes unnecessary:

1. Conversion or bridge tables could be constructed to transform other agency data items into data items contained in the HMIS database so RSPA could conduct nonreporting analyses.

2. Data items required for matching could be added to other agency report forms and databases.

OTA finds that HMIS misses numerous releases recorded in other Federal databases, in part because bulk marine releases and those occurring during solely intrastate commerce need not be reported, and because the reporting requirement is not enforced. Furthermore, little effort is made to include data other than that reported on Form F5800.1 in RSPA's annual report, making the report an inadequate reflection of the safety of the transportation of hazardous materials.

Moreover, OTA analyses of flow and accident data indicate that relatively few of the HMIS data can be used as indicators. A major accident in $\mathrm{an}_{\mathrm{y}}$ single year or on any mode can skew the data significantly. However, when combined, current Federal accident and spill databases can provide more complete information on the dimensions of hazardous materials transportation safety problems.

A California study, being conducted for the State legislature, compared three separate databases showing highway spills and determined that at least 500 spills occur annuall on the State highwa system $_{y}$ alone, excluding the city streets. The study demonstrates that several databases must be used to generate reasonabl complete data, even for a single State. These results show driver error as the single largest cause of spills and imply that concentration on addressing truck-related issues such as driver training and qualifications is essential for safety improvements. 
The intent of the HMTA clearly indicates the need for an adequate annual summary of the safety of hazardous materials transportation, making improvement to HMIS an urgent issue. OTA coneludes that including bulk marine and intrastate releases in the HMIS reporting requirement and enforcing the requirement are important priorities. Increased cooperation and information sharing among DOT agencies, EPA, and State enforcement officials are also essential. Congress could require DOT to extend accident reporting requirements to all hazardous materials spills whether they occur during interstate or intrastate transport and regardless of mode. A coordinated national spill reporting center, with reporting procedures and common data report fields that must be implemented by all Federal agencies, could be designated. Congress might wish to require display of a toll-free number for the national report center as the place to call for reporting accidents. DOT, NRC, or HMIS staff provide natural homes for this coordinating role. Moreover, if formats including common data fields were decided on, accident reports collected at the State level could be submitted periodically to the regional DOT or EPA office. The regional Federal offices would provide annual updates to the national center. Several regional EPA offices already work with the States in their regions and have good computerized reporting systems. Spill reports should be checked at the regional level for accuracy and completeness, before being submitted to the national data-collection center.

The annual DOT reports to Congress on the transportation of hazardous materials could be required to document accidents by State, container types, mode, and cause. Improvement of the RSPA spill report Form F5800. 1 and coordination with modal administrations to develop common data fields that are less open to subjective interpretation could make the form reflect more accurately the causes and details of the spill. 
Chapter 3

\section{Containers for Hazardous Materials Transportation}

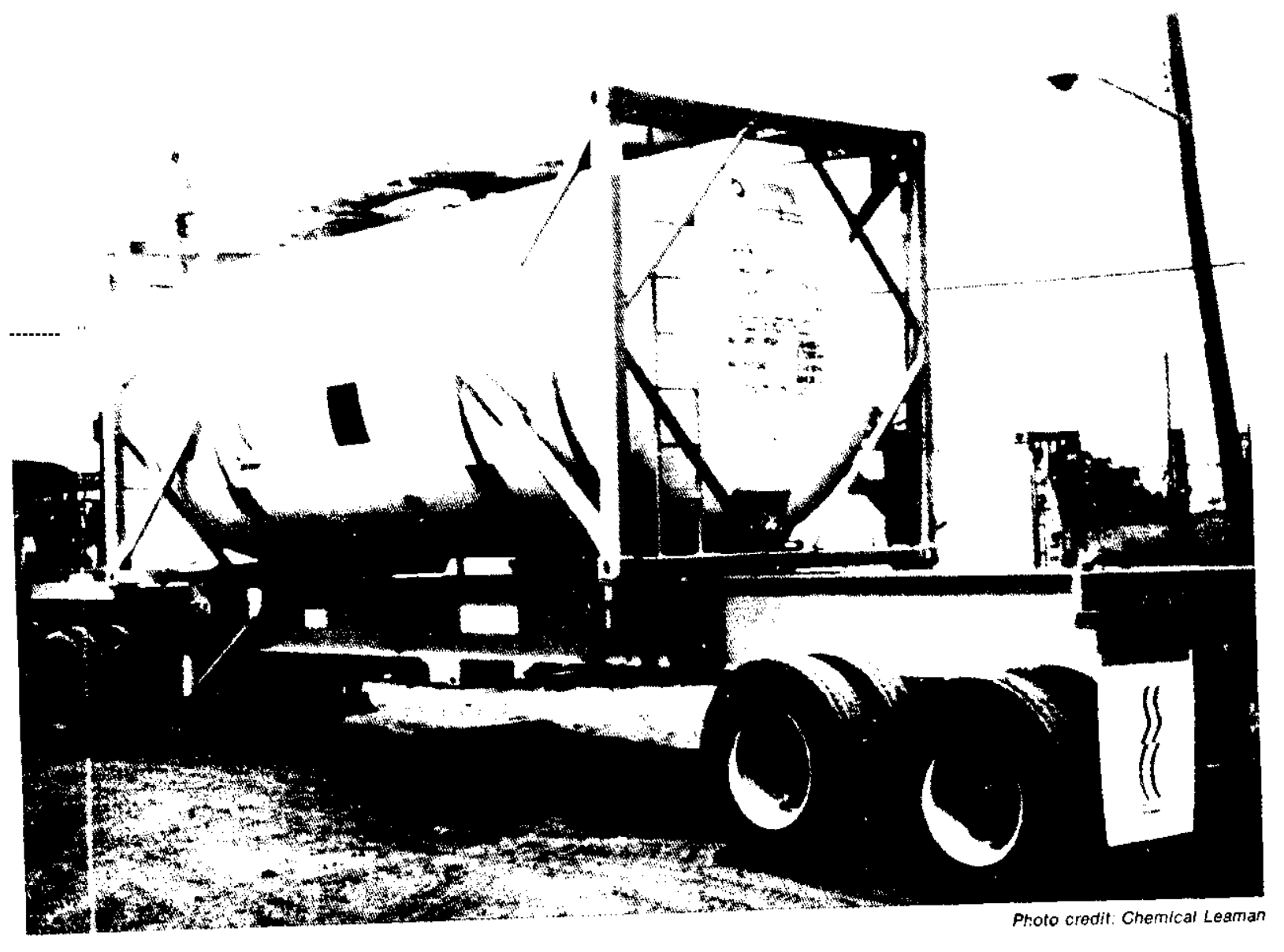




\section{Contents}

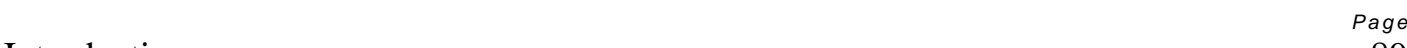

Part I: Containers for Transporting Radioactive Materials . . . . . . . . . . . . . . . 90

Regulatory Framework ................................. 93

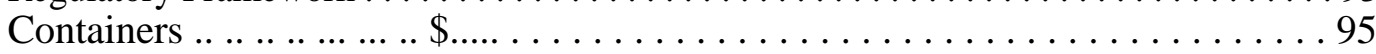

Future Spent Fuel Shipments Under the Nuclear Waste Policy Act, . . . . . . . . . 106

Spent Fuel Transportation Risks and Public Perceptions . . . . . . . . . . . . . ......IO7

Conclusions . . . . . . . . . . . . . . . . . . . . . . . ...................,109

Part II: Bulk Containers and Small Packaging for Hazardous Materials

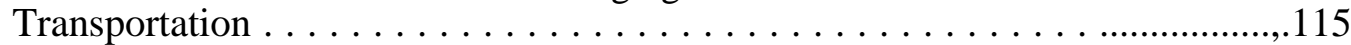

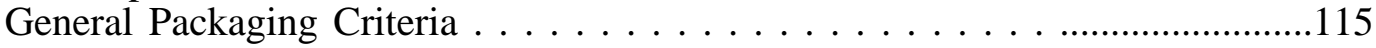

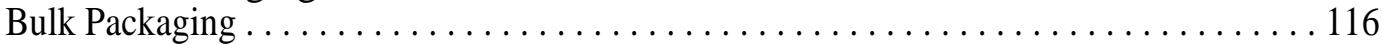

Nonbulk Containers . . . . . . . . . . . . . . . . . . . . . . . . . . . . . ., ..,...133

Third-Party Testing and Certification for All Packaging . . . . . ..................137

Training in Operations and Procedures . . . . . . . . . . . . . . . . . . . . . . . . ....137

Conclusions and Policy Options. . . . . . . . . . . . . . . . . . . . . . . . 140

\section{List of Tables}

Table No.

3-1. Summary of Unclassified Radioactive Materials Shipments by the Nuclear

Regulatory Commission Licensees and the Department of Energy Licensees . . . 91

3-2. History of Domestic Commercial Spent Fuel Shipments . . . . . . . . . . . . . . 91

3-3. Quantities of Low-Level Radioactive Waste Shipped and Buried in 1984 . . . . 92

3-4. Radioactive Material Shipments Associated With the Nuclear Fuel Cycle . . . . 92

3-5. Characteristics of the Current Generation of Nuclear Regulatory Commission

Certified Light Water Reactor Spent Fuel Casks. . . . . . . . . . . . . . . . . . 98

3-6. Radioactive Materials Involved in Transportation Accidents . ...............105

3-7. Estimated Occurrences of Accidents During the Transport of Spent Fuel. ....105

3-8. Modal Characteristics of Bulk Shipping of Hazardous Materials . ............117

3-9. Cargo Tank Table. . . . . . . . . . . . . . . . . . . . . . . . . .................118

3-10. Major Oil Company, Total Vehicle Accidents . ........................124

3-11. Minimum Tank and Jacket Plate Thickness. . . . . . . . . . . . . . . . . . . . ..., ..I27

3-12. Common Pressure Tank Cars . . . . . . . . . . . . . . . . . . . . . . . . . . 127

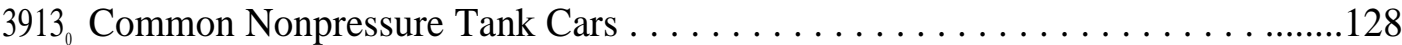

3-14. Retest Requirements for Selected Tank Cars . . . . . . . . . . . ................128

\section{List of Figures}

Figure No, $\quad$ Page

3-1. Highways Commonly Used for Radioactive Materials Shipments . ............111

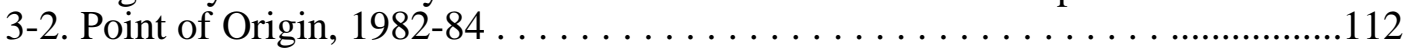

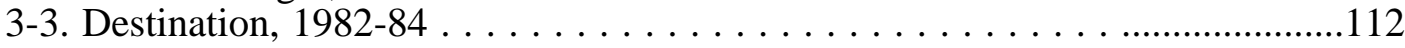




\section{Containers for Hazardous Materials Transportation}

\section{INTRODUCTION}

Ensuring the safe transportation of hazardous materials is a complex activity. If accidentally released, hazardous materials pose risks to human safety, property, and the environment. Consequently, the containers or packaging used for shipping most of these materials are required by regulation to be adequate to contain their contents during normal transport. However, standards for containers for highly radioactive materials are set differently and require that the packages withstand severe accident conditions without a dangerous radioactive release.

Over 30,000 different hazardous materials must be shipped under U.S. Department of Transportation (DOT) regulations. Among the classes of materials regulated are explosives, flammables, corrosives, combustibles, poisons, radioactive materials, and etiologic (disease-causing) agents. These materials, essential to the business and industrial economy of the United States, are shipped by air, highway, railroad, and water under regulations that reflect the history and different operating characteristics of the various modes. Hazardous products are transported in bulk by vessels, tank cars, tank trucks, intermodal portable tanks; and in smaller containers such as cylinders, drums, barrels, cans, boxes, bottles, and casks. Widely varying packaging have been developed by industry to match the strength and integrity of the containers to the characteristics and hazards of the materials they must contain

Packaging for hazardous materials during transportation is a major element of DOT's regulatory system. The Department, through its Research and Special Programs Administration and other branches, establishes technical standards for the design and testing of packages and associated transportation equipment for all hazardous materials and small quantities of radioactive materials. The $\mathrm{Nu}$ clear Regulatory Commission (NRC) sets standards for the design and performance of packages to carry highly radioactive materials.* Private shipping companies and container manufacturers, DOT, NRC, and the Department of Energy (DOE), all are exploring new technologies and possible design changes for the shipping containers used for hazardous materials and wastes, including spent nuclear fuel. Packaging issues that repeatedly confront Federal agencies include:

- the types and severity of tests necessary for determining the level of protection provided by the packaging,

- the development of new materials for packaging,

- the influence of international commerce and standards on U.S. packaging designs, and

- the impact of accident and spill frequency and consequences on container regulation.

This chapter examines a wide range of issues concerning hazardous materials packaging technology, including the development of design and testing standards and their relationship to the transportation system. Part I examines the unique container issues associated with the transportation of radioactive materials, including those related to shipment of high-level radioactive wastes, such as spent nuclear fuel. Part 11 deals with packaging for other hazardous materials commonly used, such as chemicals, petroleum products, explosives, and poisons. $\mathrm{h}$ discusses:

- the present spectrum of bulk equipment and small packages for shipping hazardous materials and wastes, and

- the impact of Federal regulation on transportation safety and container technology.

\footnotetext{
*Highly radioactive materials include fissile and greater than $A_{1}$ and $\mathrm{A}_{2}$ limits of radioactive materials. Fissile material is that containing one or more fissile radionuclides-Plutonium 238, Plutonium 239, Plutonium 241, Uranium 233, and Uranium 235. Neither natural nor depleted uranium is fissile material. $A_{1}$ and $A_{2}$ quantity limits are defined in 10 CFR 71.4 and table A-1 thereto.
} 


\section{PART 1: CONTAINERS FOR TRANSPORTING RADIOACTIVE MATERIALS}

Radioactive materials are employed extensively in modern society. In addition to their role in generating electric power, radioactive materials are used for research, manufacturing, and a wide range of industrial processes. They are also often indispensable for medical diagnosis and therapy. The pervasive use of these materials means that they and any waste products must be regularly transported. In total, some 2.8 million packages of radioactive materials are transported in about 2 million shipments each year in the United States by truck, rail, and air, out of 100 million shipments of all types of hazardous materials. Box $3 \mathrm{~A}$ defines terms used throughout this chapter.

Almost two-thirds of radioactive shipments are for medical purposes, with the balance for use in the nuclear fuel cycle to generate electricity, for industrial and research activities, and waste.* (See table 3-1.) About 7 percent of all shipments are classified as wastes (see box 3A), with the vast majority being low-level wastes. ${ }^{1}$ The total volume of lowlevel wastes shipped each year is about 2.7 million cubic feet, or enough to cover a football field with a pile 52 feet high. Between 100 and 300 shipments of high-level wastes and spent fuel, from electric utilities, and DOE and U.S. Department of Defense (DOD) research or training facilities, are made annually by truck and rail. See tables 3-2 and 3-3 for histories of commercial reactor and low-level waste shipments, respectively, and table 3-4 for the volumes and types of shipments associated with the nuclear fuel cycle. Reactor operation and the fuel cycle are summarized in box $3 \mathrm{~B}$.

Although medical and industrial shipments of radioactive materials are by far the most numerous, it is shipments of low- and high-level wastes and spent fuel that cause the greatest public concern and controversy. Federal regulations governing these

\footnotetext{
${ }^{*} \mathrm{~A}$ third category, radioactive materials for the defense industry-research, propulsion, and weapons-is not considered here, although problems related to shipments of hazardous materials by the U.S. Department of Defense are discussed briefly in ch. 5 in the enforcement training section.

${ }^{1}$ Harold S. Javits, et ' 1 'Transport of Radioactive Material in the United Stares, SAND84-7174 (Albuquerque, NM: Sandia National Laboratories, April 1985); and EG\&GIdaho, Inc., The 1984 State-by-State Assessment of Low-Level Wastes Shipped to Commercial Disposal Sites, DOE/LLW-50T (Washington, DC: U.S. Department of Energy, December 1985), p. 6.
}

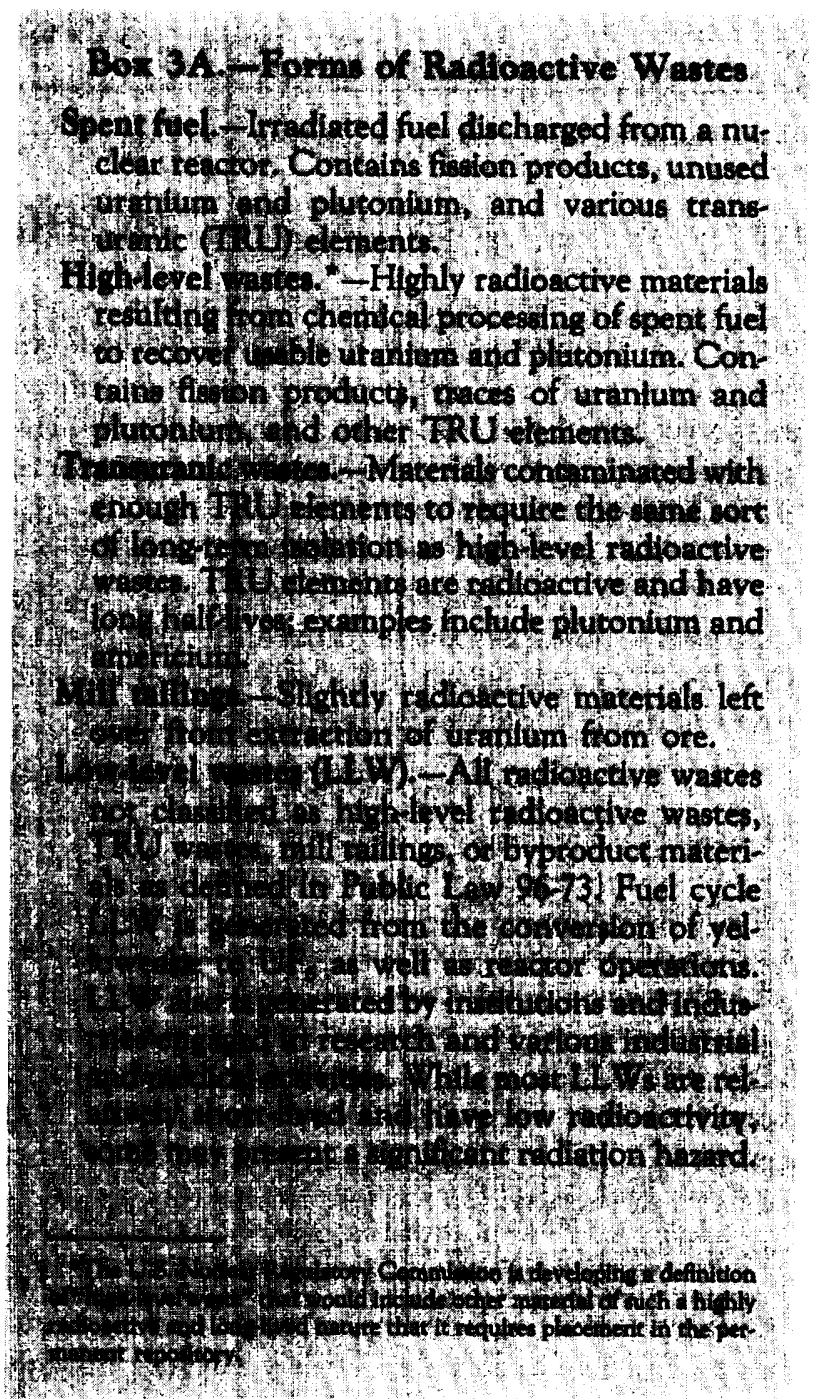

shipments are extensive, yet in the absence of widespread public confidence in Federal safety activities, over 650 additional State and local laws have been enacted attempting to control and even ban the movement of radioactive wastes.

The public is understandably apprehensive about the movement of highly radioactive materials. Even though such operations are not new here or abroad,

${ }^{2}$ N.P. Knox, et al., "Nuclear Waste Programs, " Transportation of Radioactive and Hazardous Materials: A Summary of State and Local Legislative Requirements for the Period Ending December 31, 1985, ORNL/TM-9985 (Oak Ridge, TN: Oak Ridge National Laborator for the U.S. Department of Energy, April 1986), p. v. 
Table 3-1.-Summary of Unclassified Radioactive Materials Shipments by the Nuclear Regulatory Commission (NRC) Licensees and the Department of Energy (DOE) Licensees

\begin{tabular}{|c|c|c|c|}
\hline \multirow[b]{2}{*}{ Sector } & \multicolumn{2}{|c|}{ Number of packages/year } & \multirow{2}{*}{$\begin{array}{c}\text { Percent of total } \\
\text { packages }\end{array}$} \\
\hline & NRC licensees & DOE licensees & \\
\hline Medical . . & $1,730,000$ & 16 & 61.5 \\
\hline Industrial $\ldots \ldots \ldots \ldots \ldots \ldots \ldots$ & 213,300 & - & 7.6 \\
\hline Nuclear fuel cycle . . . . . . . . . . . . . & 114,000 & 6,246 & 4.2 \\
\hline Waste (all sectors). . . . . . . . . . . . . & 181,000 & 1,146 & 6.5 \\
\hline R\&D and academic . . . . . . . . . & 17,100 & 1,802 & 0.7 \\
\hline Other . . . . . . . . . . . . . . . & 526,500 & 22,580 & 19.5 \\
\hline Total $\ldots \ldots \ldots \ldots \ldots \ldots$ & . 2,781,900 & 31,790 & 100.0 \\
\hline
\end{tabular}

SOURCE: Harold S. Javits, et al., Transport of Radioactive Material in the United States, SAN D84-71 74 (Albuquerque, NM: Sandia National Laboratories, April 1985), pp. 16 and 28.

Table 3.2.-History of Domestic Commercial Spent Fuel Shipments

\begin{tabular}{|c|c|c|c|}
\hline Year & Method & $\begin{array}{l}\text { Number of } \\
\text { shipments }^{\mathrm{a}}\end{array}$ & $\begin{array}{l}\text { Number of } \\
\text { assemblies }\end{array}$ \\
\hline \multirow[t]{2}{*}{1973} & .Truck & 83 & 185 \\
\hline & Rail & 6 & 72 \\
\hline \multirow[t]{2}{*}{1974} & .Truck & 222 & 333 \\
\hline & Rail & 1 & 13 \\
\hline \multirow[t]{2}{*}{1975} & .Truck & 166 & 198 \\
\hline & Rail & 4 & 64 \\
\hline \multirow[t]{2}{*}{1976} & .Truck & 291 & 291 \\
\hline & Rail & 18 & 324 \\
\hline \multirow[t]{2}{*}{1977} & .Truck & 444 & 444 \\
\hline & Rail & 27 & 407 \\
\hline \multirow[t]{2}{*}{1978} & .Truck & 230 & 230 \\
\hline & Rail & 24 & 256 \\
\hline \multirow[t]{2}{*}{1979} & .Truck & 79 & 83 \\
\hline & Rail & 15 & 105 \\
\hline \multirow[t]{2}{*}{1980} & .Truck & 22 & 22 \\
\hline & Rail & 5 & 32 \\
\hline \multirow[t]{2}{*}{1981} & .Truck & 81 & 242 \\
\hline & Rail & 2 & 13 \\
\hline \multirow[t]{2}{*}{1982} & .Truck & 100 & 297 \\
\hline & Rail & - & - \\
\hline 1983 & $\begin{array}{l}\text {.Truck } \\
\text { Rail }\end{array}$ & b & \\
\hline \multirow[t]{2}{*}{1984} & .Truck & 132 & 571 \\
\hline & Rail & 50 & 883 \\
\hline \multirow[t]{2}{*}{1985} & .Truck & 30 & 153 \\
\hline & Rail & 50 & 883 \\
\hline
\end{tabular}

a For 1976 to 1985 , the number of shipments was derived from the number of fuel assemblies of either $t$ he boiling water reactor (BWR) or pressurized water reactor (PWR) type sent by each mode. It was assumed that: all rail casks held 18 BWR assemblies or 7 PWR assemblies; legal weight truck casks were used up through 1980 (with a capacity of 2 BWR or 1 PWR assemblies); and overweight truck casks were used from 1981 to 1985 (with a capacity of 7 BWR or 3 PWR assemblies).

DSome of the shipments credited to 1982 actually occurred in 1983.D.F. Newman, Battelle Pacific Northwest Laboratories, personal communication, April 1986.

SOURCE: Science Concepts, Inc., "Containers for Transporting Radioactive Materials," OTA contractor report, September 1985, p. 5 (1973 to 1975 data); and D.F. Newman, Battelle Pacific Northwest Laboratories, written communication, April 1986 (1976 to 1985 data), they are complex and potentially dangerous. Concerns have been voiced that the packaging may be inadequate, packaging test criteria do not reflect realistic accident conditions, industry does not always follow safety procedures, localities cannot exercise sufficient control over routing, and the consequences of an accident could be far more severe than government and industry reports indicate. ${ }^{3}$

Unless substantial progress on resolution of issues is made, controversy over the transportation of highlevel radioactive materials will increase as greater quantities of spent fuel must be moved from reactor sites that have exhausted their onsite storage capacities. As many as 22 reactors are expected to have no more spent fuel pool capacity available between 1987 and 1993, unless alternatives now being actively explored, such as reracking, rod consolidation, or dry cask storage, can be implemented. ${ }^{4}$ The Nuclear Waste Policy Act of 1982 (NWPA) requires that, starting in 1998, DOE take title to spent nuclear fuel at commercial reactor sites and, when necessary, transport it to a repository. A permanent waste repository may not be available by that date,

${ }^{3}$ Marvin Resnikoff, The Next Nuclear Gamble (New York, NY: Council on Economic Priorities, 1983); Stephen N. Salomon, State Sur. veillance of Radioactive Material Transportation, NUREG-1015 (Washington, DC: U.S. Nuclear Regulator ${ }_{y}$ Commission, 1984); and Joseph Strohl and Lindsay Audin in U.S. Congress, Office of Technology Assessment, "Proceedings of OTA Workshop on Nuclear Materials Packaging Technology, “ unpublished typescript, Feb. 8, 1985.

${ }^{4} U$ S. Department of Energy, Spent-Fuel Storage Requirements, DOE/RL-84-1 (Washington, DC: U.S. Government Printing Office, May 1984); and Marvin Smith, Supervisor, Nuclear Engineering, VirginiaElectric Power Co., personal communication, April 1986. 
Table 3-3.-Quantities of Low. Level Radioactive Waste Shipped and Buried in 1984

\begin{tabular}{|c|c|c|c|c|}
\hline Disposal site & Volume $\left(\mathrm{m}^{3}\right)$ & Percent total & $\begin{array}{l}\text { Radioactivity } \\
\text { (curies) }\end{array}$ & $\begin{array}{l}\text { Percent } \\
\text { of total }\end{array}$ \\
\hline Barnwell, SC . . . . . . . . . . & 34,879 & 47 & 383,079 & 64 \\
\hline Beatty, NV . . . . . . . . & 2,069 & 3 & 544 & \\
\hline Richland, WA. . . . . . . & 38,481 & 51 & 215,286 & 36: \\
\hline Total quantity . . . . . . . . . . . & $\overline{75,429}$ & 100 & 600,909 & 100 \\
\hline
\end{tabular}

Table 3=4.-Radioactive Material Shipments Associated With the Nuclear Fuel Cycle (annual shipments per 1,000 megawatt reactor)

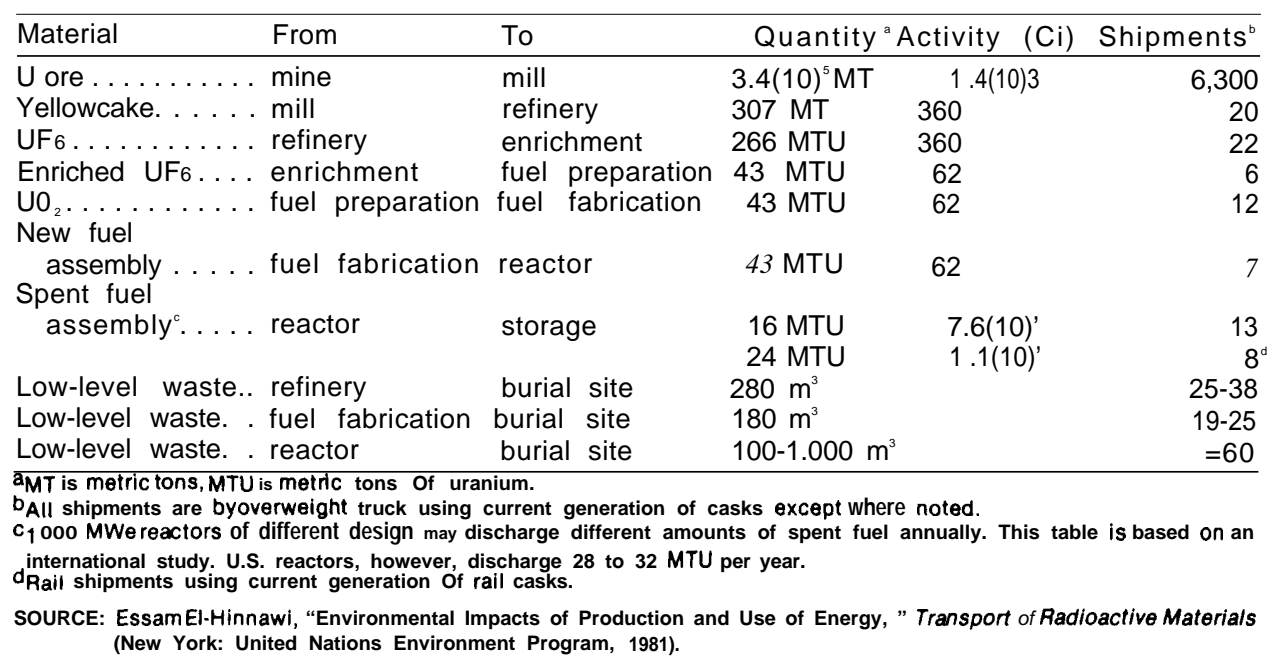

and DOE has proposed moving much of the stored spent fuel to a monitored retrievable storage facility. In the meantime, shipments of spent fuel will continue in connection with intra-utility transfer and storage plans and DOE research and development.

For these reasons, Congress asked OTA to study the issues surrounding shipments of radioactive materials, especially spent nuclear fuel and high-level wastes. The focus of this first part of chapter 3 is specifically on the containers used for spent fuel, their integrity, and the procedures surrounding their use in transportation. The technical issues related to the containers will be evaluated as will the institutional, legal, jurisdictional, and public policy issues surrounding spent fuel shipments. These latter are as important and as difficult to assess as the technical issues. In particular, this section will address these questions:
- Are current technical standards and safety analysis methods for spent nuclear fuel containers adequate?

- How safe is the transport of spent reactor fuel, and what may be the consequences of an accident?

- What improvements are necessary in the safety procedures for container manufacture, transportation, and container and vehicle inspections?

- What public concerns must be addressed as the country prepares for increased spent fuel shipments under NWPA?

- What can be done to resolve legal and jurisdictional concerns regarding the choice of safe shipping routes and other operational restrictions?

- Is the public understanding of technical issues adequate to provide a basis for resolution of contentious issues? If not, what should or can be done to improve this? 


\section{Box 3B.-Reactor Operation and Spent Fuel Production}

1. The light-water reactor (LWR) is the principal rethetor type in commercial use in the Uhited States.* Fuel for nudear reactors consists of fuel rods in the form of 12- to 13-foot long, zircallor tubes about Th inch in diameter, filled wh seramic uranium oxide pellets. These rods are bundled topether to form fuel aseemblies. In the LWR, the fuel as- semblies are immersed collectively in a coolant (wane), where they form the reactor ogre, The conmol rods interspersed among the fuel rods control the rate of fission in the reactor fuel. Heat from for ton and, to a much lesser extent, from the deW of fission produces is used to heat water to Whing, which is used to generate electricty.

After about 3 years, the buildup of flission prod14. in in a fuel assembly impedes the efindency of the Chain reaction. When the concentration of $U^{235}$ in the fuel is around 1 percent, the assembly, consid1. 7uel. LWR discharge between 60 and 175 assemThlew or a totel of about 28 to 32 metric tons of 7ntanimin" of spent fuel, each thr.

12 Because of the decay of the fill 0 h products and 1 emanuranic elements, spent fid its highly radioGctive when it is indially dischy ged from the re-

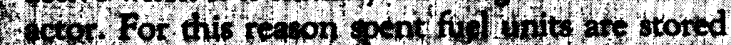
Win water baitis to provide the cooling and radia. W7on shielding that they requift. After 6 to 12 Wonths in the stotage pools, the radioactivity de-

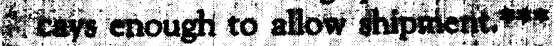

Wt The heat output and redioadt vhy of opent fuel

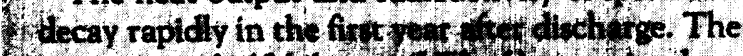

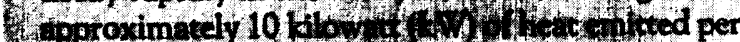
Whone afier 1 year equ

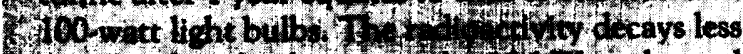
rapidly after the fing of the first year is requch to end of 10 years after dixt 1.

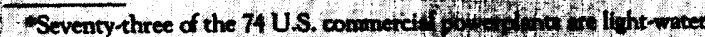

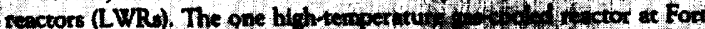

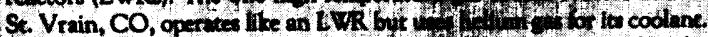

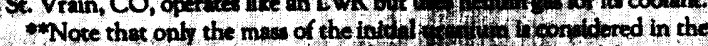

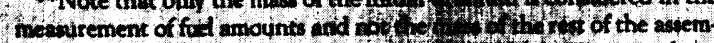

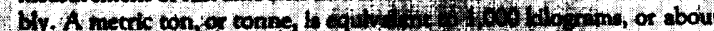
205 pound

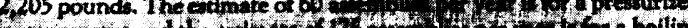

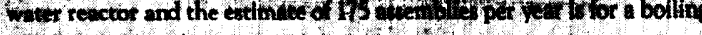
whet reactor.

* Many upent fuel ceals are lianed to tretnopoct fuel that has been cooled for 150 dar. Although coinmetcil tetittes tryically ship only fiel at least everal years old, thipmenes of 150 day old fuel by the U.S Department of Energy and the U.S. Department of Defense are not 1) tunuaral.

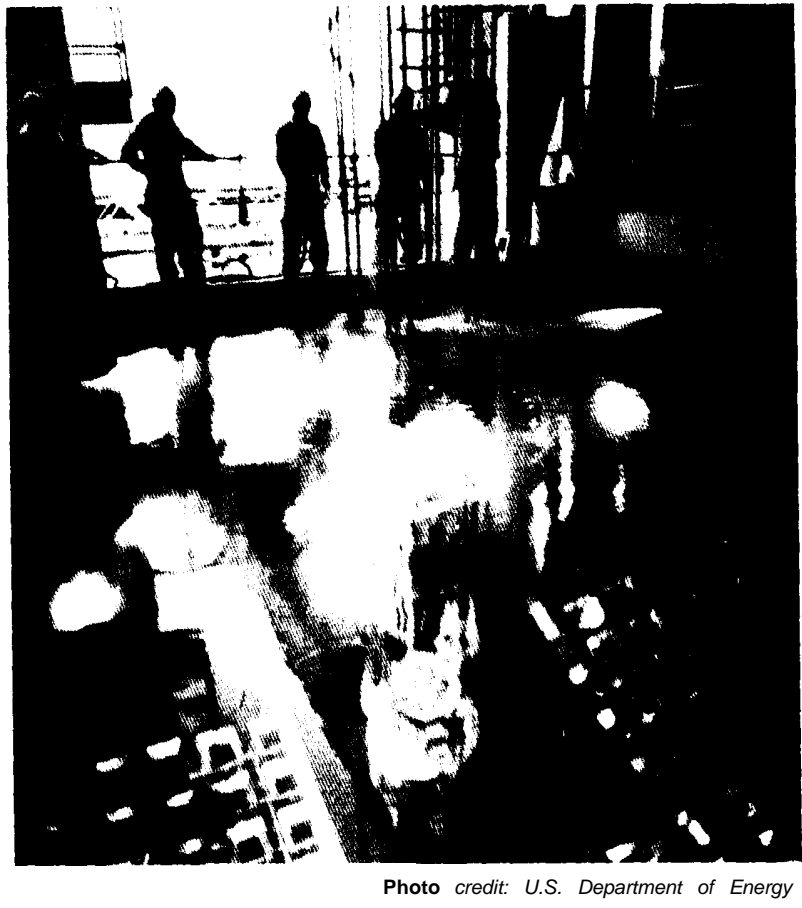

Spent fuel storage basin at a commercial nuclear powerplant.

The information in this chapter is derived from technical literature, interviews with technical experts and concerned citizens, and from an OTA workshop on nuclear materials packaging.

\section{Regulatory Framework}

While the primary Federal regulatory responsibility for shipments of radioactive materials lies with DOT, NRC and DOE also have specific responsibilities. Under its authority, DOT has issued regulations covering all aspects of transporting radioactive materials, including requirements for the containers, the mechanical condition of the transportation vehicles, and the training of personnel, as well as the routing requirements, package labels, vehicle placards, and shipping papers associated with shipments of radioactive materials. DOT also conducts carrier equipment inspections.

Under a Memorandum of Understanding, NRC and DOT cooperate closely to regulate containers for radioactive materials. NRC, under its own legislative authority, is responsible for regulating, review-

${ }^{5}$ U.S. Congress, op. cit. 
ing, and certifying the packaging and certain transportation operations for shipments of fissile and highly radioactive materials that must be packaged very securely in Type B containers (described below) when such shipments involve NRC licensees.

DOE also has authority, granted by DOT regulations,' to approve the packaging and certain operational aspects of its research, defense, and contractor-related transportation of fissile and highly radioactive materials. Although DOE is required to use standards and procedures equivalent to those of NRC in the container certification process, when DOE has chosen to exercise its own authority to use casks and procedures other than NRC-approved, substantial conflict between DOE and States and concerned citizens has arisen. Officials from New York and New Jersey were outraged to learn in July 1985 that DOE had planned to use a cask that had been refused NRC certification for nuclear waste shipments from Brookhaven National Laboratories on Long Island. Tennessee officials were similarly infuriated when they were told by DOE that a spent fuel shipment to be used for research would be moving through the State sometime in the next few months. Tennessee insisted on and received more specific information from DOE and assurances that the State procedures and requirements would be met. ${ }^{8}$

DOE has established the Office of Civilian Radioactive Waste Management to plan and establish specific regulatory and procedural guidelines for spent fuel shipments under NWPA. A more complete discussion of issues related to NWPA shipments may be found on page 106. DOD has authority similar to DOE's to use equipment and procedures equivalent to NRC'S,

DOT sets regulations for all other packaging for radioactive materials in consultation with NRC. NRC approval is required of routes for shipments needing physical protection during transport to prevent theft or sabotage, but the routes chosen must

\footnotetext{
${ }^{6} 10$ CFR 7 1.4; also, "Transportation of Radioactive Materials: Memorandum of Understanding," Federal Register, vol. 44, No. 128, July 2, 1979. Among the 22,000 Nuclear Regulatory Commission and Agreement State licensees are manufacturers and users of radiopharmaceuticals, oil exploration companies, 127 nuclear powerplants, and 90 nonpower reactors and their supply industries.

49 CFR 173.7.

${ }^{8}$ Personal communications fro $_{\mathrm{m}}$ DOE and State officials and con gressional staff, August to October 1985.
}

be compatible with DOT regulations described in chapter 4.

Guidelines for public radiation protection are established by the U.S. Environmental Protection Agency and follow international criteria established by the International Commission on Radiological Protection and the National Commission on Radiation Protection. DOT and NRC regulations are based on these guidelines, which establish upper limits on radiation levels around containers.

U.S. regulations for containers used for radioactive materials transportation are based on internationally accepted performance standards. International regulations and standards divide the materials to be shipped into three categories based on their radioactivity levels:*

1. low hazard or very low levels of radioactivity requiring "strong tight" containers,"

2. somewhat higher levels of radioactivity requiring secure containers called "Type A" packages, and

3. fissile materials and those with very high levels of radioactivity requiring exceptionally durable containers called "Type B" packages.

Federal regulations limiting the radioactive contents for the commonly used strong tight and Type A containers are based on the assumption that the containers might break open in an accident and release some of the contents. In contrast, Type B packages, frequently called casks, are required to be sufficiently strong to withstand severe accident conditions, thus

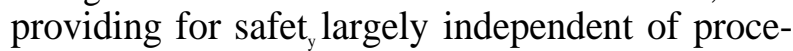
dural and other controls on the shipment. To assure that Type B packages are designed, constructed, handled, and loaded in a fashion that protects public health and safety, NRC must approve and certify container designs and make certain that quality assurance procedures are implemented for manufacturing, operating, and maintaining the casks.

While the philosophy is to use Type B containers as the first and most important device for public protection, there are additional regulations and requirements for their transportation to reduce potential radiological hazards. First, the movement of high-

\footnotetext{
*International Atomic Energy Agency Safety Series 6,1985, now contains a fourth category called "surface contaminated object," which is under consideration to become a U.S. category.
} 
level radioactive materials involves a much greater degree of scrutiny by NRC and DOT than do shipments of low-level materials. NRC monitors the quality assurance programs of its licensees for the construction and operation of spent fuel shipping casks and requires operational checks, such as leak tests, for the casks prior to each use. NRC also conducts routine checks for compliance with regulations at its licensees' facilities. To increase the number of inspections without overtaxing the agency, NRC has transferred authority for inspection of certain activities, including shipment of byproduct, source, and less than critical quantities of special nuclear materials to "Agreement" States."

However, authority for activities related to commercial spent fuel shipments remains with NRC, and its inspectors are on hand at licensees' facilities to monitor the beginning of any spent fuel shipping campaign. In the period July 1983 to June 1985, NRC conducted more than 300 inspections of spent fuel shipments at origins and destinations. ${ }^{10}$ As an added precaution, some States through which spent fuel shipments pass may require inspection of shipments by State personnel as well.

NRC also requires that the Governors of affected States be notified in advance of commercial shipments of spent fuel and certain other highly radioactive materials. The information provided must include the name, address, and telephone number of the shipping organization, as well as a description of the material and estimates of times of arrival at State boundaries. DOE notification procedures are much less explicit, creating friction with many States. Moreover, certain shipments that involve national security are exempt from this requirement, although DOT requires postnotification of many shipments of highly radioactive materials.

\footnotetext{
${ }^{9}$ E.L. Emerson and J.D. McClure, Radioactive Material (RAM) Accident/Incident Data Analysis Program, SAND 82-2156 (Albuquerque, NM: Sandia National Laboratories, March 1985), p. 7. As of 1986 , 28 States are Agreement States and responsible for regulating their 13,000 licensees. NRC is still responsible for regulating its 9,000 material licensees and its some 200 reactor (power and nonpower) licensees, even if they are physically located in an Agreement State. Stephen Salomon, Office of State Programs, U.S. Nuclear Regulatory Commission, personal communication, February 1986.

${ }^{10}$ Alfred W. Grella, Office of Inspection and Enforcement, U.S. Nuclear Regulatory Commission, "NRC Inspection Activities on Recent Shipments of Spent Fuel 1983 to Present," unpublished manuscript of speech presented at the Spent Nuclear Fuel Transportation Seminar, Chicago, IL, Aug. 1, 1985.
}

Both DOT and NRC have the authority to impose fines for violations of regulations. However, the enforcement efforts of both agencies have been the subject of severe criticism. NRC has had "too much of a closeness with industry..." according to NRC Commissioner, James K. Asselstine." The adequac, of DOT's relatively small inspection forces has been questioned for monitoring the millions of shipments of radioactive materials that do not involve spent fuel. ${ }^{12}$ For further details on inspection levels see chapter 5.

\section{Containers}

Packaging regulations and standards for shipping radioactive materials were first established in 1946 by the Interstate Commerce Commission, based on recommendations by the National Academy of Sciences. The standards were subsequently adopted by the International Atomic Energy Agency (1AEA) and 53 nations. As part of an ongoing international evaluation of the standards, there have been several updates, including provision in 1967 for Type $A$ and Type B packaging standards. The United States recently revised its regulations slightly to make them consistent with 1973 IAEA guidelines.

The need for technical improvements to the packages is examined as an ongoing part of research and development, and Type B packages have been a focus of DOE-funded research over the years. An international meeting of experts in this area, Packaging and Transportation of Radioactive Materials, is held periodically, about every 3 years, providing a forum for the exchange of information.

Procedures to ensure safe packaging for transporting radioactive materials include:

. categorizing the materials according to their levels of radioactivity and form, and

. requiring the preparation and use of packaging appropriate for the type and quantity of material.

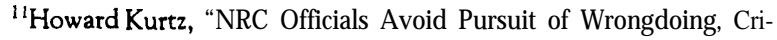
tics Say," Washington Post, Apr. 8, 1986, p. A-1.

${ }^{12}$ Paul Rothberg, science Policy Research Division, Congressional Research Service, "Hazardous Materials Transportation: Laws, Regulations, and Policy," Issue Brief IB76026, Mar. 11,1986, p. 5

${ }_{13}^{10}$ CFR 71, Federal Register, Aug. 5, 1983; International Atomic Energy Agency standards adopted in 1985 require a 200 meter submergence test to allow for transport over coastal ocean depths. Because no U.S. shipments now travel by sea, the United States has not yet considered adoption of this new requirement.
} 
The choice of packages is based on the form and quantity* of the material shipped. There are two forms: normal-form and special-form. Most materials are classified as normal-form. They are not highly radioactive, and although they constitute about 87 percent of all radioactive packages shipped annually, they include only 10 percent of the curies. Special-form materials are generally encapsulated solids that present a hazard due to direct external radiation if they escape from the package; although they constitute only about 13 percent of all radioactive packages, they include 90 percent of all the curies shipped annually. ${ }^{14}$ However, specialform solid material is not readily dispersible and has high physical integrity, and thus poses relatively little risk from inhalation or ingestion. The quantity of radioactivity in the material is indicated by four subdivisions: excepted or limited quantity, low specific activity, Type A, and Type B.

Excepted rnaterialis that which is so low in radioactivity that the hazards are negligible, and the materials can be shipped without special packages, shipping papers, or labels. Examples of such materials include smoke detectors, static elimination brushes, lantern mantles, luminous watch dials, and luminous exit signs. Excepted materials are regulated by DOT.

Low specific activity (LSA) material is that in which the specific radioactivity is sufficiently low that the radiological hazard presented by inhalation or ingestion of the material is very small. LSA materials include such things as uranium mill tailings, uranium ore, natural uranium hexafluoride, some low-level wastes, and most laboratory and medical wastes. LSA materials must be contained in strong and tight packages which permit no leakage of radioactive material under normal transportation conditions. Wooden boxes, 55 gallon drums, and special tank trailers fit this criteria. Containers for LSA materials are regulated by DOT in consultation with NRC. Some LSA materials, such as spent resins from reactors, are required to be packaged in NRCcertified Type A packages,

Type $A$ packaging is intended to prevent the loss or dispersal of its contents when subjected to a specified set of "normal" transportation conditions. The

\footnotetext{
*Quantity refershere to the degree of radioactivity.

${ }^{14}$ Javits, op. cit., p. ii.
}

conditions are actually more severe than the "normal" label implies, as is shown in box 3C. Most radiopharmaceuticals for medical uses are packaged in Type A containers, as are radioassay materials used in research and medicine, and some wastes associated with reactor operation. Type A containers are regulated by DOT in consultation with NRC.

Type B packaging requirements are the most stringent. Type B containers are employed for the larger

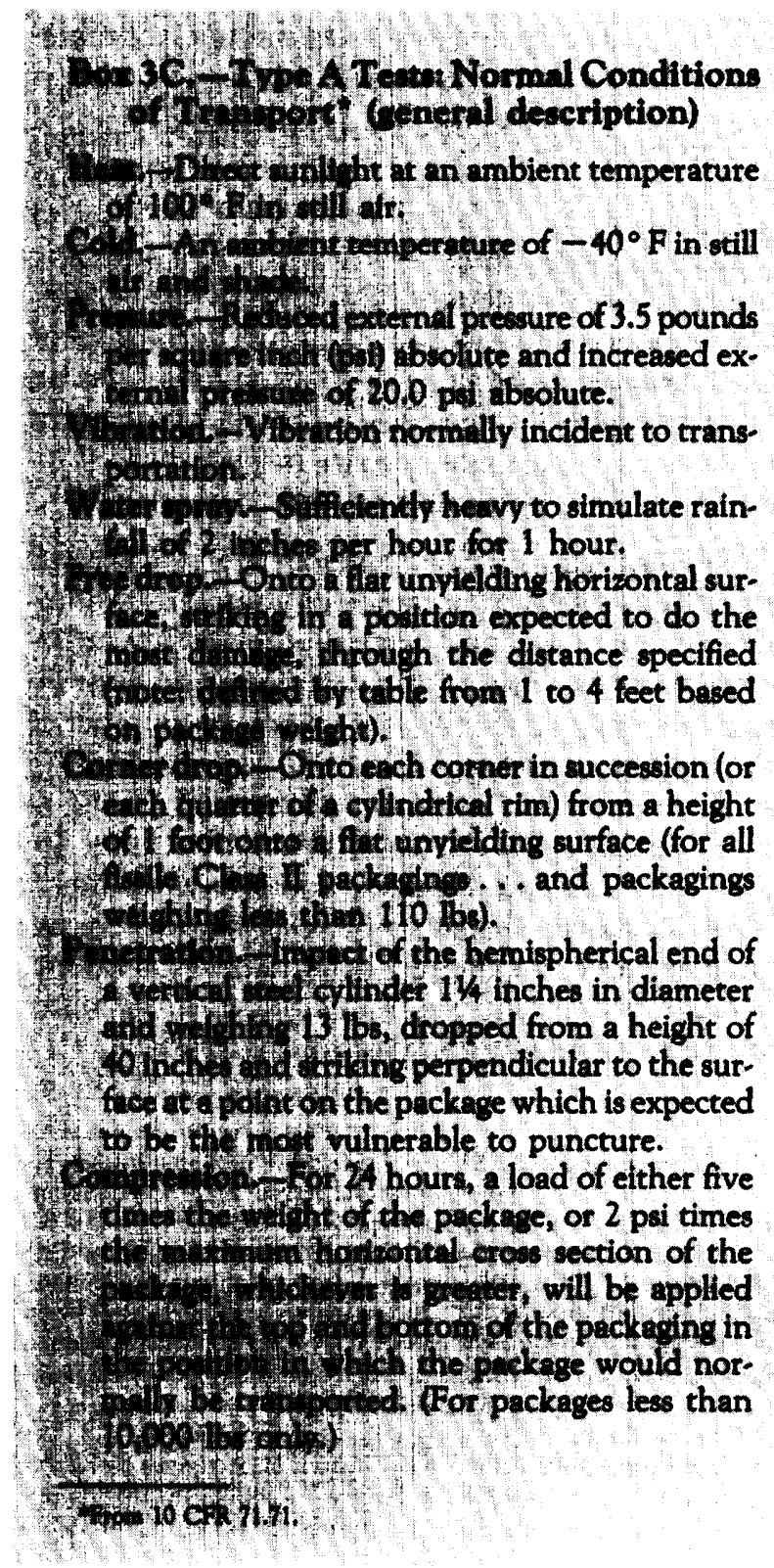




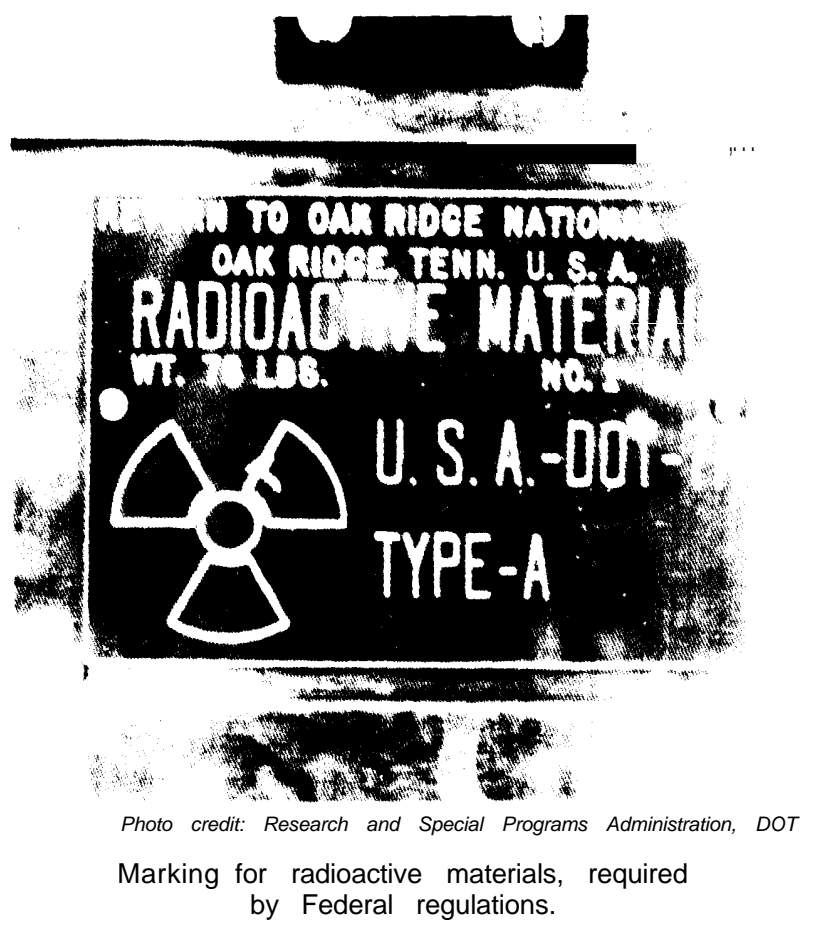

quantities and high-level radioactive materials. Type B packages are required for most fissile materials, spent fuel, highly radioactive waste, irradiated components, radioactive sources for medical therapy, industrial radiography sources, highly contaminated equipment, and power sources for pacemakers. Type B "overpacks" are frequently used for shipping many Type A packages when additional protection is required. NRC regulations contain the standards for Type B containers and certifies the designs used in their construction. The Type B test sequence-drop, puncture, and exposure to heat and water immersion-is described on page 100. DOT regulations allow the use of either DOE- or NRC-certified Type $\mathrm{B}$ and fissile packages in commerce.

\section{Type B Containers for Spent Fuel}

Underlying the Type B packaging standards is the assumption that the possibility of an accident can never be eliminated and that the package must be able to survive severe accident conditions without a dangerous release of its contents. Thus, NRC regulations provide a set of performance criteria for the containers, rather than specific design requirements. The intent is to remove the need to predict specific accident events and circumstances and to provide a set of engineering test specifications for impact, puncture, temperature, immersion, and leak tightness that encompass the types of conditions that could occur in an accident.

The basic criteria for Type B cask design are virtually the same in every nation with a commercial nuclear program. The most widely recognized Type B containers are the casks for transporting highly radioactive spent reactor fuel from commercial nuclear powerplants. The casks are 10 to over 20 feet long and are constructed of two concentric, welded, stainless steel shells typically 1 to 2 inches thick each, enclosing a gamma radiation shield of lead or depleted uranium metal and a water or other hydrogenous material neutron radiation shield. These casks were designed to contain and ship for reprocessing spent fuel that had been removed from the reactor 4 to 5 months previously and that was still relatively radioactive. However, since no reprocessing of commercial fuel is being carried out in the United States, no utilities are currently shipping fuel less than 10 years old.* A general description of the current generation of U.S. casks is as follows: ${ }^{15}$

- Truck casks (legal weight):

—weigh less than 25 tons,

- contain one to two fuel assemblies, and

- can be unloaded in less than 12 hours.

- Truck casks (overweight):

-weigh up to 40 tons and are restricted in movement,

- contain three to seven fuel assemblies, and

- can be unloaded in less than 16 hours.

- Rail casks:

—weigh up to 100 tons,

- contain between 7 and 24 fuel assemblies, and - can be unloaded in 28 to 36 hours.

Specific descriptions of spent fuel casks in use in the United States today may be found in table 3-5.**

\footnotetext{
*Th ${ }_{e}$ U.S. Department of Energy and the U.S. Department of Defense routinely make such shipments, however, for research purposes

and nuclear submarine maintenance.
${ }^{15}$ U.S. Department of Energy, Spent Fuel Storage Fact Book, DOE/ NE-0005 (Washington, DC: April 1980), p. 54.

**Monolithic, all-steel casks and nodular cast iron casks are already used in Europe and Japan. Prototypes of such casks have been submitted to the Nuclear Regulatory Commission (NRC) for testing, but none has yet been certified. In the case of nodular cast iron casks, a highly ductile cast iron is required to prevent brittle fractures, which have been a problem in casks tested to date, according to NRC.
} 


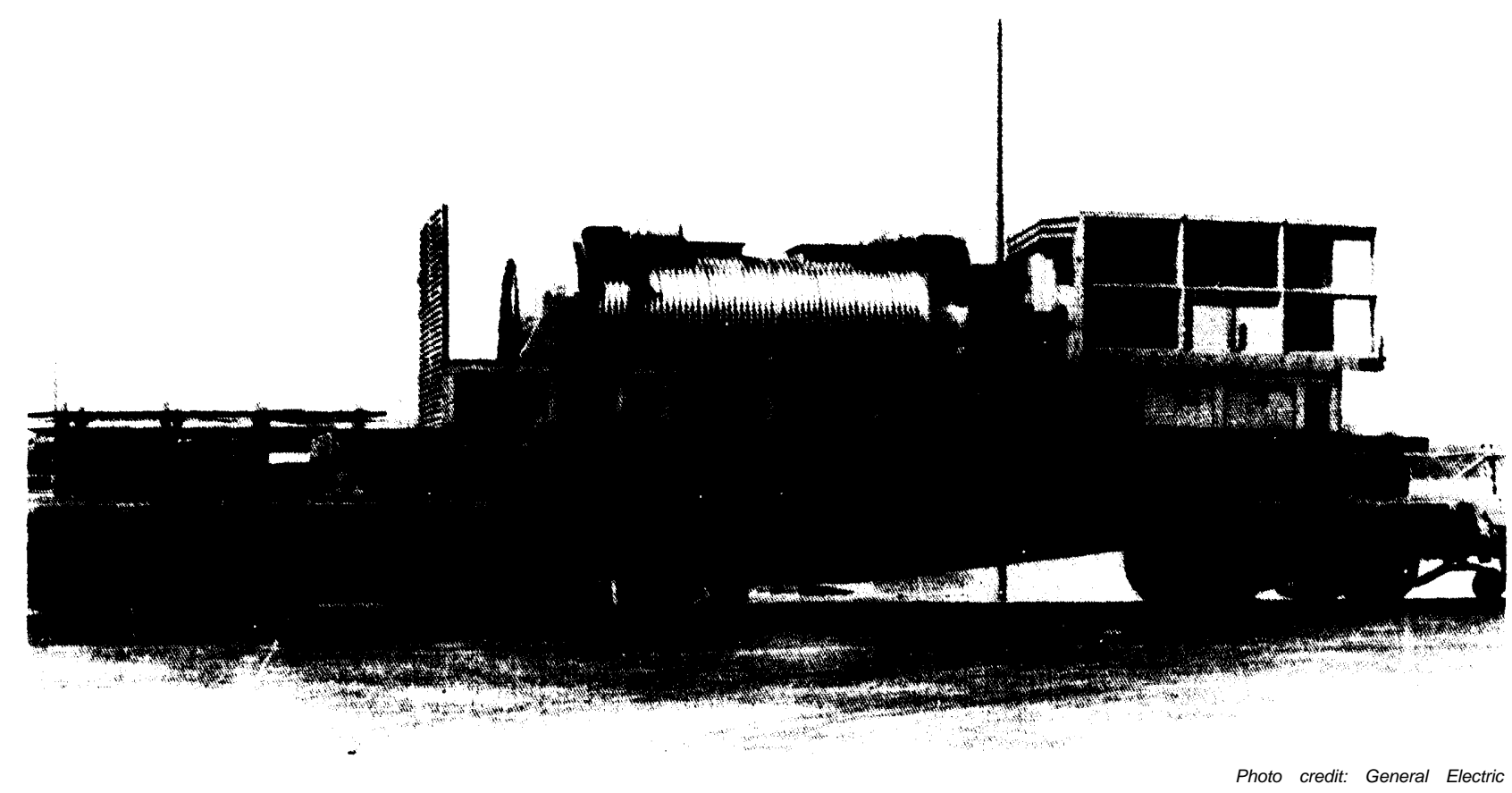

Rail cask mounted and secured on a railcar.

Table 3-5.-Characteristics of the Current Generation of Nuclear Regulatory Commission Certified Light Water Reactor Spent Fuel Casks

\begin{tabular}{|c|c|c|c|c|c|}
\hline \multicolumn{3}{|c|}{$\begin{array}{c}\text { Nuclear Assurance Corp. } \\
\text { Norcross, GA }\end{array}$} & \multirow{2}{*}{$\begin{array}{c}\text { General Electric } \\
\text { Morris, IL } \\
\text { IF-300 }\end{array}$} & \multicolumn{2}{|c|}{$\begin{array}{l}\text { Transnuclear, Inc. } \\
\text { White Plains, NY }\end{array}$} \\
\hline NAC-1/NFS-4a & $\mathrm{NL} 1-1 / 2$ & NL1-10/24 & & TN8 & TN9 \\
\hline Transport mode $^{b} \ldots \ldots \ldots \ldots$ LWT & LWT & Rail & OWT/Rail & OWT & OWT \\
\hline PWR/BWR assemblies/cask ${ }^{\mathrm{c}} .1 / 2$ & $1 / 2$ & $10 / 24$ & 7118 & $3 / 0$ & $0 / 7$ \\
\hline Loaded weight (tons) . ......22.5 & 24 & 95 & 63.5 to 70 & 38 & 38 \\
\hline Gamma shield $\ldots \ldots \ldots \ldots$ lead & lead/U & lead/U & uranium & lead & lead \\
\hline Neutron shield. . . . . . . . . berated water & water-glycol & water-glycol & water-glycol & resin & resin \\
\hline Cavity coolant $\ldots \ldots \ldots \ldots$ inert gas & helium & helium & inert gas & inert gas & inert gas \\
\hline Exterior surface. . . . . . . . . smooth & smooth & $\begin{array}{l}\text { stainless } \\
\text { steel fins }\end{array}$ & corrugated & $\begin{array}{l}\text { copper } \\
\text { spines }\end{array}$ & $\begin{array}{l}\text { copper } \\
\text { spines }\end{array}$ \\
\hline Units operating $\ldots \ldots \ldots \ldots 5^{d}$ & 5 & $2^{\mathrm{e}}$ & $4^{\prime}$ & & $2^{h}$ \\
\hline
\end{tabular}

a Notcurrentlylicensed to transport spent fuel from power reactors.

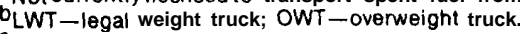

CPWR-pressurized water reactor; BWR-boiling water reactor.

dOneunit owned by Duke Power (for transporting spent fuel onsiteonly)

eCask has never been in service.
fOne unit owned by Carolina Power \& Light

${ }_{9} \mathrm{~T}_{\text {wo }}$ certified units operating in Europe.

$9 \mathrm{~T}_{\text {wo }}$ certified units operating in Europe.
$\mathrm{h}_{\text {One }}$ unit owned by Commonwealth Edison.

SOURCE: Sandia National Laboratories, Commercial Experience Involving the Transportation of Spent Fuel and HIgh Level Waste inthe United States, TTC/OOg (Albuquerque, NM: May 1981), 


\section{Accident Conditions and Test Standards}

The hazards associated with highly radioactive materials require the use of special, exceptionally durable packages for transportation. Establishing standards for the design and construction of such packages requires that the types and severity of conditions that could be experienced in an accident be understood and defined.

The Federal approach to ensuring container safety includes:

Performance standards that are specified by

NRC and converted by the cask designer to specific design requirements for the container.

Engineering test conditions that are established to encompass real accident conditions. The test conditions may be satisfied by computer analyses, model testing, full-scale tests, or a combination of all three methods.

Performance standards specify how a container must perform under specified conditions, tests, and environments. The infinite number of possible accident variables precludes development of a standard worst-case accident. Consequently, a set of engineering test conditions, based on evaluations of actual accidents, have been chosen to encompass and generally exceed the types of actual accident conditions. Having specific test criteria makes it possible to duplicate tests and compare consequences with different designs and at different times and achieve consistent results. This approach to engineering safety is the basis for current engineering practices, whether for bridges, skyscrapers, or aircraft.

To evaluate whether a cask design conforms to the regulations, NRC requires detailed structural, thermal, and nuclear safety analyses, computer modeling, and scale-model or full-scale tests. The evolution of both computers and modeling techniques has led to reliable ways to establish the adequacy of container designs without destructive testing, ${ }^{16}$ and many studies have examined the validity of

\footnotetext{
${ }^{1}$ M. Huerta, Analytical and Scale Modeling Techniques for Predicting the Response of Spent-Nuclear Fuel Shipping Systems in HighVelocity Impacts Against a Rigid Barrier, SAND77-0270 (Albuquerque, NM: Sandia National Laboratories, April 1978); see also, M. Huerta and H.R.Yoshimura, A Study and Full-Scale Test of a High-Velocity Grade-Crossing Simulated Acciden. of a Locomotive and a Nuclear-Spent-Fuel Shipping Cask, SAND79-2291 (Albuquerque, NM: Sandia National Laboratories, February 1983).
}

computer modeling and scale-model tests of casks in accident environments. Where parameters are not known with sufficient precision, assumptions are used that will overestimate damage to a cask.

Full-scale tests have shown that the mathematical analyses, computer models, and scale-model tests accurately predict the behavior of full-scale casks. ${ }^{17}$ In a series of tests, a spent-fuel cask was dropped onto several kinds of surfaces at an impact speed of $45 \mathrm{mph} .{ }^{18}$ For this velocity, analyses based on the regulatory requirement of impact with an "unyielding" surface predicted a deceleration (or measurement of the amount of energy absorbed by the cask and causing damage) of 1,200 gs. (A " $\mathrm{g}$ " is a unit of force equivalent to the force due to gravity.) The full-scale test produced 1,000 gs. For impact onto concrete, the analysis predicted $900 \mathrm{gs}$; the actual test produced 600 gs. While the models do not precisely predict the actual conditions, the difference is always conservative, predicting higher than actual impact energies. Further studies are being conducted to improve the accuracy of the computer models and to establish extremely severe accident condition bounds. ${ }^{19}$ Similar results and confidence exist in the computer models for evaluating scale-model tests. ${ }^{20}$

The engineering tests established to encompass accident conditions for Type B packages can be summarized as follows. ${ }^{21}$ The conditions are to be ap-

\footnotetext{
${ }^{17}$ J.D. McClure, et al., "Relative Response of Type B Packaging co Regulatory and Other Impact Test Environments," Proceedings of the 6rh International Symposium on Packaging and Transportation of Radioactive Materials (PA TRAM), vol. II, held in Berlin, Federal Republic of Germany (Springfield, VA: National Technical Information Service, November 1980), pp. 1247-1252.

${ }^{18} \mathrm{~W}^{\mathrm{E}}$ Wowak, Research and Development at the Transportation Technology Center, SAND TTC-0484 (Albuquerque, NM: Sandia National Laboratories, 1984); presented at the Packaging and Transportation of Radioactive Materials Seminar, Washington, DC, April 1984.

${ }^{19}$ A.A. Trujillo, et al., "Thermal and Structural Code Evaluation," Proceedings of the 7th International Symposium on Packaging and Transportation of Radioactive Materials (PA TRAM), held in New Orleans, LA (Springfield, VA: National Technical Information Service, May 1983). The Nuclear Regulatory Commission is currently sponsoring research at the Lawrence Livermore Laboratories into the engineering conditions that have resulted from very severe transportation accidents.

${ }^{20}$ W.E. Baker, "Scaling and Prediction of Impact Puncture of Shipping Casks for Radioactive Materials," The Shock and Vibration Bulletin, Bulletin 48 (Washington, DC: Naval Research Laboratory, September 1978); see also, B. Evason, "Impact Modeling and Reduced-Scale Tests," The Urban Transport of Irradiated Fuel (London: Macmillan Press, 1984), p. 233.
}

"10 CFR 71.73. 
plied sequentially to determine the cumulative effect on a package:

- Free drop.-A free drop of 9 meters onto a flat, essentially unyielding, horizontal surface, striking the surface in a position for which maximum damage is expected.

- Puncture.-A free drop of 1 meter, striking in a fashion for which maximum damage is expected, the top end of a vertical, cylindrical, mild steel bar mounted on an essentially unyielding, horizontal surface. The bar is 15 centimeters in diameter, with the top horizontal and its edge rounded to a radius of not more than 6 millimeters, and such a length as to cause maximum damage to the package, but not less than 20 centimeters long. The long axis of the bar is perpendicular to the unyielding, horizontal surface.

- Thermal test.-Exposure to a thermal test in which the heat input to the package is not less than that which would result from exposure of the whole package to a radiation environment of $800^{\circ} \mathrm{C}$ for 30 minutes, with an emissivity coefficient of 0.9 . The package may not be cooled artificially.

- Water immersion (for fissile material packages only) .- Immersion in water to the extent that all portions of the package are under at least 15 meters of water for a period of not less than 8 hours.

Familiarity with the engineering principles involved is critical to understanding the safety provided by the casks. These four conditions have been widely described, in simplified form, in popular literature on the subject of the transportation of spent fuel. ${ }^{22}$ However, simplified descriptions often cannot accurately represent the technical criteria, and at least two of these are often misunderstood-the free drop and thermal test conditions.

The free drop, or drop test criterion of 9 meters, about 30 feet, may appear substantially inadequate considering that the maximum reported falling distance for a rail accident was 76 feet and for a truck

\footnotetext{
${ }^{22}$ International Atomic Energy Agency, Safe Transport of Radioactive Material (Vienna, Austria: May 1982); George Russ, Nuclear Waste Disposal: Closing the Gap (Bethesda, MD: Atomic Industrial Forum, June 1984), p. 21; Resnikoff, op. cit., p. 20.
}

accident, 89 feet. $^{23}$ In addition, concern has been voiced over the chance of an accident in which a cask falls from a bridge 300 feet above water. ${ }^{24}$ The critical engineering condition in the criterion is the use of an unyielding surface, meaning that all of the energy resulting from impact is absorbed by the cask. Such a surface provides a worst-case and consistent basis for testing and engineering design purposes. Sandia National Laboratories have conducted tests and analyses of casks on conventional common surfaces to compare damages inflicted on casks after impact with an unyiedding surface.

However, virtually no natural surface or manmade structure encountered in the transportation environment would be unyiedding. Almost all surfaces will yield, thus absorbing some of the impact energy that would otherwise go into damaging the cask. The 30-foot drop test results in a cask velocity of $30 \mathrm{mph}$ on impact. To produce the same damage as a 30-mph collision with an unyielding surface, a cask velocity of 65 to $90 \mathrm{mph}$ is required. Sandia also dropped a smaller Type B test container 2,000 feet onto hard, undisturbed earth..$^{25}$ The cask hit the ground at $235 \mathrm{mph}$ and buried itself some $41 / 2$ feet into the ground. The cask suffered no damage other than paint abrasion, although dropping a similar cask 30 feet onto an unyielding surface at an impact velocity of $30 \mathrm{mph}$ produced visible damage. See box 3D for a description of the Sandia National Laboratories full-scale cask tests.

A British Central Electricity Generating Board demonstration in 1984, in which a locomotive crashed into a cast steel cask* at $100 \mathrm{mph}$, while dramatic, caused little damage to the cask. More to the point, the energy imparted to the cask on impact was about

\footnotetext{
${ }^{23}$ Ridihalgh, Eggers, \& Associates, Inc., Definition of Bounding Physical Tests Representative of Transport Accidents-Rail and Truck," vol. 1 (Washington, DC: U.S. Nuclear Regulatory Commission, Aug. 30, 1982), p. 98 .

${ }^{24}$ Joseph Strohl, in U.S. Congress, op. cit

${ }^{25}$ I Waddoups, Air Drop Test of Shieldin Radioactive Material Containers, SAND75-0276 (Albuquerque, NM: Sandia National Laboratories, September 1975).

*Cast steel casks do not have the weldments that have proven to be troublesome in some current casks. Although they are widely used in Europe, no cast steel casks have yet been licensed for use in the United States.
} 


\section{Box 3D.-Full-Scale Spent Fuel Cask Crash Tests}

In 1976 and 1977, a series of full-scale tests were undertaken for the U.S. Department of Energy by Sandia National Laboratories. Obsolete casks containing nonirradiated stainless tteel clad fuel were used in the tests, since the intent was not to certify the integrity of a specific operational cask, but to compare predictions to actual events involving a cask accident.

The primary purpose of the tests was to validate the computer model used to design and evaluate spent fuel shipping casks. The tests also provided other information. These were the first full-scale accident simulations conducted on a spent fuel cask. The tests allowed full instrumentation to be utilized in order to assess the magnitude of the forces and other stresses encountered in a number of accident cases. By using these measurements it was possible to validate the use of "lumped parameter" models to predict accident environments over the entire range of possibilities. The test program also included sub-scale tests (one-eighth and one-fourth scale) to evaluate the accuracy of reduced scale testing.

The program began with the development of "lumped parameter" models which were used to predict the accident environment which the spent fuel casks would encounter. Cakulations were made to determine the tiedown strengths, structural crush-up, and structural failure, all of which were translated into time v. velocity predictions for the cask. These calculations, for example, predicted that in the $60 \mathrm{mph}$ truck accident the tiedowns would not fail until very late in the event resulting in the cask impacting the wall at about $30 \mathrm{mph}$. Actual impact velocity was $27 \mathrm{mph}$. Using the same analytical tools it was predicted that in the $80 \mathrm{mph}$ impact, the tiedowns would fail early and the resulting impact velocity would be about $65 \mathrm{mph}$. Actual impact was $65 \mathrm{mph}$. The results of these "lumped parameter" calculations were ther applied in determining the effect on the shipping cask. Calculations using the widely accepted technique known as finite element analysis predicted cask deformations in each case under study. Engineers then used these analytical predictions to estimate the extent of cask failure, if any, that would be produced by the teat. Scale models were built and tested to evaluate the analytical results and the scale-model testing techniques themselves.

Cracks occurred both in the bodies of the casks and lir some of the weldments, and, in one fire test, the lead radiation shield began to vaporize. Nonetheless, the actual aceident damage to the cask was the same as or less severe than the predictions. The predictions were in good agreeinent with the results even where they overestimated damage. Any additional stresses that might have occurred had irradiated, zircalloy fuel rods (currently used throughout the nuclear fuel industry) been used or damaged in the casks were not addressed by the tests and deserve further study.

one-sixth that which would have been imparted by a 30-foot drop test onto an unyielding surface. ${ }^{26}$

The thermal test specifies a temperature of $800^{\circ} \mathrm{C}$ $\left(1,475^{\circ} \mathrm{F}\right)$ and may appear to understate real fire conditions, since typical flame temperatures for burning fuels are $1,850^{\circ}$ to $2,200^{\circ} \mathrm{F}$. The criterion requires a "radiation environment" for the whole package of $800^{\circ} \mathrm{C}$, not a flame temperature of $800^{\circ} \mathrm{C}$, and further specifies that an emissivity coefficient of the source of at least 0.9 and an absorptivity of the cask of at least 0.8 must be assumed

\footnotetext{
${ }^{26}$ Richard Cunningham, U.S. Nuclear Regulatory Commission, in U.S. Congress, Office of Technology Assessment, "Transcript of Proceedings-OTA Advisory Panel Meeting on Hazardous Materials Transportation," unpublished typescript, June 27, 1985, p. 250.
}

for calculations. Producing a thermal "radiation environment" equivalent to $800^{\circ} \mathrm{C}$ requires a flame temperature higher than $800^{\circ}$. The emissivity coefficient refers to the amount of heat that the flames are assumed to radiate ( 90 percent) compared to the maximum theoretical amount, 100 percent, that could be radiated by ideal flame sources. The cask absorptivity coefficient is specified as 0.8 , or 80 percent of the theoretical maximum heat absorption. These technical specifications require that the cask be completely enveloped in the thermal environment so that the cask absorbs virtually all of the heat, with little of it being radiated or conducted away. A stainless steel cask may have an initial absorptivity of about 0.2 and a fire about 0.5 to 0.6 . The net result is that the heat absorbed by the cask 
in the test environment is greater than it would be in a real fire.

Sandia National Laboratories conducted an experiment in which a spent fuel cask, designed to withstand a 60-minute fire, was suspended over a pit filled with burning jet fuel. However, the fuel was cut off after 100 minutes, because due to defects in cask manufacture, heat caused the outer shell of the cask to crack and the lead shielding began to vaporize. Regulations specify a 30-minute exposure to a $1,4750 \mathrm{~F}$ thermal environment; jet fuel burns at about 1,8000 F. Nonetheless, under these conditions, instruments showed that the thermal environment was less severe than the casks are required to meet. A number of technical organizations

have conducted tests confirming that a $1,475^{\circ} \mathrm{F}$ temperature is a realistic thermal environment associated with fires as hot as $1,850^{\circ} \mathrm{F}^{28}$

Such results are consistent with the fact that in a real fire, the temperature is not uniform and the cask is not totally enveloped. A fully engulfing fire, as regulations specify, is difficult to imagine since the cask will be resting on a vehicle or the ground, and will thus be partially protected from heat-and a means will exist for conducting some heat away. Natural and many accidental fires have varied temperature profiles with peak flame temperatures of about $1,850^{\circ} \mathrm{F}$. However, some railroad fires burn at higher temperatures, and the fire in the enclosed environment of the Caldecott tunnel in Oakland, California, created a thermal environment that approached that of the regulatory standards. The Federal Railway Administration is considering testing casks to determine whether internal cask temperatures remain at safe levels under extreme fire conditions. $^{29}$

Flame emissivities are strongly associated with flame thickness-the greater the flame thickness, the higher the effective emissivity. However, increasing flame thickness for open fires also reduces ventilation, and if a fire were to engulf a cask, it would

\footnotetext{
${ }^{27} \mathrm{R}$ Pope, et al., An Assessment of Accident Thermal Testing and Analysis Procedures for Radioactive Materials Shipping Packages, 80 $H T$-38 (Washington, DC: American Society of Mechanical Engineers, April 1981)

${ }^{28}$ Ibid.

${ }^{29}$ Claire L. Orth, Office of Safety Analysis, Federal Railroad Administration, U.S. Department of Transportation, personal communication, March 1986.
}

reduce ventilation for the flames surrounding the cask, and thus tend to lower flame temperatures. Finally, the very high theoretical flame temperatures for certain chemical fires can be achieved only under ideal conditions, often requiring a direct air supply to the fuel.

A third test, the puncture test, is generally well understood. However, new equations and analytical methods have been developed since the current cask designs were certified ${ }^{31}$ that will increase the accuracy of future tests.

The four criteria set out are intended to result in a cask design sufficiently robust to withstand different types of accidents and do not specifically include all types of accident events. For example, there is no requirement for the cask to withstand a torchlike flame that may be created in a tank car accident; nevertheless," tests have been conducted on shipping casks to observe and measure the effect of a torch. Test results show that because the torch introduces heat to a limited area of the cask, and the large cask has a high heat capacity and is an effective thermal conductor, the torch flame produces conditions less severe than the all engulfing fire condition. ${ }^{32}$

A crushing force is another accident condition not directly specified by the regulatory criteria. An NRC-sponsored study of this condition concluded that casks that meet the impact and puncture criteria are at least equally resistant to crushing forces. ${ }^{33}$ Another study concluded that the crushing load of an entire locomotive on the (spent fuel) packages that meet the requirements will not exceed the packages' capability, based on bounding crush

${ }^{30}$ W Dircks Nuclear Regulatory Commission, Washington, DC, "Staff Memorandum, Feb. 10. 1982." unpublished typescriot.

${ }^{31}$ Charles E MacDonald, Certification Division, Nuclear Regulatory Commission," personal communication, May 1986.

${ }^{32}$ M.G. Vigil, et al., HNPF Spent Fuel Cask Temperature Response: Torch Impinging on Water Filled Neutron Shield, SAND82-0702 (Albuquerque, NM: Sandia National Laboratories, March 1982); Philip E. Eggers, et al., "Thermal Response of HNPF Spent Fuel Shipping Container in Torch Environments," Proceedings of the 6th International Symposium on Packaging and Transportation of Radioactive Materials-1980 (Springfield, VA: National Technical Information Service, November 1982).

${ }^{33}$ U.S. Nuclear Regulatory Commission, Potential Crush Loading of Radioactive Material Packages in Highway, Rail, and Marine Accidents, NUREG/CR-1588 (Washington, DC: October 1980). 
loads of half of the 400,000 pound weight of the locomotive resting on the package. ${ }^{14}$

OTA performed independent calculations that satisfactorily verified these analytical results. ${ }^{35}$ Box $3 \mathrm{E}$ provides answers to some commonly raised questions about the casks,

The NRC cask certification process is of necessity painstaking and time-consuming. The safety record of NRC-certified casks, however, provides a degree of public confidence in the casks. The regulatory system governing the movement of radioactive materials has worked well. There have been no releases of radioactivity from the accidents involving spent nuclear fuel containers currently certified for transportation. Of the 2,552 packages for low-level radioactivity materials involved in accidents between 1971 and March 1985, only 67 were sufficiently damaged to cause releases. These packages are not required to contain the material in the event of an accident, and all releases involved low levels of activity that posed little threat to public health. (See table 3-6.)

\section{Risk-Accident Probabilities and Consequences}

An assessment of overall public risk must combine estimates of probability and consequence. Moreover, estimates of accident probabilities must include two factors: 1) the probability that any given vehicle carrying spent fuel will be in an accident, and 2) the probability that the spent fuel shipping cask will release any of its contents. The first of these is relatively easy to assess since a large amount of actuarial data about accident rates have been developed. Bureau of Motor Carrier Safety statistics show that accidents involving trucks occur once every 400,000 miles of travel, while rail statistics from the Federal Railroad Administration show that a rail accident occurs every 139,000 miles of travel. This translates into a probability of $2.5 \times 10^{-6}$ truck accidents and $7.2^{\times 6}$ rail accidents per vehicle-mile. ${ }^{36}$

\footnotetext{
${ }^{34}$ Philip E.Eggers, Severe Rail and Truck Accidents: Toward a Definition of Bounding Environments for Transportation Packages, NUREG/CR 3499(Washington, DC: Nuclear Regulatory Commission, October 1983), p. 69.

${ }^{35}$ OT A background analysis, June 1985.

${ }^{36}$ Edward W. Sheperd, Transportation Technology Center Quick Reference File, Item TTC/012,SAND79.2101 (Albuquerque, NM: Sandia National Laboratories, May 1981).
}

For the second factor, likelihood of release, estimates must be used, since there is no significant actuarial record. A report from the Transportation Technology Center at Sandia National Laboratories estimates that fewer than 1 in 100 accidents would involve conditions severe enough to cause concern over a release of some contents of the cask. ${ }^{37}$ This estimate appears consistent with analyses of the stresses involved in numerous actual highway and rail accidents of all types. The analyses show that real accident stresses do not exceed the test conditions in the regulatory standards in 99.5 and 99.9 percent of truck accidents involving impact and fire, respectively; as well as 99.6 and 99,9 percent of rail accidents involving impact and fire, respectively. ${ }^{38}$ Thus, the overall probability of a truck or rail shipment of spent fuel being involved in an accident where conditions are sufficiently severe to cause some release of radioactive materials is less than 2.5 $\times 10^{-8}$ per vehicle-mile-or less than once for every $\mathbf{4 0}$ million miles of transport.

Table 3-7 shows estimates based on an OTA analysis of truck and rail accident rates in the year 2000. Current DOE estimates indicate that there are likely to be about 1,000 annual shipments from commercial reactors to a storage site.

The consequences of a spent fuel cask accident involving radioactive material releases are proportional to the quantities of radioactivity released, the estimated health effects of the specific radioactive materials released, and the exposure of individuals or population groups to the materials. Related variables include:

- The age of the spent fuel-Older spent fuelout of the reactor for 5 or more years-is much cooler than recently discharged fuel both in thermal and radiological terms. If more spent fuel is carried in each cask to reduce the number of necessary trips, the amount of thermal activity in the cask will increase. The radioactivity available for release and the heat available to raise the temperature of the spent fuel

\footnotetext{
${ }^{37}$ Ibid.

${ }^{88} \mathrm{~T}$. Wolff, The Transportation of Nuclear Materials, SAND84-0062 (Albuquerque, NM: Sandia National Laboratories, December 1984).

${ }^{39}$ U.S. Department of Energy, "Environmental Assessment for a Monitored Retrievable Storage Facility," Monitored Retrievable Storage Submission to Congress, vol. 2, RW0035, review copy, unpublished typescript, December 1985, p. 2.23.
} 


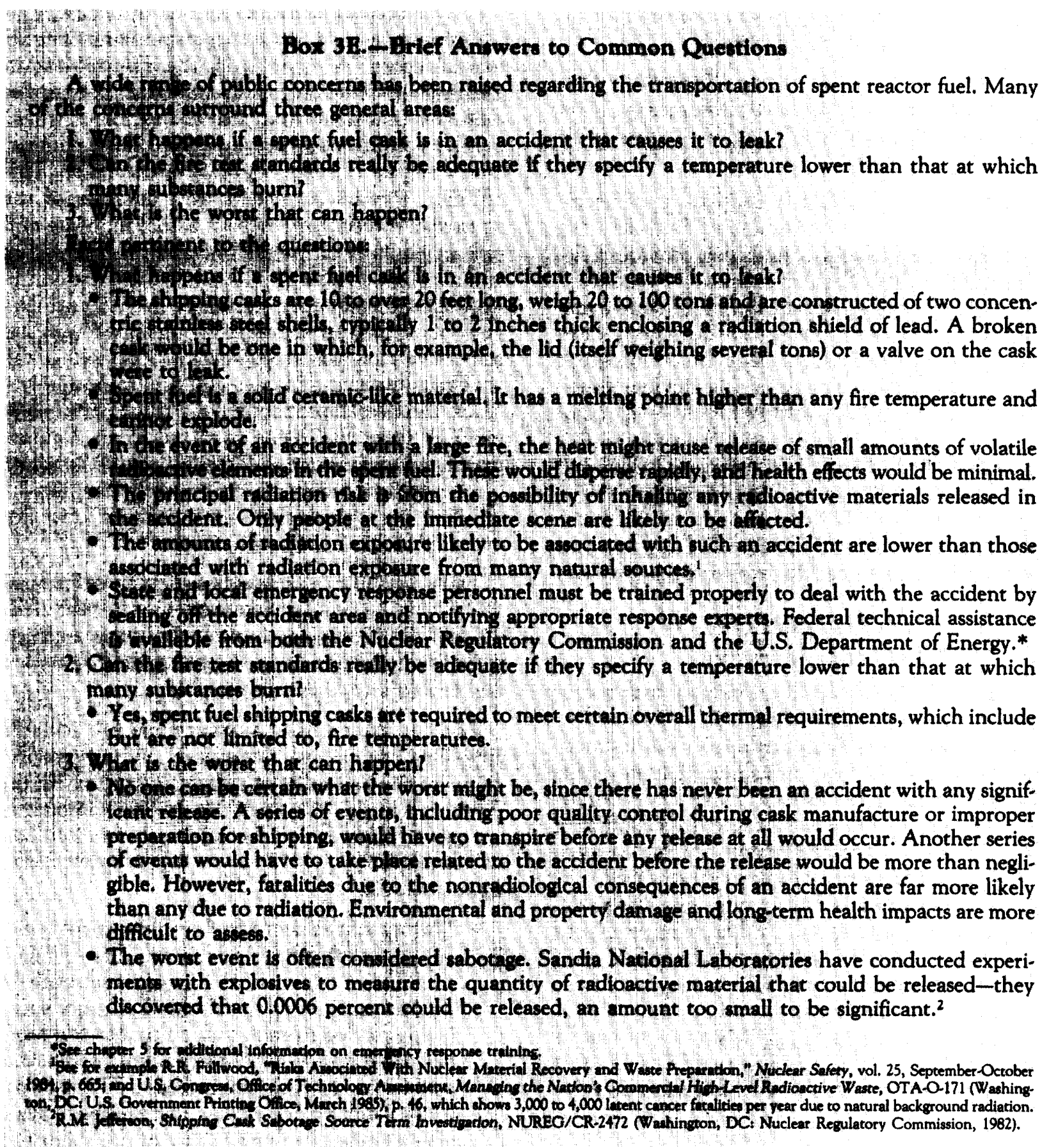

must thus be carefully analyzed. High temperatures are necessary for volatile materials to be released.

- The types of material released.-Radioactive material released from a damaged spent fuel assembly will not necessarily escape from the ship- ping cask. Small amounts of radioactive gases, mainly the inert gas Krypton 85, could escape readily from the assembly, but will dissipate relatively harmlessly in the open air. Other more critical radioactive materials, such as volatile cesium and rubidium isotopes, will tend to plate 
Table 3-\&- Radioactive Materials Involved in Transportation Accidents (January 1971 to March 1985)

\begin{tabular}{|c|c|c|c|}
\hline $\begin{array}{l}\text { Packaging category } \\
\text { contents }\end{array}$ & $\begin{array}{c}\text { Number of } \\
\text { packages involved }\end{array}$ & $\begin{array}{c}\text { Number of } \\
\text { packages failing }\end{array}$ & $\begin{array}{c}\text { Number of packages } \\
\text { releasing contents }\end{array}$ \\
\hline \multicolumn{4}{|l|}{$\begin{array}{l}\text { Strong tight industrial } \\
\text { and miscellaneous }\end{array}$} \\
\hline unclassified . . . . . . . . . & 596 & 62 & 56 \\
\hline Type A . . . . . . . . . . . . . & 1,956 & 28 & 11 \\
\hline \multicolumn{4}{|l|}{ Type B: } \\
\hline Spent fuel (see box B) . . . . . & 4 & 0 & 0 \\
\hline Medical sources. . . . . . . . . . & 24 & 0 & 0 \\
\hline $\begin{array}{l}\text { Uranium hexafluoride } \ldots \ldots \\
\text { Radiography and well }\end{array}$ & 3 & 0 & 0 \\
\hline 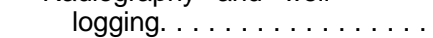 & 8 & 0 & 0 \\
\hline Other Type B . . . . . . . . . . . & 11 & 0 & 0 \\
\hline Total Type B . . . . . . . . . . . . & 50 & 0 & 0 \\
\hline
\end{tabular}

Table 3=7.-Estimated Occurrences of Accidents During the Transport of Spent Fuel

\begin{tabular}{|c|c|c|c|c|c|}
\hline Mode & $\begin{array}{l}\text { MTUs }{ }^{a} \text { per } \\
\text { shipment }\end{array}$ & $\begin{array}{l}\text { Miles per } \\
\text { shipment }\end{array}$ & $\begin{array}{c}\text { Total number of } \\
\text { shipments per year }\end{array}$ & $\begin{array}{l}\text { Accidents }^{b} \\
\text { per year }\end{array}$ & $\begin{array}{c}\text { Years between accidents } \\
\text { where stresses approach } \\
\text { performance test }\end{array}$ \\
\hline \multicolumn{6}{|l|}{ With $M R S^{d}$} \\
\hline Trucks to MRS. . . . . . . . . . . & 1.0 & 700 & 725 & 1.27 & 158 \\
\hline Rail to MRS . . . . . . . . . . . & 7.0 & 700 & 250 & 1.26 & 159 \\
\hline Rail, MRS to repository . . . . . . . & 112.5 & 2,400 & 22 & 0.38 & 526 \\
\hline \multicolumn{6}{|l|}{ Without MRS: } \\
\hline Truck . . . . . . . . . . . . . & 1.0 & 2,400 & 725 & 4.35 & 46 \\
\hline Rail . . . . . . . . . . . . & 7.0 & 2,400 & 250 & 4.32 & 46 \\
\hline
\end{tabular}

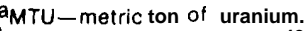

b Assumes one accident per 400,000 miles for truck (BMCS data) and one accident every 139,000 train miles for rail (FRA data)

CAssumes that 99.5 percent of highway and yail accidents are less severe than the performance tests (Robert M, Jefferson, Sandia Report SAN D64-2128, TTC-0528, danuarv 198S)

AssumesmRSis in Tennessee, Assumes the repository is in Nevada.

NOTE: Shipments will begin in the year an MRS is opened

SOURCE: Office of Technology Assessment

out on the surfaces of the cask, making them

less likely to reach the environment."

- The location (in a rural or urban area) of an accident.

Estimates have been made of the combined risks to the public based on the probability of an accident and using the consequences of the releases. Sandia National Laboratories estimates that the probability of an accident involving spent fuel causing five or more fatalities over time is low- $5 \mathrm{X}$ $10^{-6}$ a year. No more than five early fatalities were

${ }^{40}$ W. Dircks, Fission Product Release From Highly Irradiated Fuel, NUREG/CR-0722 (Oak Ridge, TN': Oak Ridge National Laboratory, 1980). A serres of experiments on irradiated fuel found a fractional release of 0.3 percent for cesium from the fuel elements-not from the cask. Such a release was estimated to produce no earlvfatalities. considered possible under worst--case accident conditions in a heavily populated urban area. Another estimate puts the risk in slightly different terms: 1 X $10^{-8}$ latent cancers per $1,000 \mathrm{MW}(\mathrm{e})^{*}$ powerplant for six trips transporting spent fuel 1,000 miles.

However, the environmental and/or economic effects of a transportation-related release require thorough examination. ${ }^{42}$ Not considered heretofore has been the extent of public injury or loss of life that

\footnotetext{
+U.S. Nuclear Regulatory Commission, Transportation of Radionuclides in Urban En virons: Draft Environmental Assessmenc, NUREG/CR-0743(Washington, DC: July 1980), p.66.

* Megau atts of eles tricits

ti Western Interstate Energy Board, "Environmental Assessment for a Monitored Retrievable Storage Facilitv," Nuclear Waste Policy Act: Monitored Retrievable Sturage Submission to Congress, vol. 2, DOE/ RW-003, unpublished ret' cW manuscript, December 1985, p. 54.1.
} 
might be caused by nonradiological risk, such as the magnitude of the accident, fire, and damage associated with an accident severe enough to damage a spent fuel cask. The nonradiological risk of death associated with moving the spent fuel is estimated to be 1 million times greater than the radiological risks. $^{43}$

Sabotage has also been used as a condition for assessing the possible consequences of a spent fuel accident. Data show that historically, sabotage and vandalism have not been problems associated with the transportation of hazardous materials (see chapter 2, part II for detailed information). However, the increase in international terrorist activities indicates that the possibility of a successful sabotage effort is not to be discounted. Early analyses for NRC indicated an estimated five to nine early fatalities and up to 1,800 latent cancer fatalities associated with radioactive material releases following a successful act of sabotage on a spent fuel cask in an urban area. ${ }^{44}$ Based on a conservative assumption that about 0.7 percent of the contents of a spent fuel cask could be released in respirable form following a successful sabotage attack, NRC developed transportation safeguard rules requiring an armed guard to accompany each spent fuel shipment. In 1981 and 1982 simulation tests were conducted to evaluate the release consequences of an explosive attack on spent fuel casks. ${ }^{45}$ The simulations showed a release of 0.0006 percent of the cask contents, ${ }^{46}$ reducing estimates to no early fatalities and, at most, 14 latent cancer fatalities in an urban population that would normally experience 250,000 cancers over the same period. ${ }^{47}$ On the basis of these revised estimates, NRC proposed relaxing the safeguard rules. Their proposal met with objections from

${ }^{43}$ R. R Fullwood, "Risks Associated With Nuclear Material Recovery and Waste Preparation," Nuclear Safety, vol. 25, No. 5, SeptemberOctober 1984, pp. 654-667.

${ }^{4}$ US. Nuclear Regulatory Commission, Transportation of Radionuclides in Urban Environs, op. cit.

${ }^{45}$ R.P. Sandoval, et al., An Assessment of the Safety of spent Fuel Transportation in Urban Environs, SAND82-2365•TTC-0398 (Albugnerme, NM: Sandia National Laboratories, June 1983).

Robert M. Jefferson, Shipping Cask Sabotage Source Term Inves tigation, NUREG/CR.2472 \{Washington, DC: U.s. Nuclear Regulatory Commission, 1982)

${ }^{4 i}$ Sandoval, et al., op.cit. a number of States, and a final decision on safeguard requirements is still pending. ${ }^{48}$

\section{Future Spent Fuel Shipments Under the Nuclear Waste Policy Act}

The passage of the NWPA of 1982 established that DOE will take title to spent fuel from utilities in 1998 and assume responsibility for its transportation and ultimate disposal. As there will be some 90,000 spent fuel assemblies in U.S. spent fuel pools by that time ${ }^{49}$ DOE may be responsible immediately for a number of shipments to a repository or monitored retrievable storage facility. Depending on the type and carrying capacity of the casks ultimately constructed and certified for these shipments, DOE estimates that approximately 250 rail and 725 truck shipments will be required annually to move spent fuel from eastern reactors to a monitored retrievable storage facility or repository .50 For NWPA shipments, DOE has agreed to meet DOT and NRC safety and security requirements in effect at the time and will use only transportation casks that have received an NRC certificate of compliance.

A new generation of casks is being designed and tested and will be employed to move spent fuel to a national repository under NWPA. Sometime in 1986 the Office of Civilian Radioactive Waste Management at DOE will issue a "Request for Proposal" for the design and construction of these casks. The new casks are likely to have somewhat different characteristics from those of the current casks, which carry between 1 and 24 assemblies (see table 3-5), because they will be designed to hold older, less

\footnotetext{
${ }^{48}$ Terry Lash, Director, Illinois Department of Nuclear Safety, at U.S. Nuclear Regulatory Commission/U.S. Department of Transportation, Spent Nuclear Fuel Transportation Seminar, Chicago, IL, Aug. $1,1985$.

${ }^{49}$ George Russ, Atomic Industrial Forum, Bethesda, MD, personal communication, 1985. See also U.S. Congress, Office of 'technolog, Assessment, Managing the Nation's Commercial High-Level Radioactive Waste, OTA-O-171 (Washington, DC: U.S. Government Printing Office, March 1985), p. 28.

${ }^{50}$ U.S. Department of Energy, "Environmental Assessment for a Monitored Retrievable Storage Facility." op. cit., p. 2.23

${ }^{51}$ US Department of Energy, Office of Civilian Radioactive Waste Management, Office of Storage and Transportation Systems, "Transportation Institutional Plan," unpublished internal review draft manuscript, Mar. 3, 1986, pp. 3 and D-57.
} 
radioactive spent fuel. Since the oldest fuel will be shipped first, most of the initial shipments will be of fuel at least 20 years old, ${ }^{52}$ and it is likely that the next generation of casks will carry significantly greater numbers of assemblies. The designs will be based on carrying the maximum possible number of spent fuel elements within weight and safety limits, to reduce the number of shipments necessary. Recent improvements in materials, such as ductile, nodular cast iron, and design, such as monolithic steel, have yielded casks that may meet many concerns voiced about today's casks.

DOE is also examining the possibility of employing very large capacity dual-use casks for transportation. These dry casks, currently under review by NRC for utility-site storage purposes only, offer an opportunity to minimize the number of shipments and the handling of the spent fuel. Once the fuel has been removed from the reactor and placed in dry, onsite storage in these dual-use casks, the handling and worker-exposure risk would be reduced if the same casks could be used to transport the spent fuel to a repository. However, the conditions for casks used for transportation are more stringent, and although NRC has pending applications for certification of two such casks, none has yet been certified for both purposes. ${ }^{53}$

Moreover, questions will need to be answered about the effects of the large, heavy casks on the stability of the carrying vehicles, whether truck or railcar. The weight would not be a concern if barge transportation were used, and water transportation has the best modal safety record. However, the increased handling necessary to transfer the cask from truck or rail to barge and the increased turnaround time required for reusable casks by the slower barge travel are trade-offs that must be considered. Finally, the integrity of the casks for transport after possible weakening from corrosion and thermal effects, subsequent to extended onsite storage of a decade or more, must be studied.

\footnotetext{
${ }^{52}$ Lake Barrett, Director, Transportation and Waste Systems Division, Office of Civilian Radioactive Waste Management, U.S. Department of Energy, personal communication, Dec. 5, 1985.

${ }^{5}$ US. Department of Energy, Office of Civilian Radioactive Waste Management, Annual Report to Congress, DOE/RW-0004/2 (Washington, DC: March 1986), p. 23.
}

\section{Spent Fuel Transportation Risks and Public Perceptions}

About 6,500 spent fuel assemblies have been shipped to date in the United States. while several accidents have occurred involving spent fuel casks in the United States (in one case the cask was empty), there has never been a shipping accident involving a Type B package carrying spent fuel that caused a significant release of radioactive material. (See box 3F for a brief description of four typical incidents involving Type B casks.)

DOT maintains a Hazardous Material Information System (HMIS) which, with additional data

\section{Box 3F.-Spent Fuel Casks involved in Transportation Accidents*}

December 8, 1971.-A tractor-trailer rig carrying a spent fuel cask with one fuel element left the highway to avoid a head-on collision. The truck rolled over and threw off the cask. The driver died of injuries. The cask sustained minor damage and did not release any contents.

February 9, 1978.-Shortly after leaving its point of origin, a trailer, carrying a cask containing six fuel elements, buckled from the weight. The cask stayed on the trailer and was not damaged. There was no leakage.

August 3, 1978.-An empty cask being loaded on a trailer broke through the trailer bed causing minor damage to the impact limiter and the cask base plate. No radioactive material was released.

December 9, 1983.-The trailer carrying a spent fuel cask, containing seven spent fuel assemblies, uncoupled from the tractor, leaving the cask sitting on the trailer supported by its rear wheels and a "jo-dog"* in front. When the air and electrical lines parted, the brakes on the trailer and "jo-dog" locked, bringing the unit to a rapid stop on the highway. The uncoupling occurred as the tractor began moving after a momentary stop in a construction zone. There was no damage to the cask and no release of radiation.

\footnotetext{
${ }^{\mathrm{I}} \mathrm{R}$. Cerson, former Manager, Transportation Technology Center, Sandia National Laboratories, Albuquerque, NM, personal communication, 1985,

"A "jo-dog" is an apparatus that connects the front end of a trailer to a tractor. It has its own set of wheels. [ $t$ was used in this case to dia. tribute the weight more evenly over the axles.
} 
from NRC files and other sources, supports the Radioactive Materials Transportation Accident/Incident Data Base developed by the Transportation Technology Center at Sandia National Laboratories under DOE contract. HMIS records since 1971 indicate that about 0.6 percent of all entries involved radioactive materials; of these, about 20 percent were transportation accidents." Table 3-6 lists the numbers and categories of all radioactive materials involved in reported transportation accidents occurring between January 1971 and March 1985.

This safety record not withstanding, public attention focuses sharply on any accident involving nuclear materials, and Federal officials must respond frequently ${ }^{55}$ to questions about the adequacy of Federal safety requirements. ${ }^{\%}$ The effect of this debate has been a heightened public awareness of the risks associated with transporting radioactive materials, especially spent reactor fuel. One result of this awareness has been the enactment of numerous State and local laws restricting operations and routing of radioactive materials, especially spent fuel and high-level waste shipments. Such restrictions have frequently led to local and national legal disputes. For further discussion of these disputes, see chapter 4 .

At the root of much of the discussion, debate, and concern over spent fuel shipments are three factors:

1. The extent to which risk and benefit issues are difficult to explain. In the case of spent fuel shipments, there is no actuarial record of public fatalities, so risk estimates must be based on calculations.

2. The extent to which the public is apprehensive about nuclear energy and radiation in general or distrusts the nuclear industry because of pre-

${ }^{54} \mathrm{OTA}$ calculations based on Sandia National Laboratories, A Re view of Accident/Incident Experience Involving the Transportation of Radioactive Material, SAND81-1330C-Summary (Albuquerque, NM: March 1982). Reported categories include handling accidents and "actual or suspected release of radiation or materials" and "surface contamination" in excess of regulatory requirements.

${ }^{55} \mathrm{R}$. Jefferson, Transporting Spent Reactor Fuel: Allegations and Responses, SAND82-2778 (Albuquerque, NM: Sandia National Laboratories, March 1983); R. Jefferson, et al., Analysis of Recent Council on Economic Priorities Newsletter, SAND82-1250 (Albuquerque, NM: Sandia National Laboratories, March 1983); Dircks, Fission Product Release From Highlv Irradiated Fuel, op. cit.

${ }^{56}$ Sierra Club, "Shipping Casks: Are They Safe?" Sierra Club Radioactive Waste Campaign Fact Sheet (Washington, DC: no date); and Resnikoff, op. cit. vious accidents and transfers this to the movement of spent fuel on routes in their State or city.

3. The extent to which the public is aware of the demonstrations and technical information now available and the extent to which it is possible to explain the relevant technical information in a popular forum.

These factors all involve problems that are common to technology and risks, and nuclear energy in general, and are not specific to the transportation of spent reactor fuel. Nonetheless, a brief examination of some of the disparities between perceived and statistically determined risks may be useful.

A large and growing body of literature is devoted to the issues of risk, public perception, risk management, and education. Nuclear energy is often used as a specific case. ${ }^{57}$ The fact that public and expert opinion diverge dramatically, for example, on the issue of nuclear safety is a case in point-in one poll, out of 30 activities involving risk, experts ranked nuclear power number 20 while the public ranked it number 1 - the most hazardous. ${ }^{58}$ The explanations for this phenomenon are not simple and are themselves a subject of debate.

The difference between the statistical risks and perceptions of risk are substantial. For example, the actuarial record for the shipment of other energy commodities provides evidence for much greater risk and a consistent record of public fatalities. There are estimated to be some 29 annual public fatalities associated with highway shipments of gasoline, 14 associated with highway shipments of propane, and 9 associated with rail shipments of chlorine. ${ }^{59}$ The record for public fatalities from spent fuel shipments to date is zero, and is estimated to be 0.0001 fatalities due to radiological factors per year with 2,000 shipments per year; ${ }^{60} 15$ to 100 fatalities are esti-

\footnotetext{
${ }^{57}$ See for example, Alvin Weinberg, "Science at Its Limits," Issues in Science and Technology, vol. II, No. 1, fall 1985, pp. 59-72; Peter Huber, "The Bhopalization of U.S. Tort Law," Issues in Science and Technology, vol. 11, No. 1, fall 1985, pp. 73-82; and Baruch Fischoff, "Managing Risk Perception," Issues in Science and Technology, vol. II, No. 1, fall 1985, p, 83.

${ }^{8}$ William F, Allman, "Staying Alive in the 20th Century," Science 85, vol. 6, 1985, pp. 31-41.

${ }^{59}$ Andrew P. Hull and Edward T.Lessard, Risk Comparisons for the Nuclear Transportation of Spent Fuel From Nuclear Reactors, BNL \#36390 (Long Island, NY: Brookhaven National Laboratory, no date). These estimates exclude fatalities due to collision forces.

${ }^{60}$ Ibid.
} 
mated for spent fuel shipments over the lifetime of a repository. Some of the radiological fatalities associated with a spent fuel accident are latent cancers calculated to occur over the life of the exposed individuals, as opposed to the prompt deaths associated with the other accidents. ${ }^{61}$

Yet such disparities are common in the area of public perceptions of risks, and the pitfalls associated with the conventional means for addressing these perceptions have been widely discussed. ${ }^{62} \mathrm{Al}-$ though OTA suggests many of these same methods in the conclusions for this chapter, their effectiveness has limitations. To paraphrase one expert's observations:

- Those presenting factual information must recognize the role that personal values play in assessing information.

- Those giving statements of regulatory philosophy must remember that people can understand risk-benefit trade-offs.

- Experts explaining technical material must communicate in an appropriate manner.

- Communities considering problems need to keep in mind that their-decisions will affect many other jurisdictions.

\section{Conclusions}

OTA finds that technical evidence and cask performance in service indicate that NRC performance standards yield spent fuel shipping cask design specifications that provide an extremely high level of public protection, much greater than that afforded in any other current hazardous materials shipping activity. However, meticulous adherence to the designs during cask manufacture and to required safety procedures during loading and transport are critical factors in ensuring public and environmental safety. Transportation accidents involving shipments of spent fuel will inevitably occur. However, OTA concludes that the probability of an accident severe enough to cause extensive damage to public health and the environment caused by a radiological release from a properly constructed cask is extremely remote. Moreover, the health and environmental consequences in the

\footnotetext{
${ }^{61}$ See for example Hull and Lessard, op. cit.; Sheperd, op. cit.; and Jefferson, op. cit.

${ }^{62}$ Fischhoff, op. cit.
}

event of a severe accident are likely to be lower than those resulting from many hazardous materials transportation accidents considered more routine.

The most difficult issue pertaining to the transportation of spent fuel is how best to reduce the risks. Areas for technical improvement to the casks often involve trade-offs that adversely affect overall transportation safety. For example, increasing the thickness of the cask walls to increase accident resistance slightly would necessitate reducing the carrying capacity of the cask to remain within weight limits. More shipments would be necessary to carry the same amount of spent fuel, increasing the probability of accidents. Moreover, an increased number of shipments would require more handling by workers, raising their total radiation exposure.

OTA further finds that continued research is needed in certain technical areas to determine where safety improvements could be effective. Such research needs include: the interface between the carrying vehicle and the casks, such as tiedowns and fasteners; the evaluation of real accident stresses as compared to those specified by the current regulations; and methods of extending accident modeling capabilities to encompass accidents more severe than those currently incorporated in the models. In addition, continued study of safe routes and different transportation modes and configurations and sharing the results of these studies with affected jurisdictions would have useful results. To enhance the risk assessment capability of jurisdictions, DOE could revise for microcomputers its existing mainframe computer program for analyzing the risks to population of differing transportation routes. This is discussed more fully in chapter 2 .

The level of public apprehension about shipments of spent fuel requires well planned and coordinated programs to address the concerns. Sensitivit to public concerns and programmatic coordination have heretofore not been outstanding at DOE, which will be responsible for NWPA shipments. The technical specifications for the shipping casks are difficult to explain and comprehend, creating widespread misunderstanding of the stringency of the standards

\footnotetext{
${ }^{6}$ Robert Jefferson, former Manager, Transportation Technology Center, Sandia National Laboratories, Albuquerque, NM, personal communication, 1985
} 
for ensuring spent fuel cask integrity. Industry and government will do well to address these apprehensions in a forthright manner.

OTA further finds that fruitful areas for improvements in the overall safety of spent fuel transportation are to be found in the institutional, procedural, and operational controls and arrangements, such as quality assurance and quality control measures in cask manufacture; maintenance activities; operator, handler, and driver training; and inspection. 64 NRC inspection and quality assurance requirements are intended to ensure that each user establishes and implements a comprehensive cask inspection and operational testing program. The duration of the inspection depends on the inspectors' confidence in the quality assurance programs, training procedures, and the shippers' ability to demonstrate that procedures are being followed. ${ }^{65}$ It is appropriate to consider actions that will ensure that the quality control standards are followed. Furthermore, tight management supervision during all transportation operations and strict accountability for adhering to procedures are crucial to ensuring safety. DOE could minimize one area of current public concern by agreeing immediately to use NRC-approved casks for all its shipments.

The nontechnical aspects of spent fuel transportation safety need continued and forceful emphasis. Special attention to shipping operations, including quality control and inspection can have a positive impact on overall safety. Especially important are those related to the carrying vehicle, and training and information programs for drivers, engineers, and other transportation personnel.

OTA finds that sustained and comprehensive public information efforts are necessary to address concerns about the level of safety provided by Federal regulations and cask specifications. Citizens and public officials repeatedly say, "show

\footnotetext{
${ }^{64}$ This aspect was a persistent theme in both the Office of Technology Assessment workshop and Advisory Panel meetings; see for example Richard Cunningham, Nuclear Regulatory Commission in U.S. Congress, Office of Technology Assessment, "Transcript of Proceedings-Transportation of Hazardous Materials Advisory Panel Meeting," op. cit., p. 230 .

${ }^{65}$ Charles E. MacDonald in U.S. Congress, Office of Technology Assessment, "Proceedings of OTA Workshop on Nuclear Materials Packaging Technology," op. cit., p. 142.
}

me" ${ }^{\prime 66}$ that the casks are safe, and experts often respond with technical evidence that, due to its extreme complexity, may not be comprehensible. Education programs for nonexpert audiences must be developed, and continued examination of the issues by nonpartisan, nonexpert individuals is important. For example, in its publication, "A Nuclear Waste Primer," the League of Women Voters, although expressing some concerns, concluded that "compared to the transport of other hazardous materials, radioactive shipments have an excellent record. "67

The broadest possible public participation and information sharing will be important for successful undertaking of NWPA shipments. The enactment of State and local regulations pertaining to this transportation reflects the desire of jurisdictions to determine for themselves the conditions under which they will accept the risks associated with spent fuel transport. Figures 3-1, 3-2, and 3-3 indicate the routes used and the most frequent origin and destination States for highly radioactive shipments. These and other States, as well as Indian tribes and local governments affected by shipments have an interest in an acceptable level of safety. States and tribal and local governing bodies have indicated that they will require negotiations with DOE to permit successful completion of NWPA shipments. The activities undertaken by utilities to accomplish spent fuel shipments are documented in box 3G. Because DOE will fill the role of the utilities for shipments made under NWPA, Congress may want to consider requiring DOE to undertake the same activities under NRC regulations.

Furthermore, OTA concludes that State, local, and Indian tribal officials must be included in the transportation planning and decisionmaking process for transportation under NWPA. A Federal approach that incorporates public perceptions, opinions, and responsibilities starting immediately could be helpful. In November 1985, DOE sponsored a workshop for State, tribal, and local officials to determine the extent and specific nature of their concerns about DOE's plans for shipments of spent nuclear fuel under NWPA. Such activities provide a

\footnotetext{
${ }^{\circ 6}$ U. S. Congress, Office of Technology Assessment, "Proceedings of OTA Workshop on Nuclear Materials Packaging Technology," op. cit.

${ }^{6}$ "League of Women Voters Education Fund, The Nuclear Waste Primer (New York: 1985), p. 42.
} 


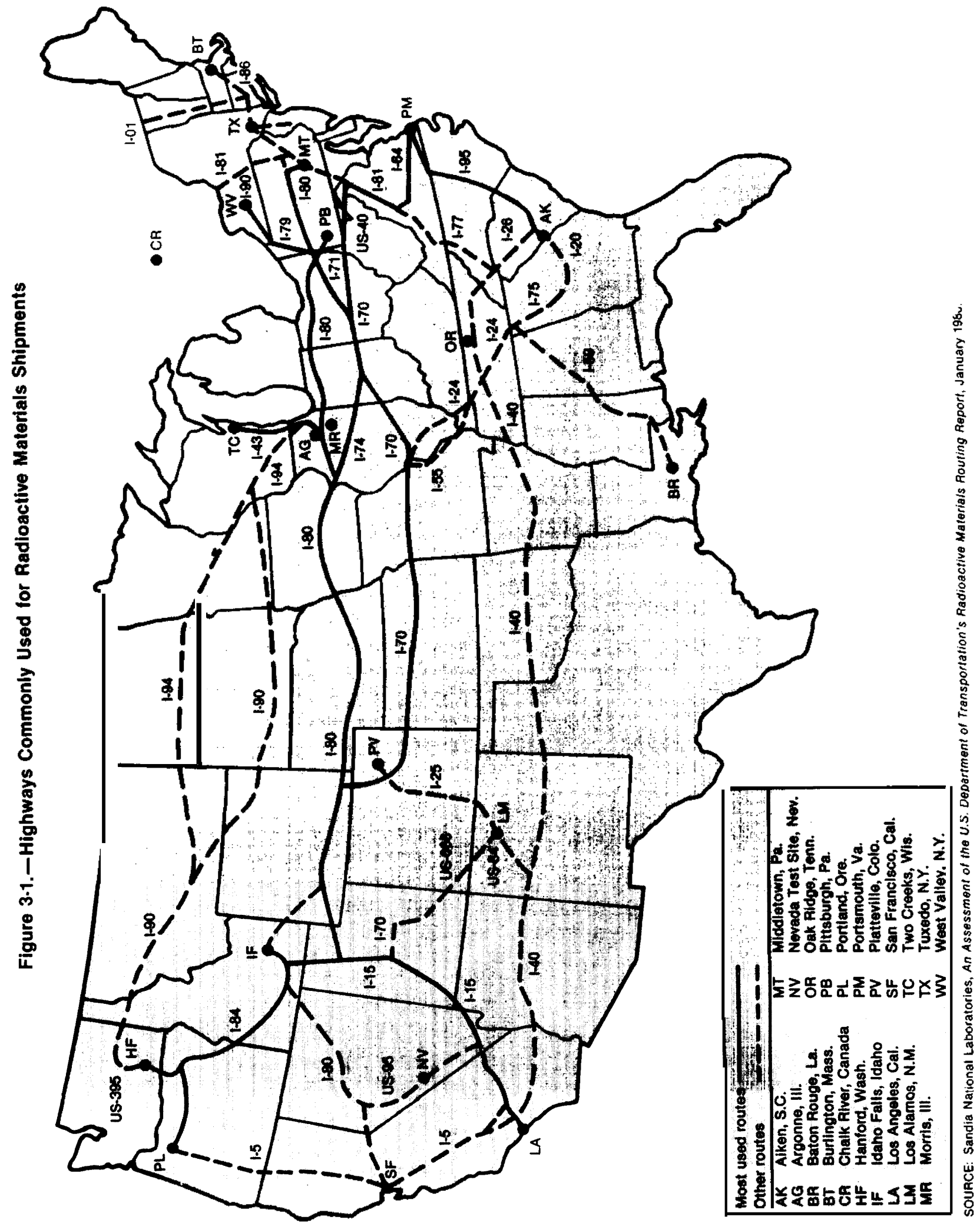


Figure 3-2.-Point of Origin, 1982-84

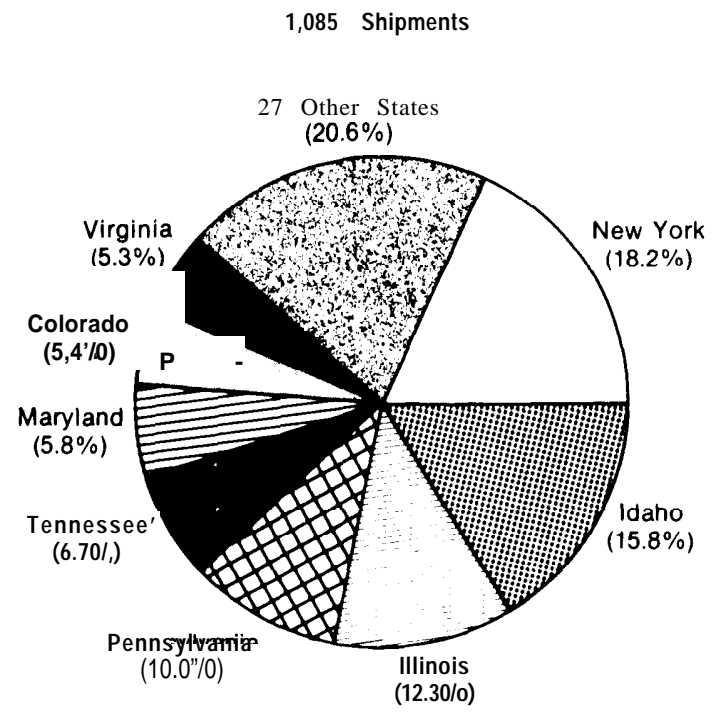

Most frequent points of origin for spent fuel, large quantity, and highway route controlled quantity shipments.

SOURCE: Sandia National Laboratories, An Assessment of the U.S. Department of Transportation's Radioactive Materials Routing Report, January $19 \mathrm{S6}$.

Figure 3-3.-Destination, 1982-84

1,085 Shipments

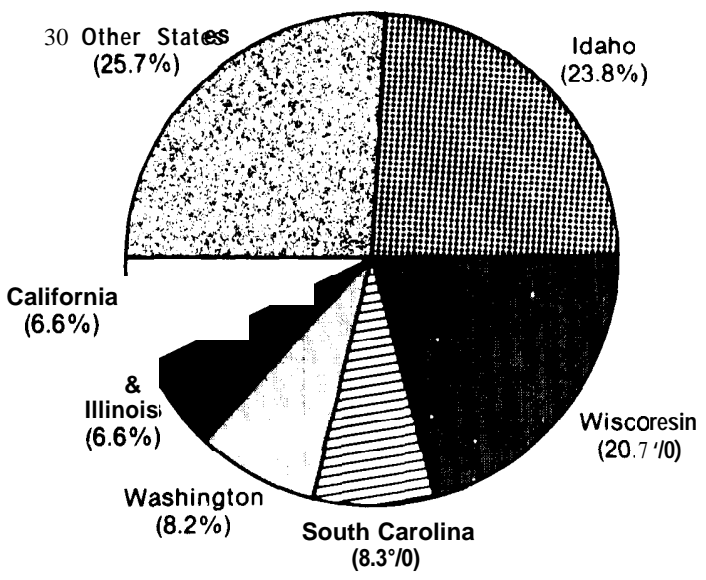

Most frequent destinations for shipments of radioactive materials. SOURCE: Sandia National Laboratories, Arr Assessment of the U.S Department of Transportation's Radioactive Materials Routing Report, January 1986.

forum for airing differences and moving toward resolution of conflicts. OTA concludes that additional meetings, sponsored jointly by DOT, NRC, and DOE, in cooperation with public interest groups such as the National Governor's Conference, the
National Conference of State Legislatures, and the International Conference of Mayors are essential to informing the public and improving intergovernmental coordination.

States and localities are greatly concerned with routing for spent fuel shipments, since they have the authority under DOT routing regulations to designate alternative shipping routes. State authorities can work with Indian tribes, local jurisdictions, and neighboring States to develop an alternative route meeting DOT guidelines. DOE and DOT may find it necessary to work together and with the States to provide guidance and support in achieving consensus on routes. (Chapter 4 gives further information on routing. )

Finally, full-scale tests of cask durability, like those conducted by Sandia National Laboratories in 1976 to 1977 (see box 3D) and Britain's Central Electricity Generating Board test in 1984 can demonstrate that accident damage and the behavior of the casks have been adequately predicted and validate the engineering models and analytical methods. ${ }^{68}$

OTA concludes that once a new generation of casks has been developed and fulfilled the analytical test requirements for NRC certification, fullscale demonstration tests could play an important role in gaining public confidence. The following considerations are important:

- Will a demonstration be for the purpose of increasing public confidence or does the technical evidence show the need for benchmark fullscale tests to prove the validity of current engineering analyses and regulations?

- If technical or material changes in the cask designs require a full-scale technical validation experiment, how can questions about any subsequent changes to cask designs be addressed?

- If a "show me" test were conducted, assurances that it would address public concerns would be essential. Organizations and individuals critical of current transportation procedures and cask standards could be included in advance planning for a test, so that their views are incorporated from an early point.

\footnotetext{
${ }^{8}$ Huertaand Yoshimura, Op. cit.; see also International Atomic Energy Agency Safety Series 6, 1985; and David Fishlock, "Nuclear Fuel Shipping Cask Comes Through Great Train Wreck With Its Virtue Intact," Energy Daily, vol. 12, No. 142, July 24, 1984, p. 3.
} 


\section{Box 3G.-Anatomy of a Spent Fuel Shipment}

Utilities have found that transporting spent nuclear reactor fuel from one storage site to another is a lengthy process, requiring careful planning and preparation. The transporter must deal with numerous complicated and seemingly conflicting Federal and State regulations as well as pressure not to expose the public to the perceived danger of such shipments. OTA asked several companies that have shipped fuel successfully to document their shipping procedures as well as the attendant legal difficulties and public discussions.

After reactor fuel has been irradiated so that it is no longer a useful part of the power-producing process, it is removed from the fuel core and termed spent fuel. Initially, spent fuel is highly radioactive, exceeding lethal radiation levels, and is consequently carefully contained. Upon removal from the reactor, the spent fuel rods are placed in water-filled containment pools. The water shields the rods while their radiation content decays to safer levels. After 6 to 12 months in the containment pool, the spent fuel is ready for either onsite storage or shipment to other storage facilities.

Spent nuclear fuel is shipped for two main reasons: 1) space in a reactor storage facility is near full capacity, or 2) lawsuit settlements between a State and a utility necessitate the removal of spent fuel to an alternate storage site. It is generally cheaper to ship spent fuel to remote storage sites than to enlarge existing onsite facilities or build new ones. Of the various transport modes, truck and rail are the most common. The truck mode is used most often because-legal and pub. lic relations difficulties notwithstanding - it provides quick, flexible, and relatively inexpensive transport.

OT $A$ asked three companies that have undertaken three different types of shipments-transshipments; multi-State, utility-operated shipments; and second party shipments-to provide information on their spent fuel transportation experiences. Transshipments, such as those carried out by Duke Power, occur between various sites operated by the same utility. Consequently, utilities carrying out these shipments deal primarily with people in their own service areas. Shipments to a remote storage site, in contrast, usually span several States and are carried out by the utility responsible for the spent fuel. An example of this type of shipment was Wisconsin Electric's transfer of spent fuel from West Valley, New York, and Morris, Illinois, to its Point Beach Nuclear Plant in 1983 and 1984. Finally, second-party shipments are those shipments conducted by a-company, such as General Electric, that is paid by a utility to transport the spent fuel. The following discussion draws in part on reports from these three companies.

As soon as it is determined that spent fuel shipments are to take place, the transporter must begin processes both to comply with regulations and to alleviate public safety concerns of communities affected by the shipments, particularly in the case of second-party shipments. The first step is usually route selection, and regulations require that the shipper submit a proposed shipping route for Nuclear Regulatory Commission approval. After final route determination, the utility often asembles mulling lists of public officials and medil contacts in areas through which the shipment is to pass. Informational material is prepared that typically touches on the following topics: the nature of spent fuel, why it must be shipped, measures being taken to prevent radioactive release during transport, and the exelllent safety record of spent fuel shipments to date. In addition, the company usually prepares a news relense, plans informational briefings for the press and puiblic officials, and arranges to monitor public reaction. Informational briefings may include films to dramatize the integrity of spent fuel casks. All of these activities are completed prior to public announcement of the shipments.

Once these preparations are made, the company malkes a public announcement that spent fuel shipments are to take place. Utility representatives brief local media, mail information to public officials and other media, send out briefing invitations to public offeits, wind as tequired by Federal regulationsnotfy the Governor or his designee in each State through which the shipment is to pass. The transporter seeks to learn as much as possible about road conditions, media, public attitudes, and State and local authorities in all areas along the route. When appropriate, company representatives meet with local officials, participate in public meetings, and give demontrations of the safety techniques used to safeguard opent fíd. These measures may help prevent the passage of local ordinances prohibiting or severely restricting the transport of radioactive materials. Compounding the shipper's diffeulties is the legal obligation not to release shipping schedules until 10 days after the hipments have occurred, such secrecy lends itself to public perception that the shipments are not as riskfree as the power company maintains. The more effective the effort to alleviate public concern, the less complicated the local constraints on transport are and the more straightforward the shipment procedures. 
The shipoer must liso accoming / he the vatious

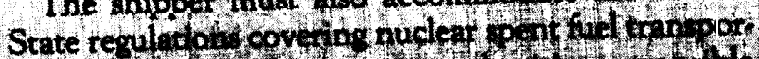

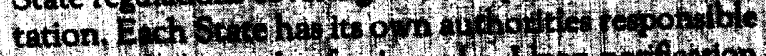

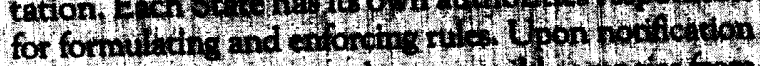

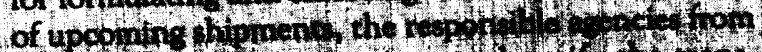
each state wal preph rations

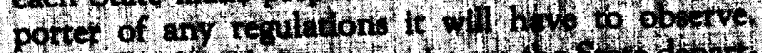

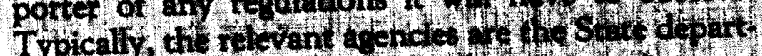
ment - or thelr equivalents - of th theortaton, naclear safery, health, and the hohw parol as well as the State Police.

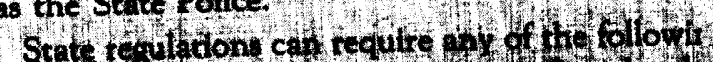

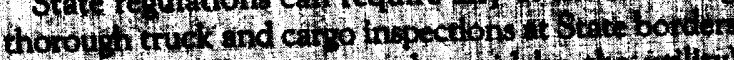

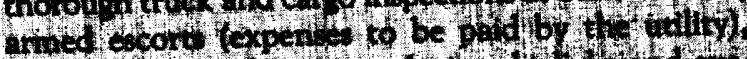

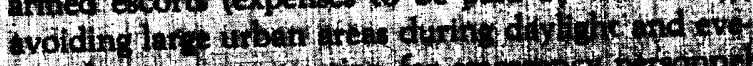

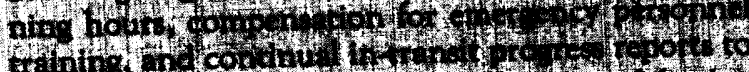

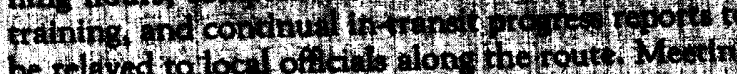

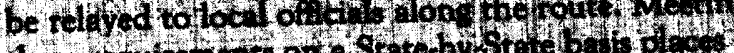

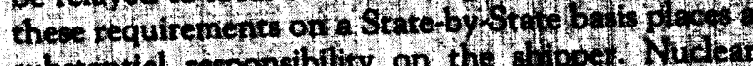
substintid responsibitity$$
\begin{gathered}
4 \\
4 \\
4 \\
4 \\
4
\end{gathered}
$$

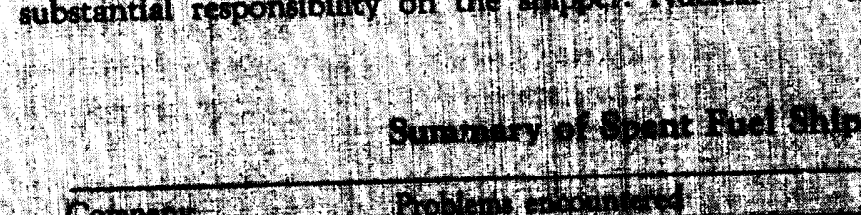

6ow 1 w

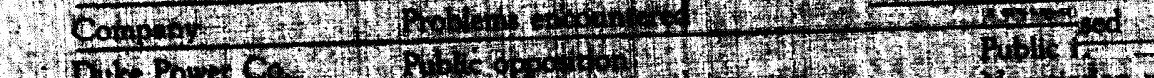

W.

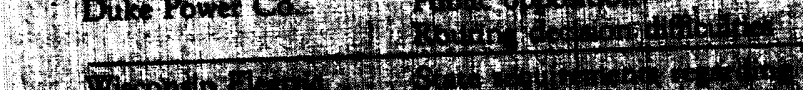

KW

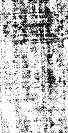
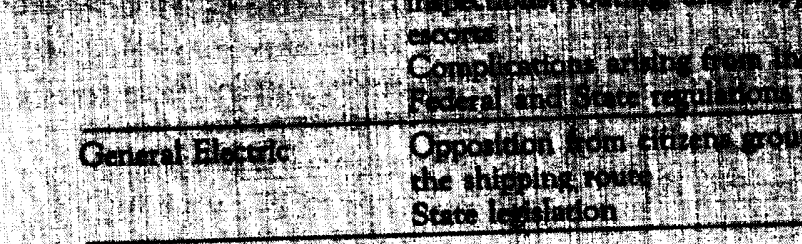

- An extensive public information program would be essential prior to the test to help the public officials, affected emergency personnel, and the general public understand the technical background for the tests to the extent feasible.

If full-scale validation testing proves unnecessary from an engineering standpoint, conducting a fullscale demonstration test could enhance public understanding and confidence. DOE, as the responsible agency under NWPA, has both a source of funds and a program in which test series could be housed, and is giving consideration to such tests. power utilities contacted by OTA noted that there seems to be little or no coordination between States tegarding rules and enforcement procedures or be tween Stres and the U.S. Department of Energy. To avoid confiet and

intilites alen cetarate agreements to abide by individ. ual State and local regulations. In the case of particulatly one out reculrements, utilite to reques puteral preemption of the regulation. Federal pteemptis is not used often, however, as it is time-consuming and damaging to public relations.

is reached between the utility and the States, the hilis reached between $\mathrm{T}$.... i tims. spent in planhibs, preparation, and negotiation prior to trate obt con unount to 2 years or more. The isoue ow dint of bote are typical of the potential legal Srdoct con of that nuclear utilities must deal with when tran porting apent nuclear fuel. The accompany. in tabic sumenat

yed for each type of shipment.
However, given the technical complexities involved, it is wise to be realistic about the extent to which a full-scale cask accident demonstration will allay all public concerns. Although a well--planned and constructed full-scale demonstration could prove persuasive to many, it would need to accommodate a wide range of interests. OTA finds that the appropriate test goals could best be determined by a panel of advisors-experts and concerned citizens to provide guidance to the technical organization conducting the demonstration. 


\section{PART II: BULK CONTAINERS AND SMALL PACKAGING FOR HAZARDOUS MATERIALS TRANSPORTATION}

Most of the estimated 180 million annual shipments of hazardous materials reach their destinations safely, both because hazardous materials transportation is heavil regulated and because industry is concerned that its products reach customers intact. The strength and integrity of packaging used to ship hazardous materials, including tank trucks, railroad tank cars, and barges, as well as bottles, boxes, and drums, are an important factor in transportation safety. The Research and Special Programs Administration (RSPA) of the Department of Transportation is responsible for issuing packaging and hazard communication regulations for all hazardous materials containers except bulk marine containers, which are regulated by the U.S. Coast Guard, and containers for highly radioactive materials (see part I of this chapter).

This part of chapter 3 discusses DOT's requirements for all packaging, then looks at the specific issues relating to bulk containers and small packagings. It focuses on issues regarding the packaging regulations codified in Parts 173, 178, and 179 of Title 49 and portions of Title 46 of the Code of Federal Regulations. Part 173 contains general requirements for shipments and packaging and lists the authorized packages that can be used for each commodity. Parts 178 and 179 contain the specific, highly detailed requirements for the authorized packages referred to in Part 173. Title 46 contains the Coast Guard regulations for the water mode. (Chapter 4 presents an overview of the entire regulatory system, including a discussion of the historical development of packaging regulations.) Sources of information included technical literature, an OTA workshop on packaging, and extensive interviews with container experts.

\section{General Packaging Criteria}

DOT requires packaging for shipping hazardous materials to be so designed and constructed, and its contents so limited, that under conditions norreally incident to transportation:

- there will be no significant release of the hazardous materials to the environment;
- the effectiveness of the packaging will not be substantially reduced; and

- there will be no mixture of gases or vapors in the package which could, through any credible spontaneous increase of heat or pressure, or through an explosion, significantly reduce the effectiveness of the packaging.

In addition, packaging materials and contents must ensure there will be no significant chemical reaction among any of the materials in the package. Closures must prevent leakage, and gaskets must be used that will not be significantly deteriorated by the contents. Polyethylene packaging must be minimally permeable to and compatible with the cargo.

DOT regulations apply to hazardous materials containers of all sizes. Some regulations apply equally to all packaging, but most of the requirements depend on whether the material is shipped in bulk or in small packages. As a general matter, the dividing line between nonbulk (small) and bulk (large) containers is 110 gallons or 1,000 pounds. Small packages of hazardous materials are carried $b_{y}$ all modes: water, rail, highway, and air. Approved packaging include drums, cylinders, boxes, cans, and bags. Bulk packages-ships and barges, railroad tank cars, tank trucks (called cargo tanks in the regulations) and intermodal portable tanks-generally do not travel by air. Analysis of incident and accident data (see chapter 2) reveals that hazardous materials packaging generally has been adequately designed, although there are some problem areas.

The premise underlying packagin design for hazardous materials other than highly radioactive materials is that the packages must maintain their integrit in the normal transportation environment, including minor accidents.

The classification of a hazardous material has a critical influence on the selection of packaging. Many commonly transported materials are listed in the regulations, and shippers need only locate the

${ }^{64} 49$ CFR 173.24 . 
listing to be guided to the required packaging. If the material is not listed, however, the shipper must determine if it is hazardous and classify it according to definitions in the regulations. There are no specific regulations in 49 CFR that tell a shipper how to classify a material, a difficult process, the results of which affect packaging, marking, labeling, and placarding. ${ }^{70}$

The sorting of hazardous materials into hazard classes by either DOT or the shipper does not necessarily mean that all the potential dangers posed by these substances have been taken into account. For example, methyl isocyanate, which caused the death of thousands in Bhopal, India, had until recently been classified by DOT as a flammable substance and could legally be transported in the least stout highway cargo tanks or rail tank cars. DOT is now in the process of adopting an international classification scheme (described in more detail in a later section of this chapter) that should better correlate the strength of regulated packaging to the hazards posed by the materials. In the meantime, large manufacturing and shipping companies have incorporated additional strength and protective features into the design of containers they use for materials with a very high hazard potential. Some of these designs have become part of the Federal specifications for packages. More often, however, these additional safety features represent industry efforts to take into account special transportation circumstances.

Containers for bulk transport, discussed next, represent the inherent possibility of larger consequences in the case of an accident than do small packages and provide opportunities for commensurately larger impacts on safety.

\section{Bulk Packaging}

More than 60 percent of accidents and spills in any mode of transport are a result of human error." thus modal safety is closely tied to the opportunities for error. The highway mode experiences

\footnotetext{
TU.S.Department of Transportation, Materials Transportation Bureau, Research and Special Programs Administration, A Guide ro the Federal Hazardous Materials Transportation Regulatory Program (Washington, DC: January 1983)

${ }^{71}$ Mark Abk ${ }_{\text {ow }}$ it $_{\mathrm{z}}$ and George " "Hazardous Materials Transportation: Commodity Flow and Information Systems," OTA contractor report, January 1986.
}

more accidents, spills, injuries, deaths, and property damage than does the rail or water mode, in both absolute numbers and accidents per ton-mile traveled,* while the rail mode experiences more than the water mode.

Several other factors also affect safety: the extent of coverage and enforcement of Federal regulations; the amount and quality of training the vessel or vehicle operators and loaders receive; the frequency of maintenance and inspection of the vessel or vehicle; and finally, the coordination between the agencies responsible for regulation, inspection, and enforcement activities. Table 3-8 presents a comparison of modal characteristics for bulk shipping of hazardous materials. Descriptions of the containers and specific safety factors will be treated separately for each mode.

\section{Bulk Highway Transport}

Of the three modes of bulk transport of hazardous materials, the highway mode is the most versatile and widely used. (See chapter 2.) While portable tanks and tank trucks are the smallest bulk containers and thus the consequences of a release on the highway will be lower than for the other modes, the probability of an accident is greatest for the highway mode because it has:

- more miles of network,

- the largest number of individual shipments,

- the largest number of operators,

- the greatest traffic density in an unrestricted right-of-way, and

- the highest average traffic speed.

Cargo tanks are the main carriers of bulk hazardous materials over the roads, although intermodal portable tanks, discussed later in this chapter, are also used. Cargo tanks are usually made of steel or aluminum alloy but can be constructed of other materials such as titanium, nickel, or stainless steel. They range in capacity from about 2,000 to 9,000 gallons depending on road weight laws and the properties (including density, vapor pressure, and corrosiveness) of the commodity or commodities to be

\footnotetext{
${ }^{*} \mathrm{~A}$ ton-mile is the product of the tons of material carried and the distanice carried in miles. For example, a truck with a load of 20 tons that traveled 100 miles would have logged 2,000 ton-miles. Ten trucks each carrying 2 tons and each traveling 100 miles would also have logged 2,000 ton-miles in the aggregate (each truck logging 200 ton-miles).
} 
Table 3-8.-Modal Characteristics of Bulk Shipping of Hazardous Materials

\begin{tabular}{|c|c|c|c|}
\hline & Highway & Rail & Water \\
\hline Containers regulated by $\mathrm{DOT}^{\mathrm{a}}$ & Most & All & All \\
\hline Inspection or testing frequency & Upon manufacture & $\begin{array}{l}\text { Upon manufacture } \\
\text { plus every } 5-10 \\
\text { years }^{c}\end{array}$ & Yearly $^{d}$ \\
\hline Commodity flow data ${ }^{e}$ & Very little & Nearly complete & Complete \\
\hline Regulators and inspectors & $\begin{array}{l}\text { RSPA, BMCS, } \\
\text { NHTSA }^{\dagger}\end{array}$ & \multicolumn{2}{|c|}{ FRA, RSPA, AAR ${ }^{g}$ USCG, RSPA $^{n}$} \\
\hline Fleet size & $\begin{array}{l}130,000 \text { cargo } \\
\text { tanks }^{i}\end{array}$ & 115,600 tank cars & $\begin{array}{l}4,909 \text { tank } \\
\text { barges }^{k}\end{array}$ \\
\hline Fleet database' & Partial (BMCS) & $\begin{array}{l}\text { Yes, complete } \\
\text { (AAR) }\end{array}$ & $\begin{array}{l}\text { Yes, complete } \\
\text { (ACofE) }\end{array}$ \\
\hline Number of operators & 260,000 & 26,000 & 45,000 \\
\hline Size of load (gals) & $4,000-12,000$ & $10,000-30,000$ & $\begin{array}{l}300,000- \\
600,000\end{array}$ \\
\hline
\end{tabular}

aFederai regulations cover the transportation of hazardous materials by railcar, aircraft, vessel, and interstate transportation by motor vehicle. Intrastate highway transport of hazardous wastes, hazardous substances, and flammable cryogenics in portable tanks or cargo tanks is also covered (49 CFR 171.1). Unless a State has specifically brought intrastate commerce under regulation, containers in such service need not meet any standards. The Department of Transportation does not know the precise extent to which the States have extended the Federal regulations to intrastate commerce. Most gasoline transport by truck is intrastate and these shipments are a large percentage of the total hazardous materials shipments.
$b_{\text {Cargo tanks must under Ran external visual examination every } 2 \text { years but generally do not have to be leak tested or pres }}$ sure tested. However, cargo tanks carrying chlorine must be pressure tested every 2 years and tanks carrying compressed gas (e.g. liquefied petroleum gas) must be pressure tested every 5 years; cargo tanks for flammable cryogenics are inspected gas (e.g., liquefied petroleum gas) must be pressure tested every 5 years; cargo tanks for flammable cryogenics are inspected prior to each loading. Most tanks, however, are not leak or pressure tested after they are built unless they have been out of service for a year or more, had repairs or modifications performed on them, are operating under an exemption to the regu-
lations, or are used in an area of nonattainment of Clean Air Act standards for ozone. (49 CFR 177.824.) lations, or are used in an area of nonattainment of Clean. Air Act standards for ozone. (49 CFR 177.824.)
cTank cars carrying some cargoes are tested more frequently, For example, tank cars carrying chlorine mUSt be tested every 2 years, Also, the frequency of inspection of some tank cars increases to once per year after they are 22 years old. General American Transportation Corp., GATX Tank Car Manual, 4th Edition (Chicago, IL: 1979).

d46FR $31.10-15$, and $31.10-17$

$\mathrm{eD}_{\mathrm{a}} \mathrm{t}_{\mathrm{s}}$ on $\mathrm{h}_{\mathrm{e}}$ identity and amount of hazardous materials shipped over the highways is collected by the Bureau Of the Census every 5 to 6 years, however the quality and comprehensiveness of the data is poor (see ch. 2). Records of 60 percent of all rail traffic are kept by the Association of American Railroads (AAR). A record of 1 to 6 percent of all rail traffic is kept by the Interstate Commerce Commission. Records of all origins and destinations of hazardous material cargo that travel on

U.S. waterways are kept by the U.S. Army Corp of Engineers (ACofE).
fThe Research and Special Programs Administration (RSPA) develops and publishes regulations on the cargo tanks. The Bureau of Motor Carrier Safety (BMCS) regulates in-use motor vehicles and drivers, and enforces regulations pertaining to the manufacture, marking, repair, etc. of cargo tanks. The National Highway Traffic Safety Administration (N HTSA) has responsibility for the original manufacture of the vehicle.

GAAR and the Federal Railroa Administration (FRA) established the basic technical specifications for tank cars. After public rulemaking and comment, ASPA adopts the final specifications in the regulations. Both AAR and FRA inspect tank cars in rain service, Both AAR and FRA inspect tank manufacturers.

Coast Guard (USCG) establishes the regulations, performs the inspections, administers licenses, and specifies the design of vessels. RSPA sets the standards for intermodal portable

tanks that can be carried on container ships and barges.
i Estimates from the 1977 Truck Inventory and Use Survey. Of these, 36,000 carry hazardous materials 25 to 49 Percent of the time, 14,000 carry them 50 to 74 percent of the time, and 67,000 carry them 75 to 100 percent of the time.

JWritten communication with AAR. This is about 60 percent of the total number of tank cars.

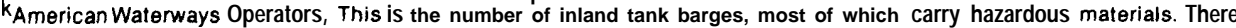
are also a small number of ocean going barges and tankers that carry hazardous materials, but tank barges are responsible

for most inland traffic.
IWhile the Army Corp of Engineers (ACofE) keeps track of the number of active and inactive vessels that may carry hazardous materials in U.S. commerce, and the AAR's UMLER file lists all tank cars by DOT specification that are in service, there is no comparable database for the highway mode. Although individual companies know how many and what types of cargo tanks or intermodal portable tanks they have, no single agency has an accounting of all bulk highway vehicles nationwide. is estimated by assuming there are two drivers per cargo tank. Large interstate private carriers often have three or more drivers per vehicle, while other carriers typically have fewer. Information on the rail mode was obtained from AAR and on the water mode from USCG. The number presented in the water mode represents all those licensed by USCG to operate commercial vessels; most of these would not routinely be involved with hazardous materials.

SOURCES: Unless otherwise indicated in footnotes, Office of Technology Assessment, based on information from participants of workshops and panel meetings or comments to draft reports by the affected parties. 
carried. Federal road weight laws usually limit motor vehicle weights to 80,000 pounds gross. Some States, however, allow higher gross weights, and in these States cargo tanks can have larger capacities. Table 3-9 lists the primary contemporary specification for cargo tanks and examples of commodities each type of cargo tank might carry.

All newly constructed cargo tanks must meet current specifications, which prescribe the requirements for the thicknesses of the bodies of the tanks, pressure relief devices, manhole covers, gauging devices, overturn protection, pressure test methods, and other features affecting safety. However, older specification tanks-for example, an MC-304 or an MC31 l-may still be used to carry hazardous materials, even though it does not meet current requirements.

The nature of the bulk trucking business differs from that of rail or water bulk transport in that there are many more carriers of a wider variety and businesses are generally much smaller. The carriers include private interstate carriers; large interstate common and contract carriers; and small common, contract, and private intrastate carriers.* The qual-

\footnotetext{
*Private carriers transport commodities that they own and the transport is integral to their business. Common carriers are transporters of freight for compensation; common carriers must accept all traffic tendered to them that is within their operating authority (to the extent that they have equipment and drivers to do so). Contract carriers are transporters of freight by motor vehicle for compensation in the exclusive service to one or more specific shipper(s) as authorized $b_{y} d_{u} l_{y}$ constituted Federal or State authority. This classification includes owner-operators under long-term lease to certificated carriers.
}

ity of the equipment varies within each of these groups, but generally the large private interstate transporters have the newest equipment and the small intrastate private carriers have the oldest, with the common carriers somewhere in between.

Turnover of equipment is slow, and cargo tanks generally go through several tiers of owners. Large private interstate carriers, primarily large petrochemical companies, have the resources to purchase new equipment and maintain it well. They use their trucks around the clock 6 to 7 days a week. After 8 to 10 years, when maintenance becomes uneconomical because of downtime for repairs, they sell the cargo tank to another firm, usuall a smaller $_{\mathrm{y}}$ one with fewer resources. The second-tier owner uses it until it becomes uneconomical and sells it to yet another owner. The useful life of a cargo tanker used to transport fuels can easily exceed 20 years.

Cargo tanks carrying some corrosive commodities have much shorter lifespans. According to one tank truck company safety director his "acid tanks are junk" after 4 years. ${ }^{72}$ In the past, a carrier frequently dedicated some of his fleet to carrying particular commodities. While this practice minimized corrosion and incompatibility problems, it often meant that the cargo tanks returned empty after delivering the product. In recent years, economic pressures have forced carriers to reduce the number of

\footnotetext{
${ }^{72}$ National Tank Truck Carriers, Inc., National Tank Truck Safety Seminar, St. Louis, MO, Apr. 14-15, 1986.
}

Table 3-9.-Cargo Tank Table

\begin{tabular}{|c|c|c|}
\hline $\begin{array}{l}\text { Cargo tank } \\
\text { specification number }\end{array}$ & $\begin{array}{c}\text { Types of } \\
\text { commodities carried }\end{array}$ & Examples \\
\hline MC-306 (MC-300, 301, 302, 303, 305) . & $\begin{array}{l}\text { Combustible and flammable } \\
\text { liquids of low vapor } \\
\text { pressure }\end{array}$ & Fuel oil; gasoline \\
\hline MC-307 (MC-304) . . . . . . . . . & $\begin{array}{l}\text { Flammable liquids, Poison B } \\
\text { materials with moderate } \\
\text { vapor pressures }\end{array}$ & Toluene diisocyanate \\
\hline MC-312 (MC-31O, 311) ., . . . . . . & Corrosives & $\begin{array}{l}\text { Hydrochloric acid; } \\
\text { caustic soda solution }\end{array}$ \\
\hline MC-331 (MC-330) $\ldots \ldots \ldots \ldots \ldots \ldots$ & Liquefied compressed gases & $\begin{array}{l}\text { Chlorine, anhydrous } \\
\text { ammonia, LPG }\end{array}$ \\
\hline MC-338 . . . & Refrigerated liquefied gases & $\begin{array}{l}\text { Oxygen, refrigerated } \\
\text { liquid; } \\
\text { methane, refrigerated } \\
\text { liquid }\end{array}$ \\
\hline
\end{tabular}




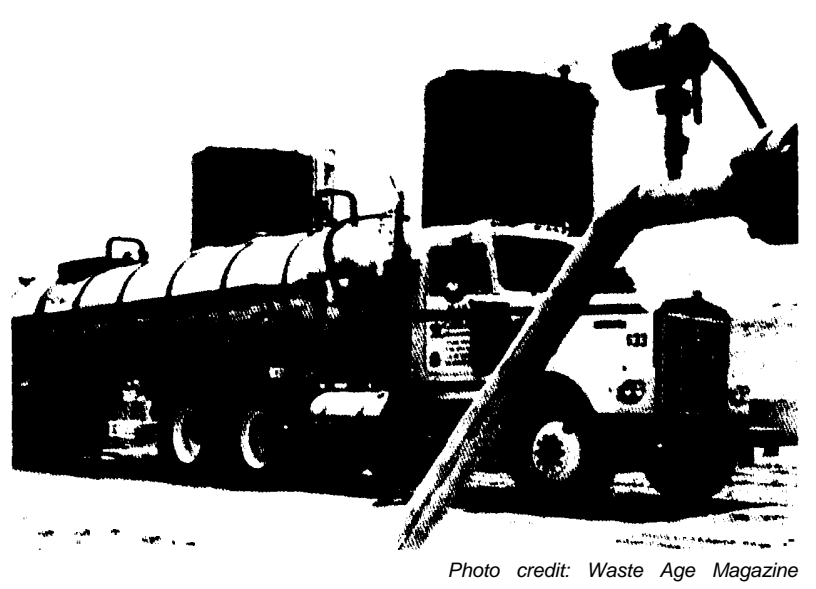

An MC-312 cargo tank delivers hazardous waste to a treatment plant. MC-312s typically carry corrosive commodities.

dedicated trucks and to seek return-trip loads (backhauls) whenever possible. Backhauls often necessitate cleaning the tank between loads to accommodate different products, thus subjecting the tank to additional wear, increasing pitting and corrosion, and shortening its lifespan.

Regulations and Intrastate Trucking.-The extent of Federal regulatory coverage for the highway mode is fundamentally different from that for rail and water modes, where all commerce is subject to Federal hazardous materials regulations. Under the predecessor statute to the Hazardous Materials Transportation Act, only interstate commerce was regulated, and this restriction was maintained when DOD issued revised hazardous materials regulations in $1976 .{ }^{73}$ However, because a large percentage of hazardous materials truck transport is in intrastate commerce, with gasoline, fuel oil, and propane deliveries comprising the bulk of it, the question of applicability of Federal regulation is important. ${ }^{74}$

${ }^{73}$ U.S. Department of Transportation, Docket No. HM-134, 41 Federal Register 38175, Sept. 9, 1976.

${ }^{74}$ About 55 percent of the hazardous materials transported over the highways is intrastate in South Dakota, for example. See U.S. Congress, Office of Technology Assessment, Transportation of Hazardous Materials: State and Local Activities, OTA-SET-301 (Washington, DC: U.S. Government Printing Office, March 1986). Gasoline comprises a large percentage of hazardous materials shipments over the highway and most gasoline deliveries are intrastate. About half of all gasoline is delivered by large interstate oil companies that are subject to Federal regulations. Much of the rest of the gasoline is delivered by intrastate operators.
Except for those transporting certain materials, ${ }^{75}$ carriers operating solely intrastate need not meet Federal standards, unless the State in which the do business has similar regulations. In some States, intrastate carriers have become the market for used equipment that no longer meets Federal standards. Moreover, new tanks built solely for intrastate trade need not meet DOT specifications, because those specifications are not applied. Such tanks also do not need to meet the periodic retest and maintenance requirements prescribed in the Federal rules. The noncompliance of these tanks with Federal standards has caused administrative problems for some States implementing the Federal rules. ${ }^{76}$ In addition, intrastate carriers have no obligation to report releases of hazardous materials to RSPA, even if they are under State regulation in other respects. This alone makes the Federal spill and accident reporting system incomplete, a problem further documented in chapter 2 .

The extent to which individual States have applied 49 CFR to intrastate commerce is an open question. In conversations with Federal and State regulators, shippers, and representatives of major bulk carriers, OTA found widespread disagreement over the degree to which Federal hazardous materials regulation has been extended to intrastate traffic. RSPA officials state that 49 CFR does not apply to all intrastate highway traffic and that some cargo tanks were never built to Federal specifications because they were for use only in intrastate commerce. Carrier representatives and BMCS staff

\footnotetext{
${ }^{75} 49 \mathrm{CFR} \overline{171}$.1. Hazardous wastes, hazardous substances, and flammable cryogenics comprise the only groups of hazardous materials whose transport is regulated by the Federal Government regardless of whether the commerce is intrastate or interstate.

${ }^{76}$ In the State of Washington, of all heavy truck accidents involving hazardous materials from 1979 to 1983, 64 percent involved private intrastate carriers of hazardous materials, unregulated by both the State and the U.S. Department of Transportation. The Utilities and Transportation Commission notes that the private carriers' terminals are not subject to survey, his driver records are not subject to review, and his safety record is known only to himself. The continuall violatin $_{g}$ private carrier cannot be removed from the highway, nor does he face any deterrent to violation in the form of administrative penalty. Washington Utilities and Transportation Commission, Summary and Analysis, Heavy Truck-Hazardous Materials Accidents 1982-1983 (Olympia, WA: 1983), p. viii.

${ }^{77}$ James O'Steen in U.S. Congress, Office of Technology Assessment "Transcript of Proceedings-OTA Workshop on State and Local Activities in the Transportation of Hazardous Materials," unpublished typescript, May 30, 1985; and Alan Roberts, in U.S. Congress, Office of Technology Assessment, "Transcript of Proceedings-Transportation of Hazardous Materials Advisory Panel Meeting, " unpublished typescript, Washington, DC, Jan. 24, 1985.
} 
counter that States participating in the Motor Carrier Safety Assistance Program must apply 49 CFR in motor vehicle inspections for all hazardous materials traffic, both intrastate and interstate.

BMCS has records of the States that have adopted 49 CFR, but not of the numerous variations to it enacted by many States. Moreover, adoption of 49 CFR by a State does not mean that intrastate highway commerce will be regulated. For example, the State of Washington adopted 49 CFR in 1978, and based on BMCS records, Washington regulates intrastate transport of hazardous materials. However, according to the Public Utilities Commission of the State of Washington, the State legislature did not decide to regulate private intrastate transport of haz-

${ }^{78}$ Clifford Harvison and AIRosenbaum, National Tank Truck Carriers, Inc., and Merritt Sargent, Bureau of Motor Carrier Safety, personal communications, March 1986. ardous materials until $1985 .{ }^{79}$ Since the new State regulations will not be promulgated until summer 1986, this transport is still unregulated.

MC-306 Tank Trucks.-The large volume of gasoline carried by MC-306 tank trucks, making over 40,000 daily deliveries to retail service stations in every locality in the country, is a primary reason that truck transportation of gasoline is responsible for more deaths, injuries, and property damage than all other hazardous materials in transportation. Most of the hazardous material highway deaths in recent years (five out of eight in 1983) have been the result of gasoline truck accidents, and many of the worst incidents are the result of tank truck rollovers

\footnotetext{
${ }^{79}$ Don Lewis, Rail and Motor Carrier Training Officer, Washington Utilities and Transportation Commission, personal communication, Mar. 21, 1986.
}

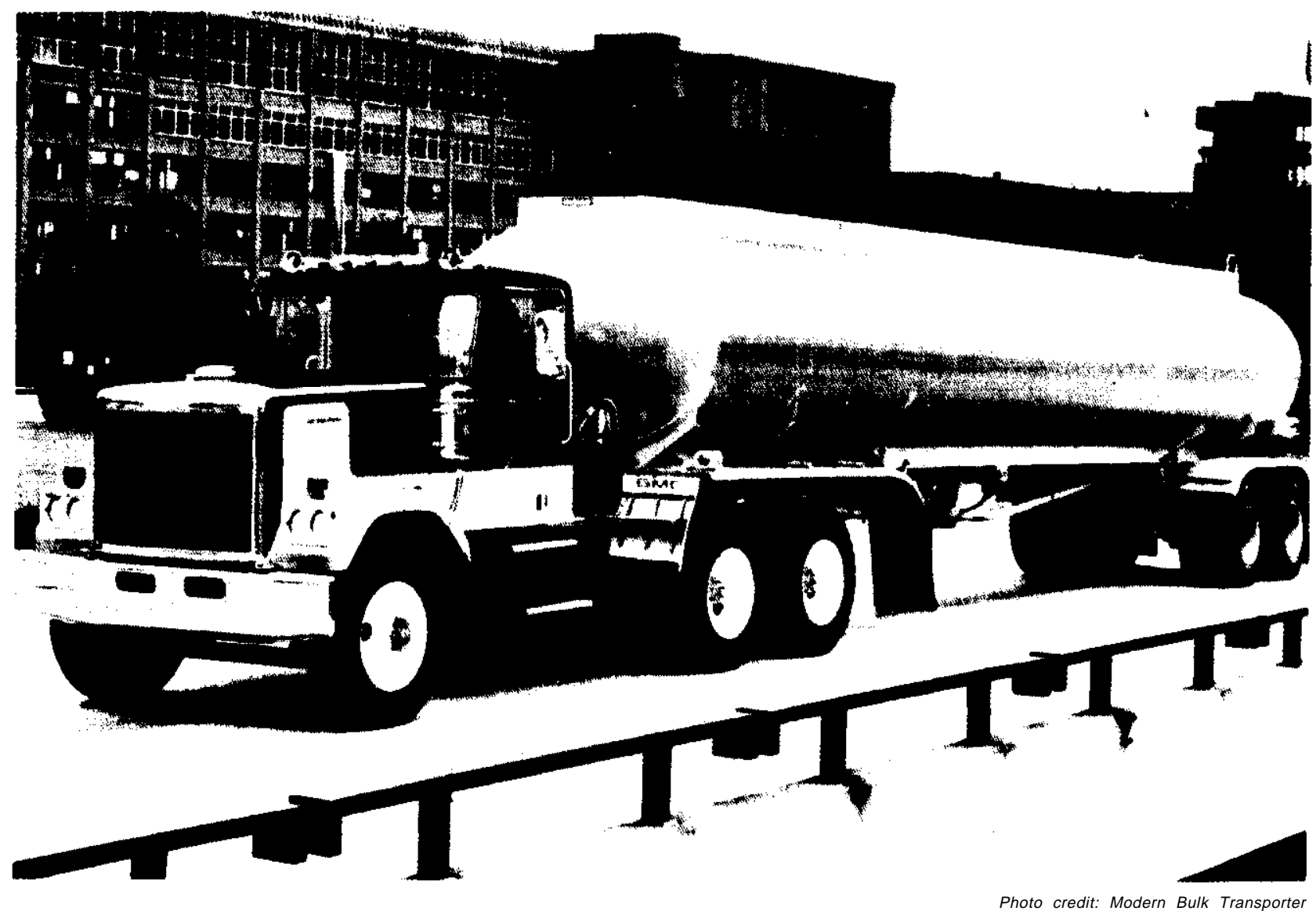

MC-306 tank trucks transport the most prevalent hazardous material, gasoline. 
and leakage of hundreds to thousands of gallons of gasoline.

The design of the MC-306, the most common cargo tank, may be an important factor in the truck's frequent involvement in accidents. The MC-306 has a high center of gravity and consequently high rollover susceptibility. Industry and academic research efforts have produced several new designs to improve the safety performance of the MC-306.

For example, the University of Michigan's Highway Safety Research Institute (HSRI) proposed a new design of large cargo tank semi-trailers for use in Michigan. ${ }^{\text {a }}$ The basic change from the standard MC-306 is an increase in the maximum width of the tank and chassis from 96 to 102 inches to allow a wider track and permit a lower center of gravity. The increased size allows the tanker combination to carry more gasoline, but also increases the gross weight. Designs with three, four, or five semi-trailer axles are needed to keep the load per axle within Michigan's legal limits. HSRI estimates that the improved stability and fewer trips of the larger vehicle would result in a 40-percent reduction in the single-vehicle-accident rollover frequency.

The Fruehauf Corp. has applied similar principles to a tri-axle trailer design that is much closer to existing tanker design, although the tank center of gravity is about 11 inches lower than that of existing units. This change makes the vehicle one-half as likely to be involved in a rollover. A prototype vehicle has been constructed and has been tested in service for at least 30,000 miles by different oil companies, and several major oil companies are purchasing some of these new trailers for use in Louisiana, where weight laws allow them to operate. The Fruehauf design has a capacity about 550 gallons greater than the standard MC-306, and this difference was very important in the decision to purchase them. A new design that did not have at least the capacity of current models would not be attractive to carriers, as many carriers use their cargo tanks so extensively that a difference in capacity of several hundred gallons is significant.

These truck designs require consideration of a . number of trade-offs. Both involve gross truck and

\footnotetext{
${ }^{80}$ R.D. Ervin, et al., Future Configuration of Tank Vehicles Hauling Flammable Liquids in Michigan (Ann Arbor, MI: University of Michigan Highway Safety Research Institute, December 1980). This research organization is now called the University of Michigan Transportation Research Institute.
}

trailer weights above the 80,000 pounds currently allowed on most of the Nation's highways. The Michigan tankers range up to 125,000 pounds, and the Fruehauf truck weighs about 86,000 pounds. Accordingly, widespread use of these or similarly designed tankers depends on whether other States are willing to approve heavier truck weights on their roads. An increase in truck weights accelerates the damage rate to road surfaces. Moreover, the new designs employ a 102-inch-wide wheel base. While this width is allowed on all Interstate and primary roads, many urban areas do not permit trucks of that width to operate in their jurisdictions. Access restrictions facing the wider cargo tankers are important factors in decisions about purchasing such vehicles. Finally, accidents involving trucks with increased load capacities have potentially more serious consequences than those involving current trucks.

The safety benefits derived from a design change would be proportional to the percentage of the fleet having the new design, and any major design change will likely be implemented gradually, as older cargo tanks are taken out of service. RSPA has estimated, in a cost-benefit analysis, that if $\$ 1$ million were expended for each annual gasoline tanker death (where the death was due to the gasoline), the amount available to make safety modifications in all existing gasoline trucks would be about $\$ 200$ per truck per year. If the average lifespan of a cargo tank is 20 years, then about $\$ 4,000$ would be available per truck, a figure that is close to the price difference between the old design and some new ones. Decreases in injuries, property damage, and deaths that are attributable to the vehicle accident rather than to the hazardous nature of the cargo (the latter are the only deaths that RSPA notes in its incident reports) would be additional benefits. OTA'S independent calculations suggest the benefits may be substantially larger and the trade-off time may be much less (box $3 \mathrm{H})$, although admittedly much uncertainty exists for several of the estimates used in calculating the costs and benefits of a design change.

Three cargo tanks built to a new design, employing fiberglass reinforced plastic (FRP), are being used for gasoline transport on a trial basis. ${ }^{81}$ The FRP tanks, built in the United Kingdom, have better im-

\footnotetext{
${ }^{81}$ George Jennings, Mobil Oil Corp., Fairfax, VA, personal communication, March 1986.
} 


\section{[Page Omitted]}

This page was originally printed on a gray background.

The scanned version of the page is almost entirely black and is unusable.

It has been intentionally omitted.

If a replacement page image of higher quality

becomes available, it will be posted

within the copy of this report

found on one of the OTA websites. 
Approximately one-half of all tollovers would be avoided using the new design, Injuries are ignored; they are about four to seven times as common as deaths. Avoided injuries would add to the benefit.

Based on these figures, it would take 4.4 years for the investment in safer equipment to pay for itself via reduced accident expenses $(\$ 220 \mathrm{million} / \$ 50 \mathrm{million} /$ $\mathrm{yr}=4.4 \mathrm{yr}$ ). The average useful lifespan of an MC306 cargo tanker is at least 20 years.

pact resistance, fire resistance, and lower rollover susceptibility than the standard aluminum MC-306. The three models on the road currently, however, have a higher tare (container) weight than most MC306 s and thus cannot carry as much gasoline. Unless the weight of the FRP tank can be reduced, it will not be widely used because of road weight law restrictions.

OTA analysis shows that highway common carriers experience the highest frequency of releases with corrosives (see chapter 2). Because they are relatively unreactive chemically, plastics and composite materials also have potential for use in cargo tanks carrying acids and corrosives, which quickly degrade metal cargo tanks. A U.S. manufacturer received DOT approval to build a composite tanker and has constructed a prototype. However, more research is needed on the durability and road-worthiness of the tankers before carriers will invest in them. Current research, sponsored jointly $b_{y}$ RSPA and BMCS, into tank truck corrosion problems should address significant industry and safety concerns, Results are expected in late 1986.

Changes to Cargo Tank Regulations.-The number of cargo tanker releases reported to RSPA averaged over 1,500 per year from 1976 through 1984, although as indicated in chapter 2, OTA finds this figure to be an underestimate. Both human and mechanical factors affect the highway spill rate. In its studies of cargo tank safety, DOT has identified widespread deficiencies in the design and maintenance of cargo tanker manhole covers, pressure relief valves, and vents. ${ }^{82}$ One stud found leaks in

\footnotetext{
${ }^{{ }^{2}}$ Dynamic Science, Inc., Cost-Effective Methods of Reducing Leak-age Occurring in Overturns of Liquid-Carrying Cargo Tanks (Washington, DC: U.S. Department of Transportation, Federal Highway Administration, September 1980); and U.S. Department of Transportation, Federal Highway Administration, Integrity of $\mathrm{MC} 307 / 312 \mathrm{Car}$ go Tanks (Washington, DC: October 1984).
}

Results of our analysis show that the costs and benefits are of comparable magnitudes and that the breakeven point lies well within the expected lifespan of the cargo tanker. A more rigorous analysis of the safety and economic impacts associated with a major redesign of the MC.306 cargo tanker would be useful. The estimates of costs of rollover accidents and the reduction in the number of deaths after adoption of the new design need refinement.

every compartment of the 20 cargo tanks tested, primarily in the areas cited above, and many of the manhole covers used on cargo tanks constructed in the 1960s and 1970s are unable to withstand the forces of a rollover and leak their contents whenever a rollover occurs.

No single governmental agency or industry group knows with any precision how many of the different types of tank trucks are in use, * kinds of commodities carried in them, and the classifications of the carriers using the trucks. Requiring registration of each tank truck on manufacture and submission of sale records for the tanker could give DOT much of this information. If tied to an inspection program and better reporting of accidents and releases, such information could help identify inadequacies in tank designs and would be useful in evaluating changes to regulations.

Problems with the maintenance of cargo tankers are well documented, and many of the problems and appropriate corrective measures could be identified through regular tests or inspections. Although pressure testing and inspection of containers are important safety tools, DOT requires periodic pressure testing of only some cargo tanks after construction. ${ }^{* *}$

*The U.S. Department of Transportation (DOT) does know how many MC- 338 cargo tanks there are. The trucks carry flammable cryogenic cargo (e.g., liquefied carbon monoxide) and comprise a very small portion of the cargo tank fleet. The highly hazardous nature of the cargo carried in them has led DOT to extend regulation to intrastate carriage and to create a special regıstry for these trucks.

**MC -331 and 338 cargo tankers that typically carry a nhydrous ammonia, liquefied petroleum gas, and cryogenic liquids are required to be pressure tested. These tanks, if covered by Federal or State regulations must be tested everv 5 vears (every 2 vearsif used for chlorine transport). All other cargo tanks must undergo an external visualexamination every 2 vearsand the inspection can be made by the operator. Gasoline (argo tanks in regions of air quality nonattainment are requiredbitheEnvironmental Protection Agency (EPA) to have annual leak tests. Most Statel have some areas of nonattainment,commonly metropolita n areas. EPA does not keep track of the tanks required to beleak tested, leaving the implementation of the regulation to the States. 
After 10 years of study, DOT has issued a Notice of Proposed Rulemaking (NPRM) for cargo tankers $^{83}$ calling for, among other things, annual pressure tests of all cargo tanks under Federal regulation. The rulemaking would greatly increase the number of cargo tanks that must be pressure-tested and would also increase the frequency of such tests. More effective pressure relief valves would be required, and many gasoline cargo tanks would have to be retrofitted with stronger manhole covers.

At a public hearing on NPRM, several industry groups expressed concern that the rulemaking would have unintended deleterious results, particularly in the areas of MC-306 body construction, tank truck inspection costs and pressure relief valve design. Rigorous estimates of increased costs under the proposed regulations were developed by industry for submission to DOT in May 1986.

Roadside inspections of vehicles carrying hazardous materials have shown that problems with the vehicles themselves - faulty brakes, tires, or lightsare more frequently the cause of accidents than are problems with the hazardous materials container itself. Increased attention to maintenance practices would help reduce accidents caused by faulty equipment.

Improving Driver Performance. -Many of the most serious hazardous materials releases during bulk transport over the highway are caused by ve-

\footnotetext{
${ }^{83}$ U.S. Department of Transportation, Research and Special programs Administration, Materials Transportation Bureau, Federal Register, Notice of Proposed Rulemaking, Requirements for Cargo Tanks, vol. 50, No. 180, Sept. 17, 1985.
}

hicle accidents, most of them the result of driver error. ${ }^{84}$ Improving driver performance could increase safety. Methods of accomplishing this include both improving equipment and improving driver training. The Shell Oil Co., employing both techniques, has experienced a 58-percent reduction in its preventable vehicular accident rate over the course of its driver safety training program instituted in $1979 .{ }^{85}$ (See table 3-10.)

The program entails several days of instruction in relevant hazardous materials regulations and vehicle operating procedures, followed by 1 or 2 weeks of field training, during which each driver is accompanied on the job by an instructor. Each of the trucks owned by Shell has a tachograph that automatically records when the motor starts, when motion starts, travel speeds, when the truck stops, distance between stops, total distance traveled, and the duration of all trips. The tachograph records make each driver aware that he is accountable for his performance, that his driving behavior can be readily evaluated. He also knows that the records can work to his benefit in the case of an unavoidable accident.

The Insurance Institute for Highway Safety (IIHS) has recommended that tachographs be required on all large trucks. Furthermore, the IIHS holds that speed limiters should be placed on trucks, better braking systems should be employed, and that recapped tires should not be allowed on front wheels. Tire failures follow brakes as the leading equipment-

\footnotetext{
${ }^{84}$ Abkowitz and List, op. cit.

${ }^{85}$ Shell Oil Co., personal communication, January 1986.
}

Table 3=10.-Major Oil Company, Total Vehicle Accidents (safety programs begun in 1979)

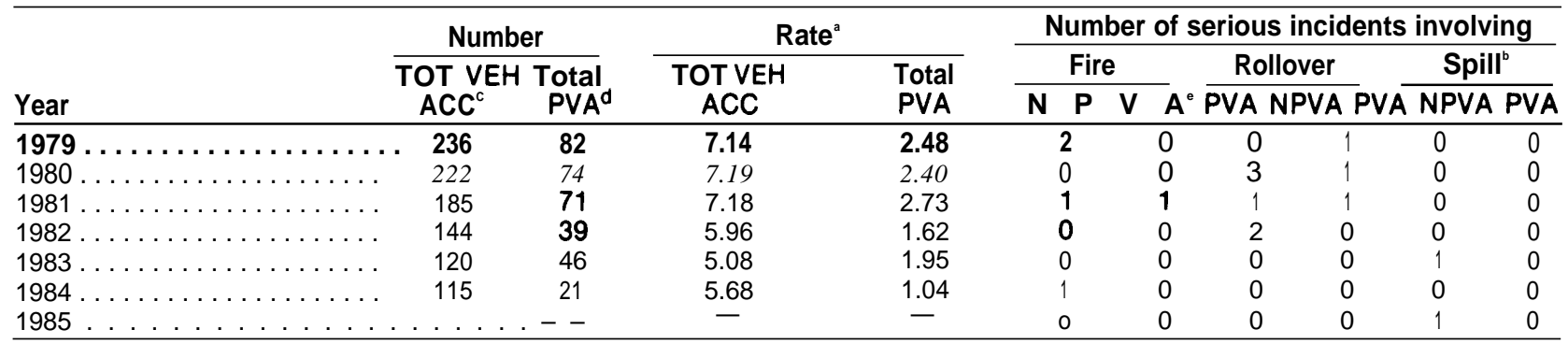

apate is the number of accidents par 1 million vehicle miles.

bThese are spills other than those associated with fires or rollovers.

accident where the driver failed to do everything possible to avoid the accident.

ONPVA-nonpreventable vehicular accidents.

SOURCE: Private written communication to Office of Technology Assessment staff. 
related causes of truck crashes. ${ }^{86}$ A pilot project could be developed to equip a number of trucks with such safety equipment and carefully monitor the safety performance of the fleet. Any change in accident rates and severity would permit evaluation of equipment's contributions to safety.

Coordination Among Federal Agencies.-Improving coordination among agencies currently regulating motor carriers is also essential. Responsibilities are currently spread over three agencies:

- RSPA - container specifications, marking and labeling, and placarding;

- BMCS - inspecting cargo tank manufacturers and motor carrier operating procedures; and

- National Highway Traffic Safety Administration-manufacture of vehicles.

Difficulties in coordinating activities and sharing accident data have resulted in disjointed and often ineffective regulation. For example, both RSPA and BMCS support accident databases, but there are few cross-checks made between them. Perhaps more importantly, specifications for cargo tanks have been developed separately from specifications for the motor vehicles on which the tanks are mounted. Thus, all components of the transportation system (including container, load, vehicle, and highway) have not been considered in developing design standards. For example, studies of a tank truck's interaction with the road system have shown that the truck's stability and resistance to rollover is dependent on such factors as the center of gravity, height, track width, suspension, fifth-wheel characteristics, and the tires of the vehicle; yet these factors are not a part of RSPA's cargo tank specifications.*

Compounding the difficulties in implementing design or technological innovations is the fact that no single trucking industry group exists to consider such issues for the cargo tanks used in truck shipments of hazardous or other materials. The Truck Trailer Manufacturers Association has a committee deal-

\footnotetext{
${ }^{86}$ Anne Fleming (cd.), Big Trucksand Highway Safety (Washington, DC: Insurance Institute for Highway Safety, 1985), p. 14.

*A stability requirement for cargo tankers need not specify any particular arrangement of tires or suspension, but might require tilt-table tests to evaluate the rollover stability of different designs. Tilt-tables are platforms on which a truck or cargo tank can be placed and tilted sideways until the wheels on one side lift off the platform. The angle to which the tilt-table must be raised before the truck wheels lift off is a measure of the static stabilit of the configuration being tested.
}

ing with tank trucks and the National Tank Truck Carriers, Inc., serves some of the for-hire tank truck industry. The American Trucking Associations, the American Petroleum Institute, and other groups also have an interest in such issues. Achieving consensus on decisions affecting tank truck designs is thus a difficult and lengthy process.

\section{Rail Tank Cars}

Rail shipments account for about 5 percent of the tonnage of hazardous materials transported annually with about 3,000 carloads shipped each day. (See chapter 2.) The numbers of daily shipments are far fewer than those made by highway, and the shipments are transported by a much smaller number of carriers. Most of the ton-miles are logged by just 9 of the 25 Class 1 railroads doing business in 1985; Class 2 and Class 3 railroads carry few hazardous materials. ${ }^{87}$

OTA analysis of RSPA and Federal Railroad Administration (FRA) data indicates that, on a tonmile basis, the rail mode has a lower release rate than the highway mode and a somewhat higher rate than the water mode. (See chapter 2.) However, modal differences such as the number of miles of network, traffic density, and average speed affect the release rates in each mode, making direct modal comparisons difficult. Moreover, the rates themselves are questionable, as documented in chapter 2.

As all hazardous materials rail traffic falls under Federal regulations, all rail containers are required to be of the proper specification regardless of the origin, destination, or duration of the trip or characteristics of the shipper or carrier. About 80 percent of annual rail shipments of hazardous materials involve tank cars, which have useful lives of 30 to 40 years. Since 1970 , the capacity of tank cars for carrying hazardous materials has been limited to 34,500 gallons or 263,000 pounds gross weight (weight of tank car and commodity).

The two main categories of tank cars are pressure and nonpressure, and different tank car designs accommodate both gases and liquids. Each categor has several classes that differ from each other in such

\footnotetext{
${ }^{87}$ Jim Reiter, American Association of Railroads, personal communication, March 1986. A Class 1 railroad has gross revenues greater than $\$ 87,935$ million; a Class 2 between $\$ 17.587$ and $\$ 87.935$ million; and Class 3 less that $\$ 17.587$ million.
} 


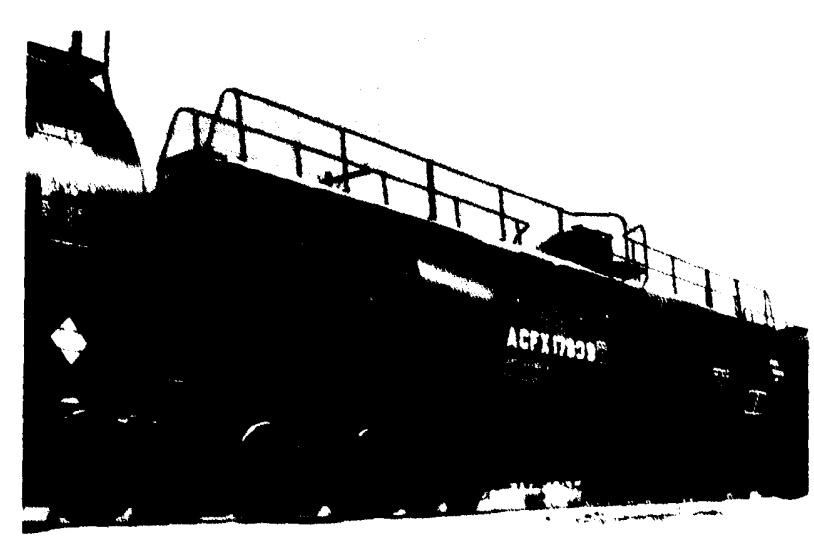

Photo credit: Association of American Railroads

A pressure tank car, DOT 112J, transports liquefied petroleum products.

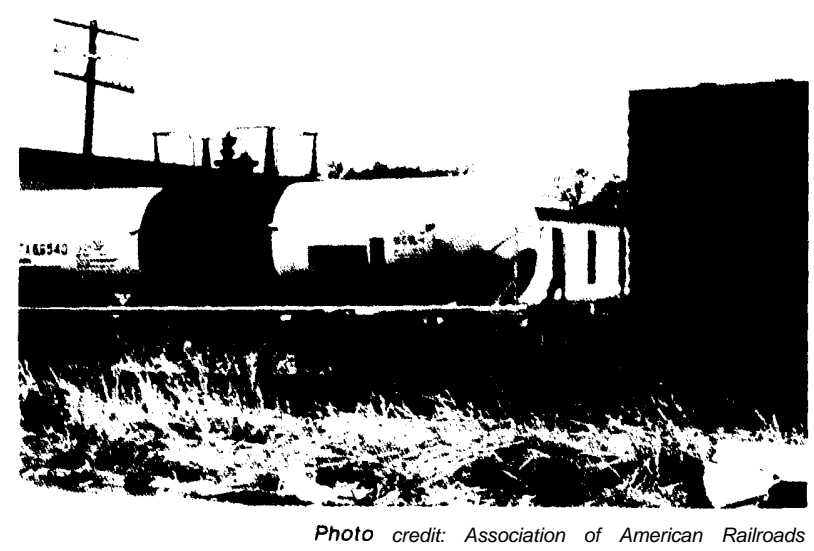

An example of a non pressure tank car, a DOT 111, used in this case to transport aqueous hydrofluoric acid.

things as test pressure, presence or absence of bottom discharge valves, type of pressure relief system, and type of thermal s!iielding. Ninety percent of tank cars are made of steel; aluminum is the second most common construction material. The thickness of the tank car shell is specified by regulation (see table 3-11).

Tables 3-12 and 3-13 list the common classes of tank cars of both categories and provide examples of typical cargo that each may carry. Approximately 66 percent of the rail tonnage consists of chemicals, and approximately 23 percent consists of petroleum products. Based on DOT's hazard classification scheme, the most common commodities are flammable liquids and corrosive materials, each accounting for about 25 percent of the tonnage. ${ }^{88}$

DOT prescribes tank car design specifications in 49 CFR Part 179 . The specifications have generally been developed from industry standards adopted by the Tank Car Committee of the Association of American Railroads (AAR). AAR, an industry organization, is involved in all aspects of railroad operations, including evaluation of new tank car designs, inspection of manufacturers, and collection and analysis of accident data. In addition, the Mechanical Division of AAR participates in the approval of tank car designs, materials, and construction, as well as the conversion or alteration of tank cars. ${ }^{89}$ Although AAR approves all new tank car designs prior to acceptance by FRA and RSPA, RSPA is not involved in the design approval activities of AAR and is not permitted to attend sessions where the designs are analyzed and evaluated. RSPA'S exclusion from these sessions makes it difficult for the agency to evaluate requests for special waivers or exemptions to design requirements. After tank cars are constructed, qualification, maintenance, and use is governed by Section 173.31, as well as by individual commodity sections of the regulations. FRA is responsible for inspecting railroad operations and tank car manufacturers.

In the mid-1970s, a series of derailments occurred, one involving the puncture of flammable gas tank cars by the couplers of adjoining cars. The ignited material venting from the punctured car impinged on other derailed flammable gas cars, simultaneously heating and expanding their contents beyond the capacity of safety relief devices and weakening the tank shells. The resulting explosions and fires caused enormous damage.

Recommendations made prior to 1978 by the National Transportation Safety Board (NTSB) and investigations by the Federal Railroad Administration led DOT to mandate installation of top and bottom shelf couplers that would be less likely to disengage and puncture adjacent cars. ${ }^{90}$ For flamma-

\footnotetext{
Abkowitz and List, op. cit.

${ }^{*}$ See 49 CFR 179.3.

"National Transportation Safety Board recommendations R-74-033 (Octoher 1974) and R-75-19 (April 1975).
} 
Table 3-il.-Minimum Tank and Jacket Plate Thickness

\begin{tabular}{|c|c|}
\hline $\begin{array}{l}\text { Minimum plate thickness } \\
\text { after forming }\end{array}$ & Common use of plate thickness \\
\hline 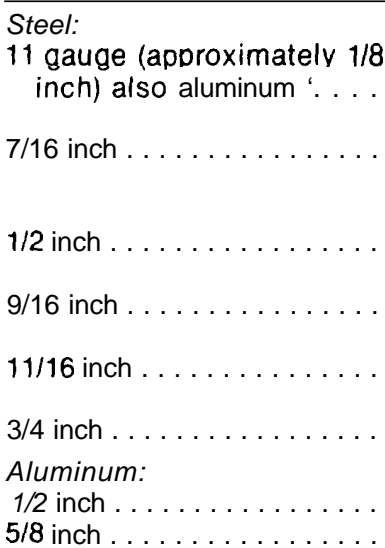 & $\begin{array}{l}\text { Jacket of insulated tank cars; or jacket for thermally protected } \\
\text { cars. } \\
\text { Tank for nonpressure tank cars; jacket for nonpressure tank } \\
\text { within a tank; or shell portion of jacket for cryogenic liquid } \\
\text { tank cars. } \\
\text { Head puncture resistance (head shield); or head portion of } \\
\text { jacket for cryogenic liquid tank cars. } \\
\text { Tank for steel pressure tank cars with tank test pressures of } \\
200 \text { psi and below. } \\
\text { Tank for steel pressure tank cars with tank test pressures of } \\
300 \text { psi and greater. } \\
\text { Tank for steel pressure tank cars in chlorine service. } \\
\text { Tank for nonpressure aluminum tank cars. } \\
\text { Tank for aluminum pressure tank cars. }\end{array}$ \\
\hline
\end{tabular}

Table 3.12.-Common Pressure Tank Cars

\begin{tabular}{|c|c|c|c|c|c|}
\hline Class & Material & Insulatio & $\begin{array}{l}\text { Test }^{\mathrm{a}} \\
\text { ressur }\end{array}$ & $\begin{array}{l}\text { Valve } \\
\text { setting }\end{array}$ & Notes \\
\hline DOT 105 & $\begin{array}{l}\text { Steel/ } \\
\text { aluminum }\end{array}$ & Required & $\begin{array}{l}100 \\
200 \\
300 \\
400 \\
500 \\
600\end{array}$ & $\begin{array}{c}75 \\
150 \\
225 \\
300 \\
375 \\
450\end{array}$ & $\begin{array}{l}\text { No bottom outlet or washout; only one opening in tank; } \\
\text { e.g., DOT } 105 \text { A } 500 \mathrm{~W}=\text { chlorine }{ }^{\mathrm{C}}\end{array}$ \\
\hline DOT 112 & Steel & None & $\begin{array}{l}200 \\
340 \\
400 \\
500\end{array}$ & $\begin{array}{l}150 \\
225 \\
280.5 \\
300 \\
330 \\
375\end{array}$ & $\begin{array}{l}\text { No bottom outlet or washout; e.g., DOT } 112 \mathrm{~J} 400 \mathrm{~W}= \\
\text { anhydrous ammonia }^{d}\end{array}$ \\
\hline DOT 114 & Steel & None & $\begin{array}{l}340 \\
400\end{array}$ & $\begin{array}{l}255 \\
300\end{array}$ & $\begin{array}{l}\text { Similar to DOT } 105 \text {; optional bottom outlet; } \\
\text { e.q., DOT } 114 \text { T } 400 \mathrm{~W}=\mathrm{LPG}\end{array}$ \\
\hline
\end{tabular}

apressure in psi to which the tank car is tested upon manufacture and Periodically thereafter.

bsetting at which pressure relief value will start to discharge, Tank cars may also be equipped with vents; the vents would operate when the pressure inside the tank reached the test pressure.
C"DOT 105" specifies the general class; "500" specifies the tank cartest pressure; the "W"indicates the method of welding of the tank; and, a number, if present

after the "W", indicates specific fittings, materials, or linings.
$\mathrm{dTh}$ " $J$ "indicates that the tank car has jacketed thermal protection, A "T"wouldindicate the presence of spray-on thermal protection. Both " $\mathrm{J}$ " and " $T$ " indicate that the tank car is equipped with head shields.

SOURCE: Charles J. Wright and Patrick J. Student, Union Pacific Railroad, "Tank Cars)" unpublished typescript, no date

ble gas, anhydrous ammonia, and ethylene oxide tank cars, the agency also required installation of head shields as further protection against coupler damage, and the addition of thermal protection to prevent rapid overheating if a neighboring tank car were on fire. AAR, its Tank Car Committee, FRA, and RSPA with participation by the Railway Progress Institute (RPI), the rail manufacturers, jointly established these tank car modifications, which have greatly improved the safety of bulk movement of hazardous materials by rail.
After the retrofits of the DOT 112/114 tank cars* were completed during 1981, the number of railroad accidents involving disastrous releases of flammable gases decreased dramatically. A 1981 study by $A A R$ and RPI showed that the frequency of head punctures for retrofitted tank cars decreased by 95 percent from the preretrofit rate, and the frequency

\footnotetext{
*These tank cars are pressure cars that carry flammable gases-for example liquefied petroleum gas-and nonflammable gases, such as anhydrous ammonia.
} 
Table 3=13.-Common Nonpressure Tank Cars

\begin{tabular}{|c|c|c|c|c|c|}
\hline Class & Material & Insulation & $\begin{array}{l}\text { Test }^{\mathrm{a}} \\
\text { pressure }\end{array}$ & $\begin{array}{l}\text { Valve }{ }^{b} \\
\text { setting }\end{array}$ & Notes \\
\hline DOT 103 & $\begin{array}{l}\text { Steel/aluminum } \\
\text { Stainless steel/ } \\
\text { nickel }\end{array}$ & Optional & 60 & 35 & $\begin{array}{l}\text { Optional bottom outlet } \\
\text { DOT } 103 \text { DW = whiskey }\end{array}$ \\
\hline DOT 104 & Steel & Required & 60 & 35 & $\begin{array}{l}\text { Similar to DOT } 103 \\
\text { optional bottom outlet }\end{array}$ \\
\hline DOT 111 & Steel/aluminum & Optional & $\begin{array}{r}60 \\
100\end{array}$ & $\begin{array}{l}35 \\
75\end{array}$ & $\begin{array}{l}\text { Optional bottom outlet and bottom washout } \\
\text { DOT } 111 \mathrm{~A} 60 \mathrm{~W} 5^{\circ}=\text { corrosive hydrochloric } \\
\text { acid } \\
\text { DOT } 111 \mathrm{~A} 60 \mathrm{~W} 1=\text { gasoline }\end{array}$ \\
\hline
\end{tabular}

apressure in psito which the tank car is tested upon manufacture and periodically thereafter.

bSetting at which pressure relief valve will start to discharge. Tank carsmay alsobe equipped with vents; the vents would operate when the pressure inside the tank reached the test pressure.
cThe "DOT 111" is the class; th."

SOURCE: Charles J. Wright and Patrick J. Student, Union Pacific Railroad, "Tank Cars,” unpublished typescript, no date.

of thermal ruptures dropped by 93 percent. ${ }^{91}$ Experience since that study shows that while the shelf couplers tend to keep the cars more securely attached to one another, which results in more car derailments per accident, they have continued to prevent punctures and ruptures. ${ }^{92}$ All DOT 111A tank cars carrying flammable gases and ethylene oxide and DOT 105 tank cars will be retrofitted with head shields and thermal protection by December 31,1986 . Because of the efficacy of the shelf cou-

\footnotetext{
${ }^{91}$ American Association of Railroads, Effectiveness of Shelf Couplers, Head Shields and Thermal Shields on DOT 112 (114) and 105 Tank Cars, Railway Progress Institute-American Association of Railroads Tank Car Safety Project Report RA-Oi-5-51 (Washington, DC: June 13, 1985).

${ }^{92}$ Charles Batten, National Transportation Safety Board staff, personal communication, 1984.
}

piers, all hazardous materials tank cars are now being fitted with them.

Table 3-14 lists the periodic inspection and test requirements for several common tank cars. Typically, the tank must be pressure tested every 5 to 10 years, although for some commodities-chlorine, for example-the tests are much more frequent. For some tank cars, the frequency of inspection increases as the car ages. In addition, some shippers inspect their cars more frequently than regulations demand, often prior to each loading. ${ }^{93}$

\footnotetext{
${ }^{93}$ Robert Christman, Mobay Chemical Corp. and Hugo Andricain, Dow Chemical U. S. A., personal communication and demonstration, October 1985.
}

Table 3-14.-Retest Requirements for Selected Tank Cars

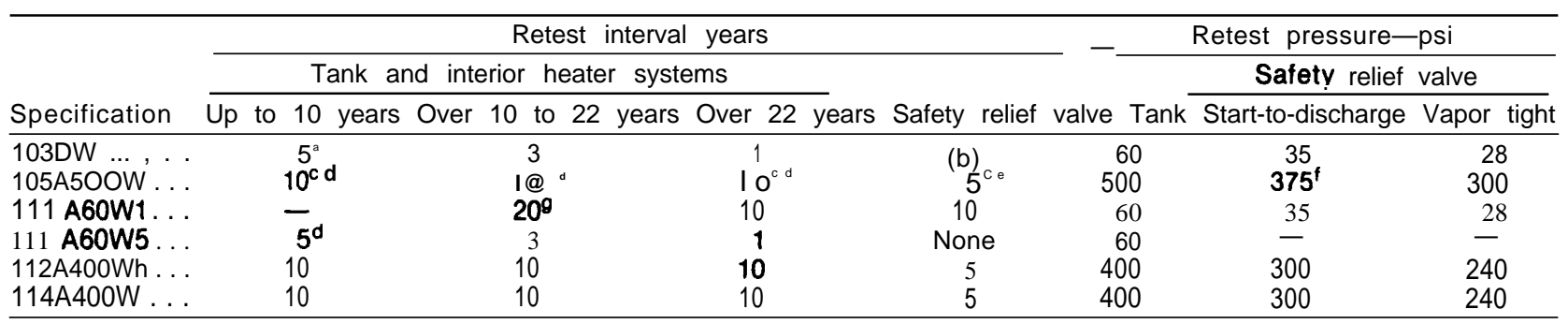

aA commodity for which a tank is approved may be used when retesting tanks in service not over 10 Years.

Safety relief valve retest period is same ss tank retest period.

cTanks and safety relief valves $i_{n}$ chiorine service must be retested every 2 years at any time during the calendar month the retest falls due.

$\mathrm{d}_{\text {Nickel clad tanks }} \mathrm{i}_{\mathrm{n}}$ bromine service and any glass, rubber, or lead lined tank neөd not be periodically retested, but the interior heater Systems and Safety relief valves must be retested at the prescribed interval.

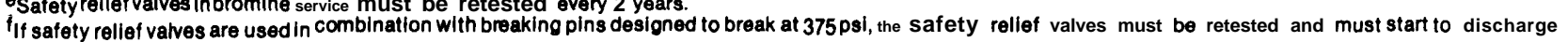
at 360 psi plus or minus 3 percent.

ORetest period for interior heater systems on cars so equipped is 10 years.

hNote: Tank cars stenciled 112S, 112T, $112 \mathrm{~J}, 114 \mathrm{~S}, 114 \mathrm{~T}$, or $114 \mathrm{~J}$ will have the same retest requirements as $112 \mathrm{~A}$ or $114 \mathrm{~A}$ respectively.

"S" indicates car equipped with tank shield and top and bottom shelf couplers.

"J". indicates car equipped with jacketed thermal protection, tank head shield, and top and bottom shelf couplers.

" $T$ " Indicates car equipped with spray-on thermal protection, tank head shield, and top end bottom shelf couplers.

SOURCE: General American Transportation Corp., GATXTank Car Manual,4th Edition (Chicago, IL: 1979), p. 14. 
Coincident with the retrofit of certain tank cars and the reduction in serious accidents, FRA also increased the number of over-the-rail inspections of railcars, which may have contributed to reducing the number of rail accidents. There are about 183,000 tank cars, approximately 63 percent of which are used for hazardous materials. FRA performed 39,000 tank car inspections in 1982 and 31,000 in 1983, twice the number of annual inspections $(16,000)$ performed in 1978 and 1979.

The coord aation of Federal agencies involved in regulating the rail mode needs improvement. FRA has primary responsibility for regulation, inspection, and enforcement of safety regulations in the rail mode. RSPA has the final say in hazardous materials tank car specifications, although FRA and AAR perform the safety evaluations. RSPA sets regulations for intermodal portable tanks, and keeps track of incidents or spills in the rail mode, while FRA must approve securement for the tanks when they are carried over the rails on flatcars.

A comparison of RSPA's database on hazardous materials incidents with the records of NTSB demonstrated that the inaccurate and incomplete accident records are serious problems for the rail mode. ${ }^{94}$ Between 1976 and 1983, 165 accidents involving hazardous materials appeared in the NTSB database that did not appear in the RSPA database. These accidents resulted in 37 deaths, 92 injuries, and $\$ 89$ million in damages. The value of damages reported to NTSB but not to RSPA exceeded the damages of all rail incidents reported to RSPA over the same time period. Better coordination of Federal activities in data collection could provide a more complete base on which to make regulatory decisions about whether changes in tank car specifications are called for.

The railroads keep detailed records of commodity flows. If this capability were combined with better reporting of releases to RSPA, problems with particular types of tank cars or with particular commodities could be rapidly identified and alleviated. For example, more than 60 percent of all spills are due to loose or defective fittings (chapter 2). This finding indicates a need to reevaluate the specifications for the fittings or the procedures to operate

${ }^{94}$ Abkowitz and List, op. cit. them, or both. Also, OTA contractor data analysis shows that corrosives had the highest release rate in rail transport. Some tank cars that carry corrosive acids (hydrochloric acid, for example) are rubber-lined and are pressure tested only before lining. Additional study is needed to determine whether there is a relationship between test data and release occurrence or whether tank cars carrying corrosives need to be redesigned.

\section{Bulk Water Transport}

The largest bulk containers are self-propelled tank ships and tank barges, which together account for about 91 percent of all marine shipping of hazardous materials. Tank barges range in size from 300,000 to 600,000 gallons, and self-propelled tankers can be 10 times larger. About 8 percent of marine shipping of hazardous materials occurs in dry cargo barges, which can carry both bulk (portable tanks) and nonbulk (drums) containers.

\footnotetext{
${ }^{95}$ Abkowitz and List, op. cit.
}

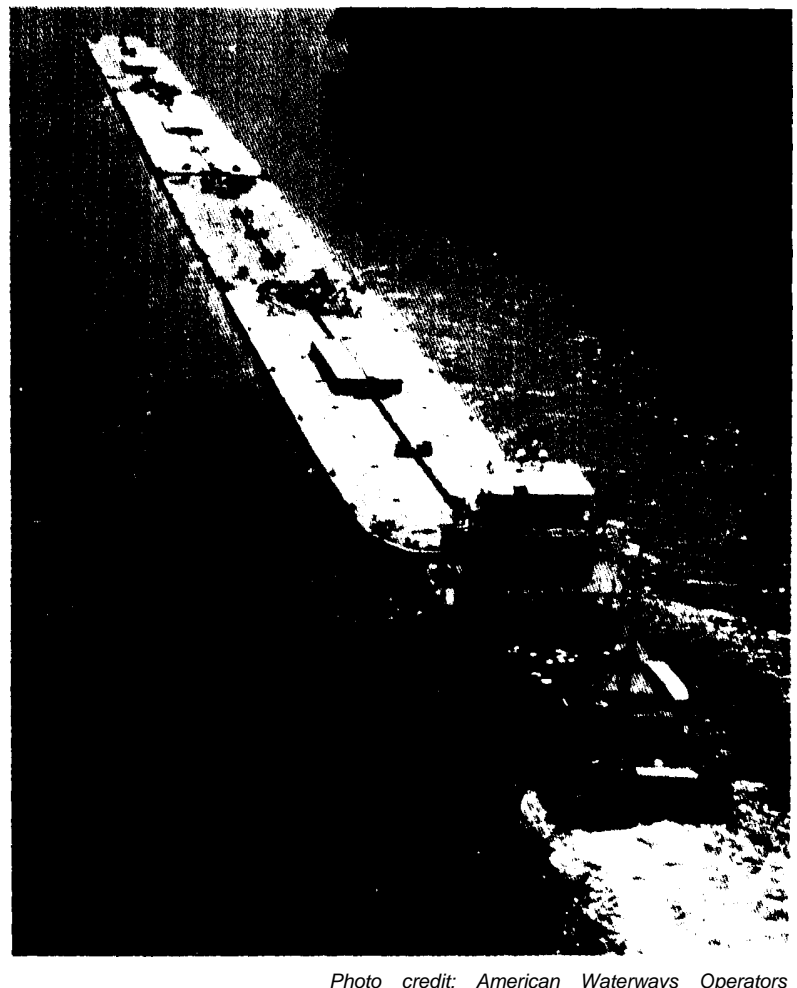

Approximately 35 percent of the hazardous materials tonnage transported in 1982, was by waterborne commerce. 
More than 90 percent of the tonnage in bulk marine transport consists of petroleum products and crude oil. Chemicals constitute about 7 percent, primarily basic chemicals, such as sulfuric acid, fertilizers, sodium hydroxide, alcohols, benzene, and toluene.

Because marine shipments typically involve very large quantities, fewer trips are required to move a given amount of product by water compared to the other modes. Bulk marine shippers and recipients are generally large companies, well aware of the potential liability they assume with each shipment. Because of the substantial economic investment these shipments represent, the companies expend the necessary resources to ensure safe transport as a matter of course. In addition, the vessels travel slowly. For all these reasons, the water mode has the lowest probability of an accident, and is statistically the safest, both in absolute numbers of accidents and spills per ton-mile, although when a spill does occur, the damage can be enormous.

However, other factors also explain why the water mode has the the fewest releases. In the first place, all vessels carrying bulk hazardous materials are subject to Federal hazardous materials regulations. Records kept by the government list every vessel in commerce in U.S. waters and note every shipment of commodities to or from every port in the United States. This recordkeeping emphasizes the accountability of those involved in bulk marine transport.

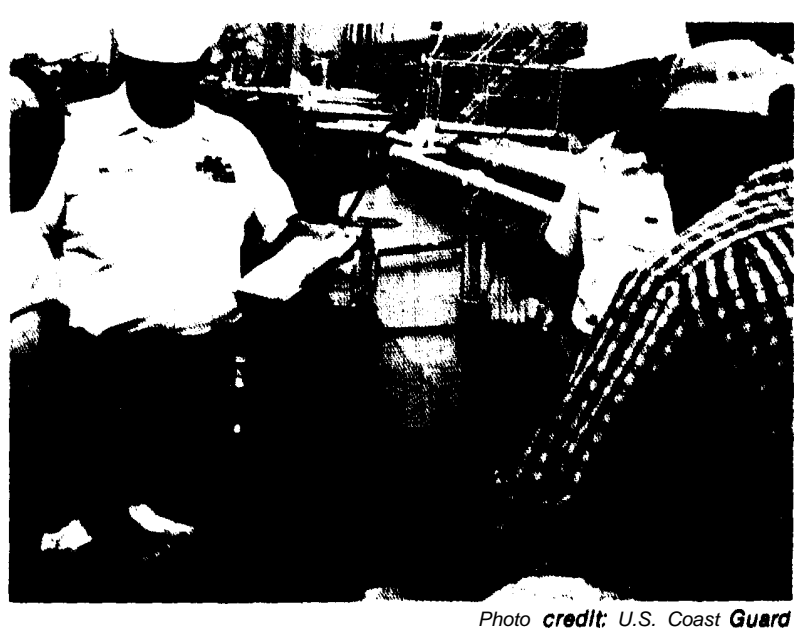

Coast Guard personnel examine a vessel carrying hazardous materials.
Moreover, the captains and operators of bulk marine vessels are tested and certified by the U.S. Coast Guard. Regulations require that the self-propelled tank ships and tank barges that carry most of the hazardous materials on water be loaded and unloaded by tankermen who have been tested and endorsed by the Coast Guard. A tankerman must demonstrate familiarity with the general arrangement of cargo tanks, suction, and discharge pipelines and valves, and be able to operate pumps and other equipment connected with the loading and discharging of cargo, as well as fire extinguishing equipment, In addition, the tankerman must demonstrate knowledge of pollution laws and regulations, procedures for discharge containment and cleanup, and methods for disposal of sludge and waste materials from cargo and fueling opera-

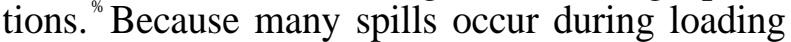
and unloading (see chapter 2), shippers generally provide special training to those who load and unload barges and self-propelled tankers.

The Coast Guard also regulates tank barges and self-propelled tank ships. All new vessels to be used for hazardous cargoes in bulk must meet the design requirements of 46 CFR. New vessels must be inspected and certificated by the Coast Guard or by the American Bureau of Shipping. All existing selfpropelled tank ships carrying hazardous cargoes must be inspected by the Coast Guard every year. Tank barges are inspected every 2 years, although an additional midterm inspection makes the effective time between inspections just 1 year. Moreover, some major shippers inspect bulk vessels prior to each loading. This frequency-of-inspection requirement may partly explain why the bulk water mode has the best safety record for hazardous materials.

Nonetheless, despite this safety record, bulk water shipments of hazardous materials have been declining; the number of active tank barges in U.S. domestic commerce decreased from 4,900 in 1982 to 4,100 in $1983 .{ }^{97}$ One reason is that chemical companies have recently been reducing inventories, partly in response to safety recommendations made

\footnotetext{
46 CFR 12.20.5.

9? The analysis of the changing business practices is based on interviews with representatives of several major chemical and petrochemical companies and on Monsanto Co., One Year Later: Report of the Monsanto Product and Plant Safety Task Force (St. Louis, MO: December 1985). The data on numbers of tank barges are from the Waterborne Commerce Statistics Center of the U.S. Army Corp of Engineers.
} 
after the Bhopal disaster, that smaller volumes of extremely hazardous substances be stored or used in batch processes. In addition, inventory reduction is also one way of making operations more efficient. Storage costs dictate that chemical companies store less and buy only what they will use immediately and that goods be delivered quickly, so production is not interrupted.

\section{Intermodal Tank Containers}

Intermodal tanks carry 4,000 to 6,000 gallons of liquid in a metal container surrounded by a rigid metal protective frame that facilitates the handling and securing of the tank container in the marine, rail, and highway modes of transport. They are versatile and efficient containers for substances that must travel long distances by several different modes. Used extensively in international trade, they are often carried by rail, water, and truck on a single journey. The capacity of a typical intermodal tank is equivalent to about 10055 -gallon drums, and intermodal tanks are displacing the 55-gallon drum in international commerce when such quantities are transported. In domestic commerce, the tanks are being used for special commodities or on long trips that involve a rail leg, and their use is rapidly increasing in this country as the volume of international trade increases.

For the most part, DOT regulations follow the International Maritime Organization guidelines for tank containers. These tanks are built either to the American Society of Mechanical Engineers Boiler and Pressure Vessel Code or to an equivalent code and must be certified by a DOT approval agency as being designed, manufactured, and tested in compliance with DOT regulations. The three largest approval agencies are the American Bureau of Shipping, Lloyds Register, and Bureau Veritas.

DOT requires a prototype of each tank design series to be performance tested in accordance with the tests required by the International Convention for Safe Containers. The tests simulate the in-service conditions of a tank container in marine, rail, and highway transport. To ensure that tank containers are maintained in good operating condition, DOT requires each tank to be visually inspected at $21 / 2$ year intervals and to undergo a hydrostatic pressure test at $1 \frac{1 / 2}{2}$ times the maximum allowable working pressure every 5 years. The visual test may be conducted by an owner, although when it coincides with a hydrostatic test bath it must be certified by inspectors of the designated approval agencies. ${ }^{98}$

For use in the United States, the tanks must be registered by serial number with DOT, and regulatory responsibility for them and their carrying vehicles is shared by RSPA and the modal administrations. The poor interagency coordination at DOT is a particularly acute problem affecting adequate regulation of the transport of these vessels.

Few appropriate truck chassis for intermodal tank containers are available in the United States. Most of the available chassis are deficient either in length, securement devices, or overall design, which typically incorporates a high center of gravity. Loaded portable tanks must generally be carried on 40-foot chassis in order to comply with bridge laws that limit the vehicle weight per axle and per wheelbase. However, only about 40040 -foot chassis in this country have twist locks that positively secure the portable tank in the center of the chassis, preventing lateral or vertical motion, although there are several thousand portable tanks available for commercial use. ${ }^{99}$ Thus, most intermodal tank containers now travel by highway on 40 -foot flatbed trucks secured by hooks and chains, legal securement under current regulations, or on 20-foot chassis, which may have proper securement devices, but which violate road weight laws. Industry leaders adamantly maintain that $\mathbf{J}$ hooks and chain binders provide grossly inadequate securement for the tanks on flatbed chassis, and accident records are beginning to corroborate this. ${ }^{100}$ As recently as November 1985,

\footnotetext{
${ }^{98} \mathrm{Much}$ of this information is derived from written communication from Donald L. Monroe, American Bureau of Shipping (ABS), Paramus, NJ, April 1986. The ABS is a private not-for-profit, international classification society comprised of shipowners, shipbuilders, naval architects, and others associated with the marine industry, concerned with assuring mechanical and structural fitness of vessels. They establish standards, adopted internationally, by which ships and other marine structures are built and maintained.

${ }^{99}$ George Graham, President, Chemical Leaman Container Corp., agents for Sea Containers Inc., a major owner, leaser, and transporter of intermodal containers, personal communication, October 1985.

${ }^{100}$ George Graham, President, Chemical Leaman Container Corp., agents for Sea Containers, Inc., has strongly advocated that intermodal tanks not be allowed to travel on flatbed trailers secured only by chains. Chain or chain binders allow for tank movement and make the vehicle dangerously unstable. His comments were made at the first semi-annual meeting of the Hazardous Materials Advisory Council, held at Hilton Head Island, SC, Nov. 14, 1985, and reported by Laurie Bradford, in "Inexperience Poses Major Threat to Safety in Transport of 'HM, " Traffic World, Nov. 25, 1985.
} 


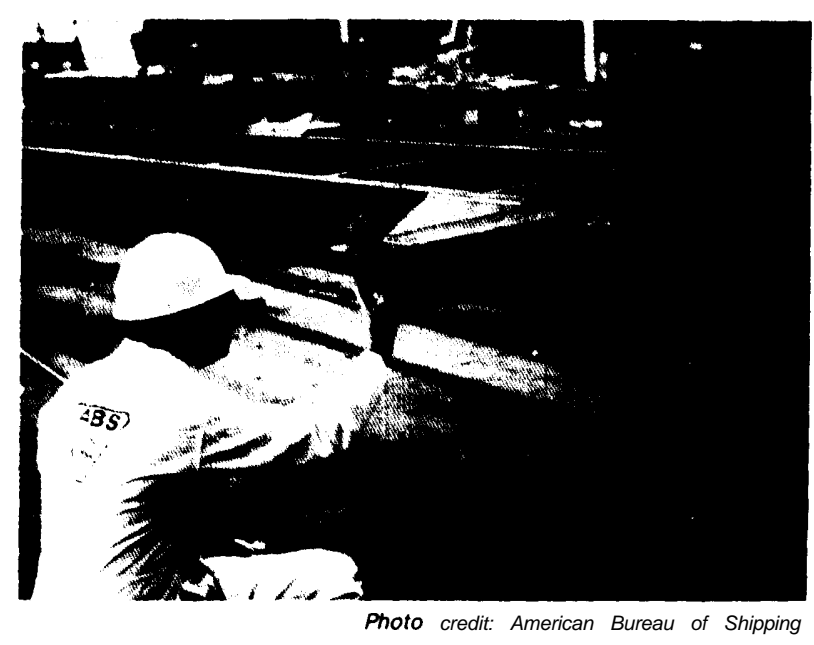

American Bureau of Shipping inspector examining the securement device, a "twist lock," on a trailer.

however, DOT officials were claiming that no new regulations were needed for the type of trailer used to transport portable tanks as long as existing securement regulations were followed. * $\mathrm{O}$ '

In addition, few chassis are specifically designed for intermodals. A "low boy" chassis with a flatbed several feet lower than normal is ideal for intermodal tank transport. The chassis design keeps the center of gravity low and the vehicle more stable. These chassis are used throughout Europe, but there are fewer than 100 appropriately configured chassis in the United States. Any requirement for increased use of low boy chassis would need to allow time for manufacture of a fleet sufficient for domestic commerce. Moreover, the concentration of the weight of a 20-foot portable tank in the middle of a 40 -foot chassis is a new design problem for some manufacturers. Flaws in the design or manufacture of some low boy chassis have caused fractures and failures at the goose neck portion where the support beams descend from the fifth wheel area to the bed of the chassis, ${ }^{102}$ and one new chassis failed within 3,000 miles of use. ${ }^{103}$

The behavior of intermodal tanks on trailers is very different from that of regular intermodal con-

\footnotetext{
${ }^{101} \mathrm{Ken}$ Pierson and Alan Roberts, in response to questions at the Hazardous Materials Advisory Council meeting, Hilton Head, SC, November 1985, as reported in Modern Bulk Transporter, January 1986.

““* Donald L. Monroe, Principal Engineer, American Bureau of Shipping, personal communication, April 1986.

${ }^{103}$ George Graham, President, Chemical Leaman Container Corp., personal communication, April 1986.
}

tainers or even cargo tankers. Intermodal tanks are rarely compartmentalized, so the effects of sloshing liquid cargo can be pronounced when the tank is not full or nearly full. Current regulations require that intermodal tanks be filled to at least 80 percent of their capacity (by volume), ${ }^{104}$ close to the level that produces the most unstable conditions in the tank. ${ }^{105}$ Not only is the configuration inherently unstable, but the driver often cannot feel the instability until it is too late. ${ }^{106}$ For certain commodities, road weight laws may limit the filling of an intermodal tank to 80 percent by volume; thus obeying all the relevant regulations could result in the least stable set of circumstances possible.

Furthermore the use of intermodal tanks in rail traffic is likely to increase, and the safety characteristics of intermodal tanks on trailers on railroad flatcars are not well known. Currently, FRA, which approves securement devices for tanks during travel by rail, is studying the safety characteristics of containers and trailers on rail flatcars. However, appropriate coordination between FRA and the Federal Highway Administration has not been established. FRA is now testing a configuration involving an intermodal tank on a 20 -foot truck chassis ${ }^{107}$ that is illegal for highway travel in most States, because the weight is not distributed over a long-enough wheelbase to satisfy highway bridge laws. Although the tank and chassis may be within the 80,000 pound gross weight limit, the configuration is either carrying too much weight per axle or for the length of wheelbase. Although FRA is aware that carrying portable tanks on the 20-foot chassis is illegal on most highways, it nonetheless is using the chassis in safety studies.

The Coast Guard monitors the acceptance of portable tanks entering the United States. It also

\footnotetext{
${ }^{104} 49$ CFR $173.32 c(j)$.

${ }^{105}$ The most unstable load for steady-state cornering is when the tank is loaded to 75 percent of capacity. R. D. Ervin, et al., University of Michigan Transportation Research Institute, Liquid Cargo Shift-

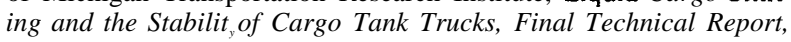
vol. 11 (Washington, DC: Federal Highway Administration, Bureau of Motor Carrier Safety, U.S. Department of Transportation, September 1985).

${ }^{106}$ Hazardous Cargo Bulletin, "Ullage and Roll Stability" June 1985.

${ }^{107}$ Clair Orth, Federal Railroad Administration (FRA), personal communication, January 1986. FRA is testing an intermodal tank on a 20-foot chassis. Such an arrangement is likely to violate highway bridge laws which specify the gross weight allowed for a given distance between axles.
} 
determines whether a tank carrying hazardous materials may be shipped out by vessel and where and how it will be stowed aboard the vessel. Much of the use of intermodal tanks in the marine mode is international.

Ton Tanks.-Certain multiunit cylindrical pressure vessels, commonly called ton tanks because of their characteristic size, ${ }^{108}$ are meant to be lifted on and off vehicles for filling and emptying. Specifications for these are published as part of the tank car rules in 49 CFR Part $1_{7} 9$. Used chiefly for chlorine transport, these are some of the heaviest and most effective containers in commerce.

\section{Nonbulk Containers}

Nonbulk containers are used to transport hazardous materials in all modes but constitute different proportions of traffic in each mode. By tonnage, small packages make up a small proportion of rail and water traffic, about half the highway traffic, and virtually all air traffic. Correspondingly, nonbulk packages constitute a small percentage of the incidents reported in the Hazardous Materials Information System in the rail and water modes, but comprise about 80 percent of the containers cited in highway releases and all the containers cited in air releases.

Materials used in nonbulk packaging include fiberboard, plastic, wood, glass, fiberglass, metal, and combinations of these. Combination packaging or packages within packages are often used in hazardous materials transport and include, for example, glass bottles in fiberboard boxes. Composite packaging are made of two or more materials such as a plastic-lined steel drum. Most containers can be used for a multitude of products, although certain types of packaging are designed for a particular commodity. Free-standing single units such as steel drums and cylinders for compressed gases are also widely used.

Factors related to the realities of the transportation system also influence container design. For example, products that are used only in small unit quantities often are transported packaged in those quantities, and many packaging that will be transported on trucks and railcars are designed to facili-

\footnotetext{
${ }^{108}$ Specifications 106 and 110.
}

tate loading, unloading, and using vehicle space efficiently. The type of handling equipment available is also a consideration. The 55-gallon steel drum, for example, has been called "man-sized" packaging, because it is about the largest unit that can fit through a normal doorway and can be handled by a single person.

Releases from nonbulk packages of hazardous materials, while numerous, generally do not have serious consequences because of the small amounts of materials in the packages. Human error, such as improper packing or handling, rather than poor container design, causes the majority of releases. Moreover, errors such as the use of improper packaging, frequently stem from ignorance, since shippers, especially small companies, find the hazardous materials regulations confusing.

Current packaging regulations are complicated and cumbersome and do not encourage development of packaging innovations. DOT has proposed a rulemaking (Docket No. HM-181) to change the current regulations from design standards specifying how a package must be constructed to performance standards that say what a package must do. * This section of chapter 3 focuses on operational changes affecting safety and on regulatory changes that would simplify and clarify packaging requirements and enable U.S. industry to be more competitive internationally.

\section{Current Design Specifications for Packaging}

Although some materials of low hazard do not require "specification packaging" (packages of such materials need only satisfy the general requirements), ${ }^{* *}$ DOT specifies detailed packaging requirements for most hazardous materials.

\footnotetext{
*performance standards are described in detail later in this chapter. Rather than stating exactly how and of what materials a package must be constructed, performance standards lay out tests that packages must pass before they can be used. If a package passes the appropriate tests (for example, a 6 -foot-drop test or a 4.8 psi pressure test) then it can be used without consideration of the details of its construction. For performance standards to work well, the tests must correlate to the stresses that packages experience in transport.

**For example, dichloromethane, classified as an ORM A material, does not require specification packaging.
} 
As described in a recent DOT advance notice of public rulemaking, a specification typically:

\begin{abstract}
... includes requirements for material, thickness, fastenings, capacity, coatings, openings, joining, carrying devices and miscellaneous other construction requirements. Much of the information is given in great detail and is repetitious. For example, there are fourteen specifications for wooden boxes, Most specifications list the acceptable types of wood from which lumber must be used to construct the box, and this list may be repeated in the next specification for a similar, but slightly different box. In addition to the types of acceptable wood being specified, the thickness and width of the boards, the kind and dimension of nails, and the spacing of the nails in joining the box may also be specified. ${ }^{109}$
\end{abstract}

While specifications developed over the years have brought a measure of uniformity and familiarity to hazardous materials packaging, they often act as an impediment to new packaging designs. Nevertheless, over the years, new packaging ideas have been developed by container makers and shippers and then discussed with the regulatory agencies. ${ }^{110} \mathrm{In}$ the era prior to the Hazardous Materials Transportation Act (HMTA), if new packaging appeared to be well designed and to have been successfully tested, regulatory agencies would issue a special permit approving its use by the developers, but would seldom authorize more general use. After the passage of the HMTA in 1975, such authorizations were formalized as exemptions and were controlled and limited. If a shipper wishes to make shipments in a container different from that specified in-the regulations, a petition for an exemption must be submitted to DOT. Each exemption is issued for up to 2 years and can be renewed. The exemption holder must report any adverse experiences in addition to any other incident reporting requirements. An ongoing rulemaking (Docket No. HM-139) exists to incorporate successful exemptions into the rules for general applicability. * However, rulemaking is sometimes too slow to keep up with the demand. For example, exemptions cov-

\footnotetext{
${ }^{109}$ Federal Register, "Performance-Oriented Packaging Standards, HM-181," vol. 47, No. 73, Apr. 15, 1982.

${ }^{110}$ See ch. 4 for a description of the evolution of hazardous materials regulations and the special relationship that industry has had with the regulatory bodies over the years.

*Rulemaking dockets are the procedural means by which new regulations are promulgated. The HM in HM-139 stands for hazardous materials
}

ering plastic drums and cryogenic cargo tank specifications were eventually incorporated into the regulations, but only many years after they were first authorized (17 years in the case of the cargo tanks).

Exemptions have become time-consuming administrative problems for both industry and government. RSPA has spent a large portion of staff time processing exemption applications over the years. ${ }^{11}$ Staff typically handles about 100 exemptions per month, about half of these dealing with small packages. Exemptions are issued to an original applicant, but other persons can become "parties to" that exemption. Exemptions that have been in effect for several renewal periods and have multiple parties to them are indicators of a deficiency in the rulemaking process. In fact, about 90 percent of all exemptions applications are for renewals or to become parties to existing exemptions.

\section{Performance Standards}

In 1969, a conference of transportation experts from government and industry ${ }^{12}$ recommended performance standards for packaging. Those experts believed performance standards could eliminate much of the Federal process for granting exemptions, approvals, or specific rulemaking petitions on packaging; eliminate many of the existing voluminous and complex regulations; and open the door to new technologies and innovations in the development of packaging designs. However, not until 1982, did DOT issue an advance notice of proposed rulemaking, Docket No. HM-181, proposing a framework of performance standards governing the design of containers with a capacity of 450 liters (119 gallons) or 400 kilograms (880 pounds) or less.

Effective performance standards require a thorough understanding of the transportation environment to determine precisely how the packaging must perform. Package designers need to know temperature variations, physical stresses during turns and

\footnotetext{
11 'U.S Congress, Congressional Research Service, Hazardous Materials Transportation: A Review and Analysis of the Department of Transportation Regulatory Program (Washington, DC: CRS, April 1979), p. 125

${ }^{112}$ National Research Council, Highway Research Board and the Committee on Hazardous Materials, A Study of Transportation of Hazardous Materials: A Report to the Office of Hazardous Materials of the U.S. Department of Transportation (Washington, DC: National Academy Press, 1969).
} 
stops, and the nature of shocks and vibrations that their packages are likely to encounter during transport. Once transportation conditions are sufficiently documented, tests can be developed to ensure that the packaging will contain its cargo during transport. Several years ago DOT issued contracts for a study of the transportation environment, ${ }^{113}$ which, while not comprehensive, provided useful information on the stresses to which packages are subjected during transportation.

The performance standards proposed by DOT are based on the United Nations Recommendations for the Safe Transport of Dangerous Goods, ${ }^{114}$ which divide hazardous materials into three "Packing Groups" depending on their relative hazards. Packing Group I consists of very dangerous materials, such as fuming sulfuric acid, a Group I corrosive. Packing Group II involves materials presenting a moderate degree of danger, such as hydrochloric acid, also a corrosive. Packing Group III addresses materials presenting only minor danger.

The U.N. Dangerous Goods standards also have general requirements for materials, construction, and maximum size, and specify tests that must be met by packages for each packing class. For example, if it is to carr yiquids, the U.N.1Al steel drum, one of two types of steel drums in the recommendations, must have welded seams and welded or mechanically seamed chimes (the edges of the drum where the side-wall meets the top and bottom); its opening may not exceed $7 \mathrm{~cm}$ in diameter, and the drum may not exceed 450 liters capacity.

Even these requirements may be waived as advances in science and technology occur, as long as the packages are able to withstand performance tests. The strength and integrity of the drums are established by a series of performance tests the drum must pass before it is authorized to carry hazardous materials in each packing group. The principal tests are a drop test, a stacking test, a leak test for containers for liquids, and a hydraulic pressure test. The drop test consists of filling the drum as if for shipment and allowing it to fall to a level, unyielding

\footnotetext{
${ }^{13}$ Fred E. Ostrem and Basil Libovicz, General American Transportation Corp., General American Research Division, A Survey of Environmental Conditions Incident to the Transportation of Materials Phase II (Washington, DC: U.S. Department of Transportation, April 1978).

${ }^{114}$ See ch. 4 for a discussion of the U.S. involvement in the development of these recommendations.
}

surface without spilling its contents. The height specified for the drop test is determined by the packing group of the hazardous materials to be transported. The steel drum would have to survive a drop from a height of 1.8 meters ( 6 feet) if it were to carr a material in Packing Group I, 1.2 meters for Group 11, and 0.8 meters for Group 111. ${ }^{115}$ Thus the most dangerous materials, Packing Group I, must be packaged in the most robust containers.

Adoption of the U.N. recommendations would include not only the U.N. system of packaging, but also the U.N. materials classification, labeling, and shipping descriptions. Unlike the DOT classification system, the U.N. classification system classifies commodities within a given hazard class $b_{y}$ degree of hazard, and the placards displaying the hazard class show degree of hazard as well. This aspect is important to emergency response personnel, as these distinctions give an immediate indication of the level of danger during response to an incident.

Some U.S. industry representatives hold that the U.N. standards by themselves will not result in packaging adequate to withstand the rigors of international commerce. They feel that the correlation between the performance tests and the stresses of the transportation environment is not well established and that some minimum design specifications should be retained. For example, a drum manufacturer contends that steel drums intended to contain liquids belonging to Packing Groups I or II should be of $1 \mathrm{~mm}$ minimum thickness, equivalent to a thickness of 19 to 20 gauge, to ensure against external puncture. ${ }^{116}$

Moreover, some of the U.N. tests are not as stringent as current DOT specifications. For example, leak test pressures that are part of DOT's current specifications for steel drums are in ever case greater than those that would be required under the U.N. system; DOT's requirements range from 7 to 15 pounds per square inch (psi) while the U.N. 'S range from 2.8 to 4.3 psi. Some U.S. additions to the tests to address inadequacies in the international standard may be proposed. For example, DOT is expected to require a vibration test as part of the perform-

\footnotetext{
${ }^{115}$ Much of this discussion is taken from the Supplementary Information section of HM-181, Federal Register, "Performance-Oriented Packaging Standards," op. cit.

${ }^{116}$ William H. Gushard, Grief Brothers Corp., Springfield, NJ, written communication, February 1986.
} 
ance standards test program in an effort to model more closely the transportation environment. However, additional testing requirements for packaging used in the United States could become barriers to international trade, a result that the U.N. standards are designed to avoid.

Because of the uncertainty about the appropriateness of the performance tests in mimicking the transportation environment, it is important to collect data on releases from small packages to permit evaluation of the adequacy of the tests. ${ }^{117}$

Adoption of performance standards would constitute a major change in the way regulations address design of small packaging for hazardous materials transportation. However, DOT and some package manufacturers already have experience with performance standards. For example, the approval process for pressurized cylinders, many steel drums, and many combination packaging of glass bottles inside fiberboard boxes includes performance tests. Comments received by DOT on the proposed performance-oriented packaging standards have generally been favorable, citing the removal of unnecessary impediments to the flow of international commerce, and making the DOT exemption process either unnecessary or at least less cumbersome.

The fate of current U.S. container specifications, once U.N. performance standards are accepted here, is still a subject of debate. Smaller container manufacturers and shippers will probably limit themselves to proven packaging described in the current 49 CFR. DOT has stated that many, if not most, existing DOT packages would successfully pass the performance tests and could continue to be used with U.N. markings.

${ }^{117}$ U.S. Department of Transportation (DOT) has published an "Advanced Notice of Proposed Rulemaking" ("Detailed Hazardous Materials Incident Reports," Docket No. HM-36B, Federal Register, 10042, Mar. 16, 1984), which would reduce the reporting requirements for incidents involving small packages. If a small package releases hazardous materials, the incident would not need to be reported unless: the material was a hazardous waste, someone was injured or killed, people were evacuated, the package involved was shipped under the Research and Special Programs Administration's exemption program, or property damage including cleanup and decontamination costs exceeded $\$ 1,000$. While such a rulemaking would relieve carriers of reporting releases with small consequences, it would also deprive DOT of information regarding the safety of particular container types. The cost of a particular release is related more to the contents of the container than its safety. Upon adoption of performance-based standards, it may be prudent to retain the current comprehensive reporting requirements so that the performance tests can be evaluated.
Moreover, there is little indication that removal of regulatory constraints would bring about significant changes in packaging because the factors leading to a design - such as new products or materialswere never regulatory. Developing a system of performance standards does open the way for greater design flexibility and should smooth the authorization process. Performance standards themselves are unlikely to stimulate greater innovation, although they have the potential for allowing innovations to be implemented more quickly than they are today. Finally, DOT will still be required to consider major innovations and new technologies not addressed in performance standards.

\section{Assessing Small Package Performance}

Currently, neither industry (with a few exceptions) nor government appears to monitor systematically the success rate of small packages. An OTA sampling of manufacturers and shippers indicated that customer complaints and package failure reports are the primary means of assessing package performance in the field.

A packaging problem area that may require attention is the compatibility of wastes and their containers. Carriers have unwittingly accepted loads of wastes from shippers unaware of the wastes' composition or properties, and have had corrosion problems in their containers as a result. ${ }^{118}$ With many small-quantity generators of hazardous wastes soon becoming subject to Federal regulation under the Resource Conservation and Recovery Act, the potential for mispackaging becomes enormous. These generators will need both information and assistance from EPA and DOT in complying with the new law. (See appendix A.)

Metal drums and glass bottles are the containers that appear most frequently in the incident reports (they were involved in about 2,000 incidents per year from 1976 to 1984 according to RSPA records), but this figure is only a small percentage of the drums and bottles carrying hazardous materials in commerce. However, release rates on either a per-tonmile or a per-package-shipped basis are nearly im-

\footnotetext{
${ }^{118}$ Robert S. Shertz, Chemical Leaman Tank Lines, personal communication, October 1985; and Richard O'Boyle, Quality Carriers Inc., in U.S. Congress, Office of Technology Assessment, "Transcript of Proceedings-OTA Workshop Proceedings on State and Local Activities," op. cit.
} 
possible to calculate because the commodity flow and release data are poor, especially for the air mode. Without this type of data, RSPA cannot adequately evaluate container design from its release reports. Release rates would yield information on the adequacy of packaging and indicate needs for revised packaging requirements.

\section{Third-Party Testing and Certification for All Packaging}

Under U.N. performance standards, the design of a container must be tested and officially certified. Under the U.S. packaging rules in 49 CFR, the marking of the specification number on a container constitutes a certification of compliance with that specification, including any prescribed tests. Testing, marking, and certification are usually done by the maker of the packaging in this country-essentially, self-certification. In Europe, governmentowned or specially designated testing laboratories do most of this testing and certification. European road and rail regulatory conventions require U.N. standards in Europe, and U.S. packaging shipped to Europe must comply with those standards, including U.N. marking and certification. Under DOT's proposed performance standard system, container manufacturers would still be able to self-certify their packages. Whether European countries will accept this certification is uncertain, but third-party testing facilities are now available in the United States to certify packages for international trade, should that prove necessary.

In DOT Docket No. HM-194, effective July 1, 1985 , DOT established a method for granting government approval to third-party testing facilities. HM-194 spells out various approval requirements for a laboratory, but allows the test facility to determine the precise equipment it needs. As of February 1986, eight such laboratories had been approved by DOT.

Third-party inspection and testing is already required by U.S. regulations for some containers, notably high-pressure compressed gas cylinders and most intermodal portable tanks. For pressure vessels in all modes except rail, construction usually must be completed in accordance with design codes of the American Society of Mechanical Engineers and must be inspected by an authorized third-party inspector. In practice this means that only MC-331 and MC-338 cargo tanks undergo third-party inspection, and there is no third-party role in the construction of most nonpressure tank trucks, the vast majority of cargo tankers. AAR's Mechanical Division is involved in approving tank car construction. Although self-certification is broadly advocated for smaller packaging, third-part testing and certification for larger units is still an open question.

\section{Training in Operations and Procedures}

OTA analysis shows that more than 60 percent of hazardous materials releases involving small packages can be attributed to human errors such as improper packing, bracing, loading, or unloading. Vehicle accidents cause another 5 percent of all hazardous materials releases, and human error causes 60 to 70 percent of these accidents. ${ }^{119}$ These failings have compromised even well-designed packages, and the greatest opportunity to reduce the frequency of spills may come from programs to address factors other than the containers themselves.

DOT's release reporting system, the Hazardous Materials Information System, cites "struck by other freight, " "cargo shifted," "improper loading," and "external puncture" as the reasons for more than 50 percent of small packaging spills. These causes usually occur because shipper or carrier personnel did not properl load, block, and brace packages inside of the vans, railroad cars, and airplane holds in which the small packages travel.

For most transport, the regulations state simply that packages must be secured against movement during normal transportation, although somewhat more specific requirements apply to individual modes or for particular hazard classes. Packages containing explosives have special loading provisions in all the modes, for example. Corrosives must not be loaded above other materials, and compressed gases must be secured in an upright position, or packaged to prevent movement, or placed horizontally on the floor of the vehicle. Other provisions prohibit certain hazard classes from being carried together in the same vehicle or vessel stowage compartment, but generally the regulations do not spe-

\footnotetext{
${ }^{119}$ Washington Utilities and Transportation Commission, op. cit., p. 8 .
} 
cify what constitutes appropriate blocking and bracing techniques. Methods of blocking and bracing for the rail mode, recommended by AAR, are referenced in 49 CFR. ${ }^{120}$ The high rate of releases associated with loading and unloading activities implies that more explicit procedures might improve safety.

Analysis of hazardous materials violations also supports a need for shippers to improve operations and procedures. A 1983 informal survey of States participating in a DOT enforcement training program identified the following as the most common hazardous materials violations found during roadside inspections of motor carriers:

- failure to display the correct placard,*

- failure to block or brace hazardous materials containers,

- leaking discharge valves on cargo tanks,

- improperly described hazardous wastes,

- inaccurate or missing shipping papers, and

- excessive radiation levels in the cab of the truck. ${ }^{121}$

In addition, a 1979 report issued by the National Transportation Safety Board cited a number of reasons for noncompliance with the hazardous materials regulations, including:

- the regulations are complex and difficult to understand,

- economic pressures,

- industrypersonneloften are unaware of the regulations, and

- lack of available training for inexperienced personnel.

Data on both accidental releases and violations of regulations raise questions about the adequacy of

12. The general requirements for loading and unloading, and blocking and bracing are presented in: 49 CFR 174.55 for the rail mode; 49 CFR 175.81 for the air mode; 49 CFR 176.57 and 49 CFR 176.69 for the marine mode; and 49 CFR 177.834 and 49 CFR 177.848 for the highway mode.

*Accurate placards and shipping papers are particularly important for the safety of first responders to hazardous materials emergencies, as they provide essential, basic information on the nature of the materials the responders face

${ }^{121}$ USDepartment of 'transportation, Research and Special 4 ro. grams Administration, "Quarterly State Hazardous Materials Enforcement Development (SHMED) Program Progress Reports: 1984 -1985," unpublished reports.

${ }^{2}$ National Transportation Safety Board, Noncompliance With Hazardous Materials Regulations, NTIS \# PB-299 432 (Washington, DC: Aug. 3, 1979), . 17. private sector training. RSPA's hazardous materials regulations contain only a general statement about training:

It is the duty of each person who offers hazardous materials for transportation to instruct each of his officers, agents, and employees having an responsibilit for preparing hazardous materials for shipment as to the applicable regulations in this subchapter, ${ }^{123}$

However, the complex regulations cover driver qualifications, hazardous materials classification, shipping papers, marking, labeling, and placarding, as well as general operational procedures for loading and unloading, and blocking and bracing of hazardous materials packages.

Good driver performance is especiall important for bulk highway transport, where 20 percent of releases are caused by vehicle accidents, most due to driver error. However, RSPA has not specified how drivers are to be instructed in the regulations and has expanded on the general training requirement for the highway transport of only two commodity types: flammable cryogenics and highly radioactive materials. RSPA based the driver training requirement for carriage of flammable cryogenics on the need to increase the driver's knowledge of the hazards of cryogenic liquids, the applicable regulations, and the handling and operating characteristics of the particular vehicle used to transport the material. A certificate indicating completion of training must be on file with the driver's employer. ${ }^{124}$

In addition, drivers hauling highly radioactive materials must receive written training on:

regulationspertaining to the radioactive materials being transported;

- the properties and hazards of the radioactive materials transported; and

$\mathrm{o}$ procedures to be followed in case of an accident or other emergency. ${ }^{125}$

The driver must have in his possession a certificate of training stating that he has received training, the dates of training, and the name ind address of the person providing the training. ${ }^{126}$ In the final rule-

\footnotetext{
'*349 CFR 173.1(b).

${ }^{124}$ Federal Register, vol. 48, No. 117, June 16, 1983, p. 27684.

${ }^{125}$ Federal Register, ${ }^{1} \mathrm{i} 46$, No. 12, Jan. 19, 1981, p. 5317.

${ }^{126}$ lbid., pp. 5298-5318.
} 
making notification, RSPA noted the possibility of extending driver training requirements to cover other commodities and of specifying a more structured training program in the future if a need exists.

Recently BMCS proposed new requirements, similar to those for drivers of flammable cryogenics and large quantity radioactive materials, for drivers of trucks carrying other hazardous materials. ${ }^{127} \mathrm{How}-$ ever, little guidance is given on how to conduct the training or how long each element of the training might take. Furthermore, no provisions are included for nondrivers who ma handle hazardous materials during loading and unloading operations.

Of the DOT modal administrations, only the Federal Aviation Administration has established an explicit training requirement for employees of commercial air carriers. All crewmembers and ground personnel with responsibilities in the acceptance, handling, and carriage of hazardous materials must complete training in an appropriate program established by the carrier. ${ }^{128}$ Some air carriers, such as Federal Express and Flying Tigers, also provide training for shippers of hazardous materials. *

The water mode also has training requirements, although they are not specific. Carriers in the water mode must be licensed by the Coast Guard, which tests ship and barge operators to ensure that they are properly trainee/. In addition, the loading and unloading of tank ships and barges must be done by licensed tankermen who have passed an examination sponsored by the Coast Guard.

Recognizing the factors leading to noncompliance and unsafe procedures, several States have instituted additional training requirements. For example, effective in 1984, Michigan began requiring that intrastate drivers of bulk hazardous materials have 80

\footnotetext{
Federal Register, "Qualification of Drivers, Notice of Proposed Rulemaking," vol. 51, No. 92, May 13, 1986, pp. 1752-17581.

${ }^{124} 14$ CFR 135.333. The Federal Aviation Administration (FAA) regulations require trainin ${ }_{\mathrm{g}}$ on: proper shipper certification, packagıng, marking, labeling, and documentation for hazardous materials; and the compatibility, loading, storage, and handling characteristics of hazardous materials. Commercial air carriers must also maintain records on initial and recurrent training given to crewmembers and ground personnel. FAA has issued an Advisory Circular that provides general guidance to air carriers for training manuals and programs. See U.S. Department of Transportation, Federal Aviation Administration, AC 121.21B, Jan. 3, 1984.

*For example, U.S. Environmental Protection Agenc employees from Region IV have attended Federal Express courses to learn how to send environmental samples to laboratories by air.
}

hours of training, of which 60 had to be in operation of the vehicle they were to handle. However, in 1985, 21 of 22 Michigan firms failed management audits, because they lacked any record of training, pointing to the necessity for enforcement if training requirements are to be effective. ${ }^{129}$ Michigan did not extend training requirements to interstate transporters of bulk hazardous materials because of concerns over preemption of their law $b_{y}$ Federal regulations. Several other States have also instituted training requirements.*

Many European countries have also recently implemented definitive training requirements for drivers of transport units carrying tanks or tank containers of hazardous materials. In many cases training courses must be approved by the government or an agency designated by the government. The training must cover:

- general requirements governing the transport of dangerous goods;

- the main types of hazards;

- appropriate prevention and safety measures for the various types of hazards;

- what to do after an accident (first aid, road safety, basic knowledge about the use of protective equipment, etc.);

- labeling and marking to indicate danger;

- what a vehicle driver should and should not do during the carriage of dangerous goods; and

- the purpose and methods of operation of technical equipment on vehicles and the behavior of vehicles carrying tanks or tank containers on the road including the movements (sloshing) of the load. ' 30

It is too early to quantify the effect of the training on road safety, but both drivers and safety officials feel it is positive."

\footnotetext{
${ }^{12}$ Sergeant Gary Koss, Michigan Motor Carrier Enforcement Division, Michigan State Police, personal communication, May 1986,

*Massachusetts, Marvland, New Hampshire, Rhode Island, Pennsylvania, California, Georgia, and New Jersey, for example, have train$\mathrm{in}_{\mathrm{g}}$ requirements for drivers of vehicles hauling either hazardous materials or, more commonly, hazardous wastes.

${ }^{130}$ United Nations, Economic Commission for Europe, Inland Transport Committee, European Agreement Concerning the International Carriage of Dangerous Goodsbv Road (ADR) and Protocol of Signature, Volume III (Annex B) (New York: 1985), p. 15.

${ }^{13 !}$ United Nations, Economic Commission for Europe, Inland Transport Committee, Driver Training Requirements, GE. 85-21354 (New York: United Nations, Apr. 4, 1985), pp. 2-4.
} 
In the United States, shippers and carriers of hazrdous materials. Recently an interactive videodisk ardous materials and some private firms have deraining program covering all aspects of railroad veloped training programs or courses designed toperation, including hazardous materials regulations instruct industry personnel on Federal and State regnd handling procedures, was developed by the Port ulations. The recent collective bargaining agreemeferminal Rail Authority in Houston, Texas, as a of the Teamsters Union calls for at least 3 houdsemonstration supported by FRA. ${ }^{134}$ Arranged in of mandatory training of certain workers, includbodules so the trainee can learn at his or her own ing drivers, dock workers, clerical workers, and shpace, the training program can be customized for employees, on specified sections of hazardous malfferent railroads, and one of the demonstration terials regulations.However, the duration and conditions was that the program be made available intensity of the training is left to the discretion of other railroads. Marine shippers generally prothe shipper or carrier.

The American Trucking Association (ATA) vides compliance training through its State organizations and through sale of items such as the publication, Handling Hazardous Materials, which describes the hazardous materials regulations in layman's terms, and a five-part slide program that consists of 20-minute modules on specific hazardous materials requirements, such as shipping papers or marking and labeling. The National Tank Truck Carriers, Inc. (NTTC), has produced and sells a slide program and accompanying manual for tank truck drivers on flammable liquids, the most commonly transported hazard class carried by its members. NTTC has nearly completed development of a similar training program on corrosives. Both of these programs were put together by the safety officers of major carriers affiliated with NTTC. Some trucking companies also provide hazardous materials training for their personnel, although small transport companies are generally not able to provide the same level of training as larger firms.

AAR offers training courses for railroad employees, and large railroads instruct transport and yard personnel in hazardous materials regulations and emergency response procedures. * Shippers of tank car quantities of hazardous materials are often large companies that own or lease their tank cars. Such companies frequently have training programs for employees involved with loading and unloading haz-

\footnotetext{
${ }^{132}$ National Master Freight Safety\& Health Committees, 1985-1988 National Master Freight Agreement, Hazardous Materials Employee Protection/Training Program (Washington, DC: International Brotherhood of Teamsters, Dec. 19, 1985), pamphlet.

${ }^{133}$ U S Congress, Office of Technology Assessment, "Proceedings of Hazardous Materials Packaging Technology Workshop," unpublished typescript, Jan. 24, 1985.

${ }^{*}$ For example, Union Pacific Systems, Conrail, and Boston \& Maine Co. provide hazardous materials compliance training.
} vide special training to those who load and unload barges and self-propelled tankers.

In addition to the modal trade and professional associations, other private organizations and individual companies offer hazardous materials compliance training. The Chemical Manufacturers Association sponsors training seminars nationwide and on request to industr ${ }_{y}$ employees. The Chlorine Institute provides training publications and films on chemical and physical properties of chlorine, appropriate regulations, and handling procedures for normal and emergency operations. Training courses are also available through private consulting firms. However, the courses vary in content and emphasis.

\section{Conclusions and Policy Options}

Federal regulations specify the design, physical characteristics, and method of construction for all packages subject to the hazardous materials regulations, and generally, with a few exceptions, the packages perform adequately. However, the correct use of the packaging and the quality of procedures and operations affecting them are equally important to safe transportation. Conclusions and policy options for this section of chapter 3 address regulatory, technical, and procedural issues.

Federal hazardous materials regulations apply to all commerce in all modes with the exception of intrastate commerce by motor carrier.* Release of hazardous materials from trucks owned by a compan that operates solel intrastate need not be reported to DOT, and equipment not meeting Federal re-

\footnotetext{
"+Larry Helms, Port Terminal Rail Authority, Houston, TX, personal communication, 1986.

*49 CFR 171.1. Certain materials are covered by Federal regulations even during intrastate commerce. These are hazardous wastes, hazardous substances, and flammable cryogenics,
} 
quirements maybe used in some States. Although States are now required to extend enforcement of hazardous materials regulations to intrastate commerce to qualify for Motor Carrier Safety Assistance Program funds, it is not clear how the reporting requirement and container regulations will be handled. OTA concludes that explicitly extending the reporting requirement and container regulations in 49 CFR to cover intrastate highway commerce would provide important information about container performance, improve safety, and make enforcement and enforcement training more consistent and efficient. This policy option is also discussed in chapters 2 and 4.

The highway mode has more shipments and more releases of hazardous materials than the other modes, and more than 20 percent of bulk highway releases are caused by vehicle accidents, most of these due to driver error. The qualifications required for a truck driver's license vary from State to State, although the concept of a national truck driver's license has been endorsed by ATA, insurance industry representatives, and State motor vehicle administrators and enforcement personnel. OTA coneludes that establishing national requirements for a truck driver's license, with a special certification class for hazardous materials that requires over-the-road training in the type of vehicle specified on the license and a good driving record, could greatly improve the safety of the highway mode. National license requirements and driver training standards could be developed by DOT in cooperation with the States, labor, and industry. However, responsibilit for issuing licenses and certifying that the training requirements are met might remain with the States, which could set appropriate fees to cover program costs. The licenses should differentiate between types of vehicles, as varying configurations have different handling characteristics. Special training is important for drivers of tractor-trailers carrying intermodal tanks. If a national drivers license is instituted, special training could be required of carriers of intermodal tanks. Their high center of gravity, concentration of weight in the middle of the chassis, and slosh effects give them unique handling characteristics that demand special training. Ensuring that experienced, safe drivers operate vehicles carrying hazardous materials could reduce the risk to the public significantly.
Analysis of the data on accidental releases of hazardous materials and violations of hazardous materials regulations indicates a need for increased industry training on operating procedures, such as loading, unloading, blocking and bracing, and applicable regulations, particularly for the highway mode. OTA finds that expanded and more specific guidance for shippers and carriers on the content and extent of training courses for carrier personnel is an important priority. Congress might wish to require DOT to establish guidelines for training course content and duration through a consensus process including Federal, shipper, carrier, and freight forwarder expertise to utilize existing resources. Federal encouragement for expanded motor carrier industry compliance education could be accomplished through the Motor Carrier Safety Assistance Program.

Problems with all varieties of cargo tanks have been studied by DOT over the past 10 years. DOT found that many of the releases from cargo tanks come from discharge valves, pressure relief valves, and manhole covers, and that poor maintenance and inspection of the tanks contributed to the spill problem. Many parts of a rulemaking proposed $b_{y}$ DOT in September 1985 address these shortcomings. OTA finds that adoption of the proposed changes calling for higher and more specific manufacturing standards, annual leak testing of all cargo tanks, and stronger manhole covers on gasoline tankers, would improve the safety performance of cargo tanks. These requirements, would directly address many of the inadequacies uncovered in the DOT studies.

Furthermore, because gasoline cargo tankers are involved in a high percentage of highway deaths and damages due to hazardous materials, Congress may wish to have DOT carefully evaluate more stable designs for this vehicle, the MC-306. The evaluation should take into account both safet ${ }_{\mathrm{y}}$ and economic considerations. RSPA and the Federal Highway Administration would need to work together effectively to bring about improvements in cargo tank design.

Intermodal portable tank containers are being used in steadily increasing numbers in domestic and international commerce. They present special problems during truck transport, chief among them, the 
method of securement onto their chassis. Currently, the regulations permit intermodal tanks to travel on flatbed trucks secured by chains, an inexact and frequently unsafe method. OTA finds that immediate and intensive study of the motor vehicle chassis and securement methods for intermodal portable tanks is urgently needed. Some chassis built specially for intermodal tanks have twist locks that positively secure the tank against vertical or lateral motion (such chassis are required in Europe). In addition, although currently there are few of them in the United States, the "low boy" chassis with a flatbed several feet lower than normal is ideal, for carrying the tanks, as it keeps the center of gravity low and the vehicle more stable.

Data shows that many releases of hazardous materials arise from failures in the fittings used in sealing the package. In the rail mode, defective or loose fittings were cited as the package failure in more than 60 percent of all spills. Congress could require DOT to continue research into the design of effective closures and fittings on packages.

Because many packages containing hazardous materials are mailed by people with no understanding of the hazardous nature of the materials they are shipping, public education has an important impact on safety. The problem is especially severe in the air transport of small packages, where both mailers and passengers unknowingly violate regulations. An ongoing and widespread public information program on safety and packaging requirements for hazard- ous materials, directed at both the handlers of small packages and the general public, could reduce the misuse of packaging and improve safety, especially in the air mode. In addition, generators of small amounts of hazardous wastes, who will soon be brought under Federal regulation, will need assistance from DOT and EPA in complying with packaging requirements.

Performance standards for small packages are likely to be adopted within the next few years, and the prospective changeover has been widely supported by most of the affected parties. OTA finds that the new system will simplify the regulations making compliance with them easier; bring U.S. regulations into greater conformity with those of our international trading partners, and make packaging innovations easier and faster to evaluate and implement. Adoption of performance standards should reduce the time required of the relatively small RSPA staff to handle exemption applications and free them for other functions such as data and trend analysis, and planning. If the revised regulations allow packages that meet current specifications to be manufactured after performance testing is adopted, small manufacturers and shippers that do not have full design and testing divisions will not be unduly harmed by the new requirements. To ensure that performance tests adequately represent the stresses of the transportation environment, collection of release data for small packages needs to be continued to identify and remedy packaging deficiencies. 


\section{Chapter 4 Hazardous Materials Transportation Regulations}

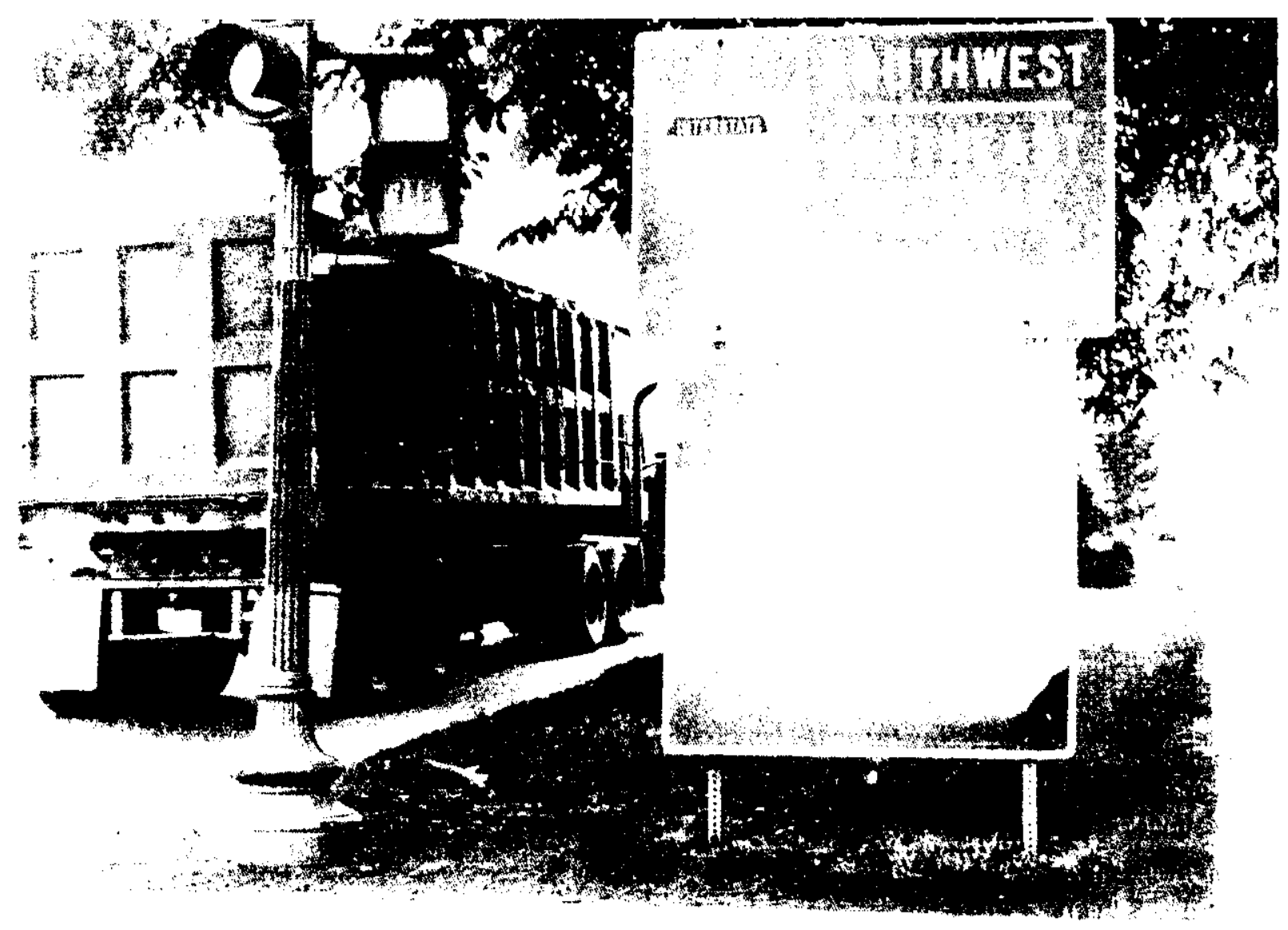




\section{Contents}

The Federal Role. . . . . . . . . . . . . . . . . P..............145

Early History . . . . . . . . . . . . . . . . . . . . . ............................145

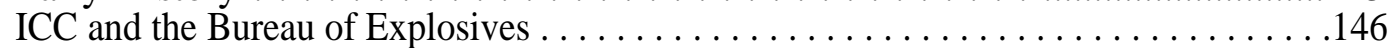

Formation of the Department of Transportation . .........................147

The Hazardous Materials Transportation Act of 1975. . .....................147

The Current Regulatory Environment . . . . . . . . . . . . . . . . . . . . . . . . . 149

Related Federal Agencies and Programs . . . . . . . . . . . . . . . . . . . . . . . . . 169

State and Local Regulation . . . . . . . . . . . . . . . . . . . . ................172

Evolution of State Programs . . . . . . . . . . . . . . . . . . . . . . . . . . . . . . . ....I772

Current State and Local Activities . . . . . . . . . . . . . . . . ..................176

Regulatory Consistency . . . . . . . . . . . . . . . . . . . . . . . .....190

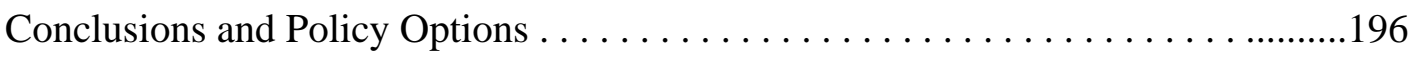

\section{List of Tables}

Table No.

4-1. Federal and International Regulatory Framework for

Transportation of Hazardous Materials . . . . . . . . . . ........................149

4-2. Summary of U.S. Department of Transportation Hazardous Materials

Regulations in Title 49 of the Code of Federal Regulations . ..................151

4-3. Sample Page From the Hazardous Materials Table . . . . . . . . . . . . ..............153

4-4 Department of Transportation Hazard Classes . ...........................154

4-5, Department of Transporation Placarding Table 1 ........................162

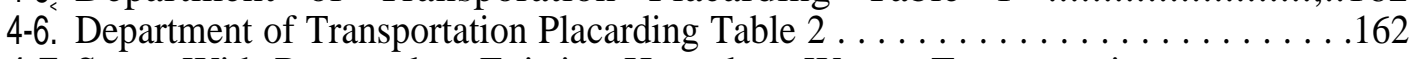

4-7 States With Proposed or Existing Hazardous Wastes Transportation

Fee or Registration Requirements, 1986 . . . . . . . . . . . . . . ............178

4-8. Commodities Covered by Notification Requirements, 1985 .. ................182

4-9* State Right-to-Know Laws, 1985. . . . . . . . . . . . . . . . . . ....................187

\section{List of Figures}

Figure No. $\quad$ Page

4-1. U.S. Department of Transportation . . . . . . . . . . . . . . . . . . . . ....150

4-2. Sample Shipping Document . . . . . . . . . . . . . . . . . . . . . . . . . . . ... .157

4-3. Examples of Labels for Hazardous Materials Packages . . . . . . . . . .............159

4-4. Examples of Hazardous Materials Placards.. . ............................161

4-5. Department of Transportation Segregation and Separation Chart

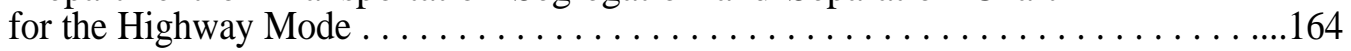

4-6. States Participating in the State Hazardous Materials

Enforcement Development Program . . . . . . . . . . ...................,......174

4-7. States Participating in the Motor Carrier Safety Assistance Program . ..........175

4-8. Procedures for Inconsistency Rulings . . . . . . . . . . . ..............................191

4-9. Procedures for Nonpreemption Determinations . . . . . . . . . . . . . . ...........193 


\section{Hazardous Materials Transportation Regulations}

The current Federal regulatory system governing the transportation of hazardous materials developed over the past century with substantial industry involvement. Existing U.S. Department of Transportation (DOT) regulations are extensive and consist of detailed engineering specifications for containers, hazard communication requirements such as vehicle placarding, and handling and operating requirements for each mode of transport. Shippers and carriers of hazardous materials must also comply with general safety requirements for vehicles and vessels and with regulations pertaining to specific types of hazardous materials, worker safety, and environmental protection issued by other Federal agencies.

However, regulations contained in Title 49 of the Code of Federal Regulations (49 CFR), are not applied to most intrastate highway shipments. Moreover, international codes, less complex than their U.S. counterparts, are now widely used in the air and water modes. Finally, while many States have adopted 49 CFR wholly or in part, there is great variation among State regulations. Many State and local jurisdictions have enacted laws and regulations where there is an absence of Federal action or where
Federal requirements are believed to be insufficient; examples include requirements for permits and registration, licensing of hazardous materials drivers, and notification requirements. Such requirements cause considerable controversy, as industry compliance may require substantial expenditures of time and money. Differing State and local requirements also impede the development of nationally standardized enforcement training. Although the Hazardous Materials Transportation Act (HMTA) contains a provision preempting State and local requirements that are inconsistent with their Federal counterparts, there have been no comprehensive efforts to assess the validity of existing non-Federal laws and regulations.

This chapter is divided into two major sections: the first part describes the development of the Federal role and examines the current regulatory framework; the second covers State and local requirements and questions related to regulatory consistency. For additional information on State and local activities, the reader is referred to OTA's Special Report, Transportation of Hazardous Materials: State and Local Activities, March 1986.

\section{THE FEDERAL ROLE}

\section{Early History}

In 1866, the first Federal law was passed regulating the transportation of hazardous materials, specifically shipments of explosives and flammable materials such as nitroglycerin and glynoin oil. 'An 1871 statute established criminal sanctions against persons who transported specific hazardous commodities on passenger vessels in U.S. navigable waters in violation of Treasury Department regulations. $^{2}$

\footnotetext{
${ }^{1}$ Stat. 81, July $3,{ }^{1866, "}$

${ }^{2}$ Stat. 441, Feb. 28, 1871. See Historical Note in 46 U.S.C. 170.
}

Rail shipments of explosives during and after the Civil War were addressed by unmodified statutes and contractual obligations between shippers and carriers based on English common-law principles. Under the common law, common carriers were granted a public charter to operate and were obliged to provide service to anyone upon reasonable request, for reasonable cost, and without unjust discrimination. Carriers could, however, prescribe conditions under which certain freight would be accepted. A shipper was obliged to identify the hazards of a dangerous commodity, use adequate packaging, and provide a clear warning to the carrier of the shipment's hazards. 
The establishment of the Interstate Commerce Commission (ICC) in 1887 marked the beginning of a Federal effort to impose a degree of regulatory uniformity on all modes of transportation. ${ }^{3}$ While ICC requirements were first developed for rail transportation, they were eventually extended to other modes. As described below, ICC was the primary regulatory agenc with authorit $_{\mathrm{y}}$ over hazardous materials transportation through 1966.

\section{ICC and the Bureau of Explosives}

In 1908, Congress passed a law that would govern hazardous materials transportation for more than six decades. The Explosives and Combustibles Act (later called the Explosives and Other Dangerous Articles Act, or EODA) authorized ICC to issue regulations covering the packing, marking, loading, and handling of explosives and other dangerous substances in transit. ${ }^{4}$ The statute also prescribed criminal penalties for shippers or carriers who violated ICC regulations. EODA codified many of the contractual obligations that had developed commercially between shippers and rail carriers.

Regulations adopted by ICC in 1911 to implement EODA were based on rail safety standards developed by the Bureau of Explosives, a division of the Association of American Railroads (AAR). Founded in 1905, the Bureau of Explosives developed standards for handling explosives and other dangerous materials $b$ the railroads and assisted with the management of private contracts between shippers and rail carriers to promote development of uniform requirements. EODA amendments enacted by Congress in 1921 authorized ICC to utilize the services of groups such as the Bureau of Explosives in its haz-

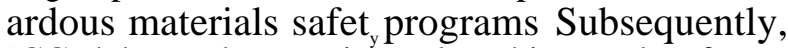
ICC delegated extensive rulemaking and enforcement responsibilities to the Bureau.

Under EODA, all hazardous materials transportation activity was barred unless specifically authorized $b_{y}$ ICC. As a consequence, ICC regulations were developed on a case-by-case basis in response

'The Interstate Commerce Commission was created by the Interstate Commerce Act, 24 Stat. 529, Feb. 4, 1887.

${ }^{4} 18$ u.s.c. $831-835$ (831 has been substantiall rewritten, and 832 835 have been repealed).

${ }^{5} 41$ Stat. 144, Mar. 4, 1921. See 18 U.S.C. 834, Historical and Revision Notes. to specific industry initiatives. Each time a new commodity or container was produced, a special permit had to be approved by ICC. This process is still used, and new permits are now known as exemptions. (For more information, see chapter 3.) Periodically, if ICC had granted a series of requests pertaining to a particular section of the regulations, that section would be revised and streamlined, usually for specific commodities. This pattern has continued, so that today's packaging authorizations are ad hoc and individual in character.

Over the next 40 years, the roles of ICC and the Bureau of Explosives continued to grow as rules originally designed for the railroads were applied to other modes of transport. ${ }^{6}$ The U.S. Coast Guard was required to adopt ICC regulations for classification of hazardous materials and for marking, labeling, packing, and certification of portable containers. Regulatory authority over highway transportation was given to ICC in the 1930s. The Civil Aeronautics Board (CAB), in conjunction with safety officials in the U.S. Department of Commerce, developed the first regulations for transportation of hazardous materials by air in the early 1940s. This was also done through wholesale adoption of ICC rules.

ICC relied heavil on the technological expertise of nongovernmental groups for the development of

\footnotetext{
${ }^{6}$ In addition $t$ the extension of Interstate Commerce Commission (ICC) rules to other modes of transport, other amendments to the Explosives and Other Dangerous Articles Act passed after 1921 increased the list of hazardous materials addressed by ICC and regulated shippers and common carriers (for rail and highway). See Historical and Revision Notes in 18 U.S.C. Chapter 39.

46 U.S.C. 170(7)(a). Additional laws were passed that applied to vessels carrying dangerous cargoes, some of which covered international shipments. See, for example, The International Convention for Safety of Life at Sea, 50 Stat. 1121, 1929; Tank Vessel Act of 1936, Chapter 729, 49 Stat. 1889, June 23, 1936; and the Dangerous Cargo Act of 1940, 54 Stat. 1023, Oct. 9, 1940. The influence of international regulations is discussed more fully later in this chapter. The U.S. Coast Guard was established by an act of Congress on Jan. 28, 1915 (14 U.S.C. 1).

${ }^{8}$ The Civil Aeronautics Board (CAB) was created in 1938 by the Civil Aeronautics Act. The purpose of the law was to regulate air carriers and promote the development of safe air commerce. The Federal Aviation Act, Public Law 85-726, Aug. 23, 1958, contained provisions authorizing the assessment of penalties for violations of the hazardous materials regulations and allowing exemptions from existing rules and regulations. See 49 U.S. C. 1472(h) and 142 l(c). The Federal Aviation Administration was established by this statute and assumed the noneconomic regulatory functions of $\mathrm{CAB}$. $\mathrm{CAB}$ was continued as an economic regulatory agency.
} 
new regulations, because the size and professional knowledge of in-house staff was limited. ${ }^{9}$ In 1960 , Congress extended ICC'S ability to use the services of outside organizations by authorizing the use of carrier and shipper associations in addition to the Bureau of Explosives.]" As a result of this action, the Tank Car Committee of AAR was given the authority to approve applications submitted to ICC for designs, materials, construction, conversions, or alterations of tank cars.

\section{Formation of the Department of Transportation}

In 1966, authority to regulate the transportation of hazardous materials was transferred from ICC, the Department of the Treasury, and CAB to a new Federal agency, DOT. "Within DOT, separate modal administrations were retained to preserve organizational continuity. Moreover, modal administration functions specified by the act could not be delegated to other Department administrations by the Secretar of Transportation. ${ }^{12}$ Thus, although the Secretary had Cabinet-level responsibility for all transportation safety standards (including hazardous materials), each modal administration was allowed to promulgate independent regulations.

Under the new organization, the Federal Aviation Administration (FAA) was responsible for air transportation, the Federal Highway and Railroad Administrations for land, and the Coast Guard for water, Regulations for each mode of transport were published in different parts of the Code of Federal Regulations (CFR), The National Transportation Safety Board (NTSB) was also established to determine and report the cause of transportation accidents and conduct special studies related to safety

"See U.S. Congress, Senate Committee on Commerce, Science and Transportation, Hazardous Materials Transportation (Washington, DC: U.S. Government Printing Office, 1979), pp. 24-25.

18U.S.C. 834(e).

"The US. Department of Transportation was created by the Department of Transportation Act, Public Law 89-670, 49 U.S.C.1651. Economic regulatory functions stayed with the Interstate Commerce Commission, the Civil Aeronautics Board, and the Federal Maritime Commission.

"The Department of Transportation Act states that: "The functions, powers, and duties specified in this Act to be carried out by each administrator shall not be transferred elsewhere in the Department unless submitted pursuant to provisions of Chapter 9 of Title 5, U. S, C., or by Statute." See 49 U.S.C. 1652(e). and accident prevention. A separate entity, the Hazardous Materials Regulations Board, was created by the Secretary of Transportation to coordinate all hazardous materials activities within the Department. The Office of Hazardous Materials, which served as the staff for the Board, proposed revisions to the existing hazardous materials regulatory program. ${ }^{13}$ However, each proposed change had to be considered and approved first by the affected modal administrations. Some of the major revisions planned by the Board, such as the development of container performance standards, have still not been implemented by DOT, although a rulemaking for such standards is now in progress.

Legislation pertaining to hazardous materials transportation was passed in 1970 imposing modest requirements on DOT. ${ }^{14}$ However, DOT was unable to implement the statute as staff increases requested by the Department were not approved $b_{y}$ Congress. ${ }^{15}$ The provisions of this law were incorporated into the HMTA of 1975.

\section{The Hazardous Materials Transportation Act of 1975}

Persistent administrative and organizational difficulties in the early 1970s led DOT to seek legislation that would consolidate hazardous materials regulatory authority. However, little happened until the crash of a 707 cargo jet hauling several tons of hazardous materials in 1973. "The accident inquiry clearly showed a general lack of compliance

\footnotetext{
${ }^{13}$ Regulatory revisions proposed by the Hazardous Materials Regulations Board in 1968 addressed the following topics: modal requirements, international consistency, container performance standards, labels for packages, and vehicle placards. In addition, the Board recommended the establishment of a centralized system for data collection, an increase in shipper and manufacturer inspections, and the development of training programs for emergency response personnel. See U.S. Congress, op. cit., pp. 31-32.

${ }^{14}$ The Hazardous Materials Transportation Control Act of 1970, Title 111 of Public Law 91-458, 49 U.S. C. 1761. The Secretary of Transportation was required to establish facilities and technical staff for evaluating hazards associated with hazardous materials; establish a central reporting system for hazardous materials accidents; conduct a review of all aspects of hazardous materials transportation and recommend appropriate steps to be taken immediately to provide greater control over shipments; and prepare an annual report for Congress on regulatory, enforcement, and exemption activities as well as accident and casualty statistics.

${ }^{15}$ U.S. Congress, o p . cit., p. 33.

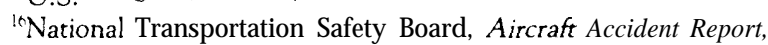
NTSB-AAR-74-16 (Washington, DC: 1974).
} 
with existing requirements due to fragmentation of the regulatory authorities, complexity of the regulations, lack of industry familiarity at the working level with Federal regulations, and inadequate government surveillance. ${ }^{17}$ These findings echoed the conclusions of studies conducted by the National Research Council, the Comptroller General to Congress, and DOT. ${ }^{18}$

The HMTA was finally passed in 1975." The intent of the law was to improve regulatory and enforcement activities by providing the Secretary of Transportation with broad authority to set regulations applicable to all modes of transport. Specifically, the HMTA:

- expanded DOT's potential jurisdiction to any traffic "affecting" interstate commerce (49 U.S.C. 1802);

- authorized the designation of hazardous materials, defined as materials or classes of materials in quantities and forms that the Secretar of Transportation determines may pose an unreasonable risk to health and safety or property (49 U.S.C. 1803);

- authorized DOT to issue regulations related to packing, repacking, handling, labeling, marking, placarding, and routing; and expanded the regulated community to include those who manufacture, test, maintain, and recondition containers or packages used to transport hazardous materials (49 U.S.C. 1804);

- authorized the establishment of a registration program for shippers, carriers, and container manufacturers and reconditioners (49 U.S.C. 1805);

- codified DOT procedures for granting regulatory exemptions (49 U.S.C. 1806);

- provided the Secretary with the ability to conduct surveillance activities (e.g., hold hearings and conduct investigations), establish record-

\footnotetext{
"Ibid., p. 37.

$18^{*}$ National Academy of Sciences, National Research Council, A Study of Transportation of Hazardous Materials (Washington, DC: National Academy Press, 1969); and U.S. Congress, Senate Committee on Commerce, Transportation Safety Act of 1974, Report No. 931192 accompanying S. 4057 (Washington, DC: U.S. Government Print-

ing Office, Sept. 30 1974)
Title I of Public Law 93-633, Jan. 3, 1975, 49 U.S.C.1801. Title

II addressed rail safety and Tide 111 made the National Transportation Safety Board an independent agency. The Explosives and Other Dangerous Articles Act was repealed by this statute.
}

keeping requirements, and conduct inspections. Provisions of the 1970 Act were also included in this section of the HMTA, such as submission of an annual report to Congress (49 U.S.C. 1808);

- authorized DOT to assess civil and criminal penalties for violations of the HMTA (49 U.S.C. 1809); and

- defined the relationshi between the Federal regulations and those of State and local governments, preempting non-Federal rules found to be inconsistent with the Federal program and establishing a procedure whereb $b_{\mathrm{y}}$ DOT could waive preemption (49 U.S.C. 181 1).

Shortly after the HMTA was enacted, the Secretary created the Materials Transportation Bureau (MTB) within the Research and Special Programs Administration (RSPA), which was designated the lead DOT agency for hazardous materials regulation.* MTB was delegated responsibilit for issuing all hazardous materials transportation regulations except those governing bulk transport by water; these remained with the Coast Guard. However, the modal administrations continued to be responsible for safety regulations, including the development of hazardous materials regulations, applicable to each mode. Inspection and enforcement authority was divided between MTB and the modal administrations.

In 1976, MTB consolidated and amended the hazardous materials regulations based on changes originally proposed in the late 1960 s, prior to passage of the HMTA. ${ }^{20}$ FAA and part of the Coast Guard regulations, contained in Titles 14 and 46 of CFR, were incorporated into 49 CFR which already contained the highway and rail regulations. Regulations for bulk transport by water remained in 46 CFR. In addition, MTB amended existing requirements for shipping papers, marking, labeling, and placarding, and added new hazard classes. The format of the regulations has essentiall remained the same since 1976. Subsequent regulatory amendments, though numerous, have been narrowly focused.

\footnotetext{
* The Hazardous Materials Board was terminated and the responsibilities of the Office of Hazardous Materials were transferred to the newly formed Materials Transportation Bureau.

* "See footnote 13. Proposed rules were published on Jan. 24, 1974 (Docket HM-103, 39 F.R. 3164 and Docket HM-112,39 F.R.3022). Final rules were published on Apr. 15, 1976, 41 F.R. 15972.
} 


\section{The Current Regulatory Framework}

\section{Overview}

While RSPA issues most of the hazardous materials regulations under the HMTA, DOT modal administrations, other Federal agencies, private domestic groups, and international organizations significantly influence the movement of hazardous materials in the United States. ${ }^{21}$ Table 4-1 indicates the modes of transport addressed by the major regulatory and standard-setting bodies concerned with the transportation of hazardous materials.

The regulatory responsibilities of RSPA and the four modal administrations within DOT are indicated in figure 4-1.22 Regulations issued by RSPA cover activities of both shippers and carriers of hazardous materials for all four modes of transport (except for bulk shipments by barge or ship, which are governed by Coast Guard regulations) as well as container manufacturers. RSPA also carries out inspection and enforcement activities for multimodal shippers and container manufacturers. RSPA regulations, summarized in table 4-2, are located in 49 CFR. More than 30,000 hazardous materials are subject to these regulations. Although the HMTA authorized DOT to regulate both interstate and intrastate transportation of hazardous materials by all modes, the regulations have not been applied to most intrastate highway shipments. ${ }^{23}$ Thus, unless State and local governments adopt 49 CFR and specifically apply it to intrastate highway trans-

\footnotetext{
${ }^{21}$ In 1985, the Research and Special Programs Administration (RSPA) was reorganized. The Materials Transportation Bureau was abolished and its responsibilities were transferred to the Office of Pipeline Safety and the Office of Hazardous Materials Transportation within RSPA.RSPA has both rulemaking and enforcement functions pertaining to the transportation of hazardous materials. See 50 F.R. 45728, Nov. 1, 1985.

${ }^{22} 49$ CFR $1.46,1.47,1.48,1.49$, and 1.53 contain delegations of authority for the U.S. Coast Guard, the Federal Aviation Administration, the Federal Highway Administration, the Federal Railroad Administration, and the Research and Special Programs Administration, respectively.

'Intrastate shipments of hazardous wastes and substances (designated by the U.S. Environmental Protection Agency) and flammable cryogenic liquids in portable tanks and cargo tanks are covered by Federal regulations. See 49 CFR 171.1.
}

Table 4-1.-Federal and International Regulatory Framework for Transportation of Hazardous Materials

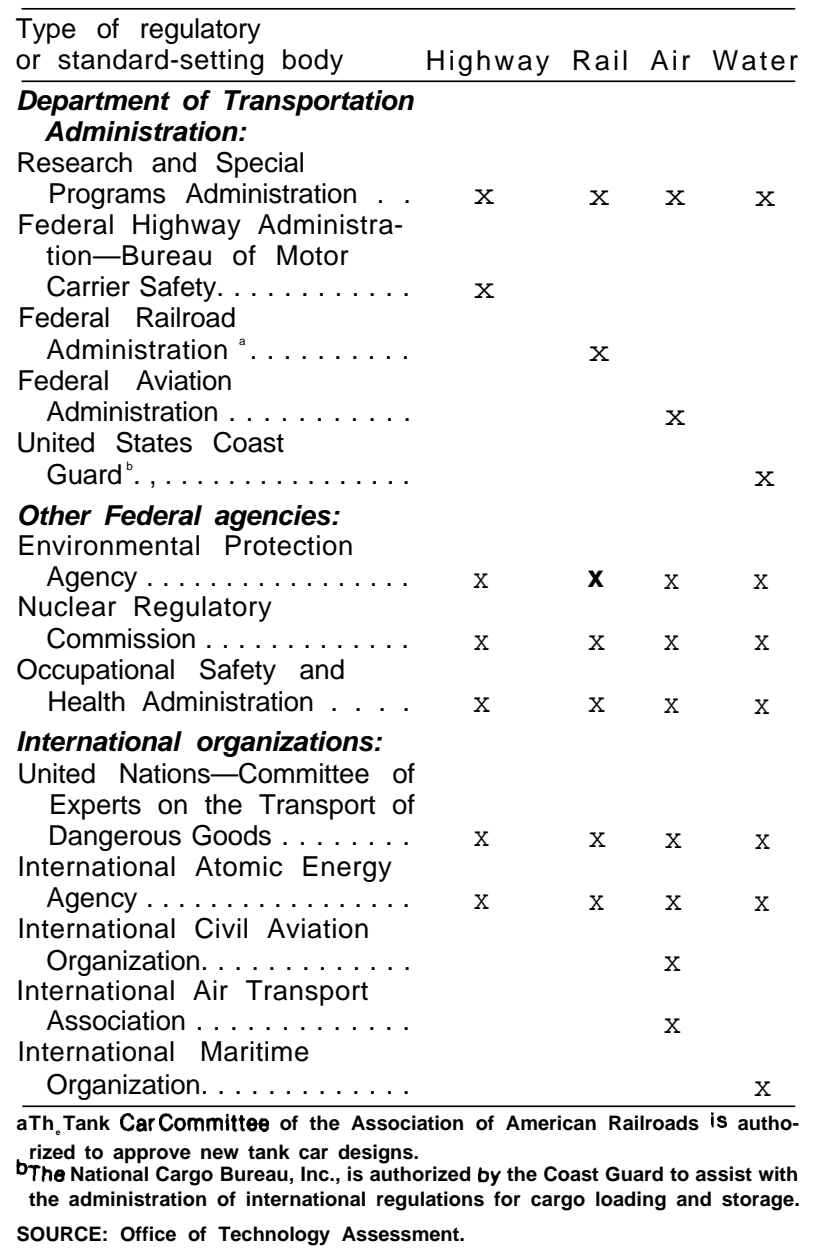

port, most local shipments of gasoline and other hazardous materials are not subject to Federal regulation.

Data collection is another activity undertaken by RSPA, other DOT administrations, and other Federal agencies. Chapter 2 describes these activities in more detail, focusing on the limitations of existing efforts to obtain commodity flow and accident information, It is significant from a regulatory perspective that although the HMTA allows DOT to establish a registration program, current registration requirements are limited to certain groups of shippers, carriers, and container manufacturers 
and reconditioners. ${ }^{24}$ A more comprehensive registration program would provide DOT with basic data on the industry it regulates.

The modal administrations are also responsible for developing and enforcing hazardous materials regulations applicable to each mode. In addition, they have jurisdiction over general safety regulations for operations, vehicles, and vessels under other Federal statutes. ${ }^{25}$ Despite monthly intermodal meetings, there is little coordination among the DOT agencies.

Two other Federal agencies, the U.S. Environmental Protection Agency (EPA) and the Nuclear Regulatory Commission (NRC), establish transportation-related requirements for hazardous substances and wastes and radioactive materials. The Occupational Safety and Health Administration (OSHA) is responsible for the safety of workers employed by shippers and carriers of hazardous materials. While the regulatory role of ICC has been diminished, carriers are required to publish rates and obtain operating certificates. The Department of Defense (DOD) and the Department of Energy (DOE), as major shippers and carriers of hazardous materials, have also established some additional transportation requirements for their own shipments. In addition, packages containing hazardous materials sent by mail must comply with DOT and U.S. Postal Service regulations; chapter 5 describes training available for Postal Service employees.

\footnotetext{
${ }^{24}$ The following are examples of registration requirements that have been established by the U.S. Department of Transportation (DOT): shippers and carriers of flammable cryogenic liquids must comply with registration and driver training requirements (see 49 CFR 173.11, 177.816, and 177.826); reconditioners of steel drums (DOT specifications $17 \mathrm{C}, 17 \mathrm{E}$, and $17 \mathrm{H}$ ) must obtain registration numbers from DOT and mark drums qualified for reuse with such numbers (see 49 CFR 173.28(m)(3)(ii)); manufacturers of DOT specification containers must register a symbol with DOT if their full names are not provided on containers (see "marking sections" for each specification in 49 CFR 178); independent inspection agencies who wish to perform cylinder inspections and verifications must obtain DOT approval (see 49 CFR $300(a)$ ); and shippers of highway route controlled quantities of radioactive materials, such as spent fuel, must file specified information with DOT within 90 days after a package is accepted by a carrier (see 49 CFR 173.22(d)).

${ }^{\text {s } F o r ~ e x a m p l e, ~ B u r e a u ~ o f ~ M o t o r ~ C a r r i e r ~ S a f e t y ~ a c t i v i t i e s ~ a r e ~ a u t h o r-~}$ ized by the Motor Carrier Safety Act of 1980 (Public Law 96-296), the Surface Transportation Act of 1982 (Public Law 97-424), and the Motor Carrier Assistance Act of 1984 (Public Law 98-554). Federal Railroad Administration activities are authorized by the Federal Railroad Safety Act of 1970, as amended (45 U.S.C. 431 et seq.). Federal Aviation Administration activities are authorized $b$ the Federal Aviation Act of 1958 (72 Stat. 744).
}

Table 4-2.-Summary of U.S. Department of Transportation Hazardous Materials Regulations in Title 49 of the Code of Federal Regulations

Part 106 prescribes general rulemaking procedures for adopting Office of Hazardous Materials Transportation regulations. $^{\text {a }}$

Part 107 contains procedures for the submission and review of packaging exemption applications, inconsistency rulings, and nonpreemption determinations. Enforcement authorities are also described.

Part 171 is a general introduction to the hazardous materials regulations. Special requirements for hazardous wastes are included, as well as definitions of terms and a list of technical documents incorporated by reference into the regulations. Reporting requirements for hazardous materials accidents are also specified.

Part 172 contains the Hazardous Materials Table. The table lists the hazardous materials and hazard classes subject to regulation; appropriate requirements for labels, packaging, and air and water shipments are referenced. In addition, Part 172 includes detailed regulations for shipping papers, markings, labels, and placards.

Part 173 indicates the types of packaging that maybe used by shippers of hazardous materials. General shipment and packaging regulations are followed by more specific requirements for certain hazard classes. Hazard class definitions are also contained in Part 173.

Part 174 prescribes regulations for rail transport. General operating, handling, and loading requirements are specified, as well as detailed requirements for certain hazard classes.

Part 175 applies to passenger and cargo aircraft shipments of hazardous materials. The regulations include quantity limitations, loading and handling requirements, and special requirements for certain hazard classes.

Part 176 addresses nonbulk transportation of hazardous materials by waterborne vessels. Requirements for accepting freight, handling, loading, and stowage are prescribed. Coast Guard regulations for bulk shipments of hazardous materials are contained in Title 46 of the Code of Federal Regulations.

Part 177 contains regulations for the highway mode; they apply to common, contract, and private carriers. In addition to regulations for handling, loading, and stowage, routing rules for high-level radioactive materials and other intransit requirements are specified.

Part 178 presents detailed specifications for the fabrication and testing of packaging described in Part 173.

Part 179 prescribes detailed specifications for rail tank cars. Procedures for obtaining Association of American Railroads approval of new tank car designs or changes to existing ones are provided.

aThe Off Ice of Hazardous Materials Transportation was formerly the Materials Transportation Bureau.

SOURCE: Office of Technology Assessment.

RSPA serves as the DOT liaison with other Federal agencies for hazardous materials. Memoranda of Understanding have been signed with EPA, NRC, and DOE delegating responsibilities under specific laws. One Federal coordinating group does exist, the National Response Team (NRT), but it 
is concerned primarily with emergency response activities. Aside from these agreements and NRT, however, there are no formal mechanisms for interagency coordination of regulatory matters. While the division of responsibilities among multiple Federal agencies means that modal safety concerns and questions relating to radioactive or hazardous waste materials are addressed by those with appropriate expertise, it also means that when issues arise that require the attention of more than one agency, a method of ensuring effective coordination does not exist. Interagency regulatory issues generally take years to resolve, and the range of options considered by one agency to address a problem is often limited because actions involving others are not studied. Chapters 2, 3, and 5 illustrate some interagency coordination problems that exist.

Private domestic organizations continue to play an influential role in the development and implementation of regulations governing the transportation of hazardous materials. Such reliance on industry for technical input is inevitable in light of RSPA's small staff and budget restrictions. For example, staff levels have decreased from 143 positions in 1979 to 111 in $1985 .^{26}$ These decreases have occurred despite increasing regulatory demands on RSPA staff and rising public concerns about safety.

Other organizations, like AAR, develop standards and testing requirements, conduct inspections, and provide their members with information on existing and proposed regulations. ${ }^{27}$ Moreover, a number of international regulatory bodies have established recommendations and standards affecting all modes of transport. At an accelerating pace, international regulations governing the transportation of hazardous materials are being used instead of

\footnotetext{
${ }^{26}$ Staff levels are for both hazardous materials transportation and pipeline safety offices. There have not been any significant trends in the U.S. Department of Transportation's budget. Funding appropriated by Congress in 1985 was $\$ 6.114$ million. Data provided by the Research and Special Programs Administration, Apr. 15, 1986.

${ }^{27}$ Various organizations publish general standards for hazardous materials that are applied to the transportation field. These groups include the American Society of Mechanical Engineers, the American Society for Testing and Materials, the Compressed Gas Association, the Institute of Makers of Explosives, the National Association of Corrosion Engineers, and the National Fire Protection Association.49CFR 171,7 indicates the organizations and standards incorporated into the hazardous materials regulations by the U.S. Department of Transportation.
}

DOT regulations. This is particularly true for the air and water modes where international requirements that must be followed for overseas shipments are recognized by DOT for domestic use.

State and local governments also regulate matters that can be classified as accident prevention and protection of public safety, such as routing, permits, or licenses. Requirements set by States and localities focus primarily on highway and rail transport and often vary from those established by the Federal Government and other jurisdictions. Interjurisdictional issues are addressed later in this chapter.

The following sections describe existing hazardous materials regulations relevant to all four modes (intermodal) and those applicable only to the highway, rail, air, or water mode. Each section also discusses the private domestic and international organizations active in the regulatory process. The responsibilities of other Federal agencies are presented in a separate section at the end of the chapter. Enforcement activities and training are discussed in chapter 5 .

\section{Intermodal}

Regulations applicable to all modes of transport consist of two basic types of requirements set by RSPA: use of authorized packaging to ensure effective containment during transport; and clear communication of the hazards of the cargo through shipping papers, markings, labels, and vehicle placards. Shippers begin the regulatory process by identifying the hazards of their cargo.

Classification of Hazardous Materials.-Hazardous materials subject to RSPA regulations are listed in the Hazardous Materials Table in Part 172.101 of 49 CFR. A sample page of the table is shown in table 4-3. The Hazardous Materials Table indicates the hazard class to which each material belongs and references the packaging, labeling, and special requirements applicable to rail, air, and water transportation that must be met by shippers and carriers. The hazard classes designated by RSPA are defined in table 4-4.

In those instances where a material is not listed in the Hazardous Materials Table, the shipper must evaluate it against the criteria for all of the hazard classes. However, the regulations contain no explicit 
Table 4.3.-Sample Page From the Hazardous Materials Table

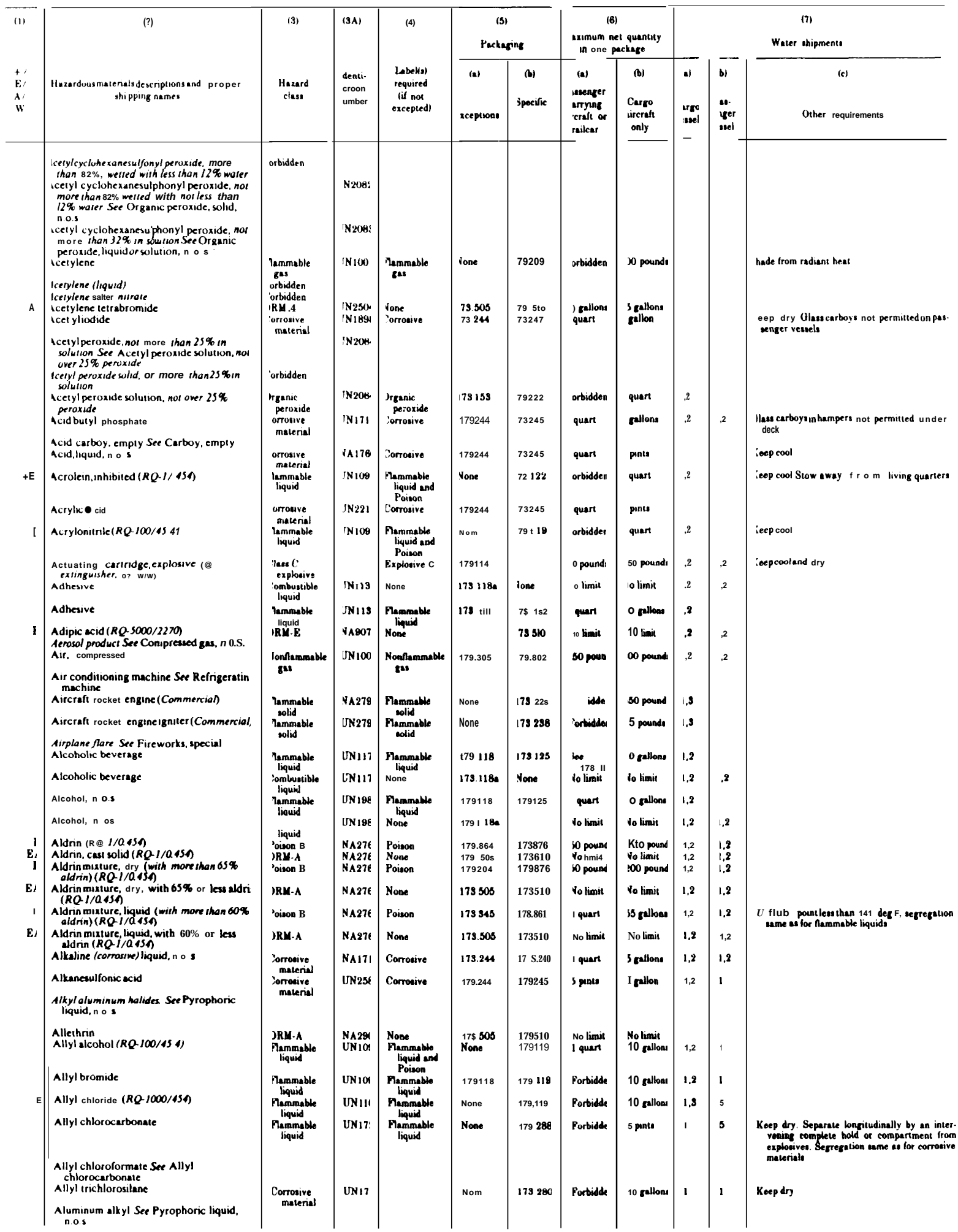

SOURCE: 49 CFR 172.101 
Table 4-4.-Department of Transportation Hazard Classes

\begin{tabular}{|c|c|}
\hline Hazard class & Definition \\
\hline Flammable liquid & $\begin{array}{l}\text { Any liquid having a flash point below } 100^{\circ} \mathrm{F} \text { as determined by tests } \\
\text { listed in } 49 \text { CFR } 173.115(\mathrm{~d}) \text {. Exceptions are listed in } 49 \text { CFR } \\
173.115(\mathrm{a}) \text {. }\end{array}$ \\
\hline Combustible liquid & $\begin{array}{l}\text { Any liquid having a flash point at or above } 100^{\circ} \text { and below } 200^{\circ} \mathrm{F} \\
\text { as determined by tests listed in } 49 \text { CFR } 173.115(\mathrm{~d}) \text {. Exceptions } \\
\text { are listed in } 49 \text { CFR } 173.115(\mathrm{~b}) \text {. }\end{array}$ \\
\hline Flammable solid & $\begin{array}{l}\text { Any solid material, other than an explosive, liable to cause fires } \\
\text { through friction or retained heat from manufacturing or process- } \\
\text { ing, or which can be ignited readily creating a serious transpor- } \\
\text { tation hazard because it burns vigorously and persistently ( } 49 \\
\text { CFR 173.150). }\end{array}$ \\
\hline
\end{tabular}

Oxidizer

A substance such as chlorate, permanganate, inorganic peroxide, or a nitrate, that yields oxygen readily to stimulate the combustion of organic matter (49 CFR 173.151).

Organic peroxide

An organic compound containing the bivalent -O-O- structure and which may be considered a derivative of hydrogen peroxide where one or more of the hydrogen atoms have been replaced by organic radicals. Exceptions are listed in 49 CFR 173.151(a).

Corrosive

Liquid or solid that causes visible destruction or irreversible alterations in human skin tissue at the site of contact. Liquids that severely corrode steel are included (49 CFR 173.240(a)).

Flammable gas

Nonflammable gas

A compressed gas, as defined in 49 CFR 173.300(a), that meets certain flammability requirements (49 CFR 173.300(b)).

A compressed gas other than a flammable gas,

Irritating material

A liquid or solid substance which on contact with fire or when exposed to air gives off dangerous or intensely irritating fumes. Poison A materials excluded (49 CFR 173.381).

Poison A

Poison B

Extremely dangerous poison gases or liquids belong to this class. Very small amounts of these gases or vapors of these liquids, mixed with air, are dangerous to life (49 CFR 173,326).

Substances, liquids, or solids (including pastes and semi-solids), other than Poison $\mathrm{A}$ or irritating materials, that are known to be toxic to humans. In the absence of adequate data on human toxicity, materials are presumed to be toxic to humans if they are toxic to laboratory animals exposed under specified conditions (49 CFR 173.343).

Etiologic agents

A viable micro-organism, or its toxin, which causes or may cause human disease. These materials are limited to agents listed by the Department of Health and Human Services (49 CFR 173.386, 42 CFR 72.3).

Radioactive material A material that spontaneously emits ionizing radiation having a specific activity greater than 0.002 microcuries per gram $(\mu \mathrm{Ci} / \mathrm{g})$. Further classifications are made within this category according to levels of radioactivity (49 CFR 173, subpart I).

Explosive

Any chemical compound, mixture, or device, the primary or common purpose of which is to function by explosion, unless such compound, mixture, or device is otherwise classified (49 CFR 173.50).

Explosives are divided into three subclasses:

Class A explosives are detonating explosives (49 CFR 173,53); Jet thrust unit, explosive booster

Class B explosives generally function by rapid combustion rather than Torpedo, propellant exdetonation (49 CFR 173.88); and plosive

Class C explosives are manufactured articles, such as small arms Toy caps, trick matches, ammunition, that contain restricted quantities of Class $A$ and/or Class B explosives, and certain types of fireworks (49 CFR 173.100).

Blasting agent

A material designed for blasting, but so insensitive that there is very Blasting cap little probability of ignition during transport (49 CFR 173.1 14(a)).

Ethyl alcohol, gasoline, acetone, benzene, dimethyl sulfide.

nk, methyl amyl ketone, fuel oil

Nitrocellulose (film), phosphorus, charcoal

Potassium bromate, hydrogen peroxide solution, chromic acid

Urea peroxide, benzoyl peroxide

Bromine, soda lime, hydrochloric acid, sodium hydroxide solution

utadiene, engine starting fluid, hydrogen, liquefied petroleum gas

Chlorine, xenon, neon, anhydrous ammonia

gas, monochloroacetone

ydrocyanic acid, bromoacetone, nitric oxide phosgene

henol, nitroaniline, parathion, cyanide, mercurybased pesticides, disinfectants

Vibrio cholerae, clostridium botulinum, polio virus, salmonella, all serotypes

Thorium nitrate, uranium hexafluoride signal flare, fireworks 
Table 4-4.-Department of Transportation Hazard Classes-Continued

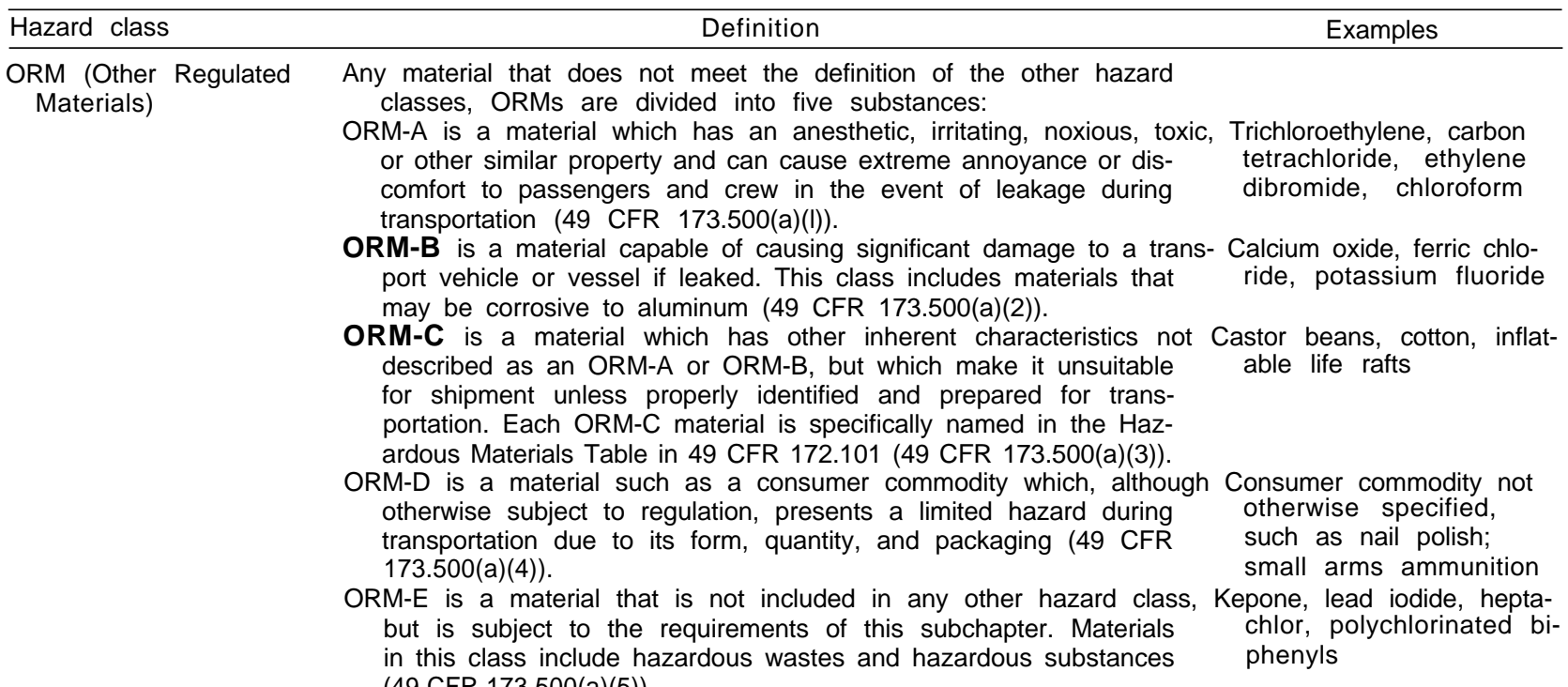

SOURCE: 49 CFR 172,101 and 173.

guidance for shippers on how to classify a hazardous material. The criteria set by DOT for these hazard classes vary; some are based entirely on a quantifiable test, such as flash point determinations for flammable liquids, while others require shippers to exercise their judgment, as for the flammable solid definition. If a material falls into more than one hazard class, a shipper must follow a specified hierarchy of hazards based on the quality of packaging associated with each hazard class. ${ }^{28}$

Many of the hazard classes currently in use were initially established by ICC decades before the HMTA was passed. These early regulations focused on materials likely to cause immediate injury to carrier personnel and the public if they were unexpectedly released during transport. ${ }^{29}$ DOT did not expand the list of hazard classes covered by the regulations until the early 1970s.

Corrosive solids were added to the list of hazard classes in 1974, and when DOT consolidated the

\footnotetext{
${ }^{28} 49$ CFR 173.2.

${ }^{20}$ The Explosive and Other Dangerous Articles Act made explicit reference to explosives and other dangerous articles such as radioactive materials, etiologic agents, flammable liquids and solids, oxidizing materials, corrosive liquids, compressed gases, and poisonous substances. See 18 U.S.C. 834(e).
}

hazardous materials regulations in 1976, a new classification, "Other Regulated Materials" (ORM), was created. The ORM hazard class consisted of four subclasses, ORM-A, B, C, and D, and was introduced by DOT to include materials that were encompassed by the hazard classifications used by FAA and the Coast Guard prior to consolidation of the regulations.

In 1980, DOT added a fifth ORM class, ORM-E, to include hazardous substances and wastes regulated by EPA that did not fit into one of the existing DOT hazard classes. The Comprehensive Environmental Response, Compensation, and Liability Act (CERCLA), a statute primarily concerned with responses to releases of hazardous substances into the environment, required DOT to expand its list of hazardous materials to include hazardous substances and wastes designated under other environ-

\footnotetext{
${ }^{30} \mathrm{ORM}-\mathrm{A}$ materials are thos $\mathrm{e}_{\mathrm{e}}$ with the potential to impair the respiratory and visual functions of aircraft crew members in the event of a spill. ORM-B materials are those corrosive to aluminum, another concern in air transport, ORM-C consists of materials that were re $\mathrm{u}$ lated by the U.S. Coast Guard as "Hazardous Articles" including those with the potential to heat spontaneously if kept in a closed, damp environment for an extended period of time. Finally, ORM-D materials are consumer commodities, such as charcoal or nail polish, which present limited hazards during transport because of their form, quantity, or packaging. See 41 F.R. 15972, Apr. 15, 1976.
} 
mental laws. ${ }^{31}$ While DOT has listed these substances in the CFR, transportation regulations for shippers and carriers are presently applicable onl to hazardous wastes under the Resource Conservation and Recovery Act and hazardous substances under the Federal Water Pollution Control Act, not the entire list of substances defined under CERCLA. ${ }^{32}$

Underlying DOT's current classification system are several assumptions-that most accidents involve fire, that only acute health effects need to be considered, and that only people close to the scene of an accident will be affected. The National Transportation Safety Board and others have asserted that these considerations are insufficient and that DOT's classification system does not adequately indicate degrees of hazard and does not take into account all of the potential dangers posed by a hazardous materials accident. ${ }^{33}$ For example, releases that do not involve fires may be just as dangerous as those that do and can affect people miles from the scene.

\footnotetext{
${ }^{31}$ These statutes include the Federal Water Pollution Control Act, the Resource Conservation and Recovery Act, the Clean Air Act, and the Toxic Substances Control Act. See Section 306 (b) of the Comprehensive Environmental Response, Compensation, and Liability Act of 1980 (42 U.S.C. 9601)

${ }^{32}$ The Comprehensive Environmental Response, Compensation, and Liability Act (CERCLA) requires that releases of designated hazardous substances in quantities equal to or exceeding certain amounts, called Reportable Quantities (RQs), be reported to the National Response Center (See 49 U.S.C. 9656(a)). Prior to the passage of CERCLA, the U.S. Environmental Protection Agency (EPA) established RQs for designated hazardous substances under the Federal Water Pollution Control Act (FWPCA); RQs were set at 1, 10, 100, 1,000, and 5,000 pounds. CERCLA, enacted in 1980, assigned a statutory RQ of 1 pound to all designated hazardous substances (except those set under the FWPCA) but authorized EPA to adjust the RQs as appropriate. In April 1985, EPA promulgated RQs for 340 substances and proposed adjustments for 105 of the remaining 358 CERCLA designated substances. DOT decided not to regulate CERCLA substances (except RCRA hazardous wastes and FWPCA substances) until EPA adjusts the RQs. See Advance Notice of Proposed Rulemaking, Docket HM-145E, 48 F.R. 3596, Aug. 8, 1983. Several industry organizations petitioned the U.S. Department of Transportation (DOT) in 1981 to require all shippers of CERCLA designated substances in excess of 1 pound to prepare shippin ${ }_{\mathrm{s}}$ papers. The petitioners believed that carriers needed to be notified that they were transporting hazardous substances as they were subject to liability requirements under CERCLA. The petition was denied by DOT. See 46 F.R. 58086, Nov. 30, 1981.

${ }^{33}$ U.S. Congress, Office of Technology Assessment, "Transcript of Proceedings-OTA Workshop on State and Local Activities," unpublished typescript, May 30, 1985; Charles Batten, National Transportation Safety Board, personal communication, April 1986; and Transportation Research Board, National Academy of Sciences, Transportation of Hazardous Materials: Toward a National Strategy: Special Report 197 (Washington DC: National Academy Press, 1983).
}

Furthermore, long-term health effects and the potential for environmental damage, such as groundwater contamination, as well as the difficulty in cleaning up released materials, should also be considered in the identification and classification of hazardous materials. Chapter 3 discusses the classification issue in the context of packaging requirements for hazardous materials.

Hazard Communication.-The regulations require shippers and carriers to communicate the hazards of their cargo by providing shipping papers, markings, labels, and placards. These requirements are important because they are intended to furnish essential information about the cargo to emergency response personnel if accidents occur.

Shipping Papers.-Most shipments of hazardous materials must be accompanied by shipping papers that describe the hazardous material and contain a certification by the shipper that the material is offered for transport in accordance with applicable DOT regulations. ${ }^{34}$ For most shipments, DOT does not specify the use of a particular document and the information can be provided on a bill of lading, waybill, or similar document. Figure 4-2 is a sample shipping document. The exceptions are hazardous waste shipments, which must be accompanied by a specific document called the Hazardous Waste Manifest. A manifest lists EPA identification numbers of the shipper, carrier, and the designated treatment, storage, or disposal facility, in addition to the standard information required by DOT.

Instructions for describing hazardous materials are provided in the regulations. These descriptions include the quantity of the material, its shipping name (taken from the Hazardous Materials Table in 49 CFR 172) and hazard class, and the United Nations/North America (UN/NA) hazard identifi-

\footnotetext{
${ }^{34}$ Certain shipments of ORM-A, B, C, and D materials do not have to be accompanied $b_{\mathrm{y}}$ shippin ${ }_{\mathrm{g}}$ papers. See 49 CFR 172.200. These exceptions do not apply if the material is a hazardous substance or a hazardous waste.

${ }^{35}$ The U.S. Department of Transportation regulations specify that a U.S. Environmental Protection Agency manifest may be used in place of a shipping paper. See 49 CFR 172.205. For additional information on hazardous waste requirements, see app. A.
} 
Figure 4-2.-Sample Shipping Document

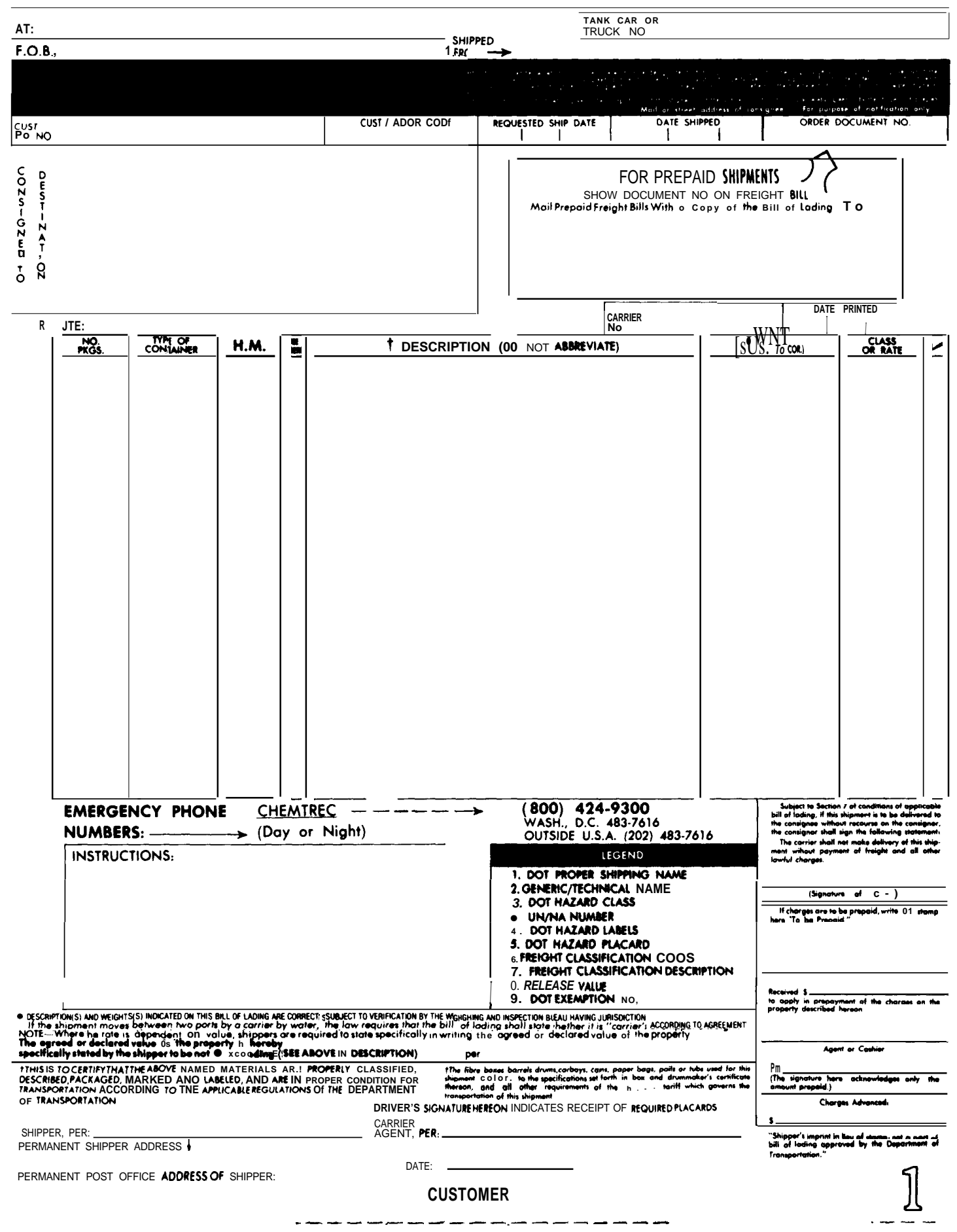


cation number assigned to it. ${ }^{36}$ UN/NA identification numbers, which also must be marked on packages and bulk containers, correspond to emergency response information provided in a guidebook that is published and distributed nationally by DOT. ${ }^{37}$ The DOT Guidebook contains information on potential health, fire, or explosion hazards and basic emergency action instructions. Isolation and evacuation information is also provided for a limited number of highly hazardous substances. DOT has requested $\$ 544,000$ for fiscal year 1987 to revise the Guidebook and print 750,000 copies. ${ }^{38}$

In those instances where a specific technical name of a hazardous material is not listed in the Hazardous Materials Table, a proper shipping name must be selected from general description and n.o.s. (not otherwise specified) entries corresponding to the hazard class of the material. ${ }^{39}$ In addition, special description requirements apply to certain types of materials, such as toxic inhalants, radioactive materials, hazardous substances, empty packaging, and each mode of transport. ${ }^{40}$

Markings.-DOT has established marking requirements for packages, freight containers, and transport vehicles. Shippers are required to mark all packages with a capacity of 110 gallons or less

\footnotetext{
${ }^{36}$ United Nations/North America (UN/NA) numbers consist of the prefix "UN" or "NA" followed by a four digit number. UN/NA numbers were adopted by the U.S. Department of Transportation in 1980 to facilitate international transportation of hazardous materials. The UN numbers are based on an international system developed by the United Nations Committee of Experts on the Transport of Dangerous Goods. The NA numbers identify materials not recognized for international shipment by the U.N. Committee except for transport between the United States and Canada. The change was intended to minimize the burden on shippers, avoid differing shipping paper descriptions and package markings for domestic and international shipments, and improve the capability of emergency response personnel to quickly identify hazardous materials. See 45 F.R. 34571 Mav 22, 1980

${ }^{37}$ US Department of Transportation, 1984 Emergency Response Guidebook, P 5800.3 (Washington, DC: 1984). Additional information on emergency response training is provided in ch. 5 .

${ }^{38}$ Paul Rothberg, Hazardous Materials Transportation: Laws, Regulations, and Policy, Issue Brief IB76026 (Washington, DC: Congressional Research Service, Science Policy Research Division, Mar. 11, 1985), p. 5.

3949 CFR 172.101 (c)(13).

@49 CFR 172.203.The U.S. Department of Transportation recently amended the regulations for describing a packaging that contains the residue of a hazardous material. Placarding requirements for rail tank cars were also changed from "Empty" to "Residue." See 50 F.R. 39005, Sept. 26, 1985. Regulations for shipping descriptions, marking, labeling, placarding, and packaging of toxic inhalants, such as methyl isocyanate, were issued on Oct. 8, 1985. See 50 F.R. 41092.
}

with the proper shipping name of the hazardous material, including its UN/NA identification number. ${ }^{41}$ This is done so that the contents of a package can be identified if it is separated from its shipping papers. Requirements for intermodal portable tanks, highway cargo tanks, and rail tank cars specify that the UN/NA identification number be displayed on a placard or an orange rectangular panel. ${ }^{42}$ Additional requirements are specified for liquids, packages containing ORM materials, and hazardous substances. For example, packages containing liquid hazardous materials must be marked "THIS SIDE UP" or "THIS END UP.," EPA also requires special markings for packages of hazardous wastes identifying the shipper and indicating that Federal law prohibits improper disposal of wastes. ${ }^{44}$ Another type of marking requirement applies to container manufacturers and other persons who test, repair, or recondition containers; DOT specification numbers, serial numbers, and test inspection dates must be marked on containers as certification that specification requirements have been met.

Labels.-Labels are symbolic representations of the hazards associated with a particular material. Figure 4-3 contains some examples of DOT labels. They are required on most packages and must be printed on or affixed near the marked shipping name. ${ }^{46}$ The Hazardous Materials Table indicates which materials require labels. Shipments of limited quantities of certain hazardous materials may not require labeling; these exceptions are referenced in the Hazardous Materials Table (in column 5(a) under packaging exceptions). Additionally, some hazardous materials are exempt from labeling requirements. Exemptions are listed in 49 CFR 172.400 and include materials classed as ORM-A, B, C, D, or $\mathrm{E}$ (if other hazardous materials that must be labeled are not contained in the same package).

\footnotetext{
${ }^{41} 49$ CFR 172.301

${ }^{42} 49$ CFR 172.326, 328 , and .330. Specific instructions regarding the display of identification number markings are provided in the regulations. It should be noted that identification numbers may not by displayed on a poison gas, radioactive, or explosives placard. See 49 CFR 172.332-.338.

${ }^{43} 49$ CFR 172.312, .316, and .324 .

${ }^{44} 40$ CFR 262.32. The U.S. Environmental protection Agency's requirements for hazardous 179.te shipments are described in app. A.

${ }^{45}$ Requirements for th placement of labels can be found in 49 CFR 172.406. Label designs by hazard class are also specified in the regulations. See 49 CFR 407-450.
} 
Figure 4-3._Examples of Labels for Hazardous Materials Packages
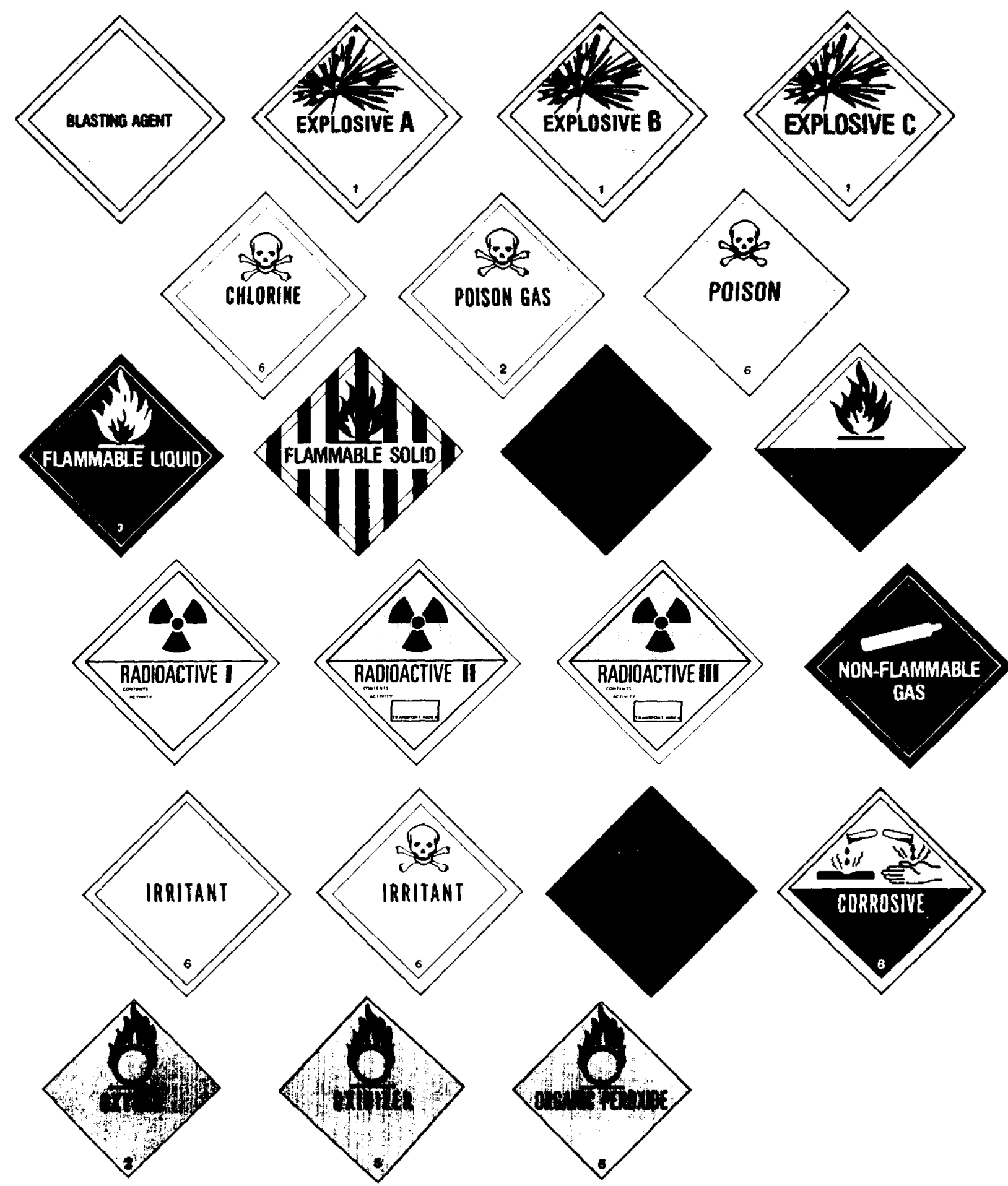

SOURCE: 49 CFR 172, Subpart E 


\section{3}

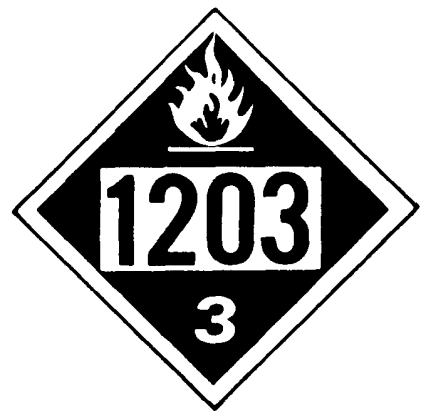

Photo credit: Office of Technology Assessment based on 49 CFR 172.332

1203 is the UN/NA identification number for gasoline.

Special labels, such as "MAGNETIZED MATERIALS" or "CARGO AIRCRAFT ONLY," are required under appropriate circumstances. In addition, packages containing materials that meet more than one hazard class definition may require multiple labels. For example, a material classed as a Poison B Liquid that also meets the definition of a Flammable Liquid must be labeled "POISON" and "FLAMMABLE LIQUID.",

Placards.-Placards are symbols that are placed on the ends and sides of motor vehicles, railcars, and freight containers indicating the hazards of the cargo. UN/NA identification numbers may be displayed on some placards, as noted above in the discussion of marking requirements. Placards are extremely important to emergency response personnel

4749 CFR 172.402, .403, .404, and .405 .
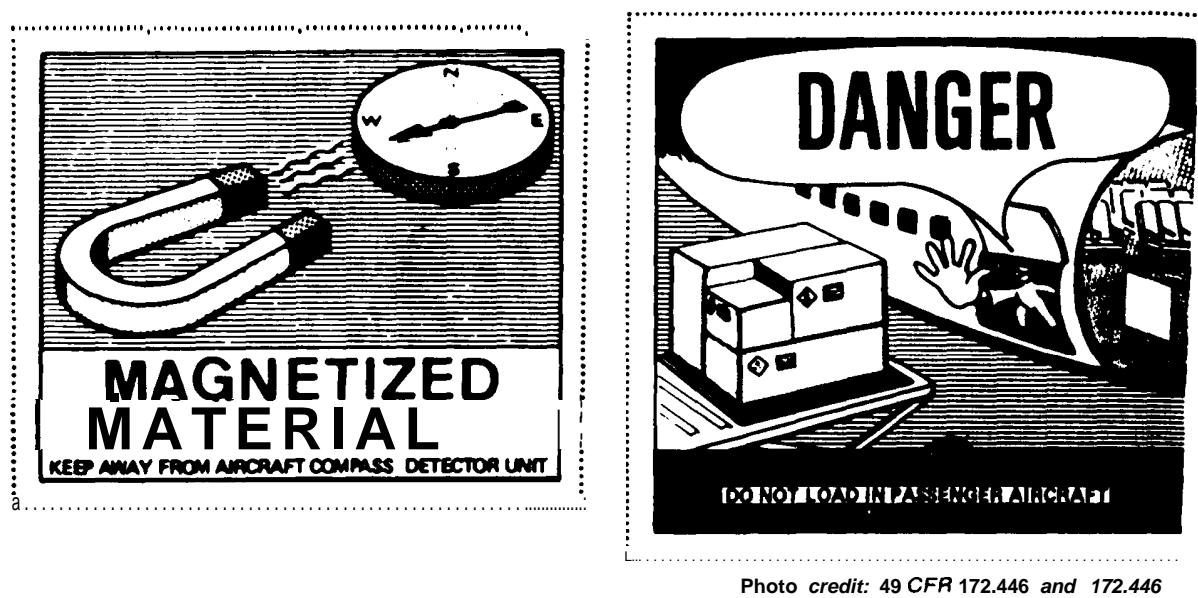

Two examples of special labels required by the Department of Transportation. in the event of an accident because they are highly visible. Sample placards are shown in figure 4-4.

DOT has developed tables, presented in tables 4-5 and 4-6, that indicate the placards required for each hazard class. For mixed loads of some hazardous materials (those listed in table 4-6) shipped in freight containers, motor vehicles, or railcars, a "DANGEROUS" placard may be substituted for the placards required for each hazard class; however, if the weight of one material in a mixed load exceeds 5,000 pounds, a separate placard for it must also be affixed. ${ }^{48}$ Placarding is the joint responsibility of shippers and carriers. Placard designs and rules for providing and affixing placards are specified by DOT.

Placards are not required for all shipments of hazardous materials, such as etiologic agents; materials classed as ORM-A, B, C, D, or E; or limited quantities of hazardous materials. ${ }^{\text {so }}$ Moreover, motor vehicles or freight containers transported by highway containing less than 1,000 pounds of certain types of hazardous materials (those listed in table 4-6) do not have to be placarded. This exclusion also applies to motor vehicles or freight containers carried by railcar (e.g., piggyback service). ${ }^{5}$

\footnotetext{
${ }^{48} 49$ CFR 172.504 (b)

${ }^{49}$ Rules for providing and affixing placards are contained in 49 CFR $172.506, .507, .508, .512$, and .514 . Special placarding provisions for railcars are listed in 49 CFR 172.510. Display and design specifications are specified in 49 CFR 172.516-.558. ${ }^{50} 49$ CFR 172.500 .
} 
Figure 4-4.-Examples of Hazardous Materials Placards

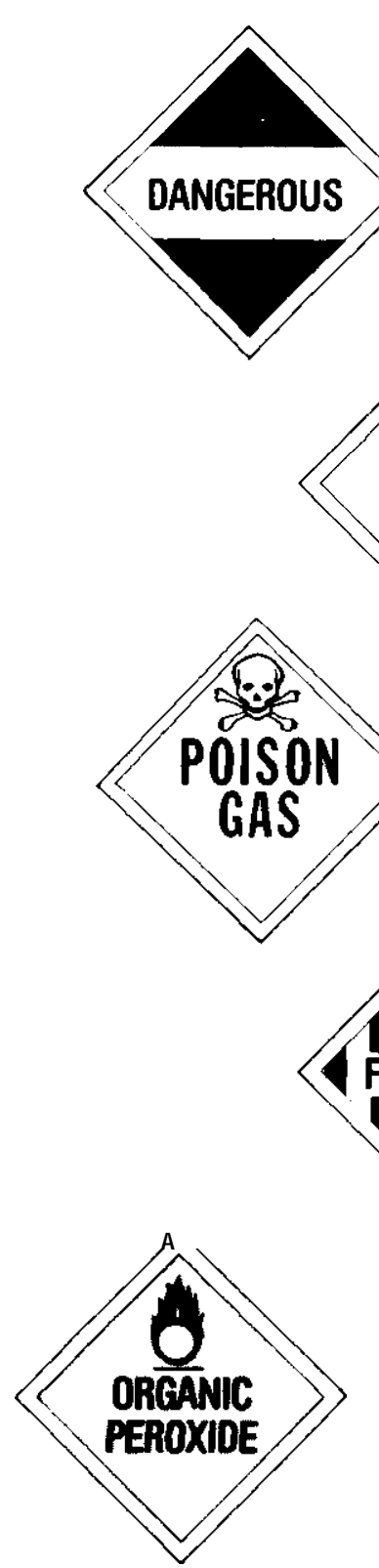

SOURCE: 49 CFR 172 , Subpart F.

Packaging Requirements.-The historical summary at the beginning of this chapter underscores the fact that current packaging regulations, published in 49 CFR 173, 178, and 179, are a compilation of detailed specifications developed over a 70year period. Part 173 indicates the types of pack- ages authorized for each hazard class as well as regulations governing the reuse and reconditioning of packagings and qualification, maintenance, and use requirements for rail tank cars, highway cargo tanks, intermodal portable tanks, and cylinders. Small quantities of some hazardous materials maybe trans- 
requirements for intermodal shipments of hazardous materials: the United Nations (U. N.) and the International Atomic Energy Agency (IAEA). RSPA representatives participate in the development of these international codes and others that deal solely with air and water transportation (see discussion below). Comments are solicited from industry and the public on proposed international regulatory activities, even though a formal public participation mechanism, comparable to the Administrative Procedures Act for domestic regulations, does not exist. ${ }^{53} \mathrm{Reg}$ ulations for the transportation of hazardous materials adopted by these international agencies are applicable to U.S. shippers and carriers that trade abroad.

The main body of the United Nations dealing with hazardous materials transportation policy is the Economic and Social Council (ECOSOC), which reports to the U.N. General Assembl in New York. ECOSOC works through specialized commissions and committees. The primary groups concerned with hazardous materials are the Economic Com-mission for Europe and the Committee of Experts on the Transport of Dangerous Goods. The Committee of Experts is comprised of 10 members including the United States, Canada, several European Nations, and the U. S.S.R. ${ }^{54}$

The Committee of Experts has published a set of recommendations regarding classification and identification numbering systems for hazardous materials, labeling, and placarding requirements, and the use of objective performance standards for nonbulk packaging. ${ }^{55}$ DOT has adopted some of the U.N. recommendations, such as the identification numbering systems for hazardous materials. Other recommendations, such as performance standards,

\footnotetext{
${ }^{53}$ The Administrative procedures Act (APA) prescribes rules for the adoption of regulations by Federal agencies. Agencies are required to publish proposed and final rulemakings in the Federal Register and provide an opportunity for public comment. Any international requirements proposed for incorporation into the U.S. Department of Transportation's hazardous materials regulations are subject to APA procedures. See 5 U. SC. 553.

${ }^{54} \mathrm{~A}$ working group under th Committee of Experts, the Group " Rapporteurs on the Transport of Dangerous Goods, is responsible for developing detailed positions on various issues for formal consideration by the full committee. Another subgroup is the Group of Experts on Explosives.

${ }^{55}$ United Nations, Transport of Danrerous Goods-Recommen dations of the Committee of Experts on the Transport of Dangerous Goods, third revised edition (New York: 1984).
}

have not yet been adopted by DOT, although an advance notice proposing their adoption has been published in the Federal Register. ${ }^{56}$ Additional information on the U.N. performance standards is presented in chapter 3 .

The Canadian Government has recently adopted new rules, the Transportation of Dangerous Goods (TDG) Regulations, based on the U.N. system. ${ }^{5}$ Transport Canada, a multimodal national agency responsible for these requirements, issued rules in July 1985 covering classification, placarding, marking, labeling, and shipping papers. In October 1985, DOT issued a rule permitting shipments between Canada and the United States in conformance with Canada's TDG Regulations and certain additional DOT requirements. Packaging standards, except for specific types of hazardous materials (limited quantities and consumer commodities), have not yet been published by Transport Canada.

The International Atomic Energy Agency first became involved with the transportation of radioactive materials in the late 1950s. The first set of recommendations-Regulations for theSafeTransport of Radioactive Materials, Safety Series No. 6was published in 1961. The recommendations have been revised and updated over the years and serve as the basis for regulatory programs established by IAEA member nations. DOT has incorporated Safety Series No. 6 into its regulations $b_{y}$ reference with certain modifications for application to radioactive materials being imported to or exported from the United States. ${ }^{59}$ Other international organizations such as the International Maritime Organiza-

\footnotetext{
“47 FR 16268, Apr. 15, 1982.

${ }^{5}$ Until the early 1970s, the U.S. Department of Transportation's hazardous materials regulations were adopted by the Canadian Transport Commission (CTC) and applied to rail transport in Canada (49 CFR 173.8 stated that hazardous materials shipped in accordance with CTC regulations were acceptable for transport in the United States). CTC did not establish national regulations for the highway mode. Thus, shippers and carriers involved with transborder shipments of hazardous materials were not concerned with conflicting regulatory requirements. As new regulations were adopted by the United States in the late 1970s, CTC did not amend its code accordingly.

${ }^{5} 50$ FR 41516, Oct. 11, 1985.49 CFR 173.8 was replaced by a new section, 49 CFR 171.12a, describing requirements for U.S.-Canadian shipments.

49 CFR 171.12(e), 173.416, and 173.417. Radioactive materials passing through the United States in the course of being shipped between places outside the United States are included.
} 
tion and the International Civil Aviation Organization (discussed below) have incorporated IAEA requirements into their codes. IAEA recommendations include package design, testing, and inspection procedures; requirements for limiting human exposure to radiation; and controls for transport and storage while in transit.

\section{Highway}

RSPA regulations for the highway mode apply to common, contract, and private carriers. Part 177 of 49 CFR specifies regulations for accepting freight, loading and unloading, stowage, routing, and handling. A special chart, shown in figure 4-5, is provided in the regulations indicating materials that must not be loaded or stored together (similar charts are provided for other transport modes). A general requirement applicable to all highway shipments is that they be transported without unnecessary delay, from loading to arrival at their destinations. ${ }^{60}$ Recognizing the safety concerns associated with tunnels, the regulations allow State and municipal requirements restricting hazardous materials shipments (except radioactive materials) through vehicular tunnels used for mass transport. ${ }^{61}$ Other intransit regulations cover the actions that must be taken by carriers and shippers in the event of an

${ }^{60} 49$ CFR 177.853(a).

6149 CFR 177.810. When the U.S. Department of Transportation issued HM-164, this section was amended to exclude shipments of radio. active materials so that States would be able to: "evaluate the site-specific risks involved over various routes without being hampered by locally imposed constraints which may be counterproductive. " See 46 F.R. 5308, Jan. 19, 1981.

Figure 4=5.-Department of Transportation Segregation and Separation Chart for the Highway Mode

\section{Segregation and Separation Chart of Hazardous Materials}

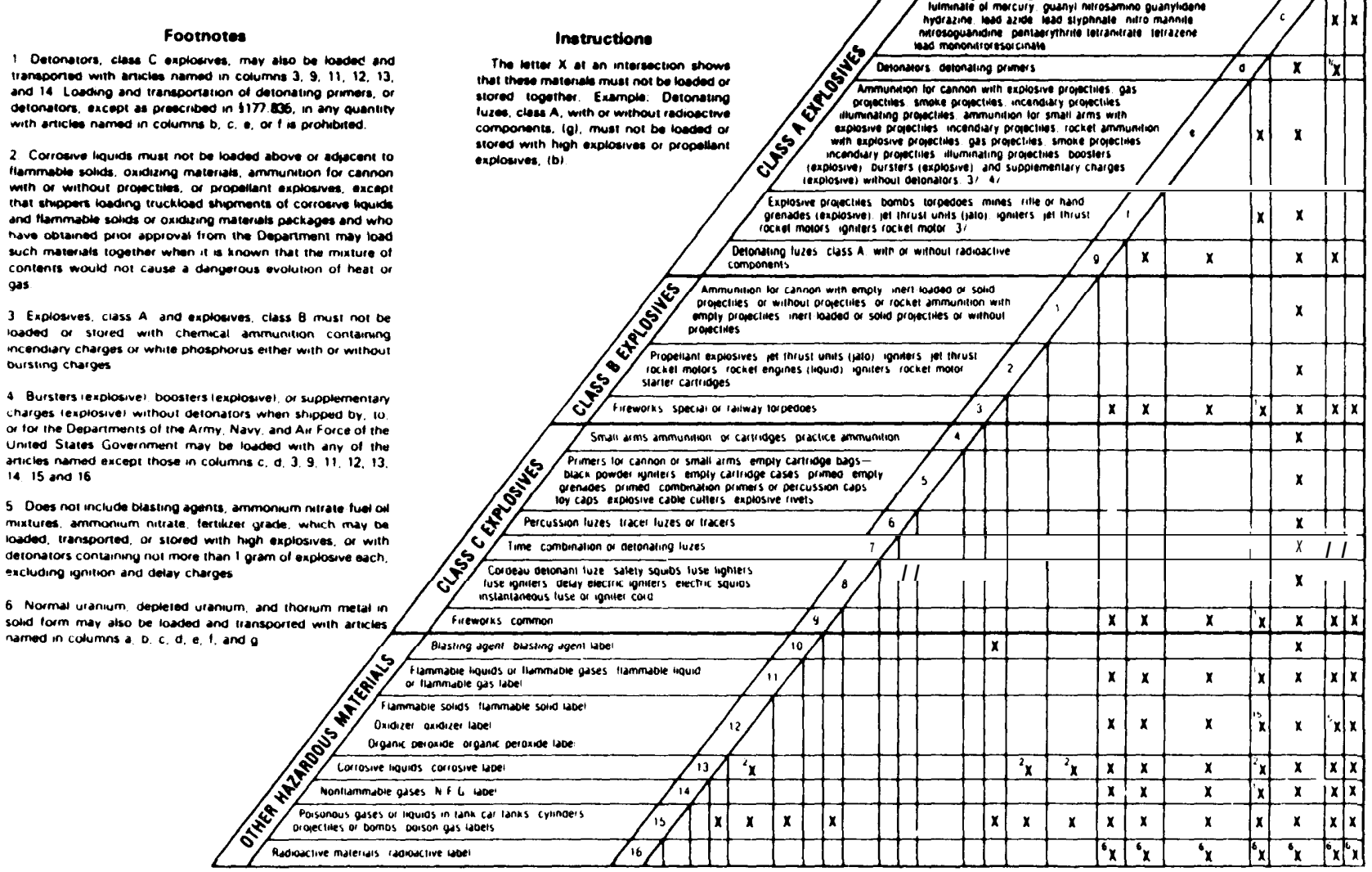


accident. ${ }^{6}$ In addition, carriers of flammable cryogenic liquids in portable tanks or cargo tanks are required to register with RSPA and undergo training.

While routing regulations are generally considered to be an appropriate local-level responsibility, RSPA has established a national highway routing rule for radioactive materials. ${ }^{64}$ This rule, commonly referred to as DOT Docket HM-164, was promulgated because a large number of States and localities had proposed or enacted legislation banning or restricting the transport of radioactive materials through their jurisdictions. Following an extensive public comment period, DOT concluded that, "the public risks in transporting these materials by highway are too low to justify the unilateral imposition by local governments of bans and other severe restrictions. " However, DOT found that certain actions could further minimize the risks associated with such shipments. Thus, HM-164 requires carriers of all placarded shipments of radioactive materials, including radiopharmaceuticals and low-level wastes, to operate on routes that minimize radiological risk. ${ }^{66}$ Carriers of high-level radioactive materials must operate over a "preferred" route that is selected to reduce transit time. Such a route consists of either an Interstate highway system (including the use of an Interstate bypass around a city when available) or an alternative State-designated route selected by a State routing agency in accordance with DOT guidelines. ${ }^{67}$ Drivers of vehicles that transport high-level radioactive materials are also required to receive written training, and carriers must prepare a written route plan.

An appendix to HM-164 provides policy guidance for State and local authorities for establishing requirements that are consistent with Federal law and regulations. The implementation of HM-164 by RSPA, Federal routing guidelines, and existing State

\footnotetext{
${ }^{62} 49$ CFR 177, Subpart D.

${ }^{6} 49$ CFR 177.816 and 177.826 .

${ }^{4} 49$ CFR 177.825. The routing rule, Docket HM-164, was published on Jan. 19, 1981, 46 F.R. 5316.

${ }^{65} 46$ F.R. 5299, Jan. 19, 1981. See also 43F.R. 36492, Aug. 17, 1978, and 45 F.R. 7140 Jan. 31, 1980

to 49 CFR 177.825 (a)

74 49 CFR 177.825 (b). This provision applies to highway route controlled quantities of radioactive materials as defined in 49 CFR 173.403(1).
}

and local routing restrictions are discussed later in this chapter.

The Bureau of Motor Carrier Safety (BMCS) within the Federal Highway Administration is responsible for developing some hazardous materials regulations and enforcing RSPA regulations for the highway mode, including requirements for tank truck manufacture and maintenance. BMCS, under its general authority to set motor carrier safety standards, also regulates motor carrier operations, drivers, and vehicles used for transporting hazardous materials.

Motor carrier safety regulations, incorporated $b$ reference into RSPA's hazardous materials regulations in 1978, are located in Parts 301 to 399 of 49 CFR. However, the driver qualification regulations are limited; for example, while drivers must take a written test, it is an open book exam and a passing grade is not required. ${ }^{68}$ In addition, the motor carrier regulations do not provide for driver disqualification based on a driver's cumulative record of convictions, and the disqualifying driver offenses appl only when a driver operates a commercial vehicle and is on duty at the time of an offense. ${ }^{69}$ Furthermore, Federal regulations cover mainly Interstate drivers, and State driver requirements vary considerably.* Improvements in driver qualification and training requirements have been proposed; these suggestions and State requirements are described later in this chapter.

Special regulations for the transportation of hazardous materials, contained in Part 397, prescribe requirements for compliance with Federal, State, and local laws; parking; attendance and surveillance of vehicles; and operating (e.g., requirements for fueling and examining tires). A general routing requirement instructs carriers to avoid routes that go through or near heavily populated areas, places where crowds are assembled, tunnels, narrow streets, or alleys, unless a practicable alternative route does not exist. ${ }^{70} \mathrm{BMCS}$ also requires written route plans

\footnotetext{
${ }^{68} 49$ CFR 391.35.

${ }^{69}$ See 49 CFR 391.15 and National Transportation Safet Board,

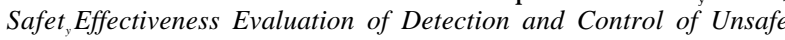
Interstate Commercial Drivers (Washington, DC: Feb. 15, 1980), pp. $15-18$

*Federalmotor carrier regulations do apply to intrastate carriers of hazardous wastes, hazardous substances, and flammable cryogenics. ${ }^{70} 49$ CFR 397.9(a). This requirement does not apply to radioactive materials covered $b_{y}$ HM-164, 49 CFR 177.825.
} 
for shipments of Class A or Class B explosives by motor vehicle that comply with the general routing rule. ${ }^{71}$ However, when the motor carrier safety regulations were incorporated into the hazardous materials regulations, these routing rules were not incorporated. Another provision in the motor carrier regulations, requiring compliance with State and local regulations unless the ${ }_{\mathrm{y}}$ are at variance with more stringent Federal regulations, was not incorporated.

In addition, BMCS has established minimum financial responsibility requirements for private and for-hire carriers of hazardous materials as required by the Motor Carrier Act of 1980. Minimum levels of coverage have been set at $\$ 1$ million and \$5 million, depending on the nature of the cargo. However, exemptions from these requirements have been established for intrastate nonbulk carriers of hazardous materials except high-level radioactive materials and motor vehicles with gross vehicle weight ratings of less than 10,000 pounds except for vehicles used to transport Class A or B explosives, poison gases, or high-level radioactive materials.

Another BMCS activity is the administration of the Motor Carrier Safety Assistance Program (MCSAP), which provides assistance to States for enforcement of motor carrier regulations, including some of those governing hazardous materials transportation on public roads. ${ }^{73}$ MCSAP is discussed later in this chapter.

In addition to the DOT regulations, the National Motor Freight Traffic Association, a division of the American Trucking Association, publishes the National Motor Freight Classification (NMFC) which prescribes packaging to be used to ship all goods by highway, including hazardous materials. Except in one instance, the NMFC rules are not referenced in the Federal regulations, but they do provide guidance for shippers handling materials that do not have to be transported in DOT specification containers. In addition, noncompliance with the NMFC requirements may limit the ability of a shipper to

7149 CFR 397.9(b), The carrier must furnish a coPY of the plan ${ }^{\circ}$ the driver. Drivers may prepare written plans when trips begin at locations other than the carrier's terminal.

${ }^{72} 49$ CFR 387

${ }^{73}$ The Motor Carrier Safety Assistance Program was authorized by the Surface Transportation Act of 1982, Public Law 97-424. collect from a motor carrier in the event of damages arising during transport.

\section{Rail}

Hazardous materials regulations for rail transport appear in 49 CFR 174. The regulations contain general operating, handling, and loading and unloading requirements, as well as detailed requirements for various hazard classes. For example, specific requirements for segregating hazardous materials in a car and for the placement of cars containing certain types of material are included. ${ }^{74}$ Carriers are also instructed to forward shipments of hazardous materials within 48 hours after acceptance at the originating point, or receipt at any yard, transfer station, or interchange point. ${ }^{75}$ Special loading and bracing requirements for container-on-flatcar, trailer-on-flatcar, and portable tanks are provided, and procedures for unloading tank cars are also specified. $^{76}$

The Federal Railroad Administration (FRA) enforces regulations pertaining to the transportation of hazardous materials $b_{y}$ rail, including those governing the manufacture and maintenance of tank cars used to ship hazardous materials. Additionally, FRA has jurisdiction over all areas of rail safety such as track maintenance, equipment standards, and operating practices. Rail safety regulations are published in 49 CFR Parts 209 to 236.

As noted previously, AAR has been involved in developing hazardous materials regulations since the early 1900s. However, the organization currently plays a less prominent role in the regulatory process. Prior to the formation of DOT, counsel for ICC recommended withdrawal of the broad delegation of authority that had been granted to the Bureau of Explosives, a legal opinion reiterated by DOT when it took over ICC's functions in 1967. In the late 1970s, DOT assumed responsibilit for approving regulator ${ }_{y}$ exemptions, a task performed by the Bureau of Explosives for decades. ${ }^{77}$ In 1985, the

\footnotetext{
${ }^{74}$ See 49 CFR 174.81 for cargo segregation requirements; a table, similar to the one for highwa $a_{y}$ shipments (see figure 4-5) is provided. Regulations regarding the placement of cars can be found in 49 CFR 174.83-.93.

"49 CFR 174.14

${ }^{76} 49$ CFR 174.61, 174.63, and 174.67.

${ }^{7}$ U.S. Department of Transportation Docket No. HM-163.
} 


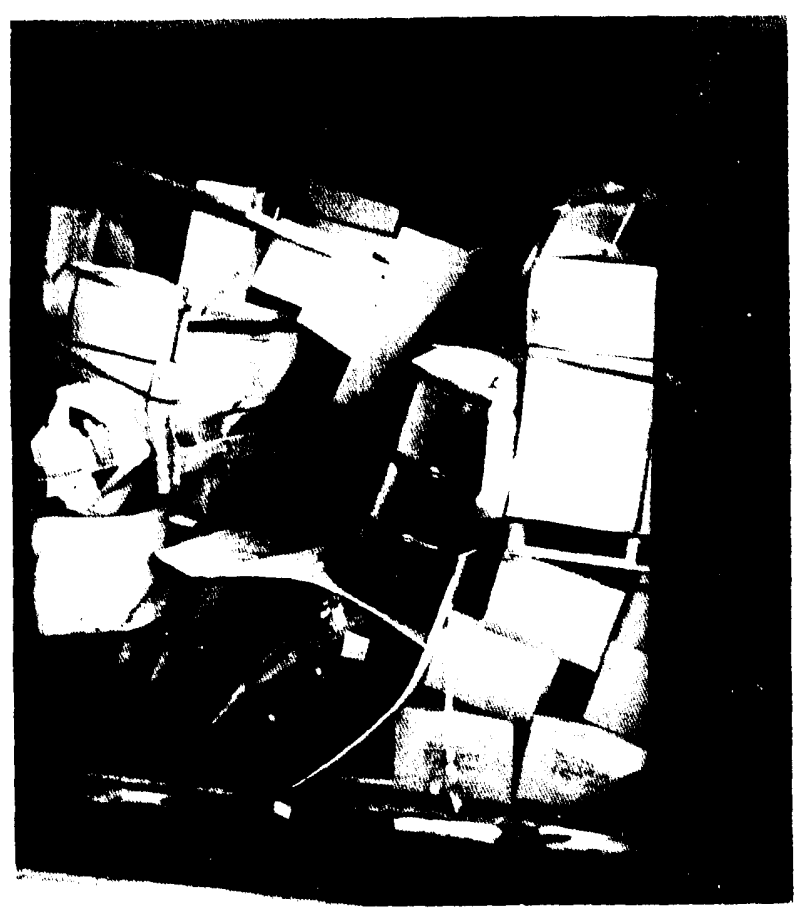

Photo credit: Research and Special Programs Administration, DOT Inadequate blocking and bracing of containers for rail transportation can cause damage and spills.

Bureau of Explosives was renamed Hazardous Materials Systems; it continues to classify and review new explosives and other materials.

Other AAR groups publish equipment standards and specifications, and engineering offices certify construction and repair shops. The AAR Tank Car Committee is involved in all aspects of tank car construction, maintenance, and repair, including those used for hazardous and nonhazardous materials. The committee must approve new tank car designs before they are submitted to DOT. The DOT hazardous materials regulations specify procedures for securing AAR approval of tank cars or changes to existing specifications, and providing certificates of construction. $^{78}$

Another organization involved with rail transport is the Uniform Classification Committee, which publishes the Uniform Freight Classification (UFC). The UFC serves a similar function to that of the NMFC for the highway mode.

\footnotetext{
${ }^{78} 49$ CFR $179.3, .4$ and .5.
}

\section{Air}

RSPA regulations for the air mode are specified in 49 CFR 175. They cover special requirements for certain hazard classes as well as general loading, unloading, and handling requirements. The Hazardous Materials Table in 49 CFR 172 indicates the quantities per package of materials that may be transported on passenger and cargo aircraft as well as those materials, such as Class A explosives, forbidden from being offered or accepted for transport. ${ }^{\top 7}$ The regulations also require that pilots be informed of any hazardous materials carried in an aircraft. 80

Responsibility for the enforcement of hazardous materials regulations for the air mode lies with FAA. Inspections of hazardous materials packages on domestic and foreign carriers are conducted at U.S. airports and in airport cargo-handling areas. FAA also issues and enforces general safety rules and regulations, such as manufacture, operation, and maintenance requirements for aircraft.

The Air Transport Association represents the concerns of domestic airlines. Its Restricted Articles Board was responsible for publishing "CAB Restricted Articles Tariff No. 6-D" in 1965. Tariff 6-D originally contained a restatement of the DOT hazardous materials regulations for air shipments as well as additional requirements established by air carriers. In 1977, Tariff 6-D was replaced by Circular 6-D in response to a $\mathrm{CAB}$ order prohibiting the publication of portions of the CFR in tariffs; Tariff 6-D was rewritten to include only more restrictive carrier regulations. ${ }^{81}$ Federal regulations were effectively replaced by Circular 6-D, because it was more readable and useful as a daily tool and could be updated more easily to accommodate regulatory amendments.

\footnotetext{
${ }^{79}$ Quantity limitations aboard aircraft are specified in 49 CFR 175.75. No person may carry more than 50 pounds net weight of hazardous materials (and in addition thereto, 150 pounds net weight of nonflammable compressed gas) on a passenger-carrying aircraft in an accessible cargo compartment or freight container, an accessible cargo container, or an accessible cargo compartment in a cargo-only aircraft. Hearings were held by the U.S. Department of Transportation during 1985 in response to a petition for rulemaking submitted by Japan Airlines to remove current weight limitations of 50 pounds allowed on passenger aircraft. See 50 F.R. 6013, Feb. 13, 1985.

${ }^{80} 49$ CFR 175.33.

${ }^{8 i}$ Civil Aeronautics Board Order 77-2-59.
} 
The role of the Restricted Articles Board has been diminished in recent years due to deregulation of domestic air carriers and the increasing influence of international organizations such as the International Air Transport Association (IATA). IATA publishes restricted articles regulations for international use similar to those in Circular 6-D. Increasing numbers of domestic carriers are relying exclusively on the IATA regulations instead of Circular 6-D, as carriers prefer to follow only one set of instructions, ${ }^{82}$ The Restricted Articles Board continues to work with carriers in restricting the types of hazardous materials accepted for transport beyond the limitations set by DOT.

In 1982, the International Civil Aviation Organization (ICAO), an affiliate of the United Nations, adopted Technical Instructions (TI) based on the U.N. recommendations for air transportation of dangerous goods. All air shipments from the United States and all U.S. flag carriers must adhere to the TI, as the United States is a signatory to the convention under which they were adopted. In addition, DOT has authorized the use of the TI for domestic air transportation and for any highway transportation related to the air distribution of a material. ${ }^{83}$ IATA has revised its regulations so that they are based primarily on the ICAO requirements.

\section{Water}

RSPA regulations for the water mode apply only to nonbulk shipments. ${ }^{84}$ Promulgated in 49 CFR 176, the regulations address requirements for accepting freight, loading and unloading, stowage, and handling. Carriers or agents are also required to prepare a dangerous cargo manifest, which must be kept in a designated holder on or near the vessel's bridge.

The Coast Guard regulates bulk transport by water. Requirements for the design, construction, equipment, maintenance, and inspection of com-

\footnotetext{
82 Frank Black, Air Transport Association of America, written communication, Feb. 12, 1986.

${ }^{83} 49$ CFR 171.11.

${ }^{84}$ Vessels subject to regulation are specified in 49 CFR 176.5. For example, public vessels not engaged in commercial service and vessels of 500 gross tons or smaller, engaged in fisheries are not covered.

${ }^{85}$ The manifest includes information about the vessel and the cargo and is prepared based on information from shipping papers. 49 CFR 176.30.
}

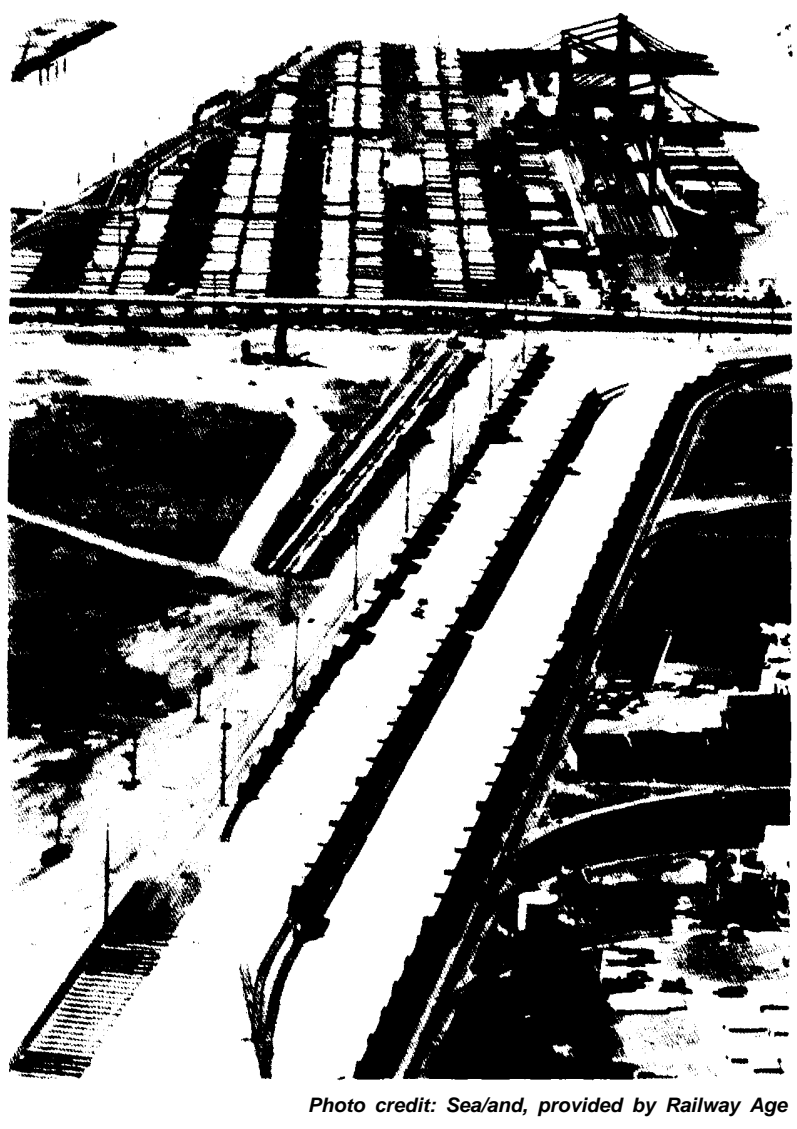

Hazardous materials travel by all modes of transportation.

mercial vessels, including those used for bulk hazardous material shipments are contained in 46 CFR Parts D, I, N, and 'O. Additional requirements for certain ships and barges that carry bulk oil shipments are prescribed in 33 CFR 157. Coast Guard requirements for dangerous cargo require vessels to notify the appropriate captain of the port in advance of arrivals and departures. ${ }^{86}$

\footnotetext{
${ }^{86} 33$ CFR 21 land213. Dangerous cargo includes Class A explosives, oxidizing materials or blasting agents, large quantity radioactive materials or certain fissile radioactive materials, and bulk shipments of a specified list of materials (see 33 CFR 160.203 and 46 CFR 153 (table 1)). General prenotification requirements have also been established for all vessels on voyages of 24 hours or more destined for the United States and for vessels bound for ports on the Great Lakes (33 CFR 160.207 and 160.209).
} 
Coast Guard inspection and enforcement activities are carried out in port areas and on domestic and foreign ships and barges operating in the navigable waters of the United States. The National Cargo Bureau, inc., has been authorized by the Coast Guard to assist with the administration of the hazardous materials regulations applicable to the safe loading of vessels. Surveyors employed by the $\mathrm{Bu}-$ reau inspect vessels to determine their suitability for loading and stowing hazardous materials, recommend stowage requirements, and issue certificates of loading.'

The Safety of Life at Sea convention of 1960 outlined requirements for ship construction and safety that set the stage for the development of an international maritime code pertaining to the movement of hazardous materials. The International Maritime Organization (IMO), formerly called the Intergovernmental Maritime Consultative Organization, worked with the U.N. Committee of Experts to establish requirements addressing classification, identification, documentation, labeling, marking, and packaging." These requirements, referred to as the International Maritime Dangerous Goods (IMDG) Code, may be followed, with certain limitations, by shippers and carriers who import to or export from the United States. ${ }^{89}$ In addition, RSPA has authorized the use of IMDG requirements for packaging, marking, labeling, classification, description, certification, and placarding for most domestic shipments by vessel, as well as for transportation by motor vehicle used in connection with the discharge or loading of a vessel if the vehicle does not operate on a public street or highway." "To facilitate the use of the IMDG Code, RSPA has incorporated

\footnotetext{
${ }^{4} 49$ CFR 176.18. The National Cargo Bureaus a nonprofit orgamiation established in 1952 to perform vesselinspections. The direc torship of the bureauscomposed of government and industry representatives. See U, S. General Accounting Office, Management Improvement Could Enhane Enfore ement of Coast Guard Marine Saferv Programs,GAO/RCED-85-59 (Washington, DC: Aug. 15, 1985).

"The Intergovernmental Maritime Organization (IMO) created by a conventionadopted by the United Nations Maritime Conference in Geneva in 1948, $u_{\text {a }}$ the first regulatory hodv to adopt the U.N. standards. Mote than 100 countries are members of IM O.

49 CFR 171.12.

49 CFR 171.12 and 176.11. International Maritime Dangerous Goods (IMDG) regulations may not he applied to transport of certain explosives, radioactive mater ials, or materials that are hazardous u nrider U.S. Department of Transportation regulations hut are not covered by the IMDG Code.
}

an optional Hazardous Materials Table into 49 CFR based on IMO classifications and requirements. ${ }^{91}$

\section{Related Federal Agencies and Programs}

While DOT has primary jurisdiction over the transportation of hazardous materials, three other Federal agencies have overlapping regulatory responsibilities-EPA, NRC, and OSHA. In addition, ICC grants motor carriers authorization to operate and requires carriers subject to its jurisdiction to publish rates. DOE and DOD as shippers of hazardous materials have also established transportation programs and requirements. Another agency, NTSB, is concerned with investigations of transportation accidents.

\section{Environmental Protection Agency}

EPA manages several programs that affect the transportation of certain hazardous materials. The Resource Conservation and Recovery Act (RCRA) requires EPA to establish requirements for transporters of hazardous wastes; EPA has adopted DOT's regulations for hazard communication, packaging, and reporting discharges and has enacted additional notification, marking, manifest, and cleanup requirements. However, the characteristics used by EPA to identify a waste are different from DOT's hazard classes. Thus, shippers and carriers of hazardous wastes must understand and comply with both classification systems. A Memorandum of Understanding between EPA and DOT refers to investigation, enforcement, and information-sharing responsibilities under RCRA. ${ }^{92}$ Appendix A contains additional information on EPA and DOT regulations for the transportation of hazardous wastes.

In 1981, a guidance manual for shippers and carriers of hazardous wastes was prepared by EPA and DOT to explain the interface between the regula-

\footnotetext{
"49 CFR 172.102. The U.S. Department of Transportation noted that this optional table is included in the interest of providing consistencywith the InternationalMaritime Dangerous Goods Code and alertin $_{\mathrm{g}}$ persons ahout the international requirements.

"45F.R.51645, Aug. 4, 1980.
} 


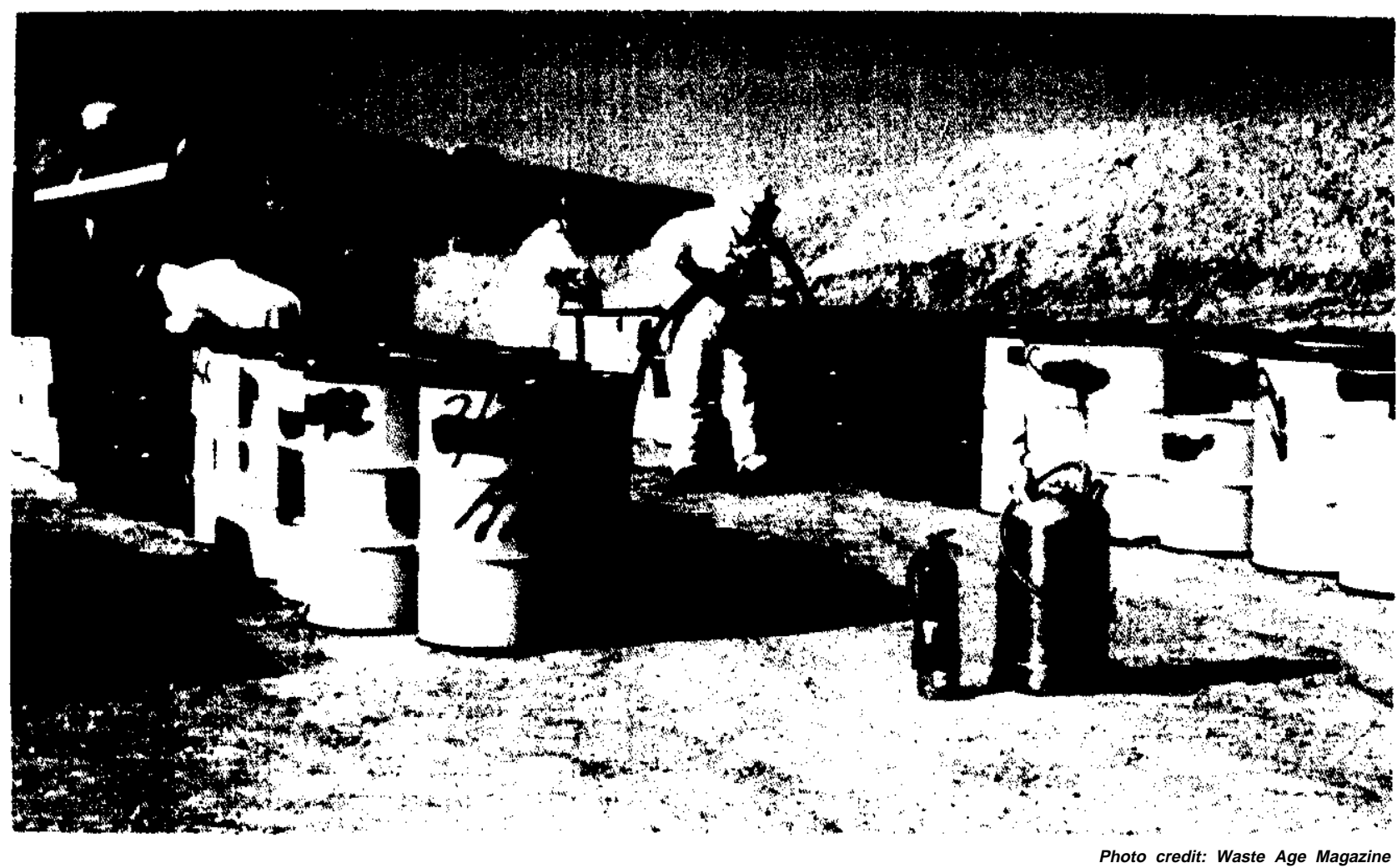

Personnel wearing appropriate equipment sample hazardous wastes in drums before transferring the wastes to a tank truck.

tions of the two agencies. ${ }^{93}$ Since then, amendments to RCRA have been passed extending the scope of the law to include more than 100,000 small generators of hazardous wastes. Given the complexity of DOT and EPA regulations, the potential for confusion and inappropriate use of containers for transport is immense. However, the 1981 guidance document has not been updated, and information distributed by EPA to small generators in 1985 did not cover DOT's transportation regulations.

The Toxic Substances Control Act (TSCA) provides EPA with broad authority to regulate chemical substances and mixtures whose manufacture, processing, distribution in commerce, use, or disposal may present an unreasonable risk of injury to health or the environment. ${ }^{94}$ One regulatory

\footnotetext{
${ }^{93}$ U.S. Environmental Protection Agency, Hazardous Waste Transportation Interface--Guidance Manual, prepared for the U.S. Department of Transportation, PB82-182361 (Springfield, VA: National Technical Information Service, November 1981).

${ }^{94} 15$ U.S. C. 2601
}

option available to EPA is to require that such substances or mixtures be accompanied by clear and adequate warnings and instructions when they are distributed, used, or disposed. ${ }^{95}$ However, EPA regulatory action under TSCA has been limited; regulations for polychlorinated biphenyls require special markings on containers, equipment, articles, and transport vehicles."

In addition to the designation of hazardous substances, CERCLA (or Superfund) and the Clean Water Act authorize EPA and the Coast Guard to provide technical information and advice to emergency response personnel and to respond to severe transportation accidents (see chapter 5). Data on accidents involving hazardous substances and wastes are also collected by EPA (see chapter 2).

${ }^{95} 15$ U.S.C. 2605(a)(3).

${ }^{96} 40$ CFR 761 , Subpart C. 


\section{Nuclear Regulatory Commission}

NRC regulates the receipt, possession, use, and transfer of byproduct, source, and special nuclear materials. ${ }^{97}$ A Memorandum of Understanding between DOT and NRC identifies the responsibilities of each agency. ${ }^{98}$ NRC sets standards for the design and performance of packages used to transport high-level radioactive materials and conducts inspections of its licensees. Other NRC regulations require advance notification to States of certain shipments and provide for physical security measures. DOT has regulatory authority over the design and performance of packages used to ship low-level radioactive materials and transportation operations for high-level materials including highway routing. Chapter 3 contains a detailed examination of the requirements for containers for transporting radioactive materials.

\section{Occupational Health and Safety Administration}

OSHA of the U.S. Department of Labor is responsible for safety and health in the workplace. However, the Occupational Safety and Health Act prohibits OSHA from acting where another Federal agency has already exercised its regulatory authority." A Memorandum of Understanding between DOT and OSHA delineates those areas in which DOT has exercised its authority. Transportation presents two major regulatory areas of concern-vehicle operator safety and the protection of workers handling packages containing hazardous materials at shipping or transfer facilities. DOT has established requirements for vehicle operators, so OSHA has not taken any regulatory action. OSHA has generally accepted DOT's packaging rules, although there have been instances where packages meeting DOT transport requirements could not be handled in the workplace.

\footnotetext{
${ }^{97}$ The Nuclear Regulatory Commission authority is derived from the Atomic Energy Act of 1954, 42 U.S.C. 2011.

${ }^{98}$ 44F.R. 38690, July 2, 1979.

${ }^{90} 29$ U.S.C. 653 (b)(1).

"'See the Occupational Safety and Health Administration (OSHA) regulations for container and portable tank storage (29 CFR 1910. 1o). The OSHA regulations require use of U.S. Department of Transportation (DOT) approved metal containers and portable tanks for flammable or combustible liquids; these requirements were based on National Fire Protection Association (NFPA) standards. However, DOT permits the use of fiber and plastic containers for certain flam-
}

OSHA also requires chemical manufacturers and importers to develop or obtain Material Safety Data Sheets (MSDSs) for hazardous substances and to label containers that are used in or leave the workplace in a manner that does not conflict with DOT regulations. Although the contents of MSDSs vary, they can provide basic information about hazardous materials present in a State or locality; however, they rarely provide any transportation-related information.

\section{Interstate Commerce Commission}

The regulatory role of ICC has been limited since the establishment of DOT. ICC requires carriers of hazardous materials to publish rates. ${ }^{102}$ In addition, ICC is required to investigate whether safe and adequate service, equipment, and facilities are provided by carriers subject to ICC jurisdiction. ${ }^{103}$ Common and contract motor carriers of hazardous materials must obtain ICC operating authority, although safety ratings for certifications are provided by BMCS. The safety rating is based on a number of factors including violations over the past 5 years, discovered by BMCS during safety management audits, and driver equipment compliance reviews; the carrier's improvement or lack thereof during the same time period; and the carrier's accident record. While BMCS currently has information stored in a computerized database on more than 200,000 interstate carriers and 25,000 hazardous materials shippers, less than 15 percent of the entries contain sufficient information for providing initial safety ratings.

\section{Department of Energy}

Under the provisions of the Nuclear Waste Policy Act (NWPA) of 1982, DOE acquired responsibility for high-level nuclear waste movement, storage, and disposal. DOE will be responsible for

mable materials. NFPA has amended their standards to conform to DOT regulations, but OSHA has not yet changed its regulation. However, industry has been advised that any approved DOT container is acceptable.

10129 CFR 19101200 The Occupational Safety and Health Adm nistration(OSHA) standard also requires employers in the manufacturing sector to develop written hazard communication programs to inform and train workers about hazardous substances. OSHA 1 considering the expansion of this standard to include employees in other Industrial sectors.

10249 U.S.C. 10702 and 10761

49 U.S.C. 11101. 
moving the waste from utility reactor sites to a geologic repository, targeted for completion in 1998, or a monitored retrievable storage facility if one is approved by Congress. DOE is authorized by DOT to approve packaging and certain operational aspects of its own research, defense, and contractor shipments, provided that DOE complies with NRC standards and employs procedures equivalent to those of NRC in the container certification process. 104 In the past, DOE has often chosen to use procedures equivalent to but not identical to $\mathrm{N} R \mathrm{C}$ regulations for its shipments; however, DOE has indicated that all NWPA shipments will be conducted in accordance with NRC and DOT regulations. ${ }^{105}$ Chapter 3 provides more information on the NWPA shipments.

\section{Department of Defense}

DOD transports many hazardous materials. When government contractors or other commercial parties transport DOD materials, DOT and NRC reg-

\footnotetext{
${ }^{104} 49$ CFR 173.7
}

105 Memorandum of Understanding between the Research and Special Programs Administration of the U.S. Department of Transportation and the Office of Civilian Radioactive Waste Management of the U.S. Department of Energy for the Transportation of Radioactive Materials Under the Nuclear Waste Policy Act, September 1985. ulations apply. Shipments undertaken by DOD itself, however, are subject to their own requirements, which are similar to those developed by DOT and NRC. ${ }^{106}$ DOD requirements and operations were not reviewed for this study.

\section{National Transportation Safety Board}

NTSB was created in 1966 as an arm of the Department of Transportation. A 1975 legislative action made NTSB an independent agency that reports directly to Congress. NTSB has a hazardous materials branch that investigates accidents for all modes and determines the probable cause. In addition, NTSB has conducted studies on topics such as hazardous materials regulatory compliance, risk analysis, railroad yard safety, and hazard classification. Although NTSB is not a regulatory agency, its recommendations have influenced DOT programs.

\footnotetext{
${ }^{10}$ U.S. Department of Defense regulations are recognized by the Research and Special Programs Administration. See 49 CFR 173.7 and 177.806 .
}

\section{STATE AND LOCAL REGULATION}

\section{Evolution of State Programs}

The entry of State governments into the field of hazardous materials transportation safety began in earnest in the early 1970s. A series of episodes involving radioactive materials prompted States to call for more vigorous efforts to monitor and control the shipment of hazardous materials. Since it was apparent that the resources committed by the Federal Government to police shipments of radioactive material-much less other, more common, forms of hazardous materials - were limited, the States began to seek ways to develop inspection and enforcement capabilities. The task was formidable since States then had virtually no organizational structure, legal authority, or personnel with specialized competence in the area of hazardous materials control.
In 1973, DOT and NRC's predecessor, the Atomic Energy Commission, undertook a program in cooperation with nine States to collect data on the amount and type of radioactive material originating in and passing through selected locations. This effort, known as the State Surveillance of Radioactive Materials Transportation (SSRMT) program, was directed at determining the magnitude of the problem posed by radioactive materials and the degree of regulatory noncompliance by shippers and carriers. The SSRMT study identified needed improvements in data collection, recordkeeping, and enforcement and pointed to the need to strengthen State-level prevention and enforcement mechanisms for all types of hazardous materials. SSRMT findings thus helped form the basis for a more substantial Federal program to aid in the development of State hazardous materials safety programs. 


\section{State Hazardous Materials Enforcement Development Program}

Shortly after the SSRMT study was completed, responsibility for administering Federal-State cooperative programs was transferred to RSPA. Under RSPA, the programs were broadened to include all classes of hazardous materials, and emphasis shifted from data collection to regulatory enforcement, especially development of State organizations that could assume a greater share of inspection and enforcement functions. ${ }^{107}$

In 1981, RSPA initiated the State Hazardous Materials Enforcement Development (SHMED) program, designed to assist States in the enforcement of hazardous materials safety standards and regulations, primarily those pertaining to highway transportation. SHMED had two objectives: 1) decreasing the number of hazardous materials transportation accidents by strengthening State enforcement capabilities, and 2) promoting uniformity in State hazardous materials safety regulations and enforcement procedures. The SHMED program offered participating States contracts to conduct a three-phase program. The first phase, funded at a maximum of $\$ 20,000$ per State, concentrated on data gathering, passage of enabling legislation, and adoption of Federal regulations. The second phase had a funding limit of $\$ 40,000$ and required States to develop and implement an inspection program. In the third phase, with funding of up to $\$ 60,000$, States had to establish enforcement procedures. In all, 25 States have participated in SHMED (see figure 4-6).

Compared to most Federal-State programs, SHMED is small. The 1984 budget was $\$ 1.1$ million, and overall expenditures through 1986, when the program expires, will amount to just over $\$ 3$ million. Nonetheless, it has had a significant influence in shaping State enforcement programs and in defining what constitutes an effective program. While some States, such as New Jersey, have established enforcement programs without SHMED support, the majority of existing State programs have had SHMED funding. Indeed, New Jersey enforcement officers participated in Maryland SHMED training programs.

\footnotetext{
${ }^{107}$ Stephen N. Salomon, State Surveillance of Radioactive Materials Transportation: Final Report, NUREG-1015 (Washington, DC: U.S. Nuclear Regulatory Commission, Office of State Programs, 1984).
}

\section{Motor Carrier Safety Assistance Program}

When the SHMED program ends this year, Federal support of State multimodal hazardous materials enforcement capabilities will diminish, and there will be no programs specifically targeted to hazardous materials transportation by rail, water, and air. However, Federal funds for State inspection and regulatory enforcement on the highways will be available through MCSAP, authorized under the Surface Transportation Assistance Act of 1982. '08

The MCSAP grant program, administered by BMCS, is designed to improve State capabilities to enforce motor carrier safety regulations and to enable States to increase safety inspections of intrastate and interstate commercial vehicles in terminals and along roadsides. The development of an accurate database on compliance with safety regulations is a secondary goal of MCSAP, and funds may be used for data collection, storage, and analysis. The act specifically indicates that MCSAP may apply to enforcement of rules pertaining to vehicles used to transport hazardous commodities. Figure 4-7 shows the States participating in MCSAP.

Under MCSAP, States may apply for two types of grants. Development grants, available for a maximum of 3 years, provide funding for States needing to establish or substantially modify an enforcement program. Implementation grants provide finding for States ready to initiate or enhance established enforcement programs. To qualify for an implementation grant, a State must:

- agree to adopt and enforce the Federal Motor Carrier Safety Regulations (49 CFR 390-399) including highway-related portions of the Federal Hazardous Materials Regulations (49 CFR 171173 and 177-178) or compatible State rules, regulations, standards, and orders applicable to motor carrier safety;

- submit an enforcement and safety program plan and designate a lead agency for administering the plan;

- agree to devote adequate resources to administration of the program and enforcement of rules, regulations, standards, and orders; and

\footnotetext{
${ }^{108}$ Public Law 97-424. Motor Carrier Safety Assistance Program grant regulations are spelled out in 49 CFR 350.
} 
Figure 4-6.-States Participating in the State Hazardous Materials Enforcement Development Program

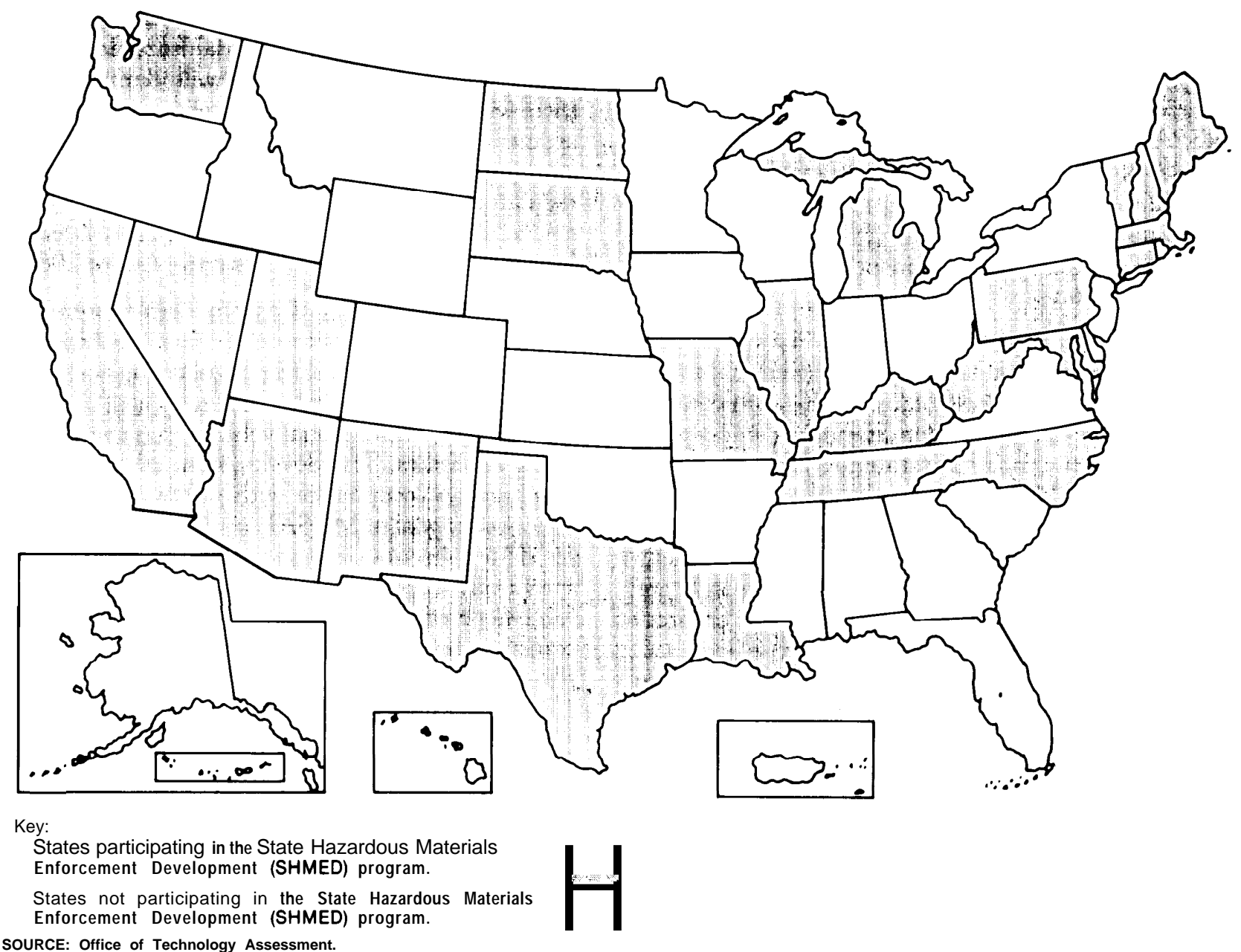

have established statutory authority to regulate private and for-hire motor carriers and provide for right of entry into vehicles and facilities.

MCSAP is financed through the Highway Trust Fund under a 5-year authorization: \$10 million was authorized for fiscal year 1984, and \$10 million was to be added each year up to a maximum of $\$ 50$ million by fiscal year 1988. The Federal grants were to be matched by States on an 80:20 basis. To date, actual appropriations have been significantly lower. The projected total amount of development and implementation grants under MCSAP is estimated to be $\$ 13$ million for 1985 ; approximately $\$ 17.4$ mil- lion is authorized for $1986 .{ }^{109}$ However, the Secretary of Transportation has requested that the $\$ 50$ million maximum funding level for MCSAP be authorized in fiscal year 1987.

State officials committed to expanding hazardous materials enforcement have expressed concern that MCSAP gives priority to general motor carrier safety programs and that hazardous materials enforcement activities-especially those for nonhighway modes-

\footnotetext{
${ }^{109}$ Gary Curtis, Chief, Operations Division, Bureau of Motor Carrier Safety, personal communication, Feb. 13, 1986.
} 
Figure 4=7.-States Participating in the Motor Carrier Safety Assistance Program

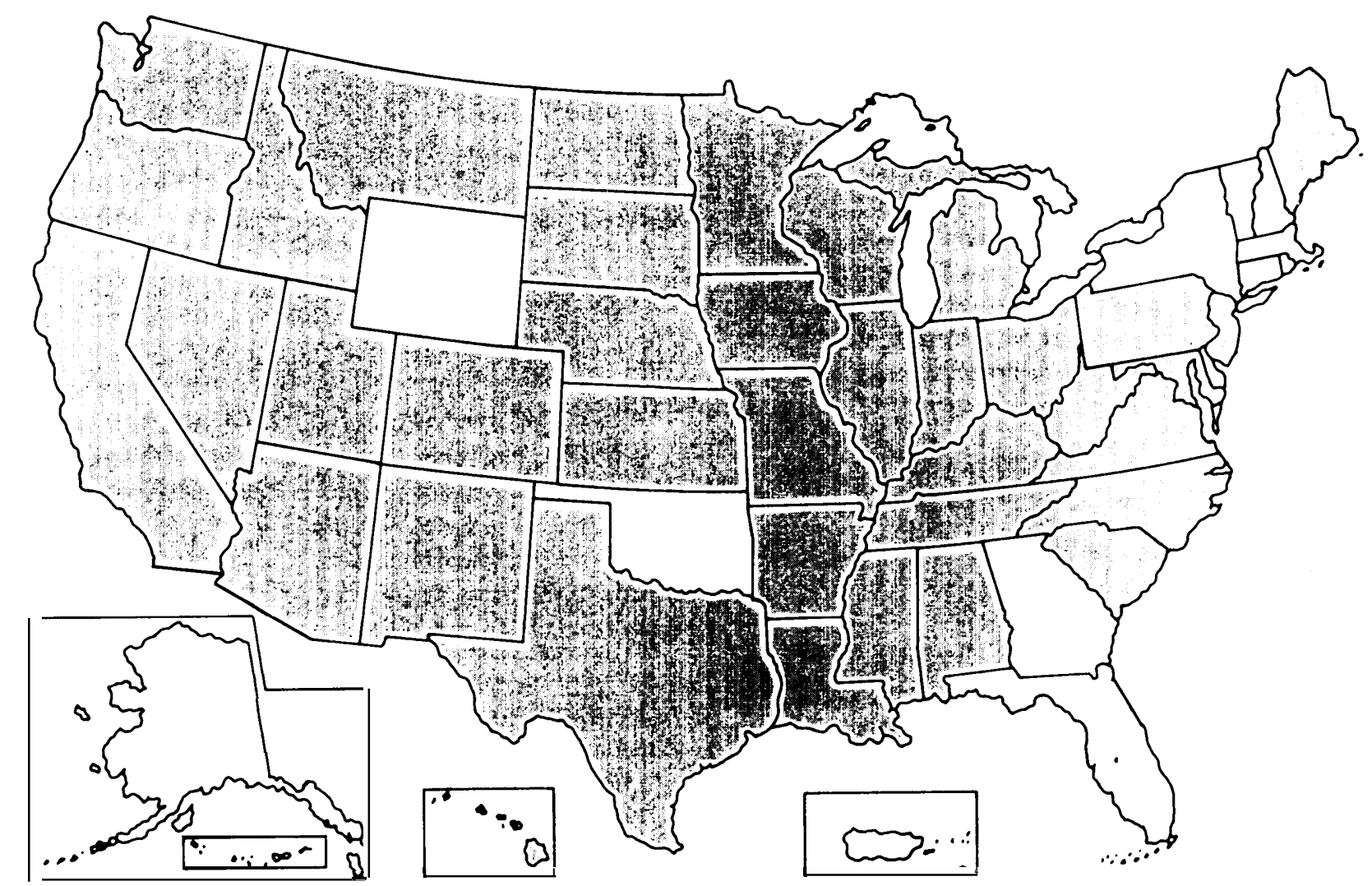

Key:

States participating in the Motor Carrier Safety Assistance Program (M CSAP).

States not participating in the Motor Carrier Safety Assistance Program (MCSAP).

SOURCE: Office of Technology Assessment.

are being slighted. Since MCSAP funds are restricted to highway safety purposes, the broader question arises of how States are to develop or improve inspection, regulation, and enforcement for other modes of transportation, because no similar Federal programs exist for water, rail, or air. Particular concern has been expressed by States with high concentrations of nonhighway hazardous materials shipments. In an effort to continue the work begun under the SHMED program, RSPA and BMCS recently sponsored four regional conferences, referred to as the Cooperative Hazardous Materials Enforcement Development Program, to help States promote uniform enforcement practices.

\section{Commercial Vehicle Safety Alliance}

In an initiative independent of the Federal Government, 26 States and the Canadian Provinces of Alberta and British Columbia have become members of the Commercial Vehicle Safety Alliance (CVSA), formed in 1980. Created under the leadership of California, Idaho, Oregon, and Washington, CVSA seeks to foster interstate cooperation in establishing uniform safety inspection standards for trucks. Under the terms of the alliance, members agree to use common inspection standards and out-of-service criteria and to honor the inspections of other jurisdictions. In this way, CVSA hopes to 
secure greater acceptance of motor carrier inspection programs by the trucking industry and to reduce delays caused by duplicative inspections of interstate truck shipments.

CVSA inspection standards and procedures have been developed in cooperation with BMCS and RSPA. The inspection process concentrates on the critical items (brakes, steering, tires, wheels, couplers, and suspension) most frequently identified as causes of truck accidents. In addition, the driver's qualifications and log book are checked. CVSA has recently added hazardous materials inspection standards and out-of-service criteria to its procedures. On passing inspection in a CVSA jurisdiction, the vehicle receives a decal valid for 3 months allowing it to travel through member States without further inspection unless a visible or audible defect is detected. Reciprocity, uniformity, and consistency are the key concepts of the alliance.

A CVSA associate membership program has recently been formed through which industry members serve in an advisory and nonvoting capacity to contribute their views, experience, and concerns. Since many of the States participating in CVSA are involved in SHMED and MCSAP as well, State agencies and personnel are developing a nationwide program of State-level hazardous materials transportation inspection and enforcement capability. The three organizations now hold joint national and regional meetings. CVSA sees its role as providing a link between Federal and State agencies responsible for motor carrier and hazardous materials inspection and enforcement.

\section{Current State and Local Activities}

A condition of State participation in MCSAP is passage of legislation adopting Federal motor carrier safety regulations and those portions of Federal hazardous materials regulations pertaining to highway shipments. MCSAP also requires States to conduct inspections of both intrastate and interstate motor carriers. As of August 1985, all but two States had adopted 49 CFR wholly or in part; however, legal processes allowing extension of 49 CFR to intrastate motor carriage have only just begun in many States.

Despite this strong encouragement for uniform regulations and enforcement policies, great regula- tory variation remains from State to State. Familiarity with numerous State laws is thus a necessity for interstate carriers, and development of nationally standardized training is difficult. Some States exempt specific commodities, such as agricultural fertilizers; others exclude private carriers from regulation. In Illinois, hazardous materials regulations apply only to quantities that require placarding by Federal law, while in South Dakota, shipments of flammable and combustible liquids are exempt. ${ }^{110}$ According to a 1985 survey of 47 States, 46 States indicated that they regulate common and contract carriers, while only 43 said that private carriers are regulated. ${ }^{11}$ Moreover, the extent to which intrastate shipments of hazardous materials are regulated also varies. For example, some jurisdictions have established more stringent container requirements for intrastate transport, while in others, second- or third-hand cargo tanks that no longer meet Federal standards may be used. ${ }^{112}$

Restrictive State and local legislation is frequently passed in an attempt to regulate the transportation of hazardous materials perceived as posing a high risk to public safety. Many of these laws establish requirements in areas not presently covered by Federal regulations; others are enacted because State and local governments believe that existing Federal requirements are inadequate. A recent DOE report identified 513 State and local laws that affect the transportation of radioactive and other hazardous materials. ${ }^{113}$ Moreover, faced with increasing re-

\footnotetext{
"US. Department of Transportation, Materials Transportation Bureau, "\&ate Hazardous Materials Enforcement Development (SHMED) Program Workshop Proceedings," unpublished typescript, 1983, pp. 121 and 183

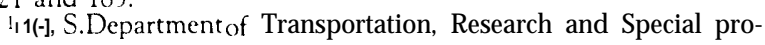
grams Administration, "State Hazardous Materials Enforcement and Development (SHMED) Hazardous Materials Survey," unpublished typescript, Sept. 30,1985.

${ }^{11}$ New York City regulations require the use of steel cargo tanks for shipments of flammable materials; Federal regulations permit the use of steel or aluminum. New York City Fire Department Directive 7-74, Mar.23,1984, andrevisions. Ch. 3 contains additional information on cargo tanks.

' N.P. Knox, et al., Transportation of Radioactive and Hazardous Materials: A Summary of State and Local Legislative Requirements for the Period Ending December 31,1984, ORNL/TM-9563 (Oak Ridge, TN: U.S. Department of Energy, September 1985). The types of requirements identified by the survey include transport approvals, conditional bans on transportation, documentation, escorts, Federal/State compliance, legal and finan ial requirements, notification, permits, placarding, transport prohibitions, routing restrictions, and vehicle specifications. Most State and local laws apply to highway and rail shipments; however, several address ports and one deals with air transport.
} 
sponsibilities for the enforcement of hazardous materials regulations and emergency response activities and a general trend of decreasing Federal financial support, some State and local governments have turned to permit, licensing, and registration fees to help cover the costs of their programs. Unlike States, local governments do not receive Federal grants for enforcement programs and must rely on alternate sources of funding.

Bridge, tunnel, and turnpike authorities also establish regulations governing shipments of hazardous materials. The potential catastrophic consequences of an accident inside a tunnel or on a bridge underscore the need for safety precautions and emergency response planning. A recent survey conducted by the International Bridge, Tunnel, and Turnpike Association found that the three primary concerns of their U.S. members are: having appropriate incident response systems, obtaining information on movements of hazardous materials, and adequate indemnification including loss of revenue coverage. ${ }^{114} \mathrm{Re}-$ quirements imposed by transportation facilities often include prenotification, escorts, and prohibitions against shipments of certain materials such as flammable gases.

\section{Licensing, Registration, and Permits}

Licensing, registration, and permit requirements enable State and local governments to monitor and obtain information from shippers and carriers operating within their jurisdictions. The three termspermit, license, and registration-are used to describe a variety of programs in different jurisdictions. However, a general distinction can be made between registration programs designed to identify shippers and carriers and permitting or licensing programs, usually intended to obtain assurances of fitness and more detailed information about company operations. Fees from such programs are often used to cover only the administrative costs of processing application forms; however, they are also used to generate funds for emergency response and enforcement activities.

\footnotetext{
${ }^{114}$ International Bridge, Tunnel, and Turnpike Association, "Hazardous Materials Transportation Survey Results, " unpublished typescript, June 8,1984.
}

State and local requirements vary; some focus on specific types of hazardous materials, while others are broader in scope. Information requested from shippers and carriers may include the types of materials they handle, origins and destinations of shipments, routes followed, miles covered in a given year, proof of insurance coverage, vehicle inspection dates, and drivers employed. There are also differences in the period of time covered by a permit and the fees levied. For example, 34 States require transport companies carrying hazardous wastes to register and pay a fee on a per vehicle or per company basis. ${ }^{115}$ Fees imposed range from a low of $\$ 3$ up to $\$ 500$ and may be good for one trip only or for as long as a year. Some States also require special driver training or certification, vehicle registration and inspection, and proof of liability insurance. Table 4-7 summarizes State hazardous waste permit requirements.

Local jurisdictions may also require separate permits for carriers operating within their boundaries. Denver requires carriers of hazardous materials (except radioactive materials, and diesel and gasoline fuel in quantities under 111 gallons) to obtain annual permits by mail. Fees are assessed based on the number of trucks in a carrier's fleet; they range from $\$ 50$ per year for a fleet of 1 or 2 trucks to $\$ 600$ per year for 500 or more trucks. A description of the material to be transported (based on historical information), proof of liability insurance as required by Federal regulations (49 CFR 397.9), and acknowledgment of the routes designated by the city for hazardous materials shipments must be submitted. Funds generated are used to support the city's hazardous materials transportation enforcement activities and administration of the permit program. '16

Data obtained through permit, licensing, or registration requirements may be used to target enforcement activities, plan emergency response programs, or develop regulations. For example, emergency response personnel would use data on the types of materials they are likely to encounter to develop

\footnotetext{
${ }^{115}$ U.S. Congress, Office of Technology Assessment, Transportation of Hazardous Materials: State and Local Activities, OTA-SET-301 (Washington, DC: U.S. Government Printing Office, March 1986). ${ }^{116}$ Article VI of Chapter 22, Denver Municipal Code; and Tony Massaro, Office of Environmental Affairs, City and County of Denver, personal communication, Feb. 11, 1986.
} 


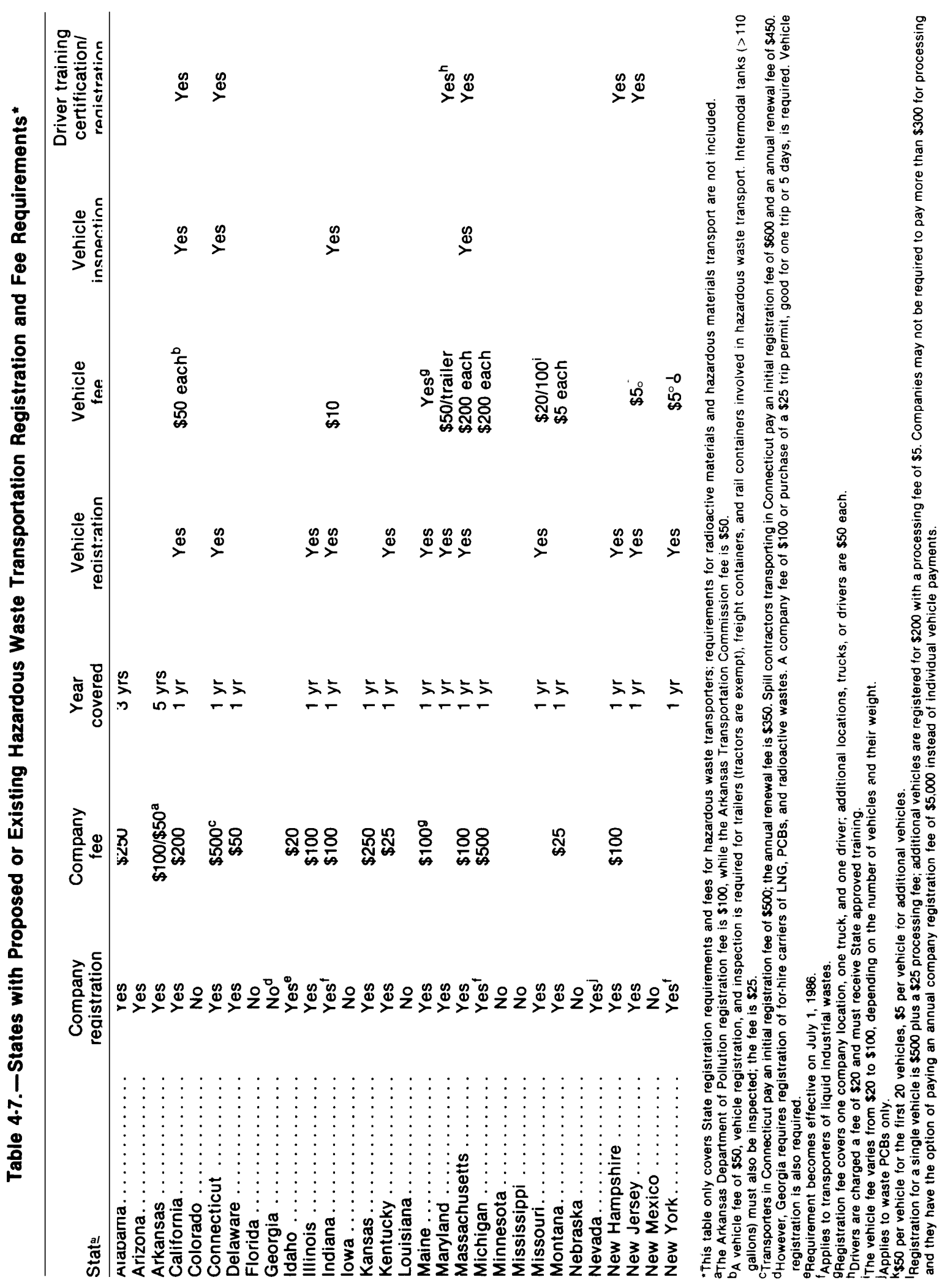




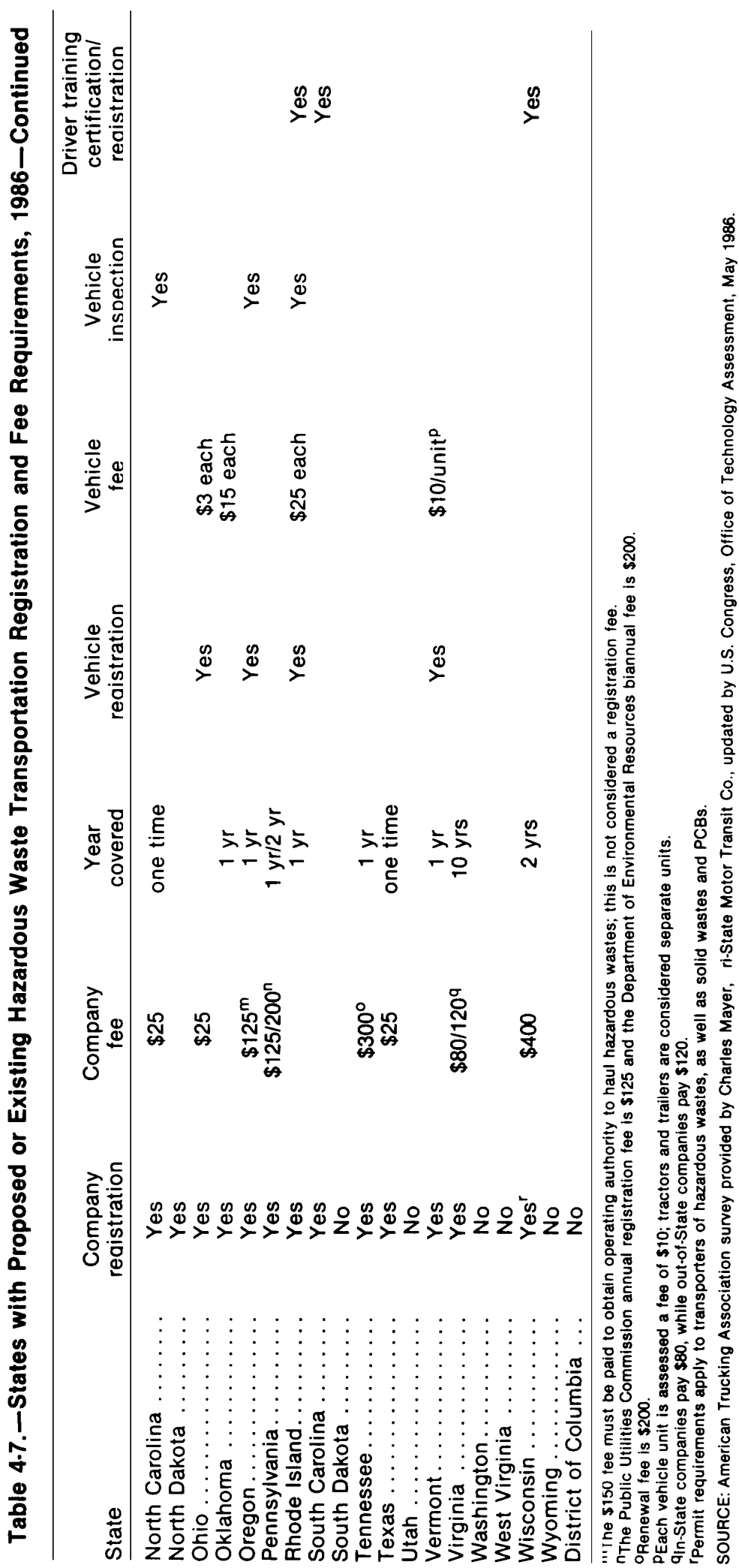


appropriate training programs. Driver or carrier information is important to enforcement officials for identifying individuals or firms with poor performance records. Regulatory agencies interested in providing industry with information on new or amended regulations must know the location of shippers and carriers of hazardous materials. An example of a strong State program, described in box $4 \mathrm{~A}$, is California's licensing and computerized statewide database and information system.

Proliferation of State and local licensing, registration, and permit requirements, usually applicable to trucks, can pose hardships for carriers. Aside from the impact of a requirement within the regulating State, transporters are concerned about the cumulative economic impact of these requirements and particularly about permits or licenses that must be obtained per vehicle or per trip. The latter can increase transit time. One carrier noted that, in order to ensure that his driver was completely prepared to transport a load of hazardous wastes from Georgia to Wisconsin, he had to telephone every State along the route, sometimes calling as many as four or five agencies within a State, before he was fully apprised of all the requirements. *17 Many trucking company officials believe that adoption of special requirements by different States impedes interstate commerce and is inconsistent with the HMTA, and have taken legal action. These court cases are described later in this chapter.

\section{Notification}

Notification requirements have been established by numerous local governments; transportation facilities, such as bridge and tunnel authorities; and States. A study conducted by Battelle Memorial Institute for DOT identified 136 notification laws pertaining to hazardous materials transportation.

\footnotetext{
${ }^{117}$ Reported at the U.S. Congress, Office of Technology Assessment, Workshop on State and Local Activities, May 30, 1985.

${ }^{118}$ Battelle Columbus Laboratories, Assessment of State and Local Notification Requirements for Transportation of Radioactive and Other Hazardous Materials (Columbus, OH: Jan. 11, 1985).
}

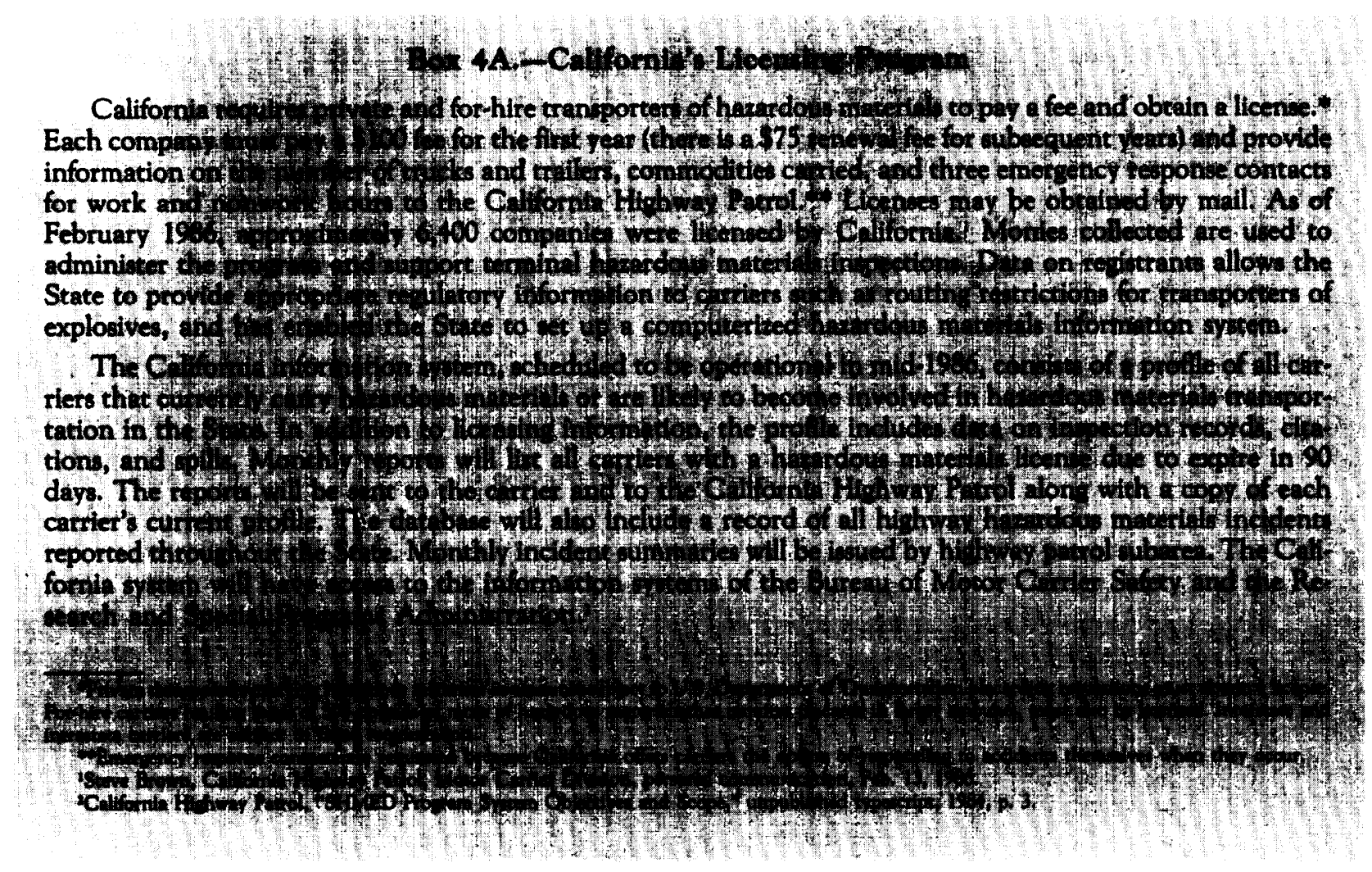


The vast majority of these apply to trucks; a few apply to rail. Notification requirements, as defined by the study, include notification prior to shipments, periodic summaries, and reports on individual shipments filed after a trip. Prenotification is required by 23 State and 77 local regulations; 14 call for periodic reporting and 22 concern individual trip reports. Transportation facilities almost universally require some type of prenotification to arrange for escorts and notify emergency response agencies; these requirements focus on radioactive materials in addition to other hazardous materials, such as explosives and flammable materials. States and municipalities have tended to regulate spent fuel or high-level radioactive wastes, although some also include other radioactive materials. Table 4-8 lists State and local notification laws and the types of hazardous materials covered.

The Battelle study found that State and local governments typically give two reasons for enacting notification requirements: to provide data for planning (including better routing and safety regulations), and to improve emergency response. However, lack of enforcement of notification regulations means that there is little reason for shippers and carriers to comply, and several local agencies were found to be unaware of the notification laws they were supposed to enforce. Some community officials reported that they have never received a notification, even though it is required by local ordinance. The Battelle study observed that, while there are instances of conscientious enforcement and data collection, many local agencies charged with enforcing regulations on prenotification give the task relatively low priority. Often when information is collected, it is simply filed and not used for planning purposes.

Transporters are concerned that proliferation of State and local notification regulations creates scheduling difficulties and increases paperwork and staff needed to monitor requirements.

\section{Hazardous Materials Driver's Licenses}

A recent insurance industry publication indicates that one out every three tractor-trailers can be expected to crash in a year. ${ }^{119}$ While BMCS required ments for motor carrier drivers include written

\footnotetext{
I'Insurance Institute for Highway Safety, "Big Trucks and Highway Safety," unpublished typescript, 1985, p. 1.
}

and road tests and a physical examination, the written test is used as an instructional tool only and a passing grade is not required. *20 Although many States have established classified commercial licenses, drivers in 19 States are allowed to operate large trucks with a general commercial license, and driving a pick-up truck is very different from driving a large cargo tanker. ${ }^{121}$ Moreover, it is common practice for many truck drivers, including those who handle hazardous materials, to possess driver's licenses from more than one State to avoid multiple violations in any given State. A 1980 investigation of drivers involved in large truck crashes by NTSB found that 44 drivers held 63 licenses, had 98 suspensions, were involved in 104 previous crashes, and had 456 traffic convictions. ${ }^{122}$ In recognition of this situation, the American Trucking Association (ATA) has urged Congress and DOT to promote the implementation of a single license by all States so that truck drivers may hold licenses from their State of legal residence only. ATA has also recommended that applicants for a truck driver's license be given written examinations and road tests applicable to the type of vehicle that will be driven.

Drivers transporting hazardous materials also should understand the special hazards associated with their cargo and the regulations governing such shipments. Data collected by DOT indicate that 62 percent of all accidents involving hazardous materials are the result of human errors. ${ }^{124}$ This statistic underscores the importance of driver training as an accident prevention tool. Under HM-164, DOT requires drivers of vehicles carrying high-level radioactive waste to undergo training. Driver training re-

\footnotetext{
$120_{49}$ CFR 391.35(b).

${ }^{121}$ Insurance Institute for Highway Safety, op. cit., p. 3.

${ }^{122}$ National Transportation Safety Board, Safety Effectiveness Evaluation of Detection and Control of Unsafe Interstate Commercial Drivers, PB1980-162969 (Washington, DC: Feb. 15, 1980), pp. 18-20.

${ }_{123}$ Thomas $\mathrm{D}_{\text {ono }} \mathrm{h}_{\text {ue }}$ president and Chief Executive officer, American Trucking Association, Statement Before the U.S. Senate, Committee on Commerce, Science and Transportation, Oct. 29, 1985. A new National Transportation Safety Board report also calls for a licensing system based on vehicle types. National Transportation Safety Board, "Training, Licensing, and Qualification Standards for Drivers of Heavy Trucks," NTSB/SS-86/02, unpublished typescript, spring 1986 ,

${ }^{124}$ Mark $\mathrm{Abk}_{\mathrm{ow}} \mathrm{it}_{\mathrm{z}}$ and George List, "Hazardous Materials Transportation: Commodity Flow and Information Systems," OTA contractor report, unpublished typescript, December 1985.
} 
Table 4.8.-Commodities Covered by Notification Requirements, 1985

\begin{tabular}{|c|c|c|c|c|}
\hline & $\begin{array}{l}\text { Spent fuel } \\
\text { and/or high- } \\
\text { level waste }\end{array}$ & $\begin{array}{l}\text { Other } \\
\text { radioactive } \\
\text { materials }\end{array}$ & $\begin{array}{c}\text { Hazardous } \\
\text { wastes }\end{array}$ & $\begin{array}{c}\text { Other } \\
\text { hazardous } \\
\text { materials }\end{array}$ \\
\hline \multicolumn{5}{|l|}{ state: } \\
\hline Arkansas $\ldots \ldots \ldots \ldots \ldots \ldots \ldots$ & $\ldots \ldots \ldots$ & $\ldots \ldots \ldots$ & $\mathrm{x}$ & $X$ \\
\hline 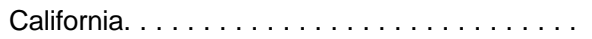 & $\mathrm{x}$ & $\ldots \ldots \ldots$ & & $\ldots \ldots \ldots$ \\
\hline Colorado . . . . . . . . . . . . . . . . . & $\ldots \ldots \ldots$ & $\ldots \ldots \ldots$ & $X$ & $\ldots \ldots \ldots$ \\
\hline Connecticut $\ldots \ldots \ldots \ldots \ldots \ldots \ldots$ & $\mathrm{x}$ & $\mathrm{x}$ & $\ldots \ldots \ldots$ & $\ldots \ldots \ldots$ \\
\hline Florida . . . . . . . . . . . . . . . & $\mathrm{x}$ & $\mathrm{x}$ & $\ldots \ldots \ldots$ & $\ldots \ldots \ldots$ \\
\hline Georgia . . . . . . . . . . . . . . & $\mathrm{x}$ & $\mathrm{x}$ & $\mathrm{x}$ & X \\
\hline 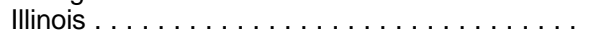 & $\ldots \ldots \ldots$ & $\ldots \ldots \ldots$ & $\mathrm{x}$ & $\ldots \ldots \ldots$ \\
\hline Louisiana . . . . . . . . . . . . . . . . . . . . . & $\ldots \ldots \ldots$ & $\ldots \ldots \ldots$ & $\mathrm{x}$ & $\ldots \ldots \ldots$ \\
\hline Maine $\ldots \ldots \ldots \ldots \ldots \ldots \ldots$ & $\ldots \ldots \ldots$ & $\mathrm{x}$ & $X$ & $\ldots \ldots \ldots$ \\
\hline 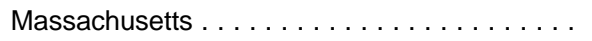 & $X$ & $\ldots \ldots \ldots$ & $X$ & $\ldots \ldots$ \\
\hline Michigan $\ldots \ldots \ldots \ldots \ldots \ldots \ldots \ldots$ & $\mathrm{x}$ & $\mathrm{x}$ & $\ldots \ldots \ldots$ & $\ldots \ldots$ \\
\hline Mississippi . . . . . . . . . . . . . . . . . & $\mathrm{x}$ & $\mathrm{x}$ & $\ldots \ldots \ldots$ & $\ldots \ldots \ldots$ \\
\hline Nevada . . . . . . . . . . . . . . & $\mathrm{x}$ & $\mathrm{x}$ & $\ldots \ldots \ldots$ & $\ldots \ldots \ldots$ \\
\hline New Hampshire . . . . . . . . . . . . . . & & $\ldots \ldots$ & $\ldots \ldots \ldots$ & $\mathrm{x}$ \\
\hline New Jersey . . . . . . . . . . . . . . . . . . & $X$ & $x$ & $\ldots \ldots \ldots$ & $\ldots \ldots \ldots$ \\
\hline New Mexico . . . . . . . . . . . . . . . . . & $\mathrm{x}$ & $\mathrm{x}$ & $\ldots \ldots \ldots$ & $\ldots \ldots \ldots$ \\
\hline North Carolina . . . . . . . . . . . . . . . . & $\mathrm{x}$ & $\ldots \ldots \ldots$ & $\ldots \ldots \ldots$ & $\ldots \ldots \ldots$ \\
\hline 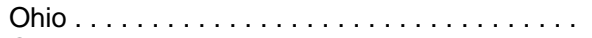 & $\mathrm{x}$ & $\mathrm{x}$ & $\ldots \ldots \ldots$ & $\ldots \ldots \ldots$ \\
\hline Oregon $\ldots \ldots \ldots \ldots \ldots \ldots \ldots \ldots$ & $\ldots \ldots \ldots$ & $\ldots \ldots \ldots$ & $\ldots \ldots \ldots$ & $\mathrm{x}$ \\
\hline Rhode Island . . . . . . . . . . . . . . & $X$ & $\mathrm{x}$ & $\mathrm{x}$ & $\ldots \ldots \ldots$ \\
\hline South Carolina . . . . . . . . . . . . . . . . . . & $\mathrm{x}$ & $\mathrm{x}$ & $\ldots \ldots$ & $\ldots \ldots \ldots$ \\
\hline Tennessee . . . . . . . . . . . . . . . . . . . & $X$ & $\ldots \ldots .$. & $\ldots \ldots \ldots$ & $\ldots \ldots \ldots$ \\
\hline Vermont $\ldots \ldots \ldots \ldots \ldots \ldots \ldots \ldots$ & $X$ & $\mathrm{x}$ & $\ldots \ldots \ldots$ & $\ldots \ldots \ldots$ \\
\hline Virginia . . . . . . . . . . . . . . . & $\mathrm{x}$ & $\mathrm{x}$ & $\mathrm{x}$ & $\ldots \ldots \ldots$ \\
\hline Total . . . . . . . . . . . . . . . . & 17 & 14 & 9 & 4 \\
\hline \multicolumn{5}{|l|}{ Local } \\
\hline$\ldots \ldots \ldots \ldots \ldots \ldots$ & $\ldots \ldots$ & . & $X$ & $\ldots \ldots \ldots$ \\
\hline Phoenix, AZ . . . . . . . . . . . . & $\ldots \ldots \ldots$ & $\ldots \ldots \ldots$ & $\mathrm{x}$ & $\mathrm{x}$ \\
\hline Tempe, AZ $\ldots \ldots \ldots \ldots \ldots \ldots$ & $\ldots \ldots \ldots$ & $\ldots \ldots \ldots$ & $\ldots \ldots \ldots$ & $X$ \\
\hline Tucson, AZ . . . . . . . . . . . . . & $\mathrm{x}$ & $\mathrm{x}$ & $\ldots \ldots \ldots$ & $\ldots \ldots \ldots$ \\
\hline Morro Bay,CA . . . . . . . . . . . . . . & $\mathrm{x}$ & $\mathrm{x}$ & $\ldots \ldots \ldots$ & $\ldots \ldots \ldots$ \\
\hline New London, CT . . . . . . . . . . . . . . . & $x$ & $x$ & $\ldots \ldots \ldots$ & $\ldots \ldots \ldots$ \\
\hline Garden City, GA.. . . . . . . . . . . . . . . . & B & $X$ & $\ldots \ldots \ldots$ & $\ldots \ldots \ldots$ \\
\hline Lawrence, KS . . . . . . . . . . . . . . . & B & $X$ & $\ldots \ldots \ldots$ & $\ldots \ldots \ldots$ \\
\hline Covington, $\mathrm{KY} \ldots \ldots \ldots \ldots \ldots \ldots \ldots$ & $\mathrm{x}$ & $\mathrm{x}$ & $\mathrm{x}$ & $\boldsymbol{X}$ \\
\hline Kenner LA . . . . . . . . . . . . . . . & $\ldots$ & & $\ldots \ldots$ & $X$ \\
\hline Kent County, MD . . . . . . . . . . . . & $\mathrm{x}$ & $\ldots \ldots \ldots$ & $\ldots \ldots \ldots$ & $\ldots \ldots$ \\
\hline Prince George's County, MD . . . . . . . . . . . . & $\mathrm{x}$ & $\mathrm{x}$ & $\ldots \ldots \ldots$ & $\ldots \ldots$ \\
\hline Newton, MA . . . . . . . . . . . . . . . & $\mathrm{x}$ & $\cdots \cdots$ & $\ldots \ldots \ldots$ & $\ldots \ldots \ldots$ \\
\hline$\ldots \ldots \ldots \ldots \ldots \ldots$ & $\mathrm{B}$ & $X$ & $\ldots \ldots \ldots$ & $\ldots \ldots \ldots$ \\
\hline Missouli, MT . . . . . . . . . . . . . . . . & $\mathrm{x}$ & $\mathrm{x}$ & $\ldots \ldots \ldots$ & $\ldots \ldots$ \\
\hline Binghamton, NY. . . . . . . . . . . . . . & $\mathrm{x}$ & $\ldots \ldots \ldots$ & $\ldots \ldots$ & $\ldots \ldots$ \\
\hline Geneva, NY . . . . . . . . . . . . . . & $\mathrm{x}$ & $\mathrm{x}$ & $\ldots \ldots$ & $\ldots \ldots$ \\
\hline Ithaca, $N Y \ldots \ldots \ldots \ldots \ldots \ldots \ldots$ & $\mathrm{x}$ & $X$ & $\ldots \ldots$ & $\ldots \ldots \ldots$ \\
\hline Jefferson County, NY . . . . . . . . . . . . . . . & $\mathrm{x}$ & $\mathrm{x}$ & $\ldots \ldots \ldots$ & $X$ \\
\hline New York, NY . . . . . . . . . . . . . . & $\mathrm{x}$ & $\mathrm{x}$ & $\ldots \ldots \ldots$ & $\ldots \ldots \ldots$ \\
\hline Rockland County, NY . . . . . . . . . . . . . & $\mathrm{x}$ & $\mathrm{x}$ & $\ldots \ldots$ & $\ldots \ldots \ldots$ \\
\hline St Lawrence County, NY . . . . . . . . . . . . & $\mathrm{x}$ & $x$ & $\ldots \ldots \ldots$ & $\ldots \ldots$ \\
\hline Syracuse, NY . . . . . . . . . . . . . . & $\mathrm{x}$ & $X$ & $\ldots \ldots \ldots$ & $\ldots \ldots \ldots$ \\
\hline Tompkins County, NY . . . . . . . . . . . . . . & $\mathrm{x}$ & $X$ & $\ldots \ldots \ldots$ & $\ldots \ldots \ldots$ \\
\hline Vestal NY . . . . . . . . . . . . . . & $\mathrm{x}$ & $\mathrm{x}$ & $\ldots \ldots \ldots$ & $\ldots \ldots \ldots$ \\
\hline Yates County, NY . . . . . . . . . . . . . . & $\mathrm{x}$ & $\ldots \ldots$ & $\ldots \ldots \ldots$ & $\ldots \ldots$ \\
\hline \multicolumn{5}{|l|}{ Facilities: } \\
\hline Golden Gate Bridge, CA . . . . . . . & $\mathrm{x}$ & $\mathrm{x}$ & & \\
\hline Delaware Memorial Bridge, DE . . . . . . . . . & $\mathrm{x}$ & $\mathrm{x}$ & $X$ & $\mathrm{x}$ \\
\hline Francis Scott Key Bridge, MD. . . . . . . . . . . & $\mathrm{x}$ & $\mathrm{x}$ & & $\mathrm{x}$ \\
\hline Harry W. Nice Memorial Bridge, MD . . . . . & $\mathrm{x}$ & $\mathrm{x}$ & $\ldots \ldots \ldots$ & $X$ \\
\hline John F. Kennedy Memorial Highway, MD. & $\mathrm{x}$ & $X$ & & $\mathrm{x}$ \\
\hline
\end{tabular}


Table 4-8.-Commodities Covered by Notification Requirements, 1985-Continued

\begin{tabular}{|c|c|c|c|c|}
\hline & $\begin{array}{l}\text { Spent fuel } \\
\text { and/or high- } \\
\text { level waste }\end{array}$ & $\begin{array}{l}\text { Other } \\
\text { radioactive } \\
\text { materials }\end{array}$ & $\begin{array}{l}\text { Hazardous } \\
\text { wastes }\end{array}$ & $\begin{array}{c}\text { Other } \\
\text { hazardous } \\
\text { materials }\end{array}$ \\
\hline $\begin{array}{l}\text { Susquehanna River Bridge, MD. . . . . . . . . } \\
\text { William Preston Lane, Jr. }\end{array}$ & $\mathrm{x}$ & $\mathrm{x}$ & $\ldots \ldots$ & $\mathrm{x}$ \\
\hline Memorial Bridge, MD . . . . . . . . . . . . . . . & $\mathrm{x}$ & $\mathrm{x}$ & $\ldots \ldots \ldots$ & $\mathrm{x}$ \\
\hline Massachusetts Turnpike Authority, MA. . . & $\mathrm{x}$ & $\mathrm{x}$ & $\ldots \ldots \ldots$ & $\ldots \ldots$ \\
\hline Blue Water Bridge, Ml. . . . . . . . . . . . . . & $\mathrm{B}$ & $\mathrm{B}$ & $\ldots \ldots \ldots$ & $\mathrm{x}$ \\
\hline Mackinac Bridge, Ml . . . . . . . . . . . . . . & $\mathrm{x}$ & $\mathrm{x}$ & $\ldots \ldots \ldots$ & $\mathrm{x}$ \\
\hline Garden State Parkway, NJ . . . . . . . . . . . . & $\mathrm{x}$ & $\mathrm{x}$ & $\ldots \ldots \ldots$ & $\ldots \ldots$ \\
\hline Newark International Airport, NJ . . . . . . & $\mathrm{x}$ & $\mathrm{x}$ & $\ldots \ldots \ldots$ & $\mathrm{x}$ \\
\hline New Jersey Turnpike, NJ , . . . . . . . . . . . . & $\mathrm{x}$ & $\mathrm{x}$ & $\ldots \ldots \ldots$ & $\mathrm{x}$ \\
\hline Bayonne Bridge, NY . . . . . . . . . . & $\mathrm{x}$ & $\mathrm{x}$ & $\ldots \ldots \ldots$ & $\mathrm{x}$ \\
\hline George Washington Bridge: & & & & \\
\hline Expressway, NY . . . . . . . . . . & B & $\mathrm{x}$ & $\ldots \ldots \ldots$ & \\
\hline Lower Level, NY. . . . . . . . . . . . . . . . . . . & $\mathrm{B}$ & $\mathrm{x}$ & $\ldots \ldots \ldots$ & $\ldots \ldots$ \\
\hline Upper Level, NY . . . . . . . . . . . . . . . . . & $\mathrm{x}$ & $\mathrm{x}$ & $\ldots \ldots \ldots$ & $\mathrm{x}$ \\
\hline Geothals Bridge, NY . . . . . . . . . . . & $\mathrm{x}$ & $\mathrm{x}$ & $\ldots \ldots \ldots$ & $\mathrm{x}$ \\
\hline Holland Tunnel, NY . . . . . . . . . . . . . . . & $\mathrm{B}$ & $\mathrm{x}$ & $\ldots \ldots \ldots$ & $\ldots \ldots$ \\
\hline Kennedy International Airport, NY . . . . . . & $\mathrm{x}$ & $\mathrm{x}$ & $\ldots \ldots \ldots$ & $\mathrm{x}$ \\
\hline La Guardia Airport, NY . . . . . . . . . . . . & $\mathrm{x}$ & $\mathrm{x}$ & $\ldots \ldots \ldots$ & $\mathrm{x}$ \\
\hline Lincoln Tunnel, NY . . . . . . . . . . . . . . . . & $\mathrm{B}$ & $\mathrm{x}$ & $\ldots \ldots \ldots$ & $\ldots \ldots \ldots$ \\
\hline
\end{tabular}

NOTE: $X=$ existing; $B=$ bans on transportation.

SOURCE: Battelle Human Affairs Research Center.

quirements have also been established by DOT for carriers of flammable cryogenic liquids. One carrier specializing in radioactive materials transport indicated to OTA that drivers employed by his firm who haul hazardous materials have better safety records than other drivers. ${ }^{125}$ Some carrier associations, insurance industry representatives, State motor vehicle administrators and enforcement personnel, and the National Hazardous Materials Transportation Advisory Committee have voiced strong support for a national hazardous materials driver's license requiring special training and testing. Driver training would emphasize how to handle hazardous materials and respond to accidents. In addition, some large shippers and a few carriers have established special training courses for their drivers; examples of these programs are described in chapter 3.

Several States have already established special certification requirements for drivers of vehicles used to transport hazardous wastes. (See table 4-7.) California recently passed legislation requiring special

\footnotetext{
${ }^{225}$ Charles Mayer, Vice president, Nuclear and Hazardous Materials Division, Tri-State Motor Transit Co., in U.S. Congress, Office of Technology Assessment, "Transcript of Proceedings-Transportation of Hazardous Materials Advisory Panel Meeting," unpublished typescript, Jan. 31, 1986.
}

certification for drivers of vehicles hauling hazardous materials, including hazardous wastes. ${ }^{126} \mathrm{Cer}-$ tification requirements include a medical examination and a written test on applicable Federal and State laws and regulations for the transportation of hazardous materials and safe driving practices. A certificate of training issued by an employer of a driver may be submitted in lieu of the written test. The California Highway Patrol and the Department of Motor Vehicles are presently developing training regulations for drivers.

In addition to driver training and licensing, there is also a need for improved access to information on driver and carrier performance on a nationwide basis. While existing Federal databases, described in chapter 2 , record data on violations and accidents, they would be more useful if they were interfaced and made accessible to State enforcement personnel. The SAFETYNET Program, being developed by FHWA, and the National Driver's Registry, being developed by the National Highway Traf-

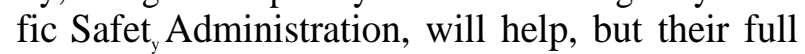
implementation is at least a decade away.

\footnotetext{
${ }^{126}$ California Senate Bill No. 895, ch. 667, Statutes of 1984. Amendments to the California law are presently under consideration.
} 


\section{Routing Requirements}

Routing is an important tool for local governments for preventing or reducing the consequences of hazardous materials accidents, and increasing numbers of cities, counties, and townships are adopting ordinances requiring hazardous materials carriers to use designated routes. Carefully made routing decisions restrict hazardous materials shipments to the safest routes, often Interstate highways and beltways, providing a low cost prevention measure that local police can enforce without additional equipment or training. On the other hand, routing requirements may lengthen and complicate trips for truckers, and sometimes bring local governments into conflict with each other or with Federal regulations governing interstate commerce. The trucking industry has challenged some local routing ordinances, claiming that they interfere with interstate commerce (see discussion below).

Two Federal regulations pertaining to the routing of hazardous materials were described earlier in this chapter. The first is a general statement directing drivers of vehicles carrying nonradioactive hazardous materials to use routes avoiding heavily populated areas and tunnels, narrow streets, or alleys. ${ }^{27}$ The second regulation, referred to as DOT Docket HM-164, applies to shipments of radioactive materials. The first part of the regulation requires carriers of all radioactive materials to operate on routes that minimize radiological risk. The second part applies only to highway route controlled quantities of radioactive materials, such as spent nuclear fuel; it requires the use of Interstate highways and beltways or State-designated alternate routes. ${ }^{122}$

To assist States and communities with the designation of routes for both radioactive and nonradioactive shipments of hazardous materials, DOT published two guidance documents. Both publications

\footnotetext{
${ }^{127} 49$ CFR 397.9(a). In 1977, the Bureau of Motor Carrier Safety Pro vided an interpretation of this provision stating:

Section 397.9(a) is not meant to preclude the use of expressways or major thoroughfares to make deliveries within a populated area. In many instances, a more circuitous route may present greater hazards due to in. creased exposure. However, in those situations where a vehicle is passin through a populated or congested area, use of a beltway or other bypass could be considered the appropriate route, regardless of the additional economic burden

42 F.R. 60088, Nov. 23, 1977

${ }_{128} 49$ CFR 177.825. Highway route controlled quantities are defined in 49 CFR 173.403(1).
}

underscore the importance of involving a broad spectrum of communit and industry members and neighboring jurisdictions in the route selection process. This approach encourages States and localities to: tap the knowledge and resources of persons and organizations experienced in the transportation of hazardous materials, identif the scope and objectives of a routing assessment at the outset, and determine whether and how to weight subjective factors in the routing analysis. It also provides a forum for addressing related safety issues such as vehicle inspections and emergency response capabilities. A 1983 demonstration program in Portland, Oregon, which successfull tested the DOT guidelines for nonradioactive materials, concluded that participation $b_{y}$ all affected parties earl $l_{y}$ in the plannin ${ }_{g}$ process increases the likelihood of consensus as to which routes are safest. ${ }^{129}$ See chapter 2 for a description of data-collection activities related to routing assessments.

Nonradioactive Materials.-The nonradioactive materials guidelines include procedures for analyzing risks associated with the use of alternative routes within a jurisdiction. ${ }^{130}$ The risk assessment is based on the probabilit of a hazardous materials accident and the consequences of such an accident measured in terms of the population and/or propert located inside the potential accident impact zone. ${ }^{{ }_{131}}$ Other

\footnotetext{
${ }^{129} \mathrm{City}$ of Portland, Oregon, offic of Emergenc ${ }_{\mathrm{y}}$ Management, Hazardous Materials Highway Routing Study (Washington, DC: U.S. Department of Transportation, 1984), p. 48. The Portland experience is summarized in U.S. Congress, Office of Technology Assessment, Transportation of Hazardous Materials: State and Local Activities, op. cit., pp. 34-35.

${ }^{130}$ E.J. Barber and L.K.Hildebrand, Peat, Marwick, Mitchell, \& Co., Guidelines for Applying Criteria To Designate Routes for Transporting Hazardous Materials, Implementation Package FHWA-IP-80-20 (Washington, DC: U.S. Department of Transportation, 1980).

${ }^{131}$ In 1985, the Ohio-Kentucky-Indiana (OKI) Regional Council of Governments discovered an error in the calculation of the population consequence factor. The U.S. Department of Transportation (DOT) acknowledged the error ("population density" for a route segment should have been used instead of "population"), notin that it does distort route analysis and that it only becomes apparent when route segment lengths are extremely disparate. S.C. Chu, DOT, Research and Special Programs Administration, letter to A.H.Hessling, Executive Director, OKICouncil of Governments, May 3, 1985. Another recent application of the DOT guidelines in Dallas-Fort Worth recognized this error and took into account the length of each link or route segment in the estimation of the impact area. Dan Kessler, "Establishin ${ }_{8} \mathrm{Haz}$ ardous Materials Truck Routes for Shipments Through the Dallas-Fort Worth Area," in Transportation Research Board, "Proceedings From the Conference on Recent Advances in Hazardous Materials Transportation Research: An International Exchange," unpublished typescript, Nov. 10-13, 1985, pp. 443-464.
} 
U.S. Refuses to Forbid Trucking Atomic Waste Through New York

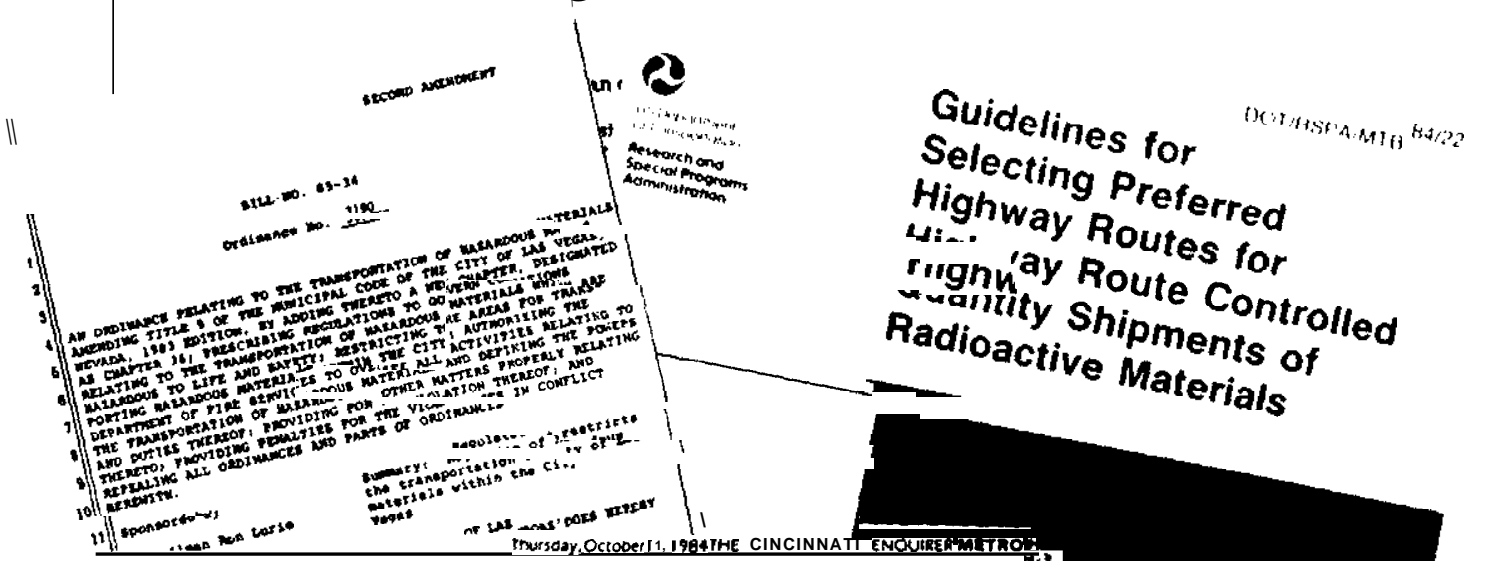

\section{Suburban Officials Leery Of Study} On Routes For Hazardous Cargoes

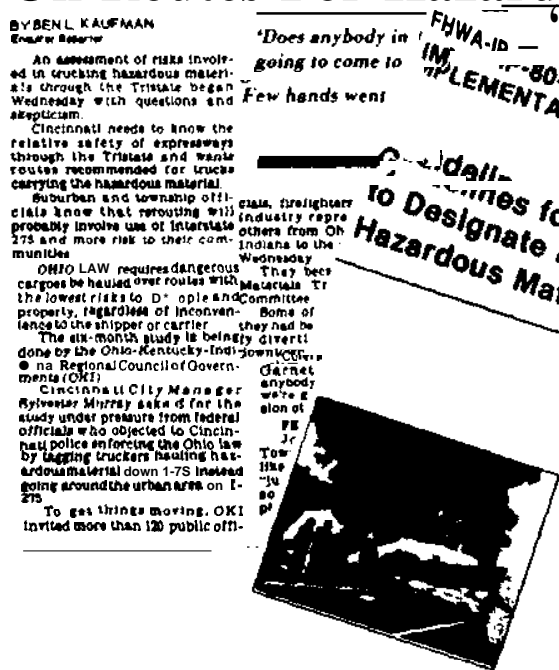
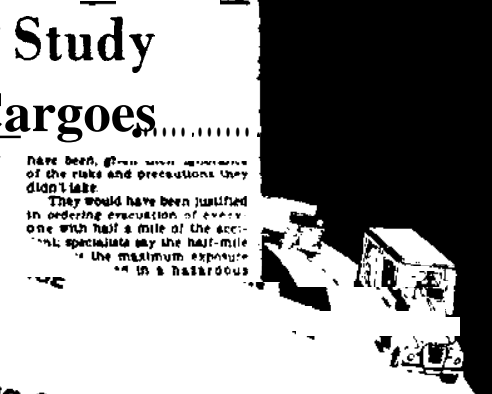
factors, such as emergency response capabilities, and proximity to sensitive ecological areas or populations that may be unable to evacuate themselves, may be applied when a risk analysis does not indicate that one alternative is clearly superior to the others. The guidelines suggest that such factors be selected $b_{y}$ consensus, reflecting community priorities.

A number of cities including Columbus, Denver, and Boston, have established hazardous materials routing restrictions based on the general routing provision of the Motor Carrier Safety Regulations. ${ }^{132}$ The types of regulations enacted by these jurisdictions include: restricting the use of certain roads, prohibiting transportation and delivery during rush hours, and specifying operating requirements.

However, reaching a regional consensus on routing is frequentl difficult, even when a broad community spectrum is consulted. Often, for example, after a community routing risk assessment has been completed, hazardous materials carriers are diverted from central city routes onto surrounding roadways - usually Interstate highways - that traverse less populated areas. Since many suburban communities do not have specialized hazardous materials response teams like their urban neighbors, they feel particularly vulnerable to increased hazardous materials traffic and resist agreeing to such routing requirements.

Since 1985, suburban townships in the Cincinnati region have opposed the city's efforts to divert through shipments from the Interstate highways passing through the city onto outlying highways. In contrast, Portland, Oregon, and neighboring jurisdictions succeeded in establishing a regional routing plan. The city enacted an ordinance banning hazardous materials shipments from a tunnel that had been used frequently by trucks carrying petroleum products from the city to other parts of the State because fire officials determined that the tunnel posed an unacceptabl high risk. (Portland also banned shipments from two grade-level rail crossings.) To compensate for any additional risks

\footnotetext{
${ }^{132}$ See, e.g., Columbus Codes, 1959, Chapter 2551: Article VI of Chapter 22 of the Denver Municipal Code; and 46 F.R. 18921, Mar. 26, 1981, for a description of Boston's regulations. The Boston regulations have been challenged by the State and national trucking associations; the lawsuit is discussed later in this chapter.
}

posed by the rerouting decisions, the city of Portland and three adjoining counties revised their mutual aid agreements to ensure that the affected counties would have access to the city's specialized firefighting equipment.

Selecting routes within an urban jurisdiction may also be difficult. In Dallas-Fort Worth, a regional routing assessment based on the DOT guidelines found that the safest route through Dallas is the Interstate. However, a Dallas ordinance enacted in 1978 prohibits local hazardous materials vehicles from using the elevated or depressed portions of the Interstate, diverting shipments onto city arterials. City, State, and regional officials are currently working together to resolve this conflict; options under consideration include restricting the times when the Interstate and city arterials can be used for transporting hazardous materials and upgrading sections of the Interstate highway. ${ }^{133}$

Radioactive Materials.-The procedures established by DOT for State officials interested in designating alternate routes for radioactive shipments under HM-164 are somewhat different, ${ }^{134}$ The objective of the route selection methodology presented in the guidance document for radioactive materials is to determine the route within a State to minimize the radiological impacts. Routing agencies in neighboring States are advised to work together, as selected routes in each State must match preferred routes in bordering States. The guidelines suggest the formation of interstate or regional coalitions for the selection of routes and note that States might also enter into agreements designating, as portions of preferred routes, ferry routes for the transport of motor vehicles on waters within their jurisdictions.

The methodolog is based on the use of comparative risk index figures, not actual risk figures. The primary route selection factors identified by DOT are the levels of radiation exposure from normal transport, and the public health and economic (decontamination costs) risks associated with the accidental release of radioactive materials. Public

\footnotetext{
${ }^{133}$ Dan Kessler, North Central Texas Council of Governments, Arlington, TX, personal communication, Mar, 11, 1986

${ }^{134}$ U.S. Department of Transportation, Research and Special Programs Administration, Guidelines for Selecting Preferred Highway Routes for High way Route Controlled Quantity Shipments of Radioactive Materials, DOT/RSPA/MTB-84/22 (Washington, DC: June 1984 (originally published in June 1981)).
} 
health risks are determined by the frequency of severe transportation accidents and the number of people that could be affected by a release. A method for determining the population within a potential impact area is suggested. Secondary factors may be used if a clear-cut choice does not emerge from evaluation of the primary factors or if unusual conditions exist in the State that increase the importance of one or more of the secondary factors. ${ }^{133}$ These factors include emergency response and evacuation capabilities, the location of special facilities, and traffic fatality and injury rates. Procedures for comparing secondary factors based on the use of arbitrary scaling systems are also provided.

The guidelines have been used independently by New York City and Connecticut to evaluate the safety of shipping spent nuclear fuel from Long Island on routes through the city and through Connecticut using a ferry to cross Long Island Sound. The New York City case, described in box 4B, provides an example of the difficulties that can be encountered when routing decisions are made without interjurisdictional consultation.

\section{Other State and Local Regulatory Activities}

A number of States and localities have passed two other types of laws concerning their ability to collect data and protect emergency responders from liability.

Right-To-Know Laws. - Many States and municipalities have passed legislation, commonly referred to as "right-to-know" laws, requiring the release of information on the hazards associated with chemicals produced or used in a given facility. (Chapter 2 discusses fixed facility inventories that have been conducted by communities.) These laws have been adopted because some manufacturers have been unwilling to comply with requests for information due to concerns about protecting trade secrets or other information considered to be proprietary.

The majority of State right-to-know laws address both community and employee access to information about workplace hazards. Table 4-9 lists the States that have passed such laws. The provisions

\footnotetext{
") Ibid, p. 7.
}

Table 4-9.-State Right-to-Know Laws, 1985

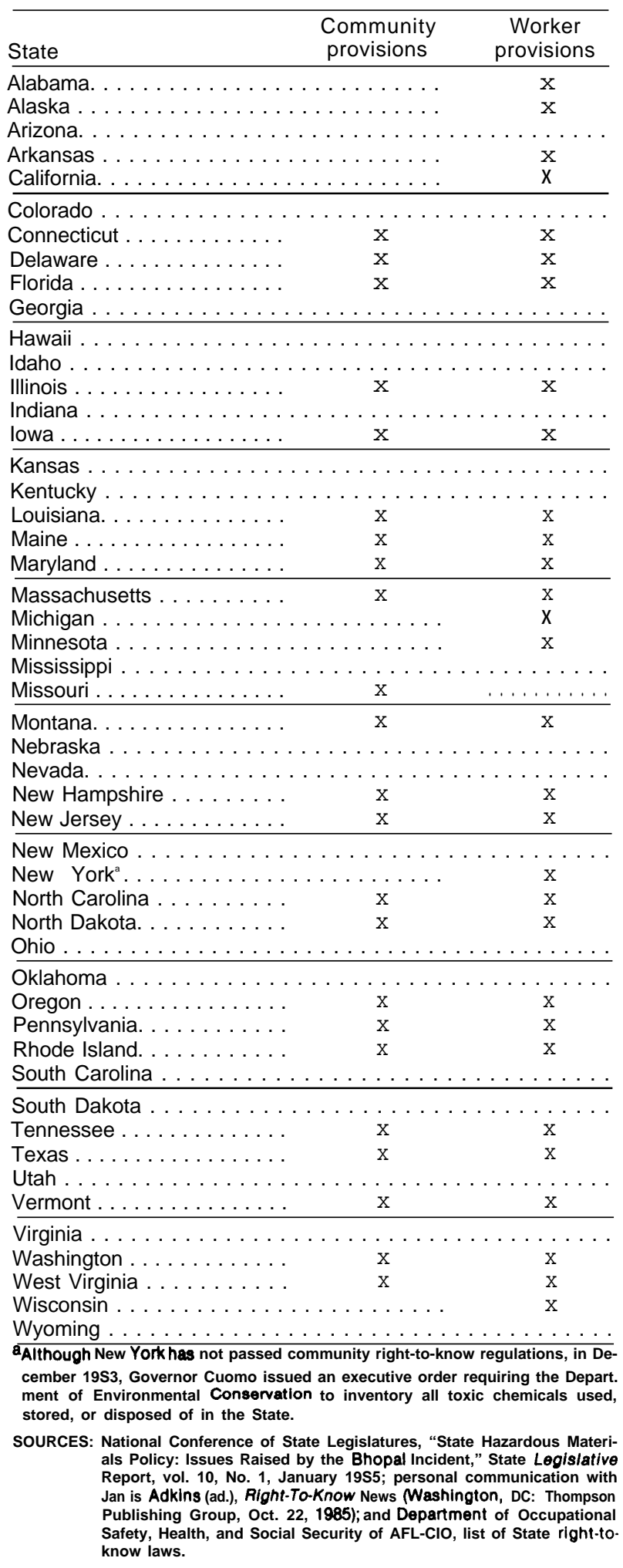




\section{[Page Omitted]}

This page was originally printed on a gray background.

The scanned version of the page is almost entirely black and is unusable.

It has been intentionally omitted.

If a replacement page image of higher quality

becomes available, it will be posted

within the copy of this report

found on one of the OTA websites. 
agency. ${ }^{7}$ New York City subsequently filed an administrative appeal with DOT. The city's appeal contends that no basis exists for the finding that a demonstration of exceptional circumstances is a necessary precondition for a nonpreemption determination; that the city does not have recourse to a State routing agency because all alternate routes go through Connecticut, which has opposed the designation of alternate routes; that DOT erred in failing to consider the city's safety analysis; and that the ruling was inconsistent with prior statements made by DOT. ${ }^{8}$ DOT has requested public comments on the city's appeal.

New York City has also indicated that it believes that existing statutory and regulatory procedures to resolve interjurisdictional conflicts are time-consuming and inadequate. The city urges that an amendment to the HMTA divesting DOT of its authority to issue nonpreemption determinations be considered by Congress. ${ }^{9}$

\footnotetext{
750 F.R. 37308, Sept. 12, 1985

550F.R. $47321-22$, Nov. 15, 1985

'Harvey W. Shultz, Commissioner, City of New York, De partment of Environmental Protection, personal communication by letter Apr 30,1986 Members of the New York State Congressional Delegation have introduced bills in the 99th Congress that would restrict the transportation of high-level radioactive materials through densely populated metropolitan areas. See H.R. 1105, introduced by Representative Mario Biaggi on Feb. 19, 1985, and H.R. 2938 intro. duced by Representative Bill Green on July 9, 1985.
}

of these laws are not uniform, either in terms of the obligations placed on industry or in terms of the types of hazardous materials covered. States have also taken different approaches to exemptions according to business size or quantities of material involved and the extent to which firms may protect trade secrets. Increasing numbers of local governments are also enacting their own right-to-know statutes.

The requirements of right-to-know laws most relevant to hazardous materials planning and emergency response include providing public access to information on hazardous materials present in a locality or State, conducting inventories or surveys, establishing recordkeeping and exposure reporting systems, and complying with container labeling regulations for workplaces. As described earlier in this chapter, OSHA now requires chemical manufacturers and importers to prepare MSDSs for all hazardous materials produced or used. Some States and localities specifically require that copies of MSDSs be made available to a State agency or local fire chief as part of their community right-to--know programs.

Good Samaritan Laws.-Governmental entities and industry are concerned that they may be held responsible for emergency response activities that result in damages. Good Samaritan laws have been enacted by at least 38 States to relieve the burden of potential liability for persons who assist during a hazardous materials transportation accident. ${ }^{136}$ While most of these laws exclude gross negligence or willful misconduct, many States have limited the scope of liability protection in other ways. These differences are significant as they may affect whether and how emergency assistance is provided in a given State.

Some laws specify that emergency response personnel who have received a certain level of training are not relieved from liability. Consequently, members of specially trained hazardous materials response teams may not be covered by certain Good Samaritan laws. In contrast, a number of statutes provide immunity to individuals possessing certain qualifications such as training or education. Furthermore, some laws require that unless assistance is requested by a State or local official, persons who provide emergency assistance may not be extended immunity from liability. Additional differences in these laws include the types of hazardous materials addressed (for instance, some are restricted to compressed gases) and whether compensation is provided to emergency responders.

\footnotetext{
${ }^{136}$ See National Conference of State Legislatures, Hazardous Materials Transportation-A Legislator's Guide (Washington, DC: Febru$\operatorname{ar}_{y}$ 1984), pp. 84-85 and app. F. Additional information was obtained from a report on State Good Samaritan Statutes, prepared by Lawrence W. Bierlein for the Chemical Manufacturers Association, Sept. 30, 1985.
} 


\section{Regulatory Consistency}

States and localities, responding to what they find to be limitations of the Federal regulatory program, have enacted their own laws and regulations. Interstate shippers and carriers, reacting to what they feel are unreasonable burdens on interstate commerce, have asked Federal courts to preempt some of these State and local requirements. DOT's efforts to resolve interjurisdictional conflicts have been focused on case-by-case advisory rulings that determine whether State and local requirements are consistent with the HMTA and the hazardous materials transportation regulations.

\section{Preemption Under the HMTA}

While Congress granted DOT a broad mandate to regulate the transportation of hazardous materials, a regulatory role for State and local governments is preserved by Section 112 of the HMTA, in deference to their inherent powers to enact legislation to protect the health, safety, and general welfare of the public. However, the legislative history of Section 112, although limited, indicates that Congress intended to "preclude a multiplicity of State and local regulations and the potential for varying as well as conflicting regulations in the area of hazardous materials transportation. ${ }^{*} 37$ Thus, while Section 112(a) preempts State or local requirements that are inconsistent with the HMTA requirements or regulations issued under it, Section 112(I3) provides that an otherwise inconsistent State and local requirement may not be preempted if DOT determines that it affords an equal or greater level of protection to the public than Federal requirements and does not unreasonably burden commerce. ${ }^{138}$ The latter provision was included because Congress also realized that certain exceptional circumstances might warrant more stringent State or local regulation.

Although the HMTA explicitly authorizes DOT to issue preemption waivers under Section 112(b), a similar delegation of authority is not made for deciding inconsistency questions under Section 112(a). To provide a forum for resolving interjurisdictional conflicts under the HMTA, DOT established procedures in 1976 allowing States, localities,

\footnotetext{
${ }^{137}$ U.S. senate, Report No. 93-1192, 93d Cong., 2d sess., 1974, pp. 37-38.

${ }^{138} 49$ U.S.C. 1811
}

affected parties, and DOT itself to initiate an administrative ruling process to determine whether State or local requirements are inconsistent. ${ }^{139}$ This administrative process is advisory only and does not preclude judicial review of a State or local requirement. Independent of the DOT procedures, a Federal court may be asked to decide whether a State or local requirement is inconsistent and therefore preempted under the HMTA or is invalid under the Commerce Clause of the U.S. Constitution.

The standards applied by DOT in determining if a State or local requirement is inconsistent are the same as those used by the courts in preemption cases:

- whether compliance with both the State or local requirement and the HMTA is possible (the dual compliance or direct conflict test), and

- the extent to which the State or local requirement is an obstacle to the accomplishment and execution of the act and regulations issued under it (the obstacle test).

The latter test is applicable irrespective of whether a direct conflict exists. The steps that must be followed to obtain an inconsistency ruling are specified in figure 4-8.

DOT has indicated that there are "strong policy reasons" for an administrative review; the process provides an opportunity to conduct a broader inquiry than one typically undertaken by a court, and it allows for diverse comments because notices are published in the Federal Register. ${ }^{141}$ A finding of inconsistency under the DOT review process can also serve as the basis for an application for a waiver of preemption.

A waiver of preemption can be granted for an inconsistent State or local requirement under the HMTA if DOT finds that it affords an equal or greater level of protection to the public than Fed-

\footnotetext{
${ }^{139} 49$ CFR 107.203 to 107.211 . The regulations were originally published on Sept. 9, 1976, 41 F.R. 38167. It should be noted that the U.S. Department of Transportation's administrative process does not address Commerce Clause considerations; these are reviewed by the courts.

${ }^{141}$ U.S. Departments of Justice and of Transportation, Brief for the Department of Transportation as Amicus Curiae, New Hampshire Motor Transport Association v. Flynn, U.S. Court of Appeals for the First Circuit, No. 84-1226, November 1984, pp. 6-7.
} 
Figure 4=8.-Procedures for Inconsistency Rulings

A. Application and comments

\begin{tabular}{l} 
Applications must be submitted to \\
RSPA by States, pollical \\
subdivisions, or any affected person \\
requesting an inconsistency ruling. \\
Application must specity the Federal \\
and State/local requirements to be \\
compared and the reasons why the \\
applicant belleves the requirement(s) \\
in question is consistent or \\
inconsistent. RSPA may also decide \\
to review a State or local requirement \\
on its own initiative. \\
\hline
\end{tabular}

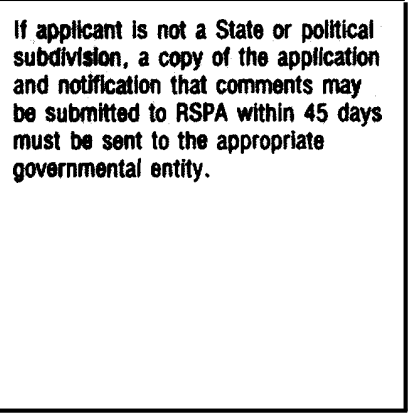

B. Processing

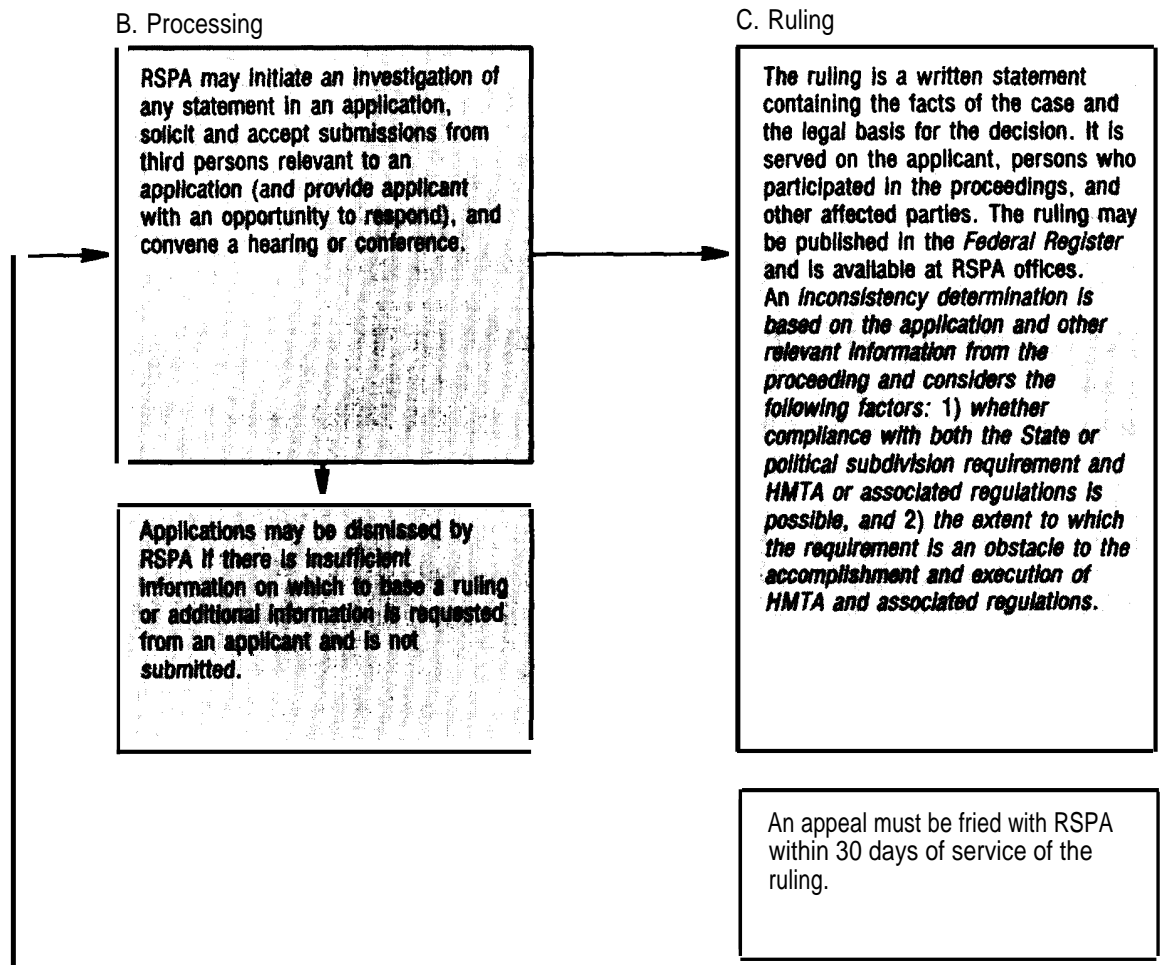

RSPA may notify other affected parties to afford those persons an opportunity to submit comments. This can be done by notice or publication in the Foderal Register.

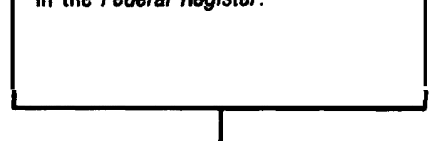

All comments submitted to RSPA must also be sent to the applicant. Commentors must certity to RSPA that this requirement has been fulfilled. ASPA may notify other

persons participating in the proceeding of these comments and provide an oportunity to respond.

NOTE RSPA $=$ Research and Special Programs Administration; HMTA $=$ Hazardous Materials Transportation Act SOURCE Office of Technology Assessment staff based on 49 Code of Federal Regulations 107203 to 107211

eral requirements and does not unreasonably burden commerce. The factors considered by DOT in assessing whether interstate commerce is unduly burdened are:

- the extent to which increased costs and impairment of efficiency result from the State or local requirement;
- whether the State or local requirement has a rational basis;

- whether the State or local requirement achieves its stated goals; and

- whether there is a need for uniformity with regard to the subject concerned, and if so, whether the State or local requirement com- 
petes or conflicts with those of other States or local entities. ${ }^{142}$

These criteria have been drawn from Supreme Court decisions regarding the validity of various State transportation safety requirements. ${ }^{143}$ The procedures that have been developed for granting a waiver of preemption are presented in figure 4-9. Applications for waivers of preemption are considered by DOT only if the State or locality acknowledges that the requirement in question is inconsistent, DOT rules that it is inconsistent, or a court decides that the requirement is inconsistent with the HMTA. ${ }^{14}$

In lieu of requesting a waiver of preemption, State and local entities have the option of petitioning DOT to establish, amend, or repeal a Federal regulation. The steps involved in undertaking such an action are also set forth in 49 CFR. ${ }^{14}$

\section{DOT Policy Guidance for State and Local Requirements}

When DOT issued routing regulations for radioactive materials, Docket HM-164, an appendix was also published containing DOT policy and advice to State and local governments regarding their authority over motor carriers in relation to HM-164. State and local rules addressed by the appendix include those that effectively redirect or otherwise significantly restrict or delay highway movements of hazardous materials, and that apply because of the hazardous nature of the cargo. Permits, fees, and similar requirements are included if they have such effects. The definition excludes State or local emergency actions and traffic controls that are not based on the nature of the cargo, such as truck routes based on vehicles' weight or size. ${ }^{146}$

DOT explicitly notes that a State routing rule is inconsistent if it prohibits transportation by high-

\footnotetext{
${ }^{142} 49$ CFR I w . ill (b)

14141 F R 38168 , Sept. 9, 1976.

${ }^{144} 49$ CFR 107.219(c).

14549 CFR 106.31. Petitions to establish, amend, or repeal a regulation must: 1) set forth the text or substance of the regulation or amendment proposed, 2) explain the interest of the petitioner in the action requested, and 3) contain any information and arguments available to the petitioner to support the action sought.

${ }^{146}$ Note that the appendix to HM- 164 is not a regulation and was intended to guide State and local governments contemplating rulemaking action as to the likelihood of such actions being deemed inconsistent. 49 F.R. 46634, Nov. 27, 1984.
}

way between two points without providing an alternate route or if it does not meet three criteria:

. it must be established by a State routing agency, . it must be based on a comparative risk assessment at least as sensitive as the one outlined in DOT guidelines, and

. $i_{1}$ must be based on solicitation and substantive consideration of views from affected States and local jurisdictions.

Local governments may regulate shipments of radioactive materials only if the routes they choose are consistent with those designated by Federal and State authorities. New York City, concerned about the safety of through shipments of spent nuclear fuel, has opposed the regulatory restrictions placed on municipalities by HM-164. This case is described in box 4B.

In addition, the appendix provides guidance on related State and local rules. It states that a requirement is inconsistent with HM-164 if it:

- conflicts with the physical security requirements of NRC or DOT requirements;

- requires additional or special personnel, equipment, or escorts;

- requires additional or different shipping papers, placards, or other warning devices;

- requires filing advance route plans containing information that is specific to individual shipments;

- requires prenotification;

- requires accident or incident reporting other than that needed for emergency assistance; or

- unnecessarily delays transport.

\section{DOT Inconsistency Rulings}

As of May 1986, 16 inconsistency rulings have been issued by DOT. The inconsistency rulings are lengthy legal analyses that address requirements established by States, local jurisdictions, and individual bridge and highway authorities. (Appendix B contains a description of each case and a summary of the inconsistency ruling decisions for the major types of requirements examined.) The scope of the requirements reviewed in these decisions ranges from regulations governing a particular aspect of hazardous materials transportation, such as shipping papers, to comprehensive regulatory programs. Most 
Figure 4=9.-Procedures for Nonpreemption Determinations

A. Application and comments

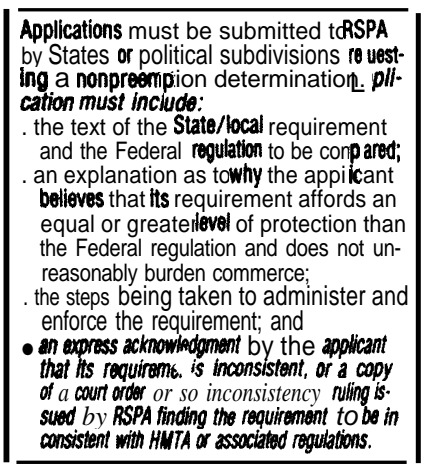

Applicant must send a copy of the collication to all affected parties. Nolficication that comments may be Notilication that comments may be
submitted to RSPA within 45 days submitted to RSPA within 45 days
must also be provided. ad pllcant belleves that ryiring allfiected parties is impractible, notification of a reasonable and practicaple list of
parties may be undertaken $A S P A$ must be provided with a description of the parties not notified. RSPA reserves the right to determine that the number of facted partiesis not impracticate that additional parties must be notified or that notice should be published in the Federal Register.

RSPA manotify other affectedparties to aford those persons an oppor. tunity to submit comments.
B. Processing

RSPA may Initiate an Investigation of any statement in an application, solicth and accopt submissions from third persons rolovant to an application (and prowide applicant with an oppor\& or conterence.

To the extent possiblo, ouch applica. tfon wiff bacedion by ASPA in a manner consistent with the disposition of previous nonpreemption determination applications.

Applicants and affoctur wantill be notified by RSPA when all substantive information haseen received.

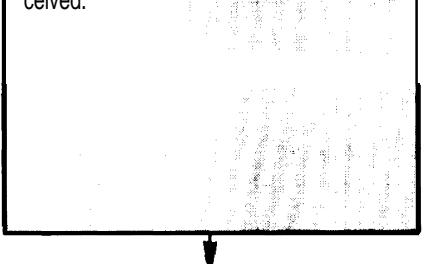

Applications may be teralseed by RSA if: there is insurficlont informatfon on which to baas* bolomina. tion, additional informat is to

guested from an apolletand is not Submitted or antrant das not comply with notficat requirements.

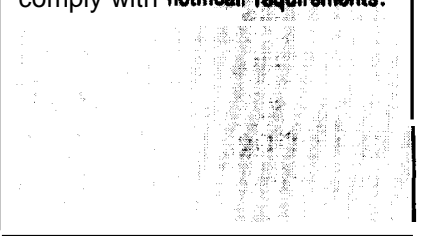

C. Ruling

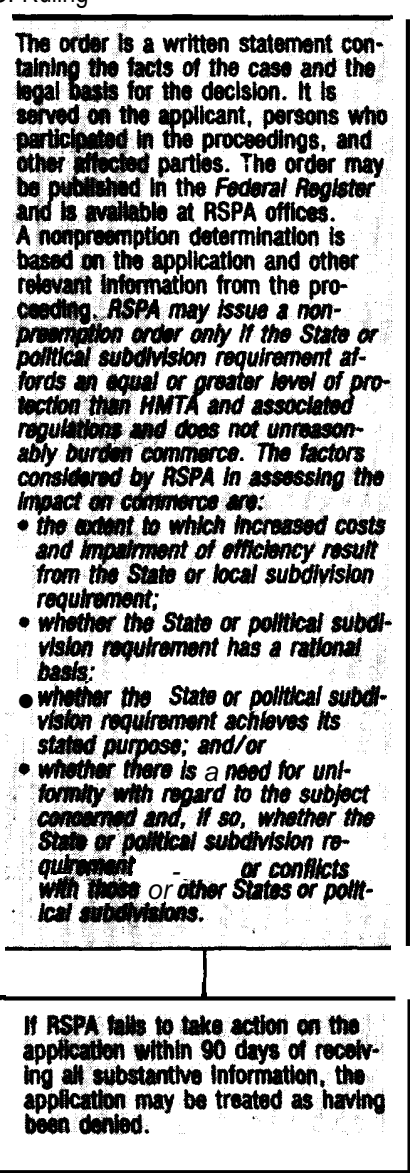

An appeal must be filled with RSPA within 30 days of sorvice of the

order. must aleo be sent to the applicant. commenters must certify to ASPA that this requirement has been fulfilled. RSPA may notify other person participating in the proceeding of these comments and provide an opportunity to respond.

NOTE RSPA $=$ Research and Special Programs Administration; HMTA = Hazardous Materials Transportation ACt

SOURCE Off Ice of Technology Assessment staft based on 49 Code of federal Regulations 107215 to 107225

of the requirements examined by DOT applied exclusively to highway transport; however, in three cases (Michigan; Vermont; and Covington, Kentucky) rail and water modes were also affected.

The decisions reached by DOT in each case were based on the application of the dual compliance and obstacle tests. The dual compliance test is a straightforward determination of whether compliance with both the State or local requirement and the appli- cable Federal requirement can be achieved. The obstacle test is somewhat more complex and involves an examination of the:

, , . full purposes and objectives of Congress in enacting the HMTA and the manner and extent to which those purposes and objectives have been carried out through MTB's regulatory program. ${ }^{147}$

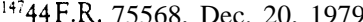


The purposes and objectives that have been identified by DOT include protecting the Nation adequately against the risks to life and property inherent in the transportation of hazardous materials, and precluding a multiplicity of State and local regulations and the potential for varying and conflicting regulations. 148 Critics of DOT argue that safety and uniformity should not be given equal weight in the decision process. It is their belief that Congress was primarily concerned with safety; therefore, State and local requirements that vary from Federal ones but provide a greater degree of protection should be allowed. ${ }^{149}$

Generally, consistent non-Federal requirements are those DOT considers appropriate areas for State and local regulation and for which comparable Federal requirements have not been promulgated. Consistent requirements pertain to traffic control and safety hazards peculiar to a local area and include immediate notification of local officials when accidents occur, the use of headlights and vehicle separation distances, vehicle inspections, the imposition of penalties associated with valid local regulations, and certain types of communication equipment. When routing regulations increase safety and are enacted in consultation with affected neighboring jurisdictions, they are considered to be consistent requirements. In addition, DOT has indicated in these rulings that permit requirements as such are not inconsistent; it is the impact of such a requirement, such as causing shipment delays, that determines its validity. However, all of the permit requirements examined by DOT to date have been found to be inconsistent. $* 50$

Other inconsistent State and local requirements pertain to areas already subject to Federal regulation or result in traffic diversions and increased transit times. These requirements encompass packaging regulations; hazard communication systems, includ-

\footnotetext{
${ }^{44} 47$ F.R. 1231, Jan. 11, 1982.

${ }^{149} \mathrm{See}$ "Defendants Memorandum of Law in Opposition to Plaintiffs Motion for Summary Judgment," National Paint and Coatings Association Inc. v. City of New York, Apr. 11, 1985, submitted to the U.S. District Court for the Eastern District of New York.

${ }^{150}$ These decisions, inconsistency rulings 2, 8, and 10 to 16 , are de scribed in app. B. In inconsistency ruling 3, while DOT found that a Boston regulation requiring transporters to carry permits in a vehicle cab was consistent, a ruling on the validity of the permitting system itself was not issued.
}

ing hazard classification; shipping papers, marking, labeling, and placarding requirements; insurance requirements; prenotification; written accident reports; permits as a precondition to transport; and the use of additional escorts or equipment. In one case, a $\$ 1,000$ fee, assessed per shipment of certain radioactive materials, was also determined to be inconsistent. ${ }^{151}$ Furthermore, transportation bans or other routing restrictions enacted without evaluation of the safety impacts and consultation with affected communities were also found to be inconsistent.

\section{The Role of the Courts}

Aside from New York's legal challenge of HM164, other Federal court decisions have been issued on the validity of specific State and local laws and regulations. 152 Most of the lawsuits have been filed by national or State trucking associations. In four cases, the lawsuits pertain to non-Federal requirements that are also the subjects of DOT inconsistency rulings. ${ }^{153}$ While a DOT inconsistency ruling does not preclude judicial review, the courts have given weight to the rulings in their decisions. '54 Preemption provisions of other Federal laws are also considered by the courts as appropriate; for example, the Atomic Energy Act is relevant to cases involving shipments of radioactive materials. A brief

\footnotetext{
${ }^{151}$ The U.S. Department of Transportation (DOT) asserted that this requirement, established by Vermont, was inconsistent because it was discriminatory, diverted shipments, and replicated Federal emergency response efforts. Monies collected were to be used for a monitoring (response) team. See inconsistency ruling 15,49 F.R. 46660, Nov. 27, 1984. As this report went to press, DOT issued inconsistency ruling 17 concerning an Illinois law that assesses a $\$ 1,000$ fee for spent nuclear fuel shipments. DOT found the Illinois fee to be consistent with the HMTA. 51 F.R. 20926, June 9, 1986.

${ }^{152}$ City of New York v. Ritter Transportation Inc., 515 F. Supp. 663 (1981); National Tank Truck Carriers, Inc. v. City of New York, 677 F. 2d 559 (1983); New Hampshire Motor Transport Association v. Flynn, 751 F. 2d 43 (1984); and American Trucking Association, Inc. v. Larson, 683 F. 2d 787 (1982). It should be noted that the Larson case upheld a Pennsylvania statute requiring periodic inspections of all motor carrier vehicles, whether or not they are used to transport hazardous materials and are registered in the State.

held a Pennsylvania statute requiring periodic inspections of all motor carrier vehicles, whether or not they are used to transport hazardous materials and are registered in the State.

${ }^{153}$ These cases include inconsistency rulings 1,2,3, and 5. App. B, which contains of a summary of inconsistency rulings, also describes related lawsuits,

${ }^{154}$ See for example, New Hampshire Motor Transport Association v. Flynn, 751 F. 2d 43 (1984) and National Tank Truck Carriers, Inc. v. Burke. 535 F. Supp. 509 (1982).
} 
overview of relevant constitutional provisions is presented in box $4 \mathrm{C}$.

Federal court decisions issued to date have generally been in agreement with DOT's inconsistency rulings. For example, the courts have struck down State and local requirements for written accident reports, vehicle equipment, vehicle markings and placards, container testing, and statewide curfews, while upholding requirements for local inspections, immediate accident reporting, operational requirements such as the use of headlights, and local curfews.
The courts have reviewed the validity of permit and license requirements established by New Hampshire, New York City, and Rhode Island. A 1983 New Hampshire law imposing license and fee requirements on vehicles transporting hazardous materials was upheld by the U.S. Court of Appeals for the First Circuit; these requirements provided transporters with the option of obtaining an annual or single-trip license. ${ }^{155}$ A New York City regulation

${ }^{155}$ New Hampshire Motor Transport Association v. Flynn, 751 F.
$2 \mathrm{~d} 43$ (1984), This opinion reversed the decision of the lower court.

\section{Box 4C.-Constitutional Considerations}

State and local entities traditionally exercise their police powers to protect public health, safety, and general welfare. On the other hand, the Federal Government is endowed with broad regulatory powers by the Supremacy and Commerce Clauses of the U.S. Constitution. The courts have established basic guidelines to be used in deciding whether State or local requirements are preempted by Federal law or are invalid because they unduly burden interstate commerce. These guidelines or tests are applicable to \&es involving the transportation of hazardous materials.

The ability of the Federal Government to preempt State laws is derived from the Supremacy Clause, under which State laws that conflict with Federal statutes are nullified. 'Existing case law on the subject of Federal preemption identifies four major factors considered by the courts in reviewing the validity of State or local regulatory actions: whether there is an explicit congressional statement in the applicable Federal statute; whether preemption can be implied (based on the legislative history, the extent to which there is Federal occupation of the subject area, and whether there is a need for national uniformity); whether compliance with both Federal and State law is possible; and whether the State law serves as an obstacle to accomplishing the purposes and objectives of Congress.

In those instances where Congress has not preempted non-Federal action, State laws can still be invalidated if they are found to violate the Commerce Clause; this constitutional provision authorizes Congress to "regulate Commerce with foreign Nations, and among the several States, and with Indian Tribes." ${ }^{\prime 3}$ While this state ment does not explicitly limit State interference with interstate commerce, the "negative implication" of the Commerce Clause has been interpreted to mean that in the absence of congressional action, States may not erect barriers to the free flow of interstate commerce.

There are two tests used by the courts in evaluating alleged violations of the Commerce Clause. First, a State or local requirement must be nondiscriminatory in order for it to be valid. An example of a discriminatory requirement is one that prohibits out-of-State shipments. Second, the courts must determine if interstate commerce is unduly burdened by balancing the impact of a non-Federal requirement on interstate commerce against the benefits it provides.

\footnotetext{
'The Supremacy Clause asserts that: "This Constitution and the Laws of the United States which shall be made in Pursuance thereof, and all treaties made, or which shall be made under the authority of the United States, shall be the supreme law of the land; and the Judges in every State shall be bound thereby, anything in the Constitution of Laws of any State to the contrary nor withstanding." U.S. Constitution, article V, clause 2.

'For additional information on Federal preemption see, L.M.Trosten and M.R. Ancarrow, "Federal-State"Local Relationships in Transporting Radioactive, Materials: Rules of the Nuclear Road," Kentucky Law Journal, vol. 68, No.2, 1979-80, p. 251; and Christopher Baum, "Banning the Transportation of Auclear

Waste: A Permissible Exercise of the States' Police Power?" Fordham Law Review, vol. 52, March 19S4, p. 663.

U.S. Constitution, article I, sec. 8, clause 3 .

'Laurence Tribe, American Constitutional Law (Mineola, NY: The Foundation Press, Inc., 1978), p. 320.

'Trosten and Ancarrow, op. cit.; Baum, op. cit.
} 
requiring tank truck carriers of hazardous gases to obtain permits was also upheld. ${ }^{156}$ The New York City permits were obtainable by telephone. On the other hand, Rhode Island permit regulations for transporters of liquefied natural gas or liquefied petroleum gas were found to be inconsistent by the U.S. District Court and the Court of Appeals. ${ }^{157}$ In this case, the court found that the regulations, which required transporters to obtain a permit not less than 4 hours before or more than 2 weeks prior to each shipment, caused unnecessary delays and were inconsistent with the HMTA. DOT also concluded that the Rhode Island permit requirements were inconsistent.

Local routing restrictions have been addressed in two lawsuits. The New York City permit regulations for transporters of hazardous gases also required transporters who did not have pick-ups or deliveries in the city to use an established alternate route around it. Shipments into the city had to conform to specified routes and times established by the local authorities. The court found that the city regulations promoted safety and did not cause unnec-

\footnotetext{
${ }^{156}$ Both the District Court and the U.S. Court of Appeals for the Second Circuit upheld the New York City requirement. See City of New York v. Ritter Transportation Inc., 515 F. Supp. 663 (1981); and National Tank Truck Carriers, Inc. v. City of New York, 677 F. 2d 270 (1982).

${ }^{157}$ National Tank Truck Carriers, Inc. v. Burke, 535 F.Supp. 509 (1982) and National Tank Truck Carriers, Inc. v. Burke, 698 F, 2d 559 (1983).
}

essary delays, and that the route around the city was a "practicable alternative. " In Boston, restrictions on the use of city streets were challenged both in Federal court and through DOT's inconsistency ruling process. After a length ${ }_{\mathrm{y}}$ review process, DOT decided that it could not reach a conclusion, because even though the routing restrictions appeared to enhance public safety, consultation with affected jurisdictions had been limited. ${ }^{158} \mathrm{~A}$ final decision by the court has not yet been reached.

State restrictions imposed on the transportation of radioactive materials have also been the subjects of lawsuits. Laws prohibiting interstate shipments of radioactive wastes but allowing intrastate transportation were found to be unconstitutional. In one case, Illinois attempted to prevent shipments of spent nuclear fuel into the State for storage at a General Electric facility in Morris, Illinois. Another case involved a Washington State statute prohibiting shipments of low-level radioactive wastes destined for a disposal site in Richmond, Washington, from entering the State. ${ }^{159}$

\footnotetext{
${ }^{158} 47$ F.R. 18457, Apr. 29, 1982. It should be noted that the U.S. Department of Transportation also cited a concern about the validity of the data used for Boston's risk determination, but concluded that further refinement of the data would not have had a substantial effect

${ }^{\text {on the outcome. }}{ }^{{ }^{*} \text { People }}{ }^{*} \mathrm{f}$ State of Illinois v. General Electric Co., 683F. $2 \mathrm{~d} 206$

(1982); and Washington Stare Building and Construction Trades, AFL. CIO v. Spellman, 684 F. 2d 627 (1982).
}

\section{CONCLUSIONS AND POLICY OPTIONS}

A driving force behind enactment of the Hazardous Materials Act of 1975 was the improvement of regulatory and enforcement activities and the consolidation of authority within the Department of Transportation. During the past 10 years, responsibility for issuing most hazardous materials transportation regulations, except for bulk marine shipments, has been shifted to one entity, RSPA. However, the modal administrations continue to be responsible for safety regulations, including the development of some hazardous materials regulations applicable to each mode. Inspection and enforcement authority is shared by RSPA and the modal administrations. Other Federal agencies also have jurisdiction over certain types of hazardous materials and worker safety.

Moreover, the roles played by States and localities and by international organizations in the regulation of hazardous materials transportation have grown considerably since the HMTA was passed. The act provided the Secretar of Transportation with broad authority to promulgate a wide range of requirements. However, DOT has made several decisions about how to exercise its authority that have limited the application of its regulations, motivating State and local governments to act where they saw a need. 
First, DOT has chosen not to apply the hazardous materials regulations to most intrastate highway transport. Thus, for example, hazardous materials released from a truck owned by a company operating wholly intrastate, need not be reported to DOT (see chapter 2) and second- or third-hand cargo tankers that no longer meet Federal requirements may be used in some States (see chapter 3). On the other hand, some jurisdictions have established container regulations that are more stringent than Federal requirements. While States accepting Federal funds to support their enforcement programs are required to apply the hazardous materials regulations to both intrastate and interstate carriers, this does not ensure that the reporting requirements and container regulations will be applied.

Second, DOT has not exercised its authority to establish a registration program for shippers and carriers. This has meant that it does not have vital data about the extent of the group it regulates and that information useful to State and local officials is not available.

The legislative history of the HMTA indicates that Congress intended to preclude a multiplicity of State and local regulations and the potential for varying and conflicting regulations. Most State and local governments understand and agree with the need for uniform regulations, especially in areas related to containers and hazard communication. However, they believe that the steps they have taken are necessary to provide adequate safety in light of the risks posed by the transportation of hazardous materials. State programs, like their Federal counterparts, are now characterized by a multiplicity and diversity of activities and areas of jurisdiction. While Federal grant programs have provided valuable assistance to States and have encouraged adoption and uniform enforcement of Federal regulations, great variation among State laws and regulations persists.

Local governments usually do not directly benefit from Federal grant programs to the States, Consequently, they must rely on alternate sources of funding, such as licensing or permitting fees. Some jurisdictions have set fee levels to cover the administrative costs associated with registration, permit, or licensing programs, while others use fees to support inspection and enforcement or emergency response activities.
As most State and local requirements apply to

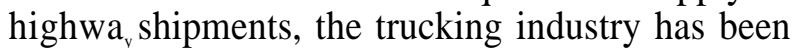
affected most heavily. Interstate shippers and carriers argue that compliance with differing laws and regulations is confusing, time-consuming, and expensive. The costs include payment of registration, permit, and licensing fees which range from several dollars up to $\$ 1,000$ per shipment, as well as operational expenses, such as driver costs, and expenses incurred by special staff to track changing requirements. Carriers have also found that certain types of requirements can cause delays in transit. Moreover, shipments may be diverted around jurisdictions that have imposed special requirements, shifting the risks to other States and communities.

There have been no comprehensive efforts to resolve existing interjurisdictional differences. Resolving questions of inconsistency between Federal, State, and local regulations, a task traditionally left to the courts, has been the focus of an advisory administrative review process established by DOT in 1976. In 16 inconsistency rulings, DOT has indicated that it believes State and local activity is limited to traffic control and narrow regulations that eliminate or reduce safety hazards peculiar to a local area. In addition, even when there is a unique local safety problem, consideration of the impacts of a requirement on other jurisdictions must be taken into account. DOT has also indicated that it is necessary to look at the impacts of State or local permit requirements, such as shipment delays, to determine their validity. Several cases reviewed by DOT have also been the subjects of lawsuits. Although case-by-case reviews by DOT and the courts, a time-consuming and costly effort, provide criteria for assessing the validity of certain types of laws and regulations, OTA believes that they will not prevent continued adoption of differing State and local requirements.

Registration, licensing, permitting, and notification requirements are important to States and localities because they provide valuable data and revenue. However, industry objects to both the fees that are assessed and the delays and diversions of shipments. Polic decisions must address both the financial and informational needs of State and local governments and ease the burden faced by interstate shippers and carriers. Thus, Congress might require development of national guidelines for State 
and local information-collection programs in three areas: 1) to determine the number and location of hazardous materials shippers and carriers (registration or inventory), 2) to obtain assurances of fitness from shippers and carriers (licensing or permitting), and 3) to obtain information on the types of hazardous materials passing through or being produced in a community or region (notification). A consensus approach involving Federal, State, local, and industry representatives could be used to formulate the guidelines. A standard form for requesting information could be created, sire. ilar to the uniform hazardous waste manifest developed jointly by DOT and EPA. If detailed commodity flow data are needed, requirements that focus on information already available, such as Material Safety Data Sheets, should be emphasized. Special consideration should also be given to the information needs of bridge and tunnel authorities; this might include prenotification of certain high hazard shipments. In those States where the guidelines are adopted, localities may be required to obtain the information they need from their State agencies. In addition, reciprocity (including information sharing) between States in a given region could be encouraged. Assuming that alternative sources of financial support are provided for enforcement and emergenc response (see discussion below), States and localities could be prohibited from assessing fees or required to limit fees to amounts sufficient to cover program administration costs. To assist interstate carriers and shippers, an annual compendium of State and local requirements and contacts, jointly developed by industry, DOT, and the States, could be published. Several public and private organizations have alread compiled some of this information.

Carrier associations, insurance industry representatives, and State motor vehicle administrators and enforcement personnel have voiced strong support for a national truck driver's license requiring special training. Congress could author. ize the development of such a license with special certification requirements for all hazardous materials, including gasoline. Driver certification could be linked to specific types of vehicles. Prerequisites for a license should include training and a clean record. Uniform license requirements and training standards could be developed by DOT, but
States would be responsible for issuing licenses and administering the training program. State license fees could be set to cover program costs. California has already developed such a program. Another model is a program created by the European Common Market countries, which requires a hazardous materials driver's license but allows each countr to pass its own implementing legislation.

In addition to the problem of differing licensing, registration, and permit requirements, the broader issue of varying State hazardous materials laws and regulations should also be addressed. Complete information about the scope of existing State laws and regulations pertaining to the transportation of hazardous materials is not presently available. While many States have adopted 49 CFR, some have excluded certain types or quantities of hazardous materials. Others have excluded private motor carriers and intrastate highway shipments are not regulated consistently, An assessment of State hazardous materials laws and regulations to determine whether they are more or less stringent than Federal regulations could be required. BMCS has alread begun, at congressional request, a 5-year review of State motor carrier laws to determine those that are more or less stringent than Federal requirements in the areas of driver qualifications and training, hours of service, and equipment maintenance. ${ }^{160}$ As part of the process, State laws will be reviewed by a panel convened $b_{y}$ the Secretar of Transportation. ${ }^{2}$ State laws that are less stringent than their Federal counterparts will be preempted; a law that is more stringent will not be preempted unless there is no safety benefit associated with it, the law is not compatible with Federal regulations, or enforcement of it causes an undue burden on interstate commerce. Another study of State motor carrier laws related to finances is being conducted by the National Governors' Association for the Federal Highway Administration. Congress could extend these ongoing efforts to encompass State hazardous materials regulations or initiate a separate review.

\footnotetext{
16. This review is authorized by the Motor Carrier Safety Act of 1984, Public Law 98-554, 98 Stat. 2829,2835-2838. State guidelines for compiling, analyzing, and submittin their laws; regulations; and other information were published by the Bureau of Motor Carrier Safety on Jan. 10, 1985 (50 F.R. 1243).

1n! Section 209 of the Motor Carrier Safety Act of 1984,98 Stat. 2838.2839
} 
In addition, Congress could consider requiring the expansion of those parts of 49 CFR administered solely by RSPA, such as the container regulations, to cover all intrastate highway transportation. Intrastate shippers and carriers of hazardous wastes and substances and flammable cryogenics are already subject to Federal regulation. Such a requirement would make RSPA regulations consistent with MCSAP requirements. If this approach is adopted, the preemption criteria noted above for existing laws and regulations should also apply to new requirements. Thus, intrastate regulations that increase safety and do not unduly burden interstate commerce would be allowed. Congress might also wish to require DOT to reduce emphasis on detailed inconsistency rulings, which occur after a regulation is in place, and to provide technical and policy assistance to States or communities during the regulation-setting process.

State and local hazardous materials enforcement activities, particularly for the highway mode, have become increasingly important during the past decade. While SHMED and MCSAP have provided States with grant monies to develop and implement enforcement programs, SHMED is ending this year and MCSAP funds must be used to support all motor carrier enforcement activities, not just hazardous materials. Moreover, financial support for emergency response training of local fire and police department personnel (described in chapter 5) is also a major concern of State and local governments. One funding mechanism that State and local governments have tapped is licensing, registration, and permit fees. States and municipalities are unlikely to discontinue such fees unless alternative funding sources are provided, Thus, Congress could consider providing additional funds to States and localities for enforcement and emergency response programs. Funding for the SHMED program could be extended and made available to all States with a requirement that State hazardous materials enforcement teams be developed. Special provisions could also be made to ensure that major metropoli$\tan$ areas that undertake inspections be allocated a portion of the grant monies. A dedicated Federal fund to support emergency response activities could also be established.

Routing is an extremely important accident prevention tool available to State and local govern- ments. Developing routing schemes that enhance overall regional safety is a difficult process, although the Portland, Oregon, experience demonstrates that it is possible. The existing BMCS routing regulation for nonradioactive hazardous materials could be amended to provide more explicit guidance to communities. States designating alternate routes under HM-164 are already required to follow DOT guidelines for routing shipments of radioactive materials; this requirement, which includes a risk assessment and interjurisdictional consultation, could be extended to all hazardous materials. The development of criteria for routing shipments of radioactive and other hazardous materials by rail and water might also be considered. DOT technical assistance to States or communities for applying the risk assessment criteria and working through the route selection process could be extremely useful. For example, the availability of computer software packages capable of comparing the risks associated with alternative routes, might be increased. One example is a computerized risk assessment model developed by Oak Ridge National Laboratory for DOD (see chapter 2). In addition, a compendium of routes designated by State and local governments might be published for motor carriers

Finally, Congress could take steps to promote improved coordination within DOT, between Federal agencies, and between the Federal Government and State and local governments. A standing coordinating committee could be established with representatives from each DOT modal administration; RSPA; other Federal agencies such as EPA, NRC, DOE, and FEMA; State and local govern. ments; and industry. This committee might be established within the framework of the National Response Team. It could be required to meet regularly with an agenda that includes:

- defining missions and roles of Federal agencies in the transportation of hazardous materials,

- coordinating Federal training programs,

- developing national guidelines as described above,

- setting a regulatory agenda for intra-agency and interagency issues, and

- coordinating common activities such as data collection and enforcement. 
Subgroups could be formed to address areas of particular concern. More specifically, DOT and EPA could be directed to develop a joint program to educate small businesses that generate and transport hazardous wastes about DOT transportation requirements and the compatibility of wastes and con- tainers. NRC, DOE, and DOT could be encouraged to develop a joint program to involve States, local governments, and Indian tribes in the decisionmaking process for Nuclear Waste Policy Act shipments and procedures. 
Chapter 5

Training for Hazardous Materials Transportation Enforcement and Emergency Response

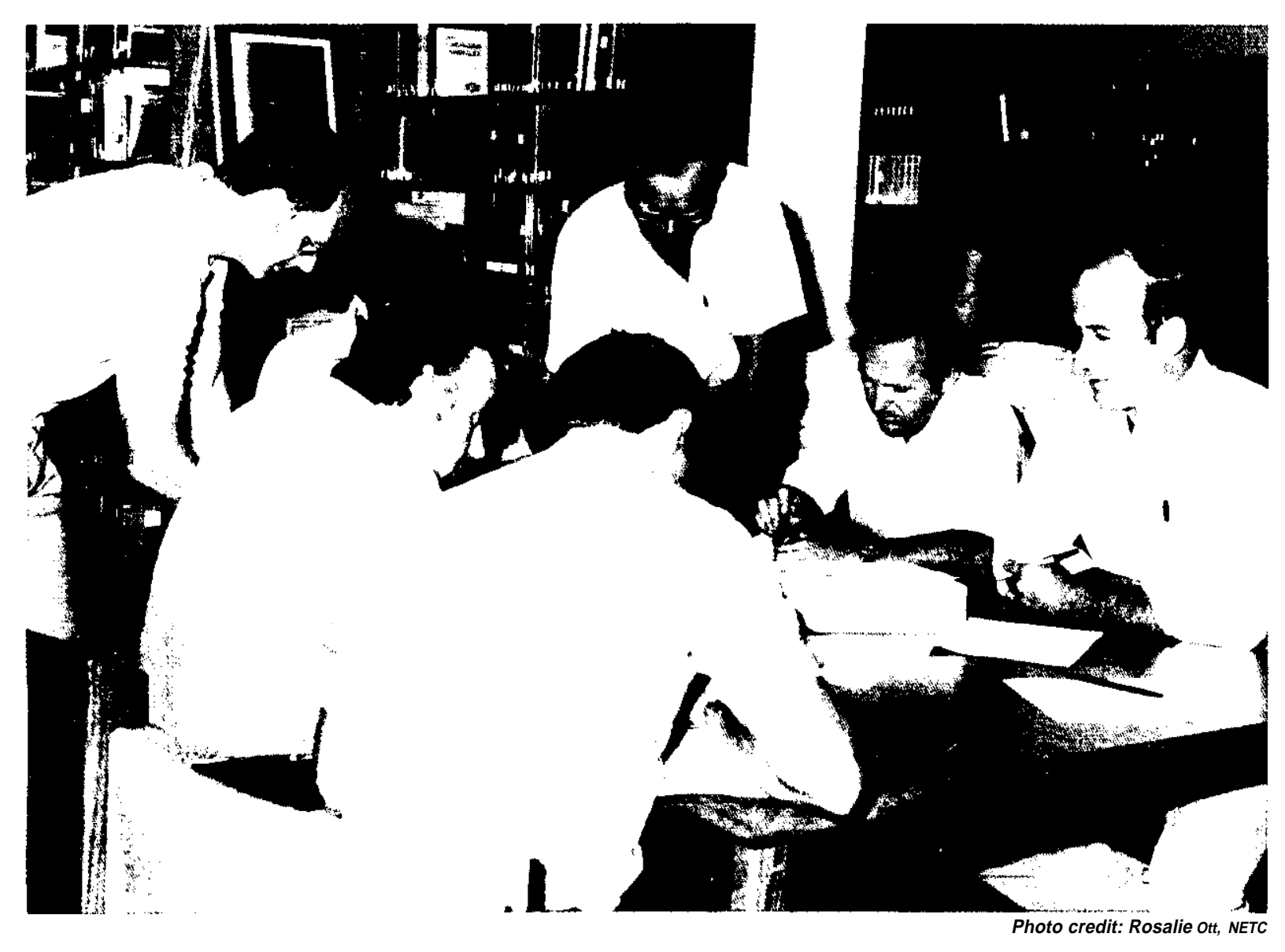




\section{Contents}

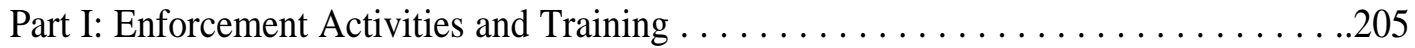

Federal Activities ......, . . . . . . . . . . . . . . . . ................205

State and Local Activities . . . . . . . . . . . . . . . . . . . . . . . . ..................2213

Conclusions and Policy Options for Enforcement Training , ,.................216

Part II Emergency Response Activities and Training . .......................217

Federal Emergency Response Activities. . . . . . . . . . . . . . . . . . . . ...218

State and Local Emergency Response Activities . ..........................220

Industry Emergency Response Activities . . . . . . . . . . . . . . . . . . . . . . . . .2222

Emergency Response Training . . . . . . . . . . . . . . . . . . . ................224

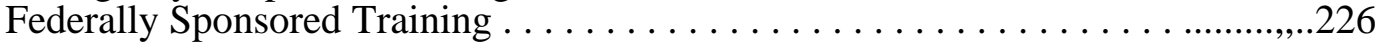

State and Local Emergency Response Training . . . . . . . . . . . . . . . .......230

Industry-Provided Emergency Response Training . .......................233

Conclusions and Policy Options for Emergency Response Training . ............234

Financing Emergency Response Training . . . . . . . . . . . . . . . . . . . . ...236

\section{List of Tables}

Table No. $\quad$ Page

5-1. Summary of Training Courses, Hours, and Students by Organization Type, 1980-84 . . . . . . . . . . . . . . . . . . . . . . . . . . . . . . . . . . . . . . . .204

5-2. Target Audiences for Compliance, Enforcement, and Response Training by Organization . . . . . . . . . . . . . . . . . . ...................205

5-3. Number of Hazardous Materials Inspections and Investigations of Vehicles and Vessels . . . . . . . . . . . . . . . . . . . . . . . ................207

5-4. Number of Hazardous Materials Inspections of Operations and Facilities .. ...207

5-5. Number of Hazardous Materials Transportation Inspectors and Work-Years ..209

5-6. Department of Transportation Hazardous Materials Compliance and Enforcement Training Courses . . . . . . . . . . . . . . . . . . . . . . . ...210

5-7. The Ten Hazards Perceived as Most Significantly Local Jurisdictions . ......218

5-8. Federal Emergency Management Agency Response Training . ................227

5-9. Number of Students Attending EPA Courses, 1979-85 . . . . . . . . . . . . . . .229

5-10. U.S. Coast Guard Emergency Response Training. . . . . . . . . . . . . . . . . 230

5-11. Calculations for Costs of Hazardous Materials Emergency Response Training for First Responders . . . . . . . . . . . . ....... ... , ............236

\section{List of Figures}

Figure Ale.

5-1. Public Hazardous Materials Response Teams . . . . . . . . . . . . . . . . . . . . 221

5-2. The Chemical Plants: Where They Are . . . . . . . . . . . . . . . . . . . . 222

5-3. CHEMNET Emergency Response Team Locations.. . . . . . . . . . . . . . . . 225 


\section{Training for Hazardous Materials Transportation Enforcement and Emergency Response}

\section{INTRODUCTION}

Hazardous materials are transported over the $\mathrm{Na}$ tion's vast system of highways, rails, waterways, and airlanes, necessitating multimodal enforcement and

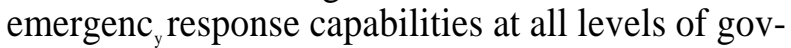
ernment. Enforcement of hazardous materials transportation and modal safety regulations is an effective accident prevention tool if it is carried out by a well-trained and experienced inspection force.

The training law enforcement officers receive-on applicable laws and regulations, vehicles and vessels used to transport hazardous materials, inspection techniques, and sometimes the chemical and physical properties of the hazardous materials themselves-directly influences the ability of those officers to conduct thorough inspections and audits.

When transportation accidents involving hazardous materials do occur, local police officers and firefighters are usually the first officials to appear at the site. How they respond to the conditions they find there depends in large part on whether they have received emergency response training for those types of accidents. Moreover, should any injuries result from exposure to toxic materials, medical personnel will be able to respond appropriately only if they have had training in the treatment of such injuries.

The population in need of enforcement and emergency response training is wide and varied. Regulations governing the transportation of hazardous ma-

\footnotetext{
'For example, under a U.S. Department of Transportation demonstration program, Utah increased the number of inspections it conducted by 330 percent; it also experienced a 43-percent reduction in accidents involving commercial vehicles during the same year. Similarly, Idaho experienced 37 percent fewer commercial accidents in the same year that it increased its inspections by 268 percent and its weigh ings by 218 percent. U.S. Department of Transportation, Federal Highwa Administration, Bureau of Motor Carrier Safety, "Interim Report, Commercial Motor Carrier Safety Inspection and Weighing Demonstration Program," unpublished typescript, August 1981.
}

terials are enforced by Federal inspectors, State department of transportation employees, State Police, State public works department personnel, and local fire and police officers. Moreover, according to the National Association of Chiefs of Police, there are between 450,000 and 500,000 local sheriffs and police personnel employed by State and local government alone.

Emergency response activities are similarly divided among numerous entities. The National Fire Academy reports there are approximately 1.2 million firefighters nationwide, 85 percent of whom are volunteers, and the remaining 15 percent paid employees of municipal, county, or local governmerits. ${ }^{3}$ Federal, State, and local government and law enforcement officials, civil defense volunteers, health professionals, and the approximately 400,000 basic emergency medical technicians also need some training in assisting victims of hazardous materials accidents, depending on the scale and location of the accident and the materials involved.

For example, in December 1981, a tank truck carrying 40,000 pounds of toluene diisocyanate (TDI) skidded off the New York State Thruway and overturned, spilling some of its contents. TDI is transported in heated, insulated tank trucks to keep it in a liquid state. When the truck overturned, TDI spilled and congealed on exposure to the cold ground, contaminating the area around the tank truck as well as the clothing of two State troopers who had been called to the accident. Upon the of-

\footnotetext{
${ }^{2}$ Gerald Arenberg, Executive Director, National Association of Chiefs of Police, personal communication, 1985

'Joseph Donovan, then Director of the National Fire Academy, Federal Emergency Management Agency,Emmitsburg, MD, personal communication, 1985 .

${ }^{4}$ Rocco ${ }^{\prime}$. Morando, Executive Director, National Registry of Emer gency Medical Technicians, personal communication, June 1986.
} 
ficers' return to their warm car, some of the TDI that had adhered to their shoes and pants vaporized, and they inhaled the toxic fumes. TDI enters tissue cells and irritates eyes, nose, and throat, and when inhaled in large quantities, damages the lungs. As a result of their exposure, both of these officers suffered permanent respiratory damage and have been unable to return to police work.

Thus, State Police officers, who may enforce hazardous materials transportation regulations as part of their regular duties, also must be familiar with the dangers posed by the materials in case of an accident. The demands of their jobs illustrate some of the different levels of enforcement and emergenc ${ }_{v}$ response training appropriate to meet the needs of some 2 million Federal, State, local, and private sector personnel.

What training is available to meet these diverse needs? In recent years, a number of studies and surveys have attempted to document the amount and type of training available.* The most recent is a congressionally mandated survey undertaken by the U.S. Department of Transportation (DOT) and the Federal Emergency Management Agency (FEMA). That survey identified 709 training organizations, public and private, that offer, or have recently offered, some form of hazardous materials training or planning, ${ }^{6}$ although it did not determine how many will continue their courses. Responses to questionnaires provided by DOT and FEMA were received from 306 of these organizations, which together offer 468 training courses in some combination of enforcement, compliance, and emergency response. ${ }^{* *}$ The survey did not ask about the percentage of each course devoted to each type of training, limiting the analysis of the information collected. The courses offer a range of training activities, from home study training courses to more advanced programs involving lectures and field exercises.

\footnotetext{
'Harvy Lipman, "Accidents Can, and Do, Happen," Times Union, Albany, NY, Apr. 7, 1985, p. 1.

*The reference section at the end of this report identifies the surveys, studies, and reports relevant to the transportation of hazardous materials.

${ }^{6} \mathrm{US}$ P. Department of Transportation and Federal Emergency Man agement Agency, "Report to the Congress: Hazardous Materials Training, Planning, and Preparedness, " unpublished draft, 1986.

** Enforcement and compliance training are similar in content but are taught from different perspectives. Enforcement training is designed for government inspectors whereas the target audience for compliance training is usually private sector employees.
}

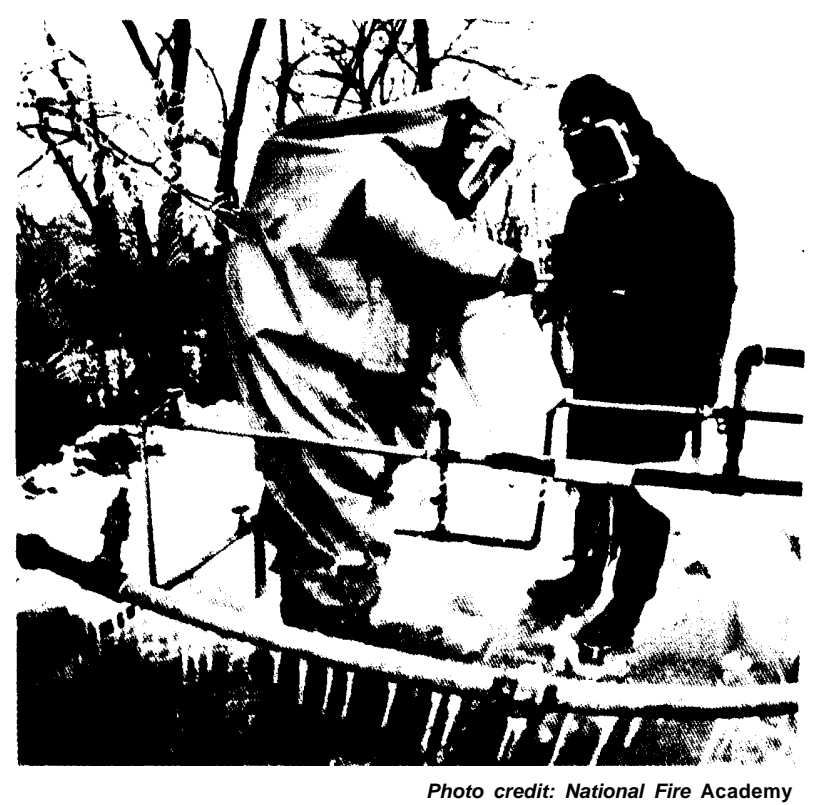

Field exercises and simulations of transportation accidents involving hazardous materials are effective training methods for emergency personnel.

The survey, covering the years 1980 to 1984 , found that the 306 organizations trained approximately 380,000 students at a total cost of $\$ 36.9$ million. Funds expended on training increased each year during the 5-year survey period, with the total annual funds spent by survey respondents rising from under \$5 million in 1980 to more than \$10 million in 1984. Educational institutions, including State training institutes, fire academies, and community colleges, offered the largest number of courses (see table 5-1). The primary audience for courses offered

Table 5.1.-Summary of Training Courses, Hours, and Students by Organization Type, 1980-84

\begin{tabular}{|c|c|c|c|}
\hline Organization type & $\begin{array}{c}\text { Number } \\
\text { of } \\
\text { courses }\end{array}$ & $\begin{array}{l}\text { Average } \\
\text { hours per } \\
\text { course }^{\text {a }}\end{array}$ & $\begin{array}{c}\text { Students } \\
\text { completing } \\
\text { per year }\end{array}$ \\
\hline $\begin{array}{l}\text { Private sector. . . . . . } \\
\text { Educational }\end{array}$ &. .45 & 7.5 & 23,187 \\
\hline institution $\ldots \ldots \ldots$ & 164 & 26.7 & 12,995 \\
\hline Local government . . . & .79 & 19.2 & 9,098 \\
\hline State government . . . . & 138 & 5.8 & 37,774 \\
\hline Federal Government , & . 42 & 51.8 & 18,862 \\
\hline
\end{tabular}

a Data are incomplete as some survey respondents did not provide information on the length of courses.

SOURCE: U.S. Department of Transportation and Federal Emergency Management Agency, "Report to the Congress: Hazardous Materials Training, Planning, and Preparedness," unpublished draft, 19S6. 
Table 5-2.-Target Audiences for Compliance, Enforcement, and Response Training by Organization

\begin{tabular}{|c|c|c|c|c|}
\hline \multirow[b]{2}{*}{ Target audiences } & \multicolumn{4}{|c|}{ Number of courses } \\
\hline & $\begin{array}{l}\text { Educational } \\
\text { institutions }\end{array}$ & $\begin{array}{c}\text { Local } \\
\text { government }\end{array}$ & $\begin{array}{c}\text { State } \\
\text { government }\end{array}$ & $\begin{array}{c}\text { Federal } \\
\text { Government }\end{array}$ \\
\hline Shippers . . . . . . . . . . . . . . . . . . . . . 20 & 47 & 2 & 39 & 6 \\
\hline Transportation companies . . . . . . . . . . . 23 & 51 & 4 & 37 & 4 \\
\hline Private personnel . . . . . . . . . . . . . . . . . . . 20 & 93 & 15 & 52 & 7 \\
\hline Elected officials . . . . . . . . . . . . . . . . . . . 11 & 30 & 9 & 53 & 5 \\
\hline City/county administrators . . . . . . . . . . 10 & 39 & 20 & 61 & 4 \\
\hline Paid fire service . . . . . . . . . . . . . . . . 28 & 248 & 127 & 149 & 14 \\
\hline Volunteer fire service . . . . . . . . . . . . . . . . . 30 & 246 & 55 & 150 & \\
\hline Law enforcement . . . . . . . . . . . . . . . . 27 & 128 & 55 & 176 & 26: \\
\hline Emergency management . . . . . . . . . . . . . . . . 24 & 152 & 61 & 132 & 10 \\
\hline Public works . . . . . . . . . . . . . . . . . 9 & 72 & 27 & 76 & 5 \\
\hline
\end{tabular}

by Federal and State governments is law enforcement officers, followed by volunteer and paid fire service and emergency management personnel. Local governments emphasize training for paid fire service employees (see table 5-2).

Although the survey identifies the bulk of Federal dollars spent and the number of students trained by federally sponsored programs, it does not provide comprehensive data on State and local training. However, data from the survey, which appear to show an abundance of training activities, have meaning only when they are compared to the number of people who need training. The Office of Technology Assessment's (OTA's) evaluation of that need, presented in this chapter, indicates that only 25 percent of the Nation's 2 million emergency response personnel have been adequately trained, and that enforcement training has reached only a portion of the State and local law enforcement officers.
The sections that follow identify the populations in need of training, analyze the availability and effectiveness of existing hazardous materials enforcement and emergency response training programs, describe industry's involvement in compliance and response training, and provide congressional policy options aimed at improving the delivery of hazardous materials training. Enforcement and emergency response activities are considered separately because they are administered and funded by different organizations, particularly at the Federal level. Additional information on industry compliance training is presented in chapter 3 .

Sources of information for this chapter include an OTA workshop on State and local activities, the DOT/FEMA study, a recent survey of State hazardous materials enforcement activities, and extensive interviews with Federal, State, regional, local, and industry officials and training officers.

\section{PART 1: ENFORCEMENT ACTIVITIES AND TRAINING}

Responsibility for enforcing hazardous materials transportation regulations is shared by Federal, State, and local agencies. In recent years, largel $_{\mathrm{y}}$ as a result of programs initiated by DOT, many States have established or improved programs to train highway enforcement officers and to educate shippers and carriers about compliance with hazardous materials regulations. Because Federal inspection capabilities have been decreasing, the importance of strong State and local efforts is underscored.

\section{Federal Activities}

Federal authority to enforce hazardous materials transportation regulations is distributed among numerous Federal agencies. Five of the agencies are within DOT: the Research and Special Programs Administration (RSPA) and four modal administrations-the U.S. Coast Guard, the Federal Aviation Administration (FAA), the Federal Railroad Administration (FRA), and the Federal Highway 
Administration (FHWA). The other agencies are the U.S. Environmental Protection Agency (EPA), the Nuclear Regulatory Commission (NRC), and, peripherally, the Occupational Safety and Health Administration (OSHA). These Federal agencies train their own enforcement officers, to ensure that their training is both adequate and readily available. Additional enforcement and compliance training is sponsored by the U.S. Postal Service, and the U.S. Departments of Justice, Energy, and Defense. Some Federal training programs, primarily those for the highway mode, are directed at improving State and local enforcement capabilities.

\section{Department of Transportation}

The Hazardous Materials Transportation Act (HMTA) provides DOT with the authority to impose both civil and criminal penalties against persons who violate the act or associated regulations. While RSPA is responsible for issuing the hazardous materials regulations under the act, it shares enforcement responsibilities with each of DOT's modal administrations. RSPA's inspection and enforcement efforts are focused primarily on container manufacturers, reconditioners and retesters, and packaging exemption holders. The Coast Guard, with assistance from the National Cargo Bureau and the American Bureau of Shipping, conducts waterfront facility and vessel inspections. FAA inspects freight at air carrier facilities, which serve as collection points for packages coming from freight forwarders and shippers. FRA has responsibility for rail shipper, carrier, and freight forwarder facilities. FRA also inspects railroad tank and freight cars as well as bulk container manufacturers. FHWA inspects motor carrier and shipper facilities in addition to roadside or terminal checks of motor vehicles. All five agencies conduct investigations of accidents and incidents involving hazardous materials. It is impor-

\footnotetext{
'Civil penalties, which may not exceed $\$ 10,000$ per violation, are used when any person "knowingly commits an act which is in violation of" the law or regulations. Standards for determining the amount of a civil penalty require the U.S. Department of Transportation to "take into account the nature, circumstances, extent, and gravity of the violation committed and, with respect to the person found to have committed such' violation, the degree of culpability, any history of prior offenses, ability to pay, effect on ability to continue to do business, and such other matters as justice may require. "Criminal sanctions apply when persons are found guilty of willful violations of the Hazardous Materials Transportation Act or a regulation; penalties under these circumstances may not exceed $\$ 25,000$ and/or 5 years in prison for each offense (49 U.S.C. 1809 (a))
}

tant to emphasize that the modal administrations are responsible for monitoring compliance with general safety regulations as well as with hazardous materials regulations.

The extent and effectiveness of DOT's enforcement activities were criticized by the U.S. General Accounting Office and the National Transportation Safety Board in several reports in the early 1980s. These studies found that the number of inspections conducted by DOT agencies was low compared with the number of businesses engaged in the transportation of hazardous materials. OTA's examination of DOT's enforcement statistics from 1978 to 1984 indicates that the situation has not changed significantly in the years after those studies. (See tables 5-3 and 5-4.) For two transport modes-air and water-inspections have actually decreased. The Coast Guard figures are the most striking; waterfront inspections dropped from 16,865 in 1978 to 828 in 1984. While highway and rail inspections have increased, they are still extremely low relative to the total number of companies, vehicles, and vessels in operation. It is estimated that more than 30,000 shippers at 100,000 locations are subject to the HMTA, yet only 5,220 inspections were undertaken in 1984. Inspections of container manufacturers are also low; in 1984, only 144 out of more than 7,000 container manufacturers were inspected.

The principal reason for the low inspection rate is the shortage of DOT personnel, especially those with training in hazardous materials enforcement. Table 5-5 shows the number of full- and part-time inspectors by agency and the total work-years they represent over a 5-year period. With the exception of FRA, all of the agencies have experienced inspection staff reductions in recent years. The total number of work-years for all agencies decreased from 236.6 years in 1979 to 111 years in 1984. As inspection forces have been decreasing, shipments of hazardous materials by truck alone have been increasing about 3 to 4 percent annually. ${ }^{9}$ OTA

\footnotetext{
${ }^{8}$ For example, see U.S. General Accounting Office, Programs for Ensuring the Safe Transportation of Hazardous Materials Need Improvement, CED-81-5 (Washington, DC: Nov. 4, 1980); and National Transportation Safety Board, Status of Department of Transportation's Hazardous Materials Regulatory Program, NTSB-SR-81-2 (Washington, DC: Sept. 29, 1981).

"Mark Abkowitz and George List, "Hazardous Materials Transportation: Commodity Flow and Information Systems," OTA contractor report, unpublished typescript, January 1986.
} 
Table 5-3.-Number of Hazardous Materials Inspections and Investigations of Vehicles and Vessels

\begin{tabular}{|c|c|c|c|c|c|c|}
\hline Agency/enforcement activity & 1979 & 1980 & 1981 & 1982 & 1983 & 1984 \\
\hline $\begin{array}{l}\text { United States Coast Guard: } \\
\text {. Vessels inspected. . . . . . . . . . . 40,886 } \\
\text {. Accidents/incidents investigated } \ldots \ldots \ldots 4,135\end{array}$ & $\begin{array}{r}39,643 \\
9,148\end{array}$ & $\begin{array}{r}39,138 \\
4,130\end{array}$ & $\begin{array}{r}35,450 \\
4,060\end{array}$ & $\begin{array}{r}28,641 \\
9^{b}\end{array}$ & 23,711 & $\begin{array}{r}20,297 \\
4\end{array}$ \\
\hline 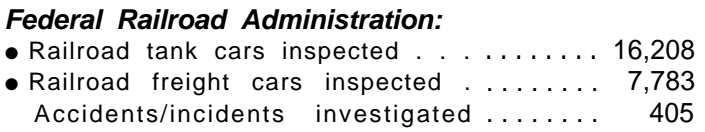 & $\begin{array}{r}15,926 \\
7,620 \\
398\end{array}$ & $\begin{array}{r}19,010 \\
7,914 \\
523\end{array}$ & $\begin{array}{r}26,580 \\
7,100 \\
629\end{array}$ & $\begin{array}{r}39,171 \\
13,024 \\
538\end{array}$ & $\begin{array}{r}31,641 \\
10,547 \\
426\end{array}$ & $\begin{array}{r}40,820 \\
13,001 \\
553\end{array}$ \\
\hline $\begin{array}{l}\text { Federal Highway Administration: } \\
\text { - Motor vehicles inspected . . . . . . . . . } \quad 3,790 \\
\text { - Accidents/incidents investigated . . . . } \quad 398\end{array}$ & $\begin{array}{c}3,470 \\
121\end{array}$ & $\begin{array}{r}3,362 \\
121\end{array}$ & $\begin{array}{r}6,061 \\
201\end{array}$ & $\begin{array}{r}5,980 \\
135\end{array}$ & $\begin{array}{r}7,536 \\
153\end{array}$ & $\begin{array}{r}6,325 \\
147\end{array}$ \\
\hline $\begin{array}{l}\text { Federal Aviation Administration: } \\
\text {. Accidents/incidents investigated } \ldots \ldots \ldots\end{array}$ & 142 & 21 & 69 & 94 & 54 & 51 \\
\hline
\end{tabular}

Research and Special Programs Administration:

. Accidents/incidents investigated

$2 \quad 2$

a $1982-84$ data include bulk and break bulk vessels. $197 \& 81$ data include only break bulk vessels. Break bulk refers to intermodal tanks and packaged goods. bprior t. 1982, data on all commercial vessel accidents and incidents, involving hazardous and nonhazardous materlals, were included in Dot's annual reports. Beginning in 1982 , data included in the annual reports were limited to hazardous materials accidents and incidents resulting in damages exceeding $\$ 50,000$, a death, or serious injury

SOURCE: Office of Technology Assessment based on U.S. Department of Transportation Annual Reports.

Table 5-4.-Number of Hazardous Materials Inspections of Operations and Facilities

\begin{tabular}{|c|c|c|c|c|c|c|}
\hline Agency/type of inspection & 1979 & 1980 & 1981 & 1982 & 1983 & 1984 \\
\hline $\begin{array}{l}\text { United States Coast Guard: } \\
\text { • Waterfront } \ldots \ldots \ldots \ldots \ldots \ldots \ldots \ldots \ldots, 865\end{array}$ & 14,784 & 19,546 & $5,661^{a}$ & 3,603 & 662 & 828 \\
\hline 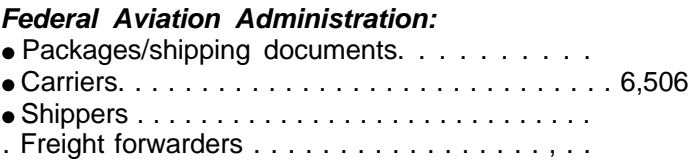 & 6,334 & 1,698 & $\begin{array}{r}6,064 \\
463\end{array}$ & $\begin{array}{r}18,758 \\
6,418 \\
587\end{array}$ & $\begin{array}{r}10,286 \\
4,055 \\
181\end{array}$ & $\begin{array}{r}9,660 \\
3,818 \\
312\end{array}$ \\
\hline 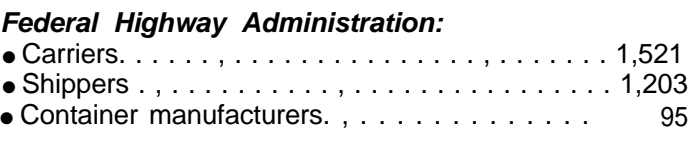 & $\begin{array}{l}1,556 \\
1,343\end{array}$ & $\begin{array}{l}1,470 \\
1,673\end{array}$ & $\begin{array}{l}2,406 \\
2,109\end{array}$ & $\begin{array}{l}3,419 \\
2,849\end{array}$ & $\begin{array}{l}3,369 \\
2,758\end{array}$ & $\begin{array}{l}2,957 \\
2,808\end{array}$ \\
\hline 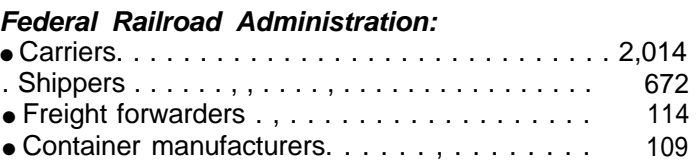 & $\begin{array}{r}1,583 \\
640 \\
89 \\
128\end{array}$ & $\begin{array}{r}1,892 \\
983 \\
76 \\
149\end{array}$ & $\begin{array}{r}3,183 \\
1,805 \\
91 \\
197\end{array}$ & $\begin{array}{r}3,969 \\
890 \\
30:\end{array}$ & $\begin{array}{r}3,976 \\
2,064 \\
108 \\
45\end{array}$ & $\begin{array}{r}4,382 \\
2,300 \\
135 \\
102\end{array}$ \\
\hline 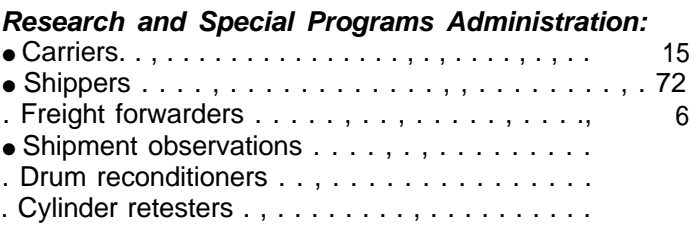 & $\begin{array}{l}62 \\
33 \\
90\end{array}$ & $\begin{array}{r}1 \\
119 \\
90 \\
117 \\
32\end{array}$ & $\begin{array}{r}136 \\
35 \\
4\end{array}$ & $\begin{array}{l}20 \\
17 \\
15\end{array}$ & $\begin{array}{l}40 \\
13 \\
11\end{array}$ & $\begin{array}{r}559 \\
15 \\
20\end{array}$ \\
\hline
\end{tabular}

aprior t. 1981, data on waterfont facillty inspections and spot checks for break bulk cargo were included In DOT's annual report. In 1981 and 1982, data on bulk liquid facility inspections were also included. Beginning in 1981, facility spot checks were discontinued due to budget reductions; the number of facility spot checks con. ducted in 1978, 1979, and 1980 were 14,988; 13,007; and 17,954, respectively. Break bulk refers to intermodal tanka and packaged goods.

SOURCE: Office of Technology Assessment based on U.S. Department of Transportation Annual Reports, 


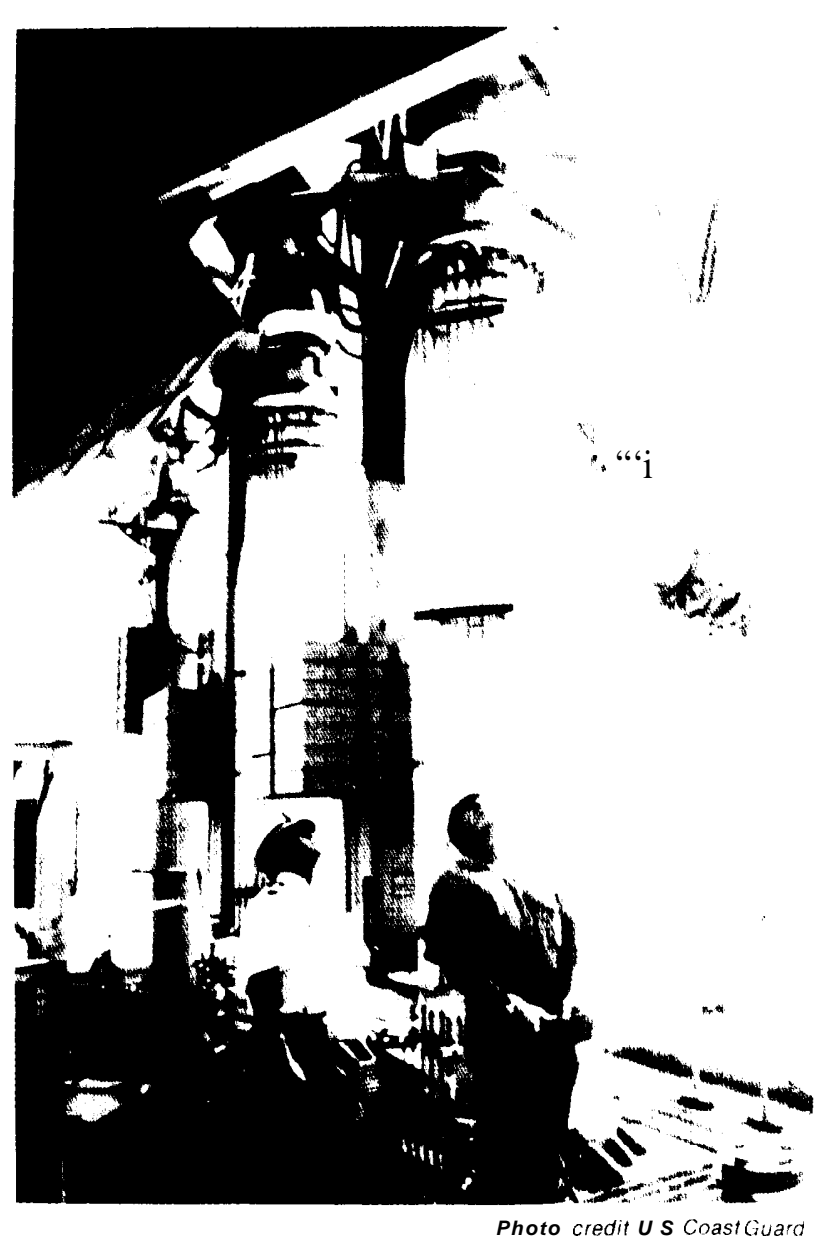

Coast Guard inspection requirements include an examination of the vessel and its loading apparatus.

concludes that the number of inspectors is insufficient to ensure adequate inspection levels.

Enforcement programs are further hampered by the absence of complete data on shippers on and car riers subject to the HMTA; one benefit of a registration program, described in chapter 2 , would be the identification of the regulated community. Moreover, procedures followed by RSPA and the modal administrations for tracking violation histories, targeting inspections, and assessing penalties vary considerably. ${ }^{10} \mathrm{An}$ intermodal working group has re-

\footnotetext{
"See L.S. General Accounting Office, op.c It.; NatmonalTrimpon tatuon Safety Board, Federal and State Enforcement Efforts m hir. ardous Materials Transportation L? Truck, NTSB SEE \&i -? (W [.1] ington, DC: Feh. 19, 1981); Colin S. Diver, "A Studs of the Etfectiventen andFairness of DOT Hazardous Materials Enfore ement P'en I lice" R. port to the General Counsel, L. S. Depart ment of I ransportatum, June
}

cently been established within DOT to improve coordination of enforcement activities."

DOT Enforcement Training. - The Transportation Safety Institute (TSI), a multimodal training establishment supported by the Department of Transportation, provides most of the hazardous materials transportation training for Federal employees. TSI courses are also open to State and local government employees and to private industry. (jeneral hazardous materials enforcement and compliance training and specialized training for each mode are available through TSI, both at TSI's facility in Oklahoma City and at State-operated sites on request.

Many States without sufficient resources to develop independent training programs send their ininecturs to TSI courses. Priority for enforcement courses has heen given to trainees from States participating in Federal grant programs. Between 1980 and 1985, 7,895 students were trained at TSl's Oklahoma ( ity facility at a total cost of $\$ 1,077,600$. State and local government employees made up more than half of the total student body for that periad. A summary of the courses offered by each DC) T agency at TSI and other locations is presented in table 5-6.

Courses for both enforcement and inspection personnel and for shippers and carriers of hazardous materials are offered by RSPA. RSPA's general hazardous materials enforcement and inspection course has three phases: a self-study introduction that the student completes before attending class; a week of classroom instruction based on case studies; and a field exercise to be completed independently by the student once back on the joh. Specific courses on cargo tanks and radioactive materials are also offered by RSPA. The intensive radioactive materials course, cosponsored with the Bureau of Motor Car-

1960; 1 S ( Beneral Accounting ()ffice, Stronger Enforcement Would Holp Improw Motor Carrer Safoty, (BAO) R(ED)-85-64 (Washington, 1) ( S Sept. 5. 1985); arkd ( S.S. (ieneral Acounting ()ffice, Management Imporement ("wht Enhane Enforcement of Coast (iuard Marine

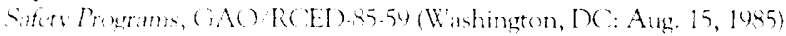
11.5. Depatinent of Tranportation, Research and Spevial Pro. grams Admmistratien, Ammal Report on Hazardous Materak Trans-

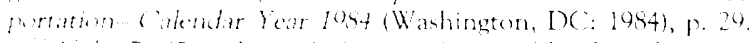

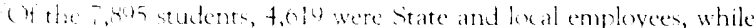

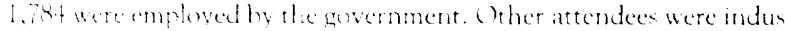

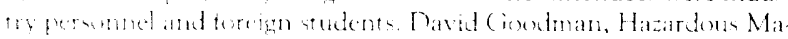

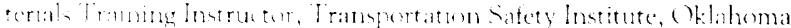

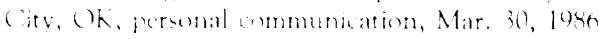


Table 5-5.-Number of Hazardous Materials Transportation Inspectors and Work-Years ${ }^{a}$

\begin{tabular}{|c|c|c|c|c|c|}
\hline 1979 & 1980 & 1981 & 1982 & 1983 & 1984 \\
\hline \multicolumn{6}{|l|}{ inspectors-ful14im9: } \\
\hline United States Coast Guard . . . . . . . . . . . . . . . . . . . . . . . . . 0 & 0 & 0 & 0 & 0 & 0 \\
\hline Federal Aviation Administration . . . . . . . . . . . . . . . . . . . . . . 12 & 12 & 10 & 0 & 10 & 11 \\
\hline 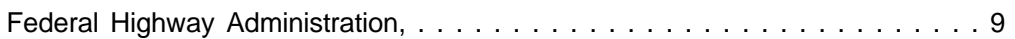 & 9 & 9 & 0 & 8 & 7 \\
\hline Federal Railroad Administration . . . . . . . . . . . . . . . . . . . . . . 19 & 24 & 25 & 23 & 33 & 34 \\
\hline Research and Special Programs Administration . . . . . . . . . . . . & 10 & 7 & 6 & 6 & 7 \\
\hline 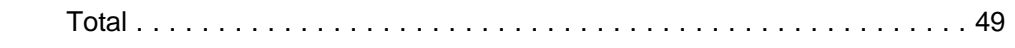 & 55 & 51 & 29 & 57 & 59 \\
\hline \multicolumn{6}{|l|}{ Inspectors -part-time: } \\
\hline 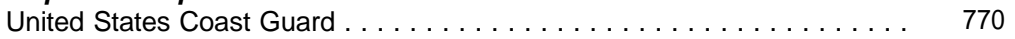 & 770 & 1,298 & 403 & 570 & 570 \\
\hline Federal Aviation Administration $\ldots, \ldots \ldots \ldots \ldots \ldots \ldots$ & 176 & 155 & 138 & 102 & 102 \\
\hline Federal Highway Administration. . . . . . . . . . . . . . . . . & 161 & 153 & 149 & 144 & 142 \\
\hline Federal Railroad Administration . . . . . . . . . . . . . . . . . . . . . . . . . 61 & 64 & 129 & 129 & 158 & 166 \\
\hline Research and Special Programs Administration . . . . . . . . . . 0 & 0 & 1 & 1 & 1 & 1 \\
\hline 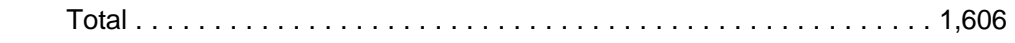 & 1,171 & 1,736 & 820 & 975 & 981 \\
\hline \multicolumn{6}{|l|}{ Total work-years: } \\
\hline United States Coast Guard . . . . . . . . . . . . . . . . . . . . . . . . . 115.50 & 115.50 & 155.76 & 50.00 & 40.00 & 12.00 \\
\hline Federal Aviation Administration . . . . . . . . . . . . . . . . . . . . . 36.90 & 19.04 & 17,75 & 8.20 & 14.08 & 15.00 \\
\hline Federal Highway Administration. . . . . . . . . . . . . . . . . . . . 47.00 & 49.25 & 47.25 & 40.20 & 25.28 & 28,00 \\
\hline Federal Railroad Administration . . . . . . . . . . . . . . . . . . . . . . . . 28.20 & 33.60 & 34.65 & 33.00 & 46.40 & 48.00 \\
\hline Research and Special Programs Administration . . . . . . . . . . . . 9.00 & 10.00 & 7.50 & 6,75 & 6.75 & 7.50 \\
\hline Total . . . . . . . . . . . . . . . . . . . . . . . . . . . . . . . . . .236.60 & 227.39 & 262.91 & 138.15 & 132.51 & 110.50 \\
\hline
\end{tabular}

aThe term work-years refers to the aggregate annual time spent by all inspectors in a mode.

SOURCE: Office of Technology based on U.S. Department of Transportation Annual Reports.

rier Safety, trained 120 students between 1980 and $1984 .^{13}$ Another course, designed to provide management-level employees of companies involved in the transportation of hazardous materials with basic working knowledge of the regulations, is taught at TSI.

In addition, a hazardous materials "train-the-trainer" course is offered by RSPA; train-the-trainer courses instruct individuals at a central location and then provide trained students with additional materials so that they can return to their jurisdictions and train others. This approach is a cost-effective way to augment training at the State and local levels. A network of such trained trainers, affiliated with the Commercial Vehicle Safety Alliance, is described later in this chapter.

The Federal Highway Administration's Bureau of Motor Carrier Safety (BCMS) currently offers a basic 8-hour training course in hazardous materials for State agencies. This course is given primarily to State law enforcement personnel by BMCS field staff; approximately 145 of these classes are

\footnotetext{
${ }^{13}$ Data on numbers of courses and students were obtained from the Bureau of Motor Carrier Safety survey form completed for the U.S. Department of Transportation/Federal Emergency Management Agency study.
}

offered each year. BMCS estimates that 14,460 students attended the basic 8-hour class during the period $1980-84 .{ }^{14}$ In addition, courses on general motor carrier safety regulations are offered at TSI.

Hazardous materials training for FRA inspectors is also available from TSI. Two courses-basic and advanced-provide instruction on the hazardous materials regulations applicable to the rail mode, with an emphasis on packaging and labeling of hazardous commodities. FRA inspectors who have attended a TSI training course may attend training programs at the Association of American Railroad's Transportation Test Center in Pueblo, Colorado. ${ }^{16}$ Extensive training in general rail safety is also available at TSI.

\footnotetext{
"Ibid.

${ }^{15}$ More extensive hazardous materials courses and a course on hazardous wastes transport were taught for a limited period of time, but they have been discontinued. Two new training programs will be introduced in 1986 and 1987. The first, which will be given at U.S. Department of Transportation regional offices, is on motor carrier safety organization and management objectives; the other is a 40-hour course at the Transportation Safety Institute covering hazardous materials and wastes enforcement. Bill Herster, Bureau of Motor Carrier Safety, Federal Highway Administration, personal communication, Apr. 3, 1986.

${ }^{16}$ Federal Railroad Administration inspectors may also participate in training programs offered by a chemical company in Milford, PA. Frank Fanelli, Federal Railroad Administration, U.S. Department of Transportation, personal communication, Apr. 2, 1986.
} 
Table 5-6.-Department of Transportation Hazardous Materials Compliance and Enforcement Training Courses

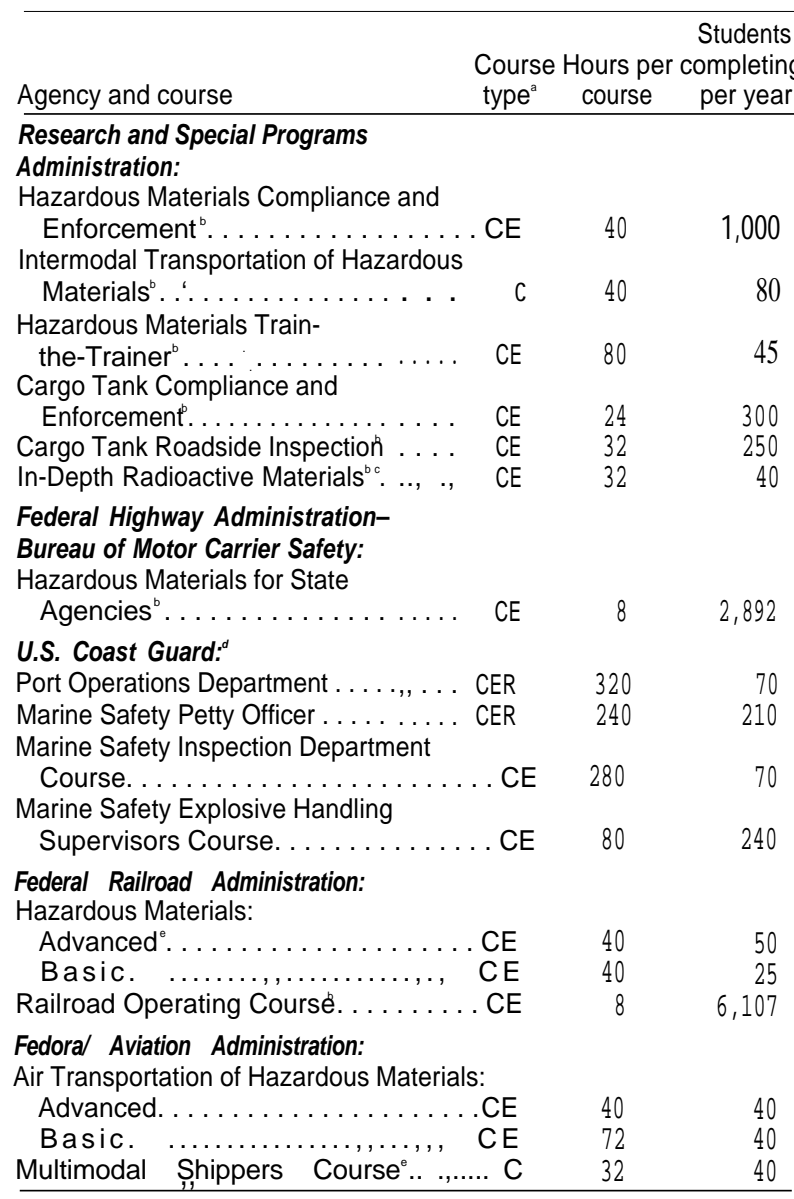

aC - Compliance, E - Enforcement, R - Response.

DCourses offered at Transportation Safety Institute and Statelocations

CThis course isofferedby Research and Special Programs Administration and cosponsored by

the Federal Highway Administration.
All courses offered at Yorktown, Virginia Training Center

${ }^{\circ}$ Courses Offered at Transportation Satety Institute.

SOURCE: Offlce of Technology Assessment based on U.S. Department of Transportation and Federal Emergency Management Agency, "Reporl to the Congress: Hazardous Materials Training, Planning, and Preparedness, " unpublished draft, 1986.

FRA has also sponsored the development of a video program for railroad and hazardous materials training. The Port Terminal Rail Authority (PTRA) in Houston received a grant from FRA to produce a demonstration program in conjunction with the Southern Pacific Railroad. One condition of the grant was that the training be made available to other railroads. The new system has been used to train an estimated 500 PTRA and Southern Pacific employees, and it has been demonstrated in several other locations. Other railroads have expressed in- terest in the program and are purchasing the necessary computer equipment. ' 7

The Coast Guard offers hazardous materials enforcement training at its Marine Safety School in Yorktown, Virginia. Although Yorktown courses are open to civilians and industry as space is available, most students are Coast Guard personnel. A 7-week course, offered by the Marine Safety Inspection Department, provides training on domestic and international hazardous materials regulations. A shorter class on explosives is also taught at Yorktown. Two additional courses, one for petty officers and another for officers, address basic marine safety; these courses cover both emergency response and enforcement. In addition to the Yorktown courses, occasional seminars are conducted in major port and harbor areas for shippers and carriers.*

FAA requires all new inspection and enforcement staff to attend a basic 2-week training course at TSI concerning the air transportation of hazardous materials. Subsequently, inspectors attend a l-week advanced refresher course every 2 years; this course was attended by 190 inspectors from 1980 to $1984 .{ }^{18}$ In addition, a multimodal course, emphasizing the highway and air modes, is given at TSI for FAA depot and other staff responsible for handling, storing, and shipping hazardous materials.

\section{Other Federal Agencies}

Two other Federal agencies-EPA and NRChave enforcement responsibilities relevant to the transportation of hazardous materials. EPA and NRC have delegated substantial regulatory and enforcement authority to the States. However, while NRC provides training for State personnel, most courses emphasize facility regulations. EPA enforcement efforts are focused on land disposal facility activities, and no formal enforcement training is offered to the States. EPA and NRC activities are described in box 5A. In addition, OSHA, responsible for the safety of workers employed by shippers and carriers of hazardous materials, offers courses

\footnotetext{
${ }^{17}$ Larry Helms, Port Terminal Rail Authority, personal communi cation, Apr. 1, 1986

${ }^{*}$ A U.S. Coast Guard seminar on hazardous materials for shippers and carriers held at the Port of New York and New Jersey in April 1986 was attended by approximately 100 persons.

${ }^{18}$ John Garrett, Federal Aviation Administration, personal communication, Apr. 2, 1986
} 


\section{Box 5A.-The Environmental Protection Agency and the Nuclear Regulatory Commingop} Enforcement Training Activities

\section{U.S. Environmental Protection Agency}

The inspection and enforcement activities of the U.S. Environmental Protection Agency (EPA) relevant to transportation concern generators and transporters of hazardous wastes. EPA requirements for transporters of hazardous wastes consist of the U.S. Department of Transportation's (DOT) regulations for hazard communication, packaging, and reporting discharges, as well additional notification, marking, manifest, and cleanup requirements. Federal legislation allows States to administer and enforce hazardous waste programs in lieu of EPA if they meet certain requirements; programs in all but 7 States have been approved by EPA, and thus, 43 States are responsible for conducting inspections.

Under a 1980 Memorandum of Understanding between EPA and DOT, EPA may bring an enforcement action involving a waste transporter if the transportation is ancillary to other activities normally under EPA's jurisdiction, such as the storage or disposal of hazardous wastes. Additionally, EPA has agreed to make available to DOT any information regarding possible Hazardous Materials Transportation Act violations.

However, only a small percentage of EPA and State inspections target generators or transporters of hazardous wastes. Guidance for EPA regional and State hazardous waste regulatory programs requires only that sufficient resources be reserved to inspect 4 percent of the generators and transporters in their jurisdictions.' Moreover, few EPA inspectors receive formal training in the DOT hazardous wastes regulations. Three EPA regional offices have sent employees to Transportation Safety Institute training courses in the past, and only one region meets annually with DOT regional staff to coordinate inspection and enforcement activities and discuss any relevant regulatory changes. $^{2}$ At the State level, Federal funding under

\footnotetext{
U.S. Environmental Protection Agency, 1987 Resource Conserv ation and Recovery Act Implementation Plan, unpublished typescript, 1986, p. 14. Recovery Act Implementation Plan, unpublished typescript, 1986 , p. 14.
'Information on regional activities was provided by the following Environmental Protection Agency staff members: Jerry Levi and Dennis Huebner, Region I; Drew Leaman, Region 11; Jim Webb and Bruce Smith, Region 111; Alan Antley, Region IV; William Miner, Region V; Jim Stiebing and Dave Peters, Region VI; Bob Dona, Region VII; Diana Shannon, Region VIII; Philip Bobel, Region LX; and Dick Bauer and Betty Wiese, Region X, March 1986. The lack of coordination between EPA and DOT inspectors was also described in a 1983 congressional report. U.S. Congress, House Committee on Government Operations, Improving the Effectiveness of the Bureau of
}

he Resource Conservation and Recovery Act my je used for staff training; EPA recommends that up :o 5 purcent of State grants be earmarked for trainng activities. ${ }^{3}$ (See appendix $A$ for additional infornation on EPA's hazardous wastes program.)

\section{Nuclear Regulatory Commission}

Responsibility for regulating the transportation of ' radioactive materials is divided between the Nuclear . Regulatory Commission (NRC) and DOT. Under a Memorandum of Understanding, NRC is responsible for the design and performance of packages used to transport high-level radioactive materials; DOT has regulatory authority over packages used to ship lowlevel radioactive materials. Inspection and enforcement authority is similarly divided, although the agen cies have agreed to consult each other on the results of inspections when they are related to each other's requirements. States participating in the NRC's Agreement State program have been granted regulatory and enforcement authority for certain types of radioactive materials. * NRC inspectors from three program areas-reactors, fuel facilities, and materials licensees-conduct both facility and transportationrelated inspections. $* *$ Nationwide there are 30 to 40 reactor inspectors, 10 to 12 fuel facility inspectors, and 30 to 40 materials inspectors.'

Numerous training courses have been developed for NRC staff, some pertaining to specific subjects such as the transportation and packaging of radioactive materials. In addition, inspection and enforcement training for Federal and State employees is offered by NRC's Technical Training Center in Chattanooga,

Motor Carrier Safety and Its Enforcement of Hazardous Materials Regulations, Report No. 98-562 (Washington, DC: U.S. Government Printing Office, Nov. 17, 1983), pp. 52-55.

U.S. Environmental Protection Agency, op. cit., p. 25

*Twenty-ight agreement States are responsible for byproduct material ( $r a-$ dioisotopes), source materials (raw materials for atomic energy), omall quantities of special nuclear materials, uranium and thorium tailings, and ${ }^{*}$ permanent disposal of low-level radioactive wastes. In addition, States hove always had primary responsibility for the regulation of $\mathrm{X}$-ray machines $\mathrm{ad}$, : other radiation producing equipment, accelerator-produced radioactive m: terials, and radium.

** The Nuclear Regulatory Commission is responsible for inspecting it licensees, which include public utilities, universities with accelerators and nuclear laboratories, hospitals, and industries that handle radioactive mese rials. Materials inspectors cover 5,000 to 6,000 small licensee $\%$ houpitals, lab. oratories, accelerators, etc.

${ }^{4}$ Alfred Grella, U.S. Nuclear Regulatory Commission, personel communication, May 1986. 


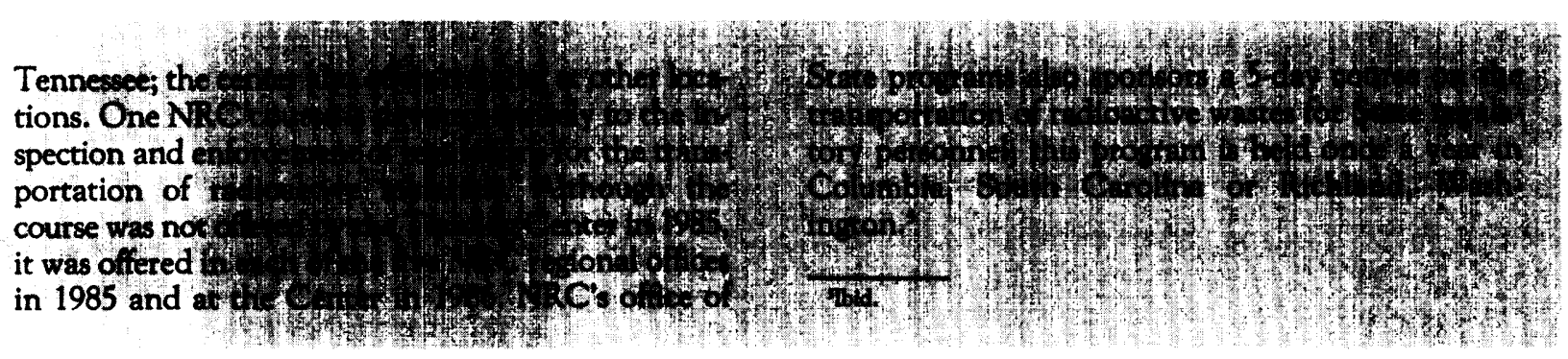

on hazardous materials and fire safety principles. The National Mine Health and Safety Academy, also affiliated with the Department of Labor, provides compliance, enforcement, and response training on hazardous materials.

Limited hazardous materials training is also offered to employees of the U.S. Postal Service. The Postal Service generally permits the mailing of hazardous materials classified by DOT as Other Regulated Material, as well as other hazardous materials such as etiologic agents and radioactive substances. ${ }^{19}$ Packages containing hazardous materials sent by mail must comply with DOT regulations. Because Postal Service personnel generally may not open sealed mail, information on the contents of a package are obtained only from the mailer or if a package releases its contents. Thus, virtually all Postal Service employees need training in several areas: determining whether packages containing hazardous materials can be mailed, ensuring that DOT packaging and marking requirements are met, handling packages containing hazardous matter, and responding appropriately in the event of a hazardous materials release. A special hazardous materials training program was initiated by the Postal Service in 1982 . As part of standard employee training, six training modules on hazardous materials are now offered at some 100 Postal Employee Development Centers. One module is a general awareness presentation, and the others are directed at specific employee groupssupervisors, acceptance clerks, transfer clerks, carriers, and mail handlers. Since the hazardous materials training program began, more than 37,000

\footnotetext{
${ }^{19}$ Oneexample of an OtherRegulated Material is a consumer com modity; the U.S. Department of Transportation hazard classes are defined in table 4-4, ch. 4. The US. Postal Service mailability requirements for hazardous materials are specified in U.S. Postal Service, Acceptance of Hazardous, Restricted, or Perishable Matter, publication 52 (Washington, DC: May 15, 1981 (periodically updated by transmittal letters)).
}

employees have been trained $;^{20}$ however, this number is only a small percentage of the total Postal Service force. *

More generalized inspection and enforcement training for Federal inspectors is available through the Department of Justice's Federal Law Enforcement Training Center (FLETC). FLETC, located in Glynco, Georgia, provides 12 basic law enforcement training programs to 56 participating organizations, including Federal employees and some State and local enforcement personnel. ${ }^{21}$

The Department of Defense (DOD) and the Department of Energy (DOE), as shippers and carriers of hazardous and radioactive materials, also provide compliance training for their employees. A recent addition to hazardous materials enforcement training at TSI is a course for DOD personnel. The course, patterned after other TSI enforcement courses, is expected to begin in 1986 and will accommodate 50 students per class. The Air Force has developed courses on air and surface transportation of hazardous materials, and the Army Logistics Management Center provides training on handling hazardous materials.

The Transportation Management Program of the Department of Energy offers basic and advanced workshops on the transportation of radioactive materials, at which DOT and NRC regulations are covered. DOE courses are primarily for DOE employees and contractors, although commercial carriers and other government personnel may attend some courses as space permits. DOE also offers short ori-

\footnotetext{
20The U.S. Postal Service trained 7,139 employees in 1982, 9,556 in 1983 , 9,734 in 1984, and 10,730 in 1985. Steve Gordon, U.S. Postal Service, personal communication, Apr. 3, 1986.

*The employee figure is for fiscal year 1985. Of the 744,490 employees, 585,943 are full-time staff.

${ }^{21}$ Peggy Haywood, Public Affairs Officer, Federal Law Enforcement Training Center, Glynco, GA, personal communication, Apr. 2, 1986.
} 
entation seminars on the transportation of hazardous materials for State and local police and fire officials. $^{22}$

\section{State and Local Activities}

The contribution made by State and local inspection and enforcement forces to accident prevention has become increasingly important in light of a declining Federal enforcement presence and rising numbers of hazardous materials shipments. The number of State and local law enforcement officers is estimated to be 450,000 to $500,000 .{ }^{23}$ Two Federal programs, directed at increasing State capabilities in managing the transportation of hazardous materials, grew out of studies conducted in the 1970s that identified needed improvements in State enforcement, data collection, and recordkeeping activities.

The first program, the State Hazardous Materials Enforcement Development (SHMED) program, was begun in 1981 by RSPA and is scheduled to end this year. Under SHMED, 25 States conducted programs funded by Federal contracts to strengthen State enforcement capabilities and promote uniformity in State hazardous materials safety regulations and enforcement procedures. Although all modes are covered by the program, highway transportation programs have been emphasized by many States. Training of enforcement personnel, especially for highway inspections, has been a major activity.

Initially, SHMED training involved a 2-week residential course at DOT's Transportation Safety Institute. However, this arrangement proved to be too expensive for the States; thus, RSPA's three-phase inspection and enforcement course was developed, and hazardous materials training within the States was offered. The train-the-trainer program at TSI was also initiated. By government standards, the SHMED program is small; by the time it expires, it will have expended only about $\$ 3$ million. Nevertheless, it has been extraordinarily influential in shaping State enforcement activities and in determining the components of an effective program.

\footnotetext{
${ }^{22}$ Five seminars have been held since the program began in 1985 and were attended by 223 people. Theresa Yearwood, Science Applications International Corp., Oak Ridge, TN, personal communication, Apr. $11,1986$.

${ }^{23}$ Gerald Arenburg, Executive Director, National Association of Chiefs of Police, personal communication, July 1985.
}

The second Federal grant program is the Motor Carrier Safety Assistance Program (MCSAP), which funds State enforcement and regulatory enforcement activities for highways. MCSAP is administered by the Bureau of Motor Carrier Safety. The thrust of the 5-year program is to help States enforce motor carrier safety regulations and increase safety inspections of intrastate and interstate commercial vehicles. General safety and hazardous materials activities are eligible for funding. Both development and implementation grants are available under MCSAP. To receive implementing funds, a State must develop an enforcement and safety program plan and designate a lead agency; set aside adequate resources to administer the program and enforce the regulations; and have statutory authority to enter vehicles and facilities. In addition to financial and regulatory development support, a basic 8-hour hazardous materials training course for State law enforcement personnel is offered by BMCS field staff. Actual appropriations for MCSAP have been lower than the amounts authorized; however, the maximum funding level of $\$ 50$ million has been requested for fiscal year 1987 .

The end of the SHMED program in 1986 means that Federal support of State multimodal hazardous materials enforcement capabilities will decrease. MCSAP will continue to provide States with funds for the highway mode, but monies are not targeted exclusively for hazardous materials inspection and enforcement activities. Without sustained Federal support, many States will be stymied in their efforts to develop or improve inspection, regulation, and enforcement for air, water, and rail modes of transportation. This prospect especially concerns States with high concentrations of nonhighway hazardous materials shipments. Even where State inspectors have been trained in rail safety procedures, they cannot conduct hazardous materials inspections, because authority to do so has not been granted to States.

Moreover, Federal grant programs have not provialed any direct support for local inspection and enforcement activities. Major metropolitan areas, responsible for enforcing Federal, State, and local regulations often turn to general revenues or permit, registration, or licensing fees to support their inspection and enforcement programs. (For more information on SHMED, MCSAP, and local requirements, see chapter 4.) 


\section{State Inspections and Enforcement}

Although some States, such as Maryland, Michigan, and Massachusetts, have taken steps to centralize hazardous materials inspection activities, ${ }^{24}$ hazardous materials inspection authority in many States is divided among several agencies. Usually, the State Police or highway patrol is charged with roadside inspections, and another agency, such as the department of transportation, has authority to conduct inspections of terminals. In addition, a special agency may be empowered to inspect carriers of radioactive materials.

Systematic and consistent inspection procedures are important if widespread compliance with hazardous materials transportation regulations is to be achieved. A recent survey of 47 States, conducted by SHMED States, found that 42 States have established inspection procedures based on manuals or guidance provided by DOT, the Commercial Vehicle Safety Alliance (CVSA), or their own agencies. ${ }^{25}$ Created in 1980, CVSA now includes 26 States and the Canadian Provinces of Alberta and British Columbia, and promotes the use of uniform truck safety inspection standards developed in cooperation with BMCS and RSPA.

However, violations of laws and regulations governing the transportation of hazardous materials are often treated differently from State to State and among different agencies in the same State. In about half of the States, inspectors have enforcement powers and can issue citations for violations. In the other half, inspectors can only report violations to a separate agency empowered to enforce regulations and assess penalties. Some States provide only for civil penalties; others give the enforcing agency the option of civil or criminal penalties depending on the severity of the violation and the violator's record.

\footnotetext{
${ }^{24}$ U.S. Congress, Office of Technology Assessment, Transportation of Hazardous Materials: Stare and Local Activities, OTA-SET-301 (Washington, DC: U.S. Government Printing Office, March 1986), p. 22.

procedures were based on Motor Carrier Safety Assistance Program guidance in 25 States, on Commercial Vehicle Safety Alliance guidance in 21 States, and on Research and Special Programs Administration guidance in 6 States. Fourteen States indicated that they developed their own procedures. U.S. Department of Transportation, State Hazardous Materials Enforcement and Development (SHMED) program, Hazardous Materials Enforcement Survey, results summarized in the State of New Hampshire, Department of Safety Report, Sept. 30, 1985. The survey was compiled at the spring 1985 SHMED Conference in Charleston, WV.
}

In some States, the policy is to issue written warnings to first offenders, while others use more stringent measures. Fines for similar violations also differ among the States. ${ }^{26}$

Enforcement officers report four problems commonly encountered in prosecuting hazardous materials violations. First, due to a lack of training or experience, officers often do not provide adequate documentation in the inspection report or have not followed correct procedures. As a result, many cases are set aside or the charges reduced. Second, enforcement officers find that many judges and local prosecutors have difficult understanding hazardous materials regulations and respond by dismissing cases or lowering penalties without cause. A third problem is in obtaining assistance from other agencies in preparing evidence for court proceedings. State agencies are sometimes unwilling to cooperate in testing hazardous materials or in providing other technical assistance. In some instances, State facilities $\mathrm{ma}_{\mathrm{y}}$ be willing to help, but they cannot provide certain kinds of tests or technical analyses, or they cannot do so in a timely manner. ${ }^{27}$ Fourth, State enforcement agencies complain that fines are too low to serve as a deterrent to noncompliance. Many carriers and shippers treat fines as a cost of doing business. ${ }^{28}$

\section{State Training Programs}

Although training programs sponsored by the Federal Government have increased the number of State inspectors trained in hazardous materials, there are still disparities among the sizes and capabilities of State inspection forces. Three examples of strong State enforcement training programs are described in box 5B. However, few other States have such extensive training programs. Moreover, training for local enforcement officers is limited. In some States, local officers attend State police academies, but they may not receive hazardous materials training.

According to the 1985 SHMED survey of 47 States, 36 States conduct hazardous materials train-

\footnotetext{
${ }^{26}$ U.S. Congress, op. cit., p, 23.

${ }^{27}$ Captain Richard Landis in U.S. Congress, Office of Technology Assessment, "Transcript of Proceedings-OTA Workshop on State and Local Activities in Transportation of Hazardous Materials," unpublished typescript, May 30, 1985.

${ }^{2 \mathrm{~N}}$ National Conference of State Legislatures, Hazardous Materials Transportation-A Legislator's Guide (Denver, CO: 1984), p. 36.
} 


\section{B ,x 5B.-Case Studies of State Training Programs}

Several States have developed notable enforcement training programs. The following case studies illustrate some of the achievements of California, Maryland, and Illinois.

California. - The California Highway Patrol (CHP) conducts a comprehensive State training program, during which uniformed CHP inspection officers attend a 20-week basic law enforcement training course on hazardous materials inspection procedures at the CHP Academy. Officers are then assigned to field commands where they receive 30 days of training from veteran CHP inspectors. In addition, officers receive periodic refresher training throughout the year at their field headquarters and return to the academy every 3 years for in-service training. CHP officers assigned exclusively to commercial enforcement duties at inspection and scale facilities and on mobile units are selected from veteran inspection officers. They attend an 80 -hour commercial enforcement class at the academy, with retraining every 2 years. Civilian inspectors assigned to CHP inspection duties must have at least 1 year of experience in the maintenance of heavy-duty commercial vehicles. They attend the 80 hour enforcement class at the Academy and receive additional in-service training every 2 or 3 years. CHP also provides training for other State agency personnel involved in hazardous materials management and for employees of the regulated industries. Two-day hazardous materials seminars are conducted as needed for these groups. ${ }^{1}$

Maryland.-Maryland has developed a well-trained inspection force. The State has fully utilized the Transportation Safety Institute's (TSI) outreach activities, sponsoring three courses with about 50 students enrolled in each. The first group of officers to be trained were drawn from select units of the State Police Truck Enforcement Division that patrols major Interstate highways. After the officers had completed the course conducted by TSI onsite in Maryland and were ready for field work, they received 2 months of on-the-job training under the supervision of Federal hazardous materials inspectors from the Bureau of Motor Carrier Safety and the Research and Special Programs Administration. During this time, roadside inspections were performed, but only warnings, not citations, were issued. State officials used this grace period to contact the Maryland Motor Truck Association and major independent truckers to inform them of Maryland's hazardous materials regulations and enforcement program and to solicit voluntary compliance. Maryland officials feel the grace period enabled novice inspectors to gain experience and allowed hazardous materials carriers time to adjust to the new regulatory requirements.

Illinois.-Before 1977, Illinois had no central regulatory agency responsible for hazardous materials transportation and no State enforcenent prot th onef iand y dentified these deficiencies, the legislature authorized the Illinois Department of

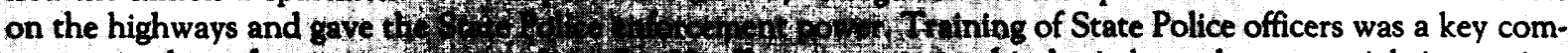
ponent in the enforcement i.

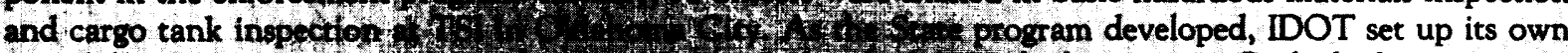
3week basic training gto $x^{2}$

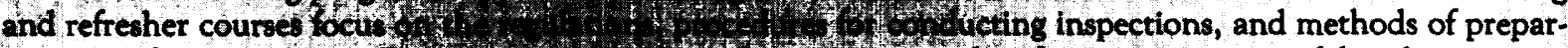

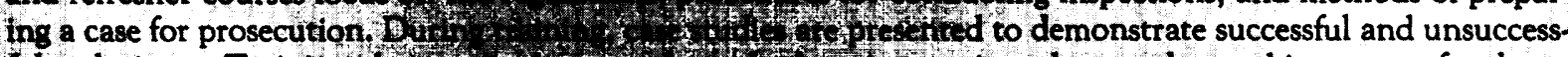
ful techniques. Training alto of

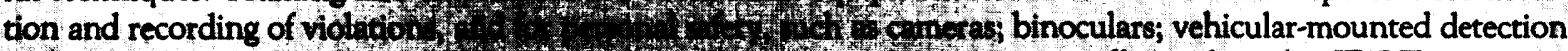

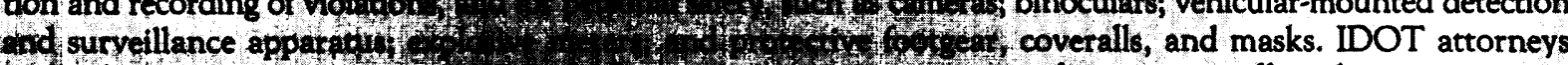
and industry represendenf ble are kept informed

U.S Depertment of Trmipot th

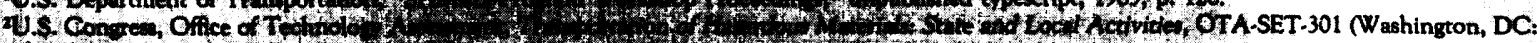
U.S. Government Printing Oftac, Metrit. 
ing. The DOT/FEMA survey found that training for compliance or enforcement, including courses that combined compliance, enforcement, and/or response training, is offered by State and local governments in 38 States and the District of Columbia.*

The SHMED survey also found that of the 36 States that conduct training, 32 offer basic hazardous materials compliance and enforcement courses. Other course offerings include cargo tank compliance, radioactive materials, and advanced hazardous materials training. However, 31 States indicated that existing hazardous materials training was not adequate to meet their needs. Four areas where additional training is needed were identified: radioactive materials, hazardous wastes, cylinders, and explosives.

Another finding of the SHMED survey was that 31 of 36 States use the three-phase training course format developed by TSI Moreover, through TSI, train-the-trainer networks have been established to further Federal training within States; California, Delaware, Idaho, New Hampshire, South Carolina, and Vermont now offer train-the-trainer courses.

A recently established network of trainers is the National Alliance of Hazardous Materials Instructors, an organization affiliated with CVSA. The National Alliance, formed in November 1985, was initiated by personnel who attended TSI train-thetrainer courses and who were experienced in hazardous materials transportation inspections and enforcement. The National Alliance plans to function as a trainers' network with the aim of disseminating information on hazardous materials transportation, providing uniform enforcement and inspection training, and developing expertise on hazardous materials transportation regulations. ${ }^{29}$

\footnotetext{
- *Differences in methodology and data between the State Hazardous Materials Enforcement Development (SHMED) and U.S. Department of Transportation/Federal Emergency Management Agency (DOT/FEMA) surveys resulted in somewhat different findings. For example, while the SHMED data shows that Michigan and West Virginia provide training, agencies from those States did not participate in the DOT/FEMA survey. In addition, only response training was identified for some States in the DOT/FEMA survey, even though the same States responded positively to the SHMED survey; these States include Georgia, Kansas, Kentucky, Florida, and New York. Because of these inconsistencies, the Office of Technology Assessment is using the results of the SHMED survey, which are more complete.

${ }^{29}$ Sergeant John Currie, National Coordinator, National Alliance of Hazardous Materials Instructors, personal communication, Nov. 5, 1985; and statement of Paul R. Henry, President, Commercial Vehicle Safety Alliance to the State Hazardous Materials Enforcement Development Workshop, Salt Lake City, UT, August 1983.
}

A desire to participate in regional training has also been expressed by 43 States. According to the SHMED survey, 23 States indicated that they were already involved in informal regional training, and 27 States said that they made their training courses available to other States. For example, although New Jersey was not a SHMED State, its enforcement officers participated in Maryland SHMED training programs. Funding for enforcement training is provided by the Federal Government or the States, or some combination thereof. Most States (32 out of 36) indicated that they do not charge a fee for their training courses.

Some States have also taken steps to educate shippers and carriers within their jurisdictions. As a matter of policy, Maryland regularly informs the trucking industry about regulations and enforcement practices. The State Police there have developed a training program for commercial carriers, and officers hold frequent meetings with industry groups. Whenever an inspector cites a truck for a violation, the State Police department sends a copy of the traffic safety report to the Maryland Truck Association for forwarding to the truck company. In this way, the company is notified of the violation in time to take whatever corrective action may be needed on other trucks in their fleet. ${ }^{30}$ The California Highway Patrol offers self-inspection and compliance seminars at no cost to participating companies. In addition, through its registration program, California is able to notify shippers and carriers of changes to the hazardous materials regulations. Illinois postponed implementation of its enforcement program for 2 years to allow industry to assimilate the regulations and move toward voluntary compliance. Compliance training for the trucking industry is also offered by State Police in New York and New Hampshire.

\section{Conclusions and Policy Options for Enforcement Training}

The number, frequency, and variety of hazardous materials shipments by all transport modes and the importance of preventing potential environmental and health damage make essential strong

\footnotetext{
${ }^{30}$ Maryland Department of Mental Health and Hygiene, "SHMED Quarterly Report, April-June 1984," unpublished report filed with the U.S. Department of Transportation, 1984.

"U.S. Congress, op. cit., p. 24; and National Conference of State Legislatures, op. cit., p.72.
} 
Federal and State inspection forces and adequate training of those forces. Despite the need, DOT inspection and enforcement teams have been significantly reduced in size over the past 5 years, and Federal inspectors visit only a small fraction of the total number of shippers, carriers, and container manufacturers in a given year. Furthermore, appropriations for increased numbers of Federal enforcement personnel have not been forthcoming.

Federal inspection and enforcement forces are well trained but limited in number, making State enforcement activities very important for all modes, but particularly for highway transport. Some Federal training programs, particularly those sponsored by DOT, are directed at improving State capabilities. However, despite increased Federal training assistance, State inspection forces still vary greatly in size and skill, and States indicate a clear need for additional training, especially for enforcement of regulations governing radioactive materials and hazardous wastes.

The SHMED program assisted many States in developing consistent enforcement training programs, using successful and relatively inexpensive training methods such as train the trainer. Additional enforcement training courses for State and local employees, provided by RSPA at DOT's Transportation Safety Institute and State locations, have also been valuable. OTA finds that the hazardous materials enforcement training and train-the-trainer courses taught by TSI provide good models for the development of State programs. The TSI program is a valuable resource, providing standardized training course development; it deserves continued support. In addition, DOT, EPA, and NRC could make existing training courses and materi- als on hazardous wastes and radioactive materials available to State and local governments in need of them.

However, financial support for inspection and enforcement programs, including training, is needed according to State and local officials contacted by OTA. Several options for additional financial assistance are available to Congress. Funding for the SHMED program could be extended so that the program could be made available to those States that have not yet participated and wish to develop hazardous materials enforcement teams with multimodal expertise.

Direct financial support for inspection and enforcement activities undertaken by local jurisdictions could also be considered. Currently, some local jurisdictions collect permit or license fees from carriers of hazardous materials to fund their enforcement programs. Another option would be to ensure that a portion of the funds provided to the States be directed to those localities that have or would like to develop enforcement capabilities. State and local governments might also be encouraged to develop joint training programs; local law enforcement officers could participate in TSI courses given at State agencies, and State inspectors that participate in train-the-trainer programs could work with local governments.

The specialized expertise required for inspecting container manufacturers indicates that responsibility for such activities might best be left with the Federal inspection forces. Current levels of inspection and enforcement in this area are not adequate. Congress might consider increasing funding levels for DOT's enforcement program.

\section{PART II: EMERGENCY RESPONSE ACTIVITIES AND TRAINING}

Developing hazardous materials emergency response capabilities so that communities across our Iarge and diverse Nation feel adequatel protected $_{\mathrm{y}}$ is a formidable task. The identification of available training programs, in the survey by the Department of Transportation and the Federal Emergency Man- agement Agency, is a preliminary step toward developing a national strategy for improving emergency response training. While this survey and numerous other studies of training programs document a spectrum of public and private training courses, defining the needs of both first responders and ad- 
vanced response personnel and establishing a systematic approach to meeting those needs are tasks yet to be undertaken.

Historically, Federal emergency management assistance programs for States and communities, administered by FEMA, have been largely directed at improving civil defense and natural disaster preparedness. However, despite common elements, planning for a hazardous materials accident and for nuclear attack are quite different. The Comprehensive Environmental Response, Compensation, and Liability Act of 1980 provides the authority for Federal emergency response, and well-trained Federal emergency response teams are available to assist when major hazardous materials disasters occur. However, little Federal action was taken until after the 1984 tragedy in Bhopal, India, to assist in the development of local response capabilities for the day-today risks posed by hazardous materials in communities.

Development of coordinated and comprehensive emergency response capabilities at the State and local levels has been hampered in the past by disinterest or low awareness; more recently, lack of funding and the fragmentation of responsibility and authority at the Federal, State, and local levels of government have proven difficult obstacles to overcome. However, documentation of the connection between the involvement of hazardous materials in a fire or accident and injury rates can trigger the development of training programs for emergency personnel. For example, in Ohio, after a computerized fire reporting system identified a significant number of injuries to fire personnel responding to emergencies involving hazardous materials, the State developed a special hazardous materials training program for firefighters.

Jurisdictions that have experienced serious hazardous materials accidents or have large chemical plants are likely to be directly concerned about developing and maintaining local emergency response capabilities. However, communities of all sizes are becoming aware of the dangers associated with the use and transportation of hazardous materials and are looking for ways to lower their risks. While large

${ }^{32}$ Federal Emergency Management Agency, Hazard Identification, Capability Assessment, and Multi-Year Development Plan (HICA/ MYDP) (Washington, DC: spring 1985). metropolitan areas may already have specially trained and equipped teams, in rural communities hazardous materials emergency response usually is an additional duty assigned to the fire or police department. A 1985 FEMA survey of 3,107 local emergency management organizations indicates that transportation accidents involving hazardous materials are major concerns of local governments (see table 5-7), ${ }^{12}$ since serious injuries or fatalities may occur if responders lack appropriate training.

Emergency response training is offered by the Federal Government, States, local jurisdictions, industries involved in the manufacture or transport of hazardous materials, professional associations, and educational institutions. However, this diffuse shouldering of responsibility has resulted in emergency response training that varies widely in content and quality and often does not reach those most in need of it, rather than in comprehensive coverage and nationally accepted, standardized levels of training.

\section{Federal Emergency Response Activities}

Federal emergency preparedness and response is coordinated by the National Response Team (NRT) under the National Oil and Hazardous Substances

\footnotetext{
${ }^{3}$ The reporting system found that 116 injuries in a single year were incurred at hazardous materials accidents. Chief Don Ryan, Ohio Fire Academy, Hazardous Materials Bureau, personal communication, Apr. 8, 1986.
}

Table 5-7.-The Ten Hazards Perceived as Most Significant by Local Jurisdictions

\begin{tabular}{|c|c|}
\hline Hazard & $\begin{array}{r}\text { Number of } \\
\text { jurisdictions } \\
\end{array}$ \\
\hline $\begin{array}{l}\text { 1. Nuclear attack. . . . . . . . . . . . . } \\
\text { 2. Hazardous materials-highway }\end{array}$ & 7 701 \\
\hline incident $\ldots \ldots \ldots \ldots \ldots \ldots \ldots \ldots$ & 2,791 \\
\hline 3. Winter storm $\ldots \ldots \ldots \ldots \ldots \ldots \ldots$ & 2,569 \\
\hline 4. Flood . . . . . . ......., . . . . . . & 2,206 \\
\hline 5. Hazardous materials-rail incident . . . . & 2,188 \\
\hline $\begin{array}{l}\text { 6. Tornado ............................ } \\
\text { 7. Hazardous materials-stationary }\end{array}$ & 2,162 \\
\hline incident $\ldots \ldots \ldots \ldots \ldots \ldots \ldots \ldots$ & 2,026 \\
\hline 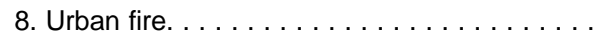 & 1,877 \\
\hline $\begin{array}{l}\text { 9. Wildfire. . . . . . . . . . . . . . . . } \ldots \ldots \ldots \\
\text { 10. }\end{array}$ & 1,519 \\
\hline incident $\ldots \ldots \ldots \ldots \ldots \ldots \ldots \ldots$ & 1,509 \\
\hline
\end{tabular}

aAll jurisdictions are subject to the effects of nuclear attack.

SOURCE: Jurisdiction responses to Federal Emergency Management Agency, Hazardous Incident Capability Assessment Multi-Year Development Plan, 1955. 
Contingency Plan. ${ }^{34}$ Composed of representatives of 12 Federal agencies with major environmental and health responsibilities, NRT is chaired by the Environmental Protection Agency; the U.S. Coast Guard serves as vice-chair. ${ }^{35}$ Thirteen Regional Response Teams formed by regional representatives of NRT agencies and States, provide the regional mechanism for emergency response planning and for coordinating technical assistance during response actions. If State and local governments cannot handle a severe hazardous materials facility or transportation accident or request Federal intervention, EPA and the Coast Guard will assume control and direct Federal emergency response activities.

EPA has also established an Environmental Response Team based in Edison, New Jersey, that has provided various degrees of management or technical support for more than 500 incidents since 1978. The Environmental Emergency Response Unit is a highly specialized technical team sponsored by the Environmental Response Team and other EPA offices that is available to provide onsite assistance. In addition, the Coast Guard operates and maintains Strike Teams on the Atlantic, Pacific, and Gulf coasts for emergency response activities. The Strike Teams have sophisticated equipment for containing, skimming, and removing oil. The Coast Guard also operates the National Response Center for DOT as the point of contact for transportation releases of hazardous materials. During hazardous materials emergencies, scientific advice is provided to the Coast Guard by the National Oceanic and Atmospheric Administration's special hazardous materials group in Seattle, Washington.

While DOT's Research and Special Programs Administration does not respond to hazardous materials transportation accidents, it publishes and distributes the most widely available response in-

\footnotetext{
${ }^{34}$ The Comprehensive Environmental Response, Compensation, and Liability Act of 1980 expanded the scope of the National Contingency Plan, originally established under the Clean Water Act to address oil spills, to include hazardous substances, 42 U.S.C. 9605 . The National Contingency Plan is published in the Code of Federal Regulations at 40 CFR 300.

${ }^{35}$ Other participating agencies include the U.S. Departments of Agriculture, Commerce, Defense, Energy, Health and Human Services, Interior, Justice, Labor, State, Transportation (the U.S. Coast Guard and the Research and Special Programs Administration), and the Federal Emergency Management Agency. Other Federal agencies, such as the U.S. Nuclear Regulatory Commission, participate on an ad hoc basis.
}

formation resource, the Emergency Response Guidebook. ${ }^{36}$ The Guidebook contains basic response and first aid information for those who are first to arrive at the scene of an accident and who have not received extensive hazardous materials training; identification numbers that must be marked on packages and bulk containers correspond to the information in the Guidebook. ${ }^{37}$

In case of radiological accidents, primary Federal responsibility is shared by FEMA, NRC, DOE, and DOT. These agencies and others are represented on the Federal Radiological Preparedness Coordination Committee, an organization formed in 1982 by FEMA. ${ }^{38}$ The Coordinating Committee has $10 \mathrm{Re}$ gional Assistance Committees throughout the country to help State and local governments develop emergency plans. ${ }^{39}$ NRC and DOE maintain authority for planning and program development for emergency response, notification, technical assistance and advice, and involvement in response activities for radiological spills. ${ }^{40}$ In addition, DOE

\footnotetext{
${ }^{36}$ U.S. Department of Transportation, 1984 Emergency Response Guidebook, DOT P 5800.3 (Washington, DC: 1984).

${ }^{3 i}$ However, first responders must be trained to use the U.S. Department of Transportation (DOT) Guidebook properly. For example, on Oct. 15, 1982, an accident in Odessa, DE, between a pickup truck and a tank truck resulted in a rollover of the tank truck and the release of 150 gallons of divinyl benzene (DVB), a moderately toxic material when inhaled. The truck carried a "combustible" placard. Approximately 100 emergency response personnel eventually responded to the accident, but only some had previous experience or training in handling a hazardous materials accident. The emergency responders who consulted the DOT Guidebook to determine appropriate procedures followed the instructions for divinyl ether, the only "divinyl" entry, because DVB was not listed by name; the correct procedure would have been to follow the instructions for combustible materials. The lack of training in this case resulted in injuries to 48 emergency response personnel.

${ }^{38}$ See 44 CFR 351, 47 F.R. 10759, Mar. 11, 1982

${ }^{30}$ The Federal Radiological Emergency Response Plan (FRERP), 49 F.R. 35896, Sept. 12, 1984, covers any peacetime radiological emergency occurring within the United States that could require a significant response by several Federal agencies. Emergencies at nuclear facilities and during the transportation of radioactive materials fall within the scope of the plan. FRERP was published as an operation plan on Nov. 8, 1985 (50 F.R. 46542) along with concurrences by each of the 12 agencies that participated in its development. A guidance document for State and local government emergency response planning for the transportation of radioactive materials has also been published $b$ FEMA; see Federal Emergency Management Agency, Guidance for Developing State and Local Radiological Emergency Response Plans and Preparedness for Transportation Accidents, FEMA-REP-5 (Washington, DC: March 1983).

$40 \mathrm{~A}$ Memorandum of Understandin $\mathrm{g}_{\mathrm{g}}$ between the Federal Emergency Management Agency and the U.S. Nuclear Regulatory Commission was published on Apr. 18, 1985 (50 F.R. 15485).
} 
maintains 30 regional response teams for radiological incidents. *

\section{State and Local Emergency Response Activities}

State authority for hazardous materials emergency response is, like that of the Federal Government, fragmented; it may rest with a State fire marshal's office or State departments of health, transportation, environment, radiological affairs, or civil defense-or, more likely, a combination of some or all of these. Just as the statutory authority for emergency response varies from State to State, so does the interest emergency response generates within the State government. States that are highly industrialized, heavily traveled, confronted with exceptional hazards (such as a large number of waste disposal or nuclear facilities, or a heavy concentration of chemical industries), or have experienced a serious hazardous materials accident are more likely to encourage and support the development of emergency response planning and training and attempt statewide coordination. Emergency response planning is discussed in appendix $\mathrm{C}$.

Because they are convinced that State assistance may be the best or even the only way of protecting rural areas in hazardous materials accidents, some States, including Delaware, Indiana, Oregon, and Tennessee, are developing statewide emergency response plans. For example, the Tennessee Emergency Management Agency (TEMA), in an effort to assure rural areas of adequate hazardous materials emergency response, divided the State into six districts, each with a district coordinator and equipped with a special response van. The district coordinators are trained by the TEMA training institute and must be recertified for hazardous materials response every 2 years. Their multiple responsibilities include training responders in their districts. As a result, Tennessee has more than 2,000 State-certified hazardous materials responders. ${ }^{41}$

\footnotetext{
*Other U.S. Department of Energy and U.S. Department of Defense response teams, primarily responsible for nuclear weapons incidents, are available to provide assistance for other accidents involving radioactive materials.

"George Kramer, Hazardous Materials Instructor, Tennessee Emergency Management Agency, personal communication, Nov. 26, 1985.
}

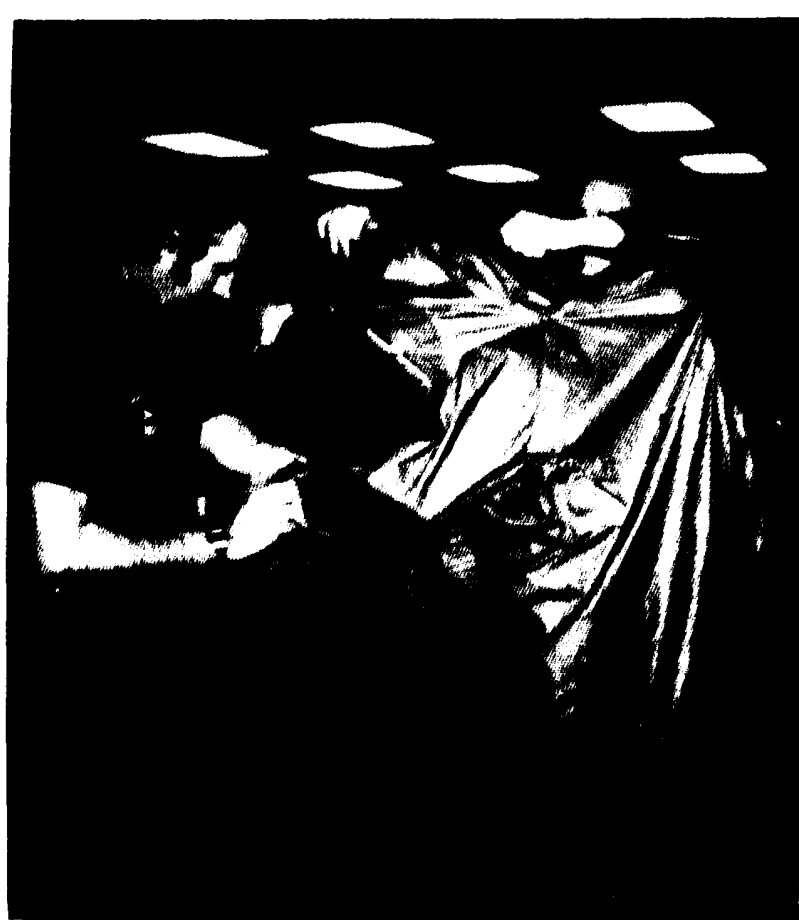

Photo credit: Hazardous Materials Bureau, Ohio State Fire Marshal's Office

Training for hazardous materials response includes learning how to don and secure personal protective equipment.

The same factors that influence State emergency response development also operate at the local level, and communities with emergency response capabilities have set up a wide variety of response systems. In rural communities, responsibility-for hazardous materials emergency response usually lies with the fire or police department. In contrast, in major metropolitan and urban areas, many public safety officers, primarily firefighters and emergency service organizations, have developed or are developing special competence to respond to hazardous materials accidents. These areas are usually transportation hubs and major manufacturing centers that handle large movements of industrial raw materials, gasoline, and fuel oils. Figure 5-1 shows hazardous materials teams, identified by a study performed by the International Association of Fire Chiefs. ${ }^{42}$ Many of these teams are located in regions of the country where there are heavy concentrations of chemical plants and transportation corridors (see figure 5-2).

\footnotetext{
"International Association of Fire Chiefs survey of local response teams, July 1985.
} 
Figure 5-1 - - Public Hazardous Materials Response Teams

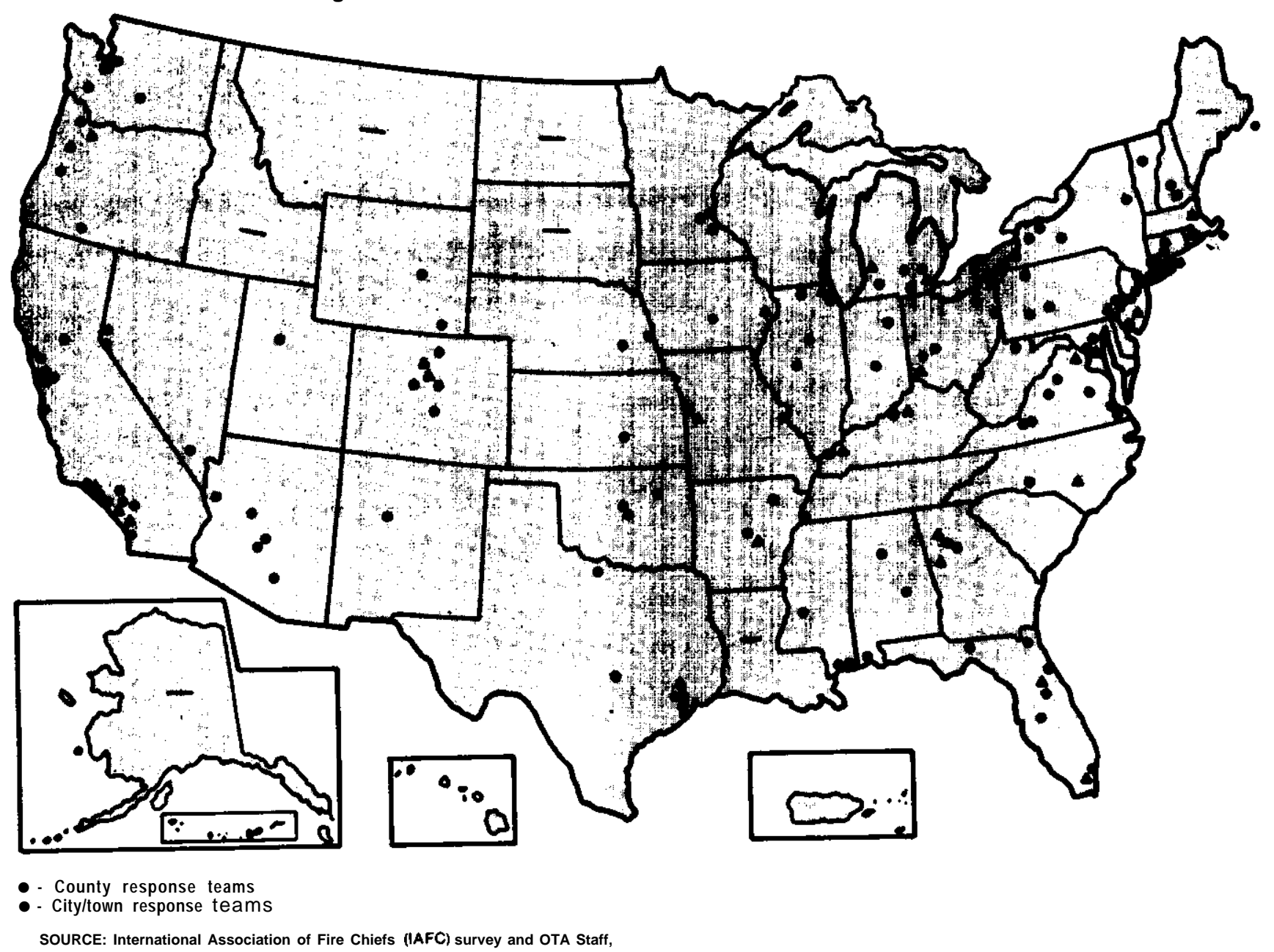

Local governments often find it difficult to justify the expense of specialized equipment, training, and manpower for events that occur rarely. Response teams in metropolitan areas are usually financed by general revenues or permit and fee systems; training and equipment may also be provided by industry. The hazardous materials team of the Houston fire department was organized in 1978 using a $\$ 7,000$ grant from the city and a renovated truck; local industry initially sponsored training for the team. Within a year, the team had developed sufficient expertise to provide basic training for fire department personnel. Industry continues to provide specialized training for tank trucks and railcars, and donates equipment for demonstration purposes. In 1986, the city of Houston budgeted $\$ 98,000$ for the hazardous materials team in addition to salary and equipment maintenance expenses. ${ }^{43}$

A series of incidents involving hazardous materials prompted the development of a special hazardous materials response team 6 years ago in Santa Clara, California. With support from the Chamber of Commerce, the fire department surveyed fixed facilities to determine the type and volume of hazardous materials stored in the county. A license and fee system based on the inventory information was established to support hazardous materials training for paid and volunteer firefighters and purchase equipment. Three chemists are now employed by

\footnotetext{
+] Max MacCrae, Chief, Hazardous Materials Teams, Houston Fire Department, personal communication, Apr. 28, 1986.
} 
Figure 5=2.-The Chemical Plants: Where They Are (places where very toxic chemicals are handled)

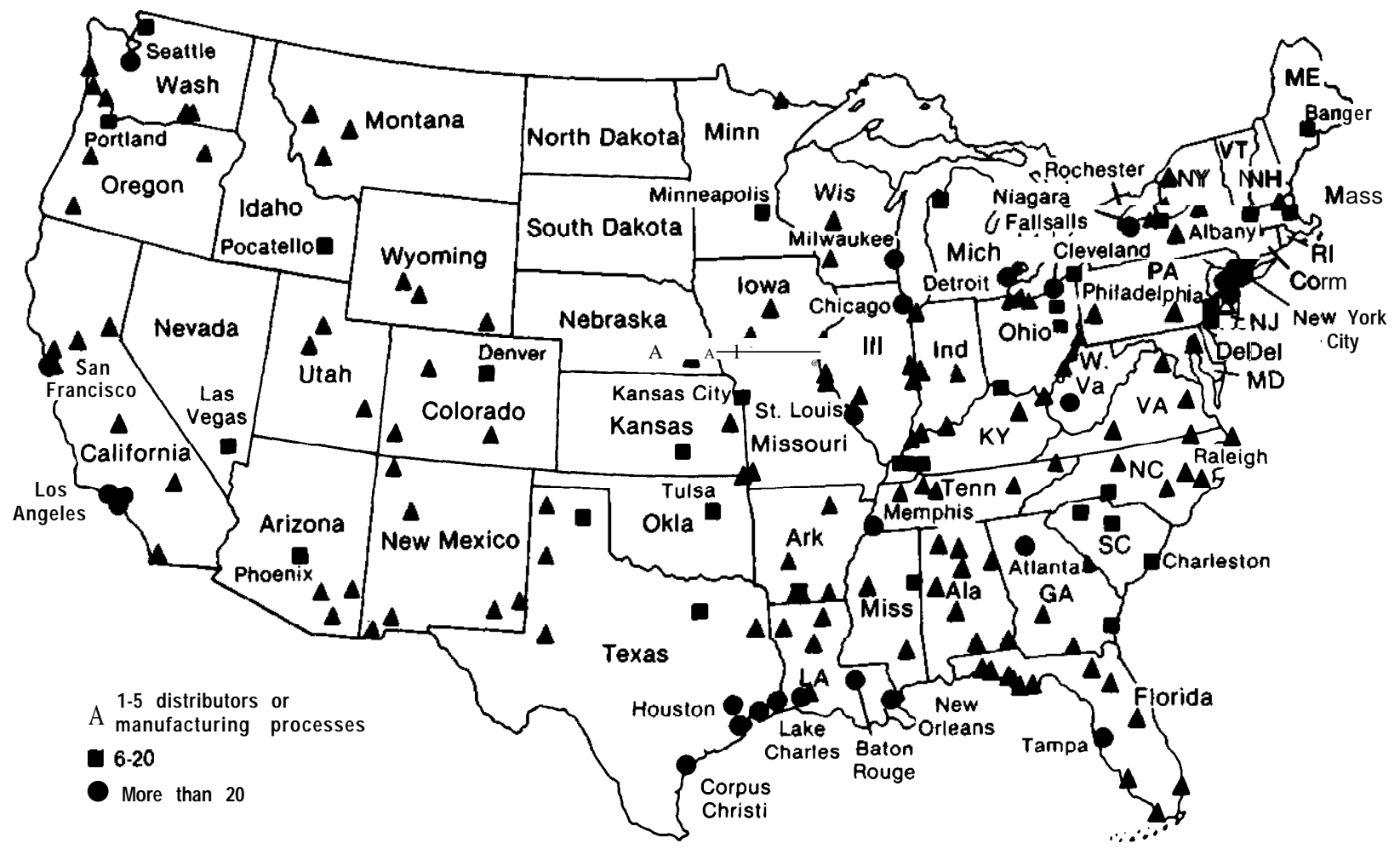

SOlJRCES: Environmental Protection Agency, SPN Directory of Chemical Producers, Chemical Week Buyers Guide, Chemsources U S A, Individual Chemical Companies.

the fire department to conduct the training courses and to educate local businesses on the proper storage and handling of chemicals.

Small urban and rural areas are much less likely to have the resources or the experienced manpower to respond appropriately to hazardous materials accidents and are less likely to be aware of the dangers of these accidents. The need for training in these areas seems less pressing, because hazardous materials transportation accidents are less likely to occur. However, when an accident does occur, the lack of trained personnel escalates the risk at the site and within the surrounding community.

Developing and maintaining a regional hazardous materials response team is a cost-effective possibility for smaller jurisdictions. Coalitions of sev-

\footnotetext{
${ }^{44}$ The 1986 budget for the chemical division of the Santa Clara Fire Department, generated by the license and fee program, is $\$ 286,000$. Larry Monette, Santa Clara Fire Department, Santa Clara, CA, personal communication, Apr. 28, 1986.
}

eral communities or of industry and local government may be able to provide specialized equipment and response capabilities even for areas with severe financial constraints. Industry participation may lessen the cost to local communities and provide a level of technical expertise in hazardous materials handling, chemical knowledge, and personnel protective equipment that is often beyond local capabilities. The cost of emergency response equipment and the difficulties faced by those who must select such gear are discussed in box SC.

\section{Industry Emergency Response Activities}

Over the past decade, hazardous materials manufacturers have evaluated their safety programs and often taken steps to address their own and the public's concerns. Industry's involvement in hazardous materials emergency response ranges from technical assistance to specialized response teams. The best 


\section{Box 5C.-Emergency Equipment}

Emergency response equipment is the primary protection and defense for first responders handling hazardous materials. The equipment must be adapted to a particular hazard in that it must be made of materials that are resistant to the hazardous chemical; and it must protect those areas and functions of the human body susceptible to the hazard.'

The lack of useful information on the appropriate type of personal protective equipment and procedures for its use is a major concern for local governments and emergency service personnel. Indeed, firefighter gear is only now being tested for chemical resistance. Firefighters and hazardous materials response teams currently rely on fire service literature, manufacturers information, and accumulated personal expertise when selecting chemical protective gear. However, if a community identifies the hazardous materials manufactured, stored, and transported through its jurisdiction, equipment selection can be made based on this information.

The appropriate choice among the varieties of equipment offered and the numerous operating procedures available depends on the hazardous materials being handled, and those responsible for equipment purchase are faced with difficult and expensive options. The factors to be considered prior to purchasing protective clothing include: the initial cost of the clothing; chemical protection capabilities of the construction material; ease of testing, use, maintenance, and decontamination; and durability and reliability of the suit. ${ }^{2}$

Personal protective equipment is currently made of a variety of materials that differ in terms of chemical resistance and durability. Butyl rubber, polyvinyl chloride, and vitron are the three most common materials used: ${ }^{3}$

- Butyl rubber is resistant to gas permeation and can be used with almost anything except chlorinated, aliphatic, or aromatic solvents.

- Polyvinyl chloride is considered excellent for use with acids and bases, and is also good for use with most organics except chlorinated and aromatic solvents. However, it allows some permeation by organics and retains some absorbed material.

- Vitron is resistant to most organics including chlorinated hydrocarbons and solvents except oxygenated solvents, such as alcohols, aldehydes, ketones, esters, and ethers. ${ }^{4}$

The cost of protective suits ranges from less than $\$ 100$ for a disposable coverall to approximately $\$ 2,000$ for a chemical splash suit with inner and outer suit protection. Self-contained breathing apparatus, important for incidents involving unknown chemicals or known highly hazardous chemicals, may cost $\$ 1,400$ each.

Equipment must fit properly, be used correctly, and be maintained appropriately if it is to provide effective protection. In the course of their activities, firefighters and other emergency responders will be exerting themselves, altering the fit and possibly reducing the effectiveness of clothing and respirators. For these reasons, emergency responders must be provided with training and explicit guidelines on the purchase, use, and maintenance of protective equipment.

1A.D. Little Co., "Protective Clothing and Equipment," Chemical Hazard Response Information System (CHRIS) Response Methods Handbook (Washington, DC: U.S. Coast Guard/U.S. Department of Transportation, December 1978), p. 7-1.

2Proceeding of a meeting of Federal and local o\&i\& sponsored by the U.S. Fire Administration, Federal Emergency Management Agency, and Public Technology Inc.. unpublished typescript. Washineton. DC. Auaust 1984.

International Society of Fire Service Instructors, Chemical Encapsulating Suit Committee, unpublished survey, June 1985.

¿U.S. Environmental Protection Agency, Edison, NJ, unpublished emergency response training information, January 1986; and A.D. Little Co., op. cit. 
known effort is the Chemical Transportation Emergency Center (CHEMTREC), established in 1970 by the Chemical Manufacturers Association (CMA). CHEMTREC maintains an online database on the chemical, physical, and toxicological properties and health effects of the thousands of products of the member companies. CHEMTREC staff provide chemical information for use in onsite decisionmaking and notify the manufacturer of an accident involving its product. CMA has also developed CHEMNET, a mutual aid network of chemical shippers and for-hire contractors, to advise and assist at chemical spills during transportation. Figure 5-3 shows locations of CHEMNET emergency response teams.

Many large petrochemical and chemical manufacturers train and maintain company emergency response teams for both their fixed facilities and transportation accidents. A team may respond itself to a report of an accident involving a company product or, under formal agreements, may request another participating company closer to the incident to respond. Industry teams observed by OTA are instructed to defer to the local on-scene commander at an accident, so that the emergency response effort remains coordinated. ${ }^{45}$

A recent effort, the CMA's Community Awareness and Emergency Response Program, encourages industry and community cooperation in the development of emergency response plans. A successful example was an evacuation drill of several Philadelphia neighborhoods located near industrial facilities, sponsored by the city and two chemical companies in October 1985. More than 600 people, out of approximately 2,000 residents, participated in the exercise, and the emergency response plan for the area was revised as a result of the drill. ${ }^{46}$

The Channel industries in Houston, Texas, the Pesticide Safety Team Network, and Chlorep are other examples of emergency response capabilities provided by industry .47 The Channel industries, a

\footnotetext{
${ }^{45}$ Shell Oil Co., Mid. Continent Distribution Area, Response Action Team Training, June 1985.

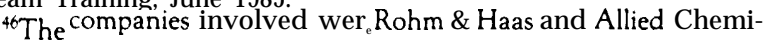
cal. Phil Stefanini, Rohm \& Haas, Philadelphia, PA, personal communication, Apr. 22, 1986.

${ }^{47}$ Pesticide Safety Team Network and Chlorep are both specialized information and response units formed by manufacturers of pesticides and chlorine products. Like CHEMNET, participating industries respond, coordinate response, or arrange contractor response to trans-
}

concentration of chemical facilities along the Texas Channel, have extensive mutual aid agreements with each other. By pooling their resources, these industries can assemble 500 firefighters and other trained personnel and equipment, including power generators for rapid response to an accident. Finally, a nuclear power industry group, The Institute for Nuclear Power Operations, has established a voluntary agreement including 42 utilities to provide assistance to another utility in the event of a radioactive materials transportation accident. *

\section{Emergency Response Training}

The population in need of hazardous materials emergency response training is widely distributed and varied. A major segment of this population includes paid and volunteer firefighters. $*$ Volunteers comprise 85 percent of the firefighter population, while the remaining 15 percent are paid employees of municipal, county, or local governments. ${ }^{48}$ Of this large number of volunteers, it is estimated that 25 percent, or roughly 255,000 firefighters, leave the fire service each year. ${ }^{49}$ Police officers are the second largest group involved in emergency response. In small urban and rural areas, police officers may serve both as enforcement officers, checking for violations of hazardous materials and other safety regulations, and as first responders to transportation accidents involving hazardous materials.

In addition, health professionals and civil defense or emergency management personnel may be required at the scene of hazardous materials accidents. There are approximately 400,000 basic emergency

portation accidents involving their products. Lawrence Norton, National Agricultural Chemical Association, personal communication, Aug. 30, 1985.

*The Institute for Nuclear Power Operation (INPO) is a nonprofit organization formed $b_{y}$ electric utilities in 1979 after the Three-Mile Island accident. INPO establishes industry standards for the operation of nuclear powerplants, including personnel and training standards.

*Call firefighters are part-time paid firefighters who are considered part of the volunteer force for statistical purposes.

${ }^{48} \mathrm{As}$ of 'December 1985, the International Association of Fire Fighters (IAFF) estimated the total fire service population to be 1,034,394 persons. Of this population, 884,600 are volunteers or call firefighters. The remaining 149,794 are paid or career firefighters. The National Fire Protection Association (NFPA) estimates the paid or career fire service population is 226,600 persons and agrees with IAFF figures on volunteer firefighters. Carl Peterson, NFPA, Quincy, MA, personal communication, December 1985.

${ }^{49}$ Chief Warren Isman, Fairfax Count Fire Department, VA, personal communication, November 1985. 
Figure 5-3.-CHEMNET Emergency Response Team Locations

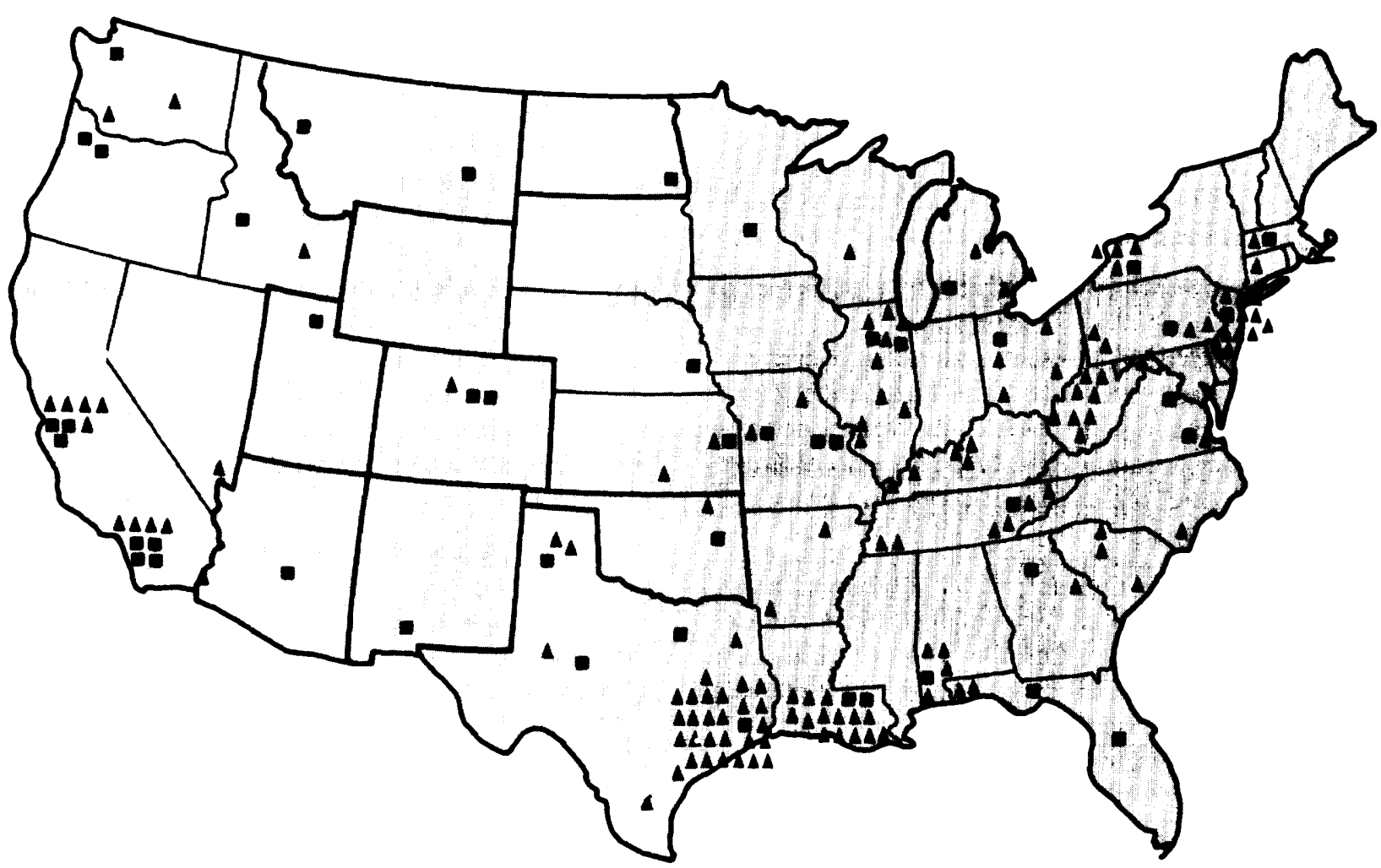

A CH EM NET chemical industry emergency response teams

- CHEMN ET contractor emergency response teams

SOURCE. Chemical Manufacturers Association

medical technicians, ${ }^{50}$ and there are about 6,500 civil defense and emergency management personnel. Employees of State and local public works, environmental health and emergency preparedness agencies, and health care facilities may also be called on to handle hazardous materials emergencies.

Some of these groups have received training in hazardous materials response pertinent to their area of expertise-for example, emergency room physicians and nurses receive training in detoxification procedures, and civil defense workers receive training in radiological response. However, few receive training in hazardous materials response, and many are unequipped to handle victims of transportation accidents or first responders who suffer effects of exposure. $^{51}$

\footnotetext{
Morando, op. cit.

"A survey of New Jersey hospitals conducted by the Workers Pol icv ProjectunNovember 1 985, found area hospitals unprepared for
}

Of this total population, OTA estimates that 1.5 million have not received any hazardous materials training or may be in need of specialized training. Of particular importance is training for the first line of response at a hazardous materials transportation accident-firefighters, police, and emergency medical personnel. What constitutes appropriate response training, who should receive it, and how it should be funded are subjects of intense debate.

\footnotetext{
chemical emergencies. Of the 32 hospitals surveyed in seven counties in northern New Jersey", less than one-quarter of the emergency rooms had a protocol for chemical emergencies, one-half had a single physician in the emergency room during the daytime, and two-thirds had a single physician in the emergency room at night. Most of the hospitals reported they would be unable to treat more than 20 critically ill patients at one time. Steven Markowitz, et al., Ability of Health Care Facilities in Northern New Jersey To Respond to Major Chemical Accidents (New York: Workers Policy Project, November 1985), p. 3; and Stuart Diamond, "Hospitals Found To Be Ill-Prepared for Toxic Spill in New York Area," The New York Times, p. AI, Dec. 4, 1985.
} 
Local elected and public safety officials responsible for the safety of the community feel strongly that adequately trained and equipped emergency response personnel are necessary. At a minimum, they believe that first responders must know how to identify hazardous materials, understand the differences between chemical emergencies and standard firefighting, and be able to alert appropriate officials and more sophisticated response teams if necessary.

High-quality training for specialized public and private hazardous materials response teams is also important. Advanced courses generally cover some elements of basic chemistry, the hazardous materials regulations, dangers posed by various chemicals and other commodities, response and cleanup procedures, and the use of specialized protective equipment.

Industry officials maintain that hazardous materials emergency response requires experience and expertise with the commodity involved and that they are in the best position to provide such assistance. However, when hazardous materials accidents occur in locations distant from transportation or manufacturing centers, industry assistance like that of the specialized Federal response teams described earlier is often not readily available.

\section{Federally Sponsored Training}

At the Federal level, a myriad of emergency response training programs are conducted by the Federal Emergency Management Agency, the Department of Transportation, the Environmental Protection Agency, the Department of Energy, and the Nuclear Regulatory Commission, among others. These programs, offered at both national and regional locations, are related to different aspects of hazardous materials emergency response, with each agency emphasizing its own area of responsibility. Although representatives of many of these agencies meet regularly as members of the National Response Team, strong Federal leadership in emergency response training has not yet been achieved. In 1985, NRT established a special training committee to identify problems, gaps, and duplicative activities and to recommend training programs and policy alternatives.

\section{The Federal Emergency \\ Management Agency}

FEMA hazardous materials training activities include residential and field programs, train-the-trainer courses, and teleconferences. Training is offered by two organizations at the National Emergency Training Center in Emmitsburg, Maryland - the National Fire Academy (NFA) and the Emergency Management Institute (EMI). (See table 5-8.) NFA provides instruction on response tactics and procedures and the chemistry of hazardous materials, while EMI sponsors training that is oriented toward planning and policymaking activities. However, both NFA and EMI training programs only recently began to focus on hazardous materials.

The National Fire Academy trains State and local fire and rescue personnel through both field and resident programs. ${ }^{52}$ Most State and local training officials contacted by OTA consider NFA courses and training materials to be extremely valuable. The resident training programs are 2 to 3 weeks in length and offer extensive training; nearly 2,000 students attended hazardous materials courses at the Academy between 1980 and mid-1985.

Shorter versions of the NFA resident training programs have been developed into field training programs; these are 16 hours long, and are designed to be offered in 3-hour segments for evening or weekend sessions for volunteer firefighters. Field training programs generally take 1 year to develop and undergo a 2-year field testing program before becoming final. Two NFA field training programs-''Hazardous Materials Incident Analysis" and "Hazardous Materials Pesticide Challenge' '-were reworked into train-the-trainer courses in July 1984. State and metropolitan fire department officials are trained as trainers by NFA and subsequently are provided with instructor guides and student manuals for further distribution.* Between July 1984 and December 1985 , these programs reached more than 18,500 students in the field. In addition, an older field pro-

\footnotetext{
${ }^{52}$ National Fire Academy training is authorized under the Federal Fire Prevention and Control Act of 1974, Public Law 93-498. *Metropolitan fire departments are those that serve populations great er than 200,000 people or have a firefighting force of greater than 400, paid and volunteer, and have centralized training.
} 
Table 5-8.-Federal Emergency Management Agency Response Training

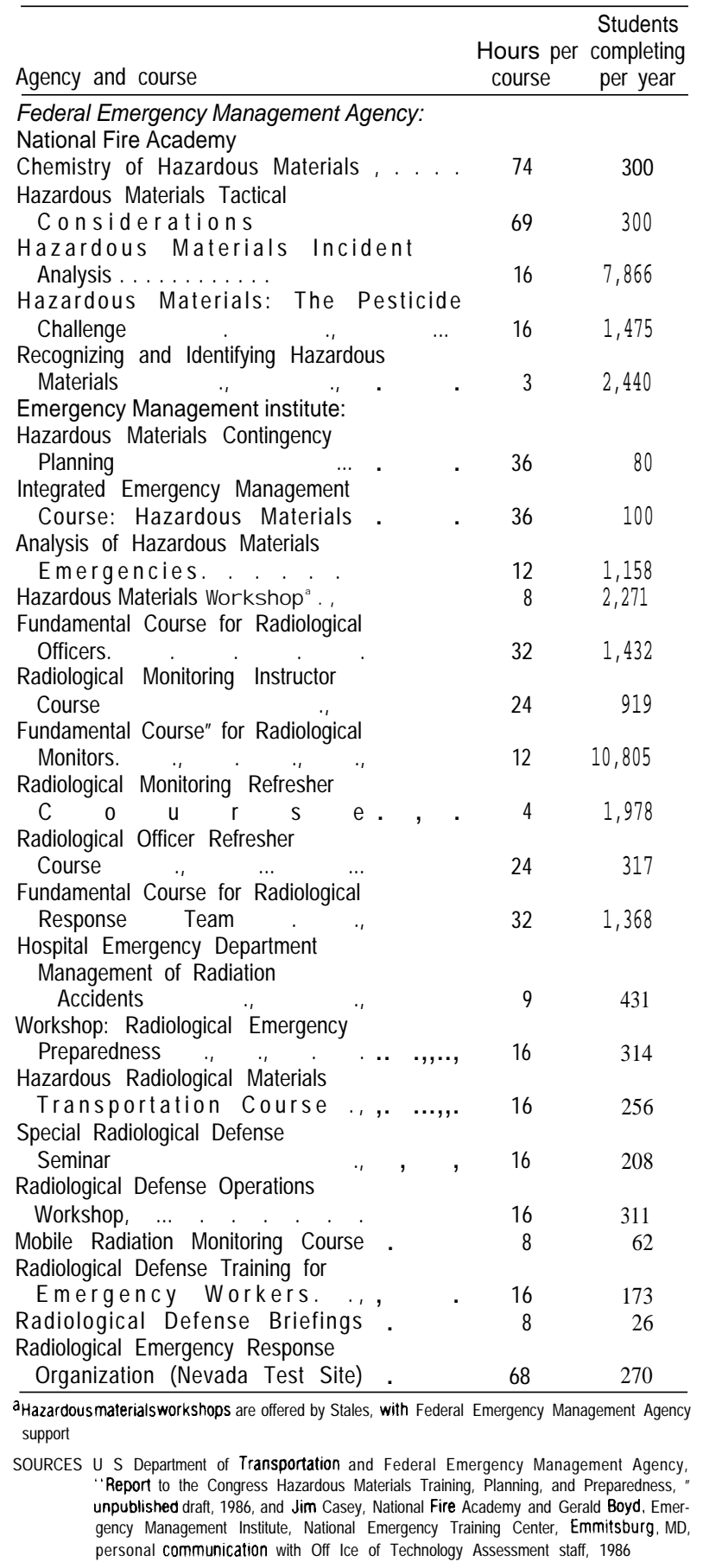

gram, "Recognizing and Identifying Hazardous Materials," was recently updated and shortened to 6 hours; 12,440 students were trained under this program from July 1984 to December $1985 .^{53}$ Training programs that have been given to State and metropolitan fire departments for train-the-trainer distribution are also available through the National $\mathrm{Au}-$ dio Visual Center.*

While EMI also conducts training programs, the majority of them are directed toward civil defense. Some flexibility is allowed by FEMA for States interested in offering workshops and more in-depth courses on hazardous materials. Indeed, States that receive training funds must use 80 percent of their training monies to send students to 22 specific FEMA courses, only 2 of which deal directly with hazardous materials. Thus, only 20 percent of FEMA funds are available for additional hazardous materials and other types of emergency training. ${ }^{54}$ These funding restrictions exist because financial assistance for emergency management provided to States and local jurisdictions by FEMA is authorized under the Federal Civil Defense Act. ${ }^{55}$ Funds obligated under this statute may be used to prepare for and respond to actual attack-related events or natural disasters, including manmade catastrophes. However, monies may be used for disaster preparedness "only to the extent that such use is consistent with, contributes to, and does not detract from attack-related preparedness.

Several EMI resident training courses address hazardous materials. One course, "Analysis of Hazardous Materials Emergencies," is a 12-hour basic awareness program conducted by State trainers using EMI

\footnotetext{
"Wayne Powell, National Fire Academy, National Emergency Training Center, Emmitsburg, MD, personal communication, Apr. 14, 1986.

*The National Audio Visual Center in Washington, DC, stores all federally supported audio visual training for publication, distribution, and sale.

${ }^{54}$ Federal Emergency Management Agency, "Draft Fiscal Year 1987 Comprehensive Cooperative Agreement Program Guidelines," unpublished typescript, February 1986.

'Federal Civil Defense Act of 1950, as amended, 50 U.S.C. App. 2251.

44 CFR 302.7; and 44 CFR 312.
} 
materials. Since 1985, when this course was first offered, 1,500 local officials have been trained. Two other courses are geared more towards emergency planning than first responder training. The target audience for one course, Integrated Emergency Management, is local officials; the purpose of the course is to provide an overview of hazardous materials regulations, incident decisionmaking, equipment, evacuation, media relations, and planning exercises. In addition, in early 1986, EMI introduced another hazardous materials planning course directed at State and local officials. The course was developed jointly with EPA and will be offered by both agencies.

In an effort to reach more first responders, FEMA is also sponsoring teleconferences several times a year on different aspects of hazardous materials emergency response. FEMA estimates these broadcasts initially reached more than 100,000 emergency response personnel and firefighters throughout the country .57 While many officials believe that this type of training is a poor substitute for classroom experience, personnel at the National Fire Academy say that the teleconferences will heighten awareness of hazardous materials for fire service personnel who have little or no training in hazardous materials response. According to FEMA, future teleconferences will focus on exercises that can be used by a community to plan for hazardous materials emergencies.

\section{The Environmental Protection Agency}

The Environmental Protection Agency conducts training for hazardous materials response through resident and on-the-road programs. Since the EPA training effort began in 1979, the number of Federal, State, local, and industry personnel trained has risen from 373 during 1979 and 1980 to more than 2,300 in $1985 .^{58}$ (See table 5-9.) Resident programs at Edison, New Jersey and Cincinnati, Ohio, include standard courses on decisionmaking, personnel protective equipment for response activities, and hazardous materials incident management. These courses and others are also offered at other sites throughout the Nation.

\footnotetext{
${ }^{57}$ Joseph Donovan, then Director of the National Fire Academy, Federal Emergency Management Agency, personal communication, Dec. $18,1985$.

${ }^{58}$ Thomas C. Sell, Training Coordinator, U.S. Environmental Protection Agency, personal communication, Dec. 18, 1985.
}

\section{The Department of Transportation}

Training given by the Department of Transportation modal administrations at the Transportation Safety Institute generally covers enforcement and compliance activities rather than emergency response and planning. However, the Coast Guard offers training in emergency response for hazardous materials spills and transportation accidents at its Yorktown, Virginia, Marine Safety School. The training is primarily intended for active and reserve Coast Guard personnel; however, limited numbers of personnel from other Federal, State, and local agencies may attend (see table 5-10).

Emergency response training is also offered by the Federal Railroad Administration through TSI; 1-day seminars for fire and emergency service personnel are offered in locations throughout the United States. In 1984, 50 seminars reached 1,749 students, and in 1985, 84 seminars reached 2,600 students. ${ }^{59}$ The Research and Special Programs Administration, which provides numerous hazardous materials compliance and enforcement courses at TSI, has offered emergency response training in the past. These courses were discontinued in 1983, as similar ones were available through FEMA.

In addition, DOT distributes, upon request, copies of its Emergency Response Guidebook and a brief guidance pamphlet for first responders. ${ }^{60}$ DOT also distributes to every State a self-contained training program on responding to accidents involving radioactive materials. ${ }^{61}$ The training program is intended for local fire, police, and ambulance emergency service personnel.

\section{Other Federal Response Training}

Other Federal agencies provide limited response training for hazardous materials transportation accidents. The Department of Energy offers emergency

\footnotetext{
${ }^{59}$ Frank Fanelli, Office of Safety Programs, Federal Railroad Admin istration, U.S. Department of Transportation, personal communication, Apr. 2, 1985.

${ }^{60}$ U.S. Department of Transportation, Research and Special Programs Administration, Materials Transportation Bureau, Radioactive Materials Transportation Information and Incident Guidance, DOT/ RSPA/ATB-81/4 (Washington, DC. ND).

${ }^{61}$ US Department of Irantsportation, Research and Special Programs Administration, Materials Transportation Bureau, Handling Radioactive Material Transportation Emergencies, DOT/RSPA/MTB7917 (Washington, DC: July 1979).
} 


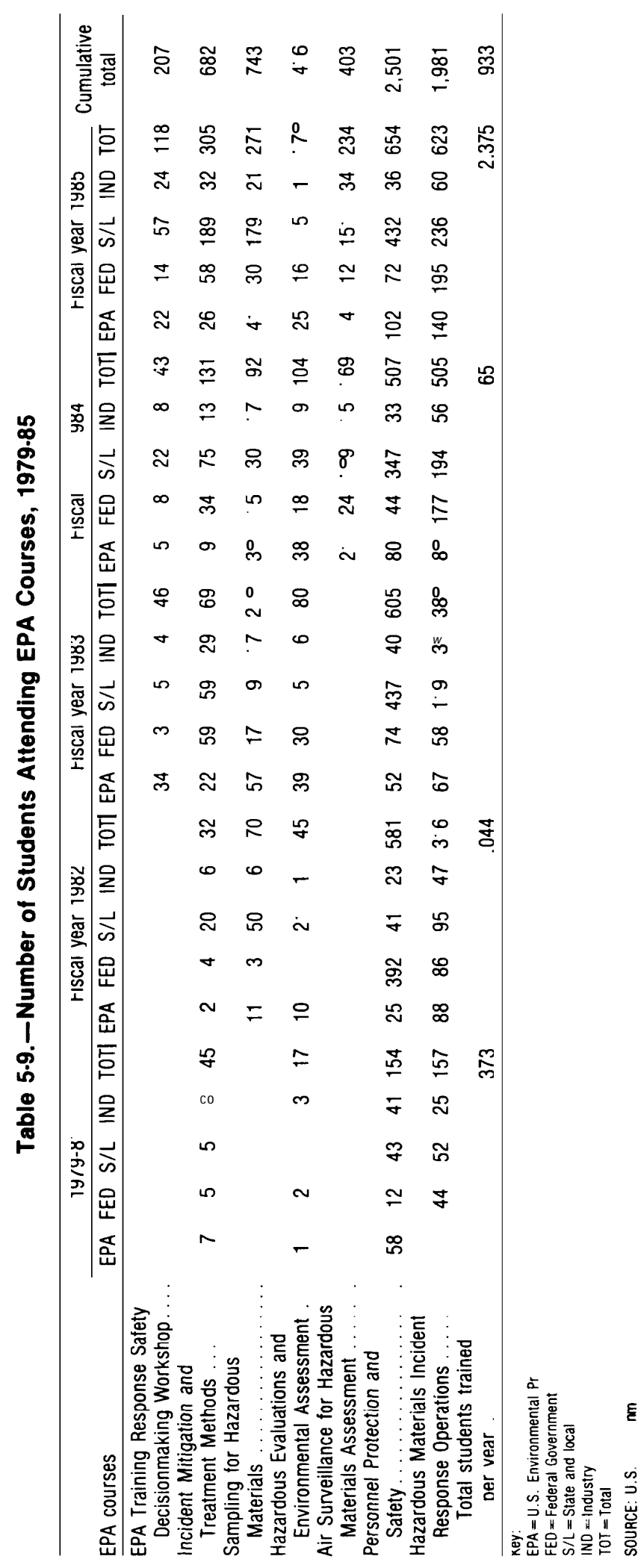


Table 5-10.-U.S. Coast Guard Emergency Response Training

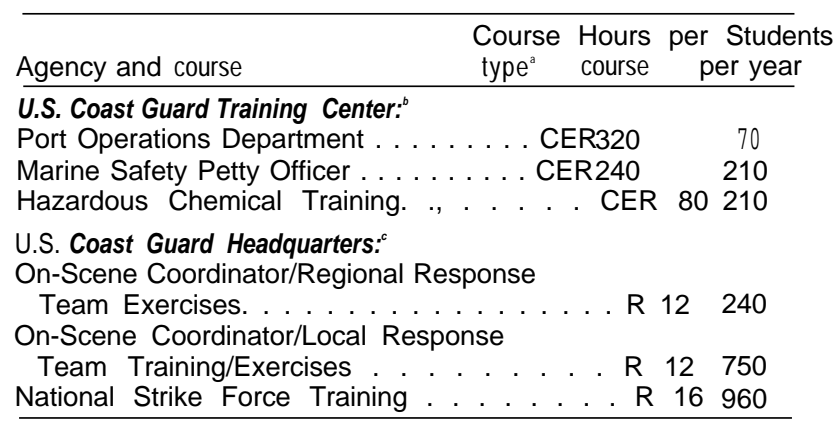

${ }^{\mathrm{a}} \mathrm{C}$ - Compliance, $\mathrm{E}=$ Enforcement, $\mathrm{R}=$ Response

blocated in Yorktown, VA.

Cocated in various locations established by national and regional response team members

SOURCE: U S. Department of Transportation and Federal Emergency Management Agency, "Report to the Congress Hazardous Materials Training, Planning, and Preparedness," unpublished draft. 1986

response training, in the form of 1-day workshops at DOE regional locations, to State and local police and firefighters. ${ }^{62}$ The Nuclear Regulatory Commission offers, through Oak Ridge Associated Universities, two training courses in health physics twice a year. Since 1960, approximately 500 State employees have been trained in "Health Physics and Radiation Protection." A similar course, "Applied Health Physics, " is available for Federal, State, local, and industry personnel. ${ }^{63}$ Both courses discuss radiation accidents, the role of a health physicist in medical emergencies, personnel decontamination and protection, environmental monitoring, and environmental sample preparation. ${ }^{64}$

\section{State and Local Emergency Response Training}

While more State and local officials are aware of the need for hazardous materials response training, a 1985 survey conducted by the National Response Team (NRT) and the Regional Response Teams (RRT) found that response capability varies greatly from State to State. Many State fire academies have recently added hazardous materials training to their

\footnotetext{
${ }^{62}$ Theresa Yearwood, Science Applications International Corp., Oak Ridge, TN, personal communication, March 1986.

${ }^{63}$ Jo Tipton, Registrar, Oak Ridge Associated Universities Professional Training Program, Oak Ridge TN, personal communication, April 1986

${ }^{64} \mathrm{Oak}$ Ridge Associated Universities professional Training Programs, course outlines for "Health Physics and Radiation Protection" and "Applied Health Physics," sponsored by the U.S. Nuclear Regulatory Commission, Office of State Programs, unpublished typescript, March 1986.
}

curricula and now offer refresher courses for firefighters and other emergency service personnel. ${ }^{65}$ Moreover, organized training programs for personnel involved in oil or hazardous materials emergency response were identified in 27 States. These training programs are generally offered by the State fire marshal's office, the State fire training agency, or the emergency preparedness agency.

In addition to State fire academies, other educational institutions also offer hazardous materials response training for State and local personnel. According to the DOT/FEMA survey, more than 500 educational institutions, including community colleges and universities, offer training in hazardous materials response. ${ }^{a}$ These institutions are widely distributed and charge only modest tuition fees; but course content and quality varies from institution to institution.

However, factors limiting State and local participation in training courses were also identified by the NRT/RRT survey; more than 80 percent of States indicated that insufficient funding for courses and for travel was an obstacle. Other problems included the lack of appropriate courses available to State and local responders, and the fact that training is often a relatively low priority for State agency managers. ${ }^{66}$

Moreover, the scope and content of State training programs and emergency response personnel requirements are not consistent. Examples of State training activities, discussed in box SD, illustrate the different types of programs that have been established.

Local training for emergency responders also varies widely, reflecting the relative importance of hazardous materials emergenc response in the community or State government and the financial resources available. The spectrum of local hazard-

\footnotetext{
${ }^{65}$ According to the Directory of State Fire Service Training Systems, 24 of the 50 States offer some form of hazardous materials training to firefighters, fire officers, or other emergency personnel. These States are: Arizona, Arkansas, California, Connecticut, Delaware, Florida, Georgia, Indiana, Iowa, Kansas, Maine, Massachusetts, Minnesota, Mississippi, Nebraska, New Mexico, North Carolina, Ohio, Oregon, Pennsylvania, Tennessee, Texas, Vermont, and Washington. National Emergency Training Center, Directory of State Fire Service Training Systems (Emmitsburg, MD: National Fire Academy, 1982)

${ }^{66}$ National Response Team/Regional Response Teams, "Federal/ State/Local Oil and Hazardous Substances Emergency Preparedness Activities," unpublished typescript, July 1985 .
} 


\section{Box 5D.-State Emergency Response Training Program}

Ohio

In 1976, Ohio developed a computerized fire reporting system. Analysts studying the results noticed that a significant number of emergency response personnel who responded to hazardous materials accidents were being injured.' This spurred the establishment of a hazardous materials training program for firefighters. A three-phase training program began in 1978.

1. Phase I is a 4-hour program that covers identification of hazardous materials, placards, labels, and methods for assessing community problem areas.

2. Phase II is an 8- to 12-hour program that deals with towththent, patching, personal protection, handson training, and other response procedures.

3. Phase III is a simulation of an actual incident in the edmingity, and includes participants from response organizations, local government agencies, and othet that might be involved in an accident.

Since 1980, 36,702 firefighters have been trained throu h 1, 637 courses. In 1982, Ohio assisted the National Fire Protection Association in the development of a similar training program for national distribution to other fire services. Ohio has also made special equipment avithe throughout the State, because many local fire departments are unable to finance such purchases. Five thicolos equipped with approximately $\$ 60,000$ worth of personal protective equipment have been stationed around the State for dispatch to hazardous materials accidents. Support for training development and equipment purchase was initially provided by two highway safety grants totaling $\$ 90,000$. Continued support of the training and equipment program is now provided by the State at a cost of $\$ 400,000$ per year.

\section{California}

A uniform standard for the training of hazardous materials response personnel, made final in December 1985 , by the California State Fire Marshal's Office is one of the first attempts by a State to develop such standards. The standard identifies two levels of hazardous materials technician training; both positions involve indepth training and knowledge of hazardous materials. A cateer development guide has been developed for the first level only. Career development guides, which are the basis of the State certification program, provide minimum performance standards for hazardous materials response; list the State training resources available; and are keyed to the National Fire Protection Association Professional Firefighter Qualifications. In addition to course material covered in the classroom, information specific to a locality is also provided. Entrance examinations are required for those seeking to enter the training program.

\section{Virginia}

Virginia has developed four levels of training.

1. Level I training, a 16-hour program, is designed for first responders. It covers an introduction to hazardous materials terms and definitions, identification and nature of hazardous materials, use of the DOT Emergency Response Guidebook and other resources such as CHEMTREC, and decontamination.

2. Level II training is based on two 16-hour courses offered by the National Fire Academy-Hazardous Materials Incident Analysis and Hazardous Materials: The Pesticide Challenge. An additional 8-hour segment involves hands-on training.

3. Level III training, a 120-hour program, focuses on the activities of an actual response team. A simulation of a hazardous materials accident is included.

4. Level IV training is still under development, but is expected to focus on incldent management and emergency planning. ${ }^{2}$ 


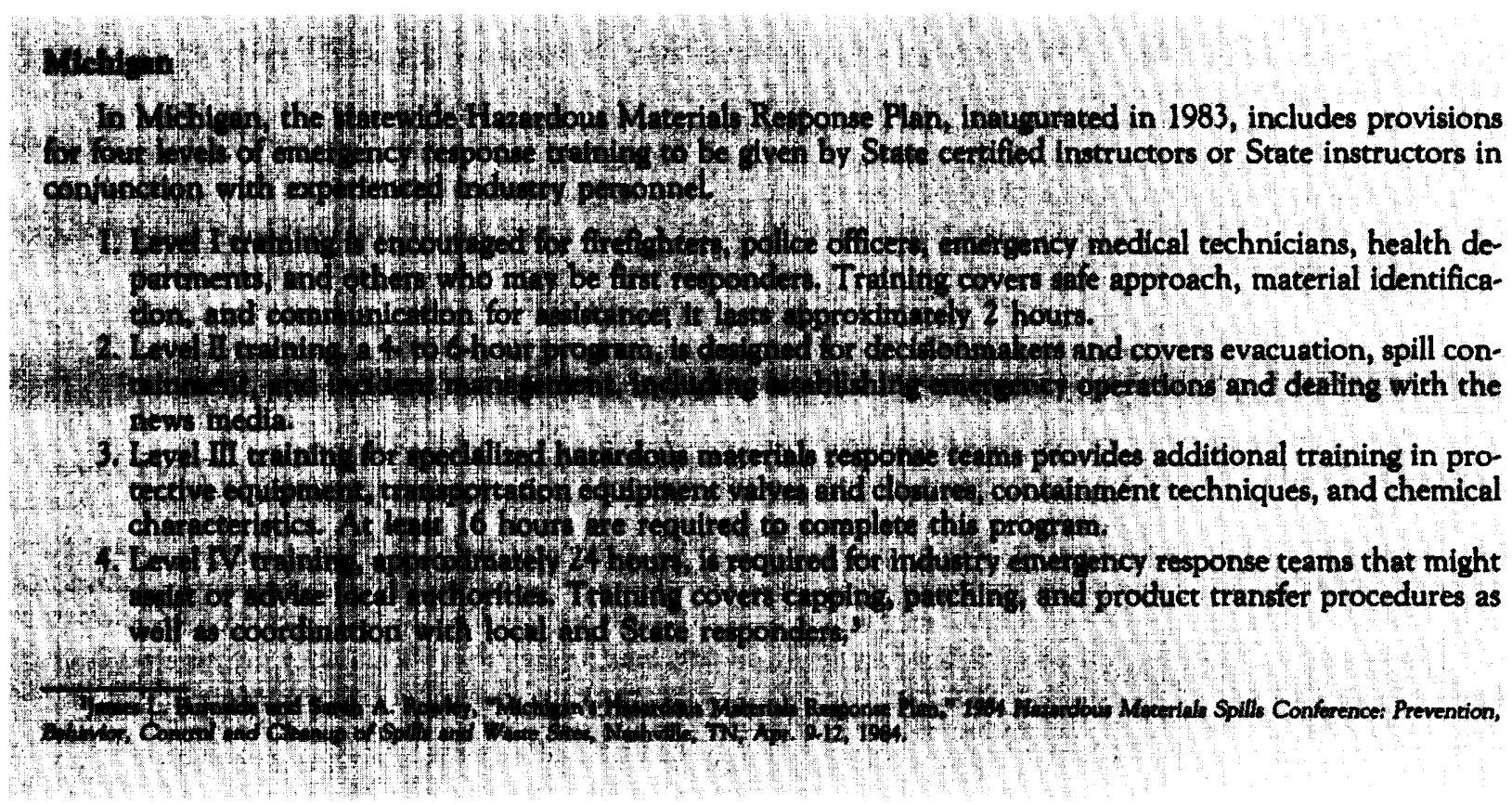

ous materials training courses ranges from well organized and funded hazardous materials offered by highly trained individuals to little or nothing. ${ }^{6}$ Moreover, some local officials feel that State programs do not meet the needs of local jurisdictions.

State officials, in conversations with OTA staff, confirmed that standardization of course materials, more coordination between programs, and better information about available courses are necessary for effective training of emergency response personnel. If State instructors are trained at FEMA's National Fire Academy and State programs are based on FEMA courses and materials, greater course uniformity can be expected. Many State training officers contend that the 3- to 6-hour introductory courses offered by many organizations are too superficial to prepare first responders adequately for hazardous materials transportation accidents. ${ }^{69}$ In addition,

\footnotetext{
${ }^{67}$ Association of Bay Area Governments, National Directory of Hazardous Materials Training Courses (San Francisco, CA: March 1985), p. 8; and data supplied by the International Association of Fire Chiefs to the Office of Technology Assessment.

${ }^{60}$ This figure is considered too low by industry trainers, due to underreporting and limited industry participation in the survey. Several wellknown industry training programs were not included in the survey, U.S. Department of Transportation and Federal Emergency Management Agency, "Report to Congress on Hazardous Materials Training, Planning and Preparedness," unpublished draft typescript, January 1986. ${ }^{69}$ Training officers $i_{n} 35$ State fire academies, personal communications, June and July 1985.
}

differing criteria are used to certify courses, instructors, and emergency response personnel. Coordination of training agencies, such as fire academies and educational institutions, within each State, is an important step toward providing more comprehensive and uniform training of State and local responders.

An interactive computer system, currently under development for FEMA, will eventually serve as an electronic bulletin board for State and local emergency response personnel, providing information on FEMA training, appropriate hazardous materials literature, State and local contacts, and summaries of properly handled hazardous materials accidents. ${ }^{70}$ While comprehensive training information will not initially be available through this system, it is a step in the right direction. Furthermore, the Secretary of Transportation has announced that DOT will establish an information clearinghouse with a tollfree number. The clearinghouse will supply details on training programs, emergency response teams, planning assistance, and other information to help

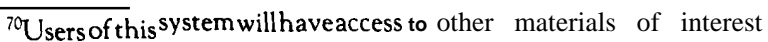
and will be able to leave messages. FEMA spent $\$ 50,000$ in 1985 and $\$ 60,000$ in 1986 for the development of this computer system. Although the system will be available free of charge, necessary hardware, such as a personal computer, must be purchased by participating State or local agencies. William Metz, Argonne National Laboratories, personal communication, Apr. 22, 1986.
} 
local communities. ${ }^{71}$ Coordination of these two Federal information-sharing efforts is important to ensure their cost-effectiveness.

\section{Industry-Provided Emergency Response Training}

Industry training is provided by individual shippers, manufacturers, and associated trade and professional organizations. Typically, the training covers hazardous materials emergency response for both fixed facilities and transportation accidents through seminars, workshops, and such aids as videotapes and films. However, these training activities are generally limited to larger industries with adequate resources, and current programs reach relatively few local personnel. Moreover, State and local emergency response personnel invited to participate often are restricted to playing themselves in industry training exercises rather than participating in more advanced activities such as unloading a cargo tank. As a result, much of the industry-provided training for emergency response personnel focuses on recognition of hazardous materials, on-scene management, and initial response actions such as spraying foam.

Among the chemical and petrochemical manufacturers that offer hazardous materials training are DuPont, Exxon Chemical, J.T. Baker, Stauffer, Union Carbide, and Mobay. ${ }^{72}$ A number of these programs have been opened to neighboring response teams or other interested response personnel. This training varies from 1-day seminars to more extensive hazardous materials training and coordination drills. $^{73}$

Recently, five chemical companies established a $\$ 400,000$ grant to setup a pilot program in New Jersey to train local emergency response personnel for hazardous materials emergencies. Administered by the Union and Middlesex Counties Hazardous Materials Advisory Council (HMAC), the program in-

\footnotetext{
"Elizabeth Hanford Dole, Secretary of Transporation, "Remarks Prepared for Delivery to the Chemical Manufacturers Association," delivered in St. Louis, MO, unpublished typescript, May 7, 1986.

"Association of Bay Area Governments, op. cit.; and Hazardous Materials Advisory Council (HMAC), "Survey of Industry Emergency Response Training," HMAC Courier, vol. 4, No. 10, Dec. 13, 1985.

"For example, Union Carbide training through its HELP program lasts for 1 week, while DuPont Chemical training lasts for 4 days. $\mathrm{Na}$ tional Response Team/Regional Response Teams, op. cit.
}

eludes a slide and tape presentation and a 6-hour training seminar. ${ }^{74}$ Between February and May 1986, 16 training seminars were held at local fire department facilities. In addition, 200 copies of the slide and tape presentation are being distributed, free of charge, to appropriate emergency response organizations; other copies may be borrowed from HMAC.

The transportation industry also provides emergency response training. Although most of this training was set up originally for shipper and carrier personnel; however, emergency response personnel are invited to participate. Companies that offer training include Flying Tigers and a number of railroad systems, such as Boston \& Maine, Burlington Northern, Chessie Systems, Conrail, Soo Line Railroad, Southern Pacific, Southern Railroad Systems, and Union Pacific Systems.

Industry also provides equipment and teaching expertise for training programs offered by other institutions. For example, Shell, Amoco, and ARCO have contributed equipment used in Texas A\&M University's annual tank truck rollover response program. ${ }^{76}$ Union Pacific Railroad, in cooperation with EPA, offers a training course in emergency response.

Trade associations offering training in hazardous materials and response procedures include the Association of American Railroads, the American Trucking Associations, the Chemical Manufacturers Association, the American Petroleum Institute, the

\footnotetext{
${ }^{74}$ The five companies participating in the grant program are DuPont, Exxon Chemical, American Cyanamid, Merck \& Co., and Union Carbide. Under the pilot program, a slide and tape show was developed for first responders while a 1-day seminar was developed for other emergency response personnel. Training materials were produced by the Institute for Life and Safety Technology and Emergency Managemen of Ashland, MA. Barry D. Bernstein, the Hazardous Materials Advisory Council, Linden, NJ, personal communication by letter, Mar. 27, 1986.

${ }^{75}$ National Response Team/Regional Response Teams, op. cit.

${ }^{7}$ Albert Stirling, Oil and Hazardous Materials Control Divisions, Texas A\&M University, College Station, TX, personal communication, Apr. 24, 1986.

'Since 1979, Union Pacific Hazardous Materials Training Activities have trained 9,383 employees and 36,106 State and local response personnel. In 1984 alone, "Recognizing and Identifying Hazardous Materials," "Defining Your Hazardous Materials Problem," and special training programs reached over 6,000 response personnel. Charles Wright, Training Director, Union Pacific Systems, personal communication, Apr. 29, 1985, and compiled data on Union Pacific hazardous materials training.
} 
National Agricultural Chemical Association, and the Chlorine Institute. Some State associations also sponsor training programs. For example, the Pennsylvania and New Jersey Motor Truck Associations provide training seminars for State Police in their respective States.

To improve the reliability and breadth of information available for hazardous materials response, the Association of American Railroads has developed an emergency action guide for first responders, and a more detailed information system for technical personnel. ${ }^{78}$ These systems include information on the 134 commodities that represent 98 percent of railroad hazardous materials traffic.

Professional associations representing emergency service personnel also offer emergency response training. Training includes basic hazardous materials recognition as well as advanced response procedures. These training programs are often more comprehensive and uniform and may be more readily available than training offered by others in the private sector. The National Fire Protection Association, the International Association of Fire Fighters, the International Association of Fire Chiefs, the International Association of Fire Service Instructors, and the International Association of Chiefs of Police are among the professional associations offering such training.

\footnotetext{
${ }^{7}$ The more detailed system, the Industrial Chemical Accident Response Information System (ICARIS), includes four categories of data:

1. general information: identification of chemicals including commod tty codes (STCC, UN/NA, IMCO), trade names and synonyms, and shipping information.

2. chemical information: the chemical properties of the materials.

3. health and hazard information: descriptions of health effects, response guidelines, and appropriate protective clothing.

4. environmental effects information; compatibility of chemicals, toxicology, and pollution effect data.

ICARIS integrates environmental models with current chemical data to provide real-time assessments of chemical spills and support response decisions $b_{y}$ technical staff. ICARIS currently performs three functions: information retrieval, air dispersion modeling, and estimation of chemical properties (e.g., volatilit from soil). Gerald A. Meier, Association of American Railroads, "The AAR Chemical Spill Response Information System " !npublished typescript, July 1983.

The National Fire Protection Association provides trainin $\mathrm{g}$ to fire and emergency service personnel, primarily through slides, ${ }^{\text {rapes, and }}$ instructors guides. National Fire Protection Association, Fire Service Training Programs, 1985 Catalog (Quincy, MA: 1985). The National Fire Protection Association also recently developed emergency response training videotapes that can be broadcast via satellite.

In addition, the International Association of Chiefs of Police recently developed a trainin program on Hazardous Materials Incidents. The Hazardous Materials Incidents training program covers basic requirements for first responders, supervisors, and commanders of hazardous materials incident scenes; on-scene safety precautions; how to estab-
}

The National Fire Protection Association (NFPA), responsible for the establishment of minimum professional competence standards for firefighters, inspectors, instructors, and officers, has recently begun to develop standards for hazardous materials response. The NFPA standard-setting process, a consensus approach, involves representatives of diverse groups such as the insurance industry; fire, police, and other emergency service organizations; chemical industry representatives; and Federal, State, and local government agencies. Thus, it usually takes 2 or 3 years until NFPA standards are completed.

\section{Conclusions and Policy Options for Emergency Response Training}

Approximately 2 million firefighters, police officers, and other emergency service personnel are potential first responders to hazardous materials transportation accidents. Despite an abundance of courses, appropriate training often does not reach these first responders either because the awareness of the need is too low, funding is not available, or uncertainty exists about the appropriate course. Participants in an April 1985 FEMA-sponsored workshop of national, State, and local experts agreed that it is emergency personnel who are most likely to be first responders-that are most in need of training.

Federal expenditures to support emergency response training have placed emphasis on lengthier, advanced level response training courses of the type offered by FEMA at Emmitsburg, Maryland, and EPA at Edison, New Jersey. Such courses are appropriate for personnel that will be part of a hazardous materials emergency response team in an area with an identified high-hazard potential, although these represent a relatively small percentage of the Nation's firefighters.

\footnotetext{
lish guidelines for containing hazardous materials; standard development for coordinating multidisciplinary response teams; how to recognize hazardous materials; and how to identify the needs, procedures, and duties of on-scene managers. International Association of Chiefs of Police, Law Enforcement Training Catalog (Gaithersburg, MD: 1986), p. 36; and Chuck Peltier, International Association of Chiefs of Police, Gaithersburg, MD, personal communication, Apr. 8, 1986.

${ }^{80}$ Martin F. Henry, Assistant Division Director, Field Services, National Fire Protection Association, Quincy, MA, personal communication, Apr. 15, 1986

${ }^{81}$ The Federal Emergency Management Agency, National Emergency Training Center ${ }_{1}$ "Proceedings-National Workshop on Hazardous Materials Training," unpublished typescript, October 1985, p. 20.
} 


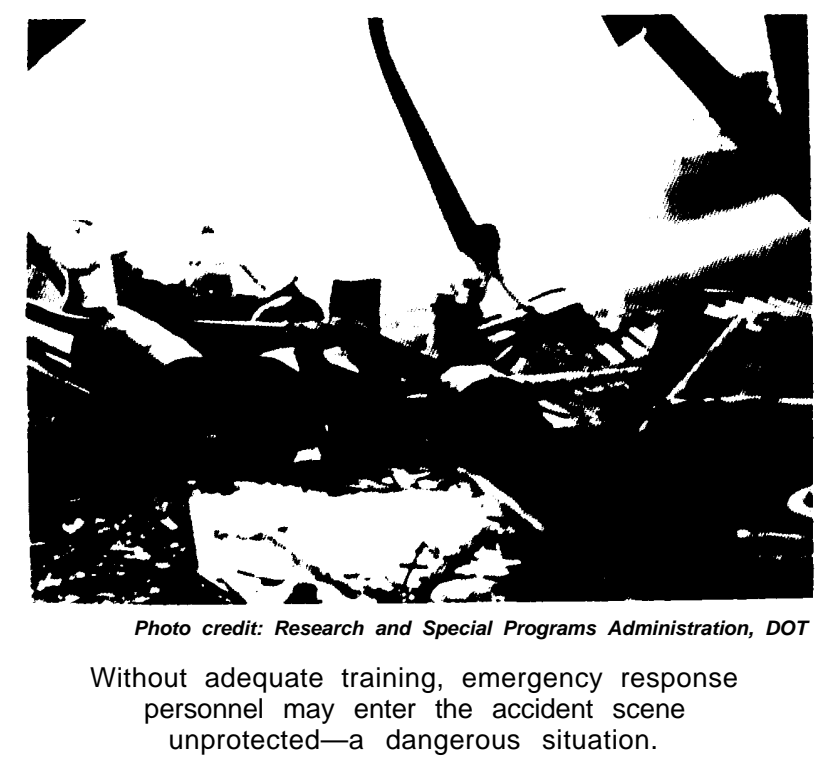

OTA concludes that a national strategy to make an appropriate level of hazardous materials response training, whether basic or advanced, available to State and local personnel is urgently needed. The Federal role in developing a training strategy could include: participating in the development of training guidelines, ensuring adequate funding levels, and establishing a training information clearinghouse. While 1.5 million emergency response personnel need additional hazardous materials training, the vast majority require only basic first response training. However, maintaining levels of expertise through refresher courses for those already trained is also important.

Better organization and utilization of existing training resources could increase the numbers trained considerably without additional funds. For example, existing Federal hazardous materials emergency response training and training support programs in FEMA, EPA, the Coast Guard (DOT), NRC, and DOE need to be coordinated and made complementary. However, choosing the right agency to coordinate Federal emergency response programs and administer any special funding program is problematic. Institutionally, that agency is FEMA. The use of FEMA grant monies to support State and local planning and training activities for hazardous materials is limited, however, by the Federal Civil Defense Act, which requires that funds be used primarily for civil defense preparedness. Moreover, while there is widespread agreement about the need for a strong, central Federal leadership role, there is equally widespread doubt about whether FEMA can provide that leadership.

One congressional option is to charge the $\mathrm{Na}-$ tional Response Team with specific responsibility for coordinating hazardous materials response training and developing national guidelines for courses and levels of training in cooperation with NFPA. Broad-based participation, similar to that in the NFPA process, in developing the guidelines is important. At the Federal level, this would mean that DOT, FEMA, EPA, and probably NRC and DOE would need to reach agreement, a possibility under the auspices of the NRT training committee. This committee has already begun to define both first responder and more specialized target audiences, and identify the tasks and core courses associated with each group. Developing quality control and certification standards for training courses and instructors is also important.

Additional expenditures of $\$ 15$ to $\$ 20$ million annually from various public and private sources could support training to large numbers of emergency response personnel. This figure assumes maximum cooperation between Federal, State, and private groups now providing training, and coordinated use of existing training resources including those of industry. Congress might wish to designate a lead agency for developing a direct contract program with the States for funding training. The lead agency could be DOT, EPA, or FEMA, all members of NRT with direct responsibility for training. Funds distributed to States for hazardous materials transportation emergency response training might carry a stipulation that some funds be passed through to local jurisdictions.

The most cost-effective training programs are those that use train-the-trainer techniques. These courses also serve as conduits for programs developed according to nationally accepted guidelines. Congress might consider giving funding priority to States whose training officials participate in Federal hazardous materials training programs, and who subsequently develop State training networks using train-the-trainer courses to improve delivery of training to local emergency response personnel. 
In addition, developing a national clearinghouse to make existing information on hazardous materials training available to State and local person" nel, both in hard copy and online, would provide an extremely useful service to emergency response forces. The DOT/FEMA survey provides basic training information already in computerized form. Moreover, the interactive computer bulletin board FEMA is developing and the proposed DOT clearinghouse for response information provide a framework for such a service. Several successful programs exist as models, most notably a DOT-sponsored, microcomputer information exchange administered through a university (see chapter 2).

\section{Financing Emergency Response Training}

While the SHMED program and MCSAP have provided basic support for enforcement training, emergency response training urgently needs, but has not received, similar Federal attention. The management of the SHMED program provides a model for a cost-effective Federal emergency response training support program. It made good use of existing resources, provided uniform training, used train-thetrainer techniques, and required that States adopt Federal regulations, designate a State lead agency, and participate in funding.

OTA concludes that an annual Federal funding level of $\$ 5$ to $\$ 7$ million, over and above monies now being spent, could provide an adequate Federal assistance program, if existing resources are reorganized and tightly managed. Table 5-11 shows an estimate for a basic hazardous materials training program for first responders. This estimate, based on modular training and a per student cost of $\$ 100$, assumes that trainees are already trained firefighters, enforcement officers, or medical technicians. ${ }^{82}$ OTA believes that this Federal funding level is adequate because considerable resources are already devoted to training, a number of sound courses have already been developed, and the type of training required by first responders is not extensive.

\footnotetext{
${ }^{82}$ OTA calculations are based on interviews with emergency response trainers and OTA staff experience with four types of emergency response training: industry, jointly sponsored public and private course for community first response personnel, Federal training for public response, and Federal training for Federal response.
}

Table 5-il.-Calculations for Costs of Hazardous Materials Emergency Response Training for First Responders'

Target audience:

First responders-firefighters, police, hospital emergency room staff, and ambulance drivers.

Size of target audience: 1.5 million (approximate)

Nature of training:

Basic training covering identification of hazardous materials, the importance of self protection, protection of the public and environment, and the notification of authorities.

Duration of training:

Modular training geared to appropriate target audiences would be developed and taught by trained instructors. Must provide opportunities for role playing and group problem solving and acquaint response personnel with the unique dangers of hazardous materials response.

Key cost components:

Course development, handout materials/workbooks, instructional services, training personnel, travel, and equipment.

Estimated average cost per trainee: $\$ 100^{b}$

Estimated trainee completions per year: 150,000 to 225,000

Required annual fundingtotal:

\section{$\$ 15$ to $\$ 22.5$ million}

aThistype of training emphasizes the difference between hazardous materials response and firefighting. Training covers the dangers inherent in hazardous materials accidents, how to identify hazardous commodities, appropriate responsea, and the application and use of protective equipment. Basic training sponsea, and the application and use of protective equipment. Basic training
is not designed to cover advanced hazardous materials response techniques or cleanup procedures.

or cleanup procedures.
bOTA estimates based on tuition for existing courses and interviews with offibOTA estimates based on tuition for existing courses and interviews with offi-
cials and course instructors. Charges very widely-one large end successful 2-day program is free, whereas another more comprehensive 3-day course charges tuition of $\$ 450$.

SOURCE: Office of Technology Assessment.

Possible Federal funding sources for emergency response training include:

- general revenue;

- other Federal funding programs related to hazardous materials transportation, such as the Surface Transportation Assistance Act (the fuel tax), the Nuclear Waste Policy Act, or Superfund; and

- creation of a dedicated fund based on user fees, such as those generated by a permit or registration fee levied against hazardous materials industries.

The fuel tax is the most broad-based of these taxes, and gasoline transport accounts for more dollar damages than all other hazardous materials. Since truck accidents require the most frequent emergency response activities, tapping fuel tax funds to support emergency response training provides for a de- 
gree of equity. The Nuclear Waste Policy Act provides some funds for State and local activities related to transportation, but such funds are generated by nuclear utilities, and their shipments represent a small percentage of all hazardous materials shipments. Superfund already has substantial claims against it.

Use of funds generated by a Federal registration or permit program could have major adverse impacts on similar State and local activities (see chapter 4). Moreover, the administrative costs for such a Federal program need to be carefully considered. Furthermore, industry will be more willing to support a new user fee to fund training if it obtains assurances that:

- the amounts assessed relate to the magnitude of local training needs,

- the funds reach those most in need,

- a fixed limit is placed on the amount it must contribute,

- local jurisdictions make maximum use of existing regional resources and participate in the funding effort in some way, and

- no individual State or local fee programs are implemented for this purpose in participating jurisdictions.

Two independent groups have supported the concept of a dedicated fund, generated by user fees levied against shippers and carriers to support State and local hazardous materials program development and emergency response training. The groups are the National Hazardous Materials Transportation Advisory Committee, formed by the Secretary of Transportation, and the Hazardous Materials Coalition, formed several years ago by State and local government organizations and some industry representatives. Arguing against this concept are the facts that many jurisdictions already impose registration or permit fees, using them for a variety of purposes frequently unrelated to emergency response, and that requiring payment of another such fee is unacceptable to many industries. ${ }^{83}$ Restrictions on their own fee programs, suggested for jurisdictions choosing to benefit from the Federal fund, may be difficult for States to accept.

Equity in apportionment of funds is an important consideration, although an appropriate basis is difficult to determine. Funds could be apportioned to States on the basis of population or of hazardous materials transportation density. However, areas such as the Gulf Coast, California, and the Pennsylvania, Ohio, Indiana, and Illinois corridor, that have the largest amounts of hazardous materials traffic, also have the largest number of industry response teams. Moreover, the need for emergency response training is often not recognized in small urban or rural areas where the probability of an accident is low, but where the consequences of an accidental spill for untrained response personnel could be severe. In addition, jurisdictions that already have well-developed emergency response capabilities have made it clear that they need financial assistance for maintaining training levels and equipment.

Additional local industry involvement in development and delivery of community hazardous materials emergency response training could be encouraged to defray training costs. Support from Federal and private sources for financial assistance to State and local jurisdictions will be more readily forthcoming if jurisdictions can show that they:

- have developed an emergency response plan;

- know what their training needs are;

- have local matching funds or resources available; and

- have cooperated with neighboring jurisdictions in such efforts as joint planning, information collection, and mutual aid agreements.

\footnotetext{
${ }^{8}$ Two major industry groups, the Association of American Railroads (AAR) and the Chemical Manufacturers Association (CMA) have opposed such a fund in the past. CMA is modifying its opposition, requesting further study to quantify the need; AAR remains opposed.
} 
Appendixes 


\section{Int roduct ion}

The transportation of hazardous wastes is regulated $b_{y}$ both the Hazardous Materials Transportation Act (HMTA) and the Resource Conservation and Recovery Act (RCRA) of 1976. Subtitle C of RCRA, which is administered by the U.S. Environmental Protection Agency (EPA), is the primary Federal statute governing hazardous wastes. Although the regulatory program developed by EPA is chiefly concerned with the disposal of hazardous wastes, Section 3003 of RCRA directed EPA to establish certain standards for transporters and to coordinate regulatory activities with the U.S. Department of Transportation (DOT).

It is estimated that 264 million metric tons ('71 billion gallons) of hazardous wastes are generated each year in the United States.' Ninety-six percent of these wastes are disposed of at the site where are they generated. Most of the waste that is shipped offsite for disposal or treatment is transported by truck; these waste shipments are usually less than 100 miles. ${ }^{3}$ Information on highway, rail, and water shipments of hazardous wastes is limited for two reasons. First, EPA does not compile information on waste shipments on a nationwide basis. Instead, the States are responsible for tracking the movement of hazardous wastes through the use of manifests. Only a few States have computerized databases capable of extracting this kind of information. Second, general transportation databases maintained by the Interstate Commerce Commission (ICC), DOT, the Bureau of the Census, and other organizations are not capable of distinguishing hazardous waste shipments. Data on the numbers of hazardous waste spills that occur during transport and the impacts associated with such incidents are also limited (see chapter 2).

\section{RCRA Overview}

The regulatory program established by RCRA is intended to ensure that hazardous wastes generated by industrial and commercial operations are transported and treated, stored, or disposed of in a manner that protects human health and the environment. Significantly, both interstate and intrastate activities are covered.

' $V$. 'estat, Inc., National Survey of Hazardous Waste Generators and Treatment: Storage and Disposal Facilities Regulated Under RCRA in 1981 (Washington, DC: U s. Environmental Protection Agency, Office of Solid Waste, 1984). Estimate ، [ग ersonlv198 1 "regulated" wastes.

Ilide.

'IC.F.Inc, Assessing the Releases and Costs Associated With Truck Transport of Hazardous Wastes (Washington, DC: U.S. Environmental Protection Agency, ()ffice of Solid Waste, January 1984), pp. 2 and 16 .
Under RCRA, EPA is responsible for developing regulations in four major areas: identification and listing of hazardous wastes; standards for generators, transporters, and owners and operators of treatment, storage, and disposal facilities; permit requirements for all such facilities; and a manifest system, which is used to track the movement of hazardous wastes. RCRA specifies that generator standards include requirements for recordkeeping, reporting, use of appropriate containers, container label$\mathrm{i}_{\mathrm{ng}}$, providing information on the chemical composition of wastes, and complying with the manifest system. Standards for transporters must include recordkeeping and labeling requirements. Transporters also must comply with the manifest system, and restrict the transportation of hazardous wastes to permitted facilities.

States are authorized to administer and enforce a hazardous waste program in lieu of the Federal Government if their programs are at least as stringent as the Federal requirements and are consistent with the Federal program and other State programs. ${ }^{4} \mathrm{EPA}$ regulations specify two ways in which a State program would be considered inconsistent: if a program unreasonabl restricts, $_{\mathrm{y}}$ impedes, or operates as a ban on the free movement of hazardous wastes across State borders; or if a State law or program has no basis in human health or environmental protection and acts as a prohibition on the treatment, storage, or disposal of hazardous wastes. ${ }^{5}$ It should be noted that the HMTA allows DOT to preempt inconsistent State and local requirements."

EPA estimates that in 1981 over 14,000 generators produced hazardous wastes and that there were 12,367 transporters of hazardous wastes. ${ }^{7}$ The number of generators covered by RCRA has recently increased by more than 100,000 because a 1984 legislative amendment extended the scope of the law to small-quantity generators of hazardous wastes (those generating $100 \mathrm{~kg}$ to $1,000 \mathrm{~kg}$ per month). As most small-quantity generators will be shipping their wastes to offsite facilities, the number of shipments is also expected to increase.

${ }^{4} 40$ CFR 271 contains the requirements for authorization of a State Resource Conservation and Recovery Act program.

${ }^{5} 40$ CFR 271.4

${ }^{6}$ The U.S. Department of Transportation (DOT) hasincluded a special provssion in its hazardous wastes regulations noting that any State or local require ment is inconsistent if it applies only to waste materials and appliesdifferencly from or in addition to the DOT requirements. See 49 CFR 171.3(c). As described later in this appendix, DOT exercised its preemption authority when it required the use of a uniform manifest. Ch. 4 contains additional information on pre emption under the Hazardous Materials Transportation Act.

?This is the most recent data available. Sec Westat, Inc., op. cit.

'The U.S. Environmental ProtectIon Agencv recently published final rules for small-quantity generators, Transporter requirements are explicitly addressed. See 51 F.R.10146, Mar. 4, 1986. The regulations become effective in September 1986. 


\section{DOT and EPA Coordination}

RCRA explicitly states that regulations promulgated by EPA for transporters be consistent with DOT regulations established under the HMTA, and authorizes EPA to make recommendations to DOT regarding the regulation of hazardous wastes and the addition of materials covered by the HMTA. In February 1980, EPA promulgated final regulations for transporters of hazardous wastes and adopted DOT regulations for labeling, marking, placarding, using proper containers, and reporting discharges. DOT amended its hazardous materials regulations in May 1980, to make them applicable to hazardous wastes and to incorporate additional requirements for the transportation of hazardous wastes. In 1984, a uniform hazardous wastes manifest, jointly developed by DOT and EPA, was published. To coordinate the activities of DOT and EPA, a Memorandum of Understanding (MOU) was signed in 1980. The MOU delineates the responsibilities of each agency with respect to investigations, enforcement, and information exchange. EPA enforcement activities and training under RCRA are discussed in chapter 5 .

\section{Shippers and Carriers Subject to RCRA Regulation}

DOT considers a shipper to be any entity that performs any of the functions in 49 CFR 172 and 173, such as labeling or packaging, EPA calls a person or firm fitting DOT's description of a shipper a waste "generator." A generator is defined as, "an person, $b_{y}$ site, whose act or process produces hazardous waste . . . or whose act first causes a hazardous waste to become subject to regulation. $"{ }^{\prime 9}$

EPA's definition of a generator includes any person who removes hazardous waste sludges and any residues in transport vehicles or vessels that have carried products or raw materials. '" If a person other than the owner of the transport vehicle or vessel is hired to remove and dispose of sludges and residues, or a vehicle or vessel is taken to a central facility for cleaning, EPA believes that all parties are generators and can be held jointly and severally liable if the regulations are violated."

Carriers are defined by DOT as persons engaged in the transportation of passengers or property by land or water, as a common, contract, or private carrier, or civil aircraft, 'z EPA refers to carriers as "transporters" and defines transporters as persons, "engaged in the offsite transportation of hazardous waste by air, rail, highway, or water.'"] EPA regulations do not apply to onsite shipments of hazardous wastes by generators or owners/ operators of permitted facilities.

Under special circumstances, transporters can become generators of hazardous wastes: by importing hazardous wastes into the United States ${ }^{14}$ by mixing hazardous wastes of different DOT shipping descriptions by placing them into a single container, or by being responsible for cleanup of a discharge of hazardous wastes or commercial chemical product that occurred during transport. In the latter case, the transporter may become a generator of the discharged material and any resulting debris, such as contaminated soil or water.'

If a generator or transporter accumulates hazardous wastes for more than 90 days, a RCRA storage facility permit must be obtained.'" However, if a transport vehicle, vessel, tank, or container is used only for neutralizing wastes because they are corrosives, a facility permit is not required. ' 8 In addition, transfer facilities that store manifested shipments of hazardous wastes for 10 days or less are not required to obtain a facility permit. "

\section{Generator Requirements}

Generators of hazardous wastes are responsible for complying with the regulations established by DOT for all hazardous materials as well as additional regulations promulgated by both EPA and DOT. The regulations can be divided into four major categories: identification and notification; preparation of wastes for transport; compliance with manifest requirements; and recordkeeping and reporting. Table A-1 summarizes these requirements, indicates the responsible agency, and provides a reference to the Federal Code of Regulations.

\section{EPA Identification and Notification}

Generators begin the regulatory process by determining whether their wastes are hazardous according to EPA's criteria. A waste is considered to be hazardous if it satisfies the following conditions:

. $\mathrm{i}_{\mathrm{t}}$ is a solid waste as defined by EPA;

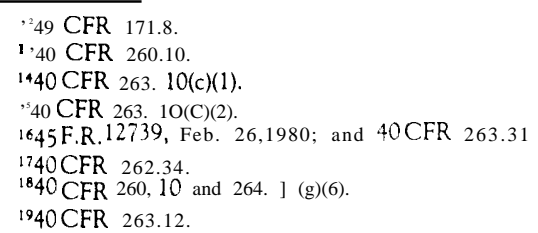


Table A-1 .-U.S. Environmental Protection Agency (EPA) and U.S. Department of Transportation (DOT) Hazardous Waste Transportation Regulations

\begin{tabular}{|c|c|c|}
\hline Requirements & Agency & Code of Federal Regulations \\
\hline \multicolumn{3}{|l|}{ Generator/shipper: } \\
\hline 1. Determine if waste is hazardous according to EPA listing criteria & EPA & 40 CFR 261 and 262.11 \\
\hline $\begin{array}{l}\text { 2. Notify EPA and obtain I.D. number; determine that transporter and } \\
\text { designated treatment, storage or disposal facility have I.D. numbers }\end{array}$ & EPA & 40 CFR 262.12 \\
\hline $\begin{array}{l}\text { 3. Identify and classify waste according to DOT Hazardous Materials Table } \\
\text { and determine if waste is prohibited from certain modes of transport }\end{array}$ & DOT & $\begin{array}{l}49 \text { CFR } 172.101 \text { (see also } 49 \\
\text { CFR 173-177) }\end{array}$ \\
\hline 4. Comply with all packaging, marking, and labeling requirements & EPA & 40 CFR 262.32(b), \\
\hline & & $\begin{array}{l}49 \text { CFR } 173 \text {, } \\
49 \text { CFR 172, subpart D, and } \\
49 \text { CFR 172, subpart E }\end{array}$ \\
\hline $\begin{array}{l}\text { 5. Determine whether additional shipping requirements must be met for the } \\
\text { mode of transport used }\end{array}$ & DOT & 49 CFR $174-177$ \\
\hline 6. Complete a hazardous waste manifest & EPA & 40 CFR 262, subpart B \\
\hline 7. Provide appropriate placards to transporter & DOT & 49 CFR 172 , subpart $F$ \\
\hline 8. Comply with recordkeeping and reporting requirements & EPA & 40 CFR 262, subpart D \\
\hline \multicolumn{3}{|l|}{ Transporter/carder: } \\
\hline 1. Notify EPA and obtain I.D. number & EPA & 40 CFR 263.11 \\
\hline $\begin{array}{l}\text { 2. Verify that shipment is properly identified, packaged, marked, and labeled } \\
\text { and is not leaking or damaged }\end{array}$ & DOT & 49 CFR 174-177 \\
\hline 3. Apply appropriate placards & DOT & 49 CFR 172.506 \\
\hline $\begin{array}{l}\text { 4. Comply with all manifest requirements (e.g., sign the manifest, carry the } \\
\text { manifest, and obtain signature from next transporter or owner/operator of } \\
\text { designated facility) }\end{array}$ & $\begin{array}{l}\text { EPA } \\
\text { DOT }\end{array}$ & $\begin{array}{l}40 \text { CFR } 263.20 \\
49 \text { CFR } 174-177\end{array}$ \\
\hline 5. Comply with recordkeeping and reporting requirements & EPA & 40 CFR 263.22 \\
\hline 6. Take appropriate action (including cleanup) in the event of a discharge & EPA & 40 CFR $263.30-31$ \\
\hline and comply with DOT incident reporting requirements & DOT & 49 CFR 171.15-17 \\
\hline
\end{tabular}

SOURCE: US. Environmental Protection Agency, Hazardous Waste Transportation /rrterface-Guidance Manual, prepared for the U.S. Department of Transportation, PB82-18281 (Springfield, VA: National Technical Information Service, November 1981).

. $i_{t}$ is listed as a hazardous waste by $\mathrm{EPA}^{*}$ or it is a mixture that contains a listed waste or exhibits one of four characteristics identified by EPA-ignitability, reactivity, corrosivity, or EP** toxicity; and

. it is not explicitly excluded from regulation by statute or rulemaking. ${ }^{20}$

Once it is ascertained that a waste is hazardous, generators are required to notify EPA and obtain an EPA identification (I. D.) number. This is done by submitting EPA Form 8700-12 to the Agency." Generators should also determine that any transporters or owners/operators of treatment, storage, or disposal facilities who will eventually handle the waste have EPA I.D. numbers.

\section{Pretransport Preparations}

Most of the requirements in this category are DOT regulations that apply to all hazardous materials. They

\footnotetext{
*The U.S. Environmental ProtectIon Agency (EPA) lists Include wastes from: specific sources; nonspecific sources; and discarded commercial chemical products, off-specification species, container residues, and spill residues thereof **EP = Extraction Procedure

2040CFR 262.11 and 40CFR 261. The 1984 amendments to the Resource Conservation and Recovery Act contain provisions regarding the listing and delisting of hazardous wastes; these provisions have not yet been fully imple mentedhy the LIS. Environmental Protection Agency. See Sec. 222 of the Hazardous and Solid W'aste Amendments of 1984, Public Law 98-616, Nov. 8, 1984 and Conference Report 98-1133, Oct.3, 198-I.

'W CFR 262.12.
}

include: identifying and classifying wastes according to the DOT Hazardous Materials Table and determining if the wastes are prohibited from certain modes of transport; complying with all packaging, marking, and labeling requirements; determining whether additional shipping requirements must be met for the mode of transport used; and providing appropriate placards to the transporter. In addition, hazardous waste transporters are also required to comply with DOT modal requirements. The following discussion focuses on particular aspects of the DOT regulations as they relate to hazardous wastes.

DOT Identification and Classification.-Identification of hazardous wastes under EPA's regulations is a separate procedure from classifying wastes under DOT's regulations. DOT considers hazardous wastes to be a subset of the hazardous materials regulated by the HMTA. Determining the proper hazard classification of hazardous wastes under DOT's system is important, because DOT hazard communication and packaging requirements correspond to these hazard classes,

First, it must be determined whether a hazardous waste is listed in the DOT Hazardous Materials Table contained in 49 CFR 172. If it is not, the characteristics of the waste must be identified, based on the DOT hazard class definitions. However, the four characteristics used by EPA to identify a waste are different from DOT's hazard classes. For example, a "reactive" waste according 
to EPA might be an "irritating material" or "explosive" according to DOT. A waste that EPA calls "ignitable" could be either a "flammable" or "combustible" material by DOT definitions. A proper DOT shipping name for a hazardous waste that is listed in the DOT Table or falls into a DOT hazard class would consist of the name of the hazardous material or hazard class as it is listed in the DOT Table preceded by the word "waste." In those instances where a waste is not listed by DOT and does not fall into one of DOT's hazard classes, it is considered to be a Hazardous Waste "not otherwise specified" (n.o.s.) and is classified as an ORM-E ${ }^{22}$ by DOT.

All small-quantity generators of hazardous wastesthose who produce $100 \mathrm{~kg}$ to $1,000 \mathrm{~kg}$ of waste per month-must comply with the DOT regulations. Moreover, generators of hazardous wastes that are exempt from EPA regulation under RCRA because they produce less than $100 \mathrm{~kg}$ of waste per month may still have to comply with DOT transportation requirements; this is true only if the waste is listed in the DOT Hazardous Materials Table or fits into one of the DOT Hazard Classes other than ORM-E.

Marking, Labeling, and Placarding.-All shipments of hazardous wastes must comply with appropriate DOT marking, labeling, and placarding regulations. However, ORM-E materials are subject only to DOT marking and general packaging requirements. ${ }^{23}$ Thus, labels and placards are not required for hazardous waste shipments classified as ORM-E.

As described in chapter 4, DOT requires shippers (generators) to mark all packages with a capacity of 110 gallons or less with a proper shipping name, including a United Nations/North American (UN/NA) identification number. There is a single UN/NA number for all hazardous wastes in the "Hazardous Waste n.o.s." category; it is NA $9189 .{ }^{24}$ In addition, EPA requires generators to mark each hazardous waste container of $110 \mathrm{gal}-$ lons or less with a statement identifying the generator and indicating that Federal law prohibits improper disposal of hazardous wastes. ${ }^{25}$

\footnotetext{
${ }^{22}$ ORM-E means Other Regulated Material not included in any other Department of Transportation (DOT') hazard classes. Materials in this class include hazardous substances and hazardous wastes. 49 CFR 173.500 and 173.1300. See ch. 4 for additional information on DOT hazard classes.

2349 CFR 173.1300; and 49 CFR 173.510.

24In1978, when the U.S. Environmental protection Agency (EPA) initially published regulations for hazardous wastes transportation, the US. Department of Transportation (DOT) had not yet adopted the United Nations/North America numbering system. At the time, EPA was concerned that there were no placarding requirements for hazardous materials presenting chronic (e.g., carcinogenic) hazards and indicated that recommendations to DOT regarding the development of additional placards were being considered. Following DOT's decision to adopt the U.N. numbering system, EPA stated that it was satisfied that DOT's requirements were fully protective of human health and the environment. See 45 F.R. 12741, Feb. 26, 1980
}

${ }^{-5} 40$ CFR 262.32.
Packaging.-OTA's data analysis (see chapter 2) indicates that corrosive materials have the highest accident and spill rate. Since many hazardous wastes are corrosives, selecting a compatible container for transport is important. While DOT packaging regulations specify acceptable containers, the potential for misusing containers exists unless generators and transporters understand and comply with these requirements. With more than 100,000 small businesses becoming subject to EPA and DOT regulations, the potential for confusion and inappropriate use of containers is immense. Significantly, information sent to small generators by EPA in 1985 merely referenced DOT regulations; detailed guidance on the transportation of hazardous wastes has not been provided to small generators. ${ }^{26}$

In addition to the regulations for all hazardous materials, DOT has promulgated two special packaging rules that apply to hazardous wastes. The first rule allows the use of an open head drum instead of a closed head drum for wastes containing solids or semisolids. ${ }^{27}$ The second rule allows the shipment of hazardous wastes in used packaging that has not been reconditioned or tested under specified circumstances.

\section{Manifest Requirements}

The purpose of the manifest system, established by Section 3002(5) of RCRA, is to assure that hazardous wastes designated for delivery to offsite treatment, storage, or disposal facilities actually reach their destination. A "manifest" is a specific form (U.S. EPA Form 8700-22 or $8700-22 \mathrm{~A}$ ) that contains information about a hazardous waste shipment and accompanies a shipment from its point of generation to its ultimate destination. A sample manifest form is shown in figure A-1. Manifests, like DOT shipping papers, provide information about the nature of the shipment to emergency responders when accidents or incidents occur. The only significant difference between a manifest and a DOT shipping paper is that a manifest lists the EPA identification numbers of the generator, transporter, and designated facility. DOT regulations specify that an EPA manifest may be used in place of a DOT shipping paper. ${ }^{29}$

Generators are responsible for originating and signing the form. They must also obtain the signature of the transporter, retain one copy of the form for their records,

\footnotetext{
${ }^{26}$ The US. Environmental Protection Agency and the U.S. Department of Transportation published a guidance manual in 1981 about the interface between their regulations; however, an updated version has not been published to reflect changes in the regulations. See U.S. Environmental Protection Agency, Hazardous Waste Transportation Interface-Guidance Manual, PB82-182361, prepared for the U.S. Department of Transportation (Springfield, VA: National Technical Information Service, November 1981).

${ }^{2} 749$ CFR 171.3(e).

2849 CFR 173.28(P)

${ }^{9} 49$ CFR 172.205.
} 
Figure A-1 .-Hazardous Waste Manifest

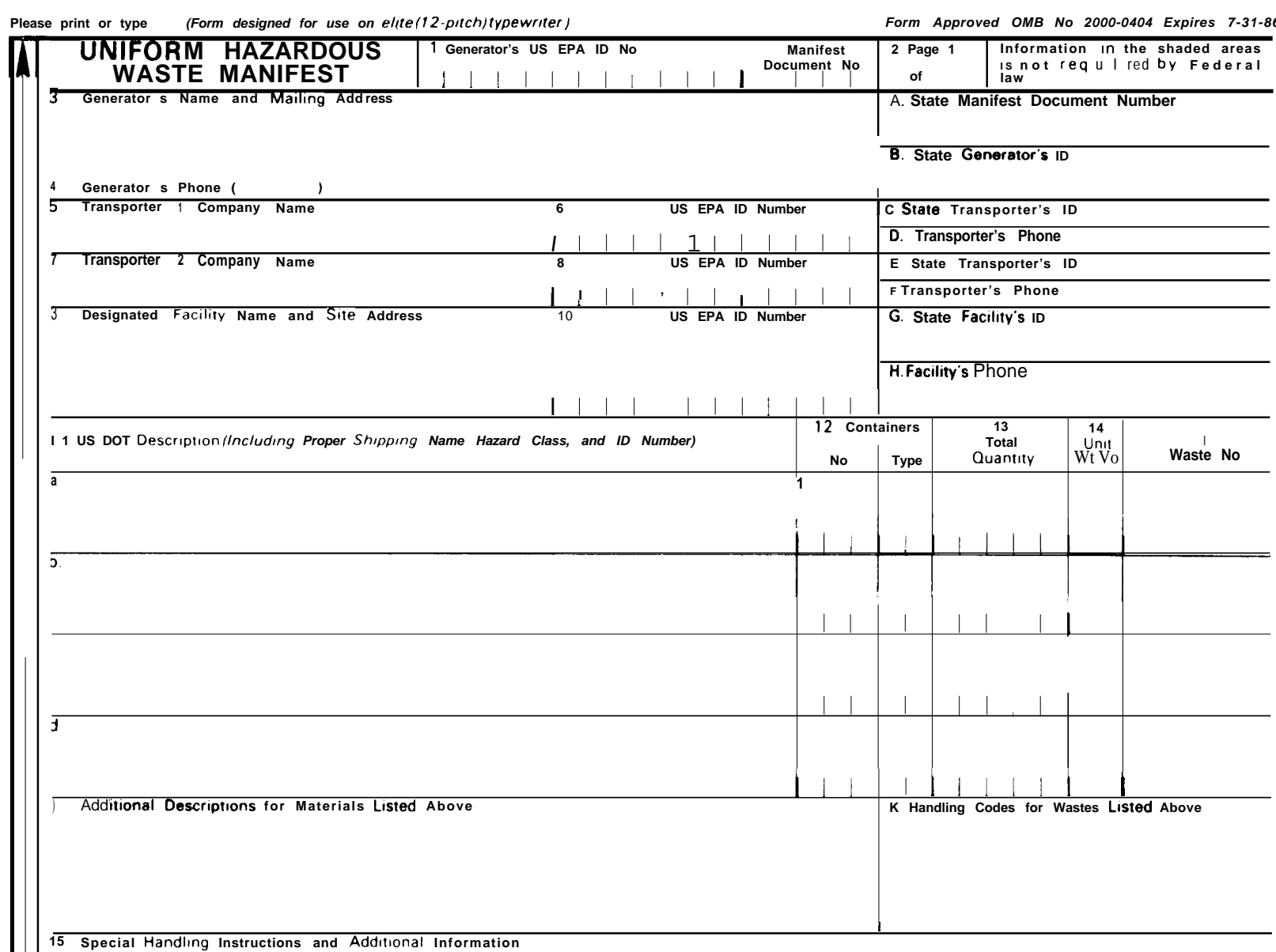

\footnotetext{
15 Special Handling Instructions and Additiona! Information
}

16 GENERATOR'S CERTIFICATION: I hereby declare that the contents of this consignment are fully and accurately described above by proper shipping name and are classified. packed, marked, and labeled, and are inail respects in proper condition for transport by highway according 10 applicable international and national government regulations

Unless I am a small quantity generator who has been exempted by statute or regulation from the duty 10 make a waste mınımızatıoncertificatıon under Section 3002(b) of RCRA, I also certify that I have a program in place to reduce the volume and toxicity of waste generated to the degree I have determined to be economically practicable and I have selected the method of treatment, storage. or disposal currently available to me which minımızes the present and future threat to human health and the environment

1

19 Discrepancy Indication Space

20 Facility Owner or Operator Certification of receipt of hazardous materials covered by this manifest except as noted in Item 19

\begin{tabular}{|l|ll}
\hline Printed/Typed Natie & Signature Month Day Yea
\end{tabular}

Form 8700-22 (Rev 4-86) Previous editionis obsolete 
and give the remaining copies to the transporter. Transporter requirements under the manifest system are described below. ${ }^{30}$

When the initial RCRA regulations were issued in 1980, EPA required only that certain types of information accompany a waste shipment. This flexible approach was taken so that information required by EPA would also fulfill DOT's shipping paper requirements. Subsequently, more than 20 States developed their own manifest forms requiring generators and transporters to provide a variety of information. Recognizing the burden created by multiple State manifests, EPA and DOT jointly developed the uniform manifest form, that became effective on September 20, 1984. The form includes space for optional information that may be requested by a State agency. (See items A through H in figure A-1.) However, this additional information may be requested only from generators and owners or operators of treatment, storage, or disposal facilities. States may also require generators or facilities to submit this additional data under separate cover. EPA and DOT determined that it was not appropriate or necessary for transporters to submit information beyond the Federal requirements.

\section{Recordkeeping and Reporting}

Generators are required by EPA to keep a copy of each signed manifest for 3 years whether or not a signed copy is returned to the generator by the designated treatment, storage, or disposal facility. Records of all test results, waste analyses, or other determinations and copies of all reports submitted to EPA (described below) must also be kept for at least 3 years. One of the reasons EPA chose a 3-year time period is that it is the same record retention time ICC requires of truckers.

Biennial reports must be submitted to EPA by all generators who ship their wastes offsite. ${ }^{33}$, The report describes all shipments initiated by the generator during a given time period. In addition, if a generator does not receive a signed copy of a manifest from the designated treatment, storage, or disposal facility within 45 days of the date the waste was accepted by the initial transporter, an Exception Report must be filed with EPA. * Exception Reports assist EPA in determining whether the waste was improperly disposed.

\footnotetext{
3040 CFR 262, Subpart B.

${ }^{31}$ See 49 F.R. 10490 and 49 F.R. 10507, Mar. 20, 1984, for a discussion regarding the development of the uniform manifest.

3245F.R.12742, Feb. 26,1980, and 40 CFR 262.40. Retention times for records can be extended by the U.S. Environmental Protection Agency for enforce-

ment or other purposes.
${ }^{3340}$ CFR 262,41. Use of the U.S. Environmental protection Agency Form $8700-13 \mathrm{~A}$ is required.

*Within 35 days, a generator must contact the designatedfacility to determine the status of the wastes.
}

\section{Transporter Requirements}

Transporters of hazardous wastes are also regulated by both EPA and DOT. There are four categories of requirements: notification and pretransport, manifest requirements, recordkeeping, and discharge cleanup. Table A-1 also summarizes the regulations applicable to transporters. Some States have also developed permit and registration programs for hazardous waste transporters. (See chapter 4, especially table 4-7.)

\section{Notification and Pretransport}

All transporters of hazardous wastes are required to notify EPA and obtain an I.D. number from EPA by submitting EPA Form 8700-12. Transporters must also be sure that DOT hazard communication and packaging requirements have been met. DOT regulations prohibit transporters in all modes from accepting hazardous materials that have not been properly identified, packaged, marked, or labeled. ${ }^{34}$ Special requirements for leaking packages or containers have been established by DOT for each transport mode."

Transporters are responsible for applying appropriate placards on motor vehicles, except for highway cargo tanks and intermodal tanks, Placards must be provided to transporters by generators of hazardous wastes, unless the vehicle is already appropriately placarded." In the case of railcars, highway cargo tanks, intermodal tanks, and certain freight containers, the generator is responsible for affixing the necessary placards. ${ }^{37}$

\section{Manifest Requirements}

EPA regulations prohibit transporters from accepting hazardous waste shipments from shippers without a manifest. Transporters who do accept manifested hazardous wastes are required to sign and date the manifest and return a signed copy of the manifest to the generator and ensure that the manifest accompanies the wastes to the designated facility. When the shipment is delivered to the designated facility or subsequent transporter, the transporter must: obtain a signature from the owner or operator of the facility or the accepting carrier upon delivery, retain one copy of the manifest, and give the remaining copies to the owner or operator of the facility or the accepting transporter. ${ }^{38} \mathrm{~A}$ transporter is responsible for a hazardous waste shipment until the manifest is signed by the receiving facility. If a hazardous waste shipment cannot be delivered to the facility designated

\footnotetext{
3449 CFR $174.3,175.3,176.3$, and 177.801 .

${ }^{35} 49$ CFR $174,175,176$, and 177

3649 CFR 172.506

3749 CFR 172.508, 172.512, and 172.514.

${ }^{38} 40$ CFR 263.20.
} 
on the manifest, the transporter must contact the generator for further instructions. ${ }^{39}$ Special manifest requirements for bulk shipments by water and rail have been established. ${ }^{40}$

\section{Recordkeeping Requirements}

Transporters must also keep a copy of each signed manifest for 3 years; this includes shipping papers that may be used in place of manifests for bulk shipments. ${ }^{41}$ For shipments of hazardous wastes outside of the United States, transporters are also required to retain copies of the manifests for a 3-year period. ${ }^{42}$

\section{Discharges and Cleanup}

In the event of a discharge of hazardous waste during transport, special requirements established by EPA and DOT must be followed. A discharge of hazardous waste is defined as: "the accidental or intentional spilling, leaking, pumping, pouring, emitting, emptying, or dumping of hazardous waste into or on any land or water. "

EPA regulations require all transporters to take appropriate immediate action in the event of a discharge. Such action could include notifying local authorities or diking an area to contain the wastes .44 In addition, DOT immediate notification requirements for hazardous materials incidents are applicable to discharges of hazardous wastes; notice is given by calling (toll-free) the National Response Center, operated by the U.S. Coast Guard. " Additional information about DOT reporting requirements is presented in chapter 2 .

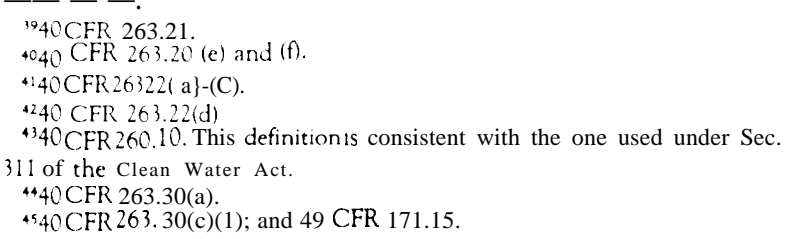

Both EPA and DOT have included provisions in their regulations authorizing Federal, State, or local government officials to permit the immediate removal of hazardous wastes by transporters who do not have EPA I.D. numbers and without a manifest. ${ }^{46} \mathrm{EPA}$ has also exempted all persons involved with treatment or containment activities taken during an immediate response to the discharge of hazardous wastes or materials from facility permitting requirements. ${ }^{47}$

All regulations for the final disposition of wastes must be followed after the emergency is over. EPA has established a procedure for rapidl $\mathrm{y}_{\mathrm{y}}$ issuing I.D. numbers to emergency response personnel, shippers, or carriers who need to transport hazardous wastes following an unanticipated release. A provisional I.D. number may be obtained by telephoning the appropriate EPA Regional Office. $^{48}$

EPA regulations also require transporters to clean up any discharges that occur during transport or take actions required or approved by appropriate government officials to mitigate human health or environmental hazards. DOT regulations do not contain a comparable provision for other hazardous materials.

Finally, DOT hazardous materials requirements for written incident or accident reports must be met (see chapter 2). For discharges of hazardous wastes, transporters are required to attach a copy of the manifest to the DOT reporting form and provide the following information: an estimate of the quantity of wastes removed from the scene, the name and address of the facility to which it was taken, and the manner of disposition of any unremoved wastes. ${ }^{49}$

\footnotetext{
4640 CFR 263.30(b); and 49 CFR $171.3(d)$.

4740 CFR 264.1(g)(8), 265.1(c)(1 1), and 270.1(c)(3).

4845F.R. 85022, Dec. 24,1980. Subsequent to Issuing a number over the telephone, the standard U.S. Environmental Protection Agency (EPA) application form is mailed to the generator or transporter and must be returned to EPA within 10 days.

4949 CFR 171. 16(a).
} 


\section{U.S. Department of Transportation Inconsistency Rulings}

\section{Introductory Note}

Part I of this appendix describes 16 inconsistency rulings and one nonpreemption determination issued by the U.S. Department of Transportation (DOT) as of May 1986. Court actions that have been brought pertaining to these cases are also noted. Each summary indicates whether the State and local requirements reviewed by
DOT were found to be inconsistent or consistent with the Hazardous Materials Transportation Act (HMTA); however, the basis for each decision is not specified. Instead, Part 11 of this appendix, a table, summarizes the reasons underlying DOT's conclusions for each of the major requirement types considered in the inconsistency rulings.

\section{PART 1: STATE AND LOCAL REQUIREMENTS CONSIDERED IN DOT INCONSISTENCY RULINGS}

\section{Inconsistency Ruling 1 New York City}

Associatecl Universities, Inc. (AUI), operators of Brookhaven National Laboratories located in Upton, Long Island, shipped spent fuel over a 6-week period each year prior to 1976. This practice ceased after New York City passed an ordinance which became effective on January 5,1976 , that effectively banned most commercial ship ments of radioactive materials in or through the city. AUI subsequently used a water crossing from Long Island to Connecticut until local jurisdictions in Connecticut prohibited the use of their roads. The Brookhaven shipments have been suspended since that time. AUI filed an inconsistency ruling application with DOT on March 1, 1977, to determine whether the New York City restrictions were inconsistent. DOT published a decision on April 20, 1978, concluding that there was no identifiable requirement in the HMTA or associated regulations providing a basis for a finding of inconsistency (43 F.R. 16954). However, DOT announced that it intended to examine the need for Federal routing requirements. On January 19, 1981, DOT issued Federal routing requirements for high-level radioactive materials such as spent nuclear fuel, Docket HM - 164; however, transportation modes alternative to the use of highways were not addressed.

New York City filed suit against DOT on March 25, 198 1, challenging the validity of the Federal routing rule. The District Court opinion, issued on February 19, 1982, found that although HM-164 was procedurall within the scope of DOT'S authority, it violated the HMTA and the National Environmental Policy Act (NEPA) as it did not address the problems posed by low-probability, highconsequence accidents. Moreover, the District Court held that the HMTA required DOT to compare the relative safety of different transport modes (536 F. Supp. 1237 (1982)). This decision was reversed by the U.S. Court of Appeals for the Second Circuit on August 10, 1983. The Court of Appeals ruled that DOT is not required to maximize public safety on a jurisdiction-by-jurisdiction basis; the Court also found that a comparison of different transportation modes was not required (715 F.2d 732 (1983)). The City and State of New York appealed to the Supreme Court, but the Court declined to hear the case (104 S. Ct. 1403 (1984)).

On December 24, 1984, New York City filed an amended application with DOT requesting a waiver of the preemptive effects of HM-164 on its routing restrictions for irradiated or spent fuel. Following a public comment period, DOT issued the first nonpreemption determination under the HMTA. DOT's decision, published on September 12, 1985, denied New York City's request because the City failed to show that HM-164 does not provide an adequate level of safety because of unique physical conditions, and that the establishment of alternate routes is the responsibility of a State routing agency (50 F.R. 37308). New York City filed an administrative appeal with DOT (50 F.R. 47321, November 15, 1985); public comments are currently under review.

\section{Inconsistency Ruling 2 Rhode Island}

The Division of Public Utilities and Carriers of Rhode Island issued rules and regulations governing the trans- 
portation of liquefied natural gas and liquefied petroleum gas that became effective on November 3, 1978. Shortly thereafter, National Tank Truck Carriers, Inc. (NTTC) filed suit against Rhode Island seeking preliminary and permanent injunctive relief preventing enforcement of the regulations, Rhode Island filed an inconsistency ruling application with DOT on December 1, 1978. The District Court denied NTTC's motion for a preliminary injunction except for three State requirements pertaining to vehiclc equipment (two-way radio, rear bumper sign, and frangible lock requirements) pending DOT's i nconsistency ruling; the preliminary Injunction was upheld on appeal by the U.S. Court of Appeals for the First Circuit (608 F.2d 819 (1979)).

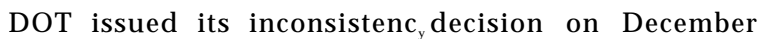
20, 1979, concluding that the following Rhode Island rules and regulations were consistent: radio communications via two-wa $a_{y}$ radios, immediate notification of the State Police of any accident, use of headlights at all times, $\backslash$ 'chicle inspections, and definitions. However, other requirements were found to be inconsistent: written notification of State agencies regarding accidents, illuminated rear bumper signs, frangible shank-type locks on trailers, permit requirements for each shipment, and prohibitions on travel during rush hours (44 F.R. 75565).

Following publication of DOT's ruling, Rhode Island decided not to enforce the bumper sign and lock requirements, but appealed those portions of the DOT ruling on the requirements for written notification of State agencies of accidents, permit requirements, and travel prohibitions during rush hours. DOT's second decision was consistent with its earlier ruling (45 F.R. 71881, October 30, 1980).

The District Court upheld DOT's inconsistency ruling on March 17, 1982, by ordering a permanent injunc$t$ ion against the permit, curfew, and written accident report requirements. Regulations concerning two-way radio communication, immediate reporting of accidents, illumination of headlights, and \'chicle inspections were found to be consistent with the HMTA and not in violation of the equal protection or commerce clauses of the Constitution (535 F. Supp. 509 (1982)). NTTC appealed the District Court opinion, but the U.S. Court of Appeals for the First Circuit affirmed the lower court decision (698 F.2d 559 (1983)).

\section{Inconsistency Ruling 3 Boston}

The Boston Fire Commissioner and the Commissioner of Health and Hospitals promulgated regulations on December 15, 1980, governing the transportation of hazardous materials, including restrictions on the use of city streets. On February 5, 1980, the Hazardous Materials
Advisory Council (HMAC) and the Massachusetts Motor Trucking Association, Inc. (MMTA) filed an inconsistency ruling application with DOT; the American Trucking Association (ATA) subsequently filed an application. In addition, on March 2, 1980, ATA and MMTA filed suit against Boston seeking an injunction and declaratory relief from the Boston regulations. A Temporary Restraining Order against the implementation and enforcement of the regulations was granted by the Federal District Court the following day.

DOT published its inconsistency ruling on March 26, 1981 (46 F.R. 18918). The decision concluded that the following regulations were consistent: immediate reporting of accidents to local officials, requiring the use of major thoroughfares except as necessary for pickups and deliveries, assessing penalties associated with valid local regulations, requiring the use of headlights, specifying separation distances between vehicles, vehicle operating requirements, and adopting Federal and State motor carrier safety regulations. However, several Boston regulations were found to be inconsistent: marking vehicles to identify products being carried, requiring signs on vehicles when residual materials are present, requiring written accident reports, restricting travel during morning rush hours, and restricting the use of certain city streets. The routing restrictions diverted traffic onto routes passing through suburban jurisdictions. DOT did not provide rulings for several other regulations. For example, a decision about the validity of a permitting system was not provided because the scope and conditions of the permits were not defined; however, DOT noted that Boston regulations requiring transporters to carry permits in a vehicle cab and to display decals, to the extent they are valid, were reasonable aids to local enforcement.

On August 10, 1981, Boston appealed DOT's ruling on the routing restrictions and written accident reports. In response, DOT upheld its earlier decision with respect to written accident reports, but rescinded its earlier inconsistency ruling on the routing restrictions, stating that it could not reach a conclusion about the validity of those requirements. The reason for DOT's opinion was that although Boston had demonstrated that its restrictions enhanced public safety, consultation with affected jurisdictions had been limited. (47 F.R. 18457).

Following publication of the first DOT decision, HMAC, MMTA, and ATA asked the Court to issue a preliminary injunction. On April 6, 1981, the Court granted a preliminary injunction against the regulations requiring trucks to carry permits and decals and for the vehicle marking requirements; by stipulation, Boston agreed to drop these requirements. Subsequently, a trial was held to consider the routing and curfew restrictions. As of May 1986, a decision had not yet been issued $b$ the District Court. 


\section{Inconsistency Ruling 4 State of Washington}

In March 1980, the Washington State Legislature approved a law requiring intrastate shipments of hazardous materials transported by motor vehicle to be accompanied by red or red-bordered shipping papers. On July 1, 1980, NTTC filed an inconsistency ruling application. DOT's ruling, published on January 11, 1982, found the Washington State law and associated regulations to be inconsistent (47 F.R. 1231).

\section{Inconsistency Ruling 5 New York City}

On August 7, 1982, a tank truck owned by Ritter Transportation was carrying liquefied petroleum gas from New Jersey to New York across the George Washington Bridge when it developed a leak, causing an extensive traffic jam. Subsequently, New York City filed suit against Ritter in a New York State Supreme Court charging that fire department regulations, adopted in 1962 and revised in 1963 and 1979, prohibiting the transportation of hazardous compressed gases in the city without a permit, had been violated. The fire department regulations also covered placarding and container testing and specified hazard class definitions for gas under pressure, combustible or flammable gas, combustible mixture, and inflammable mixture; these requirements and definitions differed from DOT regulations and hazard class definitions. Between September and November 1980, applications for inconsistency rulings regarding the definitions were submitted to DOT by Ritter Transportation, the National LP-Gas Association, and the Propane Corp. of America; DOT consolidated the proceedings into one action.

After the New York Supreme Court preliminarily enjoined Ritter from transporting hazardous compressed gases in the city, Ritter appealed to the U.S. District Court asking that the injunction be vacated. In addition, NTTC and Ritter filed an action against the city in the same Federal court seeking a declaratory judgment that the fire department regulations burdened interstate commerce and were preempted by the HMTA. The District Court denied Ritter's motion to vacate the preliminary injunction and found the fire department routing regulations to be consistent, but ruled that the truck placarding and container testing requirements were inconsistent, The District Court did not rule on the definitions (515 F. Supp. 663).

Ritter and NTTC appealed the decision on the routing and definition regulations to the U.S. Court of Appeals for the Second Circuit. The Court of Appeals upheld the routing regulations on May 3, 1982; however, the case was remanded to the District Court for a determination as to whether the definitions were preempted under the HMTA. The Court of Appeals noted the inconsistency ruling pending before DOT (677 F.2d 270). DOT's ruling, published on November 18, 1982, determined that the definitions used by the city were inconsistent (47 F.R. 51991).

\section{Inconsistency Ruling 6 Covington, Kentucky}

General Battery Corp. submitted an application to DOT on September 25, 1980, for an inconsistency ruling on an ordinance established by the city of Covington earlier in the year requiring all commercial rail, barge, and truck operators to give advance notification of their intent to transport dangerous and hazardous substances within the city. The ordinance also defined substances covered by the notification rule; the Covington definitions extended the scope of its ordinance to materials not covered by DOT's regulations. DOT concluded that both the definitions and the notification requirements were inconsistent (48 F.R. 760, January 6, 1983).

\section{Inconsistency Rulings 7 to 15}

Inconsistency rulings 7 to 15 pertain to the transportation of spent nuclear fuel from Chalk River, Ontario, Canada, to a U.S. Department of Energy reprocessing facility at Savannah River, South Carolina. The shipments were arranged $b_{y}$ the Nuclear Assurance Corp. (NAC) under a contract with Atomic Energy of Canada, Ltd. Until 1979, shipments from Canada entered the United States by crossing the St. Lawrence River using the Ogdensburg Bridge. These shipments were banned by both the Ogdensburg Bridge and Port Authority and St. Lawrence County in 1980. Alternative routes through Michigan, New York, and Vermont were subsequentl $\mathrm{y}_{\mathrm{y}}$ approved by the Nuclear Regulatory Commission (NRC). However, a series of requirements and bans enacted by these States, local jurisdictions, and bridge and highway authorities resulted in the cessation of NAC shipments. NAC filed applications for inconsistency rulings on four State and local actions (inconsistency rulings $7,8,9$, and 10 ) and DOT elected to examine several other State and local requirements (inconsistency rulings 11,12,13,14, and 15). All nine rulings were published by DOT on November 27, 1984 (49 F.R. 46632).

\section{Inconsistency Ruling 7 New York State}

On October 8, 1982, NAC filed an application for an inconsistency ruling regarding a letter sent by a desig- 
nated representative of the Governor of New York State advising NAC to suspend proposed shipments of spent fuel from Canada on two non-Interstate highway routes. The letter was sent because NAC had notified New York about its shipments, as required by NRC. NAC argued that the proposed non-Interstate routes were the only practicable highway routes available because the New York State Thruway (which is part of the Interstate Highway System) and the State of Vermont had suspended spent fuel shipments, foreclosing the use of Interstate highways through New England.

DOT concluded that the letter sent by New York State to NAC was not inconsistent because it required compliance with Federal regulations. DOT also noted that NAC properly chose to abide by the restrictions enacted by Vermont and the New York State Thruway until decisions were reached about their validity (see inconsistency ruling 9 and inconsistency ruling 10 discussions below).

\section{Inconsistency Ruling 8 Michigan}

Comprehensive rules for the transportation of radioactive materials by highway, rail, and water, issued by the Michigan State Fire Safety Board and the Department of Public Health, became effective on July 14, 1982. NAC filed an inconsistency ruling application with DOT on October 13, 1982.

DOT concluded that the following Michigan rules were consistent: confidentiality standards, inspection requirements (to the extent they apply to valid regulations), incorporation of Federal regulations, and notification of any shipment schedule changes. However, a number of regulations adopted by Michigan were determined to be inconsistent. These rules pertained to: the definition of radioactive material; submission of an application for approval of shipments; criteria for approving applications, including container testing and certification requirements that differed from Federal regulations; written notification of application approvals; communication requirements for highway, rail, and water; and notification requirements regarding delays and emergency plan implementation. Michigan has appealed the DOT ruling.

\section{Inconsistency Ruling 9 State of Vermont}

On October 14, 1982, NAC filed an application for an inconsistency ruling with DOT regarding a letter from the State of Vermont advising NAC that further highway shipments of spent fuel through the State would not be permitted until responsible Federal agencies established and enforced a uniform national policy for such shipments. Specifically, Vermont did not want to allow through shipments of spent fuel until DOT and NRC determined whether the regulations and ordinances enacted in Michigan and New York were inconsistent with the HMTA. DOT concluded that the letter could not be considered a "state order" and, therefore, the question of inconsistenc did not have to be addressed.

\section{Inconsistency Ruling 10 New York State Thruway}

An inconsistency ruling application was filed $b_{y}$ NAC on October 20, 1982, regarding a New York State Thruway Authority (NYSTA) regulation prohibiting vehicles carrying radioactive materials except under procedures adopted by the NYSTA Board. In practice, shipments of low-level radioactive materials were generally approved by NYSTA; however, shipments of highway route controlled quantities of radioactive material, such as spent nuclear fuel, were not allowed except for certain court ordered shipments. The New York State Thruwa is a preferred route under HM-164 because it is part of the Interstate Highway System and alternate routes have not been designated by New York State. DOT concluded that the NYSTA prohibition was inconsistent.

\section{Inconsistency Ruling 11 Ogdensburg-Prescott International Bridge, New York}

The Ogdensburg Bridge and Port Authority (OBPA) adopted rules governing the transportation of all radioactive materials. The rules specified crossing times, required an escort and compensation for the costs of the escort, required evidence of proper insurance coverage or indemnification (but did not quantify such coverage), and incorporated St. Lawrence County's requirements (see inconsistency ruling 12). Unlike the New York State Thruway, the Ogdensburg-Prescott Bridge is not part of the Interstate Highway System. Thus, shipments of highway route controlled quantities of radioactive material over the bridge are in violation of Federal routing regulations.

On May 12, 1983, DOT initiated inconsistency ruling proceedings on the premise that New York State could designate the Ogdensburg-Prescott Bridge and associated roads in St. Lawrence County as alternate preferred routes at some point in the future. During the public comment period, the New York State Department of Law urged DOT not to consider this hypothetical case. Other comments received by DOT pointed out that OBPA regulations covered all radioactive materials, not just spent nuclear fuel. Responding to these comments, DOT narrowed its review to the requirements imposed on the transportation of radioactive materials other than 
highway route controlled quantities and concluded that they were inconsistent.

\section{Inconsistency Ruling 12 St. Lawrence County, New York}

St. Lawrence County, New York, located at the foot of the Ogdensburg-Prescott Bridge, adopted a law on $\mathrm{Au}-$ gust 11, 1980, for the highway transportation of radioactive materials. Routes through St. Lawrence County, like the Ogdensburg-Prescott International Bridge, are not part of the Interstate Highway System.

DOT initiated inconsistency ruling proceedings for these requirements along with the OBPA rules; the scope of this ruling was also limited to radioactive materials other than highway route controlled quantities for the reasons noted in the discussion of inconsistency ruling 11 .

DOT determined that a section of the law which set forth the policy statement was consistent as it posed no obligation to act and did not suggest a regulator role for the county that conflicted with the HMTA. However, DOT found that permit requirements for certain types of radioactive materials and definitions of hazard classes that differed from Federal classifications were inconsistent,

\section{Inconsistency Ruling 13 Thousand Islands Bridge, New York}

The Thousand Islands Bridge Authority (TIBA) issued regulations governing the shipment of hazardous materials, including radioactive materials. The bridge connects Collins Landing, New York, and Ivy Lea, Ontario, and is part of the Interstate Highway System; thus, it is a preferred route for the highway transport of route controlled quantities of radioactive materials.

On March 22, 1982, TIBA applied to DOT for a nonpreemption determination without acknowledging the inconsistency of its requirements, despite a direct request from DOT; DOT suspended action on the request. On May 12, 1983, DOT initiated inconsistency ruling proceedings but limited its review to the effect of TIBA permit, fee, and escort requirements on vehicles carrying highwa $a_{y}$ route controlled quantities of radioactive materials. According to TIBA regulations, permits were to be issued by TIBA employees in charge at the bridge; a special escort and payment of fees could be required as a permit condition. DOT found these regulations to be inconsistent with the HMTA.

\section{Inconsistency Ruling 14 Jefferson County, New York}

Jefferson County, New York, located at the foot of the Thousand Islands Bridge, enacted a local ordinance gov- erning highway transportation of radioactive materials. The county requirements included 24-hour prenotification, required front and rear escorts, limited transport to the period between May and October, and prohibited shipments on holidays and during inclement weather. The county also required recognition of and adherence to the permit system established by TIBA. Jefferson County contains an Interstate highway that is a preferred route for highway transport of route controlled quantities of radioactive materials.

DOT initiated inconsistency ruling proceedings on May 12, 1983, because of the connection between the Jefferson County ordinance and the requirements imposed $b_{y}$ TIBA. DOT interpreted the types of shipments covered by the ordinance to be highway route controlled quantities of radioactive materials. Except for the escort requirement, DOT concluded that the regulations established by the county were inconsistent with the HMTA; the escort requirements were identical to NRC standards.

\section{Inconsistency Ruling 15 State of Vermont}

The Vermont Agenc of Transportation adopted comprehensive rules governing highway, rail, and water transportation of irradiated reactor fuel and nuclear waste; these rules were enacted during the comment period for DOT inconsistency rulings 7 through 14 . On August 4, 1983, DOT provided notice that it was initiating inconsistency ruling proceedings on the new Ver-mont rules as they were directl $\mathrm{y}_{\mathrm{y}}$ relevant to ongoin $\mathrm{g}$ proceedings.

DOT concluded that the following rules were consistent with the HMTA: the statement of intent included in the rules, information required as part of an application for approval of shipments that were identical to NRC requirements, confidentiality standards that were the same as Federal standards; and inspection requirements to the extent that they applied to consistent rules.

However, a number of requirements were determined to be inconsistent: application of the rules to a subset

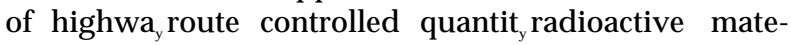
rials; submission of applications for approval of shipments (the permit application included indemnification, fee, and container certification requirements); criteria for approving applications, written notification of application approval by Vermont; notification requirements for schedule changes and delays; and monitoring of shipments by State officials such as State Police officers. Vermont has appealed the DOT ruling,

\section{Inconsistency Ruling 16 Tucson, Arizona}

Initially, a request for an inconsistency ruling on Tucson requirements for highway shipments of radioactive 
materials was submitted by the Arizona Corporation Commission on February 18, 1982. However, shortl after the application was filed, responsibility for hazardous materials transportation was transferred to the Arizona Department of Transportation. On March 25, 1983,

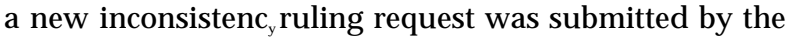

Arizona Department of Transportation, The city requirements in question, which DOT found to be inconsistent, established definitions for radioactive material that differed from Federal ones, prohibited the transportation of certain materials within or through the city, and required prenotification (50 F.R. 20S71, May 20, 1985).

\section{PART II: SUMMARY OF U.S. DEPARTMENT OF TRANSPORTATION (DOT) INCONSISTENCY RULING DECISIONS}

\footnotetext{
Inconsistency rulings Decisions by requirement type

$2,3,5,6,8$, 12,15 , and 16

\section{Definitions:}

Definitions that differed from Federal regulations (by changing the scope of materials subject to regulation or reclassifying materials) were found to be inconsistent. The basis for these decisions was that multiple definitions presented an obstacle to uniformity of hazardous materials regulations and would reduce compliance with Federal regulations. This could have a detrimental effect on emergency response capabilities resulting in a decrease in public safety.

Permits and prenotification. ${ }^{-a}$

$2,3,6,8,10$

$11,12,13$,

14,15 , and

16

In the decisions issued thus far, DOT has stated that permit and notification requirements as such are not inconsistent; it is necessary to look at what is required (for example, the type of information that must be submitted) to determine whether a permit or notification requirement is valid. With respect to hazardous materials generally, DOT has found requirements to be inconsistent if they cause delays or divert traffic onto routes not normally used by commercial vehicles. Moreover, if information required by a State, locality, or facility differed from what is required on DOT shipping papers, the permit or notification requirement was also found to be inconsistent. In one case, although DOT did not address the validity of the permit system, regulations requiring transporters to carry permits in a vehicle cab and display decals were found to be reasonable aids to local enforcement.

For high-level radioactive materials, DOT has ruled that requirements which diverted or delayed traffic did not provide for an equitable distribution of risk and were therefore inconsistent with the routing system established under HM-164. Again, if information was required that differed from NRC and DOT shipping paper regulations, the permit or notification requirement was found to be inconsistent.

Routing restrictions:

$1,2,3,10,11$

Generally, local routing regulations that increase safety and are enacted by a locality in consultation with 14 , and 16 neighboring jurisdictions are considered to be consistent requirements. In those cases where transport was banned or prohibited without a permit or some type of special approval, the State, local, or facility requirements were found to be inconsistent. Such prohibitions resulted in traffic diversions and increased transit times.

Restrictions affecting service to points of origin or destination within a city were found to be consistent. However, requirements pertaining to time restrictions (for example, no transport during rush hours), weather restrictions, and restrictions on the use of certain roads or streets were found to be inconsistent if they resulted in delays or diverted shipments.

For high-level radioactive materials, routing regulations enacted by jurisdictions that were not designated State routing agencies under HM-164 were also found to be inconsistent.

2 and 3

Accident notification:

Requirements for the immediate notification of local authorities in case of accidents were found to be consistent as there were no Federal regulations providing a basis for inconsistency. However, if written accident reports were required that differed from Federal reporting requirements, they were found to be inconsistent. DOT noted that it was not appropriate to impose additional written reporting requirements on carriers already subject to Federal regulation as information submitted to DOT was publicly available and the written reports were not required for emergency response purposes.

Operational requirements:

2 and 3 Requirements pertaining to the use of headlights, separation distances, attendance, and parking were found to be consistent because DOT considered them to be proper forms of State and local regulation and there was no direct conflict with existing Federal regulations.

Communication equipment:

2 and $8 \quad$ Requirements that conflicted with existing Federal regulations were found to be inconsistent. Where there were no Federal regulations providing a basis for inconsistency, the requirements were upheld,
} 
$2,3,8$, and 12

$11,13,14$ and 15

2 and 3

2,8, and 15

$11,13,14$ and 15

\section{Inspection and enforcement:}

Inspection requirements, to the extent that they were used to enforce consistent requirements, were considered to be valid exercises of State or local police power and, therefore, consistent. Compliance with such requirements was possible without violating Federal law or regulations.

DOT also ruled that penalty requirements that differed from Federal ones, were not inconsistent unless they were so extreme or applied so arbitrarily that they diverted or delayed hazardous materials shipments.

Escorts and monitoring:

In three cases, permit systems, including escort provisions, were found to be inconsistent. In another case, monitoring of certain radioactive shipments by State Police officers was required. DOT found that to the extent an obligation to act was imposed on transporters, causing delays, the requirements were inconsistent.

\section{Vehicle placarding:}

Vehicle placarding requirements that differed from Federal regulations were found to be inconsistent. DOT argued that State and local placards diverted attention from Federal ones and could have a detrimental effect on emergency response, and, ultimately, public safety. In one case, compliance with both Federal and State regulations was impossible.

\section{Container systems:}

Container certification requirements that were identical to Federal requirements, such as NRC regulations, were found to be consistent. Where State container design, testing, or certification requirements differed from Federal ones, they were found to be inconsistent. It is DOT's position that establishing such requirements is an exclusive Federal role and uniform standards are necessary to ensure safe and efficient transport of hazardous materials.

\section{Shipping papers:}

Shipping paper requirements that differed from Federal regulations were found to be inconsistent. The reason for this was that multiple shipping papers could have a detrimental effect on emergency response and, ultimately, public safety. In addition, DOT ruled that multiple requirements obstructed the national regulatory scheme.

Fees:

In one State, a fee of $\$ 1,000$ per shipment of certain radioactive materials was imposed to fund a monitoring (response) team. The requirement was found to be inconsistent because it was applied in a discriminatory manner (only radioactive substances), replicated Federal emergency response efforts, and diverted shipments. DOT also asserted that approval of such a requirement would encourage other States to take similar actions and undermine $\mathrm{HM}-164$.

indemnification. ${ }^{-b}$

For high-level radioactive materials, indemnification requirements that exceeded those in the Federal regulations were found to be inconsistent. The reason for this was that the requirements could result in diversions of shipments causing inequitable distributions of risk and were therefore inconsistent with the routing system established by $\mathrm{HM}-164$.

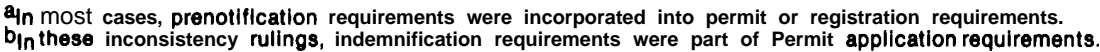

SOURCE: Office of Technology Assessment, based on U.S. Department of Transportation inconsistency rulings. 


\section{Emergency Response Planning}

Emergency response plans, if properly implemented, can help organize and coordinate the response activities of a variety of agencies. Communities concerned about hazardous materials transportation accidents are developing emergency response plans that utilize community resources. Although concerns about hazardous materials truck movements usually dominate State and local planning and training, well-prepared State and local emergency response plans will address hazardous materials transportation by all relevant transport modes.

\section{Federal Assistance}

At the Federal level, the Federal Emergency Management Agency (FEMA) is responsible for administering programs that support State and local emergency response activities.' However, since the formation of FEMA in 1979, its emergency response programs have been focused on civil defense, radiological concerns, and natural disaster planning. Despite the overwhelming evidence pointing to the need for hazardous materials response planning and training, expansion of FEMA programs to cover hazardous materials emergencies has been limited.

Through FEMA's Emergency Management Assistance Program, States receive financial support under Comprehensive Cooperative Agreements for planning, training, and response activities; localities are funded by State emergency management agencies. ${ }^{2}$ However, local agencies must meet extensive requirements, including the preparation of an integrated emergency operations plan that addresses all hazards, not just those involving hazardous materials, and completion of a Hazardous Identification Capability Assessment and Multi-Year Development Plan (HICA-MYDP). According to State and local officials, the HICA-MYDP document is detailed and requires numerous man-hours to complete for very lim-

\footnotetext{
IIn 1979, Federal emergency preparedness activities were consolidated into one agency-the Federal Emergency Management Agency (FEMA). Functions vested in the U.S. Departments of Commerce, Housing and Urban Development, and Defense, and the Executive Office of the President were transferred to FEMA under Reorganization Plan No. 3. See 43F.R. 41943, Sept. 19, 1978,

'States must apply to the Federal Emergency Management Agency (FEMA) for financial assistance for the Emergency Management Assistance Program and other FEMA assistance programs. Comprehensive Cooperative Agreements (CCAs) are negotiated program and funding agreements between FEMA and States that identify responsibilities for meeting national program objectives. As part of the CCA process, States must submit staffing, budget, and administra tive planning Information, as well as statements of work for its own program and for local (subgrantee) programs. An emergency management training plan must also be developed by each State. These requirements are specified in a special civil preparedness guidance document, Federal Emergency Management Agency, Hazard Identification, Capability Assessment, and Multi-Year Development Plan for Local Governments, CPG 1-35 (Washington, DC: January 1985).
}

ited funding that is directed essentially at civil defense preparedness. 'To support State and local planning activities, FEMA has published several guidance documents in addition to the HICA-MYDP. ${ }^{4}$

The Environmental Protection Agency (EPA), FEMA, the U.S. Department of Transportation (DOT), and other Federal agencies have recently begun to work together to implement new emergency response planning initiatives and improve interagency coordination. In 1985, EPA undertook a new effort-the Chemical Emergency Preparedness Program (CEPP) - to help States and communities develop emergency response plans. While this program focuses on accidental releases from fixed facilities as part of EPA's National Strategy for Toxic Air Pollutants, the emergency response personnel and other local officials that participate in CEPP are likely to have responsibilities related to transportation accidents as well. ${ }^{5}$ FEMA regional offices are cooperating with their EPA counterparts to support State and local CEPP efforts. CEPP is currently a voluntary program, and financial assistance for participating communities is not available, a major drawback for its implementation in many locations. However, major revisions to the Comprehensive Environmental Response, Compensation, and Liability Act under consideration by Congress are likely to affect emergency response planning and coordination at the State and local levels.

FEMA, DOT, and other Federal agencies are also revising their hazardous materials planning guide for State and local officials, FEMA-10, to reflect new technologies, regulatory requirements, and private sector initiatives; it will be issued as a joint Federal guidance document. ${ }^{6}$

\footnotetext{
${ }^{3}$ U.S. Congress, Office of Technology Assessment, "Transcript of Proceedingsworkshop on State and Local Activities," Mav 30, 1985; Buddy DeWar. Director of the State Fire Marshal's Office, Tallahassee, FL, and Chief Don Ryan, Hazardous Materials Bureau, Division of State Fire Marshals, Reynoldsburg, OH, personal communications, March 1986.

${ }^{4}$ See Federal Emergency Management Agency, Planning Guide and Checklist for Developing Hazardous Materials Contingency Plans, FEMA-10 (Washington, DC: July 1981); Federal Emergency Management Agency, Interim Guide for Development of State and Local Emergency Operations Plans, CPG 1-8 (Washington, DC: October 1985); and Federal Emergency Management Agency, Interim Guide for Rewew of State and Local Emergency Operations Plans, CPG 1-8A (Washington, DC: October 1985).

5 , guidance document was issued in November 1985 containıng basic information on community organization, data gathering, and contingency planning, and a list of almost 400 acutely toxic chemicals. The chemical list is intended to serve as a starting point for community investigations; however, as it is based on animal toxicity data, the hst does not necessary represent hazards posed from a transportation perspective such as explosive or combustible materials. The U.S. Environmental ProtectIon Agency directed those communities interested in other hazardous materials to consult the U.S. Department of Transportation's list of hazardous materials and hazard classes. See U.S. Environmental Protection Agency, Chemical Emergency Preparedness Program Interim Guidance: Revision 1, 9223.0-1A (Washington, DC: November 1985).

'See Federal Emergency Management Agency, Planning Guide and Checklist for Developing Hazardous Materials Contingency Plans, op. cit.
} 


\section{State and Local Emergency Response Planning}

As identified by State and local governments, the primary areas needing attention during planning include:

. improved coordination among Federal, State, and local agencies;

. coordination with industry response programs;

. advance agreement about who is in charge;

. adequate communication between the accident site and offsite command posts;

. other operational concerns; and

public information.

Better coordination in the following areas would ease many of the problems faced by State and local responders: funding for emergency response training and planning; information dissemination on appropriate hazardous materials emergency response procedures; and a clear delineation of Federal, State, and local hazardous materials emergency response capabilities and responsibilities.

State, regional, or local plans should outline specific responsibilities, coordinate on-site activities, and appoint a response leader to reduce the confusion at the accident site and provide a clear chain of authority for response activities and information dissemination to the media. Fire, police, and other government agencies, including emergency management and public works departments that may participate in emergency response, should be part of the planning process. Any governmental mutual aid agreements should determine the on-scene coordinator in advance. Simulations of emergency situations provide an opportunity to test these plans and discover organizational problems prior to an actual hazardous materials accident.

Industry has contributed to many local emergency response activities, but questions remain regarding emergency response on private property, such as a company facility or a railroad right-of-way. Advance arrangements between special industry response teams and existing public emergency response networks are necessary. Formal mutual aid agreements among independent industry response teams and communities are a means of achieving coordinated and comprehensive response capabilities at reduced expense, Such agreements allow neighboring communities to share equipment, fire and police department manpower, emergency medical services, and private sector resources. The Chemical Manufacturer's Association's Community Awareness and Emergency Response Program and EPA's Chemical Emergency Preparedness Program encourage industry cooperation in the development of community emergency response plans.

Communication and liability issues should also be covered during the planning process. Communication involves both hardware and organization. At the planning stage, participating response agencies should identify equipment requirements and procedures to ensure adequate communication, both on and offsite; equipment compatibility; and isolation of radio frequencies for emergency use. Liability issues are a concern for governmental entities, which may be held responsible for emergency response activities that result in damages. Carefully crafted Good Samaritan laws can relieve the burden of potential liability for qualified emergency responders who assist during a hazardous materials transportation accident.

Providing accurate reports to the press and public is another necessary part of coordinated emergency response activities. At many accidents, particularly severe ones, the media become a part of the response process and is an important public information source. Emergenc $_{y}$ response plans should include designating spokespersons skilled in giving print and electronic media interviews. The first media contact can determine how the incident is perceived by the public and can help maintain public calm and cooperation. 


\section{List of Acronyms and Other References}

\begin{tabular}{|c|c|c|c|}
\hline $111 \mathrm{~A}$, etc. & $\begin{array}{l}\text { —railroad container designations } \\
\text { (DOT) }\end{array}$ & $\begin{array}{l}\text { CVCF } \\
\text { CVSA }\end{array}$ & $\begin{array}{l}\text {-Commercial Vehicle Casualty File } \\
\text {-Commercial Vehicle Safety Alliance }\end{array}$ \\
\hline \multirow[t]{2}{*}{49 CFR } & - transportation section of the Code & DMV & -Division of Motor Vehicles \\
\hline & of Federal Regulations & DOD & -U.S. Department of Defense \\
\hline 49-series & $\begin{array}{l}\text { — series of STCCs specifically for } \\
\text { hazardous materials }\end{array}$ & $\begin{array}{l}\text { DOE } \\
\text { DOT }\end{array}$ & $\begin{array}{l}\text {-U.S. Department of Energy } \\
\text {-U.S. Department of Transportation }\end{array}$ \\
\hline 5800.1 & 一see F5800. 1 & DVB & -divinyl benzene \\
\hline $\mathrm{A} \& \mathrm{H}$ & -Alaska and Hawaii & ECE & -Economic Commission for Europe \\
\hline AAR & -Association of American Railroads & ECOSOC & -Economic and Social Council \\
\hline ABAG & $\begin{array}{l}\text {-Association of Bay Area } \\
\text { Governments }\end{array}$ & $\begin{array}{l}\text { ENC } \\
\text { EODA }\end{array}$ & $\begin{array}{l}\text {-East North Central } \\
\text {-Explosive and Other Dangerous }\end{array}$ \\
\hline \multicolumn{3}{|c|}{ ACE (ACofE)-U.S. Army Corps of Engineers } & Articles Act \\
\hline $\mathrm{AE}$ & $\begin{array}{l}\text {-Army Corps of Engineers codes } \\
\text { (WSCS code) }\end{array}$ & EPA & $\begin{array}{l}\text {-U.S. Environmental Protection } \\
\text { Agency }\end{array}$ \\
\hline ANPRM & $\begin{array}{l}\text {-Advanced Notice of Proposed } \\
\text { Rulemaking }\end{array}$ & $\begin{array}{l}\text { ESC } \\
\text { Ex Parte }\end{array}$ & $\begin{array}{l}\text {-East South Central } \\
\text {-legal proceeding before the Interstate }\end{array}$ \\
\hline APA & -Administrative Procedures Act & & Commerce Commission \\
\hline API & —American Petroleum Institute & F5800. 1 & —reporting form for HMIR \\
\hline ASME & $\begin{array}{l}\text {-American Society of Mechanical } \\
\text { Engineers }\end{array}$ & $\begin{array}{l}\text { FAA } \\
\text { FARS }\end{array}$ & $\begin{array}{l}\text {-Federal Aviation Administration } \\
\text {-Fatal Accident Reporting System }\end{array}$ \\
\hline ATA & -Air Transport Association & FCS & -Freight Carload Statistics (ICC) \\
\hline ATA & $\begin{array}{l}\text {-American Trucking Associations, } \\
\text { Inc. }\end{array}$ & FEMA & $\begin{array}{l}\text {-Federal Emergency Management } \\
\text { Agency }\end{array}$ \\
\hline AUI & -Associated Universities, Inc. & FHWA & -Federal Highway Administration \\
\hline BEA & $\begin{array}{l}\text {-Bureau of Economic Analysis (U.S. } \\
\text { Department of Commerce) }\end{array}$ & FLETC & $\begin{array}{l}\text {-Federal Law Enforcement Training } \\
\text { Center }\end{array}$ \\
\hline BEA Region & $\begin{array}{l}\text { - Bureau of Economic Analysis Region } \\
\text { (U.S. Department of Commerce) }\end{array}$ & $\begin{array}{l}\text { FR } \\
\text { FRA }\end{array}$ & $\begin{array}{ll}\text {-Federal Register } \\
\text {-Federal Railroad Administration }\end{array}$ \\
\hline \multirow[t]{2}{*}{$\begin{array}{l}\text { BMCS } \\
\text { BPNL }\end{array}$} & $\begin{array}{l}\text {-Bureau of Motor Carrier Safety } \\
\text {-Battelle Pacific Northwest }\end{array}$ & FRERP & $\begin{array}{l}\text {-Federal Radiological Emergency } \\
\text { Response P̈lan }\end{array}$ \\
\hline & Laboratory & FRP & -fiberglass reinforced plastic \\
\hline $\begin{array}{l}\text { BWR } \\
\text { CAB }\end{array}$ & $\begin{array}{l}\text {-boiling water reactor } \\
\text {-Civil Aeronautics Board }\end{array}$ & FSAC & $\begin{array}{l}\text {-Freight Station Accounting Code- } \\
\text { U.S. rail network }\end{array}$ \\
\hline CAER & $\begin{array}{l}\text {-Community Awareness and } \\
\text { Emergency Response }\end{array}$ & $\begin{array}{l}\text { FWPCA } \\
\text { GAO }\end{array}$ & $\begin{array}{l}\text {-Federal Water Pollution Control Act } \\
\text {-U.S. General Accounting Office }\end{array}$ \\
\hline CERCLA & $\begin{array}{l}\text {-Comprehensive Environmental } \\
\text { Response, Compensation, and } \\
\text { Liability Act }\end{array}$ & $\begin{array}{l}\text { GVWR } \\
\text { HICA/MYD }\end{array}$ & $\begin{array}{l}\text { - gross vehicle weight ratings } \\
\text {-Hazard Identification, Capability } \\
\text { Assessment and Multi-Year }\end{array}$ \\
\hline CFR & -Code of Federal Regulations & & Development Plan \\
\hline CHEMTREC & $\begin{array}{l}\text {-Chemical Transportation Emergency } \\
\text { Center }\end{array}$ & $\begin{array}{l}\text { HLW } \\
\text { HMIR }\end{array}$ & $\begin{array}{l}\text { - high-level waste } \\
\text {-Hazardous Materials Incident }\end{array}$ \\
\hline CHP & -California Highway Patrol & & Reports \\
\hline CHRIS & $\begin{array}{l}\text {-Chemical Hazards Response } \\
\text { Information System }\end{array}$ & HMIS & $\begin{array}{l}\text {-Hazardous Materials Information } \\
\text { Service }\end{array}$ \\
\hline CMA & -Chemical Manufacturers Association & HMTA & -Hazardous Materials Transportation \\
\hline $\mathrm{COFC} / \mathrm{TOFC}$ & $\begin{array}{l}\text {-container on flatcar/trailer on flatcar } \\
\text { (piggyback) }\end{array}$ & HSRI & $\begin{array}{l}\text { Act } \\
\text { - Highway Safety Research Institute }\end{array}$ \\
\hline CPI & -Consumer Price Index & & (University of Michigan) \\
\hline СТC & -Canadian Transport Commission & IACP & -International Association of Chiefs \\
\hline CTS & $\begin{array}{l}\text {-Commodity Transportation Survey } \\
\text { (U.S. Bureau of the Census) }\end{array}$ & IAEA & $\begin{array}{l}\text { of Police } \\
\text {-International Atomic Energy Agency }\end{array}$ \\
\hline
\end{tabular}




\begin{tabular}{|c|c|c|c|}
\hline IAFC & $\begin{array}{l}\text {-International Association of Fire } \\
\text { Chiefs }\end{array}$ & NMFC & $\begin{array}{l}\text {-National Motor Freight } \\
\text { Classification }\end{array}$ \\
\hline IAFF & $\begin{array}{l}\text {--International Association of Fire } \\
\text { Fighters }\end{array}$ & $\begin{array}{l}\text { NMTDB } \\
\text { n.o. s. }\end{array}$ & $\begin{array}{l}\text { - National Motor Truck Data Base } \\
\text { —not otherwise specified }\end{array}$ \\
\hline IATA & -International Air Transport & NPRM & -Notice of Proposed Rulemaking \\
\hline ICAO & $\begin{array}{l}\text { Association } \\
\text {-International Civil Aviation }\end{array}$ & NRC & $\begin{array}{l}\text {-National Response Center (U.S. } \\
\text { Coast Guard) }\end{array}$ \\
\hline ICC & $\begin{array}{l}\text { Organization } \\
\text {-Interstate Commerce Commission }\end{array}$ & NRC & $\begin{array}{l}\text {-U.S. Nuclear Regulatory } \\
\text { Commission }\end{array}$ \\
\hline IDOT & $\begin{array}{l}\text {-Illinois Department of } \\
\text { Transportation }\end{array}$ & $\begin{array}{l}\text { NRT } \\
\text { NTSB }\end{array}$ & $\begin{array}{l}\text {-National Response Team } \\
\text {-National Transportation Safety }\end{array}$ \\
\hline IIHS & $\begin{array}{l}\text {-Insurance Institute for Highway } \\
\text { Safety }\end{array}$ & NTTC & $\begin{array}{l}\text { Board } \\
\text {-National Tank Truck Carriers, Inc. }\end{array}$ \\
\hline $\mathrm{IM}$ & -intermodal & NWPA & -Nuclear Waste Policy Act \\
\hline IMCO & $\begin{array}{l}\text {-Intergovernmental Maritime } \\
\text { Consultative Organization }\end{array}$ & $\begin{array}{l}\text { NYSTA } \\
\text { OBPA }\end{array}$ & $\begin{array}{l}\text {-New York State Thruway Authority } \\
\text {-Ogdensburg Bridge and Port }\end{array}$ \\
\hline IMDG & $\begin{array}{l}\text {-International Maritime Dangerous } \\
\text { Goods }\end{array}$ & OHMT & $\begin{array}{l}\text { Authority } \\
\text {-Office of Hazardous Materials }\end{array}$ \\
\hline IMO & -International Maritime Organization & & Transportation \\
\hline LLW & -low-level waste & OKI & -Ohio-Kentucky-Indiana \\
\hline LNG & —liquefied natural gas & ORM & -Other Regulated Materials \\
\hline LPG & —liquefied petroleum gas & ORNL & -Oak Ridge National Laboratories \\
\hline LSA & -low specific activity & OSHA & -Occupational Safety and Health \\
\hline LWR & -light water reactor & & Administration \\
\hline LWT & -legal weight truck & OTA & -Office of Technology Assessment \\
\hline MA & -Middle Atlantic & OWT & —overweight truck \\
\hline MC-301, etc. & $\begin{array}{l}\text { - container codes applicable to trucks } \\
\text { (see } 49 \text { CFR) }\end{array}$ & PATRAM & $\begin{array}{l}\text {-Packaging and Transportation of } \\
\text { Radioactive Materials }\end{array}$ \\
\hline MCCS & $\begin{array}{l}\text {-Motor Carrier Census Survey } \\
\text { (Bureau of Motor Carrier Safety, } \\
\text { FHWA) }\end{array}$ & $\begin{array}{l}\text { PCB } \\
\text { PIRS } \\
\text { PNW }\end{array}$ & $\begin{array}{l}\text {-polychlorinated biphenyls } \\
\text {-Pollution Incident Reporting System } \\
\text {-Pacific Northwest }\end{array}$ \\
\hline MCSAP & $\begin{array}{l}\text {-Motor Carrier Safety Assistance } \\
\text { Program }\end{array}$ & $\begin{array}{l}\text { PPE } \\
\text { PSCOG }\end{array}$ & $\begin{array}{l}\text {-personal protective equipment } \\
\text {-Puget Sound Council of }\end{array}$ \\
\hline MMTA & $\begin{array}{l}\text {-Massachusetts Motor Trucking } \\
\text { Association, Inc. }\end{array}$ & psi & $\begin{array}{l}\text { Governments } \\
\text { - pounds per square inch }\end{array}$ \\
\hline MOU & -Memorandum of Understanding & Psw & —Pacific Southwest \\
\hline MRS & —monitored retrievable storage & PTRA & -Port Terminal Rail Authority \\
\hline MSDS & —material safety data sheets & PWR & —pressurized water reactor \\
\hline MSHA & $\begin{array}{l}\text {-Mine Safety and Health } \\
\text { Administration }\end{array}$ & Piggyback & $\begin{array}{l}\text { - trailers or containers carried on } \\
\text { railroad flatcars }\end{array}$ \\
\hline $\begin{array}{l}\text { MTB } \\
\text { MTU }\end{array}$ & $\begin{array}{l}\text {-Materials Transportation Board } \\
\text {-metric tons uranium }\end{array}$ & RAMRT & $\begin{array}{l}\text {-Radioactive Materials Routing } \\
\text { Report }\end{array}$ \\
\hline NAC & -Nuclear Assurance Corp. & RCRA & -Resource Conservation and \\
\hline NAHMI & $\begin{array}{l}\text {-National Alliance of Hazardous } \\
\text { Materials Instructors }\end{array}$ & RPI & $\begin{array}{l}\text { Recovery Act } \\
\text {-Railway Progress Institute }\end{array}$ \\
\hline NASS & -National Accident Sampling System & $\mathrm{RQ}$ & -reportable quantity \\
\hline $\mathrm{NCP}$ & -National Contingency Plan & RRT & -Regional Response Teams \\
\hline $\begin{array}{l}\text { NE } \\
\text { NFPA }\end{array}$ & -New England & RSPA & -Research and Special Programs \\
\hline $\begin{array}{l}\text { NEPA } \\
\text { NFPA }\end{array}$ & $\begin{array}{l}\text {-National Environmental Policy Act } \\
\text {-National Fire Protection Association }\end{array}$ & SA & $\begin{array}{l}\text { Administration } \\
\text {-South Atlantic }\end{array}$ \\
\hline NHTSA & $\begin{array}{l}\text {-National Highway Transportation } \\
\text { Safety Administration }\end{array}$ & SHMED & $\begin{array}{l}\text {-State Hazardous Materials } \\
\text { Enforcement Development program }\end{array}$ \\
\hline $\mathrm{NIOSH}$ & $\begin{array}{l}\text {-National Institute for Occupational } \\
\text { Safety and Health }\end{array}$ & $\begin{array}{l}\text { SIC } \\
\text { SOLAS }\end{array}$ & $\begin{array}{l}\text { - Standard Industrial Classification } \\
\text { - Safety of Life at Sea }\end{array}$ \\
\hline
\end{tabular}




\begin{tabular}{|c|c|}
\hline SPCL & $\begin{array}{l}\text {-Standard Point Location Code } \\
\text { (geocodification of the U. S.) }\end{array}$ \\
\hline SSRMT & $\begin{array}{l}\text { - State Surveillance of Radioactive } \\
\text { Materials Transportation }\end{array}$ \\
\hline STAA & $\begin{array}{l}\text {-Surface Transportation Assistance } \\
\text { Act }\end{array}$ \\
\hline STCC & $\begin{array}{l}\text {-Standard Transportation } \\
\text { Commodity Code (ICC) }\end{array}$ \\
\hline Schedule A & $\begin{array}{l}\text {-import commodity classification code } \\
\text { (U.S. Customs) }\end{array}$ \\
\hline Schedule E & $\begin{array}{l}\text { - export commodity codes (U.S. } \\
\text { Customs) }\end{array}$ \\
\hline TAF & -Truck Accident File (BMCS) \\
\hline TDG & $\begin{array}{l}\text {-Transportation of Dangerous Goods } \\
\text { Regulations }\end{array}$ \\
\hline TDI & —toluene diisocyanate \\
\hline TEMA & $\begin{array}{l}\text {-Tennessee Emergency Management } \\
\text { Agency }\end{array}$ \\
\hline TI & -Technical Instructions \\
\hline TIBA & -Thousand Islands Bridge Authority \\
\hline$T I \& U$ & 一 see TIUS \\
\hline TIUS & $\begin{array}{l}\text { - Truck Inventory and Use Survey } \\
\text { (U.S. Bureau of the Census) }\end{array}$ \\
\hline $\mathrm{TOFC} / \mathrm{COF}$ & $\begin{array}{l}\text {-trailer on flatcar } \\
\quad \text { (piggyback) / container on flatcar }\end{array}$ \\
\hline TRAIN II & $\begin{array}{l}\text {-railroad car location information } \\
\text { exchange network and database }\end{array}$ \\
\hline TRU & —transuranic waste \\
\hline
\end{tabular}

\begin{tabular}{|c|c|}
\hline TSC & -Transportation System Center \\
\hline TSCA & -Toxic Substances Control Act \\
\hline TSI & —Transportation Safety Institute \\
\hline TSUSA & $\begin{array}{l}\text { - Tariff Schedule for United States } \\
\text { Annotated }\end{array}$ \\
\hline UFC & —Uniform Freight Classification \\
\hline UMLER & $\begin{array}{l}\text {-Universal Machine Language } \\
\text { Equipment Register }\end{array}$ \\
\hline $\mathrm{UN} / \mathrm{NA}$ & $\begin{array}{l}\text {-United Nations/North American } \\
\text { hazardous materials code }\end{array}$ \\
\hline UNK & —region unknown \\
\hline UP & -Union Pacific \\
\hline U.S.C. & -United States Code \\
\hline USCG & -U.S. Coast Guard \\
\hline UTPS & $\begin{array}{l}\text {-Urban Transportation Planning } \\
\text { System }\end{array}$ \\
\hline VMF & $\begin{array}{l}\text {-Vessel Master File (U.S. Army } \\
\text { Corps of Engineers) }\end{array}$ \\
\hline WCSC & -Waterborne Commerce Statistics \\
\hline WCSC & $\begin{array}{l}\text { Center (Army Corps of Engineers) } \\
\text { — waterborne commodity statistical } \\
\text { codes flow database (Army Corps of } \\
\text { Engineers) }\end{array}$ \\
\hline WMF & $\begin{array}{l}\text {-Waterway Master File (U.S. Army } \\
\text { Corps of Engineers) }\end{array}$ \\
\hline WNC & -West North Central \\
\hline WSAF & -Washington State Accident File \\
\hline WSC & -West South Central \\
\hline
\end{tabular}


References 
A.D. Little Co., "Protective Clothing and Equipment," Chemical Hazardous Materials Response I nformation System (CHRIS) Response Methods Handbook (Washington, DC: U.S. Coast Guard/U. S. Department of Transportation, December 1978).

Association of American Railroads, Nuclear Emergency Response Planning for Railroads (Washington, DC: November 1984).

Association of Bay Area Governments, National Directory of Hazardous Materials Training Courses (San Francisco, CA: March 1985).

Association of Bay Area Governments, San Francisco, CA, Hazardous Spill Prevention and Response Plan (Washington, DC: U.S. Department of Transportation, Research and Special Programs Administration, 1983).

Baldwin, David M., Regulation of the Movement of Hazardous Cargoes (Washington, DC: National Cooperative Highway Research Program, Transportation Research Board/National Research Council, May 1980).

Battelle Memorial Research Laboratories, Battelle Human Affairs Research Center, Assessment of State and Local Notification Requirements for Transportation of Radioactive and Other Hazardous Materials (Columbus, OH: Jan 11, 1985).

Barber, E.J., and Hildebrand, L. K., Peat, Marwick, Mitchell, \& Co., Guidelines for Applying Criteria To Designate Routes for Transporting Hazardous Materials, Implementation Package FHWA-IP-80-20 (Washington, DC: U.S. Department of Transportation, 1980).

Federal Emergency Management Agency, Interim Guide for Development of State and Local Emergency Operations Plans, CPG 1-8 (Washington, DC: October 1985).

Federal Emergency Management Agency, Interim Guide for the Review of State and Local Emergency Operations Plans, CPG 1-8A (Washington, DC: October 1985).

Federal Emergency Management Agency, Hazard Identification, Capability Assessment, and Multi-Year De velopment Plan for Local Governments, CPG 1-35 (Washington, DC: January 1985).

Federal Emergency Management Agency, Planning Guide and Checklist for Hazardous Materials Contingency Plans, FEMA-10 (Washington, DC: July 1981).

Federal Emergency Management Agency, Digest of Federal Training Programs in Hazardous Materials (Emmitsburg, MD: ND).

Hoxie, Paul, and Woodman, Donna, Risks of Hazardous Substance Spills From Unmarked Packages or Containers (Washington, DC: U.S. Department of
Transportation, Transportation Systems Center, $\mathrm{Se}_{\mathrm{p}}-$ tember 1982).

ICF, Inc., Assessing the Releases and Costs Associated With Truck Transport of Hazardous Wastes (Washington, DC: U.S. Environmental Protection Agency, Office of Solid Waste, January 1984).

Javits, Harold S., et al., Transport of Radioactivity Material in the United States, SAND84-7174 (Albuquerque, NM: Sandia National Laboratories, April 1985).

Knox, N.P., et al., Transportation of Radioactive and Hazardous Materials: A Summary of Stare and Local Legislative Requirements for the Period Ending December 31, 2984, ORNL/ TM-9563 (Oak Ridge, TN: U.S. Department of Energy, September 1985).

Ludwigson, John (cd.), 2984 Hazardous Materials Spill Conference: Prevention, Behavior, Control and Cleanup of Spills and Waste Sites, sponsored $b_{y}$ Association of American Railroad/Bureau of Explosives, et al., held in Nashville, TN (Rockville, MD: Government Institutes, Inc., Apr. 9-12, 1984).

Maio, Domenic J., Truck Transportation of Hazardous Materials-A National Overview (Washington, DC: U.S. Department of Transportation, Research and Special Programs Administration, Transportation Systems Center, November 1983).

Markowitz, Steven, et al., Ability of Health Care Facilities in Northern New jersey To Respond to Major Chemical Accidents (New York: Workers Polic Project, November 1985).

National Academy of Sciences, Committee on Hazardous Materials, "Conference Proceedings on Bulk Transportation of Hazardous Materials $b_{y}$ Water in the Future: A Long Range Forecast, " College Park, MD, unpublished typescript, July 9-10, 1973.

National Academ of Sciences, Committee on Hazardous Materials and National Research Council, Highway Research Board, A Stud of Transportation of Hazardous Materials: A Report to the Office of Hazardous Materials of the U.S. Department of Transportation (Washington, DC: National Academy Press, 1969).

National Conference of State Legislatures, Hazardous Materials Incident Reports (Washington, DC: U.S. Department of Transportation, Research and Special Programs Administration, Februar ${ }_{\mathrm{y}}$ 1984).

National Conference of State Legislatures, Hazardous Materials Transportation: A Legislators Guide (Denver, CO: 1984).

National Transportation Safety Board, Noncompliance With Hazardous Materials Safety Regulations, NTSBHZM-79-2 (Springfield, VA: National Technical Information Service, August 1979).

National Transportation Safety Board, Safety Efiective 
ness Evaluation of Detection and Control of Unsafe Interstate Commercial Drivers, NTSB-SEE-80-1 (Springfield, VA: National Technical Information Service, February 1980).

National Transportation Safety Board, Status of Department of Transportation Hazardous Materials Regulatory Program, NTSB-SR-81-2 (Springfield, VA: National Technical Information Service, September 1981).

Price, Dennis L., et al., Multi Modal Hazardous Materials Transportation in Virginia, VDOTS/ SPO-16(Richmond, VA: Virginia Department of Transportation Safety, 1981).

Rhoads, R. E., et al., An Assessment of the Risk of Trans-porting Gasoline by Truck (Richland, WA: Battelle Pacific Northwest Laboratory, November 1978).

Rothberg, Paul, Nuclear Materials Transportation: Safety Concerns, Governmental Regulations and Activities, and Options To Improve F ederal Programs (Washington, DC: U.S. Congress, Congressional Research Service, Mar. 15, 1984).

Scanlon, Raymond D., “A Regional Study on Hazardous Materials Transportation, Howard S. Cullman Fellowship 1982-83 Report," unpublished typescript.

Simmons, J. L., et al., Battelle Pacific Northwest Laboratories, Survey of Radioactive Materials Shipments in the U. S., NUREG-0073 (Richland, WA: Sandia National Laboratories, 1976).

Salomon, Stephen N., State Surveillance of Radioactive Material Transportation, NUREG-1015 (Washington, DC: U.S. Nuclear Regulatory Commission, Office of State Programs, 1984).

Student, Patrick J., E mergency Handling of Hazardous Materials in Surface Transportation (Washington, DC: Bureau of Explosives, Association of American Railroads, 1981).

Transportation Research Circular, "The Ten Most Critical Issues in Hazardous Materials Transportation," No. 219, July 1980.

Union of Concerned Scientists, Safety Second: A Critical Evaluation of the NRC's First Decade (Washington, DC: February 1985).

U.S. Congress, Congressional Research Service, Hazardous Materials Transportation: A Review and Analysis of the Department of Transportation Regulatory Program (Washington, DC: Congressional Research Service, April 1979).

U.S. Congress, Office of Technology Assessment, Managing the Nation Commercial High-Level Radioactive Waste, OTA-O-171 (Washington, DC: U.S. Government Printing Office, March 1985).
U.S. Congress, Office of Technology Assessment, Transportation of Hazardous Materials: State and Local Activities, OTA-SET-301 (Washington, DC: U.S. Government Printing Office, March 1986).

U.S. Department of Transportation, A Guide to the Federal Hazardous Materials Transportation Regulatory Program, DOT-I-83-12 (Washington, DC: January 1983).

U.S. Department of Transportation, Guidelines for Se lecting Preferred Highway Routes for Highway Route Controlled Quantity Shipments of Radioactive Materials, DOT/ RSPA/ MTB-84/ 22 (Washington, DC: June 1984 (originally published in June 1981)).

U.S. Department of Transportation, Research and Special Programs Administration, Community Teamwork: Working Together To Promote Hazardous Materials Transportation Safey, A Guide for Local Officials (Washington, DC: U.S. Government Printing Office, May 1983).

U.S. Department of Transportation, Research and Special Programs Administration, Handling Radioactive Material Transportation Emergencies, DOT/RPSA/ MTB-7917 (Washington, DC: U.S. Government Printing Office, July 1979).

U.S. Department of Transportation, Research and Special Programs Administration, Radioactive Materials Transportation I nformation and Incident Guidance, DOT/ RSPA/ MTB-81/ 4 (Washington, DC: U.S. Government Printing Office, ND).

U.S. Environmental Protection Agency, Chemical Emergency Preparedness Program Interim Guidance: Re vision 1, 9223.0-1A (Washington, DC: November 1985).

U.S. Environmental Protection Agency, "Sources, Amounts and Characteristics of Low-Level Radioactive Solid Wastes," Low-Level Radioactive Waste Management, EPA 520/3-79-002 (Washington, DC: May 1979).

U.S. Environmental Protection Agency, Office of Water and Waste Management, Characterization of Hazardous Waste Transportation and Economic Impact Assessment of Hazardous Waste Transportation Regulations (Washington, DC: March 1979).

U.S. Environmental Protection Agency, Office of Water and Waste Management, Development of an Emergency Response Program for Transportation of Hazardous Waste (Washington, DC: March 1979).

U.S. Environmental Protection Agency, Office of Water and Waste Management, Financial Responsibility for Transporters of Hazardous Waste (Washington, DC: September 1979). 
U.S. General Accounting Office, Management Improve ment Could Enhance Enforcement of Coast Guard Marine Safety Programs, GAO/ RCED-85-59 (Washington, DC: U.S. Government Printing Office, Aug. $15,1985)$.

U.S. General Accounting Office, Stronger Enforcement Would Help Improve Motor Carrier Safety, GAO/ RCED-85-64 (Washington, DC: U.S. Government Printing Office, Sept. 5, 1985).

U.S. General Accounting Office, The U.S. Nuclear Materials Information System Can Improve Service to Its User Agencies-Report to the Secretary of Energy (Washington, DC: U.S. Government Printing Office, Jan. 14, 1985).

U.S. General Accounting Office, Programs for Ensuring the Safe Transportation of Hazardous Materials Need Improvement (Washington, DC: U.S. Government Printing Office, November 1980).

Westat, Inc., National Survey of Hazardous Waste Generators and Treatment, Storage and Disposal Facilities Regulated Under RCRA in 1981 (Washington, DC: U.S. Environmental Protection Agency, Office of Solid Waste, 1984).

Selected Surveys and Studies on Hazardous Materials Training

Federal Emergency Management Agency, Emergency Management Institute, "Teleconference Report, Haz- ardous Materials Incidents: Issues for Planning, " unpublished typescript, June 25, 1985.

Federal Emergency Management Agency, National Emergency Training Center, "Proceedings From the National Workshop on Hazardous Materials Training," unpublished typescript, October 1985.

ICF, Inc., Lessons Learned-A Report on the Lessons Learned From State and Local Experiences in Accident Prevention and Response Planning for Hazardous Materials Transportation (Washington, DC: U.S. Department of Transportation and U.S. Environmental Protection Agency, December 1985).

International Association of Fire Chiefs, "Hazardous Materials Team Survey," unpublished typescript, August 1985.

National Response Team/Regional Response Teams, "Federal/State/Local Oil and Hazardous Substance Emergency Preparedness Activities," unpublished typescript, July 1985.

U.S. Department of Transportation and Federal Emergency Management Agency, "Report to the Congress: Hazardous Materials Training, Planning, and Preparedness," unpublished draft, 1986.

U.S. Department of Transportation, Research and Special Programs Administration, "State Hazardous Materials Enforcement Development (SHMED) Hazardous Materials Enforcement Survey, " unpublished typescript, Sept. 30, 1985. 